UNIVERSIDADE DE SÃO PAULO

FACULDADE DE FILOSOFIA, LETRAS E CIÊNCIAS HUMANAS

DEPARTAMENTO DE HISTÓRIA

PROGRAMA DE PÓS-GRADUAÇÃO EM HISTÓRIA SOCIAL

\title{
SOMBRIOS UMBRAIS A TRANSPOR: \\ Arquivos e historiografia em Santa Catarina no século XX
}

Janice Gonçalves 
UNIVERSIDADE DE SÃO PAULO

FACULDADE DE FILOSOFIA, LETRAS E CIÊNCIAS HUMANAS

DEPARTAMENTO DE HISTÓRIA

PROGRAMA DE PÓS-GRADUAÇÃO EM HISTÓRIA SOCIAL

\title{
SOMBRIOS UMBRAIS A TRANSPOR:
} Arquivos e historiografia em Santa Catarina no século $\mathrm{XX}$

\author{
Janice Gonçalves
}

Tese apresentada ao Programa de Pós-Graduação em História Social, do Departamento de História da Faculdade de Filosofia, Letras e Ciências Humanas da Universidade de São Paulo, para obtenção do título de Doutor em História Social.

Orientadora:

Prof $^{\mathrm{a}}$. Dr ${ }^{\mathrm{a}}$. Ana Maria de Almeida Camargo

São Paulo

2006 
Ao meu pai, Armindo Gonçalves, com a saudade perene que a morte traz

À minha mãe, Ofélia Nascimento Gonçalves, com a saudade ligeira que um interurbano ameniza 


\section{AGRADECIMENTOS}

À Prof ${ }^{\mathrm{a}}$. Dr ${ }^{\mathrm{a}}$. Ana Maria de Almeida Camargo, que acompanha minha trajetória desde a graduação, agradeço, com admiração e afeto, pela confiança sempre renovada.

Aos professores da banca de qualificação, Prof. Dr. Elias Thomé Saliba e Prof ${ }^{\mathrm{a}}$. Dr $^{\mathrm{a}}$. Sylvia Bassetto, pelas sugestões e alertas.

À Universidade do Estado de Santa Catarina - UDESC, pela concessão de afastamento das atividades pedagógicas, por dois anos (de agosto de 2004 a julho de 2006), e pelo apoio financeiro a projeto de pesquisa relacionado à tese, antes do afastamento (de agosto de 2002 a julho de 2004).

A Felipe Matos, bolsista de pesquisa entre 2002 e 2004, dedicado, incansável e risonho.

A todos os entrevistados, gentis, atenciosos e generosos: Antônio Dario Neves, Carlos Humberto Pederneiras Corrêa, Fábio Andreas Richter, Jali Meirinho, Joana Maria Pedro, José Bento Rosa da Silva, Maria Bernardete Ramos Flores, Nelma Baldin, Neusa Rosane Damiani Nunes, Raquel S.Thiago, Sueli Maria Vanzuita Petry. Um agradecimento adicional a todos, entre esses, que facilitaram o acesso aos acervos sob sua responsabilidade. Agradeço ainda a Iaponan Soares de Araújo, Vera Pecego Estork e Walter Fernando Piazza, com quem também conversei, e a Lauro Junkes, que permitiu acesso aos dossiês dos acadêmicos, na Academia Catarinense de Letras.

Pela amizade e pelo prazer da troca de idéias, a José Roberto Severino, sempre solidário, e aos integrantes do Grupo de Estudos sobre Patrimônio Cultural, com variados índices de comparecimento às reuniões: Adelson, Elisiana, José Ricardo, Karla, Janete, Jefferson, Fábio, Daniela. E à Priscila, que faz parte do grupo de ex-alunos queridos.

À família em Santo André - Ofélia, Joana, Celso, Raquel, Roberta -, sempre oferecendo conforto e carinho nas idas e vindas entre Santa Catarina e São Paulo.

Ao Nelson, por tudo e sempre mais. 


\section{RESUMO}

A tese busca compreender os processos de definição e constituição, no século XX, em Santa Catarina, de dois campos profissionais e de conhecimento - o campo historiográfico e o campo arquivístico -, bem como suas interações. A primeira parte focaliza a historiografia sobre Santa Catarina, problematizando as tensões entre a "nova geração" (muito identificada ao meio universitário) e os representantes da "história tradicional" (em geral, associados ao Instituto Histórico e Geográfico de Santa Catarina - IHGSC), abordando as condições e locais de produção de trabalhos de caráter histórico, bem como as formas de sua disseminação. A segunda parte estuda as tentativas de estabelecer, para os arquivos em Santa Catarina, uma política, uma legislação comum e uma rede de intercâmbios, sobretudo a partir da década de 1980. Estuda-se o papel do Arquivo Público do Estado de Santa Catarina e, a partir dos anos 1970, a legislação sobre arquivos municipais. A terceira parte focaliza mais detidamente quatro instituições arquivísticas municipais - os arquivos de Blumenau, Joinville, Itajaí e Florianópolis -, salientando-se, em sua trajetória, a relação com procedimentos de instituição de memórias, de elaboração e legitimação de narrativas históricas, de racionalização

administrativa e de garantia de acesso aos documentos como condição do exercício da cidadania.

Palavras-chave: Historiografia - Arquivística - Arquivos - Santa Catarina (Estado) - Século XX 


\begin{abstract}
This thesis aims an understanding of the process of definition and constitution of two professional and knowledge fields - the historiographic field and the archivistic field - as well as their reciprocal interactions, in Twentieth Century Santa Catarina. Part I focus on the historiography on Santa Catarina, discussing the tensions between the "new generation" (strongly identified to the University environment) and the representatives of the "traditional history" (usually associated to the Santa Catarina Institute for History and Geography Instituto Histórico e Geográfico de Santa Catarina/IHGSC), investigating the places and conditions in which works of historical nature were produced, as well as their dissemination. Part II investigates the atempts to build policy, common legislation and collaborative networks for the archives of Santa Catarina, especially after the 1980's. There are also studies on the role of the State Archives of Santa Catarina (Arquivo Público do Estado de Santa Catarina) and, after the 1970's, on the legislation on City Archives. Part III has a closer focus on four City Archives - Blumenau, Joinville, Itajaí and Florianópolis Archives-, highlighting their relation with the ways memory is produced, with the elaboration and validation of historical narratives, with administrative efficiency and with the warranty of access to documents as a condition for effective citizenship.
\end{abstract}

Keywords: Historiography - Archival Science - Archives - Santa Catarina (Brazil) Twentieth Century 


\section{ÍNDICE DE QUADROS}

Quadro 1 - $\quad$ Similaridades entre o Decreto municipal (São Bento do Sul) 214 $n^{\circ} .246 / 1985$ e o Decreto estadual no $.1 .444 / 1988$.

Quadro 2 - $\quad$ Composição dos acervos dos arquivos municipais catarinenses, 218 segundo a legislação posterior a 1988: arquivos da esfera "cultural".

Quadro 3 - Composição dos acervos dos arquivos municipais catarinenses, 220 segundo a legislação posterior a 1988: arquivos entre as esferas "cultural" e "administrativa". 


\section{SUMÁRIO}

Introdução

\section{Parte I: Narrar}

Capítulo I: A “nova geração” 18

Capítulo II: Os "velhos"

Capítulo III: "Novos" e "velhos": ser historiador em Santa Catarina 95

\section{Parte II: Dispor}

Capítulo I: Arquivos em Santa Catarina: buscando definir uma política

Capítulo II: Papéis do governo de Santa Catarina: o lugar do Arquivo Público do Estado 165

Capítulo III: Arquivos públicos municipais: entre a memória-culto e a memória- direito 203

\section{Parte III: Produzir}

Capítulo I: Arquivos: depositários de heranças 233

Capítulo II: Arquivos: laboratórios de história 260

Capítulo III: Arquivos: instrumento e espelho da razão administrativa 288

Conclusão: À moda de coda

Referências $\quad 316$

Apêndices 336 
[...] é preciso desconfiar sempre quando começamos a escrever, pois não sabemos até onde a escritura poderá nos levar.

Lucien Febvre

(Honra e Pátria) 
Quando comecei a coligir dados e documentos para elas [as Notas para a história catarinense], encontrava-me distante daqui e somente nos pontos a que minha profissão me levava conseguia fazer pesquisas em arquivos e bibliotecas.

Nas poucas vezes que à nossa terra aportei, antes de publicá-las, não havia ainda conseguido transpor, com a relativa facilidade que hoje, graças à gentileza de vários patrícios, encontro, os sombrios umbrais dos nossos arquivos.

Lucas Alexandre Boiteux (RTIHGSC, $3^{\circ}$. trim. 1918) 


\section{Introdução}

Como muitas teses, esta nasceu da curiosidade e da inquietação, mas sob o foco de um olhar estrangeiro. Chegada a Santa Catarina, em 1999, eu retornaria às aulas de história depois de vários anos lidando mais diretamente com questões pertinentes ao patrimônio cultural e, em especial, ao patrimônio arquivístico. A curiosidade acerca da história dos lugares que aos poucos conhecia (e sigo conhecendo) tornou-se dever de ofício. Havia também a vontade de conhecer de perto os arquivos públicos das localidades. Por outro lado, a aproximação em relação à história de Santa Catarina era difícil: sem muitas referências, parecia-me excessiva a preocupação com temas como identidades, etnicidade, festas, turismo. Também a reiterada rejeição a um fazer historiográfico "tradicional" confundia e incomodava - afinal, quem fazia essa história? em que livros, e por meio de quais autores fora ela delineada?

O incômodo aumentava na medida em que a caracterização da história "tradicional" estabelecia vínculos grosseiros entre seus historiadores e os documentos de arquivo (sobretudo os públicos). A história tradicional seria aquela para a qual a história não existe sem documentos. Estaria, então, no domínio da chamada Escola Metódica? Mas, ao mesmo tempo, também se dizia que a história tradicional tomava os documentos como verdades, sem crítica - e o que parecia ter ficado claro voltava a turvar: pois os "metódicos" não ensinavam justamente a sempre duvidar dos documentos? Pior: a história tradicional confundia-se com uma "história oficial" (subentendida como elitista, excludente, fruto da dominação), posto que baseada em documentos “oficiais"! Uma percepção tão simplificadora dos documentos públicos - essencialmente, documentos públicos de arquivo, produzidos por órgãos governamentais - não levava em conta que os governos necessariamente interagem com os governados e, conseqüentemente, produzem também registros de aproximações, distanciamentos, negociações, tensões, conflitos abertos. Aparentemente, uma história "nãotradicional" deveria ser pensada longe dos arquivos "oficiais". Se a lógica da argumentação estava sendo bem interpretada, que implicações teria essa postura para os arquivos públicos, enquanto locais de pesquisa histórica? 
A visão negativa dos arquivos públicos não é de todo descabida. Há vinte anos, Michel Melot, em texto recheado de ironias, ${ }^{1}$ questionou os intensos investimentos de preservação que, nas últimas décadas, têm envolvido instituições custodiadoras de acervos (bibliotecas, arquivos, museus, centros de documentação): haveria um esforço de tudo conservar, em nome dos interesses de um hipotético "futuro historiador", cujo campo de interesses seria potencialmente amplíssimo. Mas, afinal, no presente, quem se interessa por tudo isso que é guardado? E, no caso dos arquivos, interessariam eles à maioria das pessoas?

Melot afirma que as pessoas comuns vão aos arquivos quando em busca de documentos de registro civil e de registro imobiliário (que possam, portanto, "atestar filiações" e "atestar a propriedade"). Reconhecidos principalmente pela guarda desse tipo de documentos (a referência do autor é a França), os arquivos são alvo constante, em processos revolucionários, de ações que visam a destruí-los. Locais de guarda de provas de direitos, também salvaguardam deveres - muitas vezes, pesados deveres, na forma de obrigações contratuais, dívidas e tudo o mais que possa traduzir algum tipo de dominação ou opressão. A queima de arquivos pode ser libertadora... Daí Melot considerar, de forma desconcertante, que a maior parte das pessoas vá aos arquivos apenas por ocasião das revoluções, e que, entre uma revolução e outra, os arquivos remanescentes só interessem aos historiadores. ${ }^{2}$

Há algumas décadas busca-se reverter esse misto de desconfiança e desinteresse em relação aos arquivos, enfatizando seu importante papel na prestação de contas dos poderes públicos aos cidadãos, na garantia de transparência administrativa, na sustentação, enfim, de princípios democráticos de governo e convívio social. Estaria esse discurso restrito, porém, aos profissionais da área de arquivos?

Vivemos tempos de expansão memorialística, contexto em que os conjuntos documentais arquivísticos e as instituições que os abrigam ganhariam, em princípio, grande importância. Como explicar, então, essa "relativa indiferença pública e social" perante os arquivos, excetuados os "arquivos sensíveis"? ? Como resposta à pergunta que lançou, Pierre Nora levanta uma hipótese: "a noção mesma de arquivos está ligada à idéia de inutilidade social". Mesmo que aquilo que perdeu seu "valor de uso" (ou seu valor primário ou imediato,

\footnotetext{
1 MELOT, Michel. Des archives considerées comme une substance hallucinogène. Traverses, Paris, v.36, janvier 1986, p.14-19.

${ }^{2}$ Ibidem, p. 18 .

${ }^{3}$ NORA, Pierre. Missions et enjeux des archives dans les sociétés contemporaines. Comma, Paris, n.2-3, 2003, p.48.
} 
como diriam os arquivistas) venha a ganhar um valor simbólico significativo (ou seja, um valor secundário ou mediato), “o arquivo conserva qualquer coisa dessa marca de nascença: fora de uso."4

Refletir, portanto, sobre o papel dos arquivos (enquanto conjuntos documentais e instituições) nas sociedades contemporâneas, e sobre sua relação com os processos de produção de memória social (com ênfase na produção historiográfica), foram objetivos gerais da pesquisa que resultou na tese. Mas toda a discussão partiu de questionamentos relativos aos arquivos e à historiografia que se percebem vinculados a questões propriamente "catarinenses".

Cabe esclarecer que "Santa Catarina" está sendo tomada aqui, antes de tudo, em sua dimensão político-administrativa - é a Santa Catarina “unidade da federação", articulando limites territoriais e fronteiras da máquina governamental. As instituições que foram examinadas no processo de pesquisa, e que se definiram como "de Santa Catarina" (como o Arquivo Público do Estado de Santa Catarina, o Instituto Histórico e Geográfico de Santa Catarina - IHGSC, a Universidade Federal de Santa Catarina - UFSC), tomaram essa dimensão como referência. O que não significa que tenham se limitado a ela: no processo de pesquisa, vários foram os elementos levantados e identificados como valores "catarinenses" defendidos por uns, questionados por outros, em distintos momentos. Mas é grande a força de coesão e agregação que a dimensão político-administrativa exerce. ${ }^{5}$ Além disso, no século XX Santa Catarina terá seus limites territoriais por mais de uma vez contestados, o que, ao menos da parte dos historiadores do IHGSC, levará à articulação da "defesa" dos interesses catarinenses. A reafirmação das fronteiras territoriais e a legitimação dessa dimensão políticoadministrativa de Santa Catarina serão, portanto, importantes na atuação de um dos grupos de historiadores aqui em causa.

Se o processo de pesquisa esteve atento à forma como diferentes experiências, no campo da história e no campo arquivístico, inscreveram-se em um dado recorte espacial

\footnotetext{
${ }^{4}$ Ibidem, p.48.

5 Bourdieu, discutindo a noção de "região", e apoiado em Benveniste, procurou demonstrar que a regio é resultado do regere fines - isto é, do ato de estabelecer limites para o território, realizado pela autoridade máxima, rex. Ou seja, reger remete, ao mesmo tempo, a governar, controlar, delimitar. Diz ele, ainda: "Este ato de direito que consiste em afirmar com autoridade uma verdade com força de lei constitui um ato de conhecimento que, por estar fundado, como qualquer poder simbólico, no reconhecimento, produz a existência do que enuncia [...]." BOURDIEU, Pierre. A força da representação. In:-. A economia das trocas lingüísticas: o que falar quer dizer. S.Paulo: EDUSP, 1998. p.109.
} 
(mesmo que problematizando-o), também procurou levar em conta os procedimentos que produziram recortes temporais. Com mais freqüência, os cortes no tempo remeteram a "gerações" - surgiram referências à "geração acadêmica", à "geração do IHGSC" e à "nova geração". No bojo da pesquisa, entretanto, a categoria "geração" não foi tomada como dado prévio, a ordenar, em grupos, estes ou aqueles sujeitos vislumbrados nas experiências estudadas. Quando usada como critério de auto-identificação - como no caso da "nova geração" de historiadores - tentou ser problematizada e investigada, antes de tudo, como prática discursiva de instituição de um coletivo e, invariavelmente, de um "outro". 6

Em linhas gerais, a pesquisa buscou compreender os processos de definição e constituição, no século XX, em Santa Catarina, de dois campos profissionais e de conhecimento - o campo historiográfico e o campo arquivístico -, tentando detectar suas aproximações, distanciamentos e interações.

A tese foi dividida em três partes, cada uma com três capítulos.

A primeira - Narrar - focaliza historiadores que, situando-se a seu modo no que entendiam ser uma perspectiva histórica, buscaram construir narrativas acerca de Santa Catarina, quer como "histórias gerais", quer como "histórias locais", quer a partir, ainda, de outros recortes. Primeiramente, é abordada a "nova geração", de forma a compreender como se auto-representa e como se constitui em termos de produção historiográfica. As manifestações da "nova geração", na imprensa, as publicações que trazem sua marca e as dissertações e teses sobre Santa Catarina produzidas nos últimos trinta anos (no âmbito de Programas de Pós-Graduação em História) foram as principais fontes utilizadas para essas reflexões. No segundo capítulo são enfocados aspectos gerais da produção de caráter histórico de sócios do IHGSC, entidade que, entre meados da década de 1890 e os anos 1960, foi a instituição-referência na produção e disseminação de conhecimento histórico acerca de Santa Catarina. Para a apreciação dessa produção, optou-se por tomar como eixo da investigação a Revista do IHGSC, nas suas várias fases: 1902, 1913-1920, 1943-1944 e 1979 em diante. Foram também examinados alguns estudos dos sócios do IHGSC, publicados como livros, artigos de outros periódicos ou separatas (caso de trabalhos de Oswaldo Cabral e Lucas

\footnotetext{
${ }^{6}$ Angela de Castro Gomes indicou os muitos problemas que carrega a categoria "geração", mas nem por isso deixou de usá-la - entendeu-a significativa se combinada à noção de "sociabilidade" e mesmo à de "campo": "entendemos que a utilização da noção de gerações, que se 'operacionaliza' pelo recurso à categoria de sociabilidade, converge para a idéia de campo intelectual". GOMES, Angela de Castro. História e historiadores: a política cultural do Estado Novo. Rio de Janeiro: Ed. da FGV, 1996.p.42.
} 
Boiteux). No terceiro capítulo da primeira parte, faz-se um esforço para discutir, mais amplamente, as condições do fazer historiográfico em Santa Catarina no século XX, tendo em vista os lugares sociais aos quais os historiadores acabavam por se vincular, em função de suas ocupações e interesses. Os depoimentos de historiadores entrevistados no processo de pesquisa estão mais presentes neste capítulo do que nos demais; também foram bastante utilizados os materiais que constam dos dossiês de acadêmicos da Academia Catarinense de Letras (vários acadêmicos foram - ou são - historiadores).

A segunda parte - Dispor - estuda as maneiras pelas quais se buscou, em Santa Catarina, tratar dos documentos públicos de arquivo de forma integrada, tendo em vista o estabelecimento de uma política, de uma legislação comum, de uma rede de intercâmbios. O primeiro capítulo estuda iniciativas de articulação da área arquivística por meio de encontros regulares de profissionais que nela atuassem - os encontros catarinenses de arquivos - e de um sistema (no caso, "subsistema") estadual de arquivos. Predominam aí, entre as fontes, os anais dos encontros. Já o segundo capítulo procura examinar de forma mais detida o papel do Arquivo Público do Estado de Santa Catarina no meio arquivístico catarinense, inclusive discutindo aspectos de seu lento processo de institucionalização. A revista Ágora e os relatórios, falas e mensagens do governo de Santa Catarina (tanto no Império como na República) foram bastante empregadas neste capítulo. O terceiro capítulo da segunda parte faz um mapeamento das leis que, em municípios catarinenses, institucionalizaram seus arquivos, tentando detectar permanências e rupturas.

A terceira parte - Produzir - focaliza mais detidamente as trajetórias de quatro instituições arquivísticas municipais de Santa Catarina: os arquivos de Blumenau, Joinville, Itajaí e Florianópolis. Para além da formalização de sua existência por meio de legislação, procura-se salientar processos sociais que produziram ou buscam produzir vocações específicas para tais instituições. De um lado, há a ênfase nos arquivos como depositários de heranças preciosas para determinados segmentos das populações locais (particularmente no caso de Joinville e Blumenau). De outro, os arquivos também são produzidos como laboratórios de história (por meio de seus usuários, sem dúvida, mas também pelos instrumentos de pesquisa priorizados e disponibilizados, e pelos temas e períodos ressaltados nas exposições e nas publicações promovidas - em Joinville, Blumenau e Itajaí). Destaca-se ainda a tentativa de constituir os arquivos como instrumento e espelho da razão administrativa (como em Florianópolis e Itajaí). Os dados relativos à trajetória das instituições foram obtidos 
basicamente a partir da consulta de relatórios de atividades, alguns deles publicados em informativos ou boletins (como no caso de Joinville). No Arquivo de Florianópolis também foi consultada a correspondência que integra o arquivo corrente da instituição, e que foi referida quando pertinente à discussão.

Completam o trabalho diversos apêndices que sistematizam grande parte dos dados levantados na pesquisa, e que se articulam com questões trabalhadas nos vários capítulos.

Um último comentário, quanto aos depoimentos a mim concedidos. Cabe esclarecer que foram gravados, transcritos e em seguida fornecidos aos entrevistados, que tiveram total liberdade para realizar as alterações entendidas como necessárias. As citações dos depoimentos foram feitas a partir das versões transcritas finais. Não tive, portanto, nenhuma intenção em captar afirmações "espontâneas", a serem perenizadas a qualquer custo: apenas aquilo que se quisesse deixar registrado. A seleção dos entrevistados não pretendeu constituir uma espécie de panteão de historiadores catarinenses, mas ouvir, a respeito de suas trajetórias, pessoas que tivessem atuado (ou ainda atuassem) no campo historiográfico ou no arquivístico, ou mesmo em ambos. Claro que não só isso: pessoas que tivessem tido a oportunidade de vivenciar experiências de interesse para a pesquisa. Por exemplo: a graduação na Universidade Federal de Santa Catarina - UFSC; a graduação em outras instituições e municípios; os inícios do Mestrado na UFSC; o doutorado em outro estado; a orientação de pós-graduandos; a participação na atual Associação Nacional de História ANPUH ou na Sociedade Brasileira de Pesquisa Histórica - SBPH; a participação no IHGSC, em cargos na diretoria; a experiência docente; a experiência com o atendimento ao público, em um arquivo, ou com atividades de difusão cultural. Provavelmente, o uso que fiz dos depoimentos - relativamente pontual - ficou muito aquém de sua riqueza. Mas quero aqui registrar sua importância no processo continuado de pensar e repensar a tese. 


\section{PARTE I:}

NARRAR

[..] a história não cessou de dizer os fatos e gestos dos homens, de contar, não a mesma narrativa, mas narrativas de formas diversas.

François Hartog (“A arte da narrativa histórica") 


\section{Parte I \\ Capítulo 1}

\section{A "nova geração"}

Em 3 de maio de 1999, o jornal A Notícia alertava os leitores: "É hoje o lançamento do livro História de Santa Catarina: estudos contemporâneos, organizado por Ana Brancher e publicado pela [editora] Letras Contemporâneas." Lançado na capital catarinense, na galeria de arte da Assembléia Legislativa, o livro reunia um conjunto de "ensaios escritos por uma nova geração de historiadores, todos formados pela UFSC [Universidade Federal de Santa Catarina]". Com ele pretendia-se contribuir para renovar, no conteúdo e na forma, a abordagem da história catarinense, uma vez que "quase sempre ela foi contada pelos vencedores", deixando a desejar também quanto ao tratamento dado à "diversidade cultural do Estado."1

Em fins de 2001, lançado em outra galeria de arte (a da UFSC), surgia o segundo volume do que viria a ser uma trilogia: História de Santa Catarina no século XIX, organizado por Ana Brancher e Sílvia Arend. Mantendo alguns autores que participaram do volume anterior, e incluindo outros, o livro apresentava - segundo, novamente, o jornal A Notícia trabalhos de integrantes "de uma nova geração de historiadores", que em suas pesquisas buscavam incorporar "os atores da história sempre preteridos em antigas abordagens históricas",2. Três anos depois, encerrou-se a trilogia, com o lançamento de História de Santa Catarina: séculos XVI a XIX ${ }^{3}$ e o anúncio dos mesmos propósitos: “dar voz a personagens

\footnotetext{
${ }^{1}$ Não foi bem assim: livro reúne ensaios de nova geração de historiadores. A Notícia, Joinville (SC), 3 maio 1999 (caderno “Anexo”). Autores dos ensaios: Ana Brancher, Américo Augusto da Costa Souto, Cláudia Mortari, Cynthia Machado Campos, Cristina Scheibe Wolff, Henrique Luiz Pereira Oliveira, Hermetes Reis Araújo, João Batista Bitencourt, Karen Cristine Rechia, Luiz Felipe Falcão, Paulino de Jesus Francisco Cardoso, Reinaldo Lindolfo Lohn, Rodrigo Lavina.

${ }^{2}$ Nova geração de historiadores: grupo lança "História de Santa Catarina no século 19". A Notícia, Joinville (SC), 12 dez.2001 (caderno “Anexo”). Autores presentes no volume sobre o século XIX: Ana Brancher, Antonio Carlos Güttler, Antônio Manoel Elíbio Junior, Henrique Luís Pereira Oliveira, Itamar Siebert, Janine Gomes da Silva, Paulo Pinheiro Machado, Reinaldo Lindolfo Lohn, Rosângela Miranda Cherem, Sílvia Maria Fávero Arend, Vanderlei Machado.

${ }^{3}$ Autores presentes no volume relativo ao período colonial: Ana Paula Wagner, Antônio Luiz Miranda, Fábio Kuhn, Luiz Felipe Falcão, Marcelo Gonzalez Brasil Fagundes, Marlon Salomon, Norberto Dallabrida, Reinaldo Lindolfo Lohn, Rodrigo Lavina.
} 
que em geral ficam relegados a segundo plano", "ir além da historiografia oficial para tentar entender uma época levando em conta suas complexidades - como a cultura, as formas de saber e o imaginário de sua gente."4

Na cobertura jornalística dos lançamentos, os indícios quanto a uma história que não pretende ser assumida pela "nova geração": aquela "contada pelos vencedores", pouco atenta à diversidade cultural, marginalizadora de determinados "atores da história". Os próprios livros - em especial, suas apresentações - ajudam a compor um quadro mais nítido da história a ser renovada e ultrapassada: uma história que,

em linhas gerais, caracteriza-se por um tratamento factual, enfatizando a história política. Por pretender manter uma posição de não intervenção (neutralidade) e para reforçar a idéia de recuperação fiel do passado, não é explicitada nem a metodologia, nem as questões que norteiam tal investigação. Neste sentido, para os que seguem esta concepção de história, tudo o que evidencie o trabalho do historiador deve desaparecer, de modo a transparecer a objetividade da narrativa. ${ }^{5}$

A história que não se quer: "a chamada "história tradicional". 6 Não mais a história "concebida como um conjunto de gavetas que devem ser preenchidas e etiquetadas com datas, nomes e eventos importantes", como apontou criticamente Henrique Luiz Pereira Oliveira; não mais a história que compreende o passado como algo "alojado em um tempo distante, aguardando que o ato heróico de um historiador o resgate". 7

Entre os dois primeiros volumes da trilogia de História de Santa Catarina, uma outra coletânea foi publicada, Visões do Vale, na qual também se fazia investida contra a "história tradicional". Para as organizadoras, Cristina Ferreira e Méri Frotscher, aquele "conjunto diversificado de ensaios escritos por historiadores" convergia ao menos para dois pontos: o objeto de estudo - o vale do Itajaí - e o questionamento do " "paradigma tradicional' da História, entendido enquanto uma narrativa linear, factual e acrítica”. A maioria dos ensaios, segundo as organizadoras, partiria

\footnotetext{
${ }^{4}$ A história sob um novo olhar. Diário Catarinense, Florianópolis, 9 nov. 2004 (capa do caderno "Variedades"). ${ }^{5}$ BRANCHER, Ana, OLIVEIRA, Henrique L. Pereira. Apresentação. In: BRANCHER, Ana (org.). História de Santa Catarina: estudos contemporâneos. Florianópolis: Letras Contemporâneas, 1999. p.8.

${ }^{6}$ Ibidem.

${ }^{7}$ OLIVEIRA, Henrique Luiz Pereira. Prefácio. In: BRANCHER, Ana; AREND, Sílvia Maria Fávero (orgs.). História de Santa Catarina: séculos XVI a XIX. Florianópolis: Ed da UFSC, 2004. p.9-10.
} 
da formulação e desenvolvimento de um problema, através do qual se questiona o presente, o passado e a própria história que se escreveu sobre a região. ${ }^{8}$

Salientaram que o livro fora organizado com o pressuposto de que

não há neutralidade na construção do saber histórico, de que o historiador não 'resgata' o passado tal como ele ocorreu, visão por demais ingênua, perspectiva positivista da História e que permeia muitos dos trabalhos historiográficos existentes também em nosso meio. ${ }^{9}$

E mais: objetivava-se, com os ensaios, dar "visibilidade a personagens que muitas vezes permanecem à margem ou mesmo excluídos da historiografia regional”, a saber: "os indígenas, os negros, as mulheres, os operários, entre outros, aqui qualificados enquanto sujeitos e não como meros coadjuvantes do processo histórico."10

O viés excludente da corrente entendida como "tradicional", em Santa Catarina, sobretudo no que tange aos afrodescendentes, tem sido assinalado com freqüência. Paulino de Jesus Cardoso, em 2000, destacou que o trabalho Cor e mobilidade social em Florianópolis, publicado originalmente em 1960, a partir de pesquisa realizada em julho de 1955 por Fernando Henrique Cardoso e Octávio Ianni, “contribuiu para um questionamento frontal do mito da democracia racial brasileira, e para a denúncia das péssimas condições de vida de milhões de afrodescendentes neste país”. Mas

sua adesão acrítica a alguns marcos interpretativos da historiografia local tradicional [catarinense] tem contribuído para a invisibilidade histórica das populações de origem africana em Santa Catarina. ${ }^{11}$

Esclareceu que a pesquisa de Octávio Ianni e Fernando Henrique Cardoso envolveu "uma releitura da produção dos principais historiadores catarinenses daquele tempo,

\footnotetext{
${ }^{8}$ FERREIRA, Cristina, FRÓTSCHER, Méri (orgs.). Visões do Vale: perspectivas historiográficas recentes. Blumenau (SC): Nova Letra, 2000. p.7. Autores presentes no volume: André Voigt, Cristina Ferreira, Cristina Scheibe Wolff, João Klug, José Roberto Severino, Marlon Jaison Salomon, Marlus Niebuhr, Méri Frotscher, Norberto Dallabrida, Roberto Marcelo Caresia, Roseli Zimmer, Rosilene Alves, Rute Coelho Zendron.

${ }^{9}$ Ibidem, p. 8 .

${ }^{10}$ Ibidem, p.8.

${ }^{11}$ CARDOSO, Paulino de Jesus. Apresentação. In: CARDOSO, Fernando Henrique. Negros em Florianópolis: relações sociais e econômicas. Florianópolis: Insular, 2000. p.21. Grifos meus.
} 
como Henrique Fontes, Carlos da Costa Pereira e, principalmente, Oswaldo Rodrigues Cabral". 12

Em 1996, a antropóloga Ilka Boaventura Leite, em coletânea por ela organizada, e referindo-se à historiografia catarinense, comentara: "Percorrendo a historiografia, é impressionante o silêncio que paira sobre a população negra". ${ }^{13}$ Dando referências do percurso historiográfico realizado, a autora citava Crispim Mira (Terra catarinense), Heitor Blum (A campanha abolicionista na antiga Desterro), Oswaldo Cabral (Laguna e outros ensaios; História de Santa Catarina), Walter Piazza ( $O$ escravo numa economia minifundiária; Santa Catarina: sua história). Autores cujas publicações citadas cobriam um largo período entre a década de 1920 e a de 1980. Se acrescentarmos a esse rol Henrique Fontes e Carlos da Costa Pereira, referidos por Paulino de Jesus Cardoso, encontraremos alguns pontos em comum, entre eles: a atividade jornalística e a vinculação (com exceção de Crispim Mira) a entidades como o Instituto Histórico e Geográfico de Santa Catarina e a Academia Catarinense de Letras, o que fornece pistas para pensar os locais sociais de produção da historiografia criticada.

Na mesma coletânea, texto coletivo assinado por seis historiadores - Joana Maria Pedro, Lígia Czesnat, Luiz Felipe Falcão, Orivalda Lima e Silva, Paulino de Jesus Cardoso e Rosângela Miranda Cherem - assinalava, em sua abertura:

Na historiografia catarinense, uma ausência notável é aquela das populações de origem africana. Se não chega a haver omissão total, têm sido bastante reduzidas as iniciativas nesta direção. Podem-se contar nos dedos as obras que enfocam esta temática, as quais, em sua maior parte, dedicam-se ao período da escravidão; mesmo assim, apenas algumas têm buscado explicações para a permanência, nos dias atuais, do preconceito racial e da discriminação. ${ }^{14}$

Comentário que apontava a pouca presença das populações afrodescendentes até mesmo na produção historiográfica recente. As críticas eram mais claramente dirigidas,

\footnotetext{
12 Ibidem, p.20-21.

${ }^{13}$ LEITE, Ilka Boaventura. Descendentes de africanos em Santa Catarina: invisibilidade histórica e segregação. In: LEITE, Ilka B. (org.). Negros no sul do Brasil: invisibilidade e territorialidade. Florianópolis: Letras Contemporâneas, 1996. p.43.

${ }^{14}$ PEDRO, Joana Maria et al. Escravidão e preconceito em Santa Catarina: história e historiografia. In: LEITE, Ilka B. (org.). Negros no sul..., op.cit., p.233.
} 
contudo, a Walter Piazza (O escravo numa economia minifundiária) e Oswaldo Cabral (Nossa Senhora do Desterro), pois sua concepção de história excluiria

[...] a discussão explícita dos problemas vividos no momento da elaboração das obras. Esperava-se, embora inutilmente, que o historiador tivesse uma atitude de neutralidade frente à narrativa que articulava com os documentos coletados. ${ }^{15}$

No texto de 1996, cabe notar, as críticas à historiografia faziam-se mais contundentes do que no livro em que, oito anos antes, os mesmos autores haviam analisado as relações entre escravidão e preconceito em Santa Catarina no século XIX. ${ }^{16}$

Marlene de Fáveri frisou ser "possível questionar uma história sobre a cidade [no caso, Itajaí] que exclui as diferenças étnicas na construção de uma suposta identidade para um 'sul dito branco'."17 Não à toa, seu comentário está presente em texto de outra coletânea, lançada em 2001, desta vez voltada para a presença das mulheres na história de Santa Catarina. Como a reforçar seu sentido de grupo, a "nova geração" aprecia se expressar por meio de obras coletivas, que em geral disseminam, ao menos em parte, dissertações e teses produzidas recentemente (ou em processo de elaboração). ${ }^{18} \mathrm{Na}$ "orelha" daquela publicação de 2001, Itamar Siebert caracterizou-as como o "resultado das pesquisas e reflexões de uma nova geração de estudiosos".

As mulheres reapareceriam de forma destacada em obra coletiva editada em 2003: Práticas proibidas: práticas costumeiras de aborto e infanticídio no século XX. Apresentando o livro (fruto de pesquisas iniciadas em 1995, no âmbito do Laboratório de História Social da UFSC), Maria Teresa Santos Cunha ressaltou como “estas questões tão candentes” eram

\footnotetext{
${ }^{15}$ Ibidem, p.235. Dissertação de mestrado realizada junto ao Programa de Pós-Graduação em História da UFSC destacou justamente a questão da presença/ausência das populações afrodescendentes na produção de Cabral e Piazza: FREITAS, Patrícia de. Margem da palavra, silêncio do número: o negro na historiografia de Santa Catarina. Florianópolis: 1997. Dissertação (Mestrado em História). Universidade Federal de Santa Catarina.

${ }^{16}$ No trabalho de 1988, lê-se, ao final, o seguinte comentário: "São extremamente raras, e quase sempre pouco convincentes, as publicações históricas e sociológicas que tratam da escravidão e das relações raciais em Santa Catarina. E este silêncio, sem dúvida alguma, não é fortuito.” PEDRO, Joana Maria et al. Negro em terra de branco: escravidão e preconceito em Santa Catarina no século XIX. Porto Alegre: Mercado Aberto, 1988. p.62.

${ }^{17}$ FÁVERI, Marlene de. Personagens à beira de um porto: mulheres de Itajaí. In: MORGA, Antonio (org.). História das mulheres de Santa Catarina. Florianópolis: Letras contemporâneas, Chapecó (SC): Argos, 2001. p.31. Autores presentes na coletânea: Antonio Emílio Morga, Arlene Renk, Carlos Renato Carola, Carmen Susana Tornquist, Cristina Scheibe Wolff, Janine Gomes da Silva, Karen Christine Réchia, Karla Leonora Dahse Nunes, Maria Bernardete Ramos Flores, Maria Teresa Santos Cunha, Marlene de Fáveri.

${ }^{18}$ Dissertações e teses também têm sido publicadas: ver, a respeito, o Apêndice I-4.
} 
abordadas por meio de "vidas banais, obscuras, sem arroubos, de protagonistas anônimas da História", fazendo emergir "das entranhas do escrito, das memórias do vivido, representações de um tempo e de um lugar". E destacou, mais adiante: "outra História está sendo construída!"19

Os exemplos poderiam continuar, sendo citadas outras coletâneas responsáveis por divulgar a produção de uma geração de historiadores que se quer "nova". ${ }^{20}$ Dois aspectos ganham relevo: de um lado, a própria insistência na afirmação - veiculada em diversas publicações, na última década - da existência de uma "nova geração" de historiadores, em Santa Catarina; de outro, a necessidade de, nesse processo de afirmação, contrapor a história a ser feita pela "nova geração" a uma outra história. De forma explícita ou subentendida, essa história a ultrapassar seria a "história tradicional".

É, aliás, a crítica à "história tradicional" (no caso, a uma "história tradicional" essencialmente ocupada com a política) que permite dar algum sentido à presença de Américo Augusto da Costa Souto no livro História de Santa Catarina: estudos contemporâneos. Livredocente pela UFSC e professor aposentado pela mesma universidade, dificilmente seria identificado como integrante dessa "nova geração". Em seu texto, mobilizando simultaneamente conceitos marxistas e inspiração braudeliana, Costa Souto buscou "resgatar a História Econômica”, pois a "assim chamada 'Nova História' voltou-se, agora, para outras áreas" ${ }^{21}$. Na apresentação da coletânea, indica-se que Costa Souto dela participa na condição de homenageado: é apresentado como "inspirador de uma geração de novos historiadores", uma vez que o trabalho por ele coordenado, Evolução histórico-econômica de Santa

\footnotetext{
${ }^{19}$ CUNHA, Maria Teresa Santos. Apresentação. In: PEDRO, Joana Maria (org.). Práticas proibidas: práticas costumeiras de aborto e infanticídio no século XX. Florianópolis: Cidade Futura, 2003. p.6-7. Autores presentes na publicação: Aniele Fructuoso da Costa, Cristiani Bereta da Silva, Eliana Izabel Hawerroth, Joana Maria Pedro, Luciana Rosar Fornazari Klanowicz, Maria Conceição de Lacerda, Maristela Moreira de Carvalho, Núcia Alexandra Silva de Oliveira, Roselane Neckel, Vanderlei Machado.

${ }^{20}$ RAMPINELLI, Waldir José (org.). História e poder: a reprodução das elites em Santa Catarina. Florianópolis: Insular, 2003 (autores: Afrânio Boppré, Cristiane Manique Barreto, Delmir José Valentini, Iara Andrade Costa, Luci Choinacki, Marli de Oliveira Costa, Méri Frotscher, Pedro Uczai, Telmo Marcon, Waldir José Rampinelli). Também: FLORES, Maria Bernardete Ramos et al. (orgs.). A casa do baile: estética e modernidade em Santa Catarina. Florianópolis: Fundação Boiteux, 2006 (autores: Aldonei Machado, Cynthia Machado Campos, Edgar Garcia Jr., Eloah Rocha M. de Castro, Evandro André de Souza, Fernando C. Boppré, Jacqueline Wildi Lins, José Henrique Nunes Pires, Joseane Zimmermann, Lucésia Pereira, Luciene Lehmkuhl, Mara Rúbia Sant'Anna, Maria Bernardete Ramos Flores, Marilange Nonenmacher, Mário César Coelho, Miriam Tesserolli, Rosângela M. Cherem, Vera Collaço).

${ }^{21}$ SOUTO, Américo Augusto da Costa. Industrialização de Santa Catarina: o vale do Itajaí e o litoral de São Francisco, das origens ao mercado nacional (1850-1929). In: BRANCHER, Ana (org.). História de Santa Catarina..., op.cit., p.115.
} 
Catarina: estudo das alterações estruturais (século XVII-1960), publicado em 1980, "distanciou-se da história factual em muitos aspectos.",22

Os anos 80 do século XX marcariam, justamente, a emergência da novidade historiográfica em solo catarinense: para Ana Brancher e Henrique Pereira Oliveira, "os primeiros trabalhos desta nova geração começaram a aparecer no final dos anos 80, tendo em comum, primeiramente, a preocupação de definir o tema da investigação vinculado à formulação de um problema."23.

"Nova" no sentido de inovação, mas também "recente", essa geração já teria conseguido superar a anterior: assim consideram Américo da Costa Souto e Norberto Dallabrida, no "Prefácio" à História de Santa Catarina no século XIX, ressaltando ser a coletânea

mais uma produção da nova geração de autores no campo historiográfico de nosso Estado, apresentando releituras históricas críticas e sedutoras, e superando, assim, o que até há pouco predominava, ou seja, o tradicionalismo da História política e narrativa. ${ }^{24}$

Desde ao menos meados dos anos 1990, é possível detectar o esforço em caracterizar um determinado modelo de produção historiográfica, genericamente entendida como "tradicional", que teria prevalecido até recentemente em Santa Catarina. Em linhas gerais, seria uma produção que adotaria perspectiva linear, factual, acrítica, excludente, "positivista". A produção da "nova geração" de historiadores catarinenses, por sua vez, realizaria quase que uma inversão das características do modelo "tradicional" - portanto, proporia uma história não-linear, não-factual, problematizadora, crítica, valorizadora dos grupos e sujeitos tradicionalmente excluídos dos discursos sobre a história catarinense. Além disso, a história da "nova geração" teria uma maior abertura em relação às fontes que servem de base ao trabalho do historiador: diversificando-se, elas teriam deixado de estar restritas aos

\footnotetext{
22 BRANCHER, Ana; OLIVEIRA, Henrique L. Pereira. Apresentação, op.cit., p.8. O caráter inovador dos trabalhos de Américo da Costa Souto, no contexto catarinense, foi discutido em: DALLABRIDA, Norberto. A historiografia catarinense e a obra de Américo da Costa Souto. Revista Catarinense de História, Florianópolis, n.4, 1996, p.9-19.

${ }^{23}$ Ibidem, p.8-9.

${ }^{24}$ SOUTO, A.da Costa, DALlABRIDA, N. Prefácio. In: BRANCHER, Ana, AREND, Sílvia M. F.(orgs). História de Santa Catarina no século XIX. Florianópolis: Editora da UFSC, 2001. p.10.
} 
“documentos oficiais" (leia-se: a documentação administrativa pública de caráter arquivístico).

As referências à relação com as fontes são, neste sentido, significativas. Para Ana Brancher e Henrique Pereira Oliveira,

Ao ampliar a sua atenção para os mais variados aspectos da experiência humana, a produção histórica passou a buscar informações em diferentes tipos de documentos. Além da documentação produzida pelas instituições vinculadas ao Estado, habitualmente consultada pelos historiadores, uma ampla gama de produções humanas tem servido como fonte para as pesquisas. Atualmente podemos dizer que qualquer objeto é potencialmente um documento para a pesquisa histórica. ${ }^{25}$

Neste como em outros pontos, os autores compartilharam uma visão acerca das transformações da produção de caráter histórico, em Santa Catarina, que havia sido sistematizada em texto de 1994 - e que foi, aliás, o primeiro, entre os autores da "nova geração", a propor uma apreciação mais detida sobre a historiografia catarinense.

\section{Reflexões acerca da historiografia catarinense}

Em artigo de 1994, Cristina Scheibe Wolff, atendo-se ao que denominou de historiografia "recente" de Santa Catarina, classificou-a da seguinte forma, tendo em vista o "objeto de estudo do historiador": a "abordagem estadual tradicional" (mais voltada para "eventos políticos de âmbito estadual"); a "abordagem local tradicional" (preocupada com questões de âmbito mais restrito, de recorte municipal ou local); a "abordagem temática" (que traria à luz uma "história centrada em temas e questões-problema"). ${ }^{26}$

\footnotetext{
${ }^{25}$ BRANCHER, Ana, OLIVEIRA, Henrique L. Pereira. Apresentação. op.cit., p.9.

${ }^{26}$ WOLFF, Cristina Scheibe. Historiografia catarinense: uma introdução ao debate. Revista Catarinense de História, Florianópolis, n.2, 1994, esp. p.6-9. Note-se que a autora entende por "recente" o que foi produzido a partir da década de 1940. A autora justifica o recorte pelas seguintes razões: "em primeiro lugar porque estas são as obras que podem ser encontradas com maior facilidade nas bibliotecas e livrarias de nosso Estado. Em segundo, porque foram estas as obras com as quais trabalhei até hoje, em minhas pesquisas e minha experiência de ensino, e portanto não pretendo generalizar meu esquema classificatório de forma aleatória” (p.6).
} 
Wolff baseou sua definição de história tradicional na discussão feita por Peter Burke a respeito da "nova história" e, por consequiência, sobre o "paradigma tradicional" em História. ${ }^{27}$ Em linhas gerais, a história articulada ao paradigma tradicional, apresentando uma ambição de objetividade, seria marcada pela narrativa de acontecimentos, sem problematização, enfatizando a esfera do político e a perspectiva das elites (história vista "de cima"), privilegiando os registros oficiais (conforme Burke, "emanados do governo e preservados em arquivos" ${ }^{\text {,28 }}$ ) bem como os personagens que neles são mais constantes. Assim, de acordo com Wolff, autores como Walter Piazza, Oswaldo Cabral (particularmente em História de Santa Catarina), Jali Meirinho e Carlos Humberto Corrêa seriam historiadores tradicionais, só que mais afinados com a abordagem “estadual tradicional”. Já um autor como Licurgo Costa, estudioso da região de Lages, integraria a vertente "tradicional local"29. Uma característica que articularia as várias vertentes da corrente "tradicional", embora acentuadamente "as obras mais gerais", seria o hábito de omitir "as fontes utilizadas e os arquivos nos quais poderiam ser encontradas, dificultando bastante o trabalho de verificação e de aprofundamento do estudo" ${ }^{30}$ A respeito desse último comentário da autora, cabe ponderar que, entre os trabalhos citados, encontravam-se obras originalmente concebidas como de referência ou didáticas, e que os historiadores em questão lidaram de forma diferenciada com a citação de fontes, conforme o veículo ou a finalidade da publicação de seus textos. ${ }^{31}$

De forma similar ao que acontece com o texto de Peter Burke, no artigo de Cristina Scheibe Wolff as características da historiografia tradicional são melhor definidas do que as da historiografia a ela contraposta - em Burke, a "nova história", em Wolff, a historiografia de "abordagem temática". A "abordagem temática" abarcaria diferentes recortes no interior da disciplina (história demográfica, história econômica) e diferentes

\footnotetext{
${ }^{27}$ BURKE, Peter. Abertura: a nova história, seu passado e seu futuro. In: BURKE, Peter (org.). A escrita da História: novas perspectivas. S.Paulo: Editora da UNESP, 1992. (Biblioteca básica) esp. p.8-15.

${ }^{28}$ Ibidem, p.13. Burke acrescenta: "Os registros oficiais em geral expressam o ponto de vista oficial. Para reconstruir as atitudes dos hereges e dos rebeldes, tais registros precisam ser suplementados por outros tipos de fonte."

${ }^{29}$ WOLFF, Cristina Scheibe. op.cit., p.8-10.

${ }^{30}$ Ibidem, p.9.

31 A História de Santa Catarina, por exemplo, de Oswaldo Cabral, publicada em 1968 e alvo constante de críticas dos "novos historiadores", foi escrita com o intuito de servir de suporte às atividades de professores do que hoje chamamos de ensino fundamental e médio, em função de alterações curriculares que tornaram obrigatório o ensino de história de Santa Catarina. No prefácio à primeira edição, Cabral esclarece ter procurado "reunir e compilar os fatos já narrados pelos clássicos das nossas letras históricas", além dos que ele mesmo teria reconstituído "através de documentação original que, em mais de trinta anos", compulsara "nos arquivos e nos velhos jornais.” CABRAL, Oswaldo R. História de Santa Catarina. 4 ed. Florianópolis: Lunardelli, 1994. p.8.
} 
posicionamentos teóricos (tanto historiadores marxistas como, a partir de fins dos anos 1980, historiadores que valorizam o fragmentário, os sujeitos habitualmente excluídos do discurso histórico e a diversidade cultural). Em relação a este último grupo, Wolff destacou o papel inovador de dissertações e teses defendidas entre fins da década de 1980 e inícios da de 1990, como a de Hermetes Reis Araújo (dissertação defendida em 1989), a de Henrique Luiz Pereira Oliveira (dissertação de 1990), a de Maria Bernardete Ramos Flores (tese de 1991) e a de Joana Maria Pedro (tese de 1992). ${ }^{32}$

A proposta de classificação de Cristina Scheibe Wolff, vista até mesmo pela autora como "provisória, sem pretensões de ser absoluta", "experimental"33, é cabível, e mesmo assim com restrições, para variados trabalhos de caráter histórico. Mas certamente não pode ser estendida in totum a seus autores. Se historiadores como Oswaldo Cabral e Walter Piazza dedicaram-se a escrever histórias gerais de Santa Catarina, não o fizeram de forma exclusiva, produzindo também textos mais voltados para uma história de dimensão local ${ }^{34}$ ou para temas específicos ${ }^{35}$. Além disso, a autora, ao remeter-se ao debate sobre a chamada "nova história" (a partir de texto-síntese de Peter Burke), articulou-se a uma rede de armadilhas simplificadoras. De um lado, são detectáveis as interpretações reducionistas que autores da "nova história" montaram e disseminaram intensamente desde a década de 1960, nas quais a história a combater aparece como a história "tradicional" e "positivista"; de outro, os ecos, nos debates, de questionamentos anteriores feitos sobretudo por Lucien Febvre, no

\footnotetext{
${ }^{32}$ ARAÚJO, H. R. A invenção do litoral: reformas urbanas e reajustamento social em Florianópolis na Primeira República. São Paulo, 1989. Dissertação (Mestrado em História). PUC-SP; OLIVEIRA, H. L. P. Os fillhos da falha: assistência aos expostos e remodelações das condutas em Desterro (1828-1887). São Paulo, 1990. Dissertação (Mestrado em História). PUC-SP; FLORES, M. B. Ramos. Teatros da vida, cenários da história: a Farra do Boi e outras festas na Ilha de Santa Catarina - leitura e interpretação. São Paulo, 1991. Tese (Doutorado em História). PUC-SP; PEDRO, Joana M. Mulheres honestas, mulheres faladas: uma questão de classe. São Paulo, 1992. Tese (Doutorado em História). USP.

${ }^{33}$ WOLFF, Cristina Scheibe. op.cit, p.5 e 7.

${ }^{34}$ Dos autores, publicados depois de 1940: Nova Trento; São Miguel e seu patrimônio histórico (Piazza); Os primeiros povoadores de Gaspar; Brusque; Nossa Senhora do Desterro (Cabral).

${ }^{35}$ Dos autores, publicados depois de 1940: A venerável Ordem Terceira de São Francisco da ilha de Santa Catarina; A música em Santa Catarina no século XIX; Médicos, Medicina e charlatões do passado; Fritz Müller; João Maria - interpretação do Contestado (Cabral); A modernização e as elites emergentes: a contribuição alemã; O escravo numa economia minifundiária: o negro em Santa Catarina; O Poder Legislativo catarinense (Piazza).
} 
âmbito dos Annales. ${ }^{36}$

Convenientes num cenário historiográfico de disputas por legitimidade e autoridade, os rótulos e simplificações, reduzindo a complexidade de um conjunto diversificado de estudos, reflexões e concepções, ao longo de períodos históricos freqüentemente não pequenos, pouco contribuem para a compreensão das experiências que estigmatizam. ${ }^{37}$ Embora críticas a esse reducionismo estivessem presentes no meio acadêmico brasileiro na própria década de $1990^{38}$, ele continuou a ser difundido em cursos de graduação e pós-graduação em História. ${ }^{39}$

Não foram localizados textos que contestassem frontalmente as propostas de Cristina Scheibe Wolff - apenas trabalhos contendo sinais de discordância ou apresentando reparos. O artigo de Wolff provavelmente estava no horizonte de Ana Brancher e Henrique Pereira Oliveira, por exemplo, quando assinalaram que a adoção de um tema de pesquisa nem sempre está articulada a uma abordagem verdadeiramente problematizadora. ${ }^{40}$ Mas

\footnotetext{
${ }^{36}$ Para Le Goff, "a história nova nasceu em grande parte de uma revolta contra a história positivista do século XIX, tal como havia sido definida por algumas obras metodológicas por volta de 1900 [referindo-se a textos de Langlois e Seignobos]". LE GOFF, Jacques. A história nova. In: LE GOFF, Jacques (org.). A história nova. São Paulo: Martins Fontes, 1998. p.28. Le Goff, portanto, filia a "história nova" aos "combates" dos primeiros Annales contra a história "historizante", em defesa da história-problema. Para uma crítica das posições dos Annales a este respeito, ver: NADER, Pedro Eduardo Portilho de. Histórias adversas: a confrontação entre a história dos Annales e a chamada história positivista. Revista USP, São Paulo, n.23, set.-nov.1994, p.63-67.

${ }^{37}$ Rogério Forastieri da Silva, destacando a força dos investimentos que tentaram distinguir "a boa história dos Annales" do "resto", considerou que provavelmente "gerações e gerações de profissionais se recusaram a tomar contato com a chamada 'história positivista', ou a chamada 'história tradicional', ou simplesmente a ignoraram. Os juízos foram suficientemente severos para se desqualificar qualquer outra forma de história que não estivesse conforme as propostas dos Annales." SILVA, Rogério Forastieri da. História da historiografia: capítulos para uma história das histórias da historiografia. Bauru (SC): Edusc, 2001. p.142.

${ }^{38}$ Ver, por exemplo: GOMES, Angela de Castro. História e historiadores..., op.cit., p.12 (ressalta, como generalizante e empobrecedor, o "postulado de uma historiografia 'positivista', tão profícua em informações minuciosas e inúteis, quanto parca em interpretações abrangentes e interessantes."); REIS, José Carlos. A história, entre a filosofia e a ciência. 2 ed. São Paulo: Ática, 1999. p.20 (aponta "as críticas contundentes da escola dos Annales, que transformavam os 'positivistas' em portadores de uma anti-história, e os congelavam em uma descrição caricatural").

${ }^{39}$ Segue aqui um exemplo ligado ao caso catarinense. Graduado e na condição de mestrando em História pela UFSC, Camilo Buss Araújo publicou, em 2004, livro sobre o trabalho do padre Vilson Groh na comunidade Mont Serrat (morro da Cruz, Florianópolis), no qual comentou: “[...] essas populações [grupos populares] foram desconsideradas pela historiografia tradicional, que privilegiou os grandes acontecimentos políticos bem como os cidadãos ilustres. Deparamo-nos, portanto, com o problema da ineficácia das fontes oficiais cujo conteúdo pouco esclarece a nossa problemática. A invisibilidade dessas pessoas perante os documentos oficiais nos fez buscar outros tipos de fontes, como jornais, entrevistas, panfletos e informativos comunitários com o objetivo de dar voz àqueles que fazem parte da história de Florianópolis, porém foram, na maioria das vezes, silenciados." Mais adiante, entendeu como "insuficiente a concepção positivista que considera que o documento é, sobretudo, um texto." ARAÚJO, Camilo Buss. A sociedade sem exclusão do padre Vilson Groh: a construção dos movimentos sociais na comunidade do Mont Serrat. Florianópolis: Insular, 2004. p.17 e 89. Grifos meus.

${ }^{40}$ BRANCHER, Ana, OLIVEIRA, Henrique L. Pereira. Apresentação, op.cit. p.9.
} 
comentário mais direto foi feito na mesma Revista Catarinense de História, por Norberto Dallabrida, dois anos depois da publicação do artigo de Wolff. ${ }^{41}$

Dallabrida não se ateve apenas à historiografia catarinense "recente", fazendo um esforço maior de periodização, em que podem ser percebidas convergências com a perspectiva de Walter Piazza, principalmente aquela presente em texto de $1981 .^{42}$ Da mesma forma como em Piazza podem ser percebidas quatro vertentes historiográficas, no texto de Dallabrida o leitor é apresentado a quatro momentos da historiografia catarinense. No entanto, se para Piazza a historiografia catarinense teve início com cronistas e viajantes do período colonial, para Dallabrida ela teria seu momento inicial entre meados do século XVIII e inícios do século XX, quando a história de Santa Catarina foi escrita por membros da "elite administrativa, militar e eclesiástica" - visão com a qual Piazza concordaria ao menos em parte $^{43}$.

A partir de inícios do século XX, ainda segundo Dallabrida, teria surgido "um novo momento historiográfico, marcado pela produção da chamada 'história tradicional'”, caracterizada pela

narrativa de acontecimentos essencialmente políticos, administrativos e militares de indivíduos da elite e pela utilização quase exclusiva de documentos escritos - geralmente oficiais -, visando atingir a objetividade. ${ }^{44}$

Suas figuras de relevo seriam Lucas Alexandre Boiteux (1880-1966), Oswaldo Rodrigues Cabral (1903-1978) e Walter Fernando Piazza (nascido em 1925), “apesar das

\footnotetext{
${ }^{41}$ DALLABRIDA, Norberto. A historiografia catarinense e a obra de Américo da Costa Souto, op.cit.

${ }^{42}$ PIAZZA, Walter F. Historiografia de Santa Catarina. Revista do IHGSC, Florianópolis, $3^{\mathrm{a}}$. fase, n.3, 1981, p.57-75. Uma espécie de esboço desse artigo está contida em texto de Piazza de 1970, no qual realiza um breve balanço das principais produções acerca da história de Santa Catarina, desde inícios do século XIX, bem como do que entendeu serem seus traços fundamentais: PIAZZA, Walter F. Elementos básicos da história catarinense. In: SILVA, Jaldyr B. Faustino da et al. Fundamentos da cultura catarinense. Rio de Janeiro: Laudes, 1970. p.21-48. A questão foi novamente retomada em: PIAZZA, Walter F. Historiografia de Santa Catarina. In: -. Santa Catarina: sua história. Florianópolis: Editora da UFSC, Lunardelli, 1983. Cabe salientar que Norberto Dallabrida refere-se ao texto de Piazza de 1983.

${ }^{43}$ DALLABRIDA, Norberto. op.cit., p.10. Piazza destacou a contribuição historiográfica, nos séculos XVIII e XIX, de pessoas de alguma forma ligadas à máquina de governo de Santa Catarina, que compilaram dados ou traçaram linhas gerais sobre a história daquela área administrativa; o que possibilitaria abordá-las em conjunto seria, contudo, o fato de serem "obras gerais”. PIAZZA, Walter F. Historiografia de Santa Catarina. [1981], op.cit., esp. p.58-66.

${ }^{44}$ DALLABRIDA, Norberto. op.cit., p.10-11. Note-se que, neste artigo, Dallabrida sempre se refere à história tradicional empregando aspas, como que acatando apenas provisoriamente a classificação adotada por Wolff.
} 
especificidades próprias de seu tempo"45

Dallabrida entende ainda que, a partir da década de 1970, o cenário hegemônico do paradigma tradicional teria começado a ser alterado "por várias obras de autores provenientes de diferentes espaços intelectuais" - caso, por exemplo, da visão antropológica de Sílvio Coelho dos Santos, com sua Nova História de Santa Catarina (1974). Também a criação do Programa de Pós-Graduação em História na UFSC, em 1975, colaboraria para uma maior diversificação de perspectivas quanto à história catarinense, inclusive dando origem a uma "leva de obras de História demográfica e econômica baseadas no método quantitativo". 46 Esse momento corresponderia, em Piazza, à vertente historiográfica situada na segunda metade do século XX, que assinalaria "uma sistemática historiográfica com bases científicas", nitidamente influenciada pelo

espírito universitário, já existente no país e, a partir de 1960, apesar de tímida, já se tem uma nova dimensão da Historiografia Catarinense, afirmada de maneira mais corajosa, a partir de $1975 .{ }^{47}$

A data de 1975 alude à criação do Programa de Pós-Graduação em História da UFSC, e a de 1960, à da própria Universidade. Mas o "espírito universitário" de alguma forma habitava a Faculdade Catarinense de Filosofia, criada no início da década de 1950 (efetivamente em funcionamento, porém, em 1955). Afinal, segundo o fundador da Faculdade, Henrique Fontes, "é uma Faculdade de Filosofia um esboço de Universidade, é uma Universidade em ponto pequeno."48

Piazza tende a interpretar as mudanças, na segunda metade do século XX, ressaltando as permanências - tanto que, para ele, a quarta vertente historiográfica não se contrapõe à terceira: visa complementá-la, aperfeiçoá-la. ${ }^{49}$ As mudanças são, assim, nuances,

\footnotetext{
${ }^{45}$ Ibidem, p.13. Piazza entende que a primeira metade do século XX caracterizou-se por uma produção de caráter histórico veiculada em revistas voltadas para esse tipo de estudos (como a revista do IHGSC); sugere, no entanto, que estudiosos como Lucas Boiteux e Oswaldo Cabral, em seu esforço de síntese da história de Santa Catarina, estabeleceram uma linha de continuidade com os autores dos séculos XVIII e XIX. Cf.: PIAZZA, Walter F. Historiografia de Santa Catarina [1981], op.cit., p.63-66 e 72-73.

${ }^{46}$ DALLABRIDA, Norberto. op.cit., p.13-14.

${ }^{47}$ PIAZZA, Walter F. Historiografia de Santa Catarina [1981], op.cit., p.58.

${ }^{48}$ FONTES, Henrique da Silva. Pensamentos, palavras e obras: Primeiro caderno - Da Faculdade de Filosofia. Florianópolis: [Edição do Autor], 1960. p.18.

${ }^{49}$ Fora sentida a necessidade de revisar a história de Santa Catarina, "não no sentido de demolir o que era apresentado pelos vários estudiosos da História, mas de completar determinados quadros ou preencher alguns claros, notadamente, no que tange à História Social e Econômica.” PIAZZA, Walter F. Historiografia de Santa Catarina [1981], op.cit., p.73.
} 
derivações. Já no artigo de Dallabrida, a ênfase é dada às rupturas. Do ponto de vista teóricometodológico, a primeira ruptura importante estaria representada por Américo da Costa Souto e seu viés braudeliano de abordagem da economia catarinense ${ }^{50}$. Em seguida, e mais propriamente a partir de fins dos anos 1980, houve a emergência de

uma nova conjuntura historiográfica catarinense - 'pós-moderna'? -, marcada pela exploração de novos objetos históricos, que demandam novas abordagens. A partir de novos olhares, a História catarinense passa a se sintonizar cada vez mais com o mundo, principalmente por influência das universidades paulistas. ${ }^{51}$

Em tais leituras, os cortes e períodos historiográficos propostos estão longe de ser arbitrários, relacionando-se ao próprio momento em que os textos foram escritos, à forma como os autores então percebiam a historiografia catarinense e, nela, posicionavam a si próprios. Apesar das diferenças, tanto Norberto Dallabrida quanto Cristina Scheibe Wolff, ao abordarem a historiografia catarinense contemporânea, convergiram para a percepção de mudanças mais significativas no final da década de 1980, com o rompimento em relação ao modelo "tradicional" do fazer historiográfico. Um aspecto que não pode ser desconsiderado é que Cristina Scheibe Wolff e Norberto Dallabrida, com sua própria produção historiográfica, situam-se, concretamente, entre os "novos historiadores"

Os textos de Piazza aqui citados são anteriores ao momento de ruptura mais profunda apontado por Wolff e Dallabrida, e conseqüentemente não fazem alusão a ele. O mesmo acontece na dissertação de Valter Manoel Gomes que, orientada por Walter Piazza e defendida em 1985, discutia a historiografia catarinense, buscando identificar "o modo catarinense de pensar a História de Santa Catarina.",53

\footnotetext{
${ }^{50}$ DALLABRIDA, Norberto. op.cit., esp. p.14-18.

${ }^{51}$ Ibidem, p.18-19.

52 Cristina Scheibe Wolff defendeu sua dissertação de mestrado em 1991, na PUC-SP, sob orientação de Déa Ribeiro Fenelon (As mulheres da colônia de Blumenau: cotidiano e trabalho, 1850-1900); Norberto Dallabrida defendeu sua dissertação de mestrado em 1993, na UFSC, sob orientação de Carlos Humberto Pederneiras Corrêa (À sombra do campanário: o catolicismo romanizado na área de colonização italiana do Médio Vale do Itajaí-Açu - 1892-1918).

53 GOMES, Valter Manoel. Formas do pensamento historiográfico catarinense. Florianópolis, 1985. Dissertação (Mestrado em História). UFSC ("Resumo").
} 
Para Élio Cantalício Serpa ${ }^{54}$, Valter Gomes procurou detectar tal "pensamento historiográfico" em função do pressuposto de uma identidade catarinense a partir da qual demandas e anseios da população de Santa Catarina poderiam ser interpretados e defendidos. Neste sentido, Serpa vislumbrou no trabalho de Valter Gomes a postura predominante entre os membros do Instituto Histórico e Geográfico de Santa Catarina, no que se refere a uma preocupação marcante com a questão identitária, em termos regionais (Gomes é, aliás, sócio do IHGSC, assim como seu orientador). Valter Gomes associa os diferentes momentos da historiografia catarinense à "evolução lítero-científica de Santa Catarina", sua proposta de periodização seguindo de perto as fases da literatura catarinense, conforme estudiosos como Osvaldo F. Melo e Celestino Sachet. ${ }^{55}$ A fase mais recente, ou "quinto período", estaria marcada pelo dinamismo cultural, a partir de 1948 (criação da revista modernista "Sul", realização do $1^{\circ}$. Congresso de História Catarinense, expansão de meios de comunicação rádios, jornais - , criação da Universidade). Para Gomes,

[...] no quinto período nasceu a historiografia de Santa Catarina: formou-se uma comunidade científica, controladora, inovadora, incentivadora; o historiador passou a cultivar uma severa autocrítica, tanto em relação à seriedade da pesquisa, quanto à utilização dos conceitos e adoção de valores $[\ldots]^{56}$

Carlos Humberto Corrêa igualmente atribuiu especial relevância ao $1^{\circ}$. Congresso de História Catarinense, em 1948, que teria provocado abalos positivos nas concepções de História vigentes entre os estudiosos catarinenses:

O Congresso de 1948 permitiu, aos historiadores da terra, sentirem a necessidade de casarem a literatura e o diletantismo, até então bases para a

\footnotetext{
${ }^{54}$ SERPA, Élio Cantalício. A identidade catarinense nos discursos do Instituto Histórico e Geográfico de Santa Catarina. Revista de Ciências Humanas, Florianópolis, v.14, n.20, 1996, p.63-79.

${ }^{55}$ GOMES, Valter Manoel. Formas do pensamento..., op.cit., p.38. Embora Gomes baseie sua periodização na da história da literatura catarinense, cabe esclarecer que Celestino Sachet fez uma proposta diferenciada para os estudos históricos em Santa Catarina, dividindo-os em "três etapas": "apresentação do fato histórico como simples acontecimento provocado pelo indivíduo", até fins do século XIX; "preocupação com os aspectos sociológicos e culturais da colonização", até a década de 1960; "estudos setorializados, com o rigor da pesquisa científica na coleta de dados e respectiva interpretação”. SACHET, Celestino. A literatura catarinense. Florianópolis: Lunardelli, 1985. p.306.

${ }^{56}$ Ibidem, p.47.
} 
produção e justificativa para o conhecimento histórico, com os modernos processos firmemente científicos da produção do conhecimento histórico. ${ }^{57}$

O germe da Faculdade Catarinense de Filosofia - e, conseqüentemente, do primeiro curso de graduação em História de Santa Catarina - estaria ali. ${ }^{58}$

Ex-professor do Departamento de História da UFSC e do Programa de PósGraduação em História, atual presidente do IHGSC, Corrêa valoriza o papel da Universidade e o do Instituto na produção historiográfica. O "gradativo afastamento" dos historiadores universitários em relação àquela entidade teria prejudicado a Universidade, que

[...] ignorou a contribuição dos membros do Instituto para a pesquisa documental da História catarinense e, conseqüentemente, para a formação da cultura regional. Ignorou também as suas próprias origens. ${ }^{59}$

Nesse "ignorar as origens", há que considerar, sim, o papel do IHGSC como entidade pioneira a abrigar estudos de caráter histórico, mas também a relevância da atuação dos membros do IHGSC na constituição do primeiro curso de graduação em História, em Santa Catarina, da primeira universidade e da primeira pós-graduação em História.

Nas interpretações da historiografia aqui destacadas, são detectáveis fragilidades e inconsistências, ligadas à adoção de periodizações e classificações pouco precisas ou pouco relevantes, além de, em função disso, pouco eficazes na tarefa de separar aquilo que é supostamente distinto. Para o período mais recente (a historiografia produzida a partir da segunda metade do século XX), há a percepção comum de uma historiografia "científica", "acadêmica", "universitária" - "profissional", enfim. Não há unanimidade quanto à sua trajetória, e as cesuras feitas por uns e outros - 1948, 1960, 1975, 1989 - são indícios disso. Para alguns, as pesquisas geradas pelo Mestrado em História da UFSC, a partir de 1975, rompiam com um fazer historiográfico anteriormente consolidado - "romântico", "tradicional", "diletante". Para outros, a ruptura viria quase quinze anos depois.

Nessa meada onde muitos são os fios reunidos para trabalhar a historiografia catarinense, vários deles conduzem ao Programa de Pós-Graduação em História da UFSC. Vale pensar mais detidamente sobre ele, para desfazer alguns nós.

${ }^{57}$ CORRÊA, Carlos Humberto P. O Primeiro Congresso de História Catarinense e as mudanças de olhar o passado. In: -. Diálogo com Clio: ensaios de história política e cultural. Florianópolis: Insular, 2003. p.177.

${ }^{58}$ Ibidem, p. 187.

${ }^{59}$ Ibidem, p.202. 


\section{A “nova geração”, a pós-graduação em História e a UFSC}

Antes mesmo de ser criado o Mestrado em História da UFSC, em 1975, dissertações sobre Santa Catarina estavam sendo desenvolvidas em outra universidade: a Universidade Federal do Paraná. Embora dissertações sobre Santa Catarina tenham sido defendidas na pós-graduação em História da UFPR desde 1974, nos três decênios seguintes o número de trabalhos foi pequeno, com defesas esporádicas (referem-se aos anos de 19741975, 1980-1981, 1993, 1996, 2001 e 2002). Em trinta e um anos (1974-2005), apenas onze dissertações e uma tese (ver Apêndice I-2). ${ }^{60}$

Na UFPR, entre 1974 e 1993 as dissertações enfocaram fundamentalmente aspectos econômicos da história catarinense, destacando-se, nas orientações, a professora Cecília Maria Westphalen (quatro dissertações orientadas). A proximidade entre Joinville e Curitiba (local de realização do Programa) provavelmente favoreceu os deslocamentos de pesquisadores interessados em investigar aspectos da história joinvilense. Mas, quanto a este último ponto, e assinalando mudanças nas perspectivas historiográficas, se em 1974 defendeuse dissertação sobre a Fundição Tupy e seu pioneirismo, em 1996 e 2002 foram apresentadas dissertações tratando das tensões sociais e identitárias em dois momentos distintos da Joinville do século XX (ver Apêndice I-1). ${ }^{61}$

Com a criação do Mestrado em História na Universidade Federal de Santa Catarina, a maior parte das dissertações e teses sobre a história catarinense passou a concentrar-se naquela instituição. A primeira defesa aconteceu em 1977, mas a dissertação

\footnotetext{
${ }^{60}$ Ressalte-se que estão sendo aqui enfocadas as dissertações e teses que, relativas à história de Santa Catarina, foram desenvolvidas e defendidas em programas de pós-graduação em História. É certo, todavia, que muitos trabalhos referentes à história catarinense vem sendo desenvolvidos junto a programas de pós-graduação de outras áreas do conhecimento.

${ }^{61}$ Convém esclarecer que a consulta e a análise dos trabalhos não foi feita em sua plenitude: das dissertações e teses de todos os programas de pós-graduação em História em que foram identificados trabalhos sobre Santa Catarina, o material consultado representa $73 \%$ do total (186 dissertações, em 241, e 27 teses, em 51). As dissertações e teses consultadas da UFSC representam 84\% do total (164 dissertações, em 191, e 7 teses, em 12). Em relação à UFSC, a maior parte do material não consultado refere-se ao período de 2004-2005. A indicação do material consultado foi feita no Apêndice I-1 (última coluna). Cabe ainda informar que parcela significativa das dissertações e teses foi levantada e consultada durante a realização do projeto de pesquisa "Arquivos e Historiografia sobre Santa Catarina (1977-2002)", coordenado por mim e desenvolvido entre agosto de 2002 e julho de 2004, na Universidade do Estado de Santa Catarina (UDESC). Foi fundamental, no desenvolvimento do projeto, a participação do bolsista de iniciação científica Felipe Matos, bem como o apoio institucional da UDESC.
} 
não elegia Santa Catarina como foco, e sim a História Oral. ${ }^{62}$ A segunda defesa ocorreu em 1978, assistindo-se a um verdadeiro boom em 1979: vinte ao todo, sendo dezenove sobre Santa Catarina. ${ }^{63}$ Um número de defesas tão significativo, em relação a trabalhos sobre a história catarinense, só seria retomado a partir de meados da década de 1990. Nesse conjunto, sempre predominaram os trabalhos voltados para Santa Catarina, embora o Programa de PósGraduação em História da UFSC tenha abrigado estudos relativos a outras áreas do país - Rio Grande do Sul e Paraná, principalmente, mas também Ceará, Espírito Santo, Minas Gerais, Maranhão, Roraima e Rio de Janeiro. Relativamente à história de Santa Catarina, o Programa gerou, entre 1977 e 2005, 191 dissertações e 12 teses (estas últimas, defendidas entre 2002 e 2005 - ver Apêndice I-2).

Nos anos iniciais do Programa, atuaram alguns professores estrangeiros (na maioria, norte-americanos) e pesquisadores com vínculos estreitos com o Instituto Histórico e Geográfico de Santa Catarina - a começar por seu ativo primeiro coordenador, Walter Fernando Piazza. ${ }^{64}$ As primeiras vinte dissertações sobre Santa Catarina foram defendidas entre 1978 e 1979, dezenove delas nesse último ano; outras vinte dissertações seriam a elas somadas, porém, dez anos depois (ver Apêndice I-2). Analisando-se dados relativos aos orientadores (ver Apêndice I-3), na primeira década do Programa, percebe-se que alguns dos professores estrangeiros (Errol Dean Jones, George Philip Browne, Kendall Walker Brown, Lawrence James Nielsen, Roger Frank Colson), assim como o geógrafo Paulo Lago e o sociólogo Nereu do Vale Pereira, não mais estiveram, após 1980, entre os orientadores de pesquisas sobre Santa Catarina. Essa tarefa coube, até 1993 (pelo que indicam as dissertações defendidas), apenas a Carlos Humberto Corrêa, Marly Anna Fortes Bustamante Mira, Rufino Porfírio Almeida (ao final do período) e Walter Piazza (o último trabalho por ele orientado sendo defendido em 1985), bem como aos professores estrangeiros Aníbal Abadie-Aicardi (uruguaio) e Ernesto Aníbal Ruiz (argentino).

\footnotetext{
${ }^{62}$ CORRÊA, Carlos H. P. O documento de história oral como fonte histórica: uma experiência brasileira. Florianópolis, 1977. Dissertação (Mestrado em História). UFSC. A orientação foi de Walter F. Piazza.

${ }^{63}$ Para um levantamento sistemático de todas as dissertações do Programa até 1997, ver: UNIVERSIDADE FEDERAL DE SANTA CATARINA. Centro de Filosofia e Ciências Humanas. Departamento de História Programa de Pós-Graduação em História Catálogo de dissertações: área de concentração - História Cultural. Florianópolis: 1998.

64 Ver, a respeito: PIAZZA, Walter. Uma idéia e os seus resultados. In: UNIVERSIDADE FEDERAL DE SANTA CATARINA. Centro de Filosofia e Ciências Humanas. Departamento de História. Programa de PósGraduação em História. Catálogo de dissertações, op.cit., p.17-20.
} 
As pesquisas deveriam estar inicialmente concentradas nas áreas de "História Social e Econômica da América e do Brasil", havendo alteração posterior para "História do Brasil Meridional.” De forma geral, as dissertações realizadas até meados da década de 1990 estavam mais voltadas para a história demográfica (orientadas por Lawrence James Nielsen e Marly Anna Fortes Bustamante Mira ${ }^{65}$, a história econômica ou a história do trabalho (orientadas geralmente por George Philip Browne, Kendall Walker Brown, Roger Frank Colson, Ernesto Aníbal Ruiz e Rufino Porfírio Almeida ${ }^{66}$ e a história política ou políticoadministrativa (orientadas quase sempre por Carlos Humberto Corrêa ou Walter Piazza) ${ }^{67}$.

${ }^{65}$ Por Lawrence James Nielsen: BARROS, Edy A. C. de. A freguesia de Nossa Senhora das Necessidades e Santo Antônio: 1841 a 1910 - a sua transição demográfica, 1979; FARIAS, Vilson Francisco. A freguesia da Enseada de Brito: evolução histórico-demográfica de 1778 a 1907, 1980. Por Marly Mira: BARRETO, Maria T. S. Os poloneses do Alto Vale do rio Tijucas: um estudo de história demográfica (1880-1950), 1979; FLORES, Maria Bernardete Ramos. História demográfica de Itajaí, 1979; PERARDT, Joaquim F. História demográfica de Angelina (1860-1950), 1990; LAZZARINI, Sérgio. História demográfica da paróquia de São João Batista de Campos Novos (1876-1940), 1993; LUZ, Sérgio R. da. Nossa Senhora da Lapa do Ribeirão da Ilha e sua população (1810-1930), 1994; SANTOS, Joaquim G. dos. A freguesia de São Miguel da Terra Firme: aspectos históricos e demográficos (1750-1894), 1996. Lawrence Nielsen e Marly Mira também orientaram dissertações relativas a outras regiões e temas.

${ }^{66}$ Por George Philip Browne: COLOMBI, Luiz V. Industrialização de Blumenau: o desenvolvimento da Gebrüder Hering, 1880-1915, 1979; PACHECO, Darcy. Um estudo sobre a Junta da Real Fazenda de Santa Catarina, período 1817-1831, 1979. Por Kendall Walker Brown: CZESNAT, Lígia de Oliveira. As estruturas das atividades comerciais da empresa de Carl Hoepcke \& Cia. no contexto catarinense, 1980. Por Roger Frank Colson: ALMEIDA, Rufino Porfírio. Um aspecto da economia de Santa Catarina - a indústria ervateira: o estudo da Companhia Industrial, 1979; BOSSLE, Ondina P. Henrique Lage e o desenvolvimento sulcatarinense, 1979; HILLESHEIM, Anselmo A. O crescimento do mercado interno numa colônia do Império: o caso de Blumenau, 1850-1880, 1979; HÜBENER, Laura. O movimento comercial do porto de Nossa Senhora do Desterro no século XIX, 1979; MARTINS, Valmir. A contribuição do imigrante para o desenvolvimento das relações capitalistas de produção no sul do Estado de Santa Catarina, 1979; PEDRO, Joana M. O desenvolvimento da construção naval em Itajaí, SC: uma resposta ao mercado local, 1900-1950, 1979; Por Ernesto Ruiz: SENA, Walmor B. de. A política do cooperativismo de eletrificação rural em Santa Catarina, 1980; PRATES, Arlete. Atuação estatal no cooperativismo agrícola catarinense: o caso da Cooperativa Regional Alfa (1957-1979), 1981; COELHO, Pedro. O desenvolvimento da pecuária bovina de Lages, 1982; DIAS, Maria de Fátima S. Sindicalismo e Estado corporativista: o caso do Sindicato dos Trabalhadores nas Indústrias de Fiação e Tecelagem de Blumenau (1941-1950), 1985. Por Rufino Almeida: SCHWAB, Aparecida B. O movimento operário: evolução do Sindicato dos Trabalhadores nas Indústrias de Fiação e Tecelagem de Blumenau (1950-1988), 1991; FERNANDES, Maria Luiz. Partidos e sindicatos, um estudo de caso: o Sindicato dos Trabalhadores na Indústria de Extração do Carvão de Criciúma, 1992; SANTOS, Nelvio. Trentinos em Santa Catarina: a evolução econômica de Nova Trento (1875-1960), 1993; CAMPOS, Marília. Marisol S.A, indústria do vestuário: sua evolução (1964-1992), 1994. George Philip Browne, Kendall Walker Brown, Ernesto Ruiz e Rufino Almeida também orientaram trabalhos sobre outros temas ou regiões.

${ }^{67}$ Por Carlos Humberto P. Corrêa: BOPPRÉ, Maria Regina. Regime eleitoral e realidade político-social no Império: o caso do altiplano catarinense nas primeiras eleições diretas (1881-1889), 1983; LAUS, Sônia P. A UDN em Santa Catarina, 1985; DUTRA, Ricardo. Florianópolis - a organização político-administrativa: a Intendência Distrital (1889-1932), 1994; VIEIRA, Jaci G. História do PCB em Santa Catarina: da sua gênese até a Operação Barriga Verde (1922-1975), 1994; Por Walter Piazza: BALDIN, Nelma. A Intendência de Marinha de Santa Catarina e seu papel na ocupação da Província Cisplatina (1817-1832), 1979; MEIRINHO, Jali. A República em Santa Catarina, 1979; S.THIAGO, Eneida Raquel. Um caso de liderança luso-brasileira na região de Joinville: Abdon Baptista, 1884-1922, 1983. Carlos H. P. Corrêa e Walter Piazza também orientaram trabalhos sobre outros temas. 
Nota-se ainda o esforço de sistematização e disponibilização de dados acerca da documentação de interesse para a história de Santa Catarina, na forma de instrumentos de pesquisa, algo que é bastante nítido nos trabalhos orientados pelo professor Aníbal AbadieAicardi $^{68}$. Errol Dean Jones e Paulo Lago orientaram estudos sobre educação. ${ }^{69}$

Ao longo da primeira metade dos anos 1990, alguns orientadores deixariam de atuar - Aníbal Abadie-Aicardi, Rufino Porfírio Almeida e Marly Mira (esta, definitivamente, depois de 1996). Surgiriam, por sua vez, novos orientadores, destacando-se, pelo grande número de trabalhos orientados, as professoras Joana Maria Pedro e Maria Bernardete Ramos: entre 1994 e 2005, foram responsáveis pela orientação, respectivamente, de 20 e 26 das dissertações e teses sobre Santa Catarina defendidas no Programa (ver Apêndice I-3). É igualmente na década de 1990 que o Programa sofre modificações curriculares que buscam uma aproximação maior com a "história cultural", tornada mais tarde (1998) sua área de concentração. $^{70}$

Depreende-se, deste cenário, que algumas discussões historiográficas bastante presentes nos meios universitários brasileiros em meados dos anos 1980, e que punham em destaque reflexões em torno de autores como Michel Foucault, Walter Benjamin e Edward Thompson, ${ }^{71}$ não encontravam eco no corpo de orientadores do Programa e nas linhas de pesquisa existentes até inícios dos anos 1990. Daí compreender-se, também, a circunstância de as duas dissertações de mestrado associadas, por Cristina Scheibe Wolff, ao "ponto de

\footnotetext{
${ }^{68}$ SILVEIRA, Adélia dos Santos. Catálogo analítico-descritivo dos jornais do Desterro (1850-1894): o jornal como fonte histórica, 1981; CUNHA, Maria Teresa S. A contribuição historiográfica de Lucas Alexandre Boiteux no Jornal do Commercio do Rio de Janeiro (1911-1957), 1982; MORAES, Laura do N. R. Catálogo analítico descritivo dos jornais de Florianópolis (1894-1914): o jornal como fonte histórica, 1985; SCHLICHTING, Aída Melo. Catálogo analítico- descritivo dos jornais de Florianópolis (1914-1930): o jornal como fonte histórica, 1989; TEIXEIRA, Arilton. Catálogo analítico-descritivo dos jornais lagunenses (18641900): o jornal como fonte histórica, 1991. Aníbal Abadie-Aicardi também orientou trabalhos sobre outros temas.

${ }^{69}$ Por Errol Dean Jones: MONTEIRO, Jaecyr. Nacionalização do ensino em Santa Catarina (1930-1940), 1979; PICK, Reinaldo J. O Colégio Catarinense, um marco na história da educação em Santa Catarina, 1979. Por Paulo Lago: VIEIRA, Amazile de H. O Instituto Polytechnico no contexto sócio-cultural de Florianópolis, 1979. 70 UNIVERSIDADE FEDERAL DE SANTA CATARINA. Centro de Filosofia e Ciências Humanas. Departamento de História. Programa de Pós-Graduação em História. Catálogo de dissertações, op.cit., p.22-23. A partir de 1998 o Programa passa também a ter o Doutorado.

71 A respeito, ver: RAGO, Margareth. A “nova” historiografia brasileira. Anos 90, Porto Alegre, n.11, jul. 1999, p.73-96; CARDOSO, Ciro F.; VAINFAS, Ronaldo (orgs.). Domínios da História: ensaios de teoria e metodologia. Rio de Janeiro: Campus, 1997; DIEHL, Astor Antônio. A cultura historiográfica brasileira nos anos 1980: experiências e horizontes. 2 ed. rev. ampl. Passo Fundo (RS): Universidade de Passo Fundo, 2004. p.224-292; FICO, Carlos, POLITO, Ronald. A historiografia brasileira nos últimos 20 anos: tentativa de avaliação crítica. In: MALERBA, Jurandir (org.). A velha história: teoria, método e historiografia. Campinas (SP): Papirus, 1996. p.189-208.
} 
virada" da historiografia catarinense - a de Hermetes Reis Araújo, em 1989, e a de Henrique Pereira Oliveira, em 1990 - terem sido desenvolvidas junto a outro Programa de PósGraduação (no caso, o da PUC-SP). A possibilidade de orientações de trabalhos mais afinados com as discussões em voga, nos debates universitários, se deu com o progressivo desligamento dos professores da fase de consolidação do Programa da UFSC, nos primeiros anos da década de 1990, e especialmente com a atuação de professoras definitivamente "em sintonia", recém-doutoras: Joana Maria Pedro (doutoramento pela USP) e Maria Bernardete Ramos (doutoramento pela PUC), que, antes mesmo da mudança da área de concentração, em 1998, abririam possibilidades de pesquisas na linha da chamada "história cultural".

A PUC-SP tem lugar especial na produção historiográfica da "nova geração", pois foi, em parte, seu laboratório de idéias. As relações entre processos de urbanização e emergência de modelos de civilidade, a normatização de condutas articulada a práticas de exclusão social, a valorização de experiências históricas de mulheres, afrodescendentes, caboclos (bem como da história oral como um caminho privilegiado para conhecê-las): tudo está de alguma forma traduzido em dissertações e teses desenvolvidas na PUC-SP, entre 1989 e 2005 .

Já a USP tem sido, desde a década de 1980, outra importante instância de formação de pesquisadores da história de Santa Catarina, em especial os já mestres (foram 20 teses e 3 dissertações). Entre 1982 e 1991, as teses concentraram-se em aspectos econômicos: industrialização, comércio, sistema bancário; apenas uma tese abordando mais diretamente disputas político-ideológicas na década de $1930 .^{72}$ Alguns dos pesquisadores então tornados doutores (Carlos Humberto P. Corrêa, Ondina Pereira Bossle, Rufino Porfírio Almeida) eram mestres pela UFSC. Na década de 1990, os trabalhos encaminharam-se para questões de gênero, imigração e práticas identitárias, instituições de saúde e práticas médicas. A formação e a atuação de elites políticas também foi um tema revisitado e renovado (ver Apêndice I-1).

Além da UFSC (concentrando a maioria das dissertações e teses), da USP, da PUCSP e da UFPR, outras seis instituições com programas de pós-graduação em História abrigaram dissertações ou teses sobre Santa Catarina: no Rio Grande do Sul, a PUC-RS, a UFRGS e a

\footnotetext{
72 Trata-se, aliás, da primeira tese de doutorado em História referente a Santa Catarina: Santa Catarina: um Estado entre duas repúblicas (a luta política num período de mudanças ideológicas, 1930-1935), de Carlos Humberto P. Corrêa, defendida em 1982.
} 
UNISINOS; em São Paulo, a UNICAMP; no Distrito Federal, a UnB; em Pernambuco, a UFPE (ver Apêndice I-2).

Com uma única exceção, em 1978, os trabalhos junto ao Programa de PósGraduação em História da PUC-RS foram defendidos a partir de 1992. Dos dezoito trabalhos (treze dissertações e cinco teses), nove estão voltados para a área de Arqueologia, abrigada, na PUC-RS, neste Programa: deu-se ênfase, nessas pesquisas, à área litorânea de Santa Catarina, sobretudo aos sambaquis e às representações rupestres. Quatro trabalhos debruçaram-se sobre um dos temas clássicos da historiografia catarinense, o da colonização e imigração (principalmente envolvendo grupos de origem italiana ou germânica). A UNISINOS também tem sido buscada como espaço privilegiado de reflexões na área de Arqueologia, com trabalhos sob a orientação de Pedro Ignácio Schmitz, entre 1990 e 2001. Ainda no Rio Grande do Sul, na UFRGS têm sido desenvolvidas, desde 1997, dissertações e teses sobre história de Santa Catarina, geralmente abordando relações de poder, projetos políticos e sociabilidades urbanas no século XX (com destaque para a cidade de Florianópolis). Nos últimos anos, a UFRGS tem sido uma alternativa importante para os mestres interessados em dar seguimento à sua formação (são mestres pela UFSC, aliás, os cinco doutores pela UFRGS que, em suas teses, estudaram aspectos da história de Santa Catarina).

A UNICAMP, embora de forma não muito regular, tem acolhido dissertações e teses abarcando temas da história catarinense. Sintomaticamente, dois dos seis trabalhos defendidos até 2005 enfocaram um dos poucos temas dessa história que costumam ser conhecidos para além das fronteiras do estado de Santa Catarina: o Contestado. ${ }^{73}$

Outros programas de pós-graduação em História foram procurados, pelos pesquisadores, de forma mais pontual, caso do da Universidade de Brasília (uma dissertação, em 1978) e o da Universidade Federal de Pernambuco (uma tese, em 2001). É possível, aliás, que dissertações e teses sobre Santa Catarina, desenvolvidas eventualmente em outros programas, tenham escapado ao levantamento (se defendidas depois de 1995), dada a expansão dos cursos de pós-graduação em História, no país, bem como as freqüentes lacunas observáveis em bases de dados que disponibilizam informações sobre essa produção.

\footnotetext{
73 GALlO, Ivone C. D’Ávila. O Contestado: o sonho do milênio igualitário, 1992; MACHADO, Paulo Pinheiro. Um estudo sobre as origens sociais e a formação política das lideranças sertanejas do Contestado (1912-1916), 2001.
} 
Foram, assim, 241 dissertações e 51 teses sobre Santa Catarina defendidas em dez programas de pós-graduação em História de universidades do país.

As universidades são habitualmente valorizadas como loci de produção da renovação, e as dissertações de mestrado e teses de doutorado, como alguns de seus principais instrumentos. Esse pressuposto tem sido enfatizado no que se refere à área de História, e isso não apenas no caso de Santa Catarina $^{74}$. Como salientado, muitos pesquisadores interessados na história de Santa Catarina buscaram aperfeiçoar sua formação em universidades de outros estados. Na década de 1990, o próprio Programa de Pós-Graduação em História da UFSC teria passado a estimular a renovação de práticas historiográficas. Em que medida "novos historiadores" teriam sido efetivamente gerados nos anos 1990?

\section{Pós-graduação em História da UFSC: permanências e rupturas}

Classificar (como já foi observado, em relação às iniciativas referentes à historiografia catarinense) é sempre um procedimento envolvendo a adoção de critérios que permitem reunir o semelhante e, simultaneamente, separar o diferente, comportando inúmeras limitações e certo grau de arbitrariedade, especialmente porque a matéria classificada freqüentemente resiste às fronteiras dos critérios adotados. Levando em conta tais problemas, são aqui esboçadas algumas possibilidades quanto a uma classificação das dissertações e teses elaboradas no âmbito do Programa de Pós-Graduação em História da UFSC, no que diz respeito a áreas temáticas (não necessariamente coincidentes com suas linhas de pesquisa).

Cinco áreas temáticas podem ser claramente definidas desde os inícios do Programa: história das instituições, história econômica, história demográfica, história política e, de forma mais específica, história da educação. ${ }^{75}$

No que está sendo denominado de "história das instituições", cabem os trabalhos mais diretamente preocupados com instituições governamentais e a trajetória de sua atuação: em 1979, as dissertações de Nelma Baldin, sobre a Intendência da Marinha de Santa Catarina, e de Darcy Pacheco, sobre a Junta da Real Fazenda de Santa Catarina; em 1994, a dissertação de

\footnotetext{
${ }^{74}$ Ver, por exemplo: FICO, Carlos, POLITO, Ronald. A historiografia brasileira nos últimos 20 anos: tentativa de avaliação crítica. op.cit., p.190; ARRUDA, José Jobson, TENGARRINHA, José Manuel. Historiografia luso-brasileira contemporânea. Bauru (SP): EDUSC, 1999, p.48-61.

${ }^{75}$ Para dados mais completos sobre os trabalhos adiante citados, ver Apêndice I-1.
} 
Ricardo Aldo Dutra, sobre a Intendência Distrital em Florianópolis. Esta última, no entanto (e revelando as limitações da classificação), prende-se muito fortemente a discussões de história política. Por outro lado, trabalhos como o de Antonio Luiz Miranda, defendido em 1998, e o de Viviani Poyer, defendido em 2000, ambos sobre a Penitenciária Estadual, em Florianópolis, estabeleceram vínculos com os anteriores, pois refletiram sobre a concepção e efetivação de políticas governamentais (no último caso, voltadas para a questão da criminalidade). Os recortes temporais são significativos: as dissertações mais recuadas referem-se praticamente ao mesmo período (Baldin: 1817-1832; Pacheco: 1817-1831), enquanto que as demais debruçamse sobre períodos mais recentes (Dutra: 1889-1932; Miranda: 1930-1940; Poyer: 1935-1945). Grosso modo, essa adesão a períodos de estudo cada vez mais recentes é uma tendência perceptível no quadro geral das dissertações e teses.

Não somente instituições governamentais foram enfocadas, percebendo-se particular atenção para instituições de ensino, o que sugere a conformação de um campo específico de preocupações ligadas à "história da educação": é o caso das dissertações sobre o Colégio Catarinense (de Reinaldo Pick) e sobre o Instituto Politécnico (de Amazile Vieira), em 1979; da dissertação sobre o Instituto Maria Auxiliadora, em 1993 (de Neide Areco); da dissertação sobre a Fundação do Ensino Superior, em Itajaí, em 1995 (de Edison d'Ávila) e, mesmo, da tese de doutorado sobre o Ginásio Catarinense, em 2001 (de Norberto Dallabrida).

Embora os enfoques sejam diferenciados (a tese de Dallabrida tem viés foucaultiano, ausente nos demais), os trabalhos apresentam esse ponto em comum, que é o de tomar como norte da discussão a trajetória histórica de uma determinada instituição, em um determinado período, seja ela um órgão governamental ou uma instituição educacional de caráter particular. ${ }^{76}$

Nem tudo o que poderia ser abarcado em uma área de "história da educação" diz respeito, entretanto, a instituições de ensino específicas (ou restringe-se a elas): veja-se, por exemplo, o trabalho de Jaecyr Monteiro sobre a nacionalização do ensino em Santa Catarina,

\footnotetext{
${ }^{76}$ Ainda no campo da história das instituições, podem ser citadas as dissertações de Osvaldo Hack, sobre a Igreja Presbiteriana (1979), a de Sílvia Ackermann, sobre o Abrigo de Menores do Estado, em Florianópolis, defendida em 2002, e mesmo a tese de Jacqueline Schmitt sobre o Lar dos Velhinhos Irmão Erasto, defendida em 2005. É certo, porém, que há nestas duas últimas dissertações menos preocupação com a história institucional do que com as experiências daqueles que viram suas vidas atreladas a elas. Em 1991, a dissertação de mestrado de João Klug dedicou-se ao estudo da Igreja Luterana, havendo também trabalhos voltados para as escolas paroquiais e confessionais (como, por exemplo, a dissertação de Moacir Heerdt, defendida em 1992).
} 
no período de 1930-1940 (dissertação defendida em 1979), e que abriu um campo de pesquisas até hoje revisitado. $^{77}$

Também entidades sindicais e cooperativas foram abordadas de forma detida: a Cooperativa de Eletrificação Rural em Santa Maria (dissertação de Walmor de Sena, 1980), o Sindicato dos Trabalhadores nas Indústrias de Fiação e Tecelagem de Blumenau (duas dissertações - a de Maria de Fátima Sabino Dias, em 1985, e a de Aparecida Schwab, em 1991), o Sindicato dos Trabalhadores na Indústria de Extração do Carvão de Criciúma (dissertação de Maria Luiza Fernandes, em 1992).

A história demográfica foi o horizonte de oito trabalhos, situados entre 1979 e 1996, referentes a Nova Trento, Itajaí, Campos Novos, Angelina, São Miguel da Terra Firme/Biguaçu, Enseada de Brito e Desterro/Florianópolis (Santo Antônio e Ribeirão da Ilha). Das áreas temáticas anteriormente citadas, é a única que, após 1996, deixou de oferecer novos trabalhos, certamente em função do desligamento do Programa do Pós-Graduação da UFSC, por aposentadoria, da professora Marly Anna Fortes Bustamante Mira.

A história econômica, importante nos anos iniciais do Programa, perdeu força, mas continuou presente, com outro enfoque: aquilo que antes era claramente abordado do ponto de vista econômico passou a aproximar-se mais da história social, particularmente da história social do trabalho, ou mesmo do que poderia ser denominado de "história urbana". Também podem ser estabelecidos nexos com a "história das instituições", no que se refere à atuação de empresas (do setor industrial, comercial, financeiro, de serviços). Assim, entre 1979 e 1982, foram defendidas dissertações e teses de viés nitidamente econômico, tratando: da indústria ervateira (e do papel da Companhia Industrial), da indústria carbonífera (através da atuação de Henrique Lage), da indústria têxtil (com destaque para a empresa Gebrüder Hering), do desenvolvimento do mercado interno (e do caso da colônia Blumenau), do movimento comercial do porto de Desterro, da construção naval em Itajaí, dos empreendimentos comerciais de Carl Hoepcke, do cooperativismo na área rural, da pecuária no planalto catarinense. Na década de 1990, os trabalhos que puseram em relevo aspectos econômicos tanto focalizaram empresas (Cia. Territorial Sul Brasil, em 1992; Marisol S/A, em 1992; Empresa Força e Luz Santa Catarina S.A., em 1998) como trabalhadores (trabalhadores da indústria têxtil de Brusque, em 1997; trabalhadores das olarias de Morro da Fumaça ou de São

\footnotetext{
77 Em 2002, Nilton José Cristofolini discutiu, em sua dissertação de mestrado defendida na UFSC, a nacionalização do ensino em Joinville.
} 
José, em 1998; trabalhadores e trabalhadoras da indústria carbonífera, em 1997 e 1999; trabalhadores da indústria frigorífica, em 2005).

A história política ganhou contornos específicos em função de preocupações relacionadas mais diretamente à política partidária, havendo certa regularidade na produção voltada para tais temas: em 1979, Jali Meirinho estudou os inícios republicanos em Santa Catarina; em 1983, Eneida Raquel S.Thiago (ou Raquel S.Thiago, como assina seus trabalhos) destacou a liderança política de Abdon Baptista, e Maria Regina Boppré, as primeiras eleições diretas no planalto catarinense; em 1985, Sônia Laus pôs em causa a UDN; em 1994, Jaci Guilherme Vieira abordou aspectos da história do Partido Comunista Brasileiro em Santa Catarina; em 1998, Lauci Cavalett enfocou o integralismo e Sirlei de Souza, o movimento militar de 1964; em 2000, Rogério Silva Luz abordou o clientelismo político em suas relações com o futebol, em Florianópolis; em 2001, Eveli de Oliveira discutiu representações acerca do movimento de 1930, também na capital.

Podem ser identificadas, ao longo dos trinta anos do Programa de Pós-Graduação em História da UFSC, várias permanências temáticas nas dissertações e teses produzidas em seu âmbito: ensino, colonização e imigração, industrialização, religiosidade. A campanha de nacionalização é um tema mais específico, mas recorrente (e não só no que tange à questão do ensino). As abordagens, porém, diferenciaram-se, notadamente quanto a certas ênfases, como já mencionado: preocupação maior com operários do que com industriais; maior interesse nos efeitos das políticas governamentais no cotidiano do que no seu processo de elaboração (e em seus elaboradores); destaque maior para as formas de religiosidade do que para as instituições religiosas; mais atenção à memória das práticas educacionais do que às estruturas das administrações escolares.

Novos temas foram agregados à produção acadêmica sobre a história de Santa Catarina, na última década?

A partir de meados dos anos 1990, surgiram com força as preocupações com identidades (de gênero, étnicas, locais), formas de sociabilidade, memória e cotidiano. Alguns títulos e subtítulos de dissertações e teses (adiante citados na sua maioria parcialmente) são, neste sentido, eloqüentes: "cotidiano e religião" (1995), "mulheres no cotidiano de Florianópolis" (1996), "espaços de sociabilidade e o idioma" (1997), "imagens \& memória da ponte Hercílio Luz" (1997); "experiências negras no cotidiano da cidade de Florianópolis" (1997); "memória e cotidiano do operário têxtil na cidade de Brusque/SC” (1997); "vozes que 
recitam, lembranças que se refazem" (1997); "espaço e memória" (1997); "tensões, trabalho e sociabilidades" (1997); "espaços de sobrevivência e sociabilidades" (1997); “cidadania e identidade na sociedade teuto-brasileira" (1998); "Itajaí e a identidade açoriana" (1998); "memórias das famílias da Vila Operária Próspera Criciúma” (1999); “cotidiano e sobrevivência em uma colônia pesqueira" (2000); "conflitos e alianças guardados pela memória" (2001); "imprensa, governo e memória" (2001); "memórias de trabalhadores e trabalhadoras" (2001); "memórias de uma (outra) guerra: cotidiano e medo durante a Segunda Guerra em Santa Catarina" (2002); "um lugar de memória” (2002); "política cultural e identidade em Santa Catarina" (2004); "histórias e memórias sobre a cidade de Joinville" (2004); "outras histórias, memórias e sociabilidades em um bairro operário em Blumenau" (2005).

Quanto aos recortes temporais e espaciais efetuados nos trabalhos, bem como às fontes consultadas, a análise de dois conjuntos significativos de dissertações - as 19 defendidas em 1979, e as 16 defendidas em 1997 - oferece indicações relevantes, por corresponderem, as primeiras, à fase inicial do Programa, e as últimas, à fase em que estavam sendo vivenciadas mudanças significativas no corpo docente e nas linhas de pesquisa.

As 19 dissertações de 1979 tenderam a abordar, predominantemente, o período entre a segunda metade do século XIX e a década de 1930, embora alguns trabalhos tenham incluído explicitamente o tempo presente em suas reflexões (como as dissertações de Sueli Petry e Reinaldo Pick) e outros tenham recuado ao século XVIII (caso das dissertações de Vilson Francisco Farias e de Sara Regina Silveira de Souza). Como recorte espacial, houve predomínio da capital de Santa Catarina e seu entorno, da região norte-nordeste (com destaque para o vale do Itajaí) e da região sul. Como muitos trabalhos fizeram girar sua análise em torno da história de determinadas instituições, os respectivos arquivos foram elemento-chave nas pesquisas, da mesma forma que os documentos de arquivo de paróquias e cartórios, para os trabalhos de demografia. Além dessa documentação específica, foram também bastante citados, pelos autores, documentos governamentais (relatórios, incluindo "falas" e "mensagens"; correspondência; legislação; levantamentos estatísticos) e periódicos (sobretudo jornais).

Uma constante, nos comentários dos autores das dissertações de 1979, foram as referências à falta de organização da documentação compulsada, aos arquivos perdidos, ao extravio ou à dificuldade de localização de documentos, às dificuldades de acesso a esses 
materiais. Por vezes, a ausência de documentos foi claramente conectada a estratégias de apagamento de práticas e memórias sociais. Sueli Petry (Os clubes de caça e tiro em Blumenau) ressaltou

[...] a exigüidade de documentação dos clubes, especialmente devido à espoliação resultante da Campanha de Nacionalização, nos impossibilitando a montagem de detalhadas histórias dos clubes ou de uma história mais rica tirada das experiências de muitos clubes e dos seus sócios. ${ }^{78}$

Em outros momentos, a falta dos documentos de arquivo é apenas assinalada, como na dissertação $O$ Instituto Polytechnico no contexto sócio-cultural de Florianópolis, de Amazile Vieira: "O grande obstáculo surgido logo no início das pesquisas foi a inexistência aqui em Florianópolis do arquivo pertencente ao Instituto."79

$\mathrm{Na}$ dissertação de Rufino Porfírio Almeida, que aborda a Companhia Industrial, fundada em 1890, em Joinville, o autor esclareceu:

Não se encontraram os documentos pertencentes à empresa, especificamente seus livros de contabilidade, porém tal falta foi suprida, até certo ponto, pela publicação de suas atas e balanços na imprensa, de onde se tiram os dados que compõem o núcleo central. ${ }^{80}$

Entenda-se o "até certo ponto" do autor:

Por motivo da Revolução Federalista de 1893, em Santa Catarina, não houve publicação das mercadorias e valores exportados. Desta maneira, nas tabelas sobre a conjuntura deste Estado existe uma lacuna. Nas fontes pesquisadas não encontrou-se também os balanços de 1892, 1900 e 1903 da Companhia Industrial, presumindo-se que não foram publicados na imprensa de Joinville $-\mathrm{SC}^{81}$

\footnotetext{
${ }^{78}$ PETRY, Sueli Maria Vanzuíta. Os clubes de caça e tiro em Blumenau. Florianópolis, 1979. Dissertação (Mestrado em História). UFSC. p.1-2.

79 VIEIRA, Amazile de Hollanda. O Instituto Polytechnico no contexto sócio-cultural de Florianópolis. Florianópolis, 1979. Dissertação (Mestrado em História). UFSC. p.3.

${ }^{80}$ ALMEIDA, Rufino Porfírio. Um aspecto da economia de Santa Catarina: a indústria ervateira - o estudo da Companhia Industrial. Florianópolis, 1979. Dissertação (Mestrado em História). UFSC. p.1.

${ }^{81}$ Ibidem, p.4.
} 
Já na dissertação de Nelma Baldin, a autora ressaltou uma das maiores dificuldades da pesquisa: "a falta de documentação sobre o sistema financeiro da Intendência da Marinha” ${ }^{\sharp 2}$. Ainda no que se refere a documentos de caráter financeiro, em especial no tocante a atividades empresariais, cabe salientar os comentários de Ondina Bossle e Luiz Vendelino Colombi. Segundo Bossle,

[...] foi bastante dificultoso reconstruir-se a atuação de Henrique Lage no sul de Santa Catarina por falta de documentos empresariais. Com a encampação de muitas empresas do grupo Lage, foram extraviados estes documentos. Para que fosse possível realizar a pesquisa, nos lançamos à busca de outras fontes mais acessíveis como: atas, estatutos, decretos, legislação jurídica, artigos de jornais e relatórios. ${ }^{83}$

Colombi, por sua vez, informou que suas fontes fundamentais - os livros contábeis da empresa Gebrüder Hering - "além de serem em pequeno número, cronologicamente apresentam grandes lacunas, dificultando a análise econômica e financeira da mesma." ${ }^{.4}$

Valmir Martins, na dissertação em que analisou a constituição e desenvolvimento da empresa Colônia Grão-Pará, entre 1882 e 1892, no município de Tubarão, ressaltou ser possível que "títulos tenham sido extraviados ou que seus dados tenham informações duvidosas" ${ }^{85}$ Pesquisando a documentação do Arquivo do Museu da Imigração Conde d'Eu, acrescentou: “As fontes históricas, amontoadas em um depósito sem um mínimo de organização, apresentam sérias dificuldades para sua utilização." ${ }^{, 86}$

No que diz respeito aos trabalhos de história demográfica, os registros existentes nas paróquias, no Arquivo Histórico Eclesiástico, em Florianópolis, bem como nos cartórios, foram essenciais. Nesses estudos, particularmente, as lacunas documentais podiam representar graves problemas, uma vez que as pesquisas objetivavam o tratamento serial dos dados. Conforme Edy Barros, em sua dissertação: “os registros para o período estudado (1841-1910)

\footnotetext{
${ }^{82}$ BALDIN, Nelma. A Intendência da Marinha de Santa Catarina e seu papel na ocupação da Província Cisplatina (1817-1832). Florianópolis, 1979. Dissertação (Mestrado em História). UFSC. p. "i".

${ }^{83}$ BOSSLE, Ondina P. Henrique Lage e o desenvolvimento sul-catarinense, Florianópolis, 1979. Dissertação (Mestrado em História). UFSC. p.15.

${ }^{84}$ COLOMBI, Luiz Vendelino. Industrialização de Blumenau: o desenvolvimento da Gebrüder Hering, 1880-1915. Florianópolis, 1979. Dissertação (Mestrado em História). UFSC. p.2.

${ }^{85}$ MARTINS, Valmir. A contribuição do imigrante para o desenvolvimento das relações capitalistas de produção no sul do Estado de Santa Catarina. Florianópolis, 1979. Dissertação (Mestrado em História). UFSC. p.3.

${ }^{86}$ Ibidem, p.4.
} 
são, de uma maneira geral, completos, com eventuais lacunas que não chegam a comprometer." ${ }^{\text {} 7}$ Já Maria Bernardete Ramos Flores ponderou que, em seu estudo, pretendia

arrolar todos os dados desde 1828, quando a paróquia [de Itajaí] conservou o seu primeiro livro de registro. Porém, constatou-se que, até 1866, existem várias falhas, ou porque os livros foram perdidos, ou talvez a paróquia tenha ficado sem vigário por determinado tempo. ${ }^{88}$

Maria Theresinha S. Barreto encontrou um único livro de registro de óbitos na Paróquia de Nova Trento e nenhum na de Boiteuxburgo. Mas indicou a importância de outras fontes, no sentido de elucidar aspectos históricos não registrados pelos documentos paroquiais consultados:

Não só as entrevistas de História Oral permitem levantar a presença de imigrantes que não são mencionados nos registros paroquiais, como também a pesquisa nas lápides mortuárias atesta a existência desses elementos na área. ${ }^{89}$

Dando prioridade, de forma geral, aos documentos de arquivo, e encontrando inúmeros problemas para o levantamento de dados, os autores das dissertações de 1979 recorreram, quando possível, a outras fontes (como fontes orais e periódicos), quase sempre no intuito de suprir as lacunas detectadas.

No caso das 16 dissertações de 1997, é visível o maior interesse pelo século XX, a partir da sua segunda década (apenas uma dissertação debruçou-se exclusivamente sobre o século $\mathrm{XIX}^{90}$ ). Quatro dissertações abarcaram claramente o tempo presente em suas considerações (as de Bitencourt, Coelho, Lohn e Zimmer). Em relação ao recorte espacial, as dissertações de 1997 assemelham-se às dissertações de 1979, pois assinalam o predomínio de pesquisas envolvendo a capital, o norte-nordeste e o sul do Estado.

\footnotetext{
${ }^{87}$ BARROS, Edy Álvares Cabral de. A freguesia de Nossa Senhora das Necessidades e Santo Antônio: 1841 a 1910 - a sua transição demográfica). Florianópolis, 1979. Dissertação (Mestrado em História). UFSC. p.36. ${ }^{88}$ FLORES, Maria Bernardete Ramos. História demográfica de Itajaí - uma população em transição, 18661930. Florianópolis, 1979. Dissertação (Mestrado em História). UFSC. p.35.

89 BARRETO, Maria Theresinha S. Os poloneses do Alto Vale do Tijucas: um estudo de história demográfica (1880-1950). Florianópolis, 1979. Dissertação (Mestrado em História). UFSC. p.7 e 17 (sobre os livros de registros de óbitos) e 137 (sobre as lápides mortuárias).

${ }^{90}$ SILVA, Janine Gomes da. Tensões, trabalho e sociabilidades: história de mulheres em Joinville no século XIX. Florianópolis, 1997. Dissertação (Mestrado em História). UFSC.
} 
Se nas dissertações de 1979 prevaleceram os documentos textuais (manuscritos ou impressos), e a consulta à documentação governamental, embora longe de exclusiva, foi freqüente, nas de 1997 o leque de fontes foi ampliado. Na dissertação de João Batista Bitencourt ${ }^{91}$ são mobilizados como "documentos" desde folhetos turísticos sobre Laguna a censos econômicos e demográficos, passando por decretos municipais, relatórios governamentais, anuários, revistas, jornais, fontes orais e até mesmo a gravação de programa radiofônico. O recurso a materiais diferenciados não teve aí caráter de "complementação", de preenchimento de lacunas, mas de busca de olhares diferenciados acerca do tema de investigação. O mesmo pode ser dito a respeito da dissertação de Roseli Zimmer, na qual fotografias, gravações de vídeo e prospectos de propaganda compartilharam espaços com decretos-lei federais, atas da Câmara Municipal de Pomerode ou livros municipais de registro de empenhos. ${ }^{92}$

Houve também, em 1997, a ampliação do rol de acervos pesquisados. No entanto, examinadas as instituições custodiadoras de acervos mais consultadas pelos diversos autores em um e outro ano (ou seja, 1979 e 1997), constata-se o importante papel desempenhado, nos dois momentos, por quatro instituições: o Arquivo Público do Estado de Santa Catarina (embora com intensidade menor em 1997); a Biblioteca Central da UFSC (também mais consultada em 1979, época em que abrigava documentos públicos da administração municipal de Desterro/Florianópolis, atualmente abrigados no Arquivo Histórico Municipal da capital); a Biblioteca Pública do Estado de Santa Catarina (antes de tudo em função de sua coleção de periódicos); o Arquivo Histórico de Joinville.

A documentação de caráter público foi bastante utilizada tanto em 1979 como em 1997, embora, neste último ano, por um número menor de autores; ganharam ainda mais peso, no entanto, os periódicos e os depoimentos orais.

$\mathrm{Na}$ dissertação de Maria das Graças Maria, os periódicos complementaram os depoimentos ${ }^{93}$. Note-se que a função de complementação não foi eliminada completamente dos trabalhos de 1997. Na dissertação de Marlus Niebuhr, os depoimentos orais (individuais e

\footnotetext{
${ }^{91}$ BITENCOURT, João B. Clio positivada: a artesania da cidade histórica de Laguna. Florianópolis, 1997. Dissertação (Mestrado em História). UFSC.

${ }^{92}$ ZIMMER, Roseli. Pomerode, a cidade mais alemã do Brasil - as manifestações de germanidade em uma festa teuto-brasileira. Florianópolis, 1997. Dissertação (Mestrado em História). UFSC.

93 “[...] os jornais da época foram outro tipo de fonte que tornou possível a complementação das informações obtidas nos relatos orais." MARIA, Maria das Graças. Imagens invisíveis de Áfricas presentes: experiências negras no cotidiano da cidade de Florianópolis (1930-1940). Florianópolis, 1997. Dissertação (Mestrado em História). UFSC. p.23.
} 
coletivos) foram a chave do trabalho: "explorei a história oral como um meio privilegiado para recuperar a prática cotidiana desses trabalhadores e trabalhadoras". Contudo, como assinalou o pesquisador, as fontes textuais não foram esquecidas: utilizou-as "lado a lado, no decorrer da pesquisa", mesmo constatando que "eram extremamente parcas", e por "motivos variados" até mesmo uma enchente teria colaborado para "silenciar registros que poderiam fornecer pistas valiosas." 94

Foi principalmente a intenção de dar voz a sujeitos históricos ausentes de versões anteriores sobre a história de Santa Catarina, e muitas vezes da própria documentação, que levou tais pesquisadores à história oral. Segundo Lucy Ostetto: "por não haver documentação escrita sobre os sujeitos desta história, encontro nas entrevistas uma possibilidade de historicizar suas experiências." 95

Ao lado das fontes orais e dos periódicos (marcadamente, jornais), os registros fotográficos (tratados individualmente ou como coleção) aparecem como fontes privilegiadas nas dissertações defendidas em 1997. Tais fontes foram provavelmente compreendidas como mais capazes de fornecer respostas a seus questionamentos, que, como já apontado, ligavam-se muito fortemente aos temas da identidade, da memória, do cotidiano e das sociabilidades. Observa-se quase uma inversão, portanto, do quadro anterior, no qual a documentação textual de caráter arquivístico (pública ou privada, conforme os interesses de pesquisa) tinha papel mais destacado. Há indícios, assim, de que a década de 1990 produziu, no âmbito do Programa de Pós-Graduação em História da UFSC, não somente novos temas e abordagens, mas também mudanças na relação dos pesquisadores com os documentos públicos de arquivo.

\section{Anotações à margem de uma polêmica}

Logo após o lançamento, em 9 de novembro de 2004, do terceiro volume da trilogia sobre História de Santa Catarina, tendo como recorte temporal o período entre os séculos XVI e XIX, as páginas do Diário Catarinense abrigaram, a respeito da publicação, uma breve mas ácida polêmica, cujos principais pontos merecem ser aqui abordados.

\footnotetext{
${ }^{94}$ NIEBUHR, Marlus. Memória e cotidiano do operário têxtil na cidade de Brusque/SC: a greve de 1952. Florianópolis, 1997. Dissertação (Mestrado em História). UFSC. p.17 e 21.

95 OSTETTO, Lucy Cristina. Vozes que recitam, lembranças que se refazem: narrativas de descendentes de italianos(as) - Nova Veneza, 1920-1950). Florianópolis, 1997. Dissertação (Mestrado em História). UFSC. p.7.
} 
Ocupando o espaço do caderno "Cultura", publicado aos sábados, o escritor e pesquisador João Carlos Mosimann insurgiu-se contra a publicação, considerando-a uma colcha de retalhos em cuja confecção não teria havido "a preocupação de compatibilizar cores e matizes", "insípida salada servida como esmerado prato da cozinha da UFSC". 96

Dois aspectos do texto de Mosimann são particularmente relevantes. O primeiro: o espanto do crítico, na leitura dos estudos contidos no livro, quanto ao que detecta como aversão de historiadores profissionais e universitários ("mestres e doutores em História") ao uso de "documentação primária" ("as fontes em que costumam abeberar-se, todas secundárias, são as mesmas de qualquer estudante de segundo grau”). O segundo: a alusão a historiadores catarinenses apresentados por Mosimann como modelos ("beneméritos de nossa História”), embora não tivessem formação universitária específica na área de História: "Lucas Boiteux, Oswaldo Cabral e Henrique Fontes; um, almirante, outro médico e jornalista, e o último, professor de Direito." Tomando para si a autoridade de um deles, considera: "Oswaldo Cabral estaria atônito, se vivo fosse, com a performance dessa agremiação de historiadores ditos catarinenses". Nas entrelinhas da crítica, portanto, o entendimento do ofício do historiador como intimamente ligado ao trabalho empírico, de pesquisa em documentos gerados na época estudada (no caso, o período entre os séculos XVI a XVIII), e seu exercício podendo prescindir de formação universitária.

$\mathrm{Na}$ réplica, duas semanas depois, as organizadoras do livro demonstram ter captado a questão central da crítica: o adequado exercício do ofício de historiador. Remetendo a publicação a um contexto de mudanças que, "nas duas últimas décadas" (e sobretudo através de dissertações de mestrado e teses de doutorado), teriam rompido "com a chamada história tradicional", afirmam as organizadoras não terem pretendido realizar "uma obra monumental" (daí a imagem da colcha de retalhos não ser, afinal, imprópria). Sem questionar a importância do recurso a fontes primárias no trabalho do historiador, indicam que elas efetivamente foram consultadas e aparecem em vários dos trabalhos da coletânea. Em sua argumentação, entretanto, as organizadoras do livro opõem "intelectuais acadêmicos" e não-acadêmicos (isto é, "intelectuais afastados das discussões epistemológicas que necessariamente o ofício de professor universitário requer"), historiadores e "historiadores", estes últimos assimilados a

96 MOSIMANN, João Carlos. Academicismo e engodo. Diário Catarinense, Florianópolis, 20 nov. 2004 (Caderno "Cultura", p.15). 
"colecionadores de curiosidades". 97 A História que é coleção de curiosidades fica então identificada a uma história linear, factual, enciclopédica - em suma, à história "tradicional".

A tréplica é de 11 de dezembro, e acusa a estocada: "alguns acadêmicos consideram-se os únicos capazes de escrever a História e, corporativamente, menosprezam os não-acadêmicos que a ela se dedicam." 98 Tentando demonstrar que a formação universitária não é garantia de qualidade para o trabalho de historiador, dedica-se a apontar, nos textos-alvo da polêmica, equívocos factuais e ausência de reflexões originais, chegando à conclusão irônica: "trata-se, realmente, de uma outra história, de uma ruptura com a história tradicional!".99

Cabe notar que João Carlos Mosimann parece ter particular afeição por polêmicas. Mal saído de uma, esboçou outra, não efetivada por força da ausência de réplica: seu alvo seguinte foi o livro História de Florianópolis ilustrada, de Carlos Humberto Pederneiras Corrêa, presidente do Instituto Histórico e Geográfico de Santa Catarina. ${ }^{100}$ Os problemas do livro seriam os seus muitos erros factuais, que prejudicarim "o rigor histórico e estofo científico"; os erros, como sugere, decorreriam da fundamentação em fontes secundárias também plenas de equívocos. Novamente, o tema do contato com as fontes primárias para a correta investigação histórica:

Quem escreve História quase sempre erra, factual ou interpretativamente. Erra-se por diversas razões: análise equivocada de fontes documentais,

97 BRANCHER, Ana; AREND, Sílvia Maria Fávero. Leviandade e ressentimento. Diário Catarinense, Florianópolis, 4 dez. 2004 (Caderno "Cultura", p.13). Seria Mosimann, então, um colecionador de curiosidades? O website da "Enciclopédia Simpozio" (http://www.simpozio.ufsc.br/Port/1-enc/y-mega/RevFilosofia/ 7460y004.htm; acesso em: 16 jan. 2006) identifica João Carlos Mosimann como professor de engenharia e historiador, além de membro da Academia Catarinense de Filosofia. É autor de Tragédia e mistério na Villa Renaux: o caso criminal que abalou Santa Catarina (Florianópolis: Insular, 2000), Porto dos Patos, 1502-1582: a fantástica e verdadeira história da Ilha de Santa Catarina na era dos descobrimentos (Florianópolis: Ed. do Autor: Fundação Franklin Cascaes, 2002; 2a . edição revista publicada em 2004 pela Eletrosul); Ilha de Santa Catarina, 1777-1778: a invasão espanhola (Florianópolis: Ed. do Autor: 2003).

${ }^{98}$ MOSIMANN, João Carlos. De polêmicas e medievais carapuças: uma tréplica a respeito de História de Santa Catarina - séculos XVI a XIX. Diário Catarinense, Florianópolis, 11 dez. 2004 (Caderno “Cultura”, p. 16).

${ }^{99}$ Não à toa, o volume da trilogia que foi objeto da polêmica tratava do período colonial - como visto, pouco estudado pela "nova geração". Autor ligado ao IHGSC, Jali Meirinho salientou: "na última década do milênio que findou", a historiografia "caminhou para a diversificação, embora a concentração dos estudos esteja centrada no contemporâneo". MEIRINHO, Jali. Momentos da historiografia catarinense. Revista do IHGSC, Florianópolis, $3^{\mathrm{a}}$. fase, n.20, 2001, p.21.

100 MOSIMANN, João Carlos. Uma história mal contada. Diário Catarinense, Florianópolis, 29 jan. 2005 (Caderno "Cultura"). Outra manifestação contundente do autor acerca da história de Santa Catarina e seus historiadores - desta vez, relativamente a tema associado à seara "tradicional" - foi publicada em fins de 2005: MOSIMANN, João Carlos. O duplo assassinato de Dias Velho. Diário Catarinense, Florianópolis, 26 nov. 2005 (Caderno "Cultura", capa). 
pesquisa superficial dos fatos, fontes secundárias que erraram antes de nós, tradução errônea de documentos, e assim por diante. Por isso, quando consultadas isoladamente, as fontes secundárias são perigosas. ${ }^{101}$

As manifestações de João Carlos Mosimann, por meio da imprensa, permitem pensar as mudanças e tensões no fazer historiográfico não só como decorrentes de distintas concepções de História, nem apenas como diferenças entre "gerações": ligam-se à conformação do campo historiográfico, em Santa Catarina, e à sua profissionalização mais recente, que envolveu (e envolve) a reconfiguração de lugares sociais de produção dos estudos de caráter histórico. Daí a importância de compreender o processo de constituição desse campo de conhecimento também como campo profissional - processo do qual emergiriam oposições entre historiadores "científicos" e "românticos", "diletantes" e "profissionais", "novos" e "velhos".

Aos "velhos", então.

${ }^{101}$ MOSIMANN, João Carlos. Uma história mal contada, op.cit. 


\section{Parte I \\ Capítulo 2}

\section{Os "velhos"}

Referindo-me particularmente aos pesquisadores mais novos, que dentro do critério da história social ou cultural a que vêm subordinando, uns nítida, outros um tanto difusamente, as suas investigações, iniciaram uma fase nova na atividade intelectual brasileira, não desconheço o muito que ainda hoje realizam, dentro de orientação diversa, historiadores e estudiosos mais antigos do passado brasileiro. Mas a verdade é que os estudiosos mais jovens representam uma força renovadora como há muito não aparecia na vida intelectual brasileira.

Gilberto Freyre, 1940

O comentário de Freyre demonstra, ainda uma vez, o encanto com os "novos". Mas talvez surpreenda, pois, em termos muito próximos aos que atualmente são usados para tratar da historiografia que nos é contemporânea, refere-se a uma novidade historiográfica no cenário brasileiro, estando suas considerações remetidas ao final da década de 1930 (o texto em que estão contidas foi originalmente concebido como uma das conferências que apresentaria em universidades portuguesas, em 1937, no bojo de "missão do presidente da República" enviada a Portugal). ${ }^{1}$ Faria alusão, então, a Sérgio Buarque de Holanda, a Caio Prado Jr. e a ele próprio - a "trindade que responde por um surto renovador", os "intérpretes do Brasil"??

\footnotetext{
${ }^{1}$ FREYRE, Gilberto. Importância dos estudos de história social e cultural para as relações entre portugueses e luso-descendentes. In: -. O mundo que o português criou: aspectos das relações sociaes e de cultura do Brasil com Portugal e as colônias portuguesas. Pref. António Sérgio. Rio de Janeiro: José Olympio, 1940 (Documentos brasileiros, 28). p. 69-93. Freyre, entretanto, não apresentou as conferências: por problemas de saúde, já em Portugal, teve de retornar ao Brasil; elas foram apresentadas (lidas) por outras pessoas e posteriormente publicadas pelo Ministério da Educação e Saúde, em 1938 (ver "Introdução do autor", p.31).

${ }^{2}$ A referência à "trindade" está em: ARRUDA, José Jobson A.; TENGÁRRINHA, José Manuel. Historiografia luso-brasileira contemporânea. Bauru (SP): EDUSC, 1999. p.42. A respeito, ver também, entre outros trabalhos: Revista USP, São Paulo, n.38, jun.-ago.1998 (Dossiê "Intérpretes do Brasil", sobre os três autores); DIEHL, Astor Antônio. A cultura historiográfica brasileira: do IHGB aos anos 1930. Passo Fundo (RS): Universidade de Passo Fundo, 1998, p.180 e ss.
} 
Antonio Candido, na década de 1960, contribuiu para a consagração desses três autores como expressões máximas de uma renovação que, nos anos 1930, teria ocorrido nas reflexões sobre o Brasil: indicou três livros-chave - Casa-grande \& senzala, Raízes do Brasil e Formação do Brasil contemporâneo - que exprimiram "a mentalidade ligada ao sopro de radicalismo intelectual e análise social que eclodiu depois da Revolução de 1930 e não foi, apesar de tudo, abafado pelo Estado Novo." "3 Tratou de salientar os autores e obras que lhe pareceram mais significativos, aqueles que representaram "impactos intelectuais sobre os moços de entre 1933 e 1942" - mais particularmente, os moços "que adotavam posições de esquerda" (como ele próprio). ${ }^{4}$ Havia, portanto, um contexto de renovação e, conseqüentemente, um leque maior de autores renovadores.

Na perspectiva de Freyre, os renovadores eram muitos: citou mais de uma centena de pesquisadores e escritores, compreensivelmente com interesses, enfoques e posicionamentos distintos. Entre eles: Caio Prado Jr., Nelson Werneck Sodré e Hélio Viana, Mário de Andrade, Prudente de Morais Neto e Rubens Borba de Morais, Rodrigo Melo Franco de Andrade, Manuel Bandeira, Sérgio Buarque de Holanda e Sérgio Milliet, Edison Carneiro, Jorge Goulart e Fernando de Azevedo, Roberto Simonsen, Octávio Tarquínio de Sousa e José Maria Bello, Múcio Leão, Cassiano Ricardo, Vianna Moog e Gustavo Barroso. A diversidade da sua produção ligava-se à ampliação do que era entendido como história brasileira, ou do que deveria ser abarcado nos estudos a ela relativos: “A nova história - social e cultural - animada do sentido de totalidade humana que faltou quase sempre à outra", pretendia pôr em relevo

[...] tudo o que é viva e diretamente relacionado com o desenvolvimento dos homens e dos grupos de homens que formaram o Brasil: com os seus esforços, com o seu trabalho, com as suas crenças, com a sua arte. ${ }^{5}$

\footnotetext{
${ }^{3}$ CANDIDO, Antonio. O significado de Raízes do Brasil [datado de dezembro de 1967]. In: HOLANDA, Sérgio Buarque de. Raízes do Brasil. Rio de Janeiro: José Olympio, 1986. p.xxxix. Os livros referidos foram publicados, respectivamente, em 1933, 1936 e 1942. A publicação de Evolução política do Brasil, em 1933, permite, entretanto, situar Caio Prado Jr. no contexto de renovação dos anos 1930. Ainda a respeito dos autores à esquerda, Francisco Iglésias ressaltou a publicação do primeiro livro de Nelson Werneck Sodré em 1938 História da literatura brasileira. Cf.: IGLÉSIAS, Francisco. Historiadores do Brasil: capítulos de historiografia brasileira. 2. impr. Rio de Janeiro: Nova Fronteira, Belo Horizonte: Ed. da UFMG, 2000. p.214.

${ }^{4}$ CANDIDO, Antonio. O significado..., op.cit., p.xli.

${ }^{5}$ FREYRE, Gilberto. Importância dos estudos..., op.cit., p.85.
} 
Era a história vivendo um choque - sociológico, antropológico, etnográfico. Contrapunha-se à "outra" história, vista por Freyre como a "história convencional, quase só preocupada com os nomes ilustres e as datas gloriosas", uma história "preocupada com o único, com o dramático, com o político, com o heróico, com o passado considerado mais nobre e mais grandioso", enquanto a história social ou cultural estaria "interessada antes no típico, no característico, no suscetível de repetir-se". ${ }^{\circ}$

Quais as implicações e consequiências dessa preocupação com o "típico", com o "característico", com o "repetível", em um cenário como o da virada da década de 1930 para a de $1940 ?$

$\mathrm{Na}$ introdução a esse mesmo livro, Freyre fez várias referências a Santa Catarina, que visitara recentemente. Blumenau, numa "primeira impressão", era "uma cidade alemã" no entanto, um olhar atento observaria que "o andar, o gesto, o ritmo" eram brasileiros, o mesmo acontecendo em Joinville ou cidades de colonização alemã ou italiana no Rio Grande do Sul. Para Freyre, era importante garantir sua integração à nossa cultura - uma cultura "luso-brasileira", a ser defendida. Defesa que, por sua vez, não deveria ser, exatamente, da exclusividade dessa cultura, mas de seu primado: as contribuições das diferentes culturas deveriam ser incorporadas, para enriquecer a cultura luso-brasileira, e assimiladas

[...] sem violência, dada a oportunidade que sempre, ou quase sempre, lhes tem dado, de se exprimirem. De modo que a assimilação se faz docemente e por interpenetração. A assimilação ou a contemporização. ${ }^{7}$

Que conexões os comentários de Freyre apresentavam, à época, com os processos culturais e políticos em andamento em Santa Catarina? Estaria a "assimilação" de grupos de origem germânica ou italiana sendo realizada "docemente"? Poderia a "nova história", por ele caracterizada, ser visibilizada também no meio catarinense? Ou haveria o domínio total da "história convencional"?

\section{A afirmação da herança portuguesa}

\footnotetext{
${ }^{6}$ Ibidem, p.71 e 83.

${ }^{7}$ FREYRE, Gilberto. Introdução do autor. In: -. O mundo que o português criou, op.cit, p.35-39.
} 
A singeleza com que, na passagem citada, Freyre refletiu sobre a assimilação cultural no Brasil (cuja suposta doçura é posta sob suspeição naquele sintomático "quase", relativizador das oportunidades de expressão "sempre" dadas a grupos de origem estrangeira), contrastava com pesados investimentos de controle, vigilância e repressão então feitos em Santa Catarina, dirigidos principalmente contra alemães, italianos e descendentes.

Afinada com as orientações do Estado Novo, a "campanha de nacionalização", promovida a partir de 1938 pelo interventor Nereu Ramos, tentou eliminar, de forma sistemática e violenta, os focos contrários à "unidade nacional". Priorizou suas ações nas regiões de colonização alemã e italiana (o que ganharia um acento ainda mais dramático a partir de 1942, com o rompimento das relações diplomáticas entre o Brasil e os "países do Eixo", bem como com a subseqüente declaração de guerra feita à Alemanha). As medidas da campanha foram várias e, entre 1938 e 1939, tenderam a se concentrar no ensino: proibição de atribuição de nomes estrangeiros às escolas e novos núcleos de povoamento (janeiro de 1938); exigência de que todas as escolas particulares adotassem o português como língua nas aulas e em seus documentos internos, e que homenageassem o "pavilhão brasileiro" todos os sábados (março de 1938); proibição de que, sem autorização oficial, aulas fossem ministradas ou salas fossem cedidas para o ensino, por particulares (janeiro de 1939); exigência de exame de português para professores de escolas isoladas (fevereiro de 1939). Além disso, escolas, sociedades e clubes recreativos nas áreas coloniais tiveram suas diretorias substituídas ou foram fechados, e nomes de ruas e de instituições, "nacionalizados". A partir de 1942, ampliaram-se as perseguições, humilhações, cerceamentos, torturas e prisões, inclusive com a criação de campos especiais de detenção (ou concentração). ${ }^{8}$

Luiz Felipe Falcão assinalou que, simultaneamente à campanha de nacionalização, foi intenso o engajamento de "intelectuais catarinenses de origem portuguesa" na reinterpretação da história de Santa Catarina,

não apenas esmaecendo o papel dos descendentes de outras tradições culturais, como também inaugurando uma temática até então inexistente ou pouco efetiva: o açorianismo, ou mais exatamente o estudo e a celebração da

\footnotetext{
${ }^{8}$ Há vários estudos sobre o período, em Santa Catarina, marcadamente sobre a campanha de nacionalização. Aqui, baseamo-nos principalmente em: FALCÃO, Luiz Felipe. Entre ontem e amanhã: diferença cultural, tensões sociais e separatismo em Santa Catarina no século XX. Itajaí (SC): Editora da UNIVALI, 2000. esp. p.167-205; FÁVERI, Marlene de. Memórias de uma (outra) guerra: cotidiano e medo durante a Segunda Guerra em Santa Catarina. Florianópolis: Ed. da UFSC, Itajaí (SC): Ed. da UNIVALI, 2004. esp. 205-289.
} 
imigração proveniente das Ilhas dos Açores (e da Ilha da Madeira), em meados do século XVIII, como definidoras da identidade catarinense e sustentáculo da brasilidade das populações residentes no Estado. ${ }^{9}$

Entre as figuras à frente da "invenção da açorianidade"10 estaria Oswaldo Rodrigues Cabral.

Médico que fora professor primário nos anos iniciais da década de 1920, tendo também atuação jornalística, Oswaldo Rodrigues Cabral publicara, em 1937, pela prestigiosa coleção "Brasiliana" da Companhia Editora Nacional, um volume sobre a história catarinense - Santa Catharina (História - Evolução). Mal se adivinha, em Santa Catharina..., o papel que os açorianos (identificados como "açoritas") passariam a ter nas reflexões de Cabral, nos anos vindouros. Ali, os colonos açorianos eram signos de fracasso: apontados como incapazes para a agricultura e avessos a qualquer tipo de trabalho braçal, por preconceito ao trabalho manual (em geral realizado por escravos), seriam responsáveis, juntamente com o governo (que requisitava seus produtos, não pagava os colonos e ainda os recrutava para o serviço militar), pelo insucesso dessa tentativa de colonização. ${ }^{11}$ Alguns de seus descendentes (bem como alguns dos descendentes dos "fundadores" das primeiras póvoas, a "brava gente vicentista") teriam escapado ao fracasso, à custa das atividades agrícolas - voltando-se para o comércio ou para a pesca, seguindo a carreira militar, dedicando-se à vida intelectual. Outros, porém, "não conseguiram fugir à prisão dos pequeninos vilarejos. Venceu-os a pobreza do meio, o isolamento a que os condenaram". ${ }^{12}$

Cabral salientou ainda, em Santa Catharina..., ter sido bem sucedida a colonização que, em especial nas áreas de vales, foi promovida no século XIX por alemães e italianos, portadores de "outra mentalidade" em relação ao trabalho e aptos para o trabalho agrícola. Como resultado, o colono alemão ou italiano "desenvolveu as culturas, estendeu as plantações, montou fábricas, trabalhou, produziu, enriqueceu." Na ótica do autor, ao menos até aquele momento, o colono italiano ou alemão não era superior ao açoriano na contribuição

\footnotetext{
${ }^{9}$ FALCÃO, Luiz Felipe. op.cit., p.179.

${ }^{10}$ Expressão cunhada pela historiadora Maria Bernardete Ramos Flores, na década de 1990: FLORES, Maria Bernardete Ramos. A farra do boi: palavras, sentidos, ficções. Florianópolis: Ed. da UFSC, 1997. esp. p.113141.

${ }^{11}$ CABRAL, Oswaldo R. Santa Catharina (História - Evolução). São Paulo: Companhia Editora Nacional, 1937. (Brasiliana - Biblioteca Pedagógica Brasileira, 80). p.95-97.

${ }^{12}$ Ibidem, p.113.
} 
feita ao desenvolvimento de Santa Catarina: "Completaram-se, estes e aqueles, aliando-se para o engrandecimento e elevação moral, cultural e material da terra catarinense." 13

Entre 1937 e 1941, vários desses argumentos seriam remodelados por Oswaldo Cabral, o que fica visível na publicação de "A vitória da colonização açoriana em Santa Catarina”, em setembro de 1941, na revista Cultura Política (seis meses depois da circulação do primeiro número daquele periódico).

Como esclareceu Angela de Castro Gomes, Cultura Política foi criada pelo Departamento de Imprensa e Propaganda com periodicidade mensal, visando "divulgar a proposta política do novo regime" para um público amplo, não especializado, sendo vendida em bancas de jornal por preço inferior ao de custo. ${ }^{14} \mathrm{O}$ perfil dos colaboradores também era amplo: na maior parte das seções, não escreviam especialistas ou intelectuais de renome; na seção "História", por exemplo, os colaboradores eram em geral

professores, membros dos institutos históricos e geográficos de vários estados e também funcionários de órgãos do aparelho de Estado. Após 1942, o número de militares cresce muito proporcionalmente à fase anterior da revista. $^{15}$

Na discussão que Cultura Política procurou promover acerca da cultura brasileira e do "espírito nacional", teve fundamental importância o debate em torno do passado brasileiro, que, ainda de acordo com a mesma autora, apresentava-se simultaneamente com duas faces: uma, a de um passado que convivia com o presente, deitando raízes profundas no tempo e estando ligado aos elementos mais permanentes da nacionalidade (tradições, costumes, língua, raça, memória), vinculado ao "povo" e caracterizando a sua "alma”; outra, a de um passado preso à sucessão, ao tempo cronológico, propriamente histórico, ligado a fatos e personagens que era preciso lembrar (quando não enaltecer), para melhor compreender o presente (presente, entretanto, do qual tal passado estava irremediavelmente separado). ${ }^{16} \mathrm{Na}$ busca de "recuperação" do passado bifronte brasileiro, ganhava peso, entre as heranças culturais que se cruzavam no "espírito nacional", a herança portuguesa. Em Cultura Política,

\footnotetext{
${ }^{13}$ Ibidem, p. 124.

${ }^{14}$ GOMES, Angela de Castro. História e historiadores: a política cultural do Estado Novo. Rio de Janeiro: Editora da Fundação Getúlio Vargas, 1996. p.16, 127.

${ }^{15}$ Ibidem, p.187-188.

${ }^{16}$ Ibidem, p.140-143, 160-163.
} 
isso é particularmente visível na seção dedicada às manifestações ditas "folclóricas". Entretanto, também estava presente em outras seções, sendo Gilberto Freyre um dos autores mais esgrimidos pelos diversos autores, em citações que funcionavam como "argumento de autoridade". ${ }^{17}$

Do recurso às referências a Gilberto Freyre não escapou Oswaldo Cabral, no estudo publicado naquela revista: nele remete a Casa-grande \& senzala e a $O$ mundo que o português criou (sobretudo, neste último, ao prefácio de António Sérgio). Os aspectos destacados acerca da colonização açoriana não diferiam fundamentalmente dos apresentados em Santa Catharina..., mas mudanças de ênfase transformaram a argumentação: sendo o "fracasso da colonização portuguesa, notadamente a açoriana", em Santa Catarina, um "fenômeno econômico", significou, através dos descendentes de açorianos, o sucesso da transmissão cultural. Uma "vitória subterrânea", portanto, mas já bastante clara no século XIX, nas cidades litorâneas catarinenses:

[...] o açoriano, pela sua descendência, venceu o meio. Venceu-o, elevou-o e o amou. E, sinal da sua capacidade, impôs-lhe as tendências lusitanas do seu sangue e da sua alma - as mesmas que perduram como marco da sua vitória. $^{18}$

Quanto aos demais colonos estrangeiros ("alienígenas"), se contribuíram (e ainda contribuíam) para o "progresso material de Santa Catarina", não tinham logrado "constituir-se elemento destacado da estrutura social da terra catarinense". Neste sentido, eram verdadeiramente "a religião, a língua, o sentimento pátrio, os costumes dos antepassados", conservados pelos descendentes de açorianos, o "fator principal da evolução históricopolítico-social de Santa Catarina.". 19 Inexistente no livro de 1937, a hierarquização da contribuição de diferentes etnias de imigrantes, nos empreendimentos coloniais, aparece no estudo publicado em Cultura Política, favorecendo os açorianos.

É sabido o quanto o regime de Vargas buscou apagar as tensões regionais em nome de uma unidade nacional. Não por acaso, historiadores marcadamente "regionais", como Cabral, procuraram então reler a história de suas "regiões", ainda mais acentuadamente,

\footnotetext{
${ }^{17}$ Ibidem, p.164-169, 188, 195.

18 CABRAL, Oswaldo R. A vitória da colonização açoriana em Santa Catarina (Separata da revista "Cultura Política", do Rio de Janeiro). Florianópolis: Imprensa Oficial do Estado, [1941]. p.7, 41-42, 48.

${ }^{19}$ Ibidem, p. 47.
} 
como segmentos da história nacional. Daí também, no caso catarinense, a ênfase atribuída ao período colonial e ao legado português, uma vez que o estudo do século XIX tendia a acentuar a importância dos núcleos de colonização constituídos, sobretudo, por imigrantes de origem germânica e italiana. ${ }^{20}$

Nas páginas de Cultura Política, Oswaldo Cabral tentou demonstrar o equívoco da idéia de uma Santa Catarina "estrangeira", marcadamente alemã ou mesmo italiana. A "alma" do povo catarinense, sua índole (seus elementos, enfim, supostamente permanentes) afinavam-se com os elementos integrantes da "alma" do "povo brasileiro", os caracteres do "espírito nacional”, alicerçados na herança portuguesa (tal como os entendia, então, parte significativa da intelectualidade brasileira). A região de Santa Catarina, respeitadas as particularidades de sua trajetória histórica (no passado "cronológico"), integrava-se (via passado "imemorial”) à unidade da Nação.

A subordinação de um fracasso econômico pontual a algo compreendido como vitória cultural abrangente, na argumentação de Cabral, não pode ser dissociada das mudanças no quadro político, em nível regional, nacional e, mesmo, internacional (dados os desdobramentos do conflito na Europa). Traduziria também, em alguma medida, os papéis sociais assumidos pelo autor e sua inserção em determinadas instituições catarinenses.

Formado em Medicina, Oswaldo Cabral exerceu a profissão inicialmente em Joinville, transferindo-se, em meados da década de 1930, para Florianópolis, onde dirigiu a Assistência Municipal até 1945. Entre 1939 e 1945, também foi presidente da filial da Cruz Vermelha Brasileira (Seção de Santa Catarina). ${ }^{21}$ Membro do IHGSC, Cabral tornou-se, na década de 1940, um dos redatores da revista da entidade (os outros redatores, à época, foram Eliezer S. Saraiva e J. Batista Pereira, sendo o periódico dirigido por Carlos da Costa

\footnotetext{
${ }^{20}$ A ênfase era ainda maior para os imigrantes de origem germânica, associados ao desenvolvimento econômico de municípios como Blumenau e Joinville. Cabe lembrar que, nessas e em outras localidades, imigrantes de outras procedências estiveram presentes (bem como não-imigrantes). Mais recentemente, a contribuição de um número maior de etnias tem sido destacada na composição histórica da população catarinense, lidando com a idéia de "mosaico" cultural. Veja-se, por exemplo, comentário contido em publicação de 2004, de clara orientação turística: "O mosaico étnico catarinense é formado por muitos povos, que moldaram o rosto multifacetado da atual população de Santa Catarina - portugueses, alemães, italianos, espanhóis, negros, indígenas, poloneses, austríacos, ucranianos, japoneses, franceses, russos, húngaros...". ZOTZ, Werner; KAISER, Jakzam. Santa Catarina - retratos: gente e paisagens. Florianópolis: Letras brasileiras, 2004. p.15. A sequiência das etnias indicadas é particularmente significativa.

${ }^{21}$ SOUZA, Sara Regina Silveira de. Oswaldo R. Cabral: páginas de um livro de memórias. Florianópolis: Ed. da UFSC, UDESC, 1993. p.49-53; Ficha de registro do acadêmico Oswaldo Rodrigues Cabral - Academia Catarinense de Letras. Florianópolis, 14 de abril de 1963. Acervo da Academia Catarinense de Letras, Dossiê Oswaldo R. Cabral.
} 
Pereira). ${ }^{22}$ Nessa fase, publicou, nos dois números de 1943 da Revista do IHGSC, outro estudo sobre os açorianos, dividido em duas partes: "Os açorianos" e "Decadência agrícola do açoriano". Provavelmente em função do público-alvo (diferente do público de Cultura Política), Cabral abordou de forma mais aprofundada as circunstâncias que cercaram a vinda de açorianos para o sul do Brasil, entre 1748 e 1756, bem como seu estabelecimento, apoiando-se em diversos documentos oficiais. Mas a ênfase, nestes artigos, recaiu novamente sobre a "índole do colono açoriano", sua "incapacidade agrícola", sua falta de "pendor para o trabalho rural". De tais artigos estão ausentes as comparações com outros grupos de colonizadores. Já em Os açorianos, trabalho apresentado por Cabral no $1^{\circ}$. Congresso de História Catarinense, em 1948, e posteriormente publicado como separata, muitas das frases vibrantes acerca dos açorianos, presentes em "A vitória...", são retomadas, com ligeiras modificações, no fecho do texto. ${ }^{23}$

Convém esclarecer que, em 1943, a publicação da Revista do IHGSC estava sendo retomada, embora por breve período (1943-1944). Sua trajetória foi, aliás, acidentada desde o início: depois dos dois primeiros números, em 1902, os números seguintes foram publicados apenas a partir de 1913, mantendo-se até 1920, quando houve nova interrupção. ${ }^{24}$ Nas duas décadas iniciais do século XX, tinha periodicidade trimestral, tal como a Revista do Instituto Histórico e Geográfico Brasileiro: era a Revista Trimensal do Instituto Histórico e Geográfico de Santa Catarina e, como afirmava o editorial do segundo volume, relativo ao $1^{\circ}$. e $2^{\circ}$. trimestres de 1913, "após a quase fatal letargia de dez anos" mantinha-se desfraldando "o mesmo estandarte sob o qual combateu em sua primeira fase", sendo "a história e a geografia, com as ciências correlatas, mormente no que se relacione com a terra

\footnotetext{
${ }^{22}$ Segundo o que a própria Revista do IHGSC registra, a partir do volume relativo ao segundo semestre de 1943 Eliezer dos Santos Saraiva foi substituído por J. Batista Pereira; quanto ao segundo semestre de 1944, indica apenas seu diretor, não mais seus redatores (o mesmo volume, à página 61, registra o falecimento de Eliezer dos Santos Saraiva em 19 de junho daquele ano).

${ }^{23}$ CABRAL, Oswaldo R. Decadência agrícola do açoriano (do livro "Nossa Senhora do Desterro"). RIHGSC, Florianópolis, $2^{\circ}$. semestre de 1943. p.22-25; Os açorianos (Separata do volume II dos Anais do I Congresso de História Catarinense). Florianópolis: Imprensa Oficial, 1950. esp. p.86.

${ }^{24}$ A interrupção da Revista entre 1902 e 1913 foi mais tarde desprezada na definição de suas fases, consideradas oficialmente três (1902-1920, 1943-1944, 1979 à atualidade). Sobre a revista, ver: PIAZZA, Walter Fernando. Santa Catarina - sua História. Florianópolis: Ed. da UFSC, Lunardelli, 1983, p.27-31; PIAZZA, Walter F. O Instituto Histórico e a sua Revista. In: SOARES, Iaponan, PRAZERES, Lêda Maria d'Ávila da Silva (orgs.). Índice analítico da Revista do Instituto Histórico e Geográfico de Santa Catarina: 1902-1987. Florianópolis: IHGSC, 1988. p.5-7; GOMES, Valter Manoel. Revista do IHGSC, $3^{\mathrm{a}}$. fase: algumas considerações críticas. RIHGSC, Florianópolis, 3ª fase, n.8, 1989. p.56-71; SERPA, Élio Cantalício. A identidade catarinense nos discursos do Instituto Histórico e Geográfico de Santa Catarina. Revista de Ciências Humanas, Florianópolis, v.14, n.20, 1996, p.66.
} 
catarinense", o seu "campo de ação". ${ }^{25}$ Mas, nas décadas de 1920 e 1930, ainda uma vez sobreveio a "quase fatal letargia". Em fins da década de 1930, surgiram sinais de mudança, confirmados, na Revista, no primeiro volume de 1943: na nota de apresentação (“In Limine”), sua republicação era contextualizada em nova fase do Instituto,

[...] de intensa atividade desde os primeiros meses de 1938, graças aos esforços e à dedicação de seu ilustre presidente, exmo. Sr. Des. Henrique da Silva Fontes, e ao franco e valiosíssimo apoio recebido do governo do eminente catarinense, exmo. Sr. Dr. Nereu Ramos. ${ }^{26}$

O apoio do interventor Nereu Ramos ao IHGSC (entidade à qual era associado) ${ }^{27}$, tentou ser traduzido na obtenção de uma sede definitiva para a entidade. Assim, o IHGSC viria a beneficiar-se diretamente das perseguições aos "súditos do Eixo", quando em curso a Segunda Guerra Mundial. Segundo Carlos Humberto Corrêa,

[...] nos anos 40, o Instituto teve sede na esquina das ruas Tenente Silveira com Álvaro de Carvalho [em Florianópolis], antigo Clube Germânia, prédio que, com a Segunda Guerra, passou ao Estado com a denominação de "Casa de Santa Catarina"28

Luiz Felipe Falcão destacou as circunstâncias de ocupação das instalações do Clube Germânia:

[...] por não ter alterado o nome, [o Clube Germânia] foi fechado e depois desapropriado por um preço irrisório para que suas instalações abrigassem a Casa de Santa Catarina, como solicitaram Henrique da Silva Fontes, pelo Instituto Histórico e Geográfico de Santa Catarina; Ivo D’Aquino, pela Academia Catarinense de Letras; Batista Pereira, pela Associação

\footnotetext{
${ }^{25}$ Revista Trimensal do Instituto Historico e Geographico de Santa Catharina - RTIHGSC, Florianópolis, v.II, $1^{\circ}$. e $2^{\circ}$. trimestres de 1913 , p.1. No primeiro número, de 1902, os organizadores da revista destacavam sua intenção de realizar "o máximo esforço em prol do levantamento intelectual deste Estado e uma constante preocupação em tornar conhecidas as riquezas históricas e naturais da estremecida pátria catarinense." RTIHGSC, Florianópolis, v.1, n.1, 1902, p.7.

${ }^{26}$ Entretanto, tais esforços, dedicação e apoio parecem não ter sido suficientes para fazer vingar a onda de transformação e dar continuidade à publicação da Revista, uma vez que, após o volume relativo ao $2^{\circ}$. semestre de 1944, reapareceu apenas em 1979 (desde então, continua a ser mantida, sem solução de continuidade).

${ }^{27} \mathrm{Na}$ Primeira República, estava entre os sócios efetivos, identificado como "bacharel em Direito”. Cf.: Relação completa dos sócios do Instituto - 1896-1918. RTIHGSC, Florianópolis, $4^{\circ}$. trim. 1918, p.454.

${ }^{28}$ CORRÊA, Carlos Humberto P. História da cultura catarinense - v. 1: O Estado e as Idéias. Florianópolis: Editora da UFSC, Diário Catarinense, 1997. p.93.
} 
Catarinense de Imprensa; Oswaldo Rodrigues Cabral, pela seção de Santa Catarina da Cruz Vermelha Brasileira; e Rogério Vieira, pela Defesa Civil (A Gazeta, 7 de outubro de 1944)"29

Apesar de o IHGSC ser representado, na solicitação, apenas por Henrique da Silva Fontes, outros solicitantes - Ivo D’Aquino, Batista Pereira e Oswaldo Cabral - também eram sócios da entidade.

Desfavorável aos sócios do Clube Germânia, o contexto político da primeira metade da década de 1940 abriu brechas para efetivar algo que, em outubro de 1929, durante o governo de Adolfo Konder, uma lei previra: a construção ou aquisição "de um prédio apropriado com a denominação de 'Casa de Santa Catarina'”, para instalação do Instituto e da Academia Catarinense de Letras (que na ocasião foram declarados de utilidade pública), podendo também abrigar outras associações "científicas ou literárias, com personalidade jurídica", que fossem organizadas na capital. ${ }^{30}$ No mês seguinte, em 23 de novembro, a Prefeitura Municipal de Florianópolis, por atos do Prefeito Heitor Blum (também sócio do IHGSC), cedeu terreno de mais de $400 \mathrm{~m}^{2}$, na avenida Hercílio Luz com rua General Bittencourt, para a construção da sede. ${ }^{31}$ Dois dias depois, no local, às 16 horas, foi promovida solenidade de "lançamento da Pedra Fundamental". ${ }^{32}$ Mas os desdobramentos políticos que levariam ao movimento revolucionário de 1930, provocando remodelações no jogo político-partidário e na organização administrativa estadual e municipal, provavelmente foram determinantes para que a sede não fosse construída. ${ }^{33}$

A proximidade do IHGSC com os governos estaduais, abalada no início dos anos 1930, mas retomada na mesma década, continuou a ser fortalecida por meio dos cargos ocupados pelos sócios na máquina estatal. Na década de 1940, membros da comissão de redação da Revista do IHGSC, por exemplo, tinham vínculos com a administração estadual:

\footnotetext{
${ }^{29}$ FALCÃO, Luiz Felipe. op.cit. p.202, nota 71.

${ }^{30}$ Lei [estadual] $\mathrm{n}^{\mathrm{o}}$. 1.664, de 15 de outubro de 1929. Apud BAHIA, Eliana. Em busca de uma casa para a cultura. Ágora, Florianópolis, v.V, n.10, dez. 1989, p.6. Nos anos 1910, Adolfo Konder já era um dos sócios do IHGSC, na categoria de "sócio correspondente": ver Relação completa dos sócios do Instituto..., op.cit., p.455.

${ }^{31}$ BAHIA, Eliana. Em busca de uma casa..., op.cit., p.8, 19-20.

${ }^{32} \mathrm{O}$ "convite geral", feito em folha volante, era assinado pela "comissão" (supõe-se, de construção do prédio) formada por José Boiteux, Henrique Fontes, Cid Campos, Artur Costa e Heráclito Ribeiro. Um exemplar do convite encontra-se no acervo da Academia Catarinense de Letras, Dossiê José Arthur Boiteux. Algumas das plantas aprovadas para o prédio foram reproduzidas em: BAHIA, Eliana. op.cit., p.16-18.

${ }^{33}$ Sobre o cenário político catarinense na primeira metade da década de 1930, ver: CORRÊA, Carlos H. Um Estado entre duas Repúblicas: a Revolução de 30 e a política de Santa Catarina até 35. Florianópolis: Editora da UFSC, Assembléia do Estado de Santa Catarina, 1984.
} 
Carlos da Costa Pereira era diretor da Biblioteca Pública do Estado (cargo que ocupou entre 1938 e 1958) e integrava a Comissão de Estudos do Serviço Público Estadual (CESPE), juntamente com Batista Pereira, diretor da Imprensa Oficial (Costa Pereira presidiu a CESPE de março de 1943 a janeiro de 1951). ${ }^{34}$ Henrique Fontes, então presidente do IHGSC e que, na Primeira República, ocupara cargos destacados no Executivo estadual (Diretor da Instrução Pública, entre 1919 e 1926, e Secretário da Viação e Obras Públicas, entre 1926 e 1929), era à época desembargador do Tribunal de Justiça do Estado. ${ }^{35}$

O tema dos açorianos, ao articular-se aos poderosos mecanismos de propaganda do Estado Novo e à intensa campanha de nacionalização de Nereu Ramos, marcou a definitiva reaproximação do Instituto em relação ao governo estadual, resignificando o papel da entidade como locus da produção, simultaneamente, dos discursos da "brasilidade" e do "catarinensismo". 36

Mas há que destacar, também, na recuperação dos açorianos e das tradições de origem portuguesa, um movimento de aproximação, por meio de Oswaldo Rodrigues Cabral, em relação à "nova história social e cultural" discutida por Freyre (que, convém lembrar, deveria valorizar a contribuição de indivíduos e grupos para a formação do Brasil, no que se referia a "seus esforços", "seu trabalho", "suas crenças", "sua arte"). E os açorianos, sujeitos coletivos, haviam contribuído, como destacou Cabral, para essa formação. A valorização dos açorianos na história catarinense era, à sua maneira, uma proposta de "história dos vencidos"

\footnotetext{
${ }^{34}$ Cf.: SACHET, Celestino. A literatura catarinense. Florianópolis: Lunardelli, 1985, p. 311-312; PEREIRA, Carlos da Costa. Minhas memórias. Florianópolis: Ed. da UFSC, FCC Edições, 1996. esp. p.76-86. Carlos da Costa Pereira, além das funções públicas acima referidas, também exerceu a de secretário de Governo durante a administração estadual de Udo Deeke (1946-1947).

35 Antes de desembargador do Tribunal, foi Procurador Geral do Estado (1934-1937). Cf.: JAMUNDÁ, Theobaldo Costa. Catarinenses ilustres. In: História de Santa Catarina. Curitiba: Grafipar, 1970. v. 2, p.23-24.

${ }^{36}$ Embora o termo "catarinensimo" tenha tido ampla circulação a partir dos anos 1970, é certo ter sido utilizado em momentos anteriores, não necessariamente com as mesmas acepções. A expressão, segundo Walter Piazza, foi divulgada primeiramente por Lucas A. Boiteux em 1920, ao elaborar um "Léxico de catarinensismo": PIAZZA, Walter F. Catarinensismo. In: Aspectos da vida e da obra de Lucas Alexandre Boiteux. Florianópolis: Conselho Estadual de Cultura, 1981. p.33. Na década de 1940, nas páginas da Revista do IHGSC, Ildefonso Juvenal referiu-se ao "sentimento de catarinensismo" como sentimento cívico e patriótico em prol de Santa Catarina (RIHGSC, Florianópolis, $2^{\circ}$. sem. 1943, p.177). Thiago Sayão considerou que o "catarinensismo", a partir dos anos 1970, significou uma guinada nas posições anteriormente assumidas por intelectuais catarinenses, pois englobava, na história catarinense, um espectro mais amplo de etnias (caracterizando o "mosaico"): SAYÃO, Thiago J. Nas veredas do folclore: leituras sobre política cultural e identidade em Santa Catarina (1948-1975). Florianópolis: 2004. 106p. Dissertação (Mestrado em História). UFSC. p.28-29. Ver também: SERPA, Élio C. A identidade catarinense nos discursos..., op.cit.
} 
economicamente (embora vitoriosos culturalmente...). ${ }^{37}$

A derivação dessa valorização para preocupações com o tema do folclore, assumidas por vários historiadores e pesquisadores catarinenses em fins da década de 1940 (inclusive Oswaldo Cabral), não deixaria também de ser um diferencial em relação àquilo que Freyre identificou como "história convencional". ${ }^{38}$

\section{A herança portuguesa e o IHGSC}

Para os membros do Instituto Histórico e Geográfico (fosse o brasileiro, fossem seus similares estaduais), a valorização da cultura portuguesa, acentuada nos anos 1930-1940, não era exatamente uma novidade. Manoel Luís Salgado Guimarães, ao estudar o Instituto Histórico e Geográfico Brasileiro, demonstrou que a entidade, desde seus inícios, em 1838, procurou articular fortemente Nação, Estado e Coroa, adotando, por conseqüência, uma visão de continuidade em relação ao projeto colonizador português, chave da civilização do país. A Nação delineada pelo Instituto, no período imperial (depois de debates acirrados entre "lusitanistas" e "indigenistas"), acabaria por excluir os sujeitos considerados não-portadores da civilização (tais como grupos indígenas e africanos, e seus descendentes), privilegiando o "elemento português", fundamento da nacionalidade. ${ }^{39}$ Pode-se, a este respeito, estabelecer paralelo com estudo clássico de Maria Odila Leite da Silva Dias, e compreender as opções do IHGB como desdobramentos do processo, iniciado em 1808, de "interiorização da metrópole" no centro-sul do Brasil colonial, tendo a Corte como foco irradiador. ${ }^{40}$

\footnotetext{
37 A incisiva inserção dos grupos açorianos na história catarinense era também uma forma de reabilitar o "homem do litoral", como destacou Maria Bernardete R. Flores (FLORES, Maria Bernardete Ramos. op.cit. esp. p.130-132). Contrapunha-se a um discurso que enfatizava a pujança das áreas de colonização alemã (como Blumenau e Joinville), fruto do trabalho, do esforço e da dedicação dessas populações, e que destacava o "atraso" das demais áreas, principalmente as litorâneas (associadas, por sua vez, a populações indolentes e indisciplinadas).

${ }^{38}$ A respeito das investigações referentes ao folclore, ver: SAYÃO, Thiago J. Nas veredas do folclore..., op.cit.

${ }^{39}$ GUIMARÃES, Manoel Luís Salgado. Nação e Civilização nos Trópicos: o Instituto Histórico e Geográfico Brasileiro e o projeto de uma história nacional. Estudos Históricos, Rio de Janeiro, n.1, 1988, p.6 e 20-21.

${ }^{40}$ DIAS, Maria Odila Leite da Silva. A interiorização da metrópole (1808-1853). In: MOTA, Carlos Guilherme (org.). 1822: dimensões. São Paulo: Perspectiva, 1972. p.160-184.
} 
Criado em meados da década de $1890^{41}$, com sede na capital, o IHGSC manteve algumas linhas mestras do IHGB. Uma delas era a preocupação com o levantamento sistemático e a divulgação de documentos de interesse para a história brasileira. Na primeira tentativa de criação do Instituto, em 1894, o convite para a reunião de fundação da entidade assinalava que, entre seus objetivos, estariam os de

[...] coligir, organizar, redigir e publicar todos os dados existentes e necessários para a elaboração da história e da geografia do Estado; publicar uma Revista Trimensal, e celebrar conferências públicas, mediante sorteio, sobre pontos obscuros da história ou geografia. ${ }^{42}$

A estreita relação do Instituto com o governo era outro ponto em comum, embora os posicionamentos políticos predominantes fossem diversos. Como assinalou Carlos Humberto Corrêa, "o Instituto Histórico e Geográfico de Santa Catarina foi criado sob a égide e o patrocínio da República e o amparo do Positivismo republicano", diferença significativa em relação aos inícios do Instituto Histórico e Geográfico Brasileiro, que a partir da década de 1850 passara a contar com a presença do próprio imperador em suas reuniões. ${ }^{43}$ Mais especificamente, o IHGSC surgiu em momento político delicado, em que ainda estavam bastante presentes, particularmente na capital do Estado, as tensões e traumas da repressão à Revolução Federalista de 1893. Figuras políticas de especial relevo, nos primeiros momentos

\footnotetext{
${ }^{41}$ Há controvérsias quanto à data de fundação do IHGSC: Carlos Humberto P. Corrêa informa que registros em jornal (o jornal República, de Florianópolis) dão conta de reunião de fundação realizada em 17 de dezembro de 1894. No entanto, segundo o pesquisador (que é membro do Instituto), não foram localizados documentos a este respeito nem no arquivo do Instituto nem do seu então secretário, José Boiteux (sendo que o arquivo pessoal de José Boiteux faz parte do acervo do IHGSC). Em 1896, quase dois anos depois, houve novo convite para reunião de fundação da entidade, em 7 de setembro, data reconhecida pelo Instituto como sendo de sua fundação "oficial". CORRÊA, Carlos Humberto P. História da cultura catarinense..., op.cit., p.81-87.

${ }^{42}$ Ibidem, p.82. Convém comparar tais objetivos com as principais diretrizes do IHGB, conforme discurso do primeiro-secretário, Januário da Cunha Barbosa, proferido a 25 de novembro de 1838: "a coleta e publicação de documentos relevantes para a história do Brasil e o incentivo ao ensino público, de estudos de natureza histórica" (GUIMARÃES, Manoel Luís Salgado. op.cit., p.8). Manoel L.S. Guimarães ainda destacou o estímulo a viagens ("expedições científicas") ao exterior (Portugal e Espanha, em especial) e ao interior do Brasil, com vistas a coletar material que subsidiasse "a escrita da história nacional" (p.23). Instituições congêneres, no país, também adotaram objetivos similares: o Instituto Arqueológico e Geográfico Pernambucano tinha por finalidade coligir "documentos, monumentos e tradições históricas", sobretudo os relativos às áreas das antigas capitanias de Pernambuco e Itamaracá, desde o período colonial; o Instituto Histórico e Geográfico de São Paulo objetivava "promover os meios de estudar documentos" por meio dos quais se pudesse conhecer "a origem dos mais importantes feitos de nossos antepassados", esclarecer equívocos ou preencher lacunas informativas. Cf.: SCHWARCZ, Lilia M. O espetáculo das raças: cientistas, instituições e questão racial no Brasil, 1870-1930. São Paulo: Companhia das Letras, 1995, p.119, 127.

${ }^{43}$ CORRÊA, Carlos Humberto P. História da cultura catarinense..., p. 89; GUIMARÃES, Manoel Luís Salgado. op.cit., p.9-10.
} 
republicanos, foram sócios-fundadores da entidade: Hercílio Luz, Felipe Schmidt, Gustavo Richard (todos governadores de Santa Catarina, entre 1894 e 1924). ${ }^{44}$

Há, além disso, na atuação do Instituto, a já mencionada continuidade em relação ao IHGB no que tange à valorização do legado lusitano. Élio Serpa, que estudou a produção do IHGSC contida em suas revistas, entendeu que, na fase oficialmente reconhecida como "terceira" (a partir de 1979), a publicação teria incorporado mais claramente preocupações com a trajetória e a contribuição de outras etnias em Santa Catarina e com áreas distintas daquelas das primeiras povoações estabelecidas por luso-brasileiros. Já a perspectiva eminentemente lusitanista seria um continuum em toda a história da Revista do IHGSC, e o diferencial dos volumes da década de 1940 residiria apenas no destaque dado aos açorianos, "tirados do esconderijo da história por Oswaldo Rodrigues Cabral."45. Convém acentuar, entretanto, que estudos envolvendo outros grupos étnicos não estiveram ausentes da produção dos membros do IHGSC, como demonstrou sua própria Revista. Mesmo na década de 1940, é possível encontrar, embora em menor escala, textos relativos à contribuição de outras nacionalidades e grupos étnicos: Carlos da Costa Pereira tratou dos "Franceses em Santa Catarina", Francisco S. O. Schaden, dos colonos alemães ("Início da organização da vida espiritual em Teresópolis"), também publicando-se estudo de Jules Henry sobre "Os índios Kaingangs de Santa Catarina, Brasil". 46

Mesmo findo o Estado Novo, os açorianos e sua contribuição para a história catarinense continuaram a ser destacados, sobretudo no $1^{\circ}$. Congresso de História Catarinense, patrocinado pelo IHGSC e realizado em 1948, como parte das comemorações do "Segundo Centenário da Colonização Açoriana”. Transcorrido em outubro, na capital, o Congresso foi antecedido por comemorações em fevereiro, que envolveram "o assentamento da pedra fundamental de um monumento comemorativo", na principal praça municipal, a Praça XV de Novembro, em frente à Câmara Municipal e à sede da Prefeitura. ${ }^{47}$ Em discurso pronunciado na cerimônia, Oswaldo Cabral teria acentuado que o monumento, nem "de ferro nem de bronze, porque estes se moldam", e sim de granito (que "quebra mas não cede"),

\footnotetext{
${ }^{44}$ Vários outros políticos de projeção, no período, eram também sócios do IHGSC: Vidal José de Oliveira Ramos, Fúlvio Aducci, Antonio Pereira da Silva e Oliveira, José Arthur Boiteux. Ver: Relação completa dos sócios do Instituto..., op.cit., p.452-459.

${ }^{45}$ SERPA, Élio Cantalício. A identidade catarinense nos discursos..., op.cit., p.66-67.

${ }^{46}$ RHIGSC, Florianópolis, $2^{\circ}$. sem. 1944.

${ }^{47}$ CORRÊA, Carlos H. P. O Primeiro Congresso de História Catarinense e as mudanças de olhar o passado. Diálogo com Clio: ensaios de história política e cultural. Florianópolis: Insular, 2003. p 188-189.
} 
exprimiria o "alto padrão moral de integridade e de pureza de caráter da gente barriga-verde, a maior herança que os açorianos legaram."48

Um outro componente a reforçar os vínculos da história catarinense com a cultura e a história brasileiras (portanto, em uma dimensão nacional e não estritamente local) era a ação bandeirante no atual território de Santa Catarina. Na Revista do IHGSC dos anos 19431944, açorianos dividiram espaço com os "fundadores" das povoações litorâneas - mas a própria capa daqueles quatro números sugeriu a importância maior deste últimos: nela foi estampada a imagem de Francisco Dias Velho, bandeirante que teria fundado a póvoa de Desterro (futura Florianópolis) no século XVII. Mais precisamente, uma representação de Dias Velho: vê-se, na capa, a figura grave e algo imponente de homem de farta e longa barba, sobriamente trajado, que, em pé, apóia as mãos no cano da espingarda, cuja coronha está assentada no chão. O desenho, feito em 1941 e assinado com as iniciais "ORC” (que remetem imediatamente a Oswaldo Rodrigues Cabral, um dos redatores da Revista), busca reproduzir a estátua de Dias Velho existente no Museu Paulista, em São Paulo.

Note-se que, apesar do destaque dado ao bandeirante, somente no volume do segundo semestre de 1943 encontra-se estudo especialmente dedicado a ele: trata-se de texto de Luiz Gualberto, presente na seção "Homens do passado", e que, segundo informa a Revista, foi originalmente escrito em 1915 e publicado em 1925 no jornal O Tempo, de Florianópolis. ${ }^{49}$ O texto do "saudoso consócio" do IHGSC é apresentado como "um dos mais valiosos até hoje publicados sobre a figura varonil e dotada das mais altas qualidades morais do primeiro povoador da ilha de Santa Catarina", tendo o autor o objetivo de "reabilitar a memória de Dias Velho, empanada por acusações passadas em julgado."50 A lembrança do texto, assim como a apresentação, muito provavelmente foram de responsabilidade de Carlos da Costa Pereira, o diretor da Revista, sucessor de Luiz Gualberto na Academia Catarinense de Letras. Costa Pereira também tinha proximidade com o tema das bandeiras: era autor do estudo "Um capítulo da expansão bandeirante: a fundação de São Francisco do Sul", originalmente publicado em 1931, nos Anais do Museu Paulista. Além disso, partilhara com

\footnotetext{
${ }^{48}$ Citado por FLORES, Maria Bernardete Ramos. op.cit., p.117. Segundo Corrêa, "a ereção do marco caiu no esquecimento através dos tempos" (CORRÊA, Carlos H. P. O Primeiro Congresso..., op.cit., p.189).

${ }^{49}$ GUALBERTO, Luiz. Francisco Dias Velho. RIHGSC, Florianópolis, 2º semestre de 1943, p.107-116.

${ }^{50}$ Ibidem, p.107 (comentários extraídos da apresentação que antecede o estudo de Luiz Gualberto).
} 
Luiz Gualberto a atividade jornalística em São Francisco do Sul (município do norte de Santa Catarina) e a vida política vinculada ao Partido Republicano Catarinense. ${ }^{51}$

Os qualificativos empregados por Luiz Gualberto para Dias Velho formam uma longa lista e dão bem o tom do texto: "célebre paulista", de "ânimo varonil", "valoroso", "homem de ação", "o mais conceituado entre os representantes da numerosa família Pires", de importância "notória", antes mesmo de integrar o Conselho Municipal de São Paulo e ser juiz ordinário; homem de "altas qualidades morais", guiado pelos "princípios da honra e da lealdade"; "honrado povoador de Santa Catarina", sempre a proceder de "modo digno"; "o primeiro brasileiro que impediu que a expansão castelhana viesse para o Norte"; "benemérito colonizador"; "bandeirante, intrépido e corajoso, habituado ao mando e à conquista", tendo "sempre pautado os seus atos pela mais escrupulosa honradez", dotado das grandes "qualidades de vontade, coragem, energia e ação". Além disso, Dias Velho "amava a terra onde se veio estabelecer", 52

Compreender o destaque dado a Francisco Dias Velho na capa da Revista do IHGSC, nos volumes da década de 1940, é tarefa que pode passar por vários caminhos. De um lado, pela perspectiva "lusitanista" do Instituto (afinal, segundo Pedro Taques, Dias Velho descendia da família lusitana "Parente Dias Velho" ${ }^{53}$; perspectiva que, existente desde seus primórdios, fora reatualizada pelas orientações gerais do nacionalismo Estado-Novista. De outro, pelo intuito de engrandecer a história local, já que a Revista, desta maneira, explicitava a articulação da história de Santa Catarina com a de insigne bandeirante paulista, em honra de quem fora erigido "monumento" existente em uma das mais importantes instituições museológicas do país. Igualmente, pela estratégia de conexão da história regional à história nacional mais ampla, dado que a "epopéia bandeirante" fora sendo lentamente transformada em matriz da história brasileira.

Kátia Abud ocupou-se da trajetória das representações acerca do bandeirante, destacando que, no século XVII, sua imagem era bastante negativa, posto que elaborada fundamentalmente pelos religiosos das reduções jesuíticas atacadas pelos sertanistas,

${ }^{51}$ Cf.: SACHET, Celestino. A literatura catarinense, op.cit., p.83, 311-312; PEREIRA, Carlos da Costa. Minhas memórias, op.cit., p.51-65, 86-87. O mesmo volume dos Anais do Museu Paulista em que Costa Pereira publicou seu estudo também continha o trabalho "Paulistas em Santa Catharina seiscentista - Dias Velho, o colonizador", do catarinense Lucas Alexandre Boiteux. Cf.: Annaes do Museu Paulista, São Paulo, tomo IV, 1931, p.429-479.

${ }^{52}$ GUALBERTO, Luiz. op. cit., p.107, 109, 113-116.

${ }^{53}$ Citado por: BOITEUX, Lucas Alexandre. Paulistas em Santa Catharina seiscentista..., op.cit., p.435. 
procedentes da Capitania de São Vicente, com o objetivo de apresar os indígenas ali reunidos. ${ }^{54}$ Caberia a Pedro Taques e a frei Gaspar da Madre de Deus, no século XVIII, alterar essa visão: no contexto dos conflitos e disputas nas áreas de mineração, ambos, sem fazer uso da expressão "bandeira" ou "bandeirante", tratariam daqueles sujeitos à luz do que consideravam "direito dos descendentes dos antigos povoadores", ameaçado por aqueles que dirigiam-se às minas recém-descobertas. ${ }^{55}$ A figura do "bandeirante" seria novamente posta em destaque, segundo a autora, apenas "quando São Paulo, graças ao café, veio ocupar um lugar de poderio econômico, no conjunto das províncias brasileiras", surgindo a partir de então "as obras matrizes dos grandes historiadores das bandeiras: Alfredo Ellis Jr., Taunay, Alcântara Machado, Paulo Prado."56

O "bandeirante" seria transformado em chave para a compreensão não só da história paulista no presente (haveria, nos paulistas do século XX, uma "alma bandeirante") mas da própria história do Brasil, ao menos no que tange à formação do território e à construção das bases da unidade nacional. A epopéia bandeirante seria desdobrada em "epopéia paulista", perenizada na pujança do Estado-locomotiva da Nação, conseguindo a figura do bandeirante, assim, compatibilizar "o regionalismo e o nacionalismo". 57

No período Vargas, as representações acerca do bandeirante realizarão a proeza de servir, de um lado, como elemento de resistência ao regime (como no movimento constitucionalista paulista de 1932) e, de outro, como motor de sua legitimação. Convém lembrar que, para o primeiro número da revista Cultura Política, Cassiano Ricardo escreveu artigo em que emprestava um "sentido bandeirante" ao Estado Novo. ${ }^{58}$

Tendo publicado, em 1940, o livro Marcha para o Oeste - a influência da bandeira na formação social e política do Brasil, Cassiano Ricardo, no artigo de Cultura Política, afirmou o caráter livre e dinâmico do bandeirante e a faceta democrática das bandeiras (havia "participação direta do povo"), ao mesmo tempo ordeiras e solidárias em sua organização. O líder bandeirante era "o protetor, o elemento de ordem, a garantia de

\footnotetext{
${ }^{54}$ ABUD, Kátia Maria. O sangue intimorato e as nobilíssimas tradições: a construção de um símbolo paulista - o bandeirante. São Paulo, 1985. Tese ( Doutorado em História). FFLCH-USP. p.3.

55 Ibidem, p.77-78, 98.

${ }^{56}$ Ibidem, p.206-207.

${ }^{57}$ Ibidem, p.3, 208 e 382.

${ }^{58}$ RICARDO, Cassiano. O Estado Novo e o seu sentido bandeirante. Cultura Política, Rio de Janeiro, v.1, n.1, março de 1941, p.110-132. Basílio de Magalhães, na mesma revista, lançara mão da metáfora do "bandeirantismo cultural", a ser realizado no "território desconhecido das tradições populares". Cf.: GOMES, Angela de Castro. op.cit., p.162.
} 
tranqüilidade em certas zonas de turbulência", que sabia usar da técnica "da bondade e da conciliação", tendo autoridade para "realizar as aspirações do grupo e manter-lhe a inquebrantável unidade". A bandeira, por sua vez, atuava como um "Estado em miniatura" que, em movimento, ganhava "feição imperialista" e já esboçava o Estado moderno, combatente dos "quistos étnicos", caracterizado pelo "comando seguro e fraterna solidariedade dos indivíduos obedientes à firme unidade do comando”. Assumindo o poder (político) de conquistar o território e povoá-lo, o bandeirante ainda criava cidades: "é ele o fundador da cidade e, portanto, o fundador do Estado". ${ }^{59}$ Para Cassiano Ricardo, o Estado Novo seria "várias vezes bandeirante":

[...] no apelo às origens brasileiras; na defesa de nossas fronteiras espirituais contra quaisquer ideologias exóticas e dissolventes da nacionalidade; no espírito unitário, um tanto antifederalista; na soma de autoridade conferida ao chefe nacional; na 'marcha para o oeste' que é também sinônimo do nosso imperialismo interno e no seu próprio conceito; isto é, no seu conceito ‘dinâmico' de Estado. ${ }^{60}$

A plasticidade da representação do bandeirante e das bandeiras era tamanha que, através de Cassiano Ricardo, Vargas tornava-se líder bandeirante e o Estado brasileiro (mais propriamente, o "Estado Novo"), uma grande bandeira, integrando, em movimento dinâmico, democraticamente (!), a diversidade na unidade da Nação.

À luz dos comentários de Cassiano Ricardo, o desenho elaborado para capa da Revista do IHGSC, por Oswaldo Rodrigues Cabral (aliás, no ano de 1941), pode ainda ganhar outra interpretação: Dias Velho seria signo do Estado, associado à ordem, à segurança, à garantia de integração territorial e unidade nacional. Signo, no limite, do próprio Estado Novo.

No contexto catarinense, porém, alterava-se em parte a imagem do bandeirantefundador, que em Cassiano Ricardo era o homem voltado para o sertão, conquistando-o na "marcha para o oeste" (o litoral sendo "a antítese do oeste") ${ }^{61}$. Em Santa Catarina, e para estudiosos como Oswaldo Cabral, o bandeirante-fundador era, sobretudo, o homem das primeiras povoações litorâneas (São Francisco do Sul, Desterro, Laguna). Sua imagem

\footnotetext{
${ }^{59}$ RICARDO, Cassiano. op.cit. p.114, 116-117, 120, 121, 123-124.

${ }^{60}$ Ibidem, p. 132.

${ }^{61}$ Ibidem, p. 128.
} 
acenava para o passado-presente (em que a herança lusitana, formadora da "alma" brasileira, revelava-se nos costumes, na língua, nas tradições) e para o passado-pretérito, já vivido por homens concretos em momentos concretos. Uma imagem, portanto, integradora das duas faces do passado, vislumbradas por Angela de Castro Gomes, nos discursos vinculados à construção do "espírito nacional" durante o Estado Novo, especialmente na revista Cultura Política. Mas a imagem apontava também, naqueles anos sombrios, para o presente imediato, em que a ascendência portuguesa, mesmo que longínqua, era instrumento de projeção social e política de determinados grupos, servindo ao controle e à dominação de grupos de ascendência distinta. As tensões do presente - um momento de guerra mundializada -, penetraram os textos da Revista do IHGSC.

Há que ressaltar ainda que os bandeirantes-fundadores, embora admiráveis, também podiam carregar, em suas trajetórias, dimensões de fracasso. Um texto de Cabral como "Os açorianos" põe em xeque a real importância de suas ações. A respeito de Desterro, afirmou que a vida naquela vila teve início,

[...] em verdade, quando os açorianos emigraram das suas ilhas abruptas e se transferiram para a de Santa Catarina.

Porque, até então, o que houve não passou de tentativas insignificantes para povoar não só esta [ilha] como também o continente em torno, com reduzidos povoadores que não puderam resistir às condições inevitáveis de isolamento e de abandono. ${ }^{62}$

Por outro lado, se tomado o exemplo de Laguna, evidencia-se que as ações decisivas dos bandeirantes são posteriores aos momentos de "fundação", propriamente. "Fundada" no século XVII por Domingos de Brito Peixoto, Laguna, no século seguinte, seria essencial como base das iniciativas de integração do território do Rio Grande ao domínio português - o que foi destacado por Cabral, no seu estudo Laguna e Rio Grande, apresentado em 1940, em congresso no Rio Grande do Sul. ${ }^{63}$

\footnotetext{
${ }^{62}$ CABRAL, Oswaldo R. Os açorianos, RIHGSC, op.cit., p.9. Grifos meus.

63 "Em Laguna e Rio Grande, estudo que apresentou no congresso de 1940 no Estado vizinho, Cabral afirma ser Laguna a 'terra mãe' do Rio Grande do Sul.” BITENCOURT, João Batista. Estado Novo, cidade velha: o governo ditatorial de Vargas desde Laguna. Porto Alegre, 2002. Tese (Doutorado em História). UFRGS, p.254255. Para Bitencourt, Cabral construiria "a imagem de Laguna como marco fundante da brasilidade no sul do país. Em um governo nacional notadamente nacionalista saído do Estado gaúcho, Cabral apresentava elementos que mostravam a brasilidade da terra de Vargas via Laguna.” (p.21)
} 
Lado a lado com a figura do "açoriano", o "bandeirante" remetia ainda à "história convencional", tal como caracterizada por Freyre: abria caminho para o dramático, o heróico, o grandioso - concentrando-se, em geral, no indivíduo. Abordagens que podiam conviver, sem atritos, na Revista do IHGSC de 1943 e 1944. No entanto, entre os bandeirantes destacados, era a representação de Dias Velho, e não a de Domingos de Brito Peixoto, ou de Francisco de Brito Peixoto (os dois últimos associados às empreitadas lagunenses) que ocupava então a capa da Revista - talvez porque Dias Velho integrasse o panteão bandeirista formado por Taunay no Museu Paulista.

Afonso de Taunay, historiador ligado, desde 1911, ao IHGB e ao Instituto de São Paulo, além do próprio IHGSC (sócio correspondente, a partir de 1902), certamente exerceu influência sobre os historiadores da entidade catarinense, ao menos ao longo da primeira metade do século XX. Tendo por muitos anos (de 1917 a 1945) dirigido instituição dedicada à temática da independência política do Brasil (o Museu Paulista), Taunay tornou-o espaço de celebração das bandeiras - bandeiras que, por sua vez, foram seu principal objeto de pesquisa. Nascido em Santa Catarina (seu pai governara a província), tinha contatos com os historiadores do IHGSC, sendo certo que trocou correspondência ao menos com José A. Boiteux e Lucas Alexandre Boiteux. ${ }^{64}$ A imagem do bandeirante era tão decisiva para Taunay que chegava a confundir-se com a do historiador, como num jogo de espelhos: em discurso pronunciado por ocasião dos 20 anos do IHGSP, em 1914, Taunay convocou os "ilustres e prezados consócios" a cerrar fileiras pelo Instituto,

[...] como se fôramos os soldados de um antigo terço - que realmente somos os membros da bandeira que do Passado procura fazer, em múltiplas, em contínuas entradas, o descimento das verdades históricas. ${ }^{65}$

\footnotetext{
${ }^{64}$ ANHEZINI, Karina. Museu Paulista e trocas intelectuais na escrita da História de Afonso de Taunay. Anais do Museu Paulista, São Paulo, N. Sér., v.10/11, 2002-2003, p.37-60; BREFE, Ana Cláudia Fonseca. O Museu Paulista: Affonso de Taunay e a memória nacional, 1917-1945. São Paulo: Ed. da UNESP, Museu Paulista, 2005, esp; p.224-285; PIAZZA, Walter F. Dois historiadores catarinenses: Afonso d'E. Taunay e Lucas A. Boiteux. RIHGSC, Florianópolis, $3^{\mathrm{a}}$. fase, n.6, 1985, p.74-84. Sobre a correspondência, ver também Parte I, Capítulo 3.

65 Apud ANHEZINI, Karina. Fundamentos da escrita da história de Afonso de Taunay ou como se escrevia a história nas primeiras décadas do século XX. In: ASSOCIAÇÃO Nacional de História - ANPUH, XXIII Simpósio Nacional de História - História: Guerra e Paz, 17 a 22 de julho de 2005 - Anais suplementares. Disponível em: <http://www.anpuh.uepg.br/xxiii-simposio/anais/textos/KARINA\%20\%20ANHEZINI.pdf> Acesso em 20 de outubro de 2005.
} 
Mesmo quando não foram objeto principal dos textos publicados, os bandeirantes imiscuíram-se em alusões e entrelinhas nos textos da Revista do IHGSC dos anos 1940. Carlos da Costa Pereira debitou o domínio lusitano da "região das Araucárias" ao "espírito aventureiro e insofrido dos bandeirantes paulistas" ${ }^{\text {,66 }}$. Ildefonso Juvenal pôs em relevo os catarinenses que agiram como "ousados bandeirantes" e "vadearam o oceano verde dos pampas, escalaram rios caudalosos e embrenharam-se no emaranhado das selvas", entendendo terem sido os lagunenses "ousados continuadores da obra ingente e patriótica dos paulistas" (estes, por sua vez, heróis que "dilataram o território pátrio"). ${ }^{67}$ Até ao valorizar aqueles que, no seu entender, eram "os verdadeiros pioneiros do desbravamento e do povoamento inicial do território catarinense" - a saber, os caboclos - Osmar R. Silva, em 1943, identificou sua atuação como "ação bandeirante dos elementos nacionais", em especial "no desbravamento e povoamento do eixo e adjacências da estrada D. Francisca", no norte de Santa Catarina. ${ }^{68}$ E Othon d'Eça, em conferência, referiu-se a Alfredo d'Escragnolle Taunay como verdadeiro "bandeirante da emoção, um aventureiro da inteligência". 69

Nota-se ainda, na Revista do IHGSC de 1943-1944, o enfoque privilegiado (por meio de estudos ou da transcrição de documentos) de áreas do território catarinense onde a presença portuguesa (ou de descendentes) era majoritária e assinalável desde o período colonial. E o destaque para personagens de origem ou ascendência lusitana: foram apresentados aspectos das trajetórias de Manoel da Silva Mafra, Feliciano Nunes Pires, João Pedro Xavier da Câmara, João Machado de Souza, Lacerda Coutinho, arcipreste Paiva, Augusto Fausto de Souza, Wenceslau Bueno de Gouvêa e até mesmo Tomás Antônio Gonzaga (como a afirmar o caráter não exclusivamente "catarinense" das preocupações do periódico).

\footnotetext{
${ }^{66}$ RIHGSC, Florianópolis, $2^{\circ}$. sem. 1943, p.35.

${ }^{67}$ RIHGSC, Florianópolis, $2^{\text {o }}$. sem. 1943, p.178; RIHGSC, Florianópolis, $1^{\text {o }}$. sem. 1944, p. 155.

${ }^{68}$ SILVA, Osmar R. da. Pioneiros esquecidos, RIHGSC, Florianópolis, $2^{\circ}$. sem. 1943, p. 27.

${ }^{69}$ Conferência de Othon d'Eça sobre o visconde de Taunay. RIHGSC, Florianópolis, 1º . sem. 1944, p.93.
} 


\section{Narrar a história da pequena pátria catarinense}

Figura de destaque no Instituto desde os anos 1910 (ver Apêndice I-5), Henrique Fontes, em outubro de 1943, na condição de presidente da entidade, considerou:

Nem se pense que o Instituto, com se decorar com o nome de Histórico, quer viver só do passado e para o passado. Não nos congregamos só para possuir e catalogar coisas de museus nem para só memorar glórias pretéritas. Temos também olhos, corações e intelectos abertos para o presente e para o futuro e para eles é que, afinal, se dirigem as nossas iniciativas [...]. ${ }^{70}$

Nada mais distante do IHGSC, portanto, do que a idéia de estudos históricos (e geográficos) que fossem um fim em si mesmos, a alimentar prazeres mesquinhos de estudiosos e eruditos: nascido no período republicano, o Instituto, por meio de seus membros, pretendia servir a Santa Catarina, tendo compromissos com o passado, o futuro e o presente.

Há que lembrar que o IHGSC, como indicava sua denominação, tinha um horizonte essencialmente "catarinense", comprometido com a história e a geografia da região, algo que nem mesmo o recalque dos regionalismos promovido pelo governo de Vargas, em especial durante o Estado Novo, conseguiu alterar. Isso envolvia a recuperação sistemática de informações julgadas pertinentes ao passado histórico e ao espaço geográfico de Santa Catarina. Quanto às informações de caráter histórico (obtidas principalmente vasculhando os arquivos e coletando documentos), havia também a preocupação com sua disseminação, visando promover o espírito cívico e patriótico.

Neste sentido, durante a Primeira República os desafios do presente colocados aos sócios do Instituto referiram-se, em especial, à manutenção da identidade geográfica catarinense, quanto aos limites territoriais (em função de contestações e reivindicações feitas pelo Paraná e, em menor escala, pelo Rio Grande do Sul). Os sócios do Instituto empenharam-se em defender o que entendiam ser os verdadeiros limites territoriais de Santa Catarina. Para tanto, recorreram à história. José Arthur Boiteux, fundador do Instituto, viajou para Lisboa em fins de 1896, no intuito de levantar documentos que apoiassem as pretensões catarinenses na questão com o Paraná (documentos que seriam posteriormente utilizados no

\footnotetext{
${ }^{70}$ Saudação de Henrique Fontes na sessão especial em homenagem a Roger Bastide. RIHGSC, Florianópolis, $1^{\circ}$. sem. 1944, p.165.
} 
estudo elaborado por Manoel da Silva Mafra, e publicado em 1899: a Exposição históricojurídica por parte do Estado de Santa Catarina sobre a questão de limites com o Estado do Paraná, submetida, por acordo de ambos os Estados, à decisão arbitral, pelo advogado Conselheiro Manoel da Silva Mafra). Lucas Alexandre Boiteux, irmão de José Arthur, foi membro da comissão de demarcação de limites com o Estado do Paraná, entre 1918 e $1922 .^{71}$

A intenção de defender os legítimos limites territoriais de Santa Catarina também ficaria registrada na Revista do IHGSC: na decisão de republicar estudos produzidos no século XIX, de interesse para o estudo dessas questões (caso das "Cartas acerca da Província de Santa Catarina”, de José Gonçalves dos Santos Silva, que apareceram em vários volumes da Revista, entre 1913 e 1918), ou na divulgação de artigos dos sócios, como Vieira da Rosa ("Questão de limites”, publicado na Revista de 1916) e Lucas Alexandre Boiteux ("Limites com o Rio Grande", publicado em seis partes, entre 1917 e 1919). Para garantir a integridade do território catarinense, a história fornecia o fundamento do direito, e os arquivos, as provas: Lucas Alexandre Boiteux, quanto às questões territoriais de Santa Catarina com o Rio Grande do Sul, afirmou:

Por felicidade os nossos arquivos ainda guardam, embora maltratados pelo tempo, os documentos indispensáveis para a prova cabal do nosso direito. Corramos, pois, aos arquivos e, armados dos elementos indispensáveis, façamos face à desmedida pretensão do Estado gaúcho. [...] o nosso direito, escudado em documentos autênticos de mór valia, é histórico, honesto e incontestável. $^{72}$

Lucas Boiteux, um dos principais construtores, na primeira metade do século XX, de uma narrativa sobre a história de Santa Catarina, publicou, em 1912, livro que de imediato tornou-se referência (e que foi, inclusive, alvo de questionamentos, em alguns de seus aspectos, na Revista do IHGSC). Na abertura daquele livro - as Notas para a história catarinense $^{73}-$, a seguinte dedicatória:

\footnotetext{
${ }^{71}$ Cf.: CORRÊA, C.H.P. História da Cultura Catarinense..., op.cit., 1997; Aspectos da vida e da obra de Lucas Alexandre Boiteux..., op.cit., p.16. Convém destacar que o IHGSP teve preocupação similar, realizando "incursões analíticas que faziam uso da história para legitimar demandas territoriais em curso", fosse com o Paraná, com Minas Gerais ou com o Mato Grosso. Cf.: FERREIRA, Antonio Celso. A epopéia bandeirante: letrados, instituições, invenção histórica (1870-1940). São Paulo: Ed. da UNESP, 2002. p.113.

${ }_{72}$ BOITEUX, Lucas A. Limites com o Rio Grande. RTIHGSC, Florianópolis, $1^{\circ}$. trim.1918, p.78-79 e 88.

${ }^{73}$ BOITEUX, Lucas Alexandre. Notas para a história catharinense. Florianópolis: Typ. a vapor da Livraria Moderna, 1912.
} 
Ao Estado de Santa Catarina, meu berço natal -

Longe de ti, terra querida, eu precisava respirar uma atmosfera toda tua. $\mathrm{E}$ foi procurando conhecer o teu desenvolvimento histórico, que eu vivi em ti e matei as minhas saudades.

Amar Santa Catarina e narrar sua história eram ações que se confundiam: muito significativamente, uma das duas epígrafes do primeiro capítulo é de Fustel de Coulanges: "O verdadeiro patriotismo não é somente o amor à terra, mas o amor ao passado, o respeito pelas gerações que nos precederam." Terra e pátria tornadas indissociáveis: conforme Lucien Febvre, a palavra pátria "tem ressonâncias carnais e sentimentais profundas", evocando, de um lado, "a terra, esse grande ossuário dos mortos" ("terra patria" é, assim, a terra dos ancestrais, a terra que os nutriu antes de nutrir aos vivos") e, de outro, as experiências humanas que se prendem a ela (é a "substância vivida que preenche a noção da pequena pátria", bem como a noção de "grande pátria", permitindo sua evocação nostálgica). ${ }^{74}$

No prefácio àquele mesmo livro, Lucas Boiteux manifestou o desejo de que sua "modesta coletânea de notícias e apontamentos sobre a fecunda e pródiga terra catarinense" fosse "de algum modo útil à terra natal.,"75 Já na Pequena história catarinense, editada em 1920, Boiteux lançou mão, no prefácio, de duas citações de Émile Faguet, ambas tematizando o patriotismo:

O amor da pequena Pátria é a própria essência do patriotismo, porque a pequena Pátria é a que amamos instintivamente e que não precisa de ser admirável para ser admirada nem de ser amável para ser amada.

Pode o historiador não ser um patriota, mas, em que lhe pese, será um semeador de patriotas. $^{76}$

Eram, aliás, trabalhos preparados para uso escolar, com nítida intenção de, através da história de Santa Catarina, estimular o amor pela pequena pátria - esforço, aliás, em si mesmo patriótico.

\footnotetext{
${ }_{75}^{74}$ FEBVRE, Lucien. Honra e pátria. Rio de Janeiro: Civilização Brasileira, 1998. p.152-153.

${ }^{75}$ BOITEUX, Lucas Alexandre. Notas para a história catharinense...., op.cit. p. V-VI.

${ }^{76}$ BOITEUX, L.A. Pequena historia catharinense (adoptada oficialmente). Florianópolis: Officinas a elect. da "Imprensa Official", 1920. Um ano antes da publicação da Pequena história..., Lucas Boiteux publicou, pela editora Melhoramentos, de São Paulo, a História de Santa Catarina: resumo didático (adotado oficialmente). A História... seria reeditada, pela mesma editora, em 1930.
} 
A dedicação à terra natal marcou indelevelmente a historiografia ligada ao IHGSC, sobretudo durante a chamada Primeira República. E a história da terra natal era uma história "cordial", feita com o coração e prenhe de civismo e espírito público - de vontade de ser "útil", como disse Lucas Boiteux, de prestar serviço à comunidade mais ampla dos "patrícios". Não à toa, os sócios do Instituto, homens em geral dedicados às letras nas suas horas vagas, tinham suas ocupações principais freqüentemente ligadas à máquina pública, em seus vários níveis. E os discursos dos homens públicos, nos inícios republicanos, estavam caracterizados pela remissão constante ao empenho cívico e patriótico. Certamente não foi por acaso que Eliseu Guilherme da Silva, quando vice-presidente de Santa Catarina, encerrou sua mensagem à Assembléia Legislativa de Santa Catarina, em 1893, considerando ser a reunião dos deputados "auspiciosa para a pátria catarinense". ${ }^{77}$ Honra pessoal e honra à pátria eram bases da ética do funcionalismo público. A este propósito, interessa destacar que a Constituição do Estado de Santa Catarina de 1892, em seu artigo 66, dispunha:

No ato de posse do cargo os funcionários públicos prestarão a seguinte afirmação: "Por minha honra e pela Pátria prometo cumprir com a maior exatidão e lealdade os deveres inerentes ao cargo de ....., tendo sempre em vista o bem do Estado e a felicidade de meus concidadãos". ${ }^{78}$

O patriotismo, afeto cívico, era também viril, pronto ao combate: as metáforas bélicas estavam presentes na Revista do Instituto, referidas à ação de seus membros. Em discurso proferido na sessão solene de 24 de fevereiro de 1913, ressaltou Joaquim Thiago da Fonseca, orador oficial da entidade: "novos e valorosos combatentes se vêm arregimentar em nossas fileiras, robustecendo o esforço dos velhos legionários, que assim se sentem fortalecidos para enfrentar novos obstáculos." O orador, "em nome dos antigos soldados", felicitava "os novos companheiros" e, mais adiante, referindo-se especificamente ao desafio aberto aos historiadores, afirmava:

\footnotetext{
${ }^{77}$ Mensagem apresentada á Assemblea Legislativa do Estado de Santa Catharina pelo cidadão tenentecoronel Elyseu Guilherme da Silva, 1'. Vice-presidente do Estado, em 7 de agosto de 1893. Desterro: Gabinete Sul-Americano, s.d. p.16.

${ }^{78}$ Constituição do Estado de Santa Catarina de 1892. In: Collecção de leis do Estado de Santa Catharina 1892. Florianópolis: Gab. Typ. d'O Dia, 1914.
} 
[...] estamos muito longe de conhecer a nossa história.

Daqui, do nosso meio, sairão os primeiros dessa cruzada, que tomarão a si o encargo de ir estudando a nossa história, iluminando os fatos com o foco intensíssimo da verdade.

A história é, segundo uma parêmia vulgar, a grande mestra da vida, razão porque o seu estudo é uma necessidade palpitante, afim de que os contemporâneos possam receber os ensinamentos que o passado lhes transmite. ${ }^{79}$

Conforme discurso de Pedro Taulois, na mesma ocasião, os sócios não deveriam contentar-se com "colecionar mapas e documentos históricos", mas, à luz deles, orientaremse, "imitando tanto quanto possível a vida dos nossos maiores, mantidos seus feitos de nobreza, repudiados atos que nos pudessem ter deslustrado no passado." 80

A história exemplar, que toma o passado como norte do presente e do futuro, para autores como François Hartog teria começado a perder sua hegemonia em fins do século XVIII, cedendo lugar, ao menos até o último quartel do século XX, a uma história voltada para o futuro, em grande medida teleológica. O século XIX, em princípio, seria marcado pela plena vigência desse novo regime de historicidade - "moderno". ${ }^{81}$ No IHGSC, em inícios do século XX, a história exemplar parecia ser, entretanto, a concepção predominante. Era preciso ensinar por meio da história, pelo exemplo - e o exemplo vinha "dos maiores", que construíram com nobreza de feitos a história da terra natal. Nos números da Revista da década de 1910, os exemplos eram fornecidos principalmente por figuras ligadas à consolidação do território catarinense e de seu governo, ou relacionados a conflitos que de alguma forma colocaram esse território em xeque.

$\mathrm{Na}$ perspectiva da "história pátria" feita tanto no período imperial como nos inícios republicanos, a guerra era um dos momentos em que os exemplos poderiam ser colhidos em abundância. Historiadores do século XIX ligados ao Instituto Histórico e Geográfico Brasileiro destacaram-na como elemento formador do espírito patriótico,

\footnotetext{
${ }^{79}$ RTIHGSC, Florianópolis, $1^{\mathrm{o}} .2^{\circ}$. trim. 1913, p.119.

${ }^{80}$ RTIHGSC, Florianópolis, $1^{\circ} \cdot-^{\circ}$. trim. 1913, p. 105.

${ }^{81}$ HARTOG, François. O tempo desorientado - Tempo e História: "Como escrever a história da França". Anos 90, Porto Alegre, n.7, jul.1997. esp. p.8-11. Ver também: HARTOG, François. Régimes d'historicité: présentisme et experiénces du temps. Paris: Éditions du Seuil, 2003.
} 
considerando as leituras acerca das guerras (principalmente aquelas em que a "pátria" dos leitores estivesse envolvida) elemento estimulador do sentimento patriótico. ${ }^{82} \mathrm{Na}$ Revista do IHGSC, a guerra contemporânea não foi objeto de discussão alentada - nem a Segunda, nem a Primeira Guerra Mundial -, embora estivesse presente em notícias e alusões mais ou menos diretas (estas últimas feitas sobretudo em discursos e conferências). Mas os conflitos bélicos não deixaram de estar presentes. As guerras tematizadas foram, contudo, mais próximas no espaço, mais distantes no tempo, como as guerras do século XIX - a guerra contra o Paraguai, ou as "campanhas no sul", nos conflitos de fronteira com o domínio espanhol.

Sobre a guerra contra o Paraguai, os materiais contidos na Revista do Instituto, no período da Primeira Guerra Mundial, incluem um artigo de Laércio Caldeira e as cartas que o combatente Fernando Machado de Souza escreveu para a esposa. Há também, em 1917, destaque para a estátua de Fernando Machado de Souza, então recentemente inaugurada. ${ }^{83}$ Nos anos 1943-44, existem textos sobre o conflito no Paraguai em todos os quatro números: foram publicados os apontamentos de João Machado de Souza, oficial catarinense que nele combateu, além de artigo (não assinado) sobre o mesmo oficial. ${ }^{84}$ Referência à guerra contra o Paraguai também aparece em conferência sobre o marechal João Pedro Xavier da Câmara, feita por Custódio de Campos em maio de 1943 (nessa guerra "as nossas forças armadas cobriram-se de louros, consolidando ali a gente catarinense pela espada de seus bravos a conquista do epíteto glorioso de 'Barriga Verde'”) ${ }^{85}$ E em palestra de Othon d'Eça, sobre o visconde de Taunay, são feitos vários comentários acerca d'A Retirada da Laguna, inclusive o seguinte depoimento, precioso pela relação que estabelece entre história, narrativa, guerra e patriotismo:

\footnotetext{
82 Foi o caso de Joaquim Manoel de Macedo, em seus compêndios sobre a história pátria, publicados originalmente em 1861 e 1863, e que tomaram as guerras holandesas como referência da construção da nacionalidade. A guerra foi então concebida como panteão da nacionalidade (mostrando os "bons" e "maus" brasileiros) e instrumento de difusão do patriotismo. Cf. MATTOS, Selma Rinaldi de. O Brasil em lições. Rio de Janeiro: Access, 2000. esp. p. 109-112.

${ }^{83}$ CALDEIRA, Laércio. Contribuição para a história dos Voluntários da Pátria de Santa Catarina. RTIHGSC, Florianópolis, $1^{\circ}$. a $4^{\circ}$. trim. 1916. As cartas que o combatente Fernando Machado de Souza escreveu para a esposa estão na revista de 1913 e 1914 (RIHGSC, Florianópolis, $1^{\circ}$. e $2^{\circ}$. trim. 1913, e $1^{\circ}$. e $2^{\circ}$. trim. 1914). Para a estátua de Fernando Machado de Souza, ver: RIHGSC, Florianópolis, $1^{\circ}$. trim. 1917. No período, há também vários estudos e relatos sobre a República Juliana.

${ }^{84}$ Cf.: Campanha do Paraguai - apontamentos de um oficial catarinense (João Machado de Souza). RIHGSC, Florianópolis, $1^{\circ}$. e $2^{\circ}$. sem. 1943, p.109-124; $1^{\circ}$. e $2^{\circ}$. sem. 1944, p.65-75; O capitão João Machado de Souza, RIHGSC, Florianópolis, $2^{\circ}$. sem. 1943, p.123-125.

${ }^{85}$ RIHGSC, Florianópolis, $2^{\circ}$. sem. 1943, p.118.
} 
Eu confesso que foi em um livro de Taunay - essa epopéia sem igual nos fastos militares do mundo contemporâneo - a 'Retirada da Laguna' - que o meu patriotismo adquiriu uma consciência e a minha fé uma convicção.

Errando sem rumo e descrendo, aos vinte anos, do heroísmo que nos compêndios escolares, nos discursos dos políticos e nas odes oficiais estourava de adjetivos e de retórica - não mais perdia o meu tempo a folhear a patriótica paspalheira que procurava demonstrar a abnegação do alferes Xavier ou a tática de Barbacena no combate do passo do Rosário.

Para mim - e creio que para todos os rapazes do meu tempo - tanto fazia morrer em Itororó, de uma bala de canhão, como de uma chifrada nas virilhas na brincadeira do Boi-na-Vara.

[...] Foi com o espírito fora do meu país e da sua beleza histórica, que eu consegui ler, dominando largos escrúpulos e desconfiado como um bugre - a 'Retirada da Laguna'.

Quanta emoção!

Como me encheram de orgulho aqueles homens abnegados, aqueles bravos como não houvera iguais nem mesmo no Grande Exército e que pareciam saídos da galeria de Heróis de Carlyle!" ${ }^{\prime 6}$.

Para Othon d'Eça, Alfredo d'Escragnolle Taunay, n'A Retirada da Laguna, “foi o soldado que soube esculpir, com o cinzel da sua espada, a epopéia máxima da nacionalidade". 87

As referências à guerra contra o Paraguai estabelecem um elo importante entre esses dois momentos da Revista do Instituto - as edições durante a Primeira República e aquelas sob o Estado Novo -, permitindo entrever a permanência do sentimento patriótico, que manteve constante intercâmbio entre a "grande" pátria brasileira e a "pequena pátria" catarinense.

Como exemplo, pode-se destacar, na década de 1910, a fala de Joaquim David Ferreira Lima, na sessão solene de 24 de fevereiro de 1913, que marcava a retomada das atividades do Instituto: para ele, a entidade deveria "incitar e desenvolver por todos os meios a educação cívica, o respeito e o amor à Pátria.” A data da sessão solene aludia, inclusive, à da promulgação da Constituição federal, "uma das datas memoráveis da República

${ }^{86}$ Conferência de Othon d'Eça sobre o visconde de Taunay, op.cit., p.95.

${ }^{87}$ Ibidem, p.102. 
Brasileira". No seu entender, daí em diante o IHGSC deveria "comemorar solenemente as grandes datas nacionais":

Sim, meus senhores, é preciso isto! Pois é um crime de leso-civismo, de leso-patriotismo, deixar-se correr no indiferentismo e no olvido as datas gloriosas da História! ${ }^{88}$

Na década de 1940, é possível detectar o jogo entre "grande pátria" e "pequena pátria" nas palavras de Ildefonso Juvenal, que afirmou, em 1943, em sessão de recepção aos novos sócios: "quanto mais enraizado o amor ao céspede querido, tanto mais devotado o interesse pela grandeza da Pátria comum." 89 Palavras que ressoam, igualmente, as falas dos sócios na década de 1910, articulando combatividade patriótica e afeto à terra natal. Pois, segundo Ildefonso Juvenal, para ingressar no IHGSC

[...] Não basta que o indivíduo possua comprovada cultura: condição também essencial é que tenha alma, sentimento nitidamente catarinense, porque este augusto templo é a gloriosa caserna onde se exercitam os denodados legionários da pena, que, nos prélios gigantes e memoráveis da inteligência, hão de sempre lutar destemerosos em defesa do rico patrimônio da história da nossa terra. ${ }^{90}$

Ao menos até meados do século XX, o IHGSC procurou manter-se como pólo produtor e disseminador de uma história escrita e entendida com o coração, cujos incansáveis combatentes, de forma mais enfática ou não, batiam-se pelo seu estremecido torrão - a terra catarinense. $^{91}$

\footnotetext{
${ }^{88}$ RTIHGSC, Florianópolis, $1^{\circ} .2^{\circ}$. trim. 1913, p.104.

${ }^{89}$ RIHGSC, Florianópolis, $2^{\circ}$. sem. 1943, p.176.

90 Ibidem.

${ }^{91}$ Cabe ponderar que as metáforas bélicas, se podem traduzir uma certa compreensão de patriotismo e civismo, também podem indicar o peso da guerra nas reflexões de quem vivenciou seus efeitos ou a conheceu por dentro: impossível não lembrar de Lucien Febvre e seus "combates pela História". Em Honra e pátria, Febvre, ao criticar os "velhos teóricos da história com vista curta", que acreditavam poder escapar de criações como a da "França", enquanto noção abstrata personificada, "professando doutamente: fujamos das abstrações personificadas", considerou: "O historiador tem tanto que fugir, quanto o soldado no campo de batalha. $O$ historiador, quando está no seu campo de batalha, deve ir à luta. Ele deve aprisionar a abstração personificada $\mathrm{e}$ tirar dela, por bem ou por mal, todas as informações de que precisa, o que vai, sem dúvida, levá-lo bem longe." FEBVRE, Lucien. Honra e pátria..., op.cit., p.47. Grifos meus.
} 


\section{Pátria narrada: amar, honrar, defender}

Durante a segunda metade do século XX, teriam ocorrido mudanças significativas na produção de caráter histórico do IHGSC, e na própria concepção de História ali hegemônica? Afinal, nesse período foram criados cursos de graduação em História, universidades, um curso de pós-graduação em nível de Mestrado - o Instituto deixou de ser o lugar por excelência da produção histórica, em Santa Catarina. Como o IHGSC teria lidado com esse cenário?

Novamente, a Revista do IHGSC, retomada a partir de 1979, pode oferecer algumas respostas. No primeiro número da " 3 a fase" do periódico, o sócio Carlos Humberto Corrêa, que em 1977 concluíra o Mestrado em História na Universidade Federal de Santa Catarina, anunciava uma mudança, uma inovação decisiva (embora não exatamente uma ruptura brusca): a nova fase da revista expressaria uma história "científica", passando a substituir a "história romântica" dos momentos anteriores do Instituto" ${ }^{92}$ Uma história científica atrelada a "metodologias próprias", manipuladas por novos sócios, "quase que todos professores universitários". Leia-se: uma história "profissional" (sob a influência da profissionalização dos estudos históricos, em função da Universidade e, antes dela, da Faculdade de Filosofia), distante dos tempos da história diletante que os homens de letras do Instituto tentaram construir em tempos outros.

A ambição de "cientificidade" - consolidada, supostamente, pela presença de historiadores "profissionais" nas páginas da Revista - em um primeiro momento conferiu maior visibilidade às pesquisas na área de história demográfica, de história econômica, de história política (áreas, então, contempladas no Mestrado em História da UFSC), em detrimento das notícias que se referiam estritamente ao próprio Instituto. Esse quadro foi sendo gradualmente modificado em meados da década de 1980, com a inserção de um número maior de informes sobre a entidade (notícias sobre atividades promovidas; transcrição de discursos e conferências; notas biográficas sobre sócios falecidos na seção "In Memoriam"). Com isso, uma presença mais e mais significativa dos pesquisadores diletantes, sem formação universitária específica em História ou Geografia.

\footnotetext{
92 “A Geografia e a História romântica[s] estudadas no passado, necessárias e importantes para uma época, dão lugar à História e à Geografia científicas do presente, com o fim de trazer à luz e de estimular novas pesquisas e trabalhos.” RIHGSC, Florianópolis, $3^{\mathrm{a}}$. fase, n.1, 1979, p.3.
} 
Assim, em 1992, toda a parte inicial da Revista do IHGSC passa a ser dedicada ao seu "ano acadêmico", ou seja, aos discursos proferidos nas sessões solenes, às conferências, às palestras, às mesas-redondas - promovidas, quase sempre, por ocasião de efemérides (centenários de nascimento/falecimento de autores catarinenses, aniversários de acontecimentos considerados marcantes, homenagens prestadas a figuras ilustres etc). ${ }^{93}$ Sintomaticamente, os artigos originados de pesquisas passam a ser englobados na seção "Colaborações especiais", inseridos entre a parte dedicada ao "ano acadêmico" e aquela dedicada ao obituário relativo aos sócios, à identificação da diretoria e à relação de membros. Nos anos finais da década de 1990, as rubricas "História" e "Geografia" voltaram a reunir artigos nas páginas iniciais da Revista, mas estes textos tiveram espaço reduzido, se comparado ao dedicado às "Solenidades e discursos", às "Notas e comentários" (geralmente alusivos ao Instituto) e aos dados biográficos reunidos na seção "In Memoriam”.

A análise dos anos mais recentes da Revista indica que o Instituto Histórico e Geográfico de Santa Catarina, nas duas últimas décadas, discutiu aspectos da história catarinense e, antes de tudo, recordou, homenageou, comemorou - voltando-se também, cada vez mais, para a comemoração de sua própria trajetória histórica.

E quanto à perspectiva patriótica? Teria desaparecido da fase mais recente da Revista do IHGSC, como poderíamos suspeitar, a partir das afirmações anteriormente citadas de Carlos Humberto Corrêa?

Se o termo "pátria" é menos presente, nos textos e discursos dos membros do Instituto das últimas décadas, a perspectiva patriótica de alguma forma pode ser detectada nas discussões que, em seu âmbito, a partir dos anos 1970, problematizaram a diversidade geográfica, étnica e cultural de Santa Catarina (percebida, com preocupação, como causadora de fragmentação e isolamento). Buscou-se, assim, pensar possibilidades de integração. Tais reflexões articularam-se àquilo que alguns denominaram de "catarinensismo", podendo-se dar relevo, neste ponto, às discussões promovidas por Celestino Sachet, Theobaldo Costa Jamundá e Victor Peluso Jr.

\footnotetext{
${ }^{93}$ Podem ser citados, por exemplo: "Centenário de Altino Flores", "Centenário do Prof. Trindade”, "Centenário do Prof. Alfredo X. Vieira”, "Centenário do Instituto Estadual de Educação”, "Centenário do jornalista Osvaldo Melo", "Centenário de Bayer Filho", "Centenário de Ildefonso Juvenal”, "Centenário de D. Jaime de Barros Câmara", "Centenário de Irineu Bornhausen", "Bicentenário de Santos Silva". Ressalte-se que, nos eventos então promovidos, não foram, em geral, os jovens pesquisadores universitários (mesmo sendo sócios do Instituto) aqueles que falaram em seu nome.
} 
Em texto de 1970, Celestino Sachet, convocado a discutir a literatura catarinense, indagou sobre a existência efetiva de um espaço catarinense, dada a constatação de áreas isoladas ("ilhas"), sem comunicação: a planície litorânea, as serras, os campos gerais, o vale do Itajaí, a Serra Geral. E questionou: "Como querer, portanto, um homem catarinense, dentro destas ilhas de gente perdidas por aí? [...] Então, de onde querer alma catarinense? De onde querer extrair um homem catarinense?" 94

Theobaldo Costa Jamundá, em estilo singular, em 1974 publicou livro que anunciava a idéia de "mosaico cultural" - ou "painel", como sugere. Pernambucano, Jamundá preparara o trabalho "na ambição de constar como bibliografia de amor à terra de Santa Catarina." 95 Amor que aparecia como chave possível para identificar entre si os diferentes sujeitos vivendo em seu território. Seu texto salienta a diversidade cultural catarinense, frisada como diversidade étnica:

O painel catarinense sai de um caldeirão onde ebuliu [sic] elementos e elementos no processo do povoamento e neste participaram paulistas e gaúchos autênticos; estrangeiros europeus e descendentes de imigrantes - em maioria - também europeus. A contribuição da raça negra é fracamente percebida onde o vicentista, perto da metade do século XVIII, plantou as povoações de Desterro, São Francisco e Laguna. ${ }^{96}$

Retomando, catorze anos depois, o texto de Sachet, o geógrafo Victor Peluso Jr., então presidente do IHGSC, problematizou a "identidade catarinense", relacionando-a ao "catarinensismo" e à "catarinização". 97 Forjada pelos "hábitos culturais e políticos" que marcariam "a comunidade que vive dentro dos limites do Estado de Santa Catarina", a identidade catarinense articulava-se, no entender de Peluso Jr., tanto à "aceitação desses vínculos comunitários" (“catarinensismo”) como aos "processos de atração, para o seio da comunidade, da parte do povo que se encontre dela afastado" (“catarinização"). ${ }^{98} \mathrm{Na}$ análise de Peluso, as fragilidades da identidade catarinense eram indicadas, em várias regiões, por baixos índices de catarinensismo (ou, a rigor, de sentimento de pertencimento a um coletivo

\footnotetext{
${ }^{94}$ SACHET, Celestino. Fundamentos da literatura catarinense. In: SILVA, Jaldyr B. Faustino da. Fundamentos da cultura catarinense. Rio de Janeiro: Laudes, 1970. p.80-83.

95 JAMUNDÁ, Theobaldo Costa. Catarinensismos. Florianópolis: UDESC, EDEME, 1974. p.16.

${ }^{96}$ Ibidem, p.43.

${ }_{97}^{97}$ PELUSO JR., Victor A. A identidade catarinense. RIHGSC, Florianópolis, $3^{\text {a }}$. fase, n.5, 1984, p.259-280.

${ }^{98}$ Ibidem, p.259.
} 
“catarinense"), e em grande medida justificadas pela trajetória histórica das relações entre os cidadãos e os governos (a percepção de afastamento ou isolamento, dada a ausência ou o pequeno número de ações do poder público estadual em prol de certas localidades). ${ }^{99}$ Em Peluso, o catarinensismo surge como sentimento que existe se estimulado - o estímulo partindo, sobretudo, do Estado. Daí que, para Peluso, as ações governamentais (do governo estadual catarinense, em princípio) tivessem papel-chave na difusão do catarinensismo e, por consequiência, no fortalecimento da identidade catarinense.

Em sentido amplo, uma dimensão patriótica também estava presente no discurso de posse de Carlos Humberto Corrêa como presidente do IHGSC, em 1997. Apesar de propor uma série de mudanças em orientações que prevaleceram durante muitos anos na entidade, o novo presidente, ao detectar responsabilidades para o Instituto - nas dimensões ética, científica, social, política, acadêmica - revisitou o empenho cívico-patriótico presente na entidade desde os seus primeiros tempos: defender os "valores mais expressivos da identidade catarinense", analisar "questões fundamentais da realidade catarinense", difundir os conhecimentos gerados, inclusive para subsidiar ações na resolução de problemas do presente. $^{100}$

Outro tema candente, na trajetória do Instituto - a definição dos limites do território e a defesa de sua integridade -, também foi retomado com força na fase mais recente da trajetória da instituição, a partir dos debates em torno do "Estado de Iguaçu".

Elaborado, em 1991, projeto de decreto legislativo que propunha a realização de plebiscito sobre a criação do Estado do Iguaçu, em áreas dos territórios de Santa Catarina e Paraná, o Instituto não só lançou um manifesto sobre a questão, em julho daquele ano, como preparou estudo encaminhado três meses depois ao governador do estado, Vilson Kleinubing. ${ }^{101}$

No manifesto, em termos similares aos de discursos e textos de membros do Instituto em décadas mais recuadas, a entidade denunciou o projeto, "não apenas aos catarinenses e paranaenses, mas a todos os brasileiros", como "crime de lesa-pátria, com

${ }^{99}$ Um exemplo extremo era dado pelo município de Porto União, cujos serviços públicos básicos eram de responsabilidade de empresas e órgãos públicos do Paraná.

${ }^{100}$ Discurso de posse do presidente do IHGSC, Carlos Humberto P.Corrêa. RIHGSC, Florianópolis, $3^{\mathrm{a}}$. fase, n.16, 1997. p.151-152 e 160-161.

${ }^{101}$ Cf.: Estado do Iguaçu, um crime contra Santa Catarina - Manifesto do Instituto Histórico e Geográfico de Santa Catarina. Florianópolis, 10 de julho de 1992; Projeto Estado do Iguaçu - análise feita pelo Instituto Histórico e Geográfico de Santa Catarina. Florianópolis, outubro de 1992. Acervo da Academia Catarinense de Letras, Dossiê Walter F. Piazza. Walter Piazza era, naquele momento, presidente do IHGSC. 
premeditação". Um "território do Iguaçu" já havia existido, entre 1943 e 1946, à época justificado por razões de segurança nacional. Apontando investimentos do governo estadual na região (situada a oeste), o manifesto declarou serem falsos os argumentos que indicavam a ausência governamental na área, afirmando que as verdadeiras razões da proposta ligavam-se à intenção de "organizar um imenso "trem-de-alegria", decorrente dos vários cargos públicos de alto escalão que seriam necessariamente criados e preenchidos. ${ }^{102}$ A mobilização patriótica escorava-se, sintomaticamente, também no argumento da traição, perpetrada por nãocatarinenses: em defesa de Santa Catarina, o Instituto procurava "levantar a opinião pública do Estado contra meia dúzia de aventureiros" (caracterizados, aliás, no início do manifesto, como um "grupo de alienígenas"), traidores da "terra que os abrigou e os enriqueceu". E, dando mostras de uma tradição de engajamento do Instituto nas causas catarinenses, bem como de seu compromisso com o presente, o passado e o futuro, o manifesto declarava:

Não vamos, pois, permanecer apenas na postura de observadores dos acontecimentos para depois cuidar de historiá-los. Seria manter o Instituto de costas para o futuro e tratando apenas de fatos consumados.

Resta-nos, pois, esperar que as forças vivas da sociedade catarinense se aliem a este Instituto nesta luta! ${ }^{103}$

No estudo, elaborado com a intenção de "ajudar os órgãos competentes, para fundamentação do documento oficial do Governo Catarinense", ${ }^{104}$ foram retomados, aprofundados e fundamentados os argumentos do manifesto. Também reapareceu, curiosamente, a tese de Oswaldo Cabral sobre a contribuição de Laguna para a formação do Rio Grande do Sul. ${ }^{105}$ Um elemento novo: a associação entre a proposta de criação do Estado de Iguaçu e os projetos separatistas que se manifestavam na região sul.

[...] os separatistas que, hoje, querem um novo Estado, são, à exceção de alguns, os mesmos que advogam, à sombra ou na penumbra, as temerárias

\footnotetext{
${ }^{102}$ Estado do Iguaçu, um crime..., op.cit., fls. 1, 3-4,

${ }^{103}$ Ibidem, fls. 5-6.

${ }^{104}$ Ofício n.216/92, do presidente do IHGSC, Walter Fernando Piazza, ao governador do estado, Vilson Pedro Kleinubing. Florianópolis, 16 de outubro de 1992. Acervo da Academia Catarinense de Letras, Dossiê Walter F. Piazza.

${ }^{105}$ Projeto Estado do Iguaçu - análise feita pelo Instituto Histórico e Geográfico de Santa Catarina..., op.cit., fl.1.
} 
idéias de formação de uma nova Nação no atual e queira Deus para sempre Brasil Meridional. ${ }^{106}$

O Instituto, conseqüentemente, posicionava-se a favor da manutenção da integridade territorial catarinense (um dos elementos fundamentais da "pequena pátria", ao lado da sua "gente" e dos seus costumes e tradições), bem como da manutenção da unidade territorial brasileira.

O interesse pelos costumes catarinenses (que, a partir de fins dos anos 1940, fora modulado para a pesquisa relacionada ao "folclore") e, mais antigo e fundamental, o interesse pelos documentos para a história de Santa Catarina, transmutaram-se, em parte, também em ações de defesa - no caso, de defesa do patrimônio cultural catarinense.

Quanto à relação dos historiadores do Instituto com os documentos - em especial, os documentos de arquivo -, foi delineada com força em vários momentos, nas páginas da sua Revista.

Abrigada na Revista Trimensal do Instituto Histórico e Geográfico de Santa Catarina, a única polêmica presente nessa publicação, nos anos de 1910, girou em torno da seguinte questão: quando teria sido criada a freguesia de Desterro, na capitania de Santa Catarina? ${ }^{107}$ Tratava-se de esclarecer os inícios da organização de um dos principais núcleos de povoamento da região, tornado capital - capital da capitania, da província, do Estado. E a preocupação com os "inícios" era grande entre tais pesquisadores - com os "inícios" da administração da capitania de Santa Catarina, das suas povoações, da sua colonização e, conseqüentemente, com os pioneiros, os primeiros povoadores, os primeiros administradores e governantes. Divergências quanto àquela data de criação mobilizaram Lucas Alexandre Boiteux, Jacinto de Mattos e Henrique Fontes. Nas Notas para a história catarinense, Boiteux apontara a data de março de 1732, contestada por Mattos e Fontes, com base na existência de um livro de casamentos da Paróquia de Desterro iniciado em 1714, e firmado por frei

\footnotetext{
${ }^{106}$ Ibidem, fl. 11-12. Em fins dos anos 1980 e inícios dos anos 1990, movimentos separatistas emergiram com força no país. Entre os que surgiram no sul, teve grande penetração em Santa Catarina o movimento "O Sul é o meu país”. A respeito, ver: FALCÃO, Luiz Felipe. op.cit., p.283-357. Luiz Felipe Falcão, em nota, e apoiado em dissertação de mestrado de Raquel Mombelli, indicou que parte significativa da população da área abarcada pela proposta do Estado de Iguaçu manifestava-se favoravelmente à idéia de sua criação. A aprovação vinha sobretudo de grupos de ascendência italiana provenientes do Rio Grande do Sul, que viviam "um processo de resignificação da sua identidade cultural, mesclando gauchismo e italianidade" (p.346, nota 17).

107 Ressalte-se que a polêmica não foi de conhecimento apenas dos leitores da Revista Trimensal do IHGSC: antes de ser nela publicado, o artigo de Lucas Alexandre Boiteux, que a integra, apareceu no semanário A Época (conforme RTIHGSC, Florianópolis, $1^{\circ}-4^{\circ}$. trim. 1919, p.10).
} 
identificado como vigário da matriz. Havia, portanto, segundo aqueles pesquisadores, um documento de arquivo que "provava" a existência da freguesia antes de 1732, sendo necessário corrigir o erro de Boiteux, o quanto antes. ${ }^{108}$

Entre as várias facetas instigantes dessa polêmica, no que tange ao ofício de historiador, conviria reter, além da percepção do documento de arquivo como elemento de prova, as manifestações acerca do estado dos arquivos públicos e do acesso a eles.

Em meio à polêmica, Lucas Boiteux - que era oficial da Marinha, tendo estado distante de Santa Catarina em vários momentos de sua vida - forneceu o seguinte depoimento a seus leitores catarinenses, seus "patrícios":

Como sabem, as minhas 'Notas' [as Notas para a história catarinense] são um simples ensaio de principiante. Quando comecei a coligir dados e documentos para elas, encontrava-me distante daqui e somente nos pontos a que minha profissão me levava conseguia fazer pesquisas em arquivos e bibliotecas. Nas poucas vezes que à nossa terra aportei, antes de publicá-las, não havia ainda conseguido transpor, com a relativa facilidade que hoje, graças à gentileza de vários patrícios, encontro, os sombrios umbrais dos nossos arquivos. ${ }^{109}$

Ressaltou os obstáculos à consulta ao arquivo municipal de Florianópolis obstáculos que, tudo indica, foram oferecidos por autoridade municipal (alguém que depois precisou de suas "pobres 'Notas' para rechear um relatório assaz florido"). Reconheceu, entretanto, o prejuízo que isso teria causado à sua pesquisa: "o meu trabalho ressente-se em vários pontos dessas fontes tão preciosas". 110

"Os sombrios umbrais" dos arquivos de Santa Catarina - foi essa a expressão utilizada por Lucas Boiteux. Mais ou menos difíceis de transpor, segundo seu depoimento, conforme o maior ou menor grau de "gentileza" daqueles que tinham poder de autorizar a

\footnotetext{
${ }^{108}$ Segundo Jacinto de Mattos, "uma excursão pelos velhos registros ainda existentes nos arquivos de nossas igrejas", que para muitos poderia parecer "lida estéril e improfícua", trazia a oportunidade de rever determinados aspectos dos estudos sobre a história de Santa Catarina - ou, mais especificamente, "oportunidade do confronto com datas e incidentes históricos, tidos como líquidos e consumados em livros de reputação feita." MATTOS, Jacinto de. Material Histórico - II. RTIHGSC, Florianópolis, $1^{\circ}$. trim. 1918, p.67.

${ }^{109}$ BOITEUX, Lucas Alexandre. Commentários á História Catharineta. RTIHGSC, Florianópolis, $3^{\circ}$. trim. 1918 , p. 329.

${ }^{110}$ Ibidem.
} 
consulta dos documentos. Já em estudo também publicado na Revista, acerca das Caldas do Cubatão, outro sócio do Instituto, Ismael da Rocha, comentara que, tendo coligido "antigos e preciosos manuscritos que jaziam ignorados no Arquivo da Secretaria do Governo e na Biblioteca Pública", além de outros materiais que lhe foram "obsequiosamente confiados", considerou oportuno de alguma forma divulgá-los, dado que tais "documentos esparsos" não se achavam "ao alcance de todos". 111

Gentileza, para Boiteux, ou obséquio, para Ismael da Rocha - uma e outro remetiam ao domínio das práticas de favor, distantes de uma lógica propriamente "republicana" que, por suposto, deveria ter se instalado em fins do século XIX, ao menos nos órgãos governamentais, e que em princípio garantiria acesso equânime dos cidadãos à coisa pública. Cabe reter esse ponto, para que possa ser retomado nos capítulos seguintes.

Mas o que mais pode ser encontrado na Revista do IHGSC sobre os arquivos existentes em Santa Catarina?

Nos vários momentos da Revista, as indicações neste sentido ressaltam em geral seu estado de extrema desorganização e péssimo estado de conservação. Nos primeiros anos, os comentários a respeito são feitos principalmente por Lucas Boiteux e Henrique Fontes. Em 1918, as referências foram pontuais mas persistentes: falou-se nos "documentos esquecidos já em nossos confusos arquivos"112; nos "infelizmente, já desfalcados arquivos estadual, municipal e eclesiástico"113; em documento de meados do século XVIII "de tal modo cortado pelas traças que é impossível ler-se". ${ }^{114}$ A mais significativa foi feita por Henrique Fontes: em discurso pronunciado em março de 1913, informou que ele e Lucas Boiteux haviam buscado o primeiro livro de vereanças de Desterro. Em vão, contudo, revolveram "a montoeira dos livros do arquivo municipal”, pois “o volume desejado não apareceu”. E acrescentou, em seguida, uma denúncia e uma proposta:

Deus sabe se [o livro de vereanças] não foi queimado ou despedaçado por velho e inútil, o que não é de admirar, pois crimes desta natureza - crimes

\footnotetext{
${ }^{111}$ ROCHA, Ismael. Caldas da Imperatriz (Caldas do Cubatão) na Província de Santa Catarina. RTIHGSC, Florianópolis, 1916, p.3.

112 Nota bibliográfica, provavelmente escrita por Lucas Alexandre Boiteux. RTIHGSC, Florianópolis, $1^{\circ}$. trim.1918, p.114.

${ }^{113}$ BOITEUX, Lucas Alexandre. Commentários á História Catharineta. op.cit, p. 327.

${ }^{114}$ Novamente, Lucas Alexandre Boiteux. RTIHGSC, Florianópolis, 4º trim. 1918, p.450.
} 
sim, e de lesa-história - já foram, há anos passados, perpetrados no arquivo do Governo Estadual e na Biblioteca Pública.

Eis aí uma lição dolorosa que nos deve trazer proveito, incitando-nos a salvar dos arquivos, por meio da impressão, documentos preciosos, já carcomidos pelas traças e quase inutilizados pela umidade, e que, mais dia menos dia, se perderão sem remédio. ${ }^{115}$

Na década de 1940 os comentários sobre a situação dos arquivos catarinenses estiveram ausentes da Revista e, no período posterior a 1979, foram poucos. Um deles surgiu em discurso de Pascoal Apóstolo Pítsica, no 90. aniversário do Instituto, em 1986, quando, após referir-se a obra de Almeida Coelho publicada em 1797, de passagem afirmou:

Bem possível que existissem outros documentos esparsos em arquivos, onde estivessem recolhidos papéis antigos secularmente armazenados, capazes de reconstituir, com maior fidelidade, nosso passado de dominação lusitana. Infelizmente muita coisa se perdeu... ${ }^{116}$

Dois anos antes, debateu-se a devolução, ao Governo de Minas Gerais, de livro do século XVIII que integrava o acervo da Biblioteca Pública Estadual de Santa Catarina (a constituição dos EUA, em francês, que supostamente pertencera a Joaquim José da Silva Xavier). O IHGSC assim se manifestou:

A obra que pertenceu a Tiradentes é inestimável relíquia do Povo Brasileiro, e como parte deste povo, deveríamos conservá-la entre nós. [...]

Nosso Estado é pobre de documentos e monumentos que lembrem os episódios da nossa história nacional. O dever do Estado de Santa Catarina é de conservar as relíquias que lembram os grandes vultos da nacionalidade e aumentar o acervo de testemunhos históricos de toda natureza para a elevação e educação do povo.

[...] Não condenamos a entrega feita, porém, porque estamos, em Santa Catarina, completamente despreparados para zelar pelo nosso patrimônio

${ }^{115}$ Discurso proferido por Henrique da Silva Fontes na sessão comemorativa do $187^{\circ}$. aniversário da criação da vila de Nossa Senhora do Desterro, em 26 de março de 1913. RTIHGSC, Florianópolis, $1^{\circ} .2^{\circ}$. trim. 1913, p.117.

${ }^{116}$ RIHGSC, Florianópolis, $3^{\mathrm{a}}$. fase, n.7, 1986-1987, p.245. 
histórico. [...] Em todo o território catarinense nossos arquivos são destruídos, e mesmo em nossa capital importantes documentos da nossa história têm sido devastados. Nossa Biblioteca Pública não tem instalações próprias [...]. Nosso Instituto Histórico e Geográfico, que possuía uma das maiores bibliotecas da cidade e numerosas relíquias históricas, quase tudo perdeu quando ruiu o prédio em que se encontrava instalado.

O 'livro de Tiradentes' pertence à Nação Brasileira. Sabe-se que em Minas Gerais terá os cuidados de que se faz merecedor. Nosso desejo, registrando o episódio, é que ele sirva para lembrar as nossas autoridades que Santa Catarina tem o dever sagrado, perante o Brasil, de também zelar por sua história e sua cultura. ${ }^{117}$

São claras as pontes com os ideais esposados pelos primeiros membros do Instituto: documentos como "relíquias", preocupação com os "grandes vultos" do passado, "testemunhos históricos" como instrumento de educação do "povo", conservação das expressões da cultura como "dever sagrado". Contudo, o dever, em Santa Catarina, não vinha sendo cumprido: perdiam-se bibliotecas e arquivos.

Impotente para zelar por aquilo que deveria ser objeto dos cuidados das "autoridades" governamentais de Santa Catarina, o Instituto tentou, ao longo dos anos, seguir o que Henrique Fontes apontara, em 1913, como missão da entidade: "salvar dos arquivos, por meio da impressão", os documentos preciosos em estado avançado de deterioração. A publicação de documentos de arquivo foi intensa no período da Revista Trimensal, entre 1902 e 1920; menor, mas ainda significativa nos anos 1940; irrisória na fase posterior - o que pode ser explicado, talvez, em função da existência, àquela altura, de alguns arquivos formalmente instituídos, em especial o Arquivo Público do Estado de Santa Catarina. Mais recentemente, há um esforço de publicar, na coleção "Catariniana", estudos sobre Santa Catarina ou memórias de pessoas que tiveram atuação destacada no estado - em geral, inéditos, cujos manuscritos integram o acervo do Instituto. ${ }^{118}$

Por fim, como a confirmar uma importante continuidade, manifestações claras de amor pela "pequena pátria" são localizáveis em três autores ligados ao IHGSC e que, em

\footnotetext{
${ }^{117}$ Um capítulo da história recente do Estado de Santa Catarina. RIHGSC, Florianópolis, 3ª fase, 1984, p.15.

${ }^{118}$ Depoimento de Carlos Humberto Pederneiras Corrêa, em 4 de novembro de 2005 - versão transcrita. Fl. 3. Arquivo pessoal de Janice Gonçalves.
} 
diferentes momentos, também se dedicaram a escrever histórias "gerais" de Santa Catarina: Lucas Alexandre Boiteux, Oswaldo Rodrigues Cabral e Walter Fernando Piazza. Mais pontualmente, nos dois últimos, e profusamente, no primeiro.

Piazza (sobrinho de José Arthur, Henrique e Lucas Alexandre Boiteux, todos historiadores ligados ao Instituto), no início da década de 1980 considerou que "ser catarinense não é, somente, nascer em Santa Catarina, é entregar-se totalmente, é enaltecer, pelo trabalho, pela inteligência, a Terra Catarinense."119 Já Cabral, ao término do livro Santa Catarina (História-Evolução), publicado em 1937, comentou:

Povo generoso, bom e trabalhador, pacífico e tímido, o catarinense, que viveu todas estas páginas que integram a História da Pátria, espera confiante a grandeza da sua terra, dentro da comunhão brasileira, com o ânimo feliz dos que trabalham por ela, vivem e sofrem com ela, amando-a, servindo-a, honrando-a. ${ }^{120}$

Em História de Santa Catarina - que escreveu em fins da década de 1960 -, Cabral mencionou a impossibilidade de incluir em suas páginas, dados os limites da publicação, "a constelação de astros de primeira grandeza que na vida nacional projetaram a pequena e querida Santa Catarina."121

E Lucas Boiteux, com suas "Achegas para a bibliografia e cartografia catarinenses", publicadas na Revista do IHGSC em 1913, esperava "interessar os curiosos, incitando-os a uma farta colheita, em bem do conhecimento da terra natal", de modo que se pudesse ter,

[...] dentro de breve tempo, assinaladas todas as fontes e mananciais donde dimana, toma vulto e se expande a serena e límpida corrente, que é a singela e pitoresca história de nosso estremecido torrão. ${ }^{122}$

Continuidades e descontinuidades são, portanto, perceptíveis na trajetória do Instituto Histórico e Geográfico de Santa Catarina. Os historiadores ligados a ele, freqüentemente com formações distintas, ocupações várias e posicionamentos políticos

${ }^{119}$ PIAZZA, Walter F. Catarinensismo. In: Aspectos da vida e da obra..., op.cit., p.31.

${ }^{120}$ CABRAL, Oswaldo R. Santa Catharina..., op.cit., p.438.

${ }^{121}$ CABRAL, Oswaldo R. História de Santa Catarina. 4 ed. Florianópolis: Lunardelli, 1994. p.361.

122 BOITEUX, Lucas Alexandre. Achegas para a bibliografia e cartografia catarinenses. RTIHGSC, Florianópolis, $1^{\circ}$. e $2^{\circ}$. trim. 1913, p. 24 . 
conservadores, não adotaram uma única maneira de escrever a história: nem apenas dedicaram-se à história política, nem somente à história dos "grandes homens", nem mesmo à uma exclusiva "história-batalha". Tendo em seus quadros, durante muito tempo (até aproximadamente os anos 1960), apenas diletantes, que ocupavam-se da história nas horas vagas de suas ocupações principais, passaram, nas últimas décadas, a compartilhar espaço com graduados e pós-graduados em História. Continuou a predominar no Instituto, todavia, uma ética cívico-patriótica. E aí reside uma diferença apreciável em relação à chamada "nova geração". 


\section{Parte I}

Capítulo 3

\section{"Novos" e "velhos": ser historiador em Santa Catarina}

Querelas entre "novos" e "velhos" marcaram a trajetória de muitas sociedades, em diferentes momentos, várias delas tendo ficado célebres - na Europa, no século XIV, o movimento musical da Ars Nova afirmando-se contra a Ars Antiqua, ou a oposição literária entre "antigos e modernos", no século XVII. ${ }^{1}$ Tensões que opuseram concepções e gerações.

Em Santa Catarina, esses confrontos, aqui já abordados na perspectiva dos debates atuais na historiografia, também existiram em relação a outros campos e em outras épocas. Entre os mais conhecidos, o confronto dos adeptos da "Idéia Nova" (Cruz e Sousa, Virgílio Várzea, Santos Lostada, Araújo Figueiredo) que, na década de 1880, influenciados pelos naturalistas, opuseram-se aos literatos românticos locais (Lacerda Coutinho, Eduardo Nunes Pires). Mais tarde, nas primeiras décadas do século XX, emergiram os jovens escritores parnasianos que, à frente da revista Terra (tendo Altino Flores como um de seus principais articuladores, além de Barreiros Filho, Laércio Caldeira e Othon d'Eça), fundariam a Sociedade Catarinense de Letras, depois transformada em Academia Catarinense de Letras. Como valorizavam os escritores da "Idéia Nova", sua "novidade" era representada principalmente por sua juventude, e a oposição básica foi estabelecida entre "mestres" e "pequenos". No final da década de 1940, a geração de Altino Flores seria questionada severamente pelos "modernos" do Grupo Sul (na imprensa, à época, as disputas verbais entre ambos os grupos foram descritas como conflitos entre "novos" e "velhos"). ${ }^{2}$ Como se observa, os "velhos" de hoje são, em geral, os "novos" de ontem.

Tornados famosos, os embates carregaram consigo, quase sempre, relatos de destempero verbal e até mesmo de agressões físicas entre os contendores. Assim, Virgílio Várzea e Eduardo Nunes Pires teriam ido "às vias de fato" por conta de farpas dirigidas pelo

\footnotetext{
${ }^{1}$ LE GOFF, Jacques. Antigo/moderno. In: -. História e memória. Campinas (SP): UNICAMP, 1996. esp. p.174-179.

${ }^{2}$ SACHET, Celestino. As transformações estético-literárias dos anos 20 em Santa Catarina. Florianópolis: UDESC, Edeme, 1974, esp. p.57-129; SACHET, Celestino. A literatura catarinense. Florianópolis: Lunardelli, 1985. esp. p.55-104.
} 
primeiro contra o segundo no jornal Regeneração, em janeiro de 1884; Altino Flores e os jovens do Grupo Sul travaram batalhas nas páginas d'O Estado, tendo a figura de Goethe como referência. ${ }^{3}$ Insultos e agressões circularam com intensidade por meio dos jornais, talvez alardeados e disseminados pelos próprios envolvidos, servindo para instituir distinções e nutrir identificações.

O IHGSC, instituição centenária e hoje associada, no que se refere à historiografia, a uma história envelhecida e ultrapassada, também soube representar o "novo". Nos seus inícios, como afirmou, em discurso perante os demais sócios, Manoel dos Passos Farias de Mendonça, em $1^{\mathrm{o}}$. de maio de 1902, a entidade era um "ninho de homens ilustres da nova geração". 4 Mas seria essa "novidade" associada à juventude de tais membros?

Surgido na década de 1890, o IHGSC foi marcado pelos intensos embates políticos da República nascente - em especial, pelos desdobramentos dos conturbados episódios do movimento federalista. A mudança de regime dera aos republicanos destaque e força que, em Santa Catarina, não correspondiam à penetração das idéias republicanas, nem ao eleitorado a elas fiel - e isso apesar do papel saliente de políticos republicanos catarinenses no cenário político brasileiro, como era o caso de Esteves Jr. ${ }^{5}$ No período de 1889 a 1894 , houve significativo tensionamento entre os representantes do novo regime (autoridades nomeadas pelo governo federal e expoentes do Partido Republicano Catarinense) e os políticos que, no Império, haviam atuado nos partidos Liberal e Conservador. Estes últimos, mesmo quando adesistas, foram sistematicamente excluídos do exercício de funções políticas e administrativas (quer no Executivo estadual, quer na representação catarinense no Congresso Nacional, quer ainda na composição da Assembléia Estadual). A exclusão resultou na sua articulação em torno do Partido União Federalista, além de seu envolvimento em episódios de contestação e até mesmo ocupação, à força, do governo e da máquina governamental.

\footnotetext{
3 SACHET, Celestino. As transformações estético-literárias..., op.cit., p.17-18; SACHET, Celestino. A literatura catarinense..., op.cit., p.95.

${ }^{4}$ RTIHGSC, 1902, v.1, n.2, p.41.

5 "Em março de 1887, era de 200 o total de eleitores republicanos em toda a província e, em 1888, apesar de já constarem espalhados 15 clubes, seu número de associados continuava bastante reduzido. Na capital, segundo cômputos de meados de 1887, o Clube Republicano era composto por apenas 17 membros. E quando em 1889 Esteves Junior e Raulino Horn concorreram às eleições para a Assembléia Geral, o primeiro não angariou mais de 153 votos e o segundo, não mais de 20." CHEREM, Rosângela Miranda. Do sonho ao despertar: expectativas sociais e paixões políticas no início republicano na capital de Santa Catarina. In: BRANCHER, Ana, AREND, Sílvia Maria Fávero (orgs.). História de Santa Catarina no século XIX. Florianópolis: Ed. da UFSC, 2001. p.301.
} 
Derrotado o movimento federalista, em 1894, os republicanos passaram a dominar a vida política catarinense, sendo que, segundo Jali Meirinho, apenas por volta de 1902 - ano em quem foram publicados os dois primeiros números da Revista do Instituto - teria havido convivência em bases mais harmônicas com os grupos até então excluídos do controle da máquina estatal e da ocupação de cargos. ${ }^{6}$ A instabilidade, porém, instalara-se no cotidiano político catarinense:

Com efeito, entre os anos de 1889 e 1902 sucederam-se 24 alternâncias no cargo de governador de Santa Catarina. Além de dez interinos, vicegovernadores, representantes legislativos e governadores que reassumiram, incluem-se dois interventores, dez governadores e duas juntas governativas, sendo que nos anos entre 1893 e 1894, quando ocorreram os enfrentamentos antiflorianistas, a cadeira de governador mudou seis vezes. ${ }^{7}$

Neste sentido, o Instituto, em seus inícios, pode ser pensado como um dos instrumentos de acomodação das tensões e, simultaneamente, de legitimação de novos agentes na arena política. Entre os elementos da "nova geração", não só pelos vínculos tênues ou inexistentes com a política local, até a República, mas também pela juventude, salientaram-se figuras como Lauro Müller e José Arthur Boiteux.

Müller foi nomeado por Deodoro da Fonseca, em fins de 1889, para governar Santa Catarina, e José Boiteux acompanhou-o na viagem da capital federal para a capital catarinense, na condição de seu oficial de gabinete. Ambos nascidos em Santa Catarina, mas não na capital, tinham ligações importantes com políticos republicanos de projeção nacional, que puderam conhecer na Corte, em função de seus estudos (inexistiam, à época, instituições catarinenses de ensino superior). Em 1889, Lauro Müller, nascido em Itajaí, tinha 25 anos e concluíra recentemente o curso de engenharia na Escola Militar, no Rio de Janeiro, tendo ali estudado com Benjamin Constant e, ao que tudo indica, aderido, por sua influência, ao ideal republicano. ${ }^{8}$ Müller marcaria a política catarinense da Primeira República, dividindo com Hercílio Luz a liderança republicana no estado.

\footnotetext{
${ }^{6}$ MEIRINHO, Jali. República e oligarquias: subsídios para a história catarinense - 1889-1930. Florianópolis: Insular, 1997. p.123.

${ }^{7}$ CHEREM, Rosângela Miranda. op.cit., p.337.

${ }^{8}$ MEIRINHO, Jali. op.cit., p.57; CHEREM, Rosângela. op.cit., p.307.
} 
Por seu turno, José Boiteux, com 23 anos em 1889, nascera na cidade catarinense de Tijucas; para estudar Medicina (que cursou apenas até o $2^{\circ}$. ano), passara a viver no Rio de Janeiro. Naquela cidade, associou-se, entre 1884 e 1885, a três clubes abolicionistas: Clube Abolicionista Preparatoriano, Centro Abolicionista Castro Alves e Centro Abolicionista 6 de Junho. Passou a estudar Direito, em São Paulo, a partir de 1887. Na capital paulista foi revisor do jornal Diário Mercantil, sem deixar de colaborar com jornais de Santa Catarina. ${ }^{9}$ No Rio de Janeiro, chegou a ser hospedado por Antônio Justiniano Esteves Jr., destacado político que reunia em torno de si significativo número de catarinenses, particularmente aqueles sensíveis às idéias republicanas, estivessem eles de passagem pela cidade ou fossem ali residentes. ${ }^{10}$ Em 1887, José Boiteux participou, com Esteves Jr., da fundação do Clube Republicano Catarinense. ${ }^{11}$ Foi provavelmente Esteves Jr. o elo entre Lauro Müller e José Boiteux.

Definitivamente engajado na nova ordem republicana, José Arthur Boiteux esteve afastado de Santa Catarina entre 1891 e 1894 (quando os federalistas conseguiram o controle do governo), período em que retornou ao Rio de Janeiro. Voltou a Santa Catarina em 1894, logo assumindo a Secretaria de Governo, na administração de Hercílio Luz. ${ }^{12}$ Enfronhado na política partidária e no jornalismo, seria o principal articulador da criação do IHGSC.

\section{Política, jornalismo, história}

Política e jornalismo, freqüentemente indissociados, foram as bases a partir das quais operaram vários dos membros do Instituto, ao longo de sua trajetória - e, conseqüentemente, muitos de seus historiadores.

Veja-se que, na relação dos trinta sócios fundadores da entidade - publicada no primeiro número da Revista do IHGSC, em 1902 -, estavam identificadas as ocupações (ou formações profissionais) de vinte e nove deles: eram quatro engenheiros civis, um engenheiro militar, três médicos, três professores, três desembargadores, dois juízes de direito, dois

\footnotetext{
${ }^{9}$ BAHIA, Eliana Maria. Perfil de José Arthur Boiteux, um construtor da cultura catarinense. Florianópolis, 1994. Dissertação (Mestrado em História). UFSC. p.12-15, 24-25.

${ }^{10}$ CORREAA, Carlos Humberto P. História da cultura catarinense - v.1: O Estado e as Idéias. Florianópolis: Ed. da UFSC, Diário Catarinense, 1997. p.74-75.

${ }^{11}$ BAHIA, Eliana Maria. Perfil de José Arthur Boiteux..., op.cit., p.25.

${ }^{12}$ CORRÊA, Carlos Humberto P. História da cultura catarinense..., op.cit., p.74, 78-79 e 81.
} 
jornalistas, dois oficiais de marinha, dois industriais, dois senadores, um funcionário público federal, um funcionário público estadual, um guarda-livros, um negociante e um capitalista. ${ }^{13}$ Equilíbrio saudável entre os representantes da máquina burocrática estatal e os profissionais liberais?

As meras informações quanto às ocupações ou formações profissionais podem ser enganadoras, pois, com exceção dos sócios identificados como senadores (Gustavo Richard e Hercílio Pedro da Luz), não explicitam a atuação político-partidária (que, na prática, significava igualmente proximidade das instâncias de governo e de representação política). O "negociante" Antônio Pereira da Silva e Oliveira, o "médico" Luiz Antônio Ferreira Gualberto e o "engenheiro civil" Polidoro Olavo de S. Thiago, por exemplo, tinham sido eleitos deputados para o Congresso Representativo de 1891 (Polidoro de S. Thiago seria, inclusive, em 1894, eleito vice-governador). O "engenheiro militar" Felipe Schmidt exercera o mandato de deputado federal e encerrava o de governador, eleito que fora para o período 1898-1902. O “jornalista” José Arthur Boiteux, como visto, já assessorara o governador Lauro Müller (1889-1891), também elegendo-se por três vezes deputado estadual, nos anos 1890, e deputado federal para o período 1900-1902. ${ }^{14}$ Entre os sócios efetivos e os correspondentes, vários tinham atuação político-partidária marcante.

Como abordado no capítulo anterior, o IHGSC procurou e freqüentemente recebeu o apoio do governo do Estado, algo provavelmente facilitado pela circunstância de vários governantes pertencerem aos quadros da entidade. Na Revista do Instituto da década de 1910, folha de rosto e capa indicavam que a publicação era feita "sob os auspícios do governo do Estado”. Em 1913, o sócio Joaquim David Ferreira Lima assinalou, em discurso, que o governador Vidal Ramos, ao presidir a entidade, emprestava-lhe "seu valioso apoio, as luzes do seu cultivado espírito, o prestígio do seu nome acatado e venerado" (o discurso, diga-se de passagem, foi proferido na presença do próprio governador). ${ }^{15}$

Outro aspecto importante da relação do Instituto com os governos (antes de tudo, o estadual, mas também o do município, em Florianópolis) foi a questão da sede da entidade.

\footnotetext{
${ }^{13}$ RTIHGSC, 1902, v.1, n.1, p.96-97.

${ }^{14}$ MEIRINHO, Jali. op.cit., p.65, 106 e 127; BAHIA, Eliana. op.cit., p.29-34.

15 Discurso inaugural proferido por Joaquim David Ferreira Lima, em 24 de fevereiro de 1913. RTIHGSC, 1913, v.II, $1^{\circ}$. e $2^{\circ}$. trimestre, p.101. Já na abertura daquele número da revista, o apoio de Vidal Ramos era ressaltado: o Instituto ressurgira "devido aos esforços do sr. dr. José Arthur Boiteux, a quem deu braço forte o exmo. sr. Coronel Vidal José de Oliveira Ramos, digno governador do Estado [...]”. RTIHGSC, 1913, v.II, $1^{\circ}$. e $2^{\circ}$. trimestre, p. 1 - "No limiar".
} 
Em fins da década de 1910, ela teria sido concedida por ato do governo estadual. ${ }^{16}$ No final da década de 1920, foi prevista por lei estadual a construção de edifício que abrigaria o Instituto e outras instituições culturais, como a Academia Catarinense de Letras - todos englobados na "Casa de Santa Catarina" -, sendo o terreno cedido pela Prefeitura Municipal de Florianópolis. A construção, contudo, não foi efetivada. Na primeira metade da década de 1940, membros do Instituto, tentando efetivar a existência da Casa de Santa Catarina, solicitaram a ocupação, na capital, do antigo Clube Germânia, desapropriado pelo governo estadual. ${ }^{17} \mathrm{~A}$ própria Constituição Estadual de 1947 teria estabelecido que o prédio do antigo clube servisse como sede das "associações de alta cultura do Estado", bem como da Associação de ExCombatentes do Brasil, e o prédio teria sido entregue "à guarda do Instituto Histórico e Geográfico de Santa Catarina" em agosto de $1951 .{ }^{18}$ Entretanto, com problemas de conservação, o prédio ruiu em 1966, em meio a fortes chuvas, ${ }^{19}$ causando sérios prejuízos principalmente aos acervos das instituições ali abrigadas - o Instituto, a Academia Catarinense de Letras, a Comissão Catarinense de Folclore e a Associação dos ExCombatentes. Segundo depoimento de Walter Piazza, registrado no Jornal da Semana, em 1980 ,

A Casa era um prédio velho, abandonado, e as instituições não tinham verba para mantê-la. O que a mantinha era o idealismo dos intelectuais dirigentes, uma vez que o Governo Estadual e o Federal despendiam apenas migalhas de dinheiro, que em pouca coisa ajudavam. Devido às péssimas condições, durante uma enxurrada o prédio desabou, e a biblioteca do Instituto Histórico e Geográfico ficou inutilizada. ${ }^{20}$

Recordando, em 2005, o desmoronamento de 1966, Carlos Humberto Corrêa destacou:

\footnotetext{
${ }^{16}$ RTIHGSC ("Expediente do Instituto"), Florianópolis, 1919, p.108.

${ }^{17}$ Sobre a Casa de Santa Catarina, entre os anos 1920 e 1940, ver Parte I, Capítulo 2.

${ }^{18}$ PIAZZA, Walter F. Instituto Histórico e Geográfico de Santa Catarina: estudo histórico-analítico (18961996). Florianópolis: Editora da UDESC, 1996. p.70.

19 BAHIA, Eliana. Em busca de uma casa para a cultura. Ágora, Florianópolis, v.V, n.10, dez. 1989. p. 22; Depoimento de Carlos Humberto Pederneiras Corrêa, em 4 de novembro de 2005 - versão transcrita. fl.6. Arquivo pessoal de Janice Gonçalves.

${ }^{20}$ O Instituto fundado por José Boiteux vive de esmola. Jornal da Semana, Florianópolis, 29 de março a 5 de abril de 1980. Acervo da Academia Catarinense de Letras, Dossiê Walter F. Piazza.
} 
[...] nós já mudamos umas sete ou oito vezes. Cada mudança era a destruição de meia biblioteca. O Instituto já teve um museu [...]. Quando estava aqui na [rua] Tenente Silveira, onde é a Biblioteca Pública hoje, na época em que eu dirigia o museu que funcionava lá, a certa altura uma parede toda da [rua] Álvaro de Carvalho caiu, que era a parede do Instituto Histórico. Então, praticamente todo o acervo da biblioteca e do museu foi perdido. [...] Foi numa noite de chuva, o que não foi perdido porque a parede caiu, a água que entrou.... ${ }^{21}$

A própria situação da sede do IHGSC denunciava abalos nas relações com a política estadual e suas principais personagens. Na mesma reportagem de 1980, Piazza assinalava que o desastre da década de 1960 ocasionara a peregrinação do Instituto (e das outras entidades) por diversos endereços, "prédios e casas alugadas pelo governo do Estado". O governo estadual, porém, forneceria parcos subsídios para a sobrevivência das instituições (“o equivalente ao aluguel e verba de correspondência”). As boas relações seriam restabelecidas em meados da década de 1980, e o simbolismo desse reencontro do Instituto com o governo estadual não poderia ser maior: passou a ocupar, por força de lei, o antigo Palácio do Governo, transformado em Palácio Cruz e Sousa, que seria sede, também, do Museu Histórico de Santa Catarina (museu, aliás, concebido a partir da contribuição intelectual de sócios do Instituto). ${ }^{22} \mathrm{Na}$ Revista do IHGSC, em sua " 3 a fase”, estão presentes os agradecimentos de praxe ao governador (Esperidião Amin), "por instalar o Instituto, definitivamente, aqui no Palácio Cruz e Sousa". ${ }^{23}$

Mais recentemente, pode ser percebida a recuperação (não explicitada) da idéia da Casa de Santa Catarina: há previsão de que o IHGSC e a Academia Catarinense de Letras ocupem o antigo prédio da Academia de Comércio, atualmente vago e aguardando restauração. $^{24}$

\footnotetext{
${ }^{21}$ Depoimento de Carlos Humberto Pederneiras Corrêa..., op.cit., fl. 6.

${ }^{22}$ PIAZZA, Walter F. Instituto Histórico e Geográfico de Santa Catarina..., op.cit., p.72. Jali Meirinho presidiu a comissão que criou o Museu, e que, segundo seu depoimento, deveria ser uma instituição voltada para a história política de Santa Catarina - daí a proposta de que ocupasse o Palácio, quando este eventualmente deixasse de ser utilizado como sede do governo. Depoimento de Jali Meirinho, em 10 de novembro de 2005 versão transcrita. fls. 11-12. Arquivo pessoal de Janice Gonçalves.

${ }^{23}$ RIHGSC, 1986-1987, n.7, p.307. O agradecimento era então estendido ao reitor da UFSC, por fazer com que a Revista fosse impressa pela gráfica da Universidade, "sem ônus para o Instituto."

${ }^{24}$ BIANCHINI, Fábio. Uma outra sede para a Academia. Diário Catarinense, Florianópolis, 20 out.2005.
} 
Da política enquanto arte de governar, o Instituto participou, apoiando governos fosse realizando estudos nas áreas de sua especialidade, e que pudessem subsidiar ações governamentais, fosse fornecendo quadros para o preenchimento de cargos dos altos escalões. Recebeu, em contrapartida, como já destacado, o apoio de governantes. Da política enquanto arte de propor, defender e criticar ações, o Instituto igualmente participou, através de inúmeros associados, sobretudo por meio da atividade jornalística. Alguns criaram, mantiveram e dirigiram periódicos - José Boiteux e Carlos da Costa Pereira, nos começos republicanos, Jali Meirinho, décadas depois. Outros preferiram usar as páginas dos jornais com regularidade tanto para comentar temas da atualidade como para discutir aspectos históricos mais recuados, ou publicar crônicas e materiais mais escancaradamente literários além dos já citados, podem ser agregados historiadores como Lucas Boiteux, Oswaldo Cabral, Walter Piazza.

Cabe salientar que, quando retornou a Santa Catarina, em 1894, José Arthur Boiteux adquiriu o jornal República, logo tornado principal veículo de divulgação do Partido Republicano Catarinense. ${ }^{25}$

Carlos da Costa Pereira iniciou-se na atividade jornalística publicando crônicas no Comércio de Joinville, mas em 1910, com vinte anos, criaria O Alpha, dedicado “à defesa dos interesses locais" de São Francisco do Sul (onde nascera e residia). Em 1913, Costa Pereira passou a gerenciar o jornal $O$ Município - simpático aos alemães, o jornal foi fechado em 1918. A partir do mesmo ano, começou a atuar no jornal $A$ Razão. ${ }^{26}$ Nos jornais, publicou, além de crônicas e sueltos, artigos de caráter político-partidário, defendendo lideranças e candidaturas. Integrou o Partido Republicano Catarinense e, após 1945, o Partido Social Democrático. $^{27}$

Em 1948, Walter Piazza, então com 23 anos, tornou-se redator do Diário da Tarde, de Florianópolis, e nos anos seguintes (até 1953) trabalhou na redação d'A Gazeta. Neste período (1947-1951), exerceu o mandato de vereador de Nova Trento, sua cidade natal. $^{28}$

\footnotetext{
${ }^{25}$ CORRÊA, Carlos Humberto P. História da Cultura catarinense..., op.cit., p.78-79.

${ }^{26}$ PEREIRA, Carlos da Costa. Minhas memórias. Florianópolis: Ed. da UFSC, FCC Edições, 1996. p.49-51, 58-59.

${ }^{27}$ Ibidem, p.94-95.

${ }^{28}$ Curriculum vitae - Walter F. Piazza. Florianópolis, 1974. Acervo da Academia Catarinense de Letras, Dossiê Walter F. Piazza.
} 
Jali Meirinho exerceu atividades jornalísticas em Santa Catarina, no Paraná (Curitiba) e no Rio Grande do Sul (Porto Alegre). Em Santa Catarina, primeiramente em sua cidade natal, Rio do Sul, em semanários como o Nova Era. E, em meados da década de 1950, fundou o semanário Últimas notícias, mantido por três anos. As relações entre jornalismo, política e história são, em sua trajetória, estreitas:

[...] eu sempre estive vinculado ao jornalismo político, e essa aproximação da política sempre, então, ensejou que a gente tivesse um conhecimento amplo de História, das questões que iam evoluindo dentro desse contexto, daí porque esse gosto, essa vinculação com a História, em função da atividade jornalística. $^{29}$

Em seu discurso de posse na Academia Catarinense de Letras, em julho de 1995 (quando tinha 62 anos), Jali Meirinho assinalou, em sua trajetória, o caráter das relações com o jornalismo e com a história:

[...] se, no jornalismo, o mote norteador foi pugnar pela afirmação da pátria catarinense, na História continuou sendo o conhecimento dos valores que devem formar gerações e instituições que dignifiquem este Estado e, por extensão, este País. ${ }^{30}$

Mas talvez tenha sido Oswaldo Cabral o historiador catarinense a estabelecer de forma mais estreita a relação entre o jornalista - um certo modelo de jornalista - e o historiador. Em entrevista concedida em 1976 ao jornalista Moacir Pereira, Cabral, em meio a considerações sobre o dever de imparcialidade do historiador (o que teria feito com que privilegiasse, em seus estudos, períodos anteriores à República), teria declarado: "Eu sou o

\footnotetext{
29 Depoimento de Jali Meirinho..., op.cit., fl. 2. Sua própria produção historiográfica está focada fundamentalmente na história política republicana. Entre seus livros: A República em Santa Catarina (1982), Dicionário político catarinense (1985), Datas históricas de Santa Catarina (1985), Nereu Ramos (1988). Mais recentemente, Jali Meirinho vem se dedicando também ao estudo da historiografia catarinense.

${ }^{30}$ Discurso do acadêmico Jali Meirinho, na sua posse (Cadeira no .30). Florianópolis, 13 de julho de 1995. Acervo da Academia Catarinense de Letras, Dossiê Jali Meirinho.
} 
cronista, o jornalista do passado."31

O diálogo com o público, através da imprensa, parece ter sido importante para Cabral, além de relativamente regular: começou a escrever na imprensa (geralmente, crônicas) na década de 1920, em jornais de várias cidades catarinenses (Joinville, Jaraguá, Laguna, Florianópolis), Curitiba e Rio de Janeiro. ${ }^{32}$ É ele exemplo acabado de historiador a usar a imprensa como veículo de divulgação de suas idéias e pesquisas e como espaço de construção de sua imagem pública: Cabral tanto "defendia-se" de acusações ou intenções que, no seu entender, o prejudicavam, como assinalava as posições por ele ocupadas em termos das relações com determinadas instituições ou pessoas. ${ }^{33}$

Claro está que as crônicas e notas jornalísticas serviam de tribuna a partir da qual podiam ser alcançados os eleitores. Pois o interesse pela política certamente não se limitou à atuação jornalística ou à ocupação de cargos no Executivo: alguns dos mais destacados historiadores do Instituto candidataram-se e elegeram-se para cargos no Legislativo. Além de José Arthur Boiteux, Carlos da Costa Pereira ${ }^{34}$ e Walter Piazza, já mencionados, também Oswaldo Cabral conheceu as entranhas da política.

Quando residia em Joinville, na primeira metade da década de 1930, Cabral integrava o Partido Liberal e, na década de 1940, filiou-se à UDN. ${ }^{35}$ Em um caso como em outro, o elo entre os partidos era o político Adolfo Konder. Elegeu-se deputado à Assembléia Constituinte Estadual, exercendo mandato de deputado entre 1947 e 1954. Para Cabral, porém, a experiência teria sido decepcionante. ${ }^{36}$

\footnotetext{
31 A Imprensa, a Política e os Partidos em SC [entrevista concedida por Oswaldo Rodrigues Cabral a Moacir Pereira, em 15 de setembro de 1976]. A Ponte, Florianópolis, maio de 1981 (1 $1^{\text {a }}$ semana), p.5. Sobre as dificuldades de estudar épocas mais recentes, teria afirmado Cabral, na entrevista: "É difícil registrar fatos recentes. Há muita gente viva, há os parentes, as famílias. Naturalmente, sou membro da comunidade, não vivo fora dela. Vivo no seu meio e isto influi. Da época passada, não, porque são documentos de um período já distante, frios, apanhados do jornal. O julgamento é mais perfeito, mais preciso.” (p.5-6)

${ }^{32}$ SOUZA, Sara Regina Silveira de. Oswaldo Cabral: páginas de um livro de memórias. Florianópolis: Ed.da UFSC, UDESC, 1993. p.66, 73.

33 No primeiro caso, pode ser citado o artigo "Mania de pichar", envolvendo uma típica polêmica entre historiadores do IHGSC: a data de fundação de Desterro. No artigo, Cabral denuncia estar sendo "usado" em polêmica que tinha o intuito de promover livro a ser lançado (ao que tudo indica, o livro A fundação de Florianópolis, de Evaldo Pauli) e comenta, irônico: "Eu vou continuar esperando pelo livro que nos dirá quando foi que Dias Velho fundou o Desterro". Cf.: CABRAL, Oswaldo Rodrigues. Mania de pichar. O Estado, Florianópolis, 23 dez. 1972. Acervo da Academia Catarinense de Letras, Dossiê Oswaldo Rodrigues Cabral.

${ }^{34}$ Carlos da Costa Pereira foi ainda eleito suplente do senador Ivo d'Aquino, em 1946. PEREIRA, Carlos da Costa. Minhas memórias, op.cit., p.95.

${ }^{35}$ SOUZA, Sara Regina Silveira de. Oswaldo R. Cabral...., op.cit., p.97-99.

${ }^{36}$ Ibidem, p.107-108.
} 
Ligadas ou não a preocupações políticas, questões de caráter histórico foram pontualmente abordadas nos jornais, bem como em outros periódicos, oferecendo sua contribuição para disseminar conhecimentos pertinentes ao campo historiográfico certamente "conteúdos" estritos, além de concepções de história. A respeito, cabe levar em conta a pequenez do meio editorial catarinense e as conseqüentes dificuldades de edição que mais de um escritor apontou. Na década de 1970, Oswaldo Cabral queixava-se a este respeito: interrompera a redação de uma alentada História Política de Santa Catarina, por não ver perspectivas de edição:

Eu vi que a obra estava ficando muito grande. [...] A História da Política daria cinco ou seis volumes. Quem é que vai editar?

[...] É muito difícil publicar em Santa Catarina. ${ }^{37}$

E Piazza, mesmo em 2004, ainda considerou: "O grande problema do escritor em Santa Catarina, principalmente nas áreas de história e ciências sociais, é a publicação.”38

Entre os periódicos que voltaram-se mais demoradamente para as questões da história catarinense, um dos primeiros, depois da própria Revista do Instituto, parece ter sido o Archivo Catharinense. Distante da terra natal, José Boiteux editou-o na capital da República, no ano de 1908 (momento em que a Revista do Instituto não estava sendo publicada). O periódico pretendia ser,

[...] para os que se interessam pelos estudos históricos e geográficos concernentes ao Estado de Santa Catarina, uma fonte de informações baseadas em trabalhos de importância reconhecida, e para quantos acompanham o desenvolvimento intelectual do mesmo Estado, uma publicação que, modestamente embora, vem colocar-se ao lado dos órgãos de publicidade cujo programa colima esse desideratum. ${ }^{39}$

\footnotetext{
${ }^{37}$ A Imprensa, a Política e os Partidos em SC, op.cit., p.4-6. A obra foi posteriormente concluída pela sobrinha de Cabral e editada em quatro volumes: CABRAL, Oswaldo R. A História da Política em Santa Catarina durante o Império. Florianópolis: Ed. da UFSC, Assembléia Legislativa do Estado de Santa Catarina, 2004. 4v. ${ }^{38}$ Entrevista de Walter Piazza [concedida a Jeferson Lima]. A Notícia, Joinville (SC), 15 jan. 2004 (Anexo, capa).

${ }^{39}$ Duas palavras. Archivo Catharinense - revista mensal illustrada, Rio de Janeiro, n.1, 1908, p.1.
} 
José Arthur e seu irmão Henrique Boiteux assinaram textos nessa breve publicação, que teve apenas seis números, circulando entre julho e dezembro de 1908, extinta pelo não-pagamento por parte dos que se comprometeram a assinar o jornal. ${ }^{40}$

Outro periódico destacou-se nos anos de 1910, saindo à luz seu primeiro volume antes da retomada da Revista Trimensal do IHGSC: a Revista Catharinense, criada por José Johanny e publicada no município catarinense de Laguna. Seus fascículos, reunidos, resultaram em três volumes de aproximadamente 400 páginas cada um, relativos aos anos de 1911-1912, 1912-1913 e 1914. De acordo com o texto de apresentação contido no primeiro deles, era o principal objetivo da Revista Catharinense

[...] arquivar e divulgar documentos históricos, notas estatísticas, páginas literárias e informações de ordem econômica, financeira, científica, política, artística etc, referentes às coisas e aos homens de Santa Catarina. Como parte acessória ocupar-se-á, também, de todo e qualquer outro assunto interessante e de atualidade.

Acrescentava-se: "Procuraremos fazer uma MAGAZINE que agrade a todas as classes da sociedade, a todas as inteligências, a todas as idades, em ambos os sexos." ${ }^{41}$ Sócios do Instituto colaboraram com a publicação - Henrique Boiteux (o mais regular) e Lucas Alexandre Boiteux -, enviando artigos sobre a história de Santa Catarina. ${ }^{42}$

A Revista Catharinense serve como alerta: a produção de caráter histórico existia em Santa Catarina para além das fronteiras de Florianópolis. São conhecidos alguns outros exemplos de periódicos que, publicados em diferentes municípios, dedicaram-se à história de Santa Catarina - e particularmente à história das regiões onde foram (ou, no caso de alguns, ainda são) editados: Blumenau em Cadernos, em Blumenau, revista publicada desde $1957^{43}$;

\footnotetext{
${ }^{40}$ Dos 445 assinantes, apenas 124 pagaram as assinaturas. Cf.: BOITEUX, José. Declarações necessárias. Archivo Catharinense - revista mensal illustrada, Rio de Janeiro, n.6, 1908, p.14.

${ }^{41}$ Revista Catharinense, Laguna (SC), 1911-1912, sem indicação de página.

${ }^{42}$ Em texto elaborado em virtude da morte de Johanny (em 25 de fevereiro de 1915), a Revista Trimensal do IHGSC assinalou a importância desse periódico, caracterizado como "precioso repositório de notícias e memórias sobre homens e fatos catarinenses", mantido "com enormes sacrifícios" por três anos. RTIHGSC, Florianópolis, 1915, p.48-49.

${ }^{43}$ Sobre Blumenau em Cadernos, ver Parte III, Capítulo 2.
} 
em Joinville, os Cadernos de Joinville, na década de $1960 ;{ }^{44}$ Notícias de Vicente Só, em Brusque (desde 1977).

Sabe-se ainda que a produção de caráter histórico de alguns dos sócios do Instituto (Lucas Alexandre Boiteux, Henrique Boiteux, Carlos da Costa Pereira e Walter Fernando Piazza, por exemplo) foi veiculada em outras publicações periódicas surgidas ao longo do século XX, como almanaques, indicadores, anuários, álbuns. ${ }^{45}$

\section{Do historiador-jornalista ao historiador-professor}

Referência, por muitas razões, no cenário historiográfico catarinense, Oswaldo Cabral é personagem emblemático de um momento de transição: da era de predomínio do historiador-jornalista para a de predomínio do historiador-professor.

É certo que Cabral, antes de ser médico, foi professor - professor primário. Instituiu-se como historiador, contudo, por meio de suas leituras, pesquisas e trabalhos publicados. Reconhecido como importante pesquisador, na década de 1950 tornou-se professor da Faculdade de Direito (disciplina de Medicina Legal) e da Faculdade Catarinense de Filosofia (História Antiga e História Medieval) - faculdades que, na década de 1960, foram incorporadas à Universidade Federal de Santa Catarina. Um dos primeiros egressos do curso de História (à época, História e Geografia) foi Walter Piazza, próximo a quem Cabral trabalharia, não só em atividades na Faculdade como nas pesquisas e atividades da

\footnotetext{
${ }^{44}$ Foi localizado, na Biblioteca Pública do Estado de Santa Catarina, um único exemplar, datado de abril de 1964. Os Cadernos, cujo redator responsável era Adolfo Bernardo Schneider, são identificados como "boletim informativo do Círculo Joinvilense de Pesquisas Históricas".

${ }^{45}$ No caso de Lucas Alexandre Boiteux, e nos anos iniciais século XX, pode-se assinalar a presença de textos seus ao menos no Anuário de Santa Catarina para 1901 ("Relação de todos os jornais publicados no Estado de Santa Catarina, desde 1830 até os nossos dias") e no Anuário Catarinense para 1904 ("História catarinense João Henriques"). O Anuário Catarinense, publicado entre os anos de 1948 e 1956, apresenta contribuições regulares de Lucas Boiteux. Cabe ressaltar que, no tocante à história naval, Lucas Boiteux publicou vários estudos na Revista Marítima Brasileira. Teve produção significativa também veiculada no Jornal do Comércio (tais artigos foram objeto da dissertação de mestrado de Maria Teresa Santos Cunha, A contribuição historiográfica de Lucas Alexandre Boiteux no Jornal do Comércio do Rio de Janeiro, 1911 e 1957, realizada no âmbito do Programa de Pós-Graduação em História da UFSC e defendida em 1982).
} 
Comissão Catarinense de Folclore. ${ }^{46}$

Cabral e Piazza teriam rompido relações na primeira metade da década de 1970. A respeito, temos a versão de Piazza:

[...] tive um "pega" com ele, em 1973. Enquanto ele foi vivo, não se lecionou história de Santa Catarina na Universidade Federal. Quando ele deixou a universidade, criei a disciplina. E depois, quando criei o mestrado em história, tenho até escrito com a letra dele: "História não precisa de aprendizagem, de formação, o sujeito nasce historiador."

Parece pouco provável que um professor dedicado a formar bacharéis em História entendesse que suas atividades fossem dispensáveis. Mas, espelhado em seu próprio exemplo, Cabral sabia que o historiador podia ser, em relação ao ofício, um autodidata e, neste sentido, é possível que tivesse afirmado que a história não exigia formação específica (ou instrução formal).

Quando criada a Faculdade Catarinense de Filosofia, na década de 1950, figuras como Oswaldo Cabral e Henrique Fontes podiam a ela se agregar como professores, dado que tinham nível superior de instrução (o primeiro, em Medicina, o segundo, em Direito). O mesmo não acontecia, porém, com outros historiadores ligados ao Instituto, como, por exemplo, Carlos da Costa Pereira (que, embora reconhecido, por seus pares, pela erudição, tivera instrução formal precária, sendo, fundamentalmente, autodidata). ${ }^{48}$

Importa notar que, na segunda metade do século $\mathrm{XX}$, o processo de profissionalização dos historiadores ganhou contornos mais nítidos em Santa Catarina, sendo cada vez mais associado às universidades como loci de formação e de exercício profissional, primeiramente através dos cursos de graduação e, a partir de 1975, de um Mestrado na capital.

\footnotetext{
${ }^{46}$ SOUZA, Sara Regina Silveira. Oswaldo Cabral...., op.cit., p.181. Piazza tornou-se bacharel em História e Geografia pela Faculdade Catarinense de Filosofia em 1957, licenciando-se em 1960. Na Faculdade, pouco depois de formado, foi auxiliar de pesquisas da cadeira de História Antiga (1957) e auxiliar de ensino das cadeiras de História Medieval e Antropologia e Etnografia (1960). Cf.: Curriculum vitae - Walter F. Piazza, op.cit.

${ }^{47}$ TERNES, Apolinário. Walter F. Piazza, historiador [entrevista]. A Notícia, Joinville (SC), 25 nov. 1996, p.E2, (A Notícia Especial, "Grandes entrevistas"). Note-se, porém, que a ficha de registro de Cabral na Academia Catarinense de Letras registra que foi professor "interino de História de Santa Catarina", na Faculdade Catarinense de Filosofia. Ficha de registro do acadêmico Oswaldo Rodrigues Cabral. Florianópolis, 14 de abril de 1963. Acervo da Academia Catarinense de Letras, Dossiê Oswaldo R. Cabral.

${ }^{48}$ PEREIRA, Carlos da Costa. Minhas memórias, op.cit., p.31-40.
} 
O IHGSC teria acusado a mudança. Conforme Carlos Humberto Corrêa, em depoimento fornecido em 2005 :

[...] os membros do Instituto não são historiadores, por ofício. São diletantes. Mas é essa gente que, historicamente, preparou toda a documentação que nós vamos estudar depois. Então falta, em termos gerais - hoje não tanto, mas faltava -, metodologia para os membros do Instituto, faltava um embasamento teórico. Eram diletantes que trabalhavam mais com a memória de Santa Catarina do que com a história de Santa Catarina. E pouco a pouco, então, começaram a entrar para o Instituto Histórico professores de História, principalmente na década de setenta, por aí. Nunca houve uma concorrência, aqui dentro, mas pouco a pouco os outros foram vendo a necessidade desse embasamento teórico, dessa metodologia. ${ }^{49}$

Os historiadores ligados ao Instituto escolhiam dedicar-se à história depois de terem optado por determinadas carreiras ou ocupações. As opções de formação eram poucas em Santa Catarina, a história dos cursos de nível superior foi construída no século XX, com a participação decisiva de membros do IHGSC na criação do Instituto Politécnico (nos anos 1910), da Faculdade de Direito (década de 1930) e, mais tarde, da Faculdade de Filosofia (década de 1950), um pouco antes da criação da primeira universidade (instalada na década de 1960). ${ }^{50}$ Alguns deslocavam-se para outros estados para conseguir a formação que não conseguiriam em Santa Catarina (José Boiteux, Henrique Fontes, Oswaldo Cabral); outros permaneciam, estudando por sua própria conta (Carlos da Costa Pereira). O que mudou, a partir do momento em que ao menos um curso de graduação passou a ser oferecido na área de História?

Nota-se que os primeiros egressos do curso de História da Faculdade Catarinense de Filosofia logo seriam incorporados ao seu quadro de pessoal, de início como assistentes entre eles, Walter Piazza. Bacharel e mestre em História pela Universidade Federal de Santa Catarina, Jali Meirinho fez a sua graduação entre 1966 e 1969, tendo entre seus professores

\footnotetext{
${ }^{49}$ Depoimento de Carlos Humberto Pederneiras Corrêa..., op.cit., fl. 1.

${ }^{50}$ SACHET, Celestino. A literatura catarinense. op.cit., p.269; VIEIRA, Amazile. O Instituto Polytechnico no contexto sócio-cultural de Florianópolis. Florianópolis, 1979. Dissertação (Mestrado em História). UFSC.
} 
Oswaldo Cabral, Jaldyr Faustino da Silva, Valter Gomes, Oswaldina Gomes, Walter Piazza e Américo da Costa Souto.

[...] era um número bastante reduzido em termos de profissionais nessa área. Não se tinha nomes que tivessem grandes obras publicadas, à exceção do Cabral. Todos estavam ainda em um período de iniciação, por assim dizer.

[...] o Walter Piazza, nessa [minha] fase como aluno, ele já era professor. Eu falei do Cabral, mas o Walter teve uma produção que até hoje é um marco dentro desse contexto da história de Santa Catarina. Ele também foi, dentro lá do Departamento, um dos grandes incentivadores, foi quem criou, inclusive, um Curso de Especialização, depois o Mestrado, dentro do contexto do Departamento de História da Universidade Federal. ${ }^{51}$

Na década de 1960, a inexistência de cursos de pós-graduação em História, em Santa Catarina, fazia com que os recém-graduados dessem aulas a graduandos, inclusive em outros municípios, como nos cursos de História em Joinville e Itajaí. Carlos Humberto Corrêa, em 2005, assim pontuou sua experiência como professor:

Comecei dando aula em 1960, numa escola de comércio no Estreito [área continental de Florianópolis], à noite. [...] Depois eu entrei para o Instituto de Educação, dei aula no Instituto durante muito tempo. Dei aula no Colégio de Aplicação também. E paralelamente a isso, em 67, acho que foi 67, eu dava aula em Joinville. Durante dez anos eu ia toda quarta-feira a Joinville. [...] Era uma época que não tinha asfalto daqui a Joinville. Saía uma hora da tarde aqui para dar aula às sete, chegava às sete para dar aula. Acabava a aula às dez horas, voltava, e às vezes chegava aqui quatro horas, três horas da manhã, com aula para dar no dia seguinte, aqui. [...] Íamos daqui, de Florianópolis, vinte e seis professores. Toda a Faculdade de Filosofia de Joinville era mantida por professores daqui. [...] Aí, do Ginásio de Aplicação eu passei para o Departamento de História [da UFSC]. E fiquei lá durante 32 anos. $^{52}$

\footnotetext{
${ }^{51}$ Depoimento de Jali Meirinho..,, op.cit., fl. 4-5.

${ }^{52}$ Depoimentos de Carlos Humberto Pederneiras Corrêa...., op.cit., fl.11.
} 
Tendo iniciado a graduação em História em 1970, em Joinville, Raquel S. Thiago destacou a importância do curso para abrir perspectivas: "eu gostava muito, porque o mundo estava se abrindo pra mim. [...] Aquilo para mim era uma maravilha”. No entanto, à distância de mais de trinta anos, reconhece fragilidades no curso, inclusive em função das condições de trabalho dos professores, deslocando-se entre Florianópolis e Joinville em tempos de estradas precárias. Além disso, havia as limitações de um curso de História ministrado durante o regime militar, e as ausência de discussões sobre a história de Santa Catarina ou de Joinville. ${ }^{53}$

Foi também na primeira metade da década de 1970 que Sueli Petry, Maria Bernardete Ramos Flores e Joana Pedro fizeram sua graduação em História, na antiga FEPEVI, hoje UNIVALI. Entre seus professores, Walter Piazza e Américo da Costa Souto. ${ }^{54}$

Como Raquel S. Thiago, no caso de Joinville, Maria Bernardete Ramos Flores destacou as precariedades e insuficiências dos cursos, à época:

[...] eram aqueles cursos bastante precários, dentro de uma visão bastante tradicional. A maioria dos professores iam daqui da Universidade Federal para dar aulas lá, ou então quase sempre emprestavam o nome, iam em algum momento (fazer a abertura do curso, e tal), mas as aulas eram dadas pelos professores da rede, da escola secundária. O que a gente lia lá era o Hélio Viana, o Burns (aquele História da Civilização, volume 1 e 2), um dicionário de História do Brasil e de História Geral. Esses eram os nossos livros básicos. A História da América era dada na base da apostila, por uma professora que vinha de Blumenau. Dentro daquele formato ainda bem escolástico, vamos dizer assim: o professor dar aula expositiva, e ter alguns capítulos para a gente estudar, fazer prova. Foi essa a nossa formação na Graduação. $^{55}$

Mas, por que fazer a graduação em História, em fins da década de 1960 e inícios da de 1970 ?

\footnotetext{
${ }^{53}$ Depoimento de Raquel S.Thiago, em 18 de novembro de 2005 - versão transcrita. fl.1-2. Arquivo pessoal de Janice Gonçalves.

${ }^{54}$ Depoimento de Sueli Petry, em 17 de novembro de 2005 - versão transcrita. fl.1. Arquivo pessoal de Janice Gonçalves; Depoimento de Maria Bernardete Ramos Flores, em 19 de abril de 2006 - versão transcrita. fl.1. Arquivo pessoal de Janice Gonçalves.

${ }^{55}$ Depoimento de Maria Bernardete Ramos Flores..., op.cit., fl.1.
} 
Dos entrevistados no processo de pesquisa, graduaram-se naquele período: Raquel S. Thiago, Nelma Baldin, Sueli Petry, Joana Maria Pedro, Maria Bernardete Ramos Flores. Todas mulheres, todas mestres em História pela UFSC, nos anos iniciais do Programa de PósGraduação em História (com exceção de Raquel S. Thiago, que defendeu a dissertação em 1983, as demais fizeram suas defesas em 1979). Todas hoje professoras de universidades: as duas primeiras, da UNIVILLE, de Joinville; a terceira, da FURB, em Blumenau; as duas últimas, da UFSC, em Florianópolis.

Nas opções, às vezes deixam-se de lado pendores, como indicou Joana Maria Pedro: "Na verdade, as escolhas que a gente faz na vida não têm necessariamente a ver com vocação. Pelo menos na minha, não." ${ }^{, 56}$ Tendo, ainda adolescente, feito curso de contabilidade e, em fins da década de 1960, começado a trabalhar no comércio, Joana Pedro constatou que a empresa em que trabalhava (a Hermes Macedo) "tinha a prática de demitir mulheres que casavam”, para não arcar com possíveis despesas com licença-maternidade. Desejando, para si, casar e ter filhos, buscou a profissão possível:

Eu nunca pensei em ser professora, porque achava que não servia para professora, e na época já havia a fama de que professora ganhava muito mal. E eu dizia, o tempo todo, que não queria ser professora. Aí, eu pensei: "Puxa, eu preciso escolher uma profissão que, casando, eu possa continuar a trabalhar." Qual era essa profissão? Ser professora. Mas não de primário, porque isso eu não queria de jeito nenhum! Então, fui escolher uma faculdade.

O que é que tinha, lá em Itajaí? Pedagogia, Letras, Filosofia, História e Geografia. E Direito. De todas essas, a disciplina de que eu mais gostava era História, sempre gostei. Mas não só: eu gostava também de Matemática, mas não tinha Matemática! Se eu pudesse, eu teria escolhido Matemática. Mas para fazer Matemática eu teria que ir pra Blumenau, ir pra Florianópolis... [...] E aí, então, qual era a escolha? História, claro, embora eu gostasse de outras disciplinas também, Matemática, Química, mas para estudar essas eu tinha que sair da cidade. Eu não só não podia sair da cidade para estudar, como também teria de pagar meus estudos. Então, fui pagar História. Eu

\footnotetext{
${ }^{56}$ Depoimento de Joana Maria Pedro, em 19 de abril de 2006 - versão transcrita. fl.1. Arquivo pessoal de Janice Gonçalves.
} 
estava na Hermes Macedo quando fiz o vestibular para História, e fui fazer História. $^{57}$

\section{Segundo Maria Bernardete Ramos Flores,}

Quando abriu o curso superior [em Itajaí], tinha lá História, Geografia, Letras e Pedagogia. Eu nunca fui boa aluna em História nem nunca tive muito interesse pela História, eu gostava mesmo de Matemática, de Desenho. Mas nesse leque de opções... E tinha Direito, mas para uma mulher casada, com filhos, não se botava como uma expectativa. E era isso. Mais tarde é que se criaram cursos de Economia e tal. Foi falta de opção mesmo. ${ }^{58}$

A busca não era exatamente por um curso de História, mas pela possibilidade de realizar um curso superior, compatível com uma certa condição feminina:

Para quem morava no interior (ou seja, fora da capital; Itajaí era considerada interior), era professora (eu era professora do Estado desde os quinze anos de idade) e casada, foi a possibilidade que se abriu para mim, e para muita gente igual a mim, fazer um curso superior, no interior. ${ }^{59}$

Mas a forte paixão pela História não está ausente, como salienta Sueli Petry:

Eu sempre gostei de História, já desde criança. E a minha leitura básica sabe qual foi? A revista $O$ Cruzeiro, aquela Seleções e aquelas coleções de livros quilométricos, como $O$ mundo pitoresco - eu lia tudo! Tinha aquele $O$ tesouro da juventude, eu li tudo! $!^{60}$

Maria Bernardete Ramos Flores situou sua formação - a graduação e o Mestrado - no contexto de expansão dos cursos de ensino superior (uma onda de cursos de graduação, seguida de uma onda de cursos de pós-graduação): em meados da década de 1970, assistia-se a uma política

\footnotetext{
${ }^{57}$ Ibidem, fls. 1-2.

${ }^{58}$ Depoimento de Maria Bernardete Ramos Flores..., op.cit., fl.1.

${ }^{59}$ Ibidem.

${ }^{60}$ Depoimento de Sueli Petry..., op.it., fl.28.
} 
[...] de criação dos cursos de Pós-Graduação. Primeiro pegamos a política de criação de cursos de ensino superior pelo interior. Nós somos de uma geração formada por essas políticas da ditadura. ${ }^{61}$

O Mestrado na UFSC deu continuidade a esse processo. Realizado em Florianópolis, o curso atraía graduados de vários municípios, em especial os egressos dos cursos de História de Itajaí e Joinville. O elo fundamental eram os professores do Departamento de História da UFSC, geralmente seus ex-professores.

Eu fiz o meu curso de História em Itajaí, na antiga FEPEVI, hoje UNIVALI e, quando concluímos o nosso Curso, os nossos professores, que eram todos de Florianópolis - Walter Piazza, Américo Souto e tantos outros -, eles nos induziram a fazer um Curso de Especialização em Florianópolis [depois transformado em Mestrado]. E fomos. Inclusive estava a Joana Maria Pedro, a Bernardete Flores fazia parte desse grupo, o Anselmo Hillesheim, o Emiliano Stolf, Nelo Osti, eu, o Luiz Vendelino Colombi, que éramos professores aqui da região de Blumenau. Isso aconteceu por volta de $1975 .{ }^{62}$

Segundo Maria Bernardete Ramos Flores, “o Prof. Walter Piazza cria o Mestrado aqui [em Florianópolis] e incentiva as suas alunas, os seus alunos de Itajaí a virem fazer a PósGraduação."63

Nos depoimentos concedidos, Walter Piazza não aparece apenas incentivando os graduados a ingressarem no Mestrado: era alguém que despertava vocações para a pesquisa. Ex-alunas como Sueli Petry e Raquel S.Thiago externaram esse reconhecimento:

[...] quem eu gostava muito e me motivou muito, e que eu devo também a ele essa estimulação pela História, foi o Walter Piazza, o professor Walter Piazza. Sem eu perceber eu estava sendo levada aos meandros da História por ele. $^{64}$

[...] o professor Piazza me marcou bastante [...] quando eu vi o professor Piazza contar como ele pesquisava, eu me encantei: "Eu quero ser um

\footnotetext{
${ }^{61}$ Depoimento de Maria Bernardete Ramos Flores..., op.cit., fl.1.

${ }^{62}$ Depoimento de Sueli Petry..., op.cit., fl. 1.

${ }^{63}$ Depoimento de Maria Bernardete Ramos Flores..., op.cit., fl.2.

${ }^{64}$ Depoimento de Sueli Petry..., op.cit., fl.28.
} 
professor assim, que produz o conhecimento e conta para os alunos como ele produziu e onde ele foi." ${ }^{, 65}$

Piazza, embora oriundo da política e do jornalismo, simbolizará um novo modelo no campo historiográfico catarinense: para os bacharéis formados em História a partir dos anos 1970, o historiador passa a ser, antes de tudo, o professor - sobretudo, o professor universitário, formado pela universidade.

\section{Encontros e desencontros}

Os historiadores ligados ao IHGSC tiveram na entidade um de seus principais canais de trocas intelectuais, tendo convivido também em espaços reservados ao exercício da política - nas redações de jornais, nos partidos, nas repartições governamentais e nos órgãos legislativos. Mas esses historiadores souberam igualmente criar vínculos com outras entidades e profissionais da área de História, e sua correspondência, mesmo que examinada de forma bastante fragmentada, dá indícios de interações significativas. Uma delas foi a estabelecida com Afonso d' Escragnolle Taunay. ${ }^{66}$

No caso dos irmãos Boiteux, as relações com Taunay assumiram o caráter de amizade e compadrio. Consultas "profissionais" e notas denotando relações de afetividade combinam-se e confundem-se em carta de 1932, de Taunay para José Boiteux:

Recebo os seus diversos bilhetes com os projetos submetidos à minha aprovação para o emblema da Faculdade de Direito de S.Catarina. Achei-os todos bons, perfeitamente em condições de serem aceitos. [...] Agora tive a grata surpresa da sua carta de Santos, pena que o Sr. não possa subir a S.Paulo com sua Snra. Nem que seja por horas. Teria muito prazer em cumprimentá-lo. [...] Assim, pois, penso que no projeto n.3 deveria ser num

\footnotetext{
${ }^{65}$ Depoimento de Raquel S. Thiago..., op.cit., fl.3.

${ }^{66}$ Cartas esparsas dos historiadores estão contidas em seus dossiês na Academia Catarinense de Letras. Algumas das cartas trocadas entre Taunay e os irmãos Boiteux encontram-se no Arquivo Permanente do Museu Paulista (Fundo Museu Paulista, Grupo Direção e Administração, Subgrupo Comunicação e Intercâmbio). Agradeço a Karine Anhezini pela colaboração, enviando cópia digital das cartas do Museu Paulista que localizou durante suas pesquisas.
} 
dos escudos ovalados aproveitada a idéia do Dr. Fontes: para mim o projeto n.3 assim constituído ficará esplêndido, muito melhor do que os de n.1 e 2 .

Desejo-lhe muito feliz estada no Rio. Recebi os jornais que me mandou, obrigado pelas palavras gentis sobre o escudo d[e] Laguna, faço muitos votos pela prosperidade do seu Instituto.

Muito obrigado pelas palavras amáveis relativas ao artigo do $\underline{\text { Cruzeiro. }}$ Quem sabe talvez nos vejamos. Meus respeitos a sua Snra. E aceite um abraço do admr. e am ${ }^{0}{ }^{67}$

Em carta dos anos 1930 - mais precisamente, de 1931 -, Taunay agradecia o "amigo e compadre" Lucas Boiteux pelo "volume da História de S.Catarina" que este lhe enviara. Menos formal do que a carta dirigida a José Boiteux, a apreciação do trabalho reforçava os laços de Taunay com Santa Catarina: "É uma excelente súmula dos fastos de nossa terra." E elogiava outros trabalhos de Lucas Boiteux, dando mostras de que acompanhava as publicações de seus estudos, no Rio de Janeiro: “Tenho lido sempre os seus excelentes artigos sobre os Ministros da Marinha. A série dará um esplêndido volume senão mais." 68

É possível que a relação com Taunay (sócio correspondente do IHGSC) fosse também uma forma de confirmar ou alterar posições dos historiadores catarinenses no campo historiográfico - ao menos, em nível regional -, na medida em que o diretor do Museu Paulista reconhecesse qualidades em seus trabalhos e externasse seu apreço pelos temas de pesquisa. Afonso de Taunay era uma "autoridade" do campo, e elogios ou críticas eram recebidos e acatados até por temperamentos mais irritadiços, como no caso de Oswaldo Cabral. ${ }^{69}$

\footnotetext{
${ }^{67}$ Carta de Afonso Taunay ao desembargador Boiteux. 13 de maio de 1932. Quanto ao "escudo de Laguna", cabe esclarecer que Taunay desenhou o brasão desse município bem como os de outros três municípios catarinenses: Joinville, Blumenau e São Francisco. Cf.: PIAZZA, Walter F. Dois historiadores catarinenses: Afonso d'E. Taunay e Lucas A. Boiteux. RIHGSC, Florianópolis, 33a. fase, n.6, 1985, p.77. Em 1926, José Boiteux enviou a Taunay, para integrar o acervo do Museu Paulista, "bandeira que conduzira um dos fanáticos em combate contra as forças do Governo na campanha do ex-Contestado". Bilhete de José Boiteux a Afonso de Taunay, encaminhando bandeira do movimento do Contestado. Florianópolis, 5 de abril de 1926. Tanto a carta de 1932 quanto o bilhete de 1926 estão no Arquivo Permanente do Museu Paulista, Fundo Museu Paulista, Grupo Direção e Administração, Subgrupo Comunicação e Intercâmbio.

${ }^{68}$ Carta de Afonso de Taunay a Lucas Boiteux. 24 de fevereiro de 1931. Arquivo Permanente do Museu Paulista, Fundo Museu Paulista, Grupo Direção e Administração, Subgrupo Comunicação e Intercâmbio.

${ }^{69}$ João Batista Bitencourt salientou: "O ensaio Laguna, por exemplo, chegou a ser criticado por Afonso d'E.Taunay, por conter afirmações impossíveis, fora o fato de que, para o crítico, a narrativa estava romanceada." Cabral teria acatado a crítica. BITENCOURT, João Batista. Estado Novo, cidade velha: o governo ditatorial de Vargas desde Laguna. Porto Alegre, 2002. Tese (Doutorado em História). UFRGS. p.247.
} 
Há que pensar, ainda, a questão das possíveis influências desses historiadores: o que liam? Que autores admiravam? A partir de quais historiadores conformavam suas visões de história? O mapeamento das influências mereceria ser feito, embora extremamente trabalhoso, pois teria que levar em conta citações de autores, obras e até mesmo epígrafes; o exame de suas bibliotecas forneceria elementos significativos, desde que tivesse sido conservada sua integridade, sem fragmentação. ${ }^{70}$ Foi possível, no entanto, recolher alguns indícios a este respeito.

"Homens de letras", esses historiadores (com pendores literários) liam autores vários. Vale referir, a título de exemplo, alguns dos autores citados por Lucas Boiteux, em seus trabalhos. No estudo Figuras do passado catarinense, estavam citados: Afonso de Taunay, o barão do Rio Branco, Capistrano de Abreu, Alfredo Ellis, Basílio de Magalhães, Oliveira Viana e vários autores de língua espanhola (na sua maioria remetendo a estudos com conexão direta com o tema das bandeiras); Boiteux reuniu ainda epígrafes de diversos escritores como Camões, Bilac, Alvarenga Peixoto, Fagundes Varela e Paulo Setúbal. ${ }^{71}$ Além disso, epígrafes de alguns de seu livros incluíram Fustel de Coulanges e Émile Faguet. E em seu discurso de posse na Academia Catarinense de Letras citou, novamente, Fustel de Coulanges, bem como Macaulay, Mommsen, Taine, Michelet, Reinach e Saint-Beuve.

Cabral reconheceu a importância que para ele tiveram aqueles que chamou de "mestres": Henrique Fontes, Barreiros Filho e, sobretudo, Altino Flores ${ }^{72}$. De Altino Flores, um dos principais articuladores da Academia Catarinense de Letras, Cabral estaria distante, em princípio, pela idade, mas dele teria se aproximado em função dos interesses em comum pelas pesquisas históricas e pela literatura. ${ }^{73} \mathrm{E}$ em outro texto publicado em jornal, Cabral chamou a atenção para a influência que Luiz Edmundo teria exercido sobre a concepção de um de seus livros mais destacados:

\footnotetext{
70 A biblioteca de Lucas Alexandre Boiteux, adquirida pela Universidade Federal de Santa Catarina, foi dispersada pelas várias áreas temáticas do acervo.

${ }^{71}$ BOITEUX, Lucas A. Figuras do passado catarinense: o capitão-mór Domingos de Brito Peixoto, senhor da Laguna - sua prole e seus serviços. Florianópolis: 1954.

${ }^{72}$ CABRAL, Oswaldo Rodrigues. Mestre Altino. O Estado, Florianópolis (SC), 6 fev. 1972. p.1; CABRAL, Oswaldo Rodrigues. Em busca da perfeição e o "Mea Culpa" (1, 2, 3 e 4). O Estado, Florianópolis (SC), abr. 1974. Acervo da Academia Catarinense de Letras, Dossiê Oswaldo Rodrigues Cabral.

${ }^{73}$ CABRAL, Oswaldo Rodrigues. Mestre Altino, op.cit. Cabral refere-se também à correspondência entre Carlos da Costa Pereira e Altino Flores, bem como à admiração de ambos pelos "mestres lusitanos".
} 
NOSSA SENHORA DO DESTERRO [...] quis fazer no estilo de Luís Edmundo, alegre, descontraído, sem a perfeição que este alcançou, mas com não menor êxito de saída". ${ }^{74}$

As influências literárias dos historiadores do IHGSC decorriam também da interação, a partir da década de 1920, com um outro espaço institucional em Santa Catarina: a Academia Catarinense de Letras. Além disso, de fins da década de 1940 em diante, muitos estariam juntos nas atividades da Comissão Catarinense de Folclore. Criada a Faculdade de Filosofia e, posteriormente, a Universidade Federal de Santa Catarina, teriam ali um local de encontros e trocas: a universidade seria transformada em instância relevante para a atuação de alguns dos antigos sócios do Instituto, bem como celeiro de novos.

As interações com todos esses espaços institucionais tenderão a fortalecer os laços entre os historiadores do Instituto, mas a dividir esforços, com prejuízo para o andamento das atividades de algumas entidades, como sugerem alguns de seus estudiosos. O próprio Oswaldo Cabral destacou, em 1976, referindo-se especificamente ao IHGSC, à Academia Catarinense de Letras e à Associação de Imprensa, que

[...] os componentes de todas estas associações culturais eram, em sua maioria, os mesmos. E isto contribuiu para que, depois de um certo tempo, as associações vissem a diminuir a sua freqüência e chegassem a ter uma vida quase simbólica. [...] Aqui, meio pequeno ainda, os homens que estudavam história eram os mesmos que escreviam contos, versos e novelas, os mesmos que tinham suas colunas nos jornais. ${ }^{75}$

No caso do IHGSC, sua Revista parece funcionar como termômetro de suas condições de funcionamento - publica-se a Revista, e a entidade vai bem; desaparece a Revista, e é sinal de que enfrenta problemas. Uma das razões da interrupção do periódico, nos anos 1920, seria a própria criação da Academia Catarinense de Letras - ou, como pontuou

\footnotetext{
${ }^{74}$ CABRAL, Oswaldo Rodrigues. Mania de pichar. op.cit.. Luís Edmundo, escritor que integrou a Academia Brasileira de Letras, provavelmente inspirou Cabral pelas seguintes obras: O Rio de Janeiro do tempo dos vicereis (1938), A Corte de D.João VI no Rio de Janeiro (1940), O Rio de Janeiro do meu tempo (1940).

${ }^{75}$ CABRAL, Oswaldo R. Introdução: Carlos da Costa Pereira; sua vida - sua obra. In: PEREIRA, Carlos da Costa. A Revolução Federalista de 1893 em Santa Catarina. Florianópolis: Governo do Estado de Santa Catarina, 1976. p.13-14.
} 
Celestino Sachet, a emergência de uma nova geração de escritores, pondo em destaque a literatura, mais que a história. Para Sachet,

[...] o ano do nascimento da Sociedade Catarinense de Letras [1920] vê esgotar-se a potencialidade dos estudos históricos e de seu Instituto, a tal ponto que, se o Dicionário Histórico e Geográfico do Estado, organizado por José Arthur Boiteux, teve o $1^{\circ}$. e o $2^{\circ}$. volumes publicados em 1916, só em 1940 - quando o ciclo da Academia está encerrado e recomeça o do Instituto Histórico - é que o $3^{\circ}$., e último volume, teria as boas graças de Nereu Ramos para sua desesperada publicação. ${ }^{76}$

Como a confirmar o ocaso da Academia e o renascimento do Instituto, Oswaldo Cabral (que pertencia às duas entidades), comentou, em carta dirigida a Arnaldo S. Thiago, de 1941:

Sobre a nossa Academia, não creio na sua ressurreição, pelo menos no momento. Há um desinteresse completo e o Governo do Estado acabou cortando a subvenção que lhe concedia - pois não tinha ela existência concreta. [...] No mais, continuamos a trabalhar no nosso Instituto Histórico, casa de menos vulto, mas atualmente de maior eficiência. ${ }^{77}$

Oito anos depois, escrevendo a Nereu Corrêa, Cabral apontava estar a Academia prestes a acordar de seu "sono hibernal". Contudo, no seu entender, o Instituto detinha o "facho sagrado": "Não fora ele e tudo estaria estagnado na pasmaceira, ouvindo o coaxar de uma ou outra rã à beira da lagoa das letras.",78

Vários foram os historiadores do IHGSC representados na Academia Catarinense de Letras, ocupando em geral as cadeiras 4, 17, 30 e 31: os irmãos Boiteux (José Arthur, Henrique e Lucas Alexandre), Henrique Fontes, Carlos da Costa Pereira, Oswaldo Cabral, Walter Piazza, Carlos Humberto Corrêa, Jali Meirinho.

Na segunda metade da década de 1940, a interrupção da Revista talvez possa ser creditada aos trabalhos de organização do $1^{\circ}$. Congresso de História Catarinense, realizado em

\footnotetext{
${ }^{76}$ SACHET, Celestino. As transformações estético-literárias..., op.cit., p.64-65.

${ }^{77}$ Carta de Oswaldo Rodrigues Cabral a Arnaldo S.Thiago. Florianópolis, 28 de abril de 1941. Acervo da Academia Catarinense de Letras, Dossiê de Oswaldo Rodrigues Cabral.

${ }^{78}$ Carta de Oswaldo Rodrigues Cabral a Nereu Corrêa. Florianópolis, 23 de maio de 1949. Acervo da Academia Catarinense de Letras, Dossiê de Oswaldo Rodrigues Cabral.
} 
1948. Contudo, não é suficiente para compreender o seu reaparecimento apenas em 1979. A esse respeito, convém lembrar, de um lado, o envolvimento de vários membros do IHGSC (com destaque para Oswaldo Cabral) na edição do boletim da Comissão Catarinense de Folclore, entre 1949 e 1963 (foi retomada após 1975). Igualmente, houve o envolvimento (principalmente de Henrique Fontes e Oswaldo Cabral) nas atividades de organização e implantação da Faculdade de Filosofia, na década de 1950. Já na década de 1960, há que considerar a desestruturação do Instituto, com o desmoronamento do prédio onde estava sediado e a conseqüente perda de significativa parcela de seu acervo (biblioteca, arquivo e museu). Além disso, o IHGSC perdeu seu presidente, que estava nessa função desde a década de 1930, e integrava a diretoria desde a década de 1910 (ver Apêndice I-5): morreu, em 1966, com 81 anos, Henrique da Silva Fontes. ${ }^{79}$

Como a indicar o encerramento de uma fase do Instituto, a década de 1960 assinalou, além da morte de Fontes, os falecimentos de dois de seus mais destacados historiadores: Lucas Alexandre Boiteux (com 80 anos, em 1966) e Carlos da Costa Pereira (com 77 anos, em 1967). Na década de 1970, ocorreu a aposentadoria de Oswaldo Cabral, na Universidade (em 1973); a morte viria em $1978 .{ }^{80}$ Sob a liderança de Walter Piazza, a partir de 1968, o IHGSC buscaria renovar-se por meio de uma história que se pretendia científica, com o selo da universidade.

Em um primeiro momento, portanto, a Universidade (no caso, a Universidade Federal de Santa Catarina) e o IHGSC estavam próximos. Uma entidade importante para os historiadores - sintomaticamente denominada Associação Nacional de Professores Universitários de História/ANPUH - tinha seu Núcleo Regional em Santa Catarina e, em 1975, a diretoria eleita era a seguinte: Walter Piazza (presidente); Walmor Senna (secretário); Rufino de Almeida (tesoureiro); Valter Gomes, Darcy Pacheco e Terezinha Barreto (comissão consultiva). ${ }^{81}$ O Núcleo assumiu tarefa não pequena: organizar o IX Simpósio Nacional de Professores Universitários de História, realizado em Florianópolis, em 1977 (o que não deixava de emprestar ainda mais "profissionalismo" ao contexto historiográfico catarinense).

\footnotetext{
${ }^{79}$ PÍTSICA, Paschoal A. Henrique Fontes: o historiador. RIHGSC, $3^{\mathrm{a}}$. fase, n.6, 1985. p.85-93.

${ }^{80}$ SOUZA, Sara Regina Silveira. Oswaldo Cabral...., op.cit., p.185 e 218.

${ }^{81}$ Jornal de Santa Catarina, Florianópolis, 2 out. 1975. Acervo da Academia Catarinense de Letras, Dossiê Walter F.Piazza.
} 
O I Encontro Estadual de História aconteceria apenas em 1986. Os anais daquele encontro informavam que o Núcleo Regional da ANPUH - "reativado", em 1985 - tivera Joana Maria Pedro como diretora da diretoria provisória, e Maria Bernardete Ramos Flores como vice-diretora; para o biênio 1986-1988, Maria Bernardete Ramos Flores foi eleita diretora e Maria Teresa Santos Cunha, vice-diretora. ${ }^{82}$

Os anais do I Encontro permitem entrever mudanças. A palestra de abertura, por exemplo, a cargo de Sandra Jatahy Pesavento, tratou de "História regional" e, tomando como exemplo a historiografia do Rio Grande do Sul (sobretudo a produzida no âmbito do Instituto Histórico e Geográfico do Rio Grande do Sul), criticou "um tipo de visão estreita e tradicional do que seja uma História Regional", que "elimina a noção de processo", que "elimina a dominação", que "elimina o conflito". ${ }^{83}$

A participação de historiadores com fortes vínculos com o Instituto foi pequena os anais registram Piazza e Licurgo Costa -, mas incisiva. Piazza apresentou comunicação com informações sobre suas pesquisas recentes no que chamou de "arquivos econômicos de Lisboa". ${ }^{84} \mathrm{Na}$ comunicação, como que comentando, indiretamente, a fala de Sandra Pesavento, afirmou que

[...] não se pode falar em História, nem se querer estabelecer modelos, estruturas e conjunturas sem fazer o que eu chamo de "trabalho de estiva". O trabalho de coletar dados empíricos em arquivos para depois trabalhá-los, depois dar-lhes forma de comunicações, depois fazer deles os grandes embasamentos da História Regional. ${ }^{85}$

Também interveio ao final de comunicação de Roselys Izabel Corrêa dos Santos, sobre a colonização italiana, a propósito do comentário da apresentadora de que, na antiga colônia catarinense de "Porto Franco" (hoje Botuverá), a colonização não tivera sucesso, sendo o caso de "uma história dos vencidos". A intervenção é significativa para demonstrar a forte presença das concepções consolidadas pelos historiadores do IHGSC nas próprias

\footnotetext{
${ }^{82}$ Anais do I Encontro Estadual de História - Florianópolis, 25 a 29 de agosto de 1986. Florianópolis: 1987. p.11-12, 14.

${ }^{83}$ PESAVENTO, Sandra J. História Regional [palestra]. Anais do I Encontro Estadual de História..., op.cit., p.21, 23, 25.

${ }^{84}$ PIAZZA, Walter F. O Brasil e Santa Catarina nos arquivos econômicos de Lisboa. Anais do I Encontro Estadual de História..., op.cit., p.46.

${ }^{85}$ Ibidem.
} 
reflexões de Piazza, não obstante sua suposta guinada "científica", favorecida pela formação universitária. Segundo Piazza:

[...] não há vencedores nem vencidos na História de Santa Catarina. Não há vencedores nem vencidos, principalmente nas áreas de povoamento e colonização. [...] nós temos que olhar sempre que o agricultor, o povoador, o colonizador, fosse ele açoriano, fosse ele italiano ou alemão das áreas agrícolas, nem sempre ele é um vencido. É muito bonito falar da história dos vencidos. Eu gosto de falar da história dos vencidos. Daqueles que são humildes, daqueles que todos pensam ser os vencidos. Às vezes são os vencedores culturalmente. São os quem marcam. E nós não podemos esquecer que o açoriano deixou o substrato cultural que amalgamou, aculturou os italianos primeiramente, os alemães, em grande parte. [...] $\mathrm{Na}$ realidade, nós temos um sobrenome italiano, um sobrenome alemão, mas no fundo, culturalmente, nós somos açorianos." ${ }^{, 86}$

Licurgo Costa, além de apresentar comunicação sobre "O que é, o que representa o Instituto Histórico e Geográfico de Santa Catarina" (basicamente, representaria "um elemento de estímulo ao estudo da História") ${ }^{87}$, ao final de uma comunicação sobre o Contestado convidou os presentes a participarem de reunião a ser promovida pelo Instituto, por ocasião dos 70 anos da assinatura do acordo Santa Catarina-Paraná - acordo pelo qual o estado de Santa Catarina, injustiçado, teria sido "roubado em cerca de $30.000 \mathrm{~km}^{2,, 88}$.

Juntamente com as falas de Walter Piazza e Licurgo Costa, o I Encontro Estadual de História, em Santa Catarina, formou um grande painel de idéias longe de coincidirem: Sandra Pesavento citou Lênin e Gramsci a propósito da questão da "região"; Dorval Nascimento e Márcia Fantin apresentaram as propostas do CEDIP, em Criciúma, um centro que pretendia ser "instrumento de apoio, de informação e de documentação histórica" dos movimentos sociais; Marcos Antônio da Silva definiu documentos históricos como "agentes significativos das práticas sociais estudadas"; Maria Bernardete Ramos Flores defendeu uma história que contribuísse para a "desocultação das contradições de outras sociedades, encobertas pela historiografia oficial", que ensinasse "a história verdadeira, a história dos

\footnotetext{
${ }_{87}^{86}$ Anais do I Encontro Estadual de História..., op.cit., p.42.

${ }^{87}$ Ibidem, p.61.

${ }^{88}$ Ibidem, p. 75.
} 
homens reais em sociedade, e não apenas a história dos mitos, dos heróis da classe dominante"; e Henrique Luiz Pereira Oliveira, na condição de coordenador do Núcleo de História de Santa Catarina, apesar da ressalva quanto aos "diversos trabalhos novos, com novas perspectivas", destacou o quanto a "produção historiográfica referente a Santa Catarina" carecia de "novos enfoques" que incorporassem "os instrumentos teóricos e metodológicos desenvolvidos nas diversas áreas da Ciências Humanas”, de abordagens que propiciassem "a reflexão dos agentes sociais sobre o processo histórico", contribuindo para "o entendimento da realidade que esses indivíduos vivem." ${ }^{89}$ Formas distintas de conceber e pensar a história estavam em jogo, em convivência e tensão.

No encontro seguinte, em 1988, os anais ainda registraram a presença de Walter Piazza, na mesa redonda sobre "escravidão negra no Brasil". 90 Mas a ANPUH, e seus encontros regionais, tornaram-se privilegiadamente espaços de encontro de profissionais de História, não havendo lugar para diletantes. Mesmo os primeiros graduados e pós-graduados em Santa Catarina, distanciando-se da ANPUH, passarão a eleger os encontros da Sociedade Brasileira de Pesquisa Histórica (SBPH) para apresentação de trabalhos e encaminhamento de discussões de seu interesse. As razões disso prendem-se a divergências quanto aos rumos da entidade e ao tensionamento maior entre os diferentes grupos de historiadores. Na perspectiva de Jali Meirinho, que participa da SBPH desde a sua fundação,

A SBPH não restringiu em termos de ideologia, o problema foi a formação. A ANPUH começou a abrir para aluno e o que se queria era uma entidade a nível de professor. E naqueles anos também eram momentos diferentes. A coisa agora, a partir de uns quatro, cinco anos para cá, o quadro está mudando em termos gerais, de Brasil, não há mais aquela radicalização, acho. [...] Eu não tenho nenhuma restrição a quem quer que seja, qualquer ponto de vista, ideologia, sei lá o que. Eu sempre estive aberto, gostando de conhecer tudo. ${ }^{91}$

Contudo, os próprios historiadores do Instituto de alguma forma reconheceram que a ANPUH e a SBPH - ao menos, em termos de discussões em torno da história de Santa

\footnotetext{
${ }^{89}$ Anais do I Encontro Estadual de História..., op.cit., p.16-17, 52, 86, 129-130, 142.

${ }^{90}$ Anais do II Encontro Estadual de História - Florianópolis, 22 a 26 de agosto de 1988. Florianópolis: 1990. p.49-56.

${ }^{91}$ Depoimento de Jali Meirinho..., op.cit, fl.15-16.
} 
Catarina - tornaram-se espaços de fazeres historiográficos distintos. Piazza, em entrevista concedida ao jornalista e historiador Apolinário Ternes, em 1996, considerou:

Sim, estão surgindo novos estudos e novas abordagens. Mas você não tem uma definição muito clara disso, não. A velha história é de homens e fatos. É factual. A nova história é uma reinterpretação da velha. Mas você não pode fugir dos dados históricos, dos dados empíricos. E hoje temos gente dos dois lados. Participo anualmente de encontros da Sociedade Brasileira de Pesquisa Histórica, que congrega número reduzido de historiadores brasileiros. Nessas reuniões, temos visto como é necessária ainda a velha história. $^{92}$

Devem ainda ser lembrados, claro, os eventos promovidos pelo IHGSC inclusive os encontros de "micro-história" que, para o Instituto, é vista como sinônima de história local. ${ }^{93}$ Por via de regra, os espaços de uns e outros historiadores, utilizados para discutir suas maneiras de ver e fazer as histórias de Santa Catarina, aparentemente permanecem sem necessidade de interação. Isso ocorre até mesmo nas revistas que veiculam sua produção, em Santa Catarina.

No ano de 1990, o Núcleo Regional de Santa Catarina da ANPUH lançou o primeiro número de sua revista - Revista Catarinense de História. Note-se que o termo "catarinense" adjetiva a revista, e não a história. Na "Apresentação", feita pelo Conselho Editorial, o periódico foi apresentado como "espaço destinado a produzir encontros entre pessoas preocupadas em divulgar experiências pertinentes ao ensino e pesquisa na área de História." Esboçando-se ali tarefas para o historiador, a história dita "tradicional" também foi delineada, em negativo:

Mais do que a tarefa de dizer a verdade, cabe ao historiador o empreendimento de investigar os modos de produção das verdades: muito mais do que esgotar os fatos sobre os grandes temas da historiografia, investigar os processos de edificação destes blocos sagrados de eventos.

\footnotetext{
92 TERNES, Apolinário. Walter F. Piazza, historiador [entrevista], op.cit., p.E2.

93 Para os programas dos quatro Encontros Catarinenses de Micro-História, realizados entre 1992 e 1995, ver o Acervo da Academia Catarinense de Letras, Dossiê de Walter F. Piazza.
} 
Uma história das coisas que aconteceram, mas também uma história dos modos de construir as coisas que aconteceram. ${ }^{94}$

Nos anos 1990, os embates entre os representantes do IHGSC e os "novos" historiadores parecem ter sido mais ásperos. Em julho de 1993, uma manifestação na seção de "Cartas" do Diário Catarinense dá mostras do nível de atritos: solidarizando-se com leitor que reclamara dos entraves burocráticos enfrentados pelos pesquisadores nas tentativas de consulta ao acervo do IHGSC, Ricardo Fernando Goulart entendeu que os problemas decorriam da

[...] orientação de uma diretoria eivada de arrogância e decrepitude no tratamento dispensado aos "novos pesquisadores", que não fazem parte da curriola dos que assaltaram a historiografia catarinense e detêm o acesso às fontes documentais. ${ }^{95}$

Ao lado do problema do acesso, em termos de autorização de consulta aos documentos, fica colocada a questão, na carta, da privatização de documentos públicos, por parte dos historiadores do IHGSC (e não exatamente por ações do Instituto enquanto entidade). ${ }^{96}$

Como destacou Joana Pedro, os confrontos de então foram duros:

Foi uma disputa bem grande. Foi uma disputa de gerações. Hoje eu faço essa leitura, na época não. Eu achava que nós éramos os certos, eles eram os que estavam errados. Eles eram os conservadores, nós éramos a esquerda militante. [...] Quando eu vim pra cá, voltei do Doutorado (estou dizendo que eu continuava um pouco arrogante), eu tive a coragem de me candidatar a ser coordenadora. Inexperiente, completamente. E aí eu assumi, e os que estavam aposentados eu não pedi para saírem, mas eu criei um item (reconheço isso), eu tirei o direito de voto deles - claro, não sozinha, em

\footnotetext{
${ }^{94}$ Apresentação [do Conselho Editorial]. Revista Catarinense de História. Florianópolis, n.1, maio 1990. p.5. O Conselho Editorial era então formado por Cynthia Machado Campos, Evaristo Kiatowski, Henrique Luiz Pereira Oliveira e Maria de Fátima Sabino Dias. A revista continua a ser editada mas, desde 1998, passou a ser denominada Fronteiras - Revista Catarinense de História.

95 Cartas. Diário Catarinense, Florianópolis, 20 jul. 1993, p.2. Acervo da Academia Catarinense de Letras, Dossiê Walter F. Piazza.

${ }^{96}$ A respeito da apropriação privada de documentos públicos por pesquisadores da história de Santa Catarina, ver Parte III, Capítulos 2 e 3.
} 
acordo com o Colegiado - no Colegiado de Pós-Graduação. Com isso, eles perderam poder. Eles imediatamente se afastaram. Com isso a gente perdeu a experiência deles, também. Hoje eu reconheço isso.

O próprio caminho na direção da História Cultural foi marcado por essa ruptura. E eu confesso que sei que essa ruptura foi feita em 1993, quando eu assumi a coordenação do Mestrado. E também sei que foi por causa disso. Eu achei que depois eles ficariam, eles voltariam, mas eles não voltaram. ${ }^{97}$

Passada uma década dos embates mais ferrenhos, desenham-se gestos que talvez sejam tímidas aproximações: veja-se que o IHGSC concedeu, em dezembro de 2005, o prêmio Lucas Alexandre Boiteux para o livro Memórias de uma (outra) guerra, de Marlene de Fáveri - professora universitária e representante da "nova geração", 98 Livro que resultou de tese de doutorado defendida justamente no Programa de Pós-Graduação em História da UFSC, sob orientação de Joana Maria Pedro.

Por seu turno, o preto e o branco da imagem da "história tradicional" ganharam nuances de cinza. Ao menos, entre aquelas que foram agentes principais da inovação, no Mestrado em História da UFSC. Maria Bernardete Ramos Flores, em livro recente sobre a presença espanhola na ilha de Santa Catarina em fins do século XVIII, prestou

[...] uma homenagem e um tributo aos historiadores de Santa Catarina: Oswaldo Rodrigues Cabral, Walter Piazza, Lucas Boiteux e, a mais jovem, Maria de Fátima Piazza, entre outros, menos conhecidos entre nós [...], que se dedicaram a procurar, colecionar documentos, ler, compreender, falar deles, indignar-se, a julgar também a história, afinal a ilha de Santa Catarina passou por um episódio de guerra $[\ldots]^{99}$

Joana Pedro, por sua vez, considerou:

Acho que com a historiografia daqui [de Santa Catarina] eu posso dizer que cada vez mais eu tenho uma relação tranqüila. Não quer dizer que eu não tenha críticas, mas é bom lembrar: quem foi que disse que meus trabalhos não têm crítica? Eu mesmo às vezes não me reconheço. Ainda segunda-feira

\footnotetext{
${ }^{97}$ Depoimento de Joana Maria Pedro..., op.cit., fl. 18-19.

${ }^{98}$ História. Diário Catarinense, Florianópolis, 5 dez. 2005.

${ }^{99}$ FLORES, Maria Bernardete Ramos. Os espanhóis conquistam a Ilha de Santa Catarina - 1777. Florianópolis: Ed. da UFSC, 2004. p.126-127.
} 
uma menina me citou, em um artigo de 1994. Eu disse: “Ah, querida, eu não me reconheço mais nesse artigo, não!”. 1994 é uma coisa, 2006 é outra. É outro olhar, é outra discussão. Então, eu acho que é um pouco por isso: a gente na época não dava, pra eles, o direito de ter uma temporalidade. Agora eu dou. ${ }^{100}$

Naquele mesmo livro sobre o final do século XVIII na ilha de Santa Catarina, Maria Bernardete Ramos Flores quis homenagear os "guardadores de arquivos": "Zelosos, cuidam do campo da escrita, quer dizer, dos documentos, onde permanece, no silêncio das pastas, a matéria da qual se extrai a narrativa histórica."101

Para os historiadores ligados ao IHGSC, o ofício de historiador estava (e ainda está) em grande medida traduzido na lida com os documentos. O enfrentamento do "pó dos arquivos", o trato da documentação, seu conhecimento e crítica (no sentido que a chamada Escola Metódica emprestou à crítica) faziam (e fazem) de alguém um historiador, ou, em imagem cara a Lucas Boiteux, um "escavador". Mas, em meio às transformações do campo historiográfico catarinense, ao longo do século XX, qual a trajetória das instituições arquivísticas de Santa Catarina? Teriam ficado menos sombrios os umbrais dos arquivos? Seriam mais facilmente transpostos?

\footnotetext{
${ }^{100}$ Depoimento de Joana Maria Pedro..., op.cit., fl.20.

${ }^{101}$ FLORES, Maria Bernardete Ramos. Os espanhóis...., op.cit., p.127.
} 


\section{PARTE II:}

\section{DISPOR}

A imobilidade das coisas que nos cercam talvez lhes seja imposta por nossa certeza de que essas coisas são elas mesmas e não outras, pela imobilidade de nosso pensamento perante elas.

Marcel Proust (No caminho de Swann) 


\title{
Parte II \\ Capítulo 1
}

\section{Arquivos em Santa Catarina: buscando definir uma política}

\author{
Desde os poderes constituídos da Nação, \\ passando pelos dos Estados até aos Municípios, \\ constata-se a predisposição para dirigir ao lixo \\ papéis e documentos, sem qualquer cuidado de consulta \\ quanto ao valor histórico presente ou que possam vir a adquirir. [...] \\ A insensibilidade das elites dirigentes principia \\ pelo arbítrio na indicação dos agentes das ações \\ a serem desenvolvidas pelas instituições \\ cuja atribuição é a conservação dos bens culturais. [...] \\ São os leigos, sem qualquer formação técnica, \\ meros burocratas, que encontramos tranqüilos, \\ contemplando a destruição do Patrimônio Histórico, inconscientes do seu valor.
}

Jali Meirinho, 1984

No comentário do historiador Jali Meirinho, os documentos em causa são os documentos públicos, produzidos nas várias esferas dos governos e que, descurados, perdemse para a história. Inevitável lembrar de Capistrano de Abreu, um século antes, quando considerou ser o descuido com os documentos uma herança que os brasileiros receberam dos portugueses. ${ }^{1}$ Mas Meirinho discordaria do historiador cearense: destacou, na mesma ocasião, ter o Brasil assegurado "15.719 quilômetros de fronteiras, com tantos países vizinhos, porque a inteligência portuguesa ao longo dos séculos soube dar devido valor aos documentos e

\footnotetext{
1 "Se os portugueses fossem gente que curasse de documentos; se os brasileiros não tivessem herdado este descuido de seus avós; existiria hoje uma grande soma de papéis de muita importância para a nossa história." ABREU, João Capistrano. Gravetos de História Pátria [1881]. In: Ensaios e estudos: Crítica e História (4 . série). Rio de Janeiro: Civilização Brasileira, Brasília: INL, 1976. p. 310. O foco de Capistrano de Abreu, no artigo publicado na Gazeta de Notícias, eram os documentos relativos às sesmarias.
} 
guardá-los em seus arquivos." Em 1984, não eram os "brasileiros" os responsáveis pelo desapego em relação à documentação pública: ganharam a cena as "elites dirigentes" do país, cuja insensibilidade estaria na base das ações que resultavam em destruição de materiais de valor histórico, já reconhecido ou provável. Como poderiam cumprir seu papel na "conservação dos bens culturais", afinal, instituições administradas por "leigos", “inconscientes do seu valor"?

Se as considerações de 1881, feitas por Capistrano de Abreu, foram partilhadas com um público leitor, as de Jali Meirinho foram dirigidas a um público ouvinte: justamente aquele que, em 21 de setembro de 1984, assistia à última sessão do I Encontro Catarinense de Arquivos, realizado em Florianópolis. Na função de relator, o historiador sistematizou, em sua fala, o que viriam a ser as conclusões do evento. Primeiro de uma longa série, ainda hoje não interrompida, o encontro sinalizava esforço de mudança na situação ali diagnosticada. Os desafios: garantir a proteção dos documentos públicos de interesse histórico, quer do governo estadual, quer dos governos municipais, fazendo com que as instituições arquivísticas fossem ocupadas por pessoas nisso engajadas; fortalecer as instituições arquivísticas existentes e criar novas, procurando integrá-las por meio de uma política para a área; dar visibilidade, enfim, às instituições, aos seus agentes, aos acervos aí envolvidos.

Tratava-se, portanto, de constituir em Santa Catarina um campo disciplinar e profissional, consolidando-o de modo a operar segundo suas próprias premissas, ficando menos sujeito a interferências externas, alheias a seus parâmetros técnicos. ${ }^{3}$ Instituições, profissionais e ações seriam privilegiadas nesse empreendimento de constituição. Bastante valorizadas, também (ao menos no início dessa empreitada), as conexões com outro campo o da História -, como claramente demonstrava Jali Meirinho, em 1984.

A construção em terreno movediço, porém, é temerária. Entre os anos 1980 e os anos iniciais do presente século, os contextos em que as atividades arquivísticas deveriam ou poderiam estar inseridas modificaram-se muito significativamente.

\footnotetext{
2 Relatório do relator do segundo dia de sessões do I Encontro Catarinense de Arquivos (relator identificado, a lápis, como o Prof. Jali Meirinho). [Florianópolis], 21 de setembro de 1984; datilografado. Acervo do Arquivo Público do Estado de Santa Catarina, Fundo Arquivo Público, G IV, SG IV.1, 60-1984-1996, s.10.

${ }^{3}$ Sigo, aqui, as indicações de Bourdieu: "quanto mais autônomo for um campo, maior será o seu poder de refração e mais as imposições externas serão transfiguradas [...]. Inversamente, a heteronomia de um campo manifesta-se, essencialmente, pelo fato de que os problemas exteriores, em especial os problemas políticos, aí se exprimem diretamente." BOURDIEU, Pierre. Os usos sociais da ciência: por uma sociologia clínica do campo científico. São Paulo: Ed. da UNESP, 2004. p.22.
} 
Em nível nacional, e no plano jurídico-legal, a década de 1990 foi aberta com boas promessas para a área de arquivos: no rastro da Constituição de 1988, o projeto de lei referente aos arquivos brasileiros, depois de muitos anos de discussão entre os profissionais, bem como de descaminhos no Congresso Nacional, ganhou aprovação e forma de lei em 1991. Uma nova entidade - o Conselho Nacional de Arquivos, criado pela mesma lei de 1991 - atuaria a partir de meados dos anos 1990, propondo diretrizes, normas, procedimentos. Os cursos de graduação em Arquivologia, aumentando em número e distribuindo-se por mais unidades da federação, começariam a alterar o perfil da produção intelectual da área, antes concentrada em instituições arquivísticas ou instituições de pesquisa especialmente dedicadas a conjuntos documentais arquivísticos. Até mesmo a Associação dos Arquivistas Brasileiros $\mathrm{AAB}$, criada em inícios da década de 1970, perdeu sua exclusividade, e a partir do final dos anos 1990 surgiram várias associações regionais autônomas (inicialmente, cabe esclarecer, reinventando os núcleos regionais da própria $\mathrm{AAB}$, extintos em 1998). ${ }^{4}$ Teve força ainda, no período, a intenção de descolar a Arquivística (ou Arquivologia) ${ }^{5}$, enquanto campo disciplinar, tanto da Biblioteconomia quanto da História (apagando a concepção de que fosse uma das "ciências auxiliares" desta última), o que freqüentemente se traduziu em tensões e

\footnotetext{
${ }^{4}$ A respeito, ver: FONSECA, Maria Odila. Arquivologia e ciência da informação. Rio de Janeiro: Editora FGV, 2005. p.67-72 e 101; JARDIM, José Maria. Sistemas e políticas públicas de arquivos no Brasil. Niterói (RJ): EdUFF, 1995. p.60-63; JARDIM, José Maria. A produção do conhecimento arquivístico: perspectivas internacionais e o caso brasileiro. In: JARDIM, José Maria, FONSECA, Maria Odila (orgs.). A formação do arquivista no Brasil: I Reunião Brasileira de Ensino de Arquivologia (REBRARQ). Niterói (RJ): EdUFF, 1999. esp. p. 87-111. Após a extinção dos núcleos regionais da AAB, em julho de 1998, foram criadas várias associações regionais autônomas, como a Associação de Arquivistas de São Paulo - ARQ-SP (a primeira a ser criada, em outubro de 1998), a Associação dos Arquivistas do Estado do Rio Grande do Sul - AARS, a Associação Brasiliense de Arquivologia - ABARQ, a Associação dos Arquivistas da Bahia - AABA, a Associação de Arquivistas do Estado do Rio de Janeiro - AAERJ e a Associação de Arquivistas do Espírito Santo - ARQES. Sobre as associações regionais, ver: <http://www.arqsp.org.br>, <http://www.aargs.com.br>, $<$ http://www.aaerj.org.br>, <http://abarq.blogspot.com>, <http://www.arquivistasbahia.org>. Acesso em: 21 mar. 2006.

${ }^{5}$ O Dicionário de Terminologia Arquivística produzido pelo Núcleo Regional de São Paulo da Associação dos Arquivistas Brasileiros, publicado em 1996, prefere o termo "Arquivística" para designar a disciplina "que tem por objeto o conhecimento da natureza dos arquivos [enquanto conjuntos documentais] e das teorias, métodos e técnicas a serem observados na sua constituição, organização, desenvolvimento e utilização"; indica, porém, que a Arquivística é "também conhecida como arquivologia". BELLOTTO, Heloísa L., CAMARGO, Ana Maria de Almeida (coord.). Dicionário de Terminologia Arquivística. São Paulo: AAB-SP, 1996. Já o Dicionário Brasileiro de Terminologia Arquivística, elaborado pelo Arquivo Nacional e publicado em 2005, dá preferência ao termo "Arquivologia", entendendo-a como a "disciplina que estuda as funções do arquivo [enquanto instituição] e os princípios e técnicas a serem observados na produção, organização, guarda, preservação e utilização dos arquivos [enquanto conjuntos documentais]”. Dicionário Brasileiro de Terminologia Arquivística. Rio de Janeiro: Arquivo Nacional, 2005. Não obstante os cursos de graduação na área, no Brasil, utilizarem o termo "Arquivologia", será dada preferência, no presente trabalho, ao termo “Arquivística”, considerando-se não só sua adoção em português (amplamente, em Portugal) como também em outras línguas (espanhol, francês, italiano).
} 
disputas acirradas entre profissionais de distintas formações que atuavam (e atuam) na área de arquivos.

Paralelamente, as transformações provocadas pela intensa disseminação de novas tecnologias da informação e de comunicação, em nível mundial, trouxeram, para a área arquivística, forte preocupação com a informatização dos procedimentos técnicos de tratamento da documentação e com os desafios gerados pelo universo digital. Como decorrência dessas transformações, a figura do especialista em informática ganhou grande visibilidade social, tendendo a obscurecer, ou mesmo a apagar, o papel de profissionais que tradicionalmente lidavam com o tratamento de documentos (ou de "informações registradas"). $\mathrm{Na}$ área de administração, por outro lado, inovações nos processos de gestão tenderiam a atropelar procedimentos arquivísticos, quer criando programas de qualidade amplamente difundidos nas organizações (como o programa "5 S"), quer abrindo novas frentes de atuação (como a "gestão da informação" e a "gestão do conhecimento"). ${ }^{6}$

Em termos mundiais, grosso modo, a década de 1990 pode ser considerada um momento de crise do campo arquivístico e, sintomaticamente, a literatura da área, nos vários países, passa a abrigar o questionamento de seus princípios fundamentais, tidos como anacrônicos. Para alguns autores, anunciava-se a transição de uma era de documentação arquivística maciçamente (embora não exclusivamente) produzida em papel para uma era digital, com o predomínio de documentos gerados diretamente (e mantidos) em meio eletrônico. Viveríamos uma transição de paradigmas: do paradigma "custodial", característico de uma Arquivística preocupada com “documentos", para um paradigma "pós-custodial”, próprio de um momento em que importam, sobretudo, as "informações", que passam a migrar

\footnotetext{
${ }^{6}$ Vários autores concordam que a expansão de programas de qualidade se dá no momento da transição, no universo do trabalho, de um modelo hegemonicamente fordista para um modelo pós-fordista ou flexível. A respeito, ver: HARVEY, David. Condição pós-moderna: uma pesquisa sobre as origens da mudança cultural. 8 ed. São Paulo: Loyola, 1999. esp. p.135-184; CATTANI, Antonio David (org.). Trabalho e tecnologia: dicionário crítico. 2 ed. Petrópolis: Vozes, Porto Alegre: Ed. da UFRGS, 1999. Luiz César Barçante considerou que, "a partir de 1990, o movimento em prol da Qualidade Total teve um crescimento avassalador" no Brasil. BARÇANTE, L.C. Qualidade Total: uma visão brasileira - o impacto estratégico na Universidade e na Empresa. Rio de Janeiro: Campus, 1998. p.16. Quanto ao programa "5 S", originalmente aplicado em empresas industriais japonesas, pautava-se na aplicação, no cotidiano de trabalho, de cinco noções: Organização (Seiri), Arrumação (Seiton), Limpeza (Seiso), Padronização (Seiketsu) e Disciplina (Shitsuke). O primeiro "S" (Seiri), dependendo de como fosse aplicado, poderia ter consequiências desastrosas para os documentos de arquivo: segundo Takashi Osada, "a Organização (Seiri) é realmente a arte de eliminar as coisas desnecessárias [...]. É prudente presumir que, quanto menos usamos uma coisa, menos necessitamos dela." OSADA, Takashi. Housekeeping 5 S's: Seiri, Seiton, Seiso, Seiketsu, Shitsuke - cinco pontos-chave para o ambiente da Qualidade Total. São Paulo: IMAM, 1992. p.45-47.
} 
livremente de um suporte a outro. ${ }^{7}$ Na nova configuração dos arquivos, haveria a exigência de uma outra Arquivística, com conceitos e procedimentos adequados ao atual momento histórico.

A crise no campo arquivístico abre o debate sobre os rumos da Arquivística e aponta diferentes caminhos. Entre os que afirmam a obsolescência da Arquivística "custodial" (ou "clássica", “convencional”, "tradicional”) encontram-se tanto os que apontam a sua nãocientificidade (devendo a Arquivística, portanto, constituir-se como ciência) quanto os que, numa perspectiva pós-moderna, criticam suas pretensões científicas; tanto os que afirmam ser seu objeto a informação, quanto os que reafirmam a posição central dos documentos nas reflexões e ações arquivísticas; tanto os que negam a possibilidade de continuar a empregar conceitos e princípios forjados no século XIX como os que entendem que eles permanecem, em essência, válidos. ${ }^{8}$ Se há concordância, parece apenas residir no entendimento de que, frente ao novo contexto histórico, a Arquivística deve ser repensada.

Em que medida esse debate teria alcançado e influenciado os esforços de constituição do campo arquivístico em Santa Catarina? Em que medida as transformações tecnológicas que anunciavam uma "sociedade da informação" teriam ressonância nas ações e reflexões que envolveram esse processo?

\footnotetext{
${ }^{7}$ Os autores que assumem essa perspectiva em geral compreendem a Arquivística como integrada à Ciência da Informação. Em português, ver: FONSECA, Maria Odila. Informação, arquivos e instituições arquivísticas. Arquivo \& Administração, Rio de Janeiro, v.1, n.1, jan-jul.1998, esp. p.33-35; FONSECA, Maria Odila. Arquivologia e ciência da informação. op.cit. esp. 9-12 e 55-66; JARDIM, José Maria. As novas tecnologias da informação e o futuro dos arquivos. Estudos Históricos, Rio de Janeiro, v.5, n.1, p.251-60, 1992; JARDIM, José Maria. A produção do conhecimento arquivístico: perspectivas internacionais e o caso brasileiro. Op. cit, p.95; SILVA, Armando Malheiro da, et al. Arquivística: teoria e prática de uma ciência da informação. Porto: Afrontamento, 1999. esp. p.35-42 e 213-214.

${ }^{8}$ A bibliografia a respeito é extensa. Tomo como referências, sobretudo: SILVA, Armando Malheiro da, et al. Arquivística..., op.cit., , 1999; COOK, Terry. Archival science and postmodernism: new formulations for the old concepts. Archival Science, Dordrecht, v.1, n.1, 2001, p.3-24; COOK, Terry. Arquivos pessoais e arquivos institucionais: para um entendimento arquivístico comum da formação da memória em um mundo pós-moderno. Estudos Históricos, Rio de Janeiro, v.11, n.21, 1998, p.129-149; COOK, Terry. What is past is prologue: a history of archival ideas since 1898, and the future paradigm shift. Archivaria, n.43, 1997. Disponível em: <http://www.mybestdocs.com/cookt-pastprologue-ar43fnl.hm>. Acesso em: 24 jan. 2006; SCHWARTZ, Joan M.; COOK, Terry. Arquivos, documentos e poder: a construção da memória moderna. Registro, Indaiatuba (SP), n.3, jul.2004, p.18-33; DURANTI, Luciana. Registros documentais contemporâneos como provas de ação. Estudos Históricos, Rio de Janeiro, v.7, n.13, 1994, p.49-64; DURANTI, Luciana. The impact of digital technology on archival science. Archival Science, Dordrecht, v.1, n.1, 2001, p.25-37; MENNE-HARITZ, Angelika. Access: the reformulation of an archival paradigm. Archival Science, Dordrecht, v.1, n.1, 2001, p.5782; MENNE-HARITZ, Angelika. What can be achieved with archives? In: The concept of record: report from the Second Stockholm Conference on Archival Science and the Concept of Record, 30-31 May 1996. Stockholm: Riksarkivet, 1998. p.11-24.
} 
$\mathrm{Na}$ tentativa de responder à questão, os encontros catarinenses de arquivos e a legislação estadual pertinente a instituições e conjuntos documentais arquivísticos, nas duas últimas décadas, serão, aqui, as principais referências.

\section{Patrimônio, memória, identidade, cidadania... e arquivos!}

Entre 1984 e 2004, aconteceram, em Santa Catarina, onze encontros de arquivos, um a cada dois anos, a maior parte deles em Florianópolis (seis), mas também nos municípios de Blumenau (dois), Itajaí (um), Joaçaba (um) e Jaraguá do Sul (um). Os três primeiros tiveram a duração de dois dias e os seguintes, de três. Setembro foi o mês mais regular de realização dos encontros (nove vezes), tendo ocorrido um em julho e outro em novembro (ver Apêndice II-1).

Sendo o evento, inicialmente, um encontro "de arquivos catarinenses", tornou-se, desde 1992, encontro "catarinense de arquivos". A presença de arquivos de outros estados já tentara ser garantida, formalmente, em 1988 e 1990, com os painéis de arquivos do sul do país. A partir de 1994, busca-se assegurar a presença dos arquivos municipais catarinenses, por meio de painéis específicos.

Na promoção dos encontros de arquivos, o Arquivo Público do Estado de Santa Catarina foi sempre instituição-eixo (sabendo mobilizar apoios no interior da máquina administrativa estadual). Sua participação direta não sofreu solução de continuidade, mesmo com as mudanças administrativas pelas quais passou - tanto de vinculação (à Secretaria da Justiça, da Administração, da Justiça e Administração e, novamente, da Administração, sucessivamente) quanto de posição na estrutura hierárquica organizacional (nos anos 1990, tornou-se gerência de uma diretoria, retornando à condição de diretoria recentemente). ${ }^{9} \mathrm{~A}$ Associação de Amigos do Arquivo Público, apoiando a quarta e a quinta edições do encontro (em 1990 e 1992) e, a partir da sexta (em 1994), passando a compartilhar com o Arquivo Público a promoção do evento, longe de mitigar a importância daquela entidade arquivística, reforçou-a. Isso porque a Associação de Amigos pode ser vista como um duplo do próprio

\footnotetext{
${ }^{9}$ A Lei Complementar no. 284 de 28 de fevereiro de 2005 estabeleceu o Arquivo Público do Estado como uma diretoria da Secretaria de Estado da Administração (a saber, a Diretoria de Gestão do Arquivo Público). Para acompanhamento dos promotores e apoiadores dos eventos, ver Apêndice II-2.
} 
Arquivo: criada em 1985, sempre teve, na composição de seus órgãos (diretoria e conselhos), participação significativa da direção e do corpo de funcionários do Arquivo Público do Estado (ver Apêndice II-8). ${ }^{10}$

$\mathrm{Na}$ rede de apoios aos encontros, houve participações mais regulares, como a de órgãos ligados ao Executivo estadual ou municipal. No caso das administrações públicas municipais, seu envolvimento foi mais marcante nos eventos realizados fora da capital, e se fez principalmente por meio dos arquivos municipais (a exceção foi Joaçaba, que sediou um dos encontros sem que tivesse arquivo municipal institucionalizado por lei; neste caso, houve a colaboração da Prefeitura Municipal). Mesmo na capital, a Prefeitura Municipal de Florianópolis chegou a apoiar o evento, ao menos em 1996 e 2002. Apoios mais pontuais igualmente existiram: de universidades (Universidade do Vale do Itajaí - UNIVALI, Fundação Universidade Regional de Blumenau - FURB), de entidades da sociedade civil (Associação Catarinense de Conservadores e Restauradores de Bens Culturais, Sindicato dos Trabalhadores na Indústria do Vestuário de Jaraguá do Sul) e de empresas (ACECO). Entre 1992 e 1996, órgãos públicos mais diretamente ligados à questão do turismo também deram apoio à realização dos encontros (ver Apêndice II-2).

Percebidos como espaço e ocasião de intercâmbio de informações, idéias e experiências, os encontros de arquivos em Santa Catarina tiveram, nos anos 1980, preocupação mais nítida com o que seria próprio da situação catarinense. A orientar o primeiro encontro, a intenção de diagnosticar a situação da área arquivística, em Santa

10 Obviamente não houve nenhum dispositivo que obrigasse à presença majoritária de funcionários na composição da diretoria e dos conselhos da Associação de Amigos. No estatuto atualmente vigente, aprovado em agosto de 2000, estabelece-se apenas, em seu Art. 20, parágrafo único, que "o Vice-Presidente será sempre o Gerente do Arquivo Público, ou seu substituto legal"; em seu Art. 31, contudo, informa-se que "poderão fazer parte da Diretoria Geral e Conselhos Fiscal e Editorial, todos aqueles que de alguma forma se interessam pela finalidade e objetivos da Associação.” ASSOCIAÇÃO DE AMIGOS DO ARQUIVO PÚBLICO DO ESTADO DE SANTA CATARINA. Estatuto 2000. [Florianópolis]: [2001]. Ainda quanto à participação de diretores (ou gerentes) e funcionários do Arquivo Público na diretoria, no conselho fiscal e no conselho editorial da Associação, o Apêndice II-8 permite verificar a estratégia de sempre deixar livre, para ocupação "externa", o cargo de presidente. Nos anos iniciais, elementos externos chegaram ainda a ocupar os cargos de $1^{\circ}$. Secretário e membro do Conselho Fiscal (período 1985-1988); a partir de 1989, com a criação do Conselho Editorial (de início, também consultivo), são designados como seus conselheiros, ou indicados para os cargos de $2^{\circ}$. Tesoureiro e $2^{\circ}$. Vice-Presidente (enquanto este último existir, isto é, até 1995); de 1997 em diante, encontram-se "externos" também no cargo de $1^{\circ}$. Tesoureiro. Entretanto, os funcionários aparecem ocupando, de forma geral, um número maior de cargos, bem como por mais tempo exercendo funções junto à Associação (mesmo que revezando-se nos cargos). Entre os mais presentes, há funcionários do Arquivo ligados aos órgãos da Associação por vários biênios: dez (Neusa Rosane Damiani Nunes), nove (Ana Maria Soares Martins de Araújo, Leda Maria d'Ávila da Silva Prazeres), oito (Talita de Almeida Telemberg Soares), sete biênios (Cleuza Regina Costa Martins, Noêmia Kühnen Lopes) e cinco biênios (Neusa Maria Schmitz). 
Catarina, de forma a desenhar para ela uma política própria, que viesse a preservar a "memória catarinense", o "patrimônio documental" catarinense e, até mesmo, a "identidade catarinense". ${ }^{11}$ A ênfase na perspectiva "patrimonial" estava articulada, nos encontros de 1988 e 1990, às demandas de implantação do Subsistema Estadual de Arquivos (criado, aliás, em 1988). Neste sentido, o Arquivo Público do Estado, ao persistentemente promover tais eventos, acaba por ser instituído como locus de coordenação das atividades arquivísticas catarinenses, para onde deveriam convergir as informações que permitiriam proceder às mudanças necessárias. Já a partir de 2000 (ao menos no que é explicitado como conjunto de objetivos), os encontros aparecem menos como instrumento de ações governamentais e mais como espaço de aperfeiçoamento de profissionais especializados (daí o destaque para o "aprimoramento técnico dos conhecimentos arquivísticos"). São percebidos ainda como meios de socialização de reflexões de todos aqueles engajados na preservação da "memória" (seja ela a memória “documental”, seja a “das comunidades”).

Seria essa mudança, nos objetivos gerais dos encontros, indício de sucesso no empreendimento de constituição e autonomização do campo arquivístico, em Santa Catarina? $\mathrm{Ou}$ sinal de fracasso na tarefa de aprofundamento do debate arquivístico na esfera governamental? Para melhor avaliar tais possibilidades, será preciso não apenas lembrar dos impasses e desafios colocados no período que medeia os dois momentos, conforme já apontado anteriormente, como conhecer mais de perto as questões, os personagens e as falas que marcaram os encontros.

Preservação, patrimônio (“documental”, “arquivístico" ou “cultural”), memória, cidadania e identidade são palavras recorrentes nos anais dos vários encontros, e são de tal maneira e tão freqüentemente interligadas, em número tão significativo de falas e trabalhos, que acabam por configurar variações de um mesmo tema: o tema do salvamento dos arquivos, que, apesar de importantes e valiosos, são relegados ao abandono ou à destruição. Aqueles termos são combinados de maneira a postular a importância dos arquivos, e justificá-la; mas,

\footnotetext{
${ }^{11}$ Para comentários acerca dos objetivos do primeiro encontro, bem como dos demais, ver Apêndice II-3. Em 1984, o então diretor do Arquivo Público do Estado, Iaponan Soares, articulou o encontro às metas da "Carta dos Catarinenses", texto programático do governo Esperidião Amin (1983-1987). Na Carta, o compromisso em relação à área de cultura era "preservar a identidade catarinense", basicamente através de três ações: "preservar a memória cultural", "apoiar a produção e a troca de bens culturais" e "divulgar os valores da cultura catarinense". Um dos encaminhamentos previstos era o incentivo, às Prefeituras municipais, para que preservassem "o patrimônio histórico-arquitetônico”. Cf.: AMIN, Esperidião, FONTANA, Victor. Carta dos Catarinenses: Santa Catarina - um compromisso com o futuro. [Florianópolis]: S.c.p., [1982].
} 
simultaneamente, servem para identificar sujeitos que assumem ou não essa valorização (que tem ou não "consciência" do valor dos arquivos). Seja anunciado de forma plena, seja apenas esboçado, o tema tem, ele mesmo, o poder de forjar um vínculo entre os profissionais reunidos nos encontros (uma vez que o compartilhem), delineando o campo arquivístico ao menos em uma dimensão discursiva comum.

Isso é perceptível desde o primeiro encontro de arquivos, em 1984, nas falas de profissionais ligados a instituições de Santa Catarina e de outras unidades da federação. Assim, o conferencista José Maria Jardim, representando o Arquivo Nacional, desejou êxito ao encontro, no sentido de que colaborasse para a "preservação do patrimônio arquivístico de Santa Catarina e, portanto, para o patrimônio documental do Brasil". Destacou a importância de adequado tratamento técnico "nas duas primeiras fases de vida do documento", sem o que seria “impossível constituir e preservar o patrimônio documental arquivístico de um país, de um estado, de um município”. Inseriu, ainda, as ações do Arquivo Nacional no horizonte de expectativa da produção de "um conhecimento arquivístico brasileiro, estimulando a preservação do patrimônio documental e a democratização da informação."12 Outra conferencista, Lia Temporal Malcher, representando, por sua vez, a Associação dos Arquivistas Brasileiros, considerou:

[...] ao Poder Público cabe a missão de conservar os registros da atuação do Estado, nos seus vários níveis, assim como garantir a preservação do patrimônio cultural e artístico nacional. É necessário, entretanto, que esta consciência seja assumida por aqueles a quem a sociedade entrega a tarefa de administrar e gerir a coisa pública.

E seguiu afirmando:

A vida cultural de uma nação que honra sua própria história e que honra as lutas e tradições de seu povo, no movimento histórico de construção de nacionalidade, não pode prescindir de arquivos, bibliotecas e museus, corretamente equipados, a serviço da cidadania.

\footnotetext{
12 JARDIM, José Maria. Política Nacional de Arquivos. In: SOARES, Iaponan (org.). Arquivos \& Documentos em Santa Catarina. Florianópolis: Secretaria da Justiça, Arquivo Público do Estado, 1985. p.15, 17 e 20. Nos anais e programas dos encontros, os termos "conferência" e "palestra" são em geral empregados para indicar as exposições dos convidados, e "comunicação" e "trabalho", para as apresentações inscritas e selecionadas. As apresentações serão aqui identificadas apenas como "conferências" e "comunicações".
} 
Em termos legais e morais, cabe ao Estado a tarefa de comandar a preservação da Memória Nacional [...]. ${ }^{13}$

No mesmo tom, a conferencista Eni Barbosa, funcionária do Arquivo Histórico do Rio Grande do Sul e professora do curso de Pós-Graduação em Arquivologia e Museologia da PUC-RS, referiu-se à necessidade de uma "legislação apropriada" que se estendesse "a toda e qualquer produção da memória de nosso povo, seja particular ou oficial." ${ }^{\prime 14}$

Do lado dos demais profissionais presentes no encontro de 1984, os elos entre arquivos, memória, patrimônio, preservação, identidade e cidadania foram estabelecidos em várias apresentações. O texto apresentado pelo historiador Walter Piazza, por exemplo, retomando idéias-força do Instituto Histórico e Geográfico de Santa Catarina, destacou a necessidade de preservação dos arquivos para melhor conhecer a história catarinense, glorificar sua terra e exaltar sua gente. ${ }^{15}$ Lawrence James Nielsen, então professor visitante do Programa de Pós-Graduação em História da UFSC, nas considerações finais de seu trabalho sobre arquivos eclesiásticos indicou aos pesquisadores a seguinte tarefa:

Para as congregações [religiosas] diversas que ainda não têm conhecimento do seu dever de preservar a sua memória para as gerações futuras, devemos esforçar-nos para conscientizá-los [sic] e mostrá-los [sic] o que deve ser feito e como fazê-lo. ${ }^{16}$

"Memória" é, igualmente, palavra presente no texto de Sueli Petry: o arquivo de Blumenau, segundo ela, seria "considerado patrimônio de guarda da memória local e

\footnotetext{
${ }^{13}$ MALCHER, Lia Temporal. O arquivo público como agente de difusão cultural. In: SOARES, Iaponan (org.). Arquivos \& Documentos..., op.cit., p.22. A conferencista apontou, entretanto, o pouco peso dos arquivos nas ações relativas ao patrimônio cultural brasileiro, destacando que a importância dos arquivos transcendia o aspecto "patrimonial": "Em que pese o reconhecimento do esforço que vem sendo empreendido pelo Governo Federal na conservação do riquíssimo patrimônio cultural da Nação, numa análise realista da situação dos nossos arquivos constatamos que ainda é grande o descaso quanto ao significado administrativo, cívico e cultural dos arquivos, assim como o desconhecimento da importância e das novas dimensões assumidas pelos arquivos modernos, na dinâmica da administração pública.” (p.22-23)

${ }^{14}$ BARBOSA, Eni. Técnicas arquivísticas. In: SOARES, Iaponan (org.). Arquivos \& Documentos..., op.cit., p.30.

${ }^{15}$ PIAZZA, Walter F. Fontes arquivais para a história de Santa Catarina. op.cit. In: SOARES, Iaponan (org.). Arquivos \& Documentos..., op.cit., p.35-42. Piazza, no mesmo encontro, criticou acordo Brasil-Portugal para "microfilmar todos os documentos brasileiros existentes em Portugal" [sic], algo que em grande medida já teria sido feito por "pesquisadores subvencionados pelo CNPq e CAPES". Cf.: Ata da conferência de Frederico Michel Litto. [Florianópolis], 20 de setembro de 1984; documento manuscrito. Acervo do Arquivo Público do Estado de Santa Catarina, Fundo Arquivo Público, G IV, SG IV.1, 60-1984-1996, s.7. f.21.

${ }^{16}$ NIELSEN, Lawrence James. A situação dos arquivos eclesiásticos em Santa Catarina. In: SOARES, Iaponan (org.). Arquivos \& Documentos..., op.cit., p.47.
} 
regional", possuindo "rico acervo referente à memória da cidade e da região do Vale do Itajaí."17 Na fala de Valmor B. Sena, coordenador do Plano Nacional de Microfilmagem de Periódicos em Santa Catarina, há referência a Iaponan Soares, então diretor do Arquivo Público do Estado de Santa Catarina, e à sua "luta pelo que há de mais caro na preservação da memória catarinense", bem como alusão aos "dois valores" que se associavam para garantir a preservação dessa mesma memória (no seu entender, "a segurança dos documentos e a facilidade do manuseio.”). ${ }^{18}$

Por sua vez, o historiador Jali Meirinho, outro membro destacado do Instituto Histórico e Geográfico de Santa Catarina, reiterou, no encerramento dos trabalhos, tal como fizera Walter Piazza, os vínculos que aquela entidade, desde seus inícios, estabelecera entre os arquivos, o exercício de direitos e a "pequena pátria" catarinense: destacou a "utilidade prática do arquivo como fonte guardiã de documentos", relembrando o trabalho do conselheiro Mafra na tensa questão de limites com o Paraná, no final do século XIX; indicou, por fim, a necessidade de "despertar para a realidade de que só as fontes históricas facultarão o conhecimento da identidade catarinense, tão discutida." 19

Foi, infelizmente, impossível detectar continuidades entre tais considerações e aquelas apresentadas no segundo encontro: os anais de 1986 não foram publicados, sendo localizadas, no processo de pesquisa, somente informações relativas ao discurso da Secretária Estadual de Justiça, ao painel com representantes de entidades públicas e particulares catarinenses e às recomendações feitas ao final do evento. ${ }^{20}$

No encontro seguinte, porém, em 1988, reaparece o tema dos valiosos arquivos a salvar: veja-se, na "Apresentação" contida nos anais, feita pelo então Secretário Estadual de Administração, Antônio Niccolló Grillo, o entendimento de Santa Catarina como "fonte riquíssima da memória brasileira", bem como o desejo de que o encontro gerasse "trabalho

\footnotetext{
${ }^{17}$ PETRY, Sueli M. V. Arquivo Histórico "Prof. José Ferreira da Silva”. In: SOARES, Iaponan (org.). Arquivos \& Documentos..., op.cit., respectivamente p.72 e 75.

18 SENA, Valmor B. Plano Nacional de Microfilmagem de Periódicos Brasileiros - Coordenação em Santa Catarina. In: SOARES, Iaponan (org.). Arquivos \& Documentos..., op.cit., respectivamente p.116 e 118.

${ }^{19}$ Relatório do relator do segundo dia de sessões do I Encontro Catarinense de Arquivos. op.cit.

${ }^{20}$ Do painel, coordenado por Walter Fernando Piazza, participaram instituições de diferentes perfis: biblioteca universitária, arquivos municipais e eclesiásticos, museus municipais, centros culturais e de pesquisa. Ata do Painel realizado durante o segundo encontro de arquivos catarinenses. Florianópolis, 19 de setembro de 1986; documento datilografado. Acervo do Arquivo Público do Estado de Santa Catarina, Fundo Arquivo Público, GIV, SG IV.1, 60-1984-1996, s.7.
} 
fecundo em prol da memória escrita nacional. ${ }^{, 21} \mathrm{Ou}$, de forma mais acabada, na fala do então Coordenador de Documentação e Publicações do governo estadual, Walter Piazza, acerca do Subsistema Estadual de Arquivos:

O vandalismo de gerações tem depauperado os arquivos da Nação Brasileira, quer destruindo os acervos quer não dando a devida proteção aos mesmos. Por isso urge, neste instante, que se desenvolva uma política ampla de preservação documental. [...]

É preciso criar uma mentalidade em todos os níveis sociais e em todas as faixas etárias da nossa população, visando defender o nosso patrimônio documental. $^{22}$

Ao apresentar proposta de reestruturação administrativa do Arquivo Público do Estado de Santa Catarina, Neusa Damiani Nunes relacionou, entre as competências a serem assumidas pelo setor de divulgação da Seção de Apoio Cultural, a de "colaborar com programas educacionais de divulgação do patrimônio documental sobre Santa Catarina"23. E "memória" aparece como palavra-chave de um dos projetos do Arquivo Público, como deixa clara a comunicação de Valéria Gouvêa Ghanem, ao mencionar o "Projeto Registro da Memória Pública de Santa Catarina". ${ }^{24}$

Em 1990, a apresentação de Maria Izabel de Oliveira estabeleceu uma articulação muito clara entre o papel dos arquivos públicos e a preservação da memória, o exercício da cidadania e o atendimento às demandas da administração (tendo como referência o Arquivo Nacional). Deu destaque, neste sentido, à gestão de documentos de arquivo, por meio do "Programa de Modernização Institucional-Administrativa", em andamento no Arquivo Nacional desde 1981, tendo entre seus objetivos “o acesso rápido da Administração Pública e

\footnotetext{
${ }^{21}$ PIAZZA, Walter F. (org.). Anais do III Encontro de Arquivos Catarinenses; I Painel de Arquivos SulBrasileiros. Florianópolis: Secretaria de Estado da Administração, Coordenadoria de Documentação e Publicações, Arquivo Público, 1986. p.3.

${ }^{22}$ PIAZZA, Walter F. O Subsistema Estadual de Arquivos. In: PIAZZA, Walter F. (org.). Anais do III Encontro..., op.cit., p.9.

${ }^{23}$ NUNES, Neusa Rosane Damiani. Proposta para a nova estrutura organizacional do Arquivo Público do Estado de Santa Catarina. In: PIAZZA, Walter F. (org.). Anais do III Encontro..., op.cit., p. 22.

${ }^{24}$ GHANEM, Valéria Gouvêa. Fundo privado: Jorge Lacerda. In: PIAZZA, Walter F. (org.), Anais do III Encontro..., op.cit., p.59. Os documentos do arquivo de Jorge Lacerda foram depositados no APESC em função deste projeto.
} 
do cidadão à informação"25. A implantação de atividades de gestão documental, tendo em vista, sobretudo, a avaliação de documentos, atenderia a demandas de racionalização administrativa, "mas atentando sempre para a preservação da memória, bem como para o papel social da instituição de arquivo no que diz respeito às questões relacionadas aos direitos do cidadão." ${ }^{26}$ Sintomaticamente, a importância do processo de avaliação de documentos de arquivo, com conseqüente elaboração de tabelas de temporalidade, está presente nas falas de Neusa Rosane Damiani Nunes e de Eliane Pinto da Luz, no mesmo encontro. ${ }^{27}$

Se os arquivos eclesiásticos foram uma instância de memória valorizada praticamente apenas nos dois primeiros encontros, os arquivos municipais tiveram atenção constante. Walter Piazza, também em 1990, enfocou a necessidade de institucionalização dos arquivos municipais a partir de seu valor para a História:

Cada parcela da Comunidade brasileira, organizando a sua documentação, facilitará a tarefa do futuro analista da evolução da nossa sociedade e, assim, a História se fará com melhor conhecimento dos fatos que a compuseram e a compõem.

É, pois, uma necessidade inadiável a organização de arquivos públicos municipais, pois, sem eles, a História do nosso Estado e, conseqüentemente, do nosso país, não terá todas as suas vertentes analisadas. ${ }^{28}$

\footnotetext{
${ }^{25}$ OLIVEIRA, Maria Izabel de. Arquivo Nacional: por uma política de gestão de documentos In: Anais do IV Encontro de Arquivos Catarinense; II Painel de Arquivos Sul-Brasileiro - [Joaçaba], 3 a 5 de julho de 1990. Florianópolis: Secretaria de Estado da Administração, 1990. p.3.

27 A primeira destaca, contudo, as dificuldades de efetuar até mesmo o diagnóstico dos arquivos da administração estadual, com o não preenchimento, ou preenchimento inadequado, dos questionários de levantamento de dados preparados para esse fim. A segunda constata o "caos documental da UFSC"; em função disso, o Sistema de Arquivos e Controle de Documentos serviria como "base de trabalho para aqueles que vão dar início à organização de seus Arquivos e Protocolos", sem esquecer da massa documental acumulada na Divisão do Arquivo Central, necessitando de "uma rigorosa análise e seleção de documentos" e do "estabelecimento urgente da Tabela de Temporalidade [...]". Cf., respectivamente: NUNES, Neusa Rosane Damiani. Levantamento preliminar da documentação da administração direta e indireta do governo de Santa Catarina para elaboração da Tabela de Temporalidade; LUZ, Eliane Pinto da. Sistema de arquivos e controle de documentos para a Universidade Federal de Santa Catarina. In: Anais do IV Encontro..., op.cit., esp. p. 9, 11 e 56.

${ }^{28}$ PIAZZA, Walter F. As lições de preservação documental. In: Anais do IV Encontro..., op.cit., p.13-14. O historiador aí retoma uma idéia que lhe era cara: a associação entre lacunas documentais e lacunas na interpretação da História. Saliente-se que naquele momento Piazza já não era mais Coordenador de Documentação e Publicações. Sua sucessora no cargo, Eliana Bahia, faz no discurso de encerramento do evento um "agradecimento especial" a ele, "idealizador deste encontro, com sua luta para melhorar a política arquivística do nosso Estado [...]". Cf.: Anais do IV Encontro..., op.cit., p.74. Sobre a atuação de Eliana Bahia como coordenadora, ver os mesmos Anais do IV Encontro..., p.31.
} 
Junte-se a isso, nas reflexões de Piazza, uma preocupação com as identidades locais, regionais, nacionais: "Todos os países defendem a sua cultura, a sua identidade, e isto é efetuado, basicamente, a partir do conhecimento da História”. Campanhas educativas como a promovida pela Coordenadoria de Documentação e Publicações, em 1989, denominada "Visite o seu Arquivo", seriam "uma forma de aprofundar a defesa da identidade local"; para Piazza, se o Decreto estadual no $n^{\circ} .444$, de 23 de março de 1988, foi medida importante para "uma ampla defesa do patrimônio documental", ela precisaria ser complementada por ações educativas que aumentassem a participação dos jovens "neste movimento preservacionista" e conscientizassem as autoridades. $^{29}$

Visível, na exposição de Walter Piazza, é a compreensão reificadora das identidades, tidas como unívocas, iguais a si mesmas, estáveis (e, por isso mesmo, facilmente assimiláveis a "tradições" locais, regionais, nacionais); não à toa, a identidade (assim como o patrimônio cultural), aparece como algo a defender. As experiências históricas contemporâneas, contudo, em especial a partir das últimas décadas do século XX, estavam a desestabilizar semelhante compreensão das identidades culturais. ${ }^{30}$

No quinto encontro, em 1992, reiterou-se o tema do necessário salvamento dos arquivos. Antes de tudo, na fala das autoridades: do Secretário Estadual de Justiça e Administração, inclusive destacando os dispositivos neste sentido existentes na Constituição Federal (Art. 216) e Estadual (Art. 9º); da então gerente do Núcleo Técnico de Monitoramento dos Documentos Oficiais (ao qual estava vinculado o Arquivo Público do Estado de Santa Catarina), Talita de Almeida Telemberg Soares, que aludiu à "causa" da "preservação da memória de nossas comunidades", ou à "difícil tarefa de defesa de um patrimônio em vias de desaparecer" ${ }^{, 31}$. E também na fala dos profissionais cujas falas integraram a programação: Maria Aparecida Rodrigues Manzan, atenta à preservação da "memória nacional" e, mais especificamente, à "preservação da memória municipal",

\footnotetext{
${ }^{29}$ PIAZZA, Walter F. As lições de preservação documental, op.cit., p.13, 15 e 16.

${ }^{30}$ Diferentes identidades (de classe, étnicas, de gênero, político-partidárias) podem ser assumidas pelos mesmos sujeitos, em diferentes contextos, muitas vezes tensionando-se umas às outras, algo que parece ter se intensificado na chamada "modernidade tardia". Ver, a respeito: HALL, Stuart. A identidade cultural na pósmodernidade. 10 ed. Rio de Janeiro: DP\&A, 2005.

31 Anais do $\mathbf{5}^{\mathbf{0}}$. Encontro Catarinense de Arquivos. Florianópolis: Fundação Catarinense de Cultura, Associação de Amigos do Arquivo Público, 1992, resp. p.13 e 16. Talita Telemberg Soares caracterizou os participantes do encontro como "um grupo de pessoas dispostas e conscientes", reunidos em torno da já referida causa da preservação da memória. Acrescentou: "nesta ocasião, quando aproximamo-nos uns dos outros, esperamos que aumente, e por certo aumentará, em todos nós, a consciência do quanto de nós espera a comunidade em que vivemos e para a qual trabalhamos." (p.16).
} 
destacou o papel dos arquivos municipais e da promoção de atividades que estreitem "os laços que prendem o Arquivo à comunidade", educando "nossas crianças, nossos jovens para o exercício da cidadania livre e consciente." 32 Wanda Ritta informou que os documentos do poder público municipal de São José estavam "em local não apropriado e sem o menor critério de organização", denotando "falta de conscientização de um modo geral, e especialmente no que se refere à guarda e preservação de documentos." ${ }^{33}$

Claro está que a articulação patrimônio-memória-identidade-cidadania-arquivos foi, nos encontros, insistentemente vinculada (desde 1984) a atitudes "conscientes", partilhadas pelos participantes, sendo freqüente que coubesse a eles lamentar a "falta de consciência" de outros atores sociais (autoridades, depositários de acervos, cidadãos em geral) ou delegar a si próprios o papel de "conscientizadores". 34 Vê-se que, neste sentido, a insistência no tema do salvamento dos arquivos é um mecanismo de positivação da atuação dos profissionais da área, cujos esforços são freqüentemente associados a palavras como "luta", "resgate", "proteção", "defesa".

Consciência, arquivos e identidade reaparecem no discurso de Norberto Ungaretti, presidente da Associação de Amigos do Arquivo Público, na abertura do sexto encontro, em 1994:

Todos sabemos que, na sociedade e freqüentemente na própria administração pública, ainda não existe o desejável nível de consciência sobre o que significam os arquivos, e quanto a defesa e conservação da memória é valiosa até mesmo para que se preserve a identidade das pessoas, das famílias, das comunidades, das associações, das empresas, das instituições. ${ }^{35}$

\footnotetext{
${ }^{32}$ MANZAN, Maria A.R. Arquivo Público de Uberaba. Anais do 5․ Encontro..., op.cit., p.21 e 23.

${ }^{33}$ RITTA, Wanda. A preocupação com a preservação do patrimônio documental do Município de São José. Anais do $5^{\circ}$. Encontro..., op.cit., p.59.

${ }^{34}$ Mesmo na área de preservação do patrimônio cultural, porém, haveria indícios de uma "consciência" precária: em breve comunicação, Eliane Veras da Veiga, técnica do Instituto de Planejamento Urbano de Florianópolis (IPUF), informou, em 1992, que o tombamento municipal de edifício que abrigou a Inspetoria de Rios e Portos não abarcou "o acervo móvel razoavelmente significativo, notadamente o acervo documental", que se encontrava em seu interior. Cf.: VEIGA, Eliane Veras da. O acervo documental da antiga Inspetoria de Rios e Portos. In: Anais do $5^{\circ}$. Encontro..., op.cit., p.60.

${ }^{35}$ Palavras do Presidente da Associação de Amigos do Arquivo Público do Estado, Sr. Desembargador Norberto Ungaretti. Anais do VI, VII e VIII Encontro Catarinense de Arquivos. Florianópolis: Secretaria de Estado da Administração, Associação de Amigos do Arquivo Público do Estado, 2000. p.3.
} 
A clareza do fundamental papel social dos arquivos, entretanto, não estaria mais sendo partilhada nem mesmo pela totalidade dos pesquisadores: foi o que afirmou, em comunicação apresentada no mesmo encontro, a historiadora Cecília Maria Westphalen, então presidente da Sociedade Brasileira de Pesquisa Histórica. No seu entender,

Os "pesquisadores", entre aspas, nacionais, sobretudo das novas gerações acadêmicas, desertaram dos arquivos. Por quê? A meu ver, na maioria dos casos, pela impossibilidade de comprovar, em fontes primárias de arquivo, hipóteses fantasiosas a partir de teorias inaplicáveis à realidade. Em segundo lugar, pelas dificuldades de leitura e de tempo consumido na pesquisa de fontes manuscritas. Em terceiro lugar, pelo pouco interesse pelo conhecimento do passado mais distante. E, finalmente, pelo desamor pela produção do conhecimento original. ${ }^{36}$

O comentário, feito em 1994 por pesquisadora que durante anos se dedicou a pesquisas e orientações na área de história econômica e demografia histórica, na Universidade Federal do Paraná, é precioso. Reconhece, de um lado, que os anos 1990 (sob tantos aspectos já bastante difíceis para instituições arquivísticas e arquivistas, nos quadros das transformações tecnológicas e gerenciais em curso) viviam uma mudança na relação dos pesquisadores com os arquivos: eles teriam se tornado o laboratório de pesquisa apenas das velhas gerações. ${ }^{37}$ Fazia pensar: o que seria dos arquivos, então, se o interesse por eles não encontrava renovação entre pesquisadores mais jovens? Por outro lado, as "novas gerações acadêmicas" eram vislumbradas de forma negativa. Aquilo que, no discurso dos "novos", aparecia como investimento teórico contra a empiria sem método e sem problema, para Cecília Westphalen resultava num conjunto de "hipóteses fantasiosas a partir de teorias inaplicáveis à realidade" (a ida aos arquivos, evitada, comprovaria a impropriedade de hipóteses e teorias). Aquilo que, para os "novos", poderia significar dar voz aos que não

\footnotetext{
${ }^{36}$ WESTPHALEN, Cecília. A contribuição da Sociedade Brasileira de Pesquisa Histórica para o conhecimento e divulgação dos arquivos brasileiros. In: Anais do VI, VII e VIII Encontro..., op.cit., p.49-50.

${ }^{37}$ Em abril de 2005, por ocasião das comemorações dos 150 anos do Arquivo Público do Paraná, foi inaugurada, naquela instituição arquivística, exposição em homenagem à historiadora Cecília Westphalen e ao historiador Ruy Wachowicz; divulgava-se também a aquisição de suas bibliotecas. No folder da exposição, o comentário: "dois renomados pesquisadores que ao longo de 40 anos de produção buscaram, nas fontes primárias, o sentido de suas teses acadêmicas com o trabalho criterioso de pesquisa em arquivos". Biblioteca Professora Doutora Cecília Maria Westphalen - Arquivo Público do Paraná. [2005]. Folder.
} 
encontravam expressão na "documentação oficial", além de recusa em identificar a história exclusivamente ao passado (valorizando as questões e os sujeitos do tempo presente), para a historiadora paranaense revelava o "pouco interesse pelo conhecimento do passado mais distante". O pragmatismo (aversão às "dificuldades" com as fontes manuscritas, "desamor pela produção do conhecimento original"), provavelmente justificado no contexto das pressões cada vez maiores quanto a prazos de elaboração de dissertações e teses, nos programas de pós-graduação, arremata o novo perfil dos pesquisadores, cuja própria condição (dado o seu distanciamento dos arquivos) é colocada em dúvida (seriam pesquisadores "entre aspas"...).

\section{Arquivos e "novas tecnologias"}

O debate em torno das "novas tecnologias" de informação e de comunicação alcançou os encontros catarinenses de arquivos, sendo antecedido pela atenção inicial a uma tecnologia não tão nova, mas bastante valorizada nos anos 1980: a que permitia a reprodução técnica de documentos a partir da microfilmagem.

No III Encontro de Arquivos Catarinenses, em 1988, a microfilmagem de documentos revelou-se motivo de grande interesse, sobretudo por parte dos órgãos do governo estadual: prevista como procedimento a ser implementado pelo Subsistema Estadual de Arquivos $^{38}$, criado meses antes, já vinha sendo adotada em algumas repartições públicas catarinenses (estaduais e federais), nos quadros do que era entendido como "modernização" dos arquivos. Assim, informa-se, quanto ao Tribunal de Justiça do Estado, que a Divisão de Arquivo e Artes Gráficas passaria a ser Divisão de Arquivo e Microfilmagem ${ }^{39}$; a microfilmagem também é referida no que diz respeito à documentação da Eletrosul Centrais

\footnotetext{
${ }^{38}$ PIAZZA, Walter F. O Subsistema Estadual de Arquivos. In: PIAZZA, Walter F. (org.). Anais do III Encontro..., op.cit., p.14.

${ }^{39}$ SANTOS, José Carlos dos. Projeto de modernização do Arquivo do Tribunal de Justiça do Estado de Santa Catarina. In: PIAZZA, Walter F. (org.). Anais do III Encontro..., op.cit., p.38.
} 
Elétricas S.A. ${ }^{40}$, à da Secretaria Estadual de Educação ${ }^{41}$, à dos hospitais estaduais ${ }^{42}$, à das Centrais Elétricas de Santa Catarina - $\operatorname{CELESC}^{43}$ e à da Fundação do Meio Ambiente FATMA $^{44}$.

Os encontros imediatamente posteriores não deram especial atenção ao tema das "novas tecnologias", privilegiando outras discussões tão ou mais importantes no processo de implementação do Subsistema Estadual de Arquivos, como a avaliação dos documentos da administração estadual, a interação com os arquivos municipais e a organização e difusão dos acervos arquivísticos.

Em 1990, o quarto encontro enfatizou, de acordo com os anais, a experiência arquivística catarinense, sobretudo o papel do Arquivo Público do Estado de Santa Catarina, tanto em sua atuação junto ao Subsistema Estadual de Arquivos quanto em suas atividades internas (seis trabalhos foram apresentados); ${ }^{45}$ sendo alvo do Subsistema, os arquivos municipais catarinenses, institucionalizados ou não, também ganharam relevo. ${ }^{46} \mathrm{Na}$ mesma linha, o encontro de 1992 enfocou aspectos gerais da prática arquivística, do ponto de vista técnico (novamente, a questão da avaliação) ${ }^{47}$ e de sua inserção no ordenamento jurídico

\footnotetext{
${ }^{40}$ CORDEIRO, Miguel Aldo Gutierrez. Arquivos especiais - documentação de engenharia da ELETROSUL. In: PIAZZA, Walter F. (org.). Anais do III Encontro..., op.cit., p.48. Os anais contêm apenas o esquema da comunicação.

${ }^{41}$ PELLIZZARO, Flávio Cândido. Microfilmagem na Secretaria da Educação. In: PIAZZA, Walter F. (org.). Anais do III Encontro..., op.cit., p.64.

42 BIANCHETTI, Carlos Roberto Andrades. Perspectivas de microfilmagem em hospitais estaduais. In: PIAZZA, Walter F. (org.). Anais do III Encontro..., op.cit., p.68. Os anais contêm apenas o esquema da comunicação.

${ }^{43}$ PELIN Jr., Leopoldo. Microfilme \& Arquivo. In: PIAZZA, Walter F. (org.). Anais do III Encontro..., op.cit., p.70. Os anais contêm apenas o esquema da comunicação.

${ }^{44}$ SALVATO, Gilberto José. Experiências e propostas da FATMA para a organização de documentos e informações. In: PIAZZA, Walter F. (org.). Anais do III Encontro..., op.cit., p.71-73. No caso da FATMA, os procedimentos de microfilmagem aparecem articulados aos de informatização.

45 NUNES, Neusa R. D. Levantamento preliminar da documentação da administração direta e indireta do governo de Santa Catarina para elaboração da Tabela de Temporalidade; PRAZERES, Lêda M. D'Ávila da Silva. O Arquivo e a comunidade; NUNES, Neusa R. D. Organização: Arquivo Público; GHANEM, Valéria G. Instrumentos de pesquisa no Arquivo Público; SOARES, Talita de A. T. et al. Arquivo Público do Estado de Santa Catarina: Laboratório de Patologia dos Documentos; GHANEM, Valéria G. Documentação privada: experiência do Arquivo Público. In: Anais do IV Encontro..., op.cit., p.8-12, 18-34 e 57-58.

46 D’ÁVILA, Edison. Os instrumentos de pesquisa e o acesso à informação do Arquivo: a proposta de um "Guia" para o Arquivo Histórico de Itajaí; TERNES, Apolinário. Arquivo Histórico de Joinville; ZACARON, Maria Dolores. Diagnóstico do Arquivo Municipal de Joaçaba; NAREOLINI, Maria. Arquivo Municipal de Curitibanos; OLIVEIRA, Pedro Lopes de. A rede, os peixes, o arquivista e o historiador [sobre o arquivo municipal de Imaruí]; BAGGIO, Eloiza Maria. Arquivo Histórico de Campos Novos Dr. Valdemar Rupp: histórico e situação atual. In: Anais do IV Encontro..., op.cit., p.36-53. O suposto arquivo de Curitibanos é, no respectivo texto, identificado como "Arquivo do Museu Histórico Antônio Granemann de Souza". Previa-se, para Imaruí, a inauguração próxima de prédio reunindo Biblioteca e Arquivo Municipais (p.50).

${ }^{47}$ PAGNOCCA, Ana Maria P.M. Avaliação e seleção de documentos - paralelo entre a teoria e a prática. In: Anais do 5'. Encontro..., op.cit., p.44-50.
} 
nacional e estadual, bem como no contexto de políticas públicas voltadas para a área ${ }^{48}$. Ainda ficou demonstrado um cuidado especial, em atenção ao tema geral do evento ("Arquivos Municipais: as atuais metodologias de organização"), com experiências envolvendo os arquivos municipais, e não apenas os de Santa Catarina. ${ }^{49}$ Nos trabalhos que constam dos anais do encontro seguinte (em 1994), observa-se a ênfase na apresentação e discussão de procedimentos técnicos adotados na organização de documentos ${ }^{50}$. Mas a questão das "novas tecnologias" não está totalmente ausente dos encontros entre 1990 e 1994: os anais do encontro de 1992 trazem ao menos duas notícias de tratamento informatizado de documentação arquivística, relativas ao arquivo da Câmara Municipal de Curitiba e ao Tribunal Regional Eleitoral de Santa Catarina. ${ }^{51}$

O VII Encontro Catarinense de Arquivos, em 1996, poderia representar, neste sentido, um ponto de virada, pois, segundo a então gerente do Arquivo Público, Neusa Rosane Damiani Nunes, tomou como eixo, ao lado dos documentos em suporte papel, "o microfilme, os meios magnéticos e ópticos". Na fala de abertura do encontro, a gerente considerou:

A adoção dessas novas tecnologias para a produção e armazenamento da informação [...] exige por parte do poder público cuidados especiais, para

${ }^{48}$ BELLOTTO, Heloísa Liberalli. Políticas governamentais de documentação. In: Anais do $\mathbf{5}^{\mathbf{0}}$. Encontro..., op.cit., p.35-43.

${ }^{49}$ Constam dos anais: MANZAN, Maria Aparecida Rodrigues. Arquivo Público de Uberaba; NUNES, Neusa Rosane Damiani. Guia de arquivos municipais do Estado de Santa Catarina; PETRY, Sueli M. V. Subsídios para a formação de arquivos [Arquivo de Blumenau]; RITTA, Wanda. A preocupação com a preservação do patrimônio documental do Município de São José; SILVA, Helena de Fátima Nunes et al. Sistema de Recuperação de Informações Históricas do Arquivo da Câmara Municipal de Curitiba; CHRISTOFOLLI, Angelo Ricardo. O Arquivo Histórico do Balneário Camboriú; ESTORK, Vera Lúcia de N.P. Arquivo Histórico de Itajaí: fundos e fotos; LOCATELLI, Nedi Terezinha. Projeto Imprensa [Arquivo de Ipumirim]. Em relação a São José e Balneário Camboriú, foi informada a intenção de implantação de arquivos municipais. Cf.: Anais do $\mathbf{5}^{\mathbf{0}}$. Encontro..., op.cit., p.21-34, 51-55, 59, 61-63, 71-79.

${ }^{50}$ MARTINS, Cleuza Regina Costa, CONCEIÇÃO, Maria Cristina d'Eça Neves Luz da. A Biblioteca Apoio do Arquivo Público do Estado de Santa Catarina; ESTORK, Vera Lúcia de Nóbrega Pecego. Jornais itajaienses: no passado, a História; na preservação, o futuro; SOARES, Maria José Silveira. Sistema de Documentação do Patrimônio Cultural Brasileiro; ZUGNO, Vera Lúcia. Metodologia de ordenação da documentação da Irmandade Santa Casa de Misericórdia e Porto Alegre; SILVA, Helena de Fátima N., PAZIN, Rosina A., BREDA, Sonia M. Indexação de Atas da Câmara Municipal de Curitiba; FERREIRA, Cristina. A pesquisa histórica através do acervo fotográfico do Arquivo Histórico de Blumenau. Cf.: Anais do VI, VII e VIII Encontro..., op.cit., p.1944, 51-66, 79-83. Curiosamente, foram destacados conjuntos documentais não-arquivísticos, que conformam, mais propriamente, coleções (de jornais, de fotografias, de materiais bibliográficos).

${ }^{51}$ SILVA, Helena de Fátima Nunes et al. Indexação de Atas da Câmara Municipal de Curitiba; ARAÚJO, Ana Maria S. M. de, SALVATO, Gilberto J. Informatização do inventário analítico da sub-série resultado de eleição: descrição automatizada mini-micro CDS/ISIS. In: Anais do $5^{\mathbf{0}}$. Encontro..., op.cit., p.61 e 64-65. 
que a modernidade não venha significar perda ou comprometimento da documentação existente ou a ser criada. ${ }^{52}$

Consultando o programa do evento, presente nos anais, pode-se verificar a previsão das seguintes conferências mais diretamente ligadas ao tema geral: "Perspectivas do profissional da informação para o século XXI" (por Heloísa Liberalli Bellotto), "Alternativas de conservação em arquivos" (por Carlos Augusto Ditadi); "Processamento de imagens: soluções para arquivamento e gerenciamento eletrônico de informações" (por Rogério Brasiliense Machado); “Conservação e preservação de acervos fotográficos" (por Denise Magda Corrêa Thomasi). Das quatro conferências, apenas a de Heloísa Bellotto foi publicada nos anais. Houve também apresentação de comunicação sobre o Laboratório de Conservação e Restauração de Documentos da Universidade Federal Fluminense. ${ }^{53}$ Os demais trabalhos (inclusive conferências) referiram-se à gestão documental ${ }^{54}$, aos arquivos municipais ${ }^{55}$, aos $\operatorname{arquivos~empresariais~}^{56}$, à política arquivística ${ }^{57}$ e às relações entre arquivos e ensino ${ }^{58}$.

Percebe-se, no caso do encontro de 1996, que a questão das chamadas "novas tecnologias" foi abordada principalmente do ponto de vista dos novos suportes documentais e, conseqüentemente, dos problemas de conservação e restauração a eles ligados. Uma visão mais abrangente, contudo, esteve presente na conferência de Heloísa Bellotto, na qual foram tocados pontos sensíveis das relações entre Arquivística e revolução eletrônica: as exigências

\footnotetext{
${ }^{52}$ Anais do VI, VII e VIII Encontro..., op.cit., p.93-94.

${ }^{53}$ OLIVEIRA, Gilson Cruz de. Conservação de documentos no Arquivo Central do Núcleo de Documentação do Laboratório de Conservação e Restauração de Documentos da Universidade Federal Fluminense. In: Anais do VI, VII e VIII Encontro..., op.cit., p.178-184.

${ }^{54}$ SOARES, Talita de Almeida Telemberg. Governo do Estado de Santa Catarina e a elaboração da tabela de temporalidade; BERWANGER, Ana Regina, VARGAS, Alice. Projeto de instalação de gerenciamento para os arquivos do Departamento Municipal de Água e Esgotos da Prefeitura Municipal de Porto Alegre-RS. Embora o texto não conste dos anais, a programação previa a conferência "Técnicas para elaboração da Tabela de Temporalidade Documental”, de Rosália Paraíso Motta de Paula. Cf.: Anais do VI, VII e VIII Encontro..., op.cit., p.154-171 e 399.

${ }^{55}$ OLIVEIRA, Daíse Apparecida, BERNARDES, Ieda Pimenta. Política para os arquivos municipais no Brasil e a contribuição do Fórum Nacional de Dirigentes de Arquivos Municipais. In: Anais do VI, VII e VIII Encontro..., op.cit., p.137-148. Além dessa conferência, devem ser acrescentadas as comunicações de representantes de arquivos municipais catarinenses.

${ }^{56}$ GHANEM, Valéria Gouvêa, FERNANDES, Leonita. Organização do Arquivo da Assessoria Jurídica das Empresas Portobello. In: Anais do VI, VII e VIII Encontro..., op.cit., p.172-177. Embora o texto não conste dos anais, a programação previa a comunicação "Documentação empresarial: os desafios da atividade de consultoria", por Maria do Rocio Fontoura Teixeira.

${ }^{57}$ SILVA, Jaime Antunes da. Sistema Nacional de Arquivos. In: Anais do VI, VII e VIII Encontro..., op.cit., p.102-123.

${ }^{58}$ SOUZA, Kátia Isabelli Melo de. Instituições arquivísticas, estabelecimentos de ensino e alunos: a busca por uma integração. In: Anais do VI, VII e VIII Encontro..., op.cit., p.150-153.
} 
de adaptação do profissional de arquivo às novas demandas ("os novos documentos exigem conhecimento, competência, métodos e meios de produção, utilização e conservação física especiais sobre os quais os arquivistas devem estar instruídos"), o repensar dos princípios arquivísticos frente às novas modalidades de produção de documentos, a integração aos processos decisórios referentes à informatização. ${ }^{59}$

A perspectiva da conservação, na abordagem dos documentos gerados pelas "novas tecnologias", seria retomada dois anos depois, quando o oitavo encontro teve como tema principal a "preservação e organização documental". Apesar do tema geral, o encontro de 1998 reuniria novamente trabalhos bastante variados, envolvendo a reprodução de documentos para sua preservação e disseminação ${ }^{60}$, a gestão documental ${ }^{61}$, a normalização de procedimentos técnicos em arquivos municipais ${ }^{62}$, a relação entre arquivos e atividades de pesquisa $^{63}$, a produção bibliográfica catarinense na área arquivística. ${ }^{64}$ Também foram apresentados trabalhos não diretamente relacionados a questões arquivísticas. ${ }^{65}$

Os encontros de 2000, 2002 e 2004 continuaram abertos a muitos temas, mas o enfoque esteve predominantemente ligado, grosso modo, ao relato de experiências, em geral realizadas nos quadros de princípios e técnicas consolidados ou da aplicação de normas internacionais. Os sinais da crise arquivística (instaurada, nas discussões internacionais, sobretudo em função dos desafios colocados pela revolução eletrônica), e que haviam sido

\footnotetext{
${ }^{59}$ BELLOTTO, Heloísa L. Perspectivas do profissional da informação para o século XXI. In: Anais do VI, VII e VIII Encontro..., op.cit., esp. p.127-128 e 132.

60 Previstos no programa: LEAL, João E. F. O projeto Resgate, a memória histórica e o catálogo de documentação; STRAUPE, Ernani Costa. Registro e recuperação de informações de fotos históricas via sistema de computador. In: Anais do VI, VII e VIII Encontro..., op.cit. p.407 e 409 (indicados no programa do encontro).

${ }^{61}$ ARAÚJO, Maria Hilda Pinto de, SILVA, Maria Leonilda Reis da. Arquivo central da Fundação Getúlio Vargas; GONÇALVES, Janice. Processos de requerimentos de cidadãos às Prefeituras Municipais: uma proposta de classificação; SOARES, Talita de A.Telemberg. Organização de um arquivo intermediário: a experiência do Arquivo Público do Estado de Santa Catarina; BORTOLOTTO, Luciana Baggio, GARCIA, Olga Maria Correa. A avaliação de documentos no Hospital Universitário de Santa Maria; PAULO, Rosemary Gomes de. Arquivos X Administração Central da Universidade Federal Fluminense: padronização de critérios. In: Anais do VI, VII e VIII Encontro..., op.cit., p.271-343 e 410.

${ }^{62}$ OLIVEIRA, Daíse Apparecida. Arquivos municipais: normalização. In: Anais do VI, VII e VIII Encontro..., op.cit., p.405 (trabalho indicado no programa do encontro).

${ }^{63}$ CASTANHO, Denise Molón, ROSSATTO, Ricardo. A política de pesquisa no Arquivo Público do Estado do Rio Grande do Sul no período de 1987 a 1997. In: Anais do VI, VII e VIII Encontro..., op.cit., p.353-376.

${ }^{64}$ OHIRA, Maria Lourdes Blatt. Arquivística: produção bibliográfica catarinense. In: Anais do VI, VII e VIII Encontro..., op.cit., p.251-263.

${ }^{65}$ ROSA, Enedy Fátima Padilha da. Sociedade Camponovense: um estudo de caso; SALEMA, Yvonne Torres. Hemeroteca: arquivo atuante para problemas emergentes. In: Anais do VI, VII e VIII Encontro..., op.cit., respectivamente p. 264-270 e 344-352.
} 
apontados por Heloísa Bellotto, em 1996, não foram retomados ou problematizados. É o que pode ser observado nas discussões de questões que, nos encontros, são recorrentes, como as tecnologias de conservação, reprodução e disseminação de documentos ${ }^{66}$ ou a gestão documental (principalmente as atividades de avaliação, com articulações importantes com a informatização) ${ }^{67}$, ou ainda os procedimentos de organização de documentos (principalmente os de classificação e descrição) ${ }^{68}$. Foi mantido o espaço para apresentação de experiências e

${ }^{66}$ Em 2000, previstos os seguintes trabalhos: REMÉDIO, Maria Aparecida. Controle do ataque de insetos utilizando CO2: uma experiência; BREDA, Sonia et al. Formação profissional em conservação e restauração: iniciativas da Universidade Federal do Paraná em parceria com a Secretaria de Estado da Cultura; BERTOLLETTI, Esther C. A reprodução de documentos de arquivo - tecnologias de digitalização e microfilmagem; SOUZA, Luiz A. Cruz. Conservação e preservação de acervos documentais (conferência não apresentada). In: Caderno de resumos do IX Encontro Catarinense de Arquivos e IV Painel de Arquivos Municipais - 6 a 8 de novembro de 2000. Blumenau (SC): 2000. Em 2002: SILVA, Sérgio Conde de Albite. Tecnologias e políticas de preservação na digitalização de acervos; ANDRADE, Ana Célia. Tecnologias para preservação e acesso a arquivos permanentes; BREDA, Sonia M. Preservação como objeto de ensino; SICHMANN, Mirdza C. Conservação preventiva de acervos documentais; transformando teoria em prática; SANTOS, Paulo Xavier dos, SÁ, Ivone P. de. O impacto das novas tecnologias em instituições de arquivo e documentação (não apresentado). In: Caderno de resumos do $\mathbf{X}$ Encontro Catarinense de Arquivos e V Painel de Arquivos Municipais - 2 a 4 de setembro de 2002. Florianópolis (SC): 2002. Em 2004: GUIMARÃES, Lygia. Preservação de Acervos; OHIRA, Maria Lourdes Blatt. Arquivos Públicos do Brasil: da realidade à virtualidade. Cf.: Programa do XI Encontro Catarinense de Arquivos - 13 a 15 de setembro de 2004. [2004]. Folder.

${ }^{67}$ Em 2000, os seguintes trabalhos: BERNARDES, Ieda P. Avaliação de documentos de arquivo e elaboração de tabela de temporalidade; GONÇALVES, Janice. Tabelas de temporalidade, bancos de dados e Intranet: um estudo de caso; BAHIA, Eliana et al. Tabela de temporalidade da UFSC; OLIVEIRA, Lúcia M. V. Tabela de temporalidade de documentos para as áreas fim e meio: a experiência do Arquivo da Fundação Casa de Rui Barbosa; FERREIRA, Neusa. M. T. Padronização e redação dos atos oficiais; LIRA, Rísia C.Silva. Sistema PTA - Módulo de eliminação de documentos autuados; FLORES, Daniel, OLIVEIRA, Carla A. B. de. Análise das novas formas de arquivos gerados pelas tecnologias da informação: a tecnologia dos documentos e a introdução de novas formas de documentos no gerenciamento eletrônico de documentos [sic]. Caderno de resumos do IX Encontro... op.cit.. Em 2002: SANTOS, Marcelo J. dos. Estudo sobre a destinação final da documentação do Poder Judiciário Estadual [Bahia]; DI BERNARDI, Reinaldo et al. Procedimentos para elaboração de tabela de temporalidade; FERREIRA, Neusa M. T. Sistema de Informação RAI Eletrônica - SIRE; MASSON, Sílvia M. Projeto SIMAP-SIMAI. In: Caderno de resumos do X Encontro..., op.cit. Em 2004: SILVA, Jaime A. da. Gestão de Documentos: recurso estratégico para a modernização dos serviços governamentais; KURTZ, C., AGOSTINI, M. L. F. Projeto de Modernização dos Arquivos da Prefeitura Municipal de Canoas: uma visão sistêmica dos Arquivos; WINKLER, U., LAZZARI, M.. Reestruturação do Arquivo Geral da Cooperativa Agrária Mista Entre Rios; ESTORK, V.L.N.P., DESCHAMPS, Paola. Gestão de Documentos na Administração Pública do Município de Itajaí. In: Programa do XI Encontro..., op.cit.

${ }^{68}$ Em 2000: FERNANDES, Maria Cristina K. Organização do acervo da repressão política. In: Caderno de resumos do IX Encontro..., op.cit. Em 2002: BELEM, Lígia A. et al. Padronização da descrição documental com vistas à construção de uma base de dados: aplicação da norma ISAD; GONÇALVES, Janice. Fontes para a história de Santa Catarina: acervos arquivísticos em Florianópolis; FERNANDES, Simone S. As normas ISAD $(\mathrm{G})$ aplicadas em acervos de centros de documentação universitários; KITA, Sílvia R.T., TOFOL, Vera de. Arranjo do Fundo Administrativo [Arquivo de Jaraguá do Sul]; ESTORK. Vera L.de N. P. et al. Banco de dados de fotografias digitalizadas. In: Caderno de resumos do X Encontro..., op.cit. Em 2004: SOARES, Talita. A. Telemberg. A Associação de Amigos e o Projeto Resgate dos Documentos Oficiais do Estado sobre Educação nos séculos XIX e XX; PETRY, Sueli. Acervo de Imagem de Blumenau: uma experiência; OHIRA, Maria Lourdes Blatt. Arquivos Públicos no Brasil: da realidade à virtualidade. In: Programa do XI Encontro..., op.cit. 
discussão de problemas relativos aos arquivos municipais ${ }^{69}$.

Cabe assinalar, nas edições do encontro catarinense de arquivos ocorridas entre 2000 e 2004, maior atenção para a discussão de atitudes gerenciais e técnicas de motivação de equipes. $^{70}$

\section{Conexões: entretecendo vínculos institucionais e profissionais}

Os encontros catarinenses proporcionaram interação entre profissionais de diferentes perfis e procedências, mas com preocupações comuns, em princípio, no que tange aos arquivos. Ao mesmo tempo, permitiram estabelecer, reforçar e reiterar vínculos com determinadas instituições e determinados profissionais, o que contribuiria para alçá-los à condição de "referências", na área, sobretudo no contexto catarinense.

Nas conferências, pode-se notar a intenção de convidar representantes de instituições cuja atuação era reconhecidamente importante no cenário arquivístico nacional, com ênfase no Arquivo Nacional, ou no CONARQ ${ }^{71}$. Também foram convidados representantes de entidades congregadoras dos profissionais da área - mas, neste último caso, a Associação dos Arquivistas Brasileiros, presente no primeiro encontro, foi menos representada do que o Fórum Nacional de Dirigentes de Arquivos Municipais, cuja representante proferiu conferências em todos os encontros a partir de 1996 (ver Apêndice II-

69 Em 2000: OLIVEIRA, Daíse A. Cooperação e integração dos arquivos municipais brasileiros; PAES, Marilena L. Subsídios para a implantação de uma política municipal de arquivos: o arquivo municipal a serviço dos cidadãos; OHIRA, Maria Lourdes B. Arquivos Públicos Municipais Catarinenses: instrumentos de exercício da cidadania. Cf.: Caderno de resumos do IX Encontro..., op.cit. Em 2002: OLIVEIRA, Daíse Apparecida. Arquivos municipais: a modernização da gestão pública; OHIRA, Maria Lourdes Blatt. Arquivos Públicos Municipais Catarinenses: instrumentos de exercício da cidadania. In: Caderno de resumos do X Encontro..., op.cit. Em 2004: OLIVEIRA, Daíse Apparecida. O Arquivo Municipal na América Latina: estratégias de modernização da Administração Pública. In: Programa do XI Encontro..., op.cit. Em todos os eventos, devem ser consideradas também as breves comunicações feitas por representantes de instituições arquivísticas municipais catarinenses, no Painel de Arquivos Municipais de Santa Catarina.

${ }^{70}$ Em 2000: LEAL, Clarisse. Empreendedorismo: acendendo as próprias luzes. In: Caderno de resumos do IX Encontro..., op.cit. p.5. Em 2002: LORO, Álvaro Jorge. Vivendo melhor, convivendo melhor, trabalhando melhor: reflexões sobre motivação, qualidade de vida, felicidade. In: Caderno de resumos do X Encontro..., op.cit. Em 2004: SOUZA, Rosali Demboski de. O ponto de vista da administração pública frente à documentação. In: Programa do XI Encontro..., op.cit.

${ }^{71}$ Presença de representantes prevista em 1984, 1990, 1992, 1996, 1998, 2000 e 2004 (ver Apêndice II-4); talvez também em 1986 (poucos dados disponíveis sobre o II Encontro não permitiram confirmá-la). Note-se que, se José Maria Jardim, Maria Izabel de Oliveira e Carlos Augusto Ditadi representaram o Arquivo Nacional, Jaime Antunes da Silva e Marilena Leite Paes tinham ligações tanto com o Arquivo Nacional quanto com o CONARQ. 
5). E, se a participação do Arquivo Nacional ou do CONARQ se fez com diferentes representantes, a do Fórum Nacional de Dirigentes de Arquivos Municipais sempre valorizou a mesma profissional, Daíse Apparecida Oliveira (presidente do Fórum, no período). ${ }^{72}$

Figuras como Daíse Apparecida Oliveira, mais do que representar instituições, parecem ter cumprido a função de representar a si próprias, no sentido de serem reconhecidas, pelos organizadores dos encontros, como profissionais de atuação relevante na área. Pela constância com que foi chamada a participar dos encontros, também destacou-se Heloísa Liberalli Bellotto (presença em 1992, 1994, 1996 e 2004). Com participações em menor número, mas significativas, Marilena Leite Paes e Ana Regina Berwanger. ${ }^{73}$

No plano estadual, a valorização dos profissionais é detectável, em geral, pela frequiência com que alguns deles são chamados a coordenar mesas de apresentação de trabalhos: casos, em especial, de Sueli Petry (diretora do Arquivo Histórico de Blumenau), de Edison d'Ávila (vinculado à Fundação Genésio Miranda Lins, à qual estava subordinado o Arquivo Histórico de Itajaí), de Sílvia Regina Toassi Kita (ligada ao Arquivo Histórico de Jaraguá do Sul) e, entre funcionárias que mantêm ou mantiveram vínculo com o Arquivo Público do Estado, Neusa Rosane Damiani Nunes e Valéria Gouvêa Ghanem. ${ }^{74}$

Nota-se ainda que, nos convites feitos a instituições e profissionais de outros estados, os organizadores voltaram suas atenções principalmente para o Rio de Janeiro, São Paulo, Minas Gerais e Rio Grande do Sul. ${ }^{75}$ Por sua vez, os profissionais atuantes em outros

\footnotetext{
${ }^{72} \mathrm{Na}$ condição de diretora do Arquivo Histórico do Município de São Paulo, também participou dos encontros de 1992 (conferência e oficina) e 1994 (oficina): ver Apêndice II-5. Note-se que, do encontro de 1990, também teria participado, como indicou Eliana Bahia, ao agradecer a presença da "Diretora Municipal de São Paulo [sic], Profa. Dra. Daíse" (In: Anais do IV Encontro..., op.cit., p.74). Os anais não contêm, contudo, texto de conferência ou comunicação de Daíse A. Oliveira. Cabe esclarecer que Daíse Oliveira é presidente do Fórum Nacional de Dirigentes de Arquivos Municipais desde a sua criação, na década de 1990; dedica-se há muitos anos às questões pertinentes aos arquivos municipais brasileiros.

${ }^{73} \mathrm{Um}$ indício dessa valorização é a participação das quatro profissionais tanto proferindo conferências como ministrando oficinas: ver Apêndice II-5. Heloísa Bellotto também participou do segundo encontro, em 1986 (mas, nos documentos consultados durante a pesquisa, não foi possível confirmar se participou como conferencista).

${ }^{74}$ A respeito, ver Apêndice II-5. Quanto a Edison d'Ávila, convém lembrar que foi também presidente e $1^{\circ}$. secretário da Associação de Amigos do Arquivo Público do Estado de Santa Catarina (ver Apêndice II-8). Entre os conferencistas, um caso especial é o de Gelci José Coelho, profissional da área de museus vinculado ao Museu de Antropologia Oswaldo Rodrigues Cabral, da Universidade Federal de Santa Catarina. Gelci Coelho foi conferencista nos dois encontros mais recentes (2002 e 2004), ambos realizados em Florianópolis, e suas falas, longe de abordar questões arquivísticas, narraram as histórias fabulosas acerca da ilha de Santa Catarina recolhidas pelo pesquisador Franklin Cascaes. Cf.: Caderno de resumos do X Encontro..., op.cit ; Programa do XI Encontro..., op.cit.

${ }^{75}$ Em 2000, estava prevista a conferência de profissional ligado ao Centro de Conservação e Restauração de Bens Culturais, da Universidade Federal de Minas Gerais; o conferencista, no entanto, não compareceu.
} 
estados, e que escolheram integrar-se aos eventos apresentando comunicações, vieram predominantemente do Rio Grande do Sul, do Paraná e de São Paulo, havendo participações esporádicas de representantes de instituições do Distrito Federal, de Minas Gerais e do Pará ${ }^{76}$. As participações “externas" aumentaram, na década de 1990. Espontâneas (mas devidamente selecionadas e aprovadas pelas comissões organizadoras dos eventos), estavam, na sua maioria, ligadas a instituições arquivísticas ou custodiadoras de acervos arquivísticos, ou a cursos universitários (de Arquivologia ou com temáticas próximas às da área - ver Apêndice II-4). Esses dados indicam, portanto, que os encontros catarinenses de arquivos, em duas décadas, tenderam a enfatizar problemas e experiências da área arquivística próprios às regiões sul e sudeste do país.

Quanto às participações espontâneas pertinentes a instituições e profissionais de Santa Catarina (apresentando comunicações, vale lembrar), foram mais regulares no que tange aos arquivos municipais, e isso por influência da própria estrutura dos encontros, que, a partir de 1994, passaram a incluir um "painel de arquivos municipais de Santa Catarina". Caracterizados por breves informes sobre as atividades gerais das entidades, os painéis, embora não tivessem essa função, freqüentemente demonstraram a fragilidade administrativa e técnica daquelas instituições. ${ }^{77}$ Entre os representantes de arquivos públicos municipais catarinenses, apresentaram comunicações com maior regularidade, ou coordenaram mesas, Sueli Petry e Cristina Ferreira (do Arquivo Histórico de Blumenau), Edison d'Ávila e Vera Lúcia Estork (do Arquivo Histórico de Itajaí), Egon Lotário Jagnow e Sílvia Toassi Kita (Arquivo Histórico de Jaraguá do Sul). A presença de representantes de arquivos eclesiásticos catarinenses, marcante nos dois primeiros encontros, não foi renovada nos seguintes.

A própria participação de funcionários do Arquivo Público do Estado de Santa Catarina, significativa até 1990 (ano em que a instituição chegou a apresentar seis comunicações acerca de suas atividades), foi reduzida nos anos seguintes, ao menos no que se refere aos trabalhos apresentados (manteve-se significativa nas coordenações de mesas e demais atividades dos encontros, a começar por sua organização).

\footnotetext{
${ }^{76}$ Arquivo de Uberaba (MG), em 1994 (objeto de conferência em 1992); UnB (DF), em 1996; UFPA, em 2000; GT Arquivos do Poder Judiciário (DF), em 2002 (ver Apêndice II-4).

${ }^{77}$ Tive a oportunidade de acompanhar pessoalmente a realização dos painéis, bem como dos encontros, a partir de 1998.
} 
Ao integrarem as atividades programadas nos encontros catarinenses de arquivos, os historiadores em geral não se apresentaram nessa condição. Aliás, a questão da formação dos profissionais que proferiram conferências, apresentaram comunicações, ministraram oficinas e coordenaram mesas foi, no geral, elidida - como se as diferenças e tensões que, a este respeito, povoam a área, devessem ser temporariamente suspensas, fazendo com que os participantes dos encontros fossem compulsoriamente irmanados na imprecisa dimensão dos "profissionais da área de arquivos". Desta perspectiva, os historiadores, quando se pronunciaram, na maior parte das vezes o fizeram a partir de suas funções junto a instituições arquivísticas ou custodiadoras de acervos arquivísticos: caso, por exemplo (em relação a profissionais atuantes em Santa Catarina), de Sueli Petry e Cristina Ferreira (que representaram o Arquivo Histórico de Blumenau), Edison d'Ávila (que representou o Arquivo Histórico de Itajaí), Eneida Raquel S. Thiago (que representou o Arquivo Histórico de Joinville), Maria Aparecida de Lima (que representou o Arquivo Histórico de São José). ${ }^{78}$

Quando assumiram a condição de historiadores, os pesquisadores que apresentaram comunicações ou relataram trabalhos repisaram, como indicado anteriormente, o tema do salvamento dos arquivos, ou apontaram a relação íntima dos arquivos com seu ofício. O destaque maior cabe, porém, a Walter Fernando Piazza, cuja atuação foi marcante nos encontros, entre 1984 e $1994 .^{79}$

Veja-se que, no encontro de 1984, Piazza deu-se a ver como pesquisador que conhecia "o valor dos arquivos", como "fruto de mais de trinta anos de pesquisa histórica ininterrupta, no desejo de melhor conhecer a História de Santa Catarina", como resultado de suas “andanças, em busca das raízes do povo catarinense." ${ }^{~}{ }^{20}$ Para comprová-lo, destacou, em sua fala, conjuntos documentais no seu entender significativos, existentes em instituições brasileiras de vários estados, bem como em instituições existentes no exterior (em especial, em Portugal e nos EUA). O papel atribuído por Piazza aos arquivos fica ainda mais claro ao final de sua exposição:

\footnotetext{
${ }_{78}^{78}$ Todos os profissionais mencionados são mestres em História pela Universidade Federal de Santa Catarina (ver Apêndice I-1). Maria Aparecida de Lima apresentou comunicações em 1994, 1998 e 2000 (ver Apêndice II-5). Eneida Raquel S. Thiago apresentou comunicação em 1988 e, segundo essa mesma comunicação, também no ano anterior. Cf.: RAQUEL, Eneida. Arquivo Histórico de Joinville. In: PIAZZA, Walter F. (org.). Anais do III Encontro..., op.cit., p.41.

${ }^{79}$ Além de participar dos encontros com comunicações, conferência e coordenação de painel, Piazza foi ainda o organizador dos anais do III Encontro de Arquivos Catarinenses (1988).

${ }^{80}$ PIAZZA, Walter F. Fontes arquivais para a história de Santa Catarina. op.cit. p.35.
} 
Há necessidade de revisão da História de Santa Catarina, com base nos arquivos disponíveis. [...] devemos reler os documentos, rever os seus conteúdos, correlacioná-los com outros documentos existentes em outros arquivos [...]. Há necessidade de um maior aprofundamento das pesquisas sobre a nossa História, quer em arquivos nacionais, quer em arquivos estrangeiros, aqui citados ou não, para um melhor conhecimento dos fatos históricos relacionados à Terra Catarinense. [...] há necessidade de se conhecer o conteúdo dos arquivos e, aqui, cabe uma sugestão, para que se apressem os catálogos do nosso Arquivo Público, com o inventário dos seus núcleos e a indexação dos seus documentos e o mesmo se faça com todos os arquivos existentes no território catarinense.

Há necessidade premente que se protejam, preservando de todos os modos possíveis os arquivos existentes em todos os nossos 199 municípios, dandolhes, tanto quanto possível, locais adequados, organizando-os tecnicamente, divulgando os seus acervos, para maior glória da nossa Terra e exaltação da nossa gente, que tem construído a nossa História, com muito sacrifício! ${ }^{81}$

Após a saída de cena de Walter Piazza, em 1994 (no que se refere aos encontros estaduais de arquivos), nenhum outro historiador-pesquisador de arquivos (apresentando-se sobretudo com essas credenciais, bem entendido) teve presença destacada. Nas conferências, comunicações, oficinas, e mesmo nas manifestações do público, nenhum sinal dos historiadores pretensamente integrantes da "nova geração". Na ausência, talvez, um indício de que algo realmente mudara na relação historiadores-arquivos, em Santa Catarina.

\section{No horizonte, uma política}

Proposições feitas ao final de encontros profissionais e acadêmicos podem indicar os itens possivelmente significativos das discussões realizadas. Consideradas as continuadas edições de um mesmo evento, permitem ainda detectar, em função da reapresentação de moções, a permanência de demandas e problemas.

\footnotetext{
${ }^{81}$ Ibidem, p.42.
} 
As recomendações, sugestões e moções encaminhadas nos encontros catarinenses de $\operatorname{arquivos}^{82}$, bastante abrangentes, referiram-se, em linhas gerais: aos arquivos públicos municipais; aos arquivos públicos estaduais; à legislação relacionada aos arquivos; aos sistemas de arquivos em Santa Catarina; à formação e valorização de pessoal tecnicamente qualificado; aos procedimentos técnicos adotados em relação aos conjuntos arquivísticos; à divulgação dos arquivos (seu papel e seus acervos); à sensibilização e ao apoio das autoridades públicas para com os arquivos; à proteção de conjuntos documentais específicos; à produção bibliográfica na área arquivística; às associações de arquivistas; aos cursos de graduação em História; aos próprios encontros. ${ }^{83}$

As proposições e recomendações que disseram respeito aos arquivos públicos municipais foram muitas e percorreram todo o período. Apontaram para a necessidade de institucionalizá-los e apoiá-los do ponto de vista de sua estrutura física, financeira e de pessoal técnico. Igualmente, a necessidade de integrá-los ao Subsistema Estadual de Arquivos (algo que foi manifestado no ano de criação do sistema - 1988 - e, dez anos depois, novamente, denotando a pouca ressonância da questão junto às administrações municipais). Chegou-se a propor que o Arquivo Público do Estado abrigasse um "Fórum de Diretores de Arquivos Municipais" (em 1992). O parco sucesso na institucionalização de um número maior de arquivos municipais, em Santa Catarina (não obstante as investidas neste sentido do Arquivo Público do Estado), foi certamente a motivação para proposta encaminhada no encontro de 2004: a de criar um "Sistema Estadual de Arquivos Públicos Municipais" ${ }^{84}$ Os encontros também parecem ter tido pouca capacidade de atrair representantes de arquivos municipais e de administrações municipais, como sugerem duas recomendações, encaminhadas por funcionários do Arquivo Público do Estado: em 1996 e em 2000, houve o apelo à maior participação dos arquivos municipais nos painéis para isto destinados. ${ }^{85}$

Lidas retrospectivamente, as proposições e recomendações atestam as poucas conquistas da área em duas décadas: a aquisição de um prédio próprio e adequado para o Arquivo Público do Estado, indicada em 1986, foi reiterada em 2000 e 2004, e ainda não

\footnotetext{
${ }^{82}$ Foram aqui excluídas as moções de agradecimento e parabenização.

${ }^{83}$ Para todas as referências às proposições e recomendações, ver Apêndice II-6.

${ }^{84}$ A proposta é bastante peculiar, pois não se coaduna com os modelos sistêmicos usuais na área de arquivos, no Brasil, além de não levar em conta o Subsistema Estadual de Arquivos criado em 1988.

${ }^{85} \mathrm{Na}$ recomendação de 2000, apelava-se para que os "dirigentes" dos arquivos municipais se comprometessem “espontaneamente" com essa participação...
} 
efetivada ${ }^{86}$; a criação de um curso de graduação em Arquivologia, em nível estadual, sugerida em 1994 e 1996 (aliás, por profissionais com atuação fora do Estado), não foi concretizada; a necessidade de sensibilização dos governantes e autoridades públicas para "os problemas crônicos dos arquivos" continua a ser periodicamente renovada. Quanto à "modernização" administrativa, entendida basicamente como informatização, as recomendações e proposições igualmente indicaram o alheamento dos arquivos dos processos decisórios: se, em 1984, o "avanço da informática" parecia exigir a "modernização das técnicas arquivísticas”, em 2002 aponta-se a necessidade de as instituições, "ao contratarem serviços de digitalização de acervos documentais", consultarem instituições arquivísticas.

Freqüentemente encaminhadas pelos próprios funcionários do Arquivo Público do Estado, as recomendações, ao serem aprovadas, ganharam respaldo coletivo da comunidade de especialistas e de interessados na preservação do patrimônio arquivístico, representada pela platéia dos encontros. E, se muitas das recomendações e propostas não conseguiram ter efetivação junto à administração estadual e às prefeituras municipais, certamente serviram ao menos para continuar a emprestar ao Arquivo Público do Estado de Santa Catarina a aura de liderança na valorização social dos profissionais de arquivo e das instituições arquivísticas catarinenses.

\section{Uma política, uma legislação}

A sustentação de uma política de arquivos, em nível estadual, procurou ser garantida, concomitantemente aos encontros estaduais de arquivos, por meio da legislação. As demandas quanto à legislação foram, aliás, algumas das poucas que, manifestadas nas moções dos encontros catarinenses de arquivos, tiveram atendimento, já a partir de 1988.

\footnotetext{
${ }^{86} \mathrm{O}$ atual governo estadual teria projeto de construir prédio próprio para o Arquivo Público do Estado; apesar disso, resolveu às pressas, em maio de 2006, transferi-lo para edifício a ser adaptado. Cf.: LIMA, Jéferson. Mudança conturbada. A Notícia, Joinville (SC), 6 jun.2006. Sobre as mudanças de endereço do Arquivo Público do Estado, ver: PIAZZA, Walter F. Arquivo Público: retrospectiva e prospectiva. In: Arquivo Público do Estado de Santa Catarina - 30 anos (1960-1990). Florianópolis: Secretaria de Estado da Administração, 1990. p. 8; Ágora, Florianópolis, n.1, jun.1985, p.10-14.
} 
Da iniciativa de garantir, por meio da legislação, uma política estadual de arquivos, participaram, fundamentalmente, os mesmos atores que procuraram dar impulso aos encontros catarinenses de arquivos, com destaque para a Coordenadoria de Documentação e Publicações, no interior da estrutura administrativa estadual. Foi nitidamente um momento de empenho de membros do Instituto Histórico e Geográfico de Santa Catarina nas questões da preservação do patrimônio arquivístico, traduzido nas ações por eles promovidas no exercício dos cargos que então ocupavam naquela estrutura. ${ }^{87}$ Nas palavras do historiador Walter Piazza, em 1988, momento em que ocupava o cargo de Coordenador de Documentação e Publicações, na Secretaria de Estado da Administração, marcava-se uma ruptura:

Pela primeira vez tem início, na História Político-Administrativa do nosso Estado, uma política de preservação documental.[...].

Até agora, os arquivos setoriais da Administração Estadual, quer direta, quer indireta [...] não eram tratados como devem ser os indicadores de uma identidade da cidadania.

Assim, em muitos momentos da vida político-administrativa de Santa Catarina, inúmeros e importantes núcleos documentais foram jogados no lixo, foram vendidos como papéis velhos e inservíveis, foram, enfim, tratados desprezivelmente. [...]

Cumprindo-se o compromisso do Governo Estadual, estampado em o "Rumo à nova sociedade catarinense", no tocante ao "patrimônio que convém preservar, desenvolver e difundir", estabeleceu-se uma programação que tem sido amparada num corpo técnico de alto nível, qual seja o da Coordenadoria de Documentação e Publicações da Secretaria de Estado da Administração, nela se incluindo, como base operacional, o do Arquivo Público do Estado. ${ }^{88}$

\footnotetext{
${ }^{87}$ A sucessora imediata de Walter Piazza na Coordenadoria de Documentação e Publicações, Eliana Bahia, era outra "consócia" do IHGSC. Jali Meirinho foi assistente de diretor e diretor da Divisão de Ciências do Departamento de Cultura da Secretaria de Estado da Educação e Cultura, entre 1960 e 1985 (Cf.: Curriculum Vitae - Jali Meirinho. Acervo da Academia Catarinense de Letras, Dossiê Jali Meirinho).

${ }^{88}$ PIAZZA, Walter F. O Subsistema Estadual de Arquivos. In: PIAZZA, Walter F. (org.). Anais do III Encontro de Arquivos Catarinenses..., op.cit., p. 11-12. "Rumo à nova sociedade catarinense" foi o programa do candidato a governador, eleito, Pedro Ivo Campos, que governou entre 1987 e 1990; sua morte, em fevereiro de 1990, fez com que o vice-governador, Casildo Maldaner, estivesse à frente do último ano da gestão.
} 
Antes mesmo que a nova Constituição fosse promulgada, um decreto de março de 1988 dispôs sobre a "política estadual de arquivos públicos e privados" em Santa Catarina. As muitas semelhanças entre o decreto estadual de 1988 e a lei federal que, em 1991, disporia sobre a política nacional de arquivos, permitem inferir ter o projeto daquela lei circulado em Santa Catarina e servido como modelo para as discussões acerca de uma legislação arquivística estadual. É assim que, tal como, mais tarde, faria a lei, o decreto procura afirmar, de um lado, o dever do poder público em proteger os documentos de arquivo, "como elemento de prova e instrumento de apoio à administração, à cultura e ao desenvolvimento científico", e, de outro, o direito dos cidadãos de consultá-los. Além disso, como a lei de 1991, abarca tanto arquivos públicos como privados, neste último caso voltando-se especialmente para os arquivos privados de interesse público. ${ }^{89}$ Assinala, do mesmo modo, o cuidado em diferenciar os arquivos em correntes, intermediários e permanentes ${ }^{90}$ e, em ambos os textos legais, há previsão de avaliação de documentos que não fossem de caráter permanente.

Mas o Decreto estadual nº $1.444 / 1988$ também tem suas peculiaridades. A começar de um problema: no parágrafo único do Art. $1^{\circ}$., os arquivos públicos são caracterizados como "inalienáveis e imprescritíveis", imprecisão que, seguida à risca, inviabilizaria procedimentos de avaliação e seleção (previstos no Art. $3^{\circ}$ ) e conseqüente eliminação de documentos. ${ }^{91}$ Uma outra singularidade do decreto estadual é a instituição de um Subsistema Estadual de Arquivos, "constituído pelos órgãos públicos estaduais e municipais" que estivessem incumbidos das "atividades de administração, recolhimento, seleção, conservação e acesso" em relação aos documentos de arquivo (Art. 11). A idéia de "subsistema" remete, necessariamente, a sistema mais amplo que o abarcaria e que, no caso, embora não seja explicitado, só poderia ser o Sistema Nacional de Arquivos - SINAR.

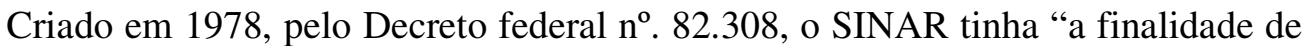
assegurar, com vistas ao interesse da comunidade, ou pelo seu valor histórico, a preservação de documentos do Poder Público" (Art. 1.). Envolvendo os arquivos de órgãos do Poder

\footnotetext{
${ }^{89}$ Decreto $\mathrm{n}^{\circ} .1 .444$, de 23 de março de 1988. In: SANTA CATARINA. Legislação estadual - 1988. Florianópolis: Secretaria de Estado da Administração, Coordenadoria de Documentação e Publicações, 1989.

${ }^{90}$ A Lei federal nº 8.159/1991 diferencia "documentos públicos" correntes, intermediários e permanentes (art. $8^{\circ}$.). Para consulta à lei, ver anexo contido em: JARDIM, José Maria. Sistemas e políticas públicas de arquivos no Brasil. Niterói (RJ): Editora da UFF, 1995. p.183-188.

${ }^{91} \mathrm{Na}$ Lei federal $\mathrm{n}^{\circ}$. 8.159/1991, são considerados inalienáveis e imprescritíveis apenas os "documentos de valor permanente" (Art. 10). Cabe ressaltar que o Decreto estadual $\mathrm{n}^{\circ}$. 1.444/1988, em um de seus artigos, veda a eliminação, mais especificamente, aos documentos que compõem arquivos permanentes (Art. 13). A imprecisão presente no Art. $1^{\circ}$., contudo, gera ambigüidade.
} 
Executivo, em nível federal, previa a agregação, através de convênios, de arquivos de outros poderes e esferas. Seu órgão central seria o Arquivo Nacional (Art. $3^{\circ}$.). ${ }^{92}$ A lei de criação do SINAR deixa clara, portanto, a vinculação fundamental com os órgãos da administração federal (direta ou indireta). Mas, depois de 1983, como apontou José Maria Jardim,

[...] diversas ações são desenvolvidas pelo Arquivo Nacional sob a justificativa do Sistema, extrapolando-se os limites legais de sua abrangência ao se priorizar, num primeiro momento, os arquivos públicos estaduais e posteriormente os municipais. ${ }^{93}$

A estratégia de "modernização", promovida pela diretora-geral Celina Vargas do Amaral Peixoto Moreira Franco, na década de 1980, esteve igualmente articulada à perspectiva de fortalecimento da posição do Arquivo Nacional no campo arquivístico brasileiro, não só como elemento articulador das demais instituições arquivísticas do país, como de instância técnica privilegiada, à qual tais instituições deveriam recorrer. ${ }^{94}$ Até mesmo a busca por maior inserção do Arquivo Nacional no cenário arquivístico internacional (maior proximidade da Associação Latino-Americana de Arquivos - ALA e do Conselho Internacional de Arquivos) emprestaria mais legitimidade às suas pretensões de vanguarda $\mathrm{e}$ guia dos arquivos brasileiros.

Foi provavelmente inspirado nas ações cada vez mais ampliadas do Arquivo Nacional, em nome do Sistema Nacional de Arquivos, que o decreto catarinense de 1988 fez os arquivos municipais integrarem o "Subsistema Estadual de Arquivos" de forma

\footnotetext{
92 Decreto no. 82.308, de 25 de setembro de 1978. In: ASSOCIAÇÃO DOS ARQUIVISTAS BRASILEIROS. Arquivologia: textos e legislação. Rio de Janeiro: 1979. p.34-38.

93 JARDIM, José Maria. Sistemas e políticas públicas..., op.cit., p.75.

${ }^{94}$ Uma visão desse processo pela própria diretora-geral está em: FRANCO, Celina do A.P. M. Uma proposta radical de trabalho. Revista do Patrimônio Histórico e Artístico Nacional, Rio de Janeiro, n.21, 1986, p.33-38. Quanto ao Arquivo Nacional como instância de articulação, José Maria Jardim assinala os encontros promovidos pelo Arquivo Nacional, que integraram representantes de instituições arquivísticas estaduais e municipais: seis Seminários Nacionais de Arquivos Estaduais (1984-1989) e três Seminários Nacionais de Arquivos Municipais (1987-1989), que por sua vez teriam fomentado a criação de espaços de encontro de instâncias diretivas (como o Fórum Nacional de Diretores de Arquivos Estaduais, em 1986, e o Fórum de Diretores de Arquivos Municipais, na década de 1990). Além da assistência técnica pontual, foram concebidos programas de treinamento regionais (1984-1986) e Estágios Nacionais de Arquivos (1986-1987). JARDIM, José Maria. Sistemas e políticas públicas..., op.cit., p.75-76. Convém destacar que, em 1988, foi também realizado o I Curso de Aperfeiçoamento em Arquivos Públicos - CAAP, reunindo alunos provenientes de várias unidades da federação, na sua maioria vinculados a instituições arquivísticas estaduais. Tinha como objetivo "promover o aperfeiçoamento de profissionais dos arquivos públicos brasileiros no que se refere ao conhecimento teórico e ao desenvolvimento de métodos e técnicas fundamentais à modernização da rede de instituições arquivísticas do país." I Curso de Aperfeiçoamento em Arquivos Públicos - Ministério da Justiça, Arquivo Nacional. [1988]. Folder.
} 
compulsória, e não conveniada. As preocupações com os arquivos municipais, por sua vez, desdobravam, em nível regional, a atuação do Arquivo Nacional. Se naquele momento a referência fundamental, em Santa Catarina, fosse, por exemplo, a experiência paulista, o encaminhamento legal da questão do sistema estadual de arquivos seria provavelmente bastante diferente. ${ }^{95}$

Outra especificidade do caso catarinense diz respeito às instâncias incumbidas de gerenciar o Subsistema Estadual de Arquivos: o decreto previa uma triangulação entre a Comissão Estadual de Arquivos, a Coordenadoria de Documentação e Publicações e o Arquivo Público do Estado. Desse modo, a Comissão seria o "órgão consultivo e de assessoramento para questões técnicas ou científicas referentes aos arquivos e à política arquivística do Estado", funcionando junto à Coordenadoria de Documentação e Publicações (Art. 11, §2º.). Já a Coordenadoria (órgão da Secretaria de Estado da Administração) assumiria propriamente o papel de órgão central do Subsistema, pois deveria "exercer funções normativas de coordenação e integração estadual de arquivos" e "supervisionar a administração dos documentos de arquivos correntes, intermediários e permanentes dos órgãos e entidades do Poder Executivo" (Art. 12), definindo "as diretrizes da política arquivística do Estado”. O Arquivo Público do Estado, então subordinado à Coordenadoria, aparece no decreto como abrigo da documentação pública de valor permanente (Art. $4^{\circ}$.) e instância de "proteção especial" da documentação privada de interesse público (Arts. $7^{\circ}$., $8^{\circ}$., $9^{\circ} ., 17$ e 18$) .{ }^{96}$

Na década de 1990, a influência de profissionais da área de arquivos ligados a instituições paulistas (arquivísticas ou universitárias), perceptível na programação dos encontros catarinenses de arquivos (em especial na escolha de conferencistas, como já

\footnotetext{
${ }^{95}$ O Sistema Estadual de Arquivos do Estado de São Paulo - SAESP foi criado pelo Decreto estadual $\mathrm{n}^{\mathrm{o}} .22 .789$, de 19 de outubro de 1984, e envolvia necessariamente órgãos do Poder Executivo estadual, além de, "mediante celebração de convênios", órgãos "dos Poderes Legislativo e Judiciário Estaduais, das Administrações municipais, as Fundações instituídas pelo Poder Público, as Empresas nas quais o Estado tenha participação majoritária e demais Entidades de Direito privado." (Art. 5.) O órgão central do Sistema seria o Arquivo do Estado de São Paulo - ou, como estava então identificado, na estrutura administrativa, a "Divisão de Arquivo do Estado, do Departamento de Museus e Arquivos da Secretaria de Cultura" (Art. 4.). Cf.: Arquivo: boletim histórico e informativo, São Paulo, v. 5, n. 4, out-dez. 1984, p.133-139.

${ }^{96} \mathrm{Em}$ relação aos arquivos privados, caberia ao Arquivo Público do Estado proceder ao seu levantamento (por meio de um "Registro Geral") e, a partir disso, identificar os que tivessem "interesse público". Tal classificação não significaria desapropriação nem "recolhimento automático" ao Arquivo Público. Em caso de alienação, contudo, o Estado teria prioridade na aquisição, sendo os documentos abrigados naquela instituição arquivística estadual.
} 
referido), revela-se ainda na legislação referente aos documentos arquivísticos da administração estadual. Após o Decreto nº 1.444/1988, foi sancionada, em 1994, a Lei nº. 9.747, de 26 de novembro, tratando especificamente da questão da avaliação. Chama a atenção, no texto da lei, a adoção de termos como "valor imediato" e "valor mediato", aplicados aos documentos, bem como a idéia de "prazo de vigência" articulado a "prazo precaucional", quanto à guarda dos referidos documentos: tais termos estavam presentes em decreto que, em 1991, estabeleceu "normas de avaliação e destinação para os documentos da Administração Pública do Município de São Paulo". 97

O exame do decreto de 1991, relativo ao Município de São Paulo, permite constatar que vários de seus artigos foram aproveitados na lei de Santa Catarina, integral ou parcialmente (em especial os artigos $2^{\circ} ., 3^{\circ}$., $4^{\circ}$. e $5^{\circ}$.), com pequenos ajustes. São, basicamente, artigos que tentam caracterizar de forma menos vaga os documentos de "valor mediato" e os de valor "imediato", articulando-os a atividades administrativas ou tipos documentais específicos. Diferentemente do decreto municipal paulista, porém, a lei catarinense não se dedica a hierarquizar as comissões de avaliação (estabelecendo uma comissão central e comissões setoriais), ou a dispor sobre suas diferentes competências. ${ }^{98}$

Mudanças mais decisivas, em termos legais, viriam a ocorrer apenas recentemente, com o Decreto $\mathrm{n}^{\mathrm{o}}$. 3.585, de 7 de outubro de 2005, que revogou parcialmente o Decreto $1.444 / 1988 .^{99}$

O que foi revogado? Basicamente, tudo o que se referia ao "Subsistema de Arquivos do Estado" (mesmo porque, os outros dispositivos diziam respeito a questões gerais

\footnotetext{
${ }^{97}$ Decreto $n^{\circ} .29 .745$, de 14 de maio de 1991. Revista do Arquivo Municipal, São Paulo, n. 199, 1991, p.153158.

${ }^{98}$ Conforme editorial do boletim informativo do Arquivo Público do Estado, o projeto da Lei no . 9.747/94 teria sido elaborado "pelos técnicos do Arquivo". Cf.: Editorial. Boletim informativo [Arquivo Público do Estado de Santa Catarina/Associação de Amigos do Arquivo Público], Florianópolis, n.8-9, jul-dez. 1994, p.1.

${ }^{99}$ Decreto no $^{\circ}$. 3.585, de 7 de outubro de 2005. Disponível em: <www.pge.sc.gov.br/Legislação $>$. Acesso em: 25 maio 2006. Deve-se salientar que, antes do decreto, a Instrução Normativa 01/2003 - DARP/SEA introduziu uma diferenciação importante em relação a vários sistemas de arquivos vigentes no país, que costumam prever um arquivo intermediário geral, quase sempre vinculado ao Arquivo Público municipal, ou estadual, ou mesmo ao Arquivo Nacional (conforme a esfera administrativa em questão). A IN 01/2003 fez com que as funções de arquivamento intermediário fossem assumidas pelas várias secretarias, fundações e autarquias, por meio do arquivo central que cada uma deveria possuir (Art. $2^{\circ}$.) Os respectivos arquivos centrais das secretarias, autarquias e fundações, por sua vez, ficaram incumbidos dos levantamentos referentes à avaliação dos documentos e do cumprimento da destinação dada a eles (Art. $3^{\circ}$.). Uma outra instrução normativa (a 011/2003 SEA) estabeleceu que os documentos de arquivo produzidos e acumulados por órgãos extintos deveriam ser assumidos pelo órgão que assumiu sua função (sendo sua transferência acompanhada pelo Arquivo Público do Estado, que receberia os documentos de caráter permanente - Art. $2^{\circ}$.).
} 
da política de arquivos, contempladas pela Lei federal $\mathrm{n}^{\circ}$. 8.159/1991). Em seu lugar, o "Sistema Administrativo de Gestão Documental", já previsto na Lei complementar no .284 , de 28 de fevereiro de 2005.

O novo sistema, que tem a Secretaria de Estado da Administração como órgão central, está todo direcionado para os órgãos da administração estadual: de acordo com o decreto de 2005, o Sistema Administrativo de Gestão Documental

visa assegurar a racionalização, a padronização, a identificação de Impresso Oficial e Formulário Contínuo, bem como a preservação, o acesso e a divulgação do patrimônio documental do Estado, no âmbito da administração direta, autárquica e fundacional do Poder Executivo" (Decreto $n^{\circ} .3 .585 / 2005$, Art. $2^{\circ}$.).

O Arquivo Público do Estado (enquanto "Diretoria de Gestão do Arquivo Público") ganha função normativa quanto às questões relacionadas "à destinação dos documentos oficiais" (Art. 10).

Apenas os órgãos componentes da administração estadual (direta e indireta) integram o Sistema Administrativo de Gestão Documental. Da parte do Arquivo Público do Estado, isso não significa, necessariamente, o abandono de funções que assumiu ao longo do tempo, em relação às instituições arquivísticas municipais (e, mesmo, em relação às prefeituras): o regulamento da Diretoria de Gestão do Arquivo Público (aprovado pelo Decreto $\mathrm{n}^{\mathrm{o}}$. 3.575, de 7 de outubro de 2005) ${ }^{100}$ prevê o estímulo à "celebração de convênios com as prefeituras, na implantação e organização de seus arquivos municipais" (Art. $2^{\circ}$., inciso X). Só o "estímulo" é possível, uma vez que a decisão acerca de qualquer convênio de assessoria, seja para instituições municipais, seja para instituições federais ou mesmo estaduais (se ligadas ao Poder Legislativo ou Judiciário), cabe ao Secretário de Estado da Administração (Art. $7^{\circ}$.).

Trata-se, portanto, de um momento de inflexão em relação à política de arquivos que tentou ser montada na década de 1980. O Subsistema criado em 1988 não teve êxito quanto aos órgãos da administração estadual, segundo indicam as proposições e recomendações encaminhadas em vários encontros estaduais de arquivos (Apêndice II-6). O

${ }^{100}$ Decreto no $^{\circ}$. 3.575, de 7 de outubro de 2005. Disponível em: <www.pge.sc.gov.br/Legislação>. Acesso em: 25 maio 2006. 
sistema vigente busca sucesso justamente equacionando a gestão dos documentos do governo estadual e, com isso, reposiciona o Arquivo Público do Estado no campo arquivístico: os laços com instituições de outras esferas administrativas deixam de ser prioritários. Mais uma mudança na trajetória atribulada da instituição. 


\section{Parte II}

\section{Capítulo 2}

\section{Papéis do governo de Santa Catarina: o lugar do Arquivo Público do Estado}

A partir da década de 1980, são claros os esforços para constituir, em Santa Catarina, o campo arquivístico, criando e fortalecendo instituições custodiadoras de arquivos de modo a garantir a guarda, organização, conservação e disponibilização dos acervos, em harmonia com recomendações mais presentes na Arquivística, em âmbito nacional e internacional. ${ }^{1}$ Ao Arquivo Público do Estado de Santa Catarina foi atribuído papel destacado, como pôde ser observado, no capítulo anterior, em relação à organização dos encontros catarinenses de arquivos e à própria legislação estadual pertinente aos acervos e instituições arquivísticas.

Neste processo, contudo, o Arquivo Público do Estado teria que ser reinventado. Com um histórico de tentativas frustradas de institucionalização, na primeira metade do século XX, só muito recentemente havia sido criado por lei (Lei estadual $n^{\circ}$. 2.378, de 28 de junho de 1960) e formalmente aberto à consulta pública como local de pesquisa. Mas faltavam-lhe ainda as condições para abrigar adequadamente os documentos de seu acervo e tratá-los corretamente do ponto de vista técnico, fornecendo, aos usuários, sala de consulta apropriada, atendimento qualificado e instrumentos de pesquisa. Depoimentos dos primeiros

\footnotetext{
${ }^{1}$ Em nível internacional, o Conselho Nacional de Arquivos, criado em 1950, junto à UNESCO, tornou-se a entidade da qual passaram a emanar as principais diretrizes para a área (quer em termos técnicos, quer em termos de política de arquivos). No caso brasileiro, grosso modo, o Arquivo Nacional, em especial sob a direção de José Honório Rodrigues, destacou-se em fins da década de 1950 e na década de 1960; na década de 1970, emergiu com força a Associação dos Arquivistas Brasileiros; a década de 1980 teve o Arquivo Nacional buscando reocupar liderança na área arquivística, compartilhada, a partir da década de 1990, com o Conselho Nacional de Arquivos (CONARQ). Cf.: FONSECA, Maria Odila. Arquivologia e ciência da informação. Rio de Janeiro: Editora FGV, 2005. p.67-72; JARDIM, José Maria. Sistemas e políticas públicas de arquivos no Brasil. Niterói (RJ): EdUFF, 1995. p.60-63; SILVA, Armando Malheiro da, et al. Arquivística: teoria e prática de uma ciência da informação - v.1. Porto: Afrontamento, 1999. p.136; IGLÉSIAS, Francisco. José Honório Rodrigues e a historiografia brasileira. Acervo, Rio de Janeiro, v.2, n.2, esp. p.6-7.
} 
diretores, acerca de suas gestões, publicados no primeiro número da revista Ágora, em junho de 1985, são, neste sentido, significativos. ${ }^{2}$

Segundo Santos Verani, coronel do Exército que dirigiu o Arquivo Público entre 1971 e 1976, o estado do acervo era então "caótico”, em função de seguidas transferências de sede, naquele período. Apesar disso, "pessoas interessadas" na consulta dos documentos eram atendidas (mas "99\% delas saíam sem obter o que buscavam"). ${ }^{3}$ Wilmar Pacheco, o diretor que sucedeu Santos Verani, relatou que, ao assumir a direção do Arquivo Público do Estado de Santa Catarina, defrontou-se com

[...] verdadeiros amontoados de papéis e volumes vergonhosamente jogados às traças num casarão velho da rua Almirante Alvim, inadequado às causas arquivísticas, além de milhares de documentos atirados nos porões da Secretaria da Administração, isso em abril de 1976.

$\mathrm{Na}$ transferência para prédio por ele considerado mais adequado, os documentos teriam ficado "novamente no chão", até a confecção de estantes de madeira por "reeducandos da Penitenciária, tão gentilmente cedidos pelo Dr. Ewaldo Vilela."

O cenário de "amontoamento" de documentos prevalecia em fins da década de 1970, segundo Ana Maria Soares Martins de Araújo e Neusa Rosane Damiani Nunes, que estagiaram no Arquivo Público do Estado, como estudantes de Biblioteconomia, entre 1978 e 1979. No início do estágio, encontraram "um acervo de documentos e livros desorganizados, muitos até amontoados pelo chão sem qualquer instrumento de busca"; além disso, a instituição contaria "com poucos funcionários, voluntariosos, mas sem nenhuma preparação técnica e sequer supervisão de um profissional habilitado."

\footnotetext{
${ }^{2}$ A revista Ágora foi lançada pela Associação de Amigos do Arquivo Público do Estado de Santa Catarina (criada no mesmo ano de 1985). No primeiro número, afirmava-se a intenção de que fosse "veículo de divulgação e debate sobre os problemas pertinentes ao Arquivo Público e, por extensão, da memória catarinense.” Ágora, Florianópolis, n.1, jun. 1985, p.3.

${ }^{3}$ VERANI, Santos. O Arquivo, de meados de 1971 a meados de 1976. Ágora, Florianópolis, n.1, jun.1985, p.12. No período, o Arquivo deixou uma sala na parte térrea do Palácio do Governo para ocupar "duas salas pequenas cedidas provisoriamente pela Imprensa Oficial, no Saco dos Limões"; na seqüência, duas salas no Edifício das Diretorias e, posteriormente, "um prédio alugado na Rua Almirante Alvim". Ibidem, p.10.

${ }^{4}$ PACHECO, Wilmar. Minha passagem pelo Arquivo Público. Ágora, Florianópolis, n.1, jun.1985, p.14. Pacheco, com formação em Direito, esteve à frente do Arquivo Público do Estado entre 1976 e 1982 (ver Apêndice II-7). Ewaldo Vilela dirigiria o Arquivo Público do Estado entre maio de 1982 e março de 1983; foi também diretor da Penitenciária do Estado.

5 ARAÚJO, Ana Maria Soares Martins de; NUNES, Neusa Rosane Damiani. Nossa experiência no Arquivo Público. Ágora, Florianópolis, n.1, jun.1985. p.16. As estagiárias tornaram-se funcionárias do Arquivo e mantêm-se na instituição.
} 
O quadro funcional, com ausência de pessoal tecnicamente preparado para a atuação em instituição arquivística, começaria a ser algo alterado a partir de fins da década de 1970 (e, de acordo com Walter Piazza, inclusive em função de demandas de pesquisa do recém-implantado Programa de Pós-Graduação em História na Universidade Federal de Santa Catarina $\left.^{6}\right)$. Mas as mudanças maiores viriam na década de 1980, todas convergindo para a construção de uma imagem positiva do Arquivo Público do Estado.

\section{O Arquivo é (boa) notícia}

Em fins de novembro de 1983, o jornal O Estado, editado em Florianópolis, publicou artigo cujo título já apontava para essa perspectiva: “Arquivo Público, ainda pobre, mas digno, atrai a pesquisa". Se a pobreza era indício de continuidade, a dignidade era sinal de transição auspiciosa: afirma-se no artigo que, mesmo em "pequeno prédio" alugado,

é ali na Rua Felipe Schmidt, bem instalado e organizado, que o Arquivo Público do Estado consegue manter sua dignidade e respeito, escudado pelos 700 mil documentos arquivados catalogados recentemente, que ganharam um novo ímpeto com a indicação do novo diretor, Iaponan Soares, professor e historiador que se diz apaixonado pela função. ${ }^{7}$

A estratégia de positivação tem bases que ficam visíveis já nesse artigo. Antes de tudo, é o próprio acervo que empresta importância ao Arquivo, considerando-se, em especial, o volume de documentos e suas "raridades" (como um documento de 1703). Outro ponto: se os problemas não podem ser negados (como em relação ao prédio), é importante que se demonstre iniciativa para resolvê-los ou, ao menos, atenuá-los: contra, por exemplo, a "dotação quase ridícula", "criatividade": convênios e parcerias com instituições públicas e

\footnotetext{
${ }^{6}$ As pesquisas teriam apontado "a necessidade de restauração de códices e documentos, o preparo de pessoal habilitado para atendimento às várias preocupações dos usuários do Arquivo." PIAZZA, Walter. O Arquivo Público do Estado de Santa Catarina e a pesquisa histórica. Ágora, Florianópolis, n.1, jun.1985. p.20.

${ }^{7}$ Cf.: Arquivo Público, ainda pobre, mas digno, atrai a pesquisa. O Estado, Florianópolis, 27 nov. 1983. Há certamente exageros, sendo pouco provável que os "700 mil” documentos (consideradas as situações anteriores de armazenamento do acervo) tivessem sido catalogados, de forma que se pudesse considerar o Arquivo "bem instalado e organizado". Menos de três anos depois, em outra reportagem, o acervo salta à cifra de 10 milhões de documentos! Ver: Um arquivo com 10 milhões de documentos. Diário Catarinense, Florianópolis, 28 jun. 1986. Acervo da Academia Catarinense de Letras (ACL), Dossiê Iaponan Soares de Araújo.
} 
entidades privadas buscavam conseguir mais pessoal e apoio financeiro para atividades desenvolvidas pelo Arquivo Público do Estado. ${ }^{8}$ E, finalmente, a certeza de que a instituição encontrava-se sob a responsabilidade de profissionais empenhados e a ela dedicados. Quanto a este último ponto, salienta-se a figura de Iaponan Soares.

Natural do Rio Grande do Norte, Iaponan Soares de Araújo (ou simplesmente Iaponan Soares, como costuma assinar a maioria de seus trabalhos) residia em Santa Catarina desde 1956 e, embora sua atuação profissional no estado estivesse inicialmente ligada ao Departamento Nacional de Estradas de Rodagem, enveredara para os estudos literários, debruçando-se sobre escritores catarinenses. Integrou, inclusive, o Grupo Litoral, cuja revista procurou divulgar textos de novos autores de Santa Catarina. Quando assumiu a direção do Arquivo Público do Estado, em março de 1983, tinha alguns livros publicados. Mais importante: também integrava um certo circuito intelectual, sendo membro da Academia Catarinense de Letras e do Instituto Histórico e Geográfico de Santa Catarina. ${ }^{9}$

Bibliófilo que, dedicado à literatura, tinha boas relações no meio jornalístico, Iaponan Soares, à frente do Arquivo Público do Estado, procurará transformá-lo em uma "boa notícia”, ocupando as páginas de jornais da capital através de textos de sua autoria ou de entrevistas concedidas. As atividades promovidas pela instituição também ofereciam motivo para notas e reportagens. Didaticamente, demonstrará a importância do Arquivo, para a administração, para os cidadãos em geral e para os pesquisadores da História em particular. ${ }^{10}$ Apontará os problemas causados pela ausência, no país, de legislação específica de proteção aos documentos de arquivo ${ }^{11}$. Destacará a necessidade de pessoal técnico capacitado para as tarefas de conservação de livros e documentos e salientará o quanto a divulgação do

\footnotetext{
${ }^{8}$ Um arquivo com 10 milhões..., op.cit.

${ }^{9}$ Foi admitido como sócio emérito do IHGSC em setembro de 1978; na Academia Catarinense de Letras, ocupa a cadeira $\mathrm{n}^{\circ}$. 36, que tem como patrono o jornalista e escritor Oscar Rosas Ribeiro de Almeida. Nos anos 1970, Iaponan Soares publicou, por editoras de Porto Alegre, os livros Marcelino Dutra - um aspecto formativo da literatura catarinense (1970), Panorama do conto catarinense (1971 e $1974-2^{\mathrm{a}}$. edição), A poesia de Oscar Rosas (1972). Cf.: Curriculum Vitae - Iaponan Soares; SOARES, Iaponan. Recebendo o título de cidadão catarinense. Florianópolis, 1993 (ambos integrantes do Acervo da Academia Catarinense de Letras, Dossiê Iaponan Soares de Araújo); CORRÊA, Carlos H. P. Lições de política e cultura: a Academia Catarinense de Letras, sua criação e relações com o poder. Florianópolis: Edições ACL, 1996. p.101; website do Instituto Histórico e Geográfico de Santa Catarina: <http://www.ihgsc.org.br/eméritos.htm>. Acesso em: 13 set. 2005.

${ }^{10}$ SOARES, Iaponan. O Arquivo Público do Estado. A Ponte, Florianópolis, jul.1985. Acervo da Academia Catarinense de Letras, Dossiê Iaponan Soares de Araújo.

${ }^{11}$ SOARES, Iaponan. Cidadania, preservação de documentos e constituição. O Estado, Florianópolis, 12 jan. 1986. Acervo da Academia Catarinense de Letras, Dossiê Iaponan Soares de Araújo.
} 
patrimônio documental é base de sua preservação. ${ }^{12}$ E, ainda, sempre que possível, enfatizará a inadequação do prédio ocupado pelo Arquivo. ${ }^{13}$

$\mathrm{Na}$ gestão de Iaponan Soares, ao lado de seu nome podemos freqüentemente encontrar o de Walter Fernando Piazza, ele também "professor e historiador", ele também "apaixonado" pelo Arquivo Público do Estado. ${ }^{14}$ Igualmente ocupou os jornais com artigos, mas seu viés foi menos "positivador" do Arquivo Público do que o do diretor Iaponan Soares. Veja-se que, em artigo de 1986, embora destacasse o "movimento cultural em torno dos arquivos", a partir dos encontros de arquivos catarinenses, indicava os vários problemas vividos pela instituição:

Está o nosso Arquivo Público do Estado sem instalações próprias e adequadas, sem quadro técnico-funcional à altura dos seus conteúdos arquivísticos, sem a preservação dos seus acervos por processos mecânicos, enfim, há ali muito que fazer para que possa bem e eficientemente cumprir a sua destinação. ${ }^{15}$

Na primeira metade da década de 1980, Iaponan Soares e Walter Piazza estiveram lado a lado na Academia Catarinense de Letras, como secretário geral e presidente, respectivamente. ${ }^{16}$ Ambos apresentaram, em outubro de 1983, na V Semana da História, em Franca (SP), trabalho referente ao processo de identificação e organização do acervo do Arquivo Público. Nele destacaram a importância dos documentos, existentes naquela instituição, relacionados à Assembléia Provincial e, posteriormente, Estadual - sobretudo

12 SOARES, Iaponan. A preservação de bens culturais. Diário Catarinense, Florianópolis, 23 jun. 1986; SOARES, Iaponan. Nossos arquivos e nossa identidade. Diário Catarinense, Florianópolis, 30 jun. 1986. Acervo da Academia Catarinense de Letras, Dossiê Iaponan Soares de Araújo.

${ }^{13}$ Em artigo de 28 de junho de 1986: “[...] o Arquivo conta com apenas 700 metros quadrados para abrigar um acervo com cerca de 10 milhões de documentos. O diretor Iaponan Soares afirma que este é o maior problema enfrentado pela instituição." (Um arquivo de 10 milhões..., op.cit.) O novo prédio, porém, seria "construído nas imediações da servidão Adélio Silva, localizada entre o Centro Integrado de Cultura e a Universidade Federal". Até mesmo nessa questão Iaponan Soares tende a apresentar uma perspectiva positiva, pois em julho de 1986 informava: "[...] já se encontra em elaboração final o projeto para a sede definitiva do Arquivo Público do Estado, que se espera não tarde o dia de ter espaço condizente para abrigar seu valioso acervo.” SOARES, Iaponan. Documentação e História. Diário Catarinense, Florianópolis, 28 jul.1986. Acervo da Academia Catarinense de Letras, Dossiê Iaponan Soares de Araújo.

${ }_{14}$ Arquivo Público, ainda pobre..., op.cit.

15 PIAZZA, Walter F. Um evento, uma reflexão. Diário Catarinense, Florianópolis, 6 de setembro de 1986. Acervo da Academia Catarinense de Letras, Dossiê Walter F. Piazza.

16 A informação está presente em ofícios circulares expedidos aos membros da Academia no ano de 1984. Acervo da Academia Catarinense de Letras, Dossiê Walter F. Piazza. 
tendo em vista o incêndio que, em 1956, destruiu o arquivo do Poder Legislativo catarinense. ${ }^{17}$ No ano seguinte, Piazza publicaria, em colaboração com Soares, livro em comemoração aos 150 anos do Legislativo de Santa Catarina.

Apesar da mudança no governo estadual, em 1987 (Pedro Ivo Campos, do PMDB, substituiu o governador Esperidião Amin, do PDS), Iaponan Soares foi mantido no cargo - e para que isso ocorresse houve a manifestação favorável de setores aos quais o diretor do Arquivo estava ligado. Ofício do então presidente da Academia Catarinense de Letras, Paschoal Apóstolo Pítsica, datado de 18 de fevereiro de 1987, exprimiu a preocupação que, segundo seus termos, se instalara, "reservadamente, no seio da intelectualidade":

Trata-se do Arquivo Público! Foi uma luta ingente que a classe empreendeu para que sua direção fosse entregue a um historiador! Mais do que isso, que ficasse entregue a um técnico especializado em restauração e que ciceroneasse todos que lá buscam subsídios para suas pesquisas históricas. Esta pessoa é IAPONAN SOARES DE ARAÚJO! Desnecessário dizer que o Arquivo Público depois que foi entregue aos cuidados do Professor Iaponan Soares de Araújo, membro da Academia Catarinense de Letras e da diretoria do Instituto Histórico e destacado historiador, dinamizou-a [sic] a ponto de o Poder Público só receber elogios de todos os que procuram aquele órgão. ${ }^{18}$

Nota-se que, embora Iaponan Soares não tivesse formação universitária em História (era bacharel em Pedagogia), e se destacasse como um estudioso da literatura, sua identificação como historiador (reforçada pelo pertencimento aos quadros da diretoria do Instituto Histórico e Geográfico de Santa Catarina) é, no ofício, um dos principais elementos a qualificarem sua manutenção no cargo (além, é claro, de seu desempenho à frente da

\footnotetext{
${ }^{17}$ PIAZZA, Walter F., SOARES, Iaponan. O Arquivo Público do Estado de Santa Catarina (fundos referentes ao Poder Legislativo Estadual). Memória da V Semana da História - 3 a 7 [de] outubro [de] 1983, campus de Franca. Franca (SP): Universidade Estadual Paulista, Instituto de História e Serviço Social, 1984. p.395-398.

${ }^{18}$ Ofício de Paschoal Apóstolo Pítsica, presidente da Academia Catarinense de Letras, ao governador eleito Pedro Ivo Campos. Florianópolis, 18 fev. 1987. Reforçando o pedido, um ofício do presidente da Assembléia Legislativa, Juarez Furtado, datado de 19 de fevereiro de 1987, argumenta: "o meu recomendado [Iaponan Soares] não tem exercido nenhum tipo de militância política ou partidária, mas tem executado zelosamente um trabalho de natureza científica que goza de reconhecimento geral e, a meu ver, não deve sofrer solução de continuidade.” Acervo da Academia Catarinense de Letras, Dossiê Iaponan Soares de Araújo.
} 
instituição e, inclusive, suas qualificações técnicas na área de arquivos). ${ }^{19}$ Isso é um indicativo importante dos impasses da área arquivística, no tocante à formação de profissionais, e da leitura particular que, a respeito, era feita em Santa Catarina, naquele momento, pelos principais articuladores do campo. À época, eram poucos os cursos de graduação em Arquivologia no país, além de muito recentes e restritos ao Rio de Janeiro e ao Rio Grande do Sul. $^{20}$ Poucos eram os profissionais graduados disponíveis para atuar em instituições arquivísticas e, conseqüentemente, também difícil era compor o quadro de docentes necessário à criação de novos cursos. Daí a opção por cursos de especialização, que permitiam maior flexibilidade na montagem da grade curricular e do corpo docente. ${ }^{21} \mathrm{Em}$ Santa Catarina, a valorização dos conhecimentos técnicos específicos da área de arquivos não se fechou à contribuição de profissionais com outra formação, como bibliotecários e historiadores, diferentemente do que aconteceu em outros estados. ${ }^{22}$ Permaneceu como

\footnotetext{
${ }^{19}$ Iaponan Soares fizera o Curso de Especialização em "Organização e Administração de Arquivos”, promovido pela UFSC. Ver, a respeito: Curriculum Vitae - Iaponan Soares. op.cit. Em sua trajetória, também se dedicou ao estudo da história do município de Biguaçu e da história de dois bairros da capital catarinense, o que resultou nas seguintes publicações: Notícia histórica de Biguaçu (1983), Vamos conhecer Biguaçu (1985), História de Biguaçu através de sua gente (com Ana Lúcia C. Locks - 1989), Estreito, vida e memória de um bairro (1990) e Santo Antônio de Lisboa, vida e memória (1990). Os dois últimos livros integraram a série "Memórias de Florianópolis", editada pela Prefeitura Municipal de Florianópolis através da Fundação Franklin Cascaes, quando Esperidião Amin era prefeito. Cf.: Uma memória para Florianópolis. O Estado, Florianópolis, 25 mar. 1990 (caderno 1, p.1); História de Santo Antônio de Lisboa. O Estado, Florianópolis, 5 ago. 1990, p.3. Acervo da Academia Catarinense de Letras, Dossiê Iaponan Soares.

${ }^{20}$ Havia o curso que, criado no Arquivo Nacional, em 1960, fora incorporado à atual UNI-Rio, bem como os cursos da Universidade Federal de Santa Maria (criado em 1977) e da Universidade Federal Fluminense (criado em 1979). JARDIM, José Maria. A Universidade e o ensino de Arquivologia no Brasil. In: JARDIM, José Maria; FONSECA, Maria Odila (orgs.). A formação do arquivista no Brasil. Niterói (RJ): EdUFF, 1999. p.40.

${ }^{21}$ Um desses cursos, criado em meados dos anos 1980 e mantido até hoje, é o Curso de Especialização em Organização de Arquivos promovido pelo Instituto de Estudos Brasileiros da Universidade de São Paulo. Em 1987, em Florianópolis, foi realizado o "I Curso de Especialização em Organização e Administração de Arquivos", promovido pela UFSC; teria contado com "38 participantes e professores da UFSC e da USP" (Ágora, Florianópolis, n.5, jun.1987, p.3). Funcionários do Arquivo Público do Estado, além do diretor Iaponan Soares, foram seus alunos. Neusa Rosane Damiani Nunes, uma das alunas de 1987, informou, em depoimento, quais foram seus professores: de outros estados, "Daíse Aparecida Oliveira, Rose Marie Inojosa, Mariângela Paiva de Oliveira, Isabel Maria F. Cunha, Gilson Cruz de Oliveira"; de Santa Catarina, "Adélia dos Santos Silveira, Napoleão Xavier do Amarante, Walter Fernando Piazza", entre outros (Depoimento de Neusa Rosane Damiani Nunes, em 15 de dezembro de 2005 - versão transcrita. fl.9. Arquivo pessoal de Janice Gonçalves).

${ }^{22}$ José Pedro Esposel, importante representante da área arquivística no Brasil (fundador e primeiro presidente da Associação dos Arquivistas Brasileiros, além de professor em cursos de graduação em Arquivologia no país), assim se manifestou, em 1984: "Em substituição a um arquivista, o Dr. Raul Lima, e contrariando frontalmente preceitos de lei, foi nomeada pelo Senhor Ministro da Justiça, em 28 de maio de 1980, para o cargo de DiretorGeral do Arquivo Nacional, uma graduada em Sociologia. Em conseqüência, nos arquivos públicos, há uma pressão no sentido de substituir antigos, dignos e dedicados funcionários, por uma numerosa e bem remunerada equipe de elementos também não qualificados como Arquivistas ou Técnicos de Arquivo.” ESPOSEL, José Pedro. Arquivos: uma questão de ordem. Niterói (RJ): Muiraquitã, 1994. p.203. Esposel referia-se à Lei federal $\mathrm{n}^{\circ}$. 6.546, de 4 de julho de 1978. Cf. ASSOCIAÇÃO DE ARQUIVISTAS BRASILEIROS. Arquivologia: textos e legislação. Rio de Janeiro: 1979.
} 
requisito importante, porém, a maior proximidade - ou, mesmo, intimidade - com o trato dos documentos. Tal abertura, se tinha justificativa nas frágeis condições de formação técnica disponíveis em Santa Catarina, também ancorava-se nas áreas de formação ou atuação e nos valores partilhados pelos personagens-chave da constituição do campo arquivístico no estado.

No governo Pedro Ivo Campos, o poder de intervenção de Walter Piazza, na questão dos arquivos, aumentaria, uma vez que passou a ocupar o cargo de Coordenador de Documentação e Publicações, dentro da estrutura da Secretaria de Estado da Administração (Coordenadoria à qual ficou subordinado o Arquivo Público do Estado, conforme apontado no capítulo anterior).

A partir de dezembro de 1988, quando Iaponan Soares deixou a direção do Arquivo Público do Estado, os diretores da instituição (ou "gerentes", nos anos 1990) passaram a ser escolhidos entre os funcionários da instituição (e isso até 2003). Mais propriamente: entre suas funcionárias, dado que o corpo técnico foi, ao longo do período, quase que exclusivamente feminino. Os primeiros anos da década de 1990 também assinalariam, por sua vez, o gradual afastamento de Walter Piazza do Arquivo Público e dos "embates arquivísticos". Primeiramente, deixa o cargo de Coordenador de Documentação e Publicações, pouco depois da morte do governador Pedro Ivo Campos, ocorrida em fevereiro de 1990. Na Associação de Amigos do Arquivo Público do Estado de Santa Catarina, por sua vez, após 1992 não mais assumiria cargos na diretoria ou nos conselhos. Sem esses dois importantes divulgadores - Iaponan Soares e Walter Piazza, ambos com acesso ao circuito jornalístico, literário e político, mais marcadamente na capital - o poder de difusão midiática positiva do Arquivo Público do Estado foi sensivelmente reduzido, na década de 1990.

\section{Um certo olhar sobre a História}

A construção e disseminação de uma imagem positiva do Arquivo Público do Estado de Santa Catarina não teve apenas os jornais da capital como veículos: esteve conectada a atividades de difusão cultural promovidas pela instituição, como publicações, exposições e visitas programadas. 
Entre as publicações, a revista Ágora foi um instrumento de visibilização mais voltado, em princípio, para profissionais de arquivo e usuários-pesquisadores. Semestral, nos seus primeiros dez anos dedicou-se prioritariamente a discutir questões relacionadas aos arquivos, do ponto de vista de uma política para o setor e de suas questões técnicas ou, ainda, da importância de seu acervo como fonte para a História. O foco principal, claro está, foram os arquivos e a história catarinenses.

Na década de 1990, as questões mais gerais de política de arquivos cederam lugar, na revista, para os textos de caráter técnico, em geral elaborados por funcionárias do Arquivo Público do Estado. ${ }^{23}$ Quando não estavam voltados para a discussão de um documento ou de uma série documental, os trabalhos de pesquisadores, na sua maioria historiadores, costumavam discutir, ao menos até 1995, aspectos da historiografia catarinense. Principalmente após 1995, entretanto, o diálogo entre profissionais de arquivo e pesquisadores (na sua maioria, na área de História), que tentara ser exercido tendo os documentos e os arquivos como eixo comum, parece ter se tornado mais difícil. Assim, se os profissionais de arquivo, de seu lado, mostram estar cada vez mais preocupados em divulgar instrumentos de pesquisa e manuais, os pesquisadores passam a utilizar a revista prioritariamente para divulgar suas pesquisas, sem demonstração de interesse em estabelecer maior proximidade com a questão dos arquivos, ou do próprio acervo do Arquivo Público do Estado. ${ }^{24}$ Concretamente, a revista, em meados da década de 1990, deixou de ser um espaço dedicado ao debate arquivístico mais amplo, sobretudo no que se refere aos arquivos catarinenses. $^{25}$

Essa mudança talvez possa ser explicada pela criação de uma outra publicação, também promovida pela Associação de Amigos do Arquivo Público do Estado, mas em conjunto com o Arquivo: o seu boletim informativo, publicado a partir de 1993. A criação do boletim coincide com um momento em que o Arquivo Público do Estado não conta nem com

\footnotetext{
${ }^{23}$ Como exemplos: o manual de conservação e restauração publicado no no ${ }^{\circ}$ 13, de julho de 1991; a relação de instrumentos de pesquisa publicada no $\mathrm{n}^{\circ}$. 14, de dezembro de 1991, além de texto sobre "o papel", do ponto de vista da conservação, no mesmo número; também o "manual de arquivo", publicado no n”. 17, de julho de 1993. Para informações sobre o conteúdo da revista Ágora, ver Apêndice II-9.

${ }^{24}$ Entre as exceções de praxe, Rosemari Conti Gonçalves (em 1999) e Walter Piazza (que não deixou de colaborar com a revista - 2002): ver Apêndice II-9. Na década de 1990, é perceptível a presença de vários artigos de alunos de graduação e pós-graduação, em especial da Universidade Federal de Santa Catarina, e não só da área de História.

${ }^{25}$ Acrescente-se que a revista Ágora com certa freqüência encontrou (e encontra) dificuldades para sua publicação.
} 
Iaponan Soares nem com Walter Piazza, de forma próxima, para divulgar seus objetivos, suas atividades, seus problemas. O boletim buscou, então, a divulgação que estava ao alcance do seu corpo de funcionários (que, como mencionado no capítulo anterior, preenchiam parte significativa dos cargos da Associação de Amigos). Trimestralmente, notícias acerca das atividades cotidianas da instituição passaram a ser disseminadas a todos os associados da Associação de Amigos, a instituições arquivísticas atuantes em Santa Catarina e em outros estados, a bibliotecas e instituições afins. Trazia, basicamente, informações sobre o acervo (doações, transferências, recolhimentos, organização de conjuntos documentais), seu público (atendimento, temas de pesquisa), visitas recebidas, demandas atendidas quanto a assessoria ou consultoria técnica, exposições realizadas, eventos dos quais o Arquivo participara por intermédio de funcionários. Concomitantemente, informações de interesse geral para os profissionais da área de arquivos, relativas ao Brasil e a outros países (normas, leis, cursos, encontros). Até 2003, o boletim conseguiu dar visibilidade ao Arquivo Público do Estado e aos arquivos de Santa Catarina, sendo um canal importante de comunicação e interação entre profissionais e instituições. ${ }^{26}$

O Arquivo Público editou ainda, nos anos 1980, alguns livros e opúsculos (estes últimos, divulgando documentos na íntegra). ${ }^{27}$ Entre os livros, três tematizando a história política catarinense, dois deles frutos de dissertações havia pouco tempo defendidas no Programa de Pós-Graduação em História da Universidade Federal de Santa Catarina, focados no tema do coronelismo (ver Apêndice II-10). O terceiro, edição fac-similar de trabalho de Henrique Boiteux (historiador que era, aliás, tio de Walter Piazza), foi publicado tendo em vista os 150 anos do movimento farroupilha e da proclamação, em Santa Catarina, da “República de Piratini”. Ainda nos anos 1980 - mais precisamente, em 1985 -, o Arquivo Público, em conjunto com a UFSC, publicou livro sobre a Secretaria da Justiça (à qual o Arquivo já estivera vinculado).

Nos anos 1990, as poucas publicações não-periódicas do Arquivo Público do Estado voltaram-se para a própria instituição (seus 30 anos) e para os arquivos municipais

\footnotetext{
${ }^{26} \mathrm{O}$ boletim, até o número 43 (jan.-jul. 2003), circulou, em geral, com 12 páginas (em formato A4). A partir do número 44, passou a circular como folder, o que reduziu substancialmente o seu teor informativo (os dados sobre o atendimento ao público e sobre os temas de pesquisa dos usuários foram excluídos, embora estes últimos tenham sido incorporados à revista Ágora).

${ }^{27}$ Em 1984, Sesmarias concedidas por Manoel Escudeiro Ferreira de Souza - 1753; em 1985, Relatório e fala no governo de Santa Catarina, 1833-1835 (ambos compondo a coleção José Arthur Boiteux).
} 
(um guia das instituições em Santa Catarina). ${ }^{28}$ Do lado da Associação, assinalaram-se obras ligadas à história de dois municípios catarinenses (Biguaçu e Laguna), dois opúsculos literários (compreensíveis em função dos interesses literários do então diretor do Arquivo) e um "inventário da produção intelectual do Arquivo", este último com nítidos sinais de publicação de final de governo, no estilo de propaganda das "realizações", pois cobria justamente o período 1983-1986 (ver Apêndice II-10).

A preocupação com a história política, ou político-administrativa, mais nítida na década de 1980, guarda relação com o perfil da instituição (que é, afinal, custodiadora de documentos do governo de Santa Catarina, quando capitania, província e estado). Mas é provavelmente mais compreensível a partir da relação do Arquivo Público do Estado com o Programa de Pós-Graduação em História da UFSC, que tinha uma de suas linhas de pesquisa voltadas para a questão. ${ }^{29}$ Entre as duas instituições, Walter Piazza era o principal elo (ver Parte I, Capítulo 3). Por outro lado, a divulgação de aspectos da história dos municípios estava relacionada não só à importância que, neste sentido, era atribuída ao acervo do Arquivo Público do Estado, como à perspectiva de uma necessária ação para preservação dos acervos governamentais municipais. A respeito, assim se posicionou o diretor do Arquivo, em 1985:

A história dos municípios catarinenses só é possível de ser escrita com critério científico a partir do conhecimento das fontes existentes no acervo do Arquivo Público, uma vez que a maioria desses municípios já não dispõe de documentação original. Nesse particular o Arquivo é rico em informações envolvendo o século XIX e início deste, período em que as câmaras municipais mantinham estreita ligação com a chefia do Poder Executivo Provincial ou Estadual..$^{30}$

Um ano depois, insistiu, em reportagem no Diário Catarinense, na tese da documentação perdida para a história, na maior parte dos municípios catarinenses: "Se não

\footnotetext{
${ }^{28}$ Houve ainda a publicação, pelo Senado Federal, de instrumento de pesquisa elaborado na instituição, por uma de suas funcionárias, relativo a fundo privado integrante de seu acervo: GHANEM, Valéria Gouvêa (org.). Inventário analítico do fundo privado do ex-governador Jorge Lacerda. Brasília: Ed. do Senado Federal, 1993.

${ }^{29}$ Histórico do Programa [de Pós-Graduação em História - UFSC]. In: UNIVERSIDADE FEDERAL DE SANTA CATARINA. Centro de Filosofia e Ciências Humanas. Departamento de História. Programa de PósGraduação em História. Catálogo de dissertações. Florianópolis: 1998. p.21-23.

${ }^{30}$ SOARES, Iaponan. O Arquivo Público do Estado. op.cit.
} 
fosse o acervo do Arquivo Público, estes municípios já não teriam como contar sua história." 31

A presença, no acervo, de documentação relativa aos municípios, tornava mais consistente a idéia de que a documentação do Arquivo Público do Estado remetia à "Memória Catarinense" (como afirmava-se na apresentação do número 1 da revista Ágora, em junho de 1985) ou que a entidade fosse identificada como "o Arquivo dos Catarinenses", em boletim informativo de $1998 .^{32}$

A forma como o potencial do acervo para a pesquisa histórica foi percebido pela instituição nos últimos vinte anos fica mais clara quando são examinados os temas das exposições promovidas (ver Apêndice II-11). Novamente, diferenças significativas são observáveis entre as décadas de 1980 e 1990: variando de seis a dez exposições anuais, entre 1985 e 1990, elas tornam-se mais raras a partir de 1991. Na segunda metade da década de 1980, prevalece, na abordagem do acervo e da história, a lógica da efeméride, muito própria do Instituto Histórico e Geográfico de Santa Catarina (ver Parte I, Capítulo 2): são aniversários de criação de freguesias e de órgãos estaduais, de fundação de municípios, de instalação de câmaras municipais, de nascimento ou falecimento de ex-governantes catarinenses (com ênfase nos presidentes da província) e de "personalidades ilustres". Sem esquecer dos grandes acontecimentos, regionais ou nacionais - os 150 anos da "Revolução Farroupilha”, os 100 anos da “Abolição”, o centenário da proclamação da República.

Embora a lógica da efeméride não tenha se ausentado do temário das exposições, é visível, entre 1990 e 1992, a intenção regular de divulgar determinados conjuntos documentais do acervo (documentos governamentais relacionados à saúde, à educação, à

\footnotetext{
${ }^{31}$ Um arquivo com 10 milhões..., op.cit. Trata-se de citação de entrevista, no corpo da reportagem. Também na comunicação feita na Sociedade Brasileira de Pesquisa Histórica, em 1988, afirmou: "Hoje, como a grande maioria dos municípios catarinenses não estão preservando a sua documentação permanente, essa correspondência das Câmaras com a chefia do Poder Executivo é fonte importante [de] que o pesquisador ainda dispõe para reconstituir a história dessas comunas." SOARES, Iaponan. Arquivo Público do Estado de Santa Catarina (1983-1986): uma experiência de ação co-participativa. Anais da VII Reunião da Sociedade Brasileira de Pesquisa Histórica. São Paulo: 1988. p.40. Alguns anos mais tarde, elaborando trabalho sobre o bairro do Estreito, de Florianópolis, Iaponan Soares teria destacado que a história daquele município estava "restrita aos acontecimentos ocorridos no núcleo administrativo", faltando documentação relativa às outras áreas. Daí a opção por colher depoimentos de moradores - e provavelmente, a razão de o trabalho não ser considerado uma "história do Estreito", mas "vida e memória" do bairro (integrava, aliás, a coleção "Memória de Florianópolis"). Cf.: Uma memória para Florianópolis. op.cit.

${ }^{32} \mathrm{O}$ editorial informava que a gerente, Neusa Rosane Damiani Nunes, além de três servidores, haviam participado do XII Congresso Brasileiro de Arquivologia, em João Pessoa, "representando o Arquivo dos Catarinenses". Boletim informativo [Arquivo Público do Estado de Santa Catarina / Associação de Amigos do Arquivo Público do Estado de Santa Catarina], Florianópolis, n.23, abr.-jun.1998, p.1.
} 
imigração, às obras públicas e estradas, às eleições). Constante, o olhar para o Arquivo Público do Estado enquanto instituição, por ocasião de seus "aniversários" (exposições em 1985, 1990, 1995, 2005, sem esquecer do “aniversário" do setor responsável pela conservação e restauração de documentos, em 1993).

A ressaltar, também, as iniciativas de buscar maior aproximação com o público, em 1989 (exposição "A memória sendo preservada - o que fazer com os documentos antigos de sua família?”) e em 1996, 1997 e 1998 (a exposição “Alguém fotografou, agora precisamos identificar as imagens: venha nos ajudar", certamente reeditada com outros documentos).

$\mathrm{Na}$ segunda metade da década de 1990, dois aspectos chamam a atenção: promoção de exposições sem qualquer vínculo com o acervo e ênfase em dimensões étnicas da história catarinense. Quanto ao primeiro, abre-se espaço tanto para discussões referentes a outros campos disciplinares (a arqueologia, por exemplo, em 1998) como para a apresentação de trabalhos de artistas catarinenses (Janice Pavam, em 2000, Dircéa Binder, em 2001 e 2003). A própria valorização do trabalho de Dircéa Binder está, por sua vez, relacionada ao segundo aspecto aqui salientado, uma vez que põe em destaque "contribuições" e "heranças", principalmente no que se refere à herança portuguesa, ou, mais precisamente, "açoriana". A ênfase na açorianidade está assinalada pelas exposições "Herança cultural açoriana" (1996), "250 anos de cultura açoriana” (1999), "Cultura açoriana” (1999), "Colonização açoriana e alemã" (1999), "Olhares catarinenses em solo açoriano" (2002), além das exposições apresentadas nas edições da "Festa da Cultura Açoriana - AÇOR", desde 1999. ${ }^{33}$

A historiadora Maria Bernardete Ramos Flores, na década de 1990, entendeu que a "açorianidade" foi uma invenção forjada "num momento de luta pela hegemonia cultural em Santa Catarina". ${ }^{34}$ Esse momento, como já examinado anteriormente (Parte I, Capítulo 2), era o conturbado contexto da nacionalização varguista e da Segunda Guerra Mundial, e entre os

\footnotetext{
33 A exposição "Antologia de uma artista”, de Dircéa Binder, supostamente "alusiva às comemorações dos 275 anos de aniversário da Capital Catarinense", reuniu "fotos, documentos, livros, periódicos, trajes (capas cerimoniais), quadros, convites e instalações do Pão por Deus e do Divino Espírito Santo". Dircéa Binder é descrita como alguém que "se dedica, há muitos anos, a estudos e pesquisas sobre a cultura luso-açoriana, especialmente o Pão por Deus e a Festa do Divino." Boletim informativo [Arquivo Público do Estado de Santa Catarina / Associação de Amigos do Arquivo Público do Estado de Santa Catarina], Florianópolis, n.34, jan.-mar.2001, p.5.

${ }^{34}$ FLORES, Maria Bernardete Ramos. A farra do boi: palavras, sentidos, ficções. Florianópolis: Ed. da UFSC, 1997. p.133. O livro é resultado da tese de doutoramento Teatros da vida, cenários da história: a Farra do Boi e outras festas na Ilha de Santa Catarina - leitura e interpretação, defendida em 1991 no Programa de PósGraduação em História da PUC-SP.
} 
intelectuais decisivos, na empreitada, estavam membros do Instituto Histórico e Geográfico de Santa Catarina, como Oswaldo Rodrigues Cabral e Henrique Fontes. Embora a valorização da herança portuguesa, ou especificamente açoriana (ou, ainda, luso-açoriana), na história catarinense, marque a trajetória de parte significativa dos membros do IHGSC, a presença de membros do Instituto influenciou as diretrizes das atividades do Arquivo Público do Estado mais intensamente na década de 1980. Na década seguinte - que é justamente aquela em que se concentram as exposições relativas à "açorianidade" - a proximidade com o IHGSC procurou ser mantida através da Associação de Amigos do Arquivo Público do Estado, optando-se por manter na presidência uma pessoa ligada àquela entidade. ${ }^{35}$ Mas o dinamismo e engajamento de figuras como Iaponan Soares e Walter Piazza não foi renovado. Como compreender, neste quadro, a recorrência do tema açoriano?

Uma hipótese é a de que a difusão da "açorianidade", mais marcante no último decênio, está relacionada aos vínculos estabelecidos pelo Arquivo Público do Estado com instituições não-arquivísticas atuantes em Santa Catarina e, mais particularmente, na capital. Vínculos que podem ter sido buscados como forma de manter a visibilidade do Arquivo no "meio cultural".

A partir do boletim informativo do Arquivo Público do Estado, é possível mapear parte da sua rede de relações institucionais. Não foi efetuado, a este respeito, um levantamento sistemático das informações contidas em todos os períodos: apenas nos boletins de 1998 a 2005. Deve-se ainda considerar que o levantamento pertinente a 2003-2005, por força da mudança das dimensões e do perfil do boletim, não é tão substancial quanto em relação ao período 1998-2002. Apesar disso, ele permite constatar, no que tange à perspectiva “açoriana', aspectos de interesse, além das já mencionadas participações na AÇOR: a participação regular de funcionários em reuniões do Núcleo de Estudos Açorianos da UFSC, ou mesmo da "Casa dos Açores"; presença em lançamento de livro com essa temática, em 1998, bem como na entrega do "Troféu Açorianidade”, em 2000 e 2003; participação em dois cursos realizados nos Açores (em 2001 e 2002) e na composição da diretoria da Casa dos

\footnotetext{
${ }^{35}$ Depois de Walter Piazza, assumiram a presidência da Associação: Maria Regina Boppré (1989-1990), Edison d'Ávila (1991-1992), Norberto Ulysséa Ungaretti (1993-1995), Geraldo Gama Salles (1995-2005), Carlos Osvaldo de Farias (2005-2007). Com exceção do atual presidente (que dirigiu o Arquivo entre 2003 e 2005), todos os demais são membros do IHGSC (ver Apêndice II-8).
} 
Açores - Ilha de Santa Catarina (2002) (ver Apêndice II-12). ${ }^{36}$

Mesmo os vínculos com o Núcleo de Estudos Museológicos, também da UFSC (representantes do Arquivo participaram de encontros e reuniões por ele promovidos), guardam relação com a questão açoriana, uma vez que está sediado no Museu Universitário Oswaldo Rodrigues Cabral, dirigido por Gelci Coelho (que, por sua vez, valoriza a contribuição de Franklin Cascaes, estudioso das influências açorianas nas práticas da cultura popular da ilha de Santa Catarina). ${ }^{37}$

Esse olhar que, lançado sobre a história catarinense, põe em relevo motivos açorianos, pouco traduz do acervo do Arquivo Público do Estado, e é igualmente bastante parcial para as pretensões de alusão a uma "memória catarinense". Parece traduzir, mais propriamente, os caminhos algo tortuosos trilhados, pela instituição, por meio da atuação de algumas de suas funcionárias, para permanecer integrada, em alguma medida, à esfera das instituições "culturais". Além de ser, também, um meio de atingir um público de nãopesquisadores: as exposições têm servido como chamariz de turmas de estudantes de escolas e colégios da capital e municípios vizinhos (ver Apêndice II-13). ${ }^{38}$

\section{Arquivo Público do Estado: para quem?}

Boa parte das atividades do Arquivo refere-se à organização do acervo, de modo a disponibilizá-lo para consulta. O boletim informativo do Arquivo oferece pistas acerca dos pesquisadores: dados estatísticos sobre o atendimento (seção "Atendimento ao público" e,

\footnotetext{
${ }^{36}$ As funcionárias mais presentes nesses eventos foram, em geral, Cleuza Regina Costa Martins e Neusa Rosane Damiani Nunes. Similarmente à forma como a preservação dos arquivos aparece nos discursos dos participantes dos encontros de arquivos catarinenses, o estudo e difusão da cultura açoriana também aparece como missão: a reunião do Núcleo de Estudos Açorianos - NEA, realizada em dezembro de 1998, teria sido encerrada com confraternização "que integrou todos os que se dedicam à causa da cultura açoriana em Santa Catarina." Boletim informativo [Arquivo Público do Estado de Santa Catarina / Associação de Amigos do Arquivo Público do Estado de Santa Catarina], Florianópolis, n.25, out.-dez. 1998, p.2.

${ }^{37}$ Lembro que Gelci Coelho, conforme apontado no capítulo anterior, proferiu conferências nos encontros catarinenses de arquivos de 2002 e 2004, sobre o folclore da ilha de Santa Catarina. Uma nota pessoal: tendo participado do encontro catarinense de 2002 como ministrante de oficina, a convite dos organizadores, recebi, ao término do evento (como os demais convidados), um presente: uma pequena "Bernúncia", em cerâmica. A "Bernúncia" (ou "Bernunça") é um dos personagens do "Boi-de-mamão", dança dramática apontada como de origem açoriana.

38 As visitas de turmas de estudantes de cursos universitários (das áreas de História, Biblioteconomia, Arquitetura, Letras e até mesmo Secretariado Executivo, conforme o Apêndice II-13) estão provavelmente mais ligadas à intenção de conhecimento do acervo e das atividades realizadas para sua organização.
} 
posteriormente, "Arquivo Público - estatística") e listagens de pesquisadores, com seus respectivos temas (“Quem está pesquisando o quê”). As listagens de pesquisadores não permitem, porém, detectar as razões da pesquisa nem o perfil do usuário (graduando, mestrando, doutorando, pesquisador diletante? Historiador, antropólogo, pedagogo, arquiteto, jornalista?). Os dados estatísticos, por seu turno, são genéricos demais na identificação do material (ver Apêndice II-14), impossibilitando conhecer os conjuntos documentais arquivísticos mais consultados (provavelmente englobados, de forma mais recorrente, na categoria "manuscritos/datilografados"). Mas hipóteses quanto às demandas de pesquisa podem ser levantadas a partir do exame dos instrumentos de pesquisa disponibilizados.

O índice topográfico, segundo informações fornecidas pela instituição, é o instrumento de pesquisa disponibilizado há mais tempo para os pesquisadores: desde 1981 (ver Apêndice II-15). Misto de obra de referência para o usuário e mecanismo de controle para os funcionários, o índice topográfico, por identificar a localização de toda a documentação do Arquivo nas estantes do depósito, tem funcionado como um grande guia de fundos. Por seu caráter geral, contudo, não permite detectar os conjuntos priorizados para a descrição, o que pode ser feito pelo exame dos demais instrumentos de pesquisa.

Elaborado o índice topográfico, as prioridades de descrição dos anos 1980 foram: processos cíveis e processos-crime; registros "de vigários" (ou seja, registros de terras gerados, no país, a partir de lei de 1850); processos e títulos definitivos de terras; correspondências das Câmaras Municipais; documentos da Coordenação de Defesa Civil; o fundo privado do general José Vieira da Rosa; documentos fotográficos. Embora não haja a data de elaboração ou disponibilização dos índices referentes aos requerimentos de terras, aos documentos do Departamento Estadual de Estatística, à correspondência entre o governo e juízes de paz (bem como Câmara Municipal, Superintendência e Intendência) e aos processos de ex-combatentes, é bem provável que todos esses instrumentos de pesquisa também tenham sido elaborados na década de 1980. Integraram-se, alguns, à preocupação de logo tornar acessíveis documentos de grande valor probatório, em termos jurídicos; outros confirmaram a visão do então diretor do Arquivo, quanto à importância dos documentos do Arquivo Público para informar sobre vários municípios. ${ }^{39}$ Se não eram demandas concretas de pesquisa,

\footnotetext{
${ }^{39} \mathrm{O}$ fundo privado de Vieira da Rosa é composto por apenas 39 documentos (daí, talvez, ter sido contemplado com sua rápida descrição). Um "índice onomástico dos memoriais de lotes e títulos definitivos e provisórios de terras" foi elaborado mais recentemente (a partir de 1997).
} 
colocavam-se (ao menos os documentos de valor jurídico-legal) como bastante prováveis. Cabe ainda lembrar que, na década de 1980, o Programa de Pós-Graduação em História da UFSC tinha linha de pesquisa voltada para a História Econômica. ${ }^{40}$

Um dado importante: no final da década de 1980, em paralelo às atividades internas do Arquivo, a Coordenação de Documentação e Publicações desenvolvia projeto de levantamento da história administrativa do governo estadual, a partir da legislação. Projetos similares vinham sendo desenvolvidos, aliás, em outras instituições arquivísticas do país. Segundo Cláudia Grillo, com base nesse levantamento seria organizado "o acervo documental do Arquivo Público do Estado, já que essa documentação provém, na sua maioria, dos organismos oficiais da administração pública."41 Não foi possível detectar, entretanto, em que medida os resultados desse projeto influenciaram uma política de descrição no Arquivo Público do Estado e, por conseqüência, seus instrumentos de pesquisa.

Nos anos 1990, muitos instrumentos de pesquisa estiveram voltados para a indexação sistemática de correspondências e relatórios oficiais, além da legislação, regimentos e regulamentos dispondo sobre o funcionamento de órgãos e repartições públicas. Destacam-se, também, os instrumentos de pesquisa de alguma forma relacionados ao tema imigração - o que pode estar tanto associado ao atendimento de pesquisas acadêmicouniversitárias (dado que o tema "imigração" é clássico na historiografia brasileira, bem como na catarinense) quanto a pesquisas pontuais, de caráter genealógico, muitas vezes objetivando requerer dupla cidadania. ${ }^{42}$ A reforçar a segunda opção, a profusão de índices onomásticos.

Surpreende o número de instrumentos que contemplam a transcrição de documentos, e não a sua descrição sintética. Na sua maioria, foram elaborados por iniciativa do Núcleo de Estudos Portugueses da UFSC, priorizando a documentação manuscrita do século XVIII e inícios do XIX. A lógica da efeméride também comparece aqui, os

\footnotetext{
${ }^{40}$ Histórico do Programa [de Pós-Graduação em História da UFSC]. op.cit., p.21-23.

${ }^{41}$ GRILLO, Cláudia de Araújo. Nota preliminar sobre o projeto "Evolução administrativa do Estado". Ágora, Florianópolis, n.9, jun.1989. p.24. Parte dos dados levantados e sistematizados foi apresentada no número seguinte da revista: FERLIN, Romualdo B. O Serviço Público visto de frente e de perfil. Ágora, Florianópolis, n.10, dez. 1989. p.29-34. Na segunda metade da década de 1980, o Arquivo do Estado de São Paulo desenvolveu o projeto "A Província de São Paulo: organização administrativa e produção documental (1822 a 1889)" (ver: Arquivo: boletim histórico e informativo, São Paulo, v.8, n.1-2, jan.-dez. 1987, p.39). O Arquivo Nacional também realizou projeto de pesquisa sobre a organização administrativa brasileira, sendo os resultados relativos ao período colonial publicados em: SALGADO, Graça (coord.). Fiscais e meirinhos: a administração no Brasil Colonial. Rio de Janeiro: Nova Fronteira, Brasília, INL, 1985.

${ }^{42}$ Tais pesquisas estão bastante presentes na seção "Quem está pesquisando o que", do boletim informativo do Arquivo Público do Estado.
} 
instrumentos de pesquisa provavelmente sendo fruto de exposições anteriormente organizadas; assim talvez possam ser compreendidos os catálogos seletivos da Revolução Farroupilha, da escravidão e do centenário da República, disponibilizados em 1993. Quer atendendo a solicitações de pesquisadores, quer sugerindo pesquisas sobre os temas, cabe destacar, quanto aos municípios, o catálogo seletivo referente à colônia/ao município de Brusque e o repertório referente a Tubarão e Laguna (1997); quanto a determinados sujeitos históricos, o "repertório sobre os índios" (1996) e o sobre "imigrantes" (1992-1997). Mais recentemente, documentos referentes a Grupos Escolares (2003).

Em 1985, o usuário em potencial visado pelos instrumentos de pesquisa do Arquivo Público do Estado poderia realizar suas consultas na parte da manhã e à tarde: a instituição mantinha oito horas de atendimento ao público, entre 8 e 18 horas, cerrando as portas apenas por duas horas, em torno do meio do dia. ${ }^{43}$ Em 2000 e 2001, o horário de atendimento ainda era extenso, embora reduzido em uma hora: das $8 \mathrm{~h} 30$ às $17 \mathrm{~h} 30 .{ }^{44}$ Mais recentemente, porém, o usuário passou a ter apenas quatro horas do período da tarde à sua disposição. É a redução do horário de atendimento, provavelmente, o principal fator para a sensível queda do número de pesquisas in loco, a partir de 2001 (ver Apêndice II-14).

Mesmo cobrindo um período bastante pequeno (1998-2003), a sistematização de dados sobre o atendimento ao público, no Apêndice II-14, oferece elementos de interesse para a análise: indica, justamente em um período de redução do horário de atendimento, a intensificação da consulta aos documentos: em apenas metade do ano de 2003 foram consultados mais documentos manuscritos e/ou datilografados do que em todo o ano de 1998 ou o de 1999. Simultaneamente, o cadastramento de novos pesquisadores, em 2002, esteve muito próximo do índice de 1998. Ou seja, a queda na quantidade de pesquisas não parece estar relacionada à diminuição do interesse dos pesquisadores pelo acervo, e sim aos horários mais restritos de pesquisa. Interesse que foi recentemente frustrado quando, em maio de 2006, a Secretaria de Estado da Administração decidiu transferir a instituição do prédio alugado que ocupava, desde 1992, para um prédio público, localizado fora da área central, compartilhando espaço com outros órgãos da mesma Secretaria. Com isso, no mesmo mês de maio, duas

\footnotetext{
${ }^{43}$ SOARES, Iaponan. Arquivo Público do Estado. op.cit.

${ }^{44}$ GOVERNO DO ESTADO DE SANTA CATARINA. Secretaria de Estado da Administração. Diretoria de Administração Patrimonial e Documentação. Gerência do Arquivo Público do Estado. Regulamento de Consulta - Setor de Pesquisa e Consulta. Florianópolis: 2000. Folder. Arquivo Público guarda três séculos de história de SC. Gestão em foco, Florianópolis, n.2, ago.2001, p.7.
} 
semanas após a decisão, o atendimento foi suspenso, com previsão de ser retomado, talvez, apenas em agosto do mesmo ano.

Com a decisão, o Arquivo Público do Estado volta a ocupar, como na década de 1970, um espaço antes utilizado pela Imprensa Oficial do Estado, no bairro Saco dos Limões. A transferência dos anos 1970, de uma "sala central" no térreo do Palácio do Governo para "duas salas pequenas cedidas provisoriamente pela Imprensa Oficial", foi feita, segundo o então diretor, Santos Verani, "atabalhoadamente". Em relação à mudança de 2006, sabe-se que, não tendo o prédio destinado ao Arquivo sido concebido para abrigar uma instituição arquivística, e havendo pressa na desocupação do prédio alugado, as adaptações necessárias tiveram que ser feitas sob o signo da velocidade. As autoridades ligadas à Secretaria de Estado da Administração provavelmente orientaram-se pela otimização de gastos e racionalização de espaços físicos - mas, teriam levado em conta que o Arquivo Público do Estado, sendo uma de suas unidades administrativas, não existe apenas para atender aos interesses da Secretaria?

\section{Papéis do governo}

Muito antes que o Arquivo Público do Estado estivesse subordinado a uma Secretaria de Estado da Administração (bem antes inclusive de existir, por lei, enquanto instituição), os conjuntos documentais que hoje compõem a maior parte de seu acervo foram produzidos. Por consequiência, mobilizavam funcionários no seu registro e arquivamento. As atividades que diziam respeito a seu gerenciamento também já existiam, em grande medida.

Tudo indica que o Arquivo Público criado em 1960 herdou fundamentalmente os conjuntos documentais que, no período imperial, foram acumulados pela Secretaria da Presidência da Província. ${ }^{45}$ Falas, discursos e relatórios dos presidentes da província de Santa

\footnotetext{
${ }^{45}$ No Paraná, um "arquivo público" foi criado em 1855, mas sintomaticamente anexo à Secretaria do Governo (funcionando, inclusive, em uma de suas salas). Cf. Lei [provincial] n ${ }^{\circ} .33$ de 7 de abril de 1855. Boletim da Associação dos Amigos do Arquivo Público [do Paraná]. Curitiba, n.6, 2001. p.1; Regulamento do Archivo Publico [11 de julho de 1855]. Boletim do Arquivo do Paraná. Curitiba, Ano 2, n.1, 1977. p.17.
} 
Catarina, nomeados ou interinos, aludem ao andamento das atividades da Secretaria da Presidência, que o presidente Teodoreto Souto considerou, em 1883, o "centro do maquinismo administrativo". 46 Embora a análise minuciosa de tais materiais não seja aqui nosso objetivo, vale pontuar alguns de seus aspectos, pois auxiliam na compreensão da formação do conjunto documental hoje abrigado no Arquivo Público do Estado.

Os pronunciamentos dos presidentes acerca dos negócios da província foram realizados basicamente em duas circunstâncias: na abertura das reuniões da Assembléia Provincial e na passagem do cargo aos sucessores. No primeiro caso, um elemento importante condiciona o discurso: a necessidade de negociação com a Assembléia, que votaria o orçamento. Em tais ocasiões, os presidentes, ao apresentarem um quadro geral do governo da província, destacavam, de seu ponto de vista, problemas que com frequiência demandavam aumento de despesas a serem aprovadas pelos deputados. Como que obedecendo a um mesmo padrão discursivo, a maioria dos presidentes, ao apontar dificuldades administrativas, tentava demonstrar que elas estavam, em geral, sob controle (sua solução dependendo, contudo, do apoio da Assembléia, quanto à destinação de verbas - despesas deveriam ser remanejadas ou tributos elevados).

Assim, a Secretaria da Presidência é de forma regular caracterizada pelas péssimas instalações e pouco mobiliário, além do pequeno número de funcionários, sobrecarregados e mal remunerados, não raro doentes e em licença; apesar disso, o pessoal da Secretaria aparece em geral descrito como dedicado e morigerado, esforçando-se por manter em dia um serviço cujo volume crescia dia-a-dia. Essa estratégia retórica é, aliás, mais

\footnotetext{
${ }^{46}$ Relatório com que o Exm. Snr. Doutor Theodoreto Carlos de Faria Souto abriu a sessão da vigessima quarta legislatura da Assembléa Provincial de Santa Catharina em 25 de março de 1883. Cidade do Desterro: Typographia do Caixeiro, 1883. p.74. Em 1889, Joaquim E. de Medeiros lembrou que a Secretaria era "a única Repartição Provincial" que trabalhava "com todos os Ministérios", sendo aquela sobre a qual pesava, igualmente, "maior soma de responsabilidade". Relatório com que o Exm. Sr. Cônego Joaquim Eloy de Medeiros, $2^{\circ}$. Vice-presidente passou a administração da província ao Exm. Sr. Dr. Abdon Baptista, $1^{\circ}$. Vice-presidente, em 26 de junho de 1889. Desterro: Typographia da Republica, 1890. p. 34. Cabe esclarecer que nem todas as falas, discursos e relatórios de presidentes da província contêm referências à Secretaria da Presidência.
} 
presente a partir da década de $1840 .{ }^{47}$

As referências dos vários presidentes ao arquivo da Secretaria são esparsas, mas significativas para compreender a construção histórica das mazelas que costumam, no Brasil, envolver documentos de caráter público. Prendem-se, sobretudo, às condições de conservação dos documentos e à sua organização.

Contundente, Francisco José de Souza Soares d'Andrea, em 1840, indicava que, numa Secretaria sem casa e com mobiliário deficiente, o arquivo achava-se "a monte em vão de escada." Alojada no Palácio da Presidência, ou do Governo, a Secretaria como um todo continuaria a exigir, em 1842, segundo Antero J. F. de Brito, "um local mais apropriado, espaçoso e decente"; a organização do arquivo, entretanto, não tardaria: achavam-se em andamento os trabalhos de "inventário e classificação do arquivo". O trabalho de inventário prosseguiria ao menos pelos dois anos seguintes, quando ainda à frente da presidência o mesmo Antero de Brito, que governou a província por oito anos (1849-1848). João José Coutinho, outro presidente a ocupar o cargo por longo tempo (1850-1859), salientou estarem a conservação e a organização dos documentos prejudicadas por uma legislação que tornara dúbia a responsabilidade pelo arquivo: no seu entender, o arquivo não podia "sem inconvenientes prescindir de um empregado hábil, e privativo do arranjo e conservação dos livros e papéis", que ao mesmo tempo fosse empregado "em renovar, copiando, aqueles que

\footnotetext{
47 Antes de 1842, algumas notas dissonantes são assinaláveis, ficando patente a impossibilidade de combinar poucos funcionários, baixas remunerações, trabalho volumoso e serviço em dia. Em 1836, José Mariano de Albuquerque Cavalcanti destacava: "o número de Oficiais de pena desta [Secretaria da Presidência] é insuficiente, e por isso a miúdo acontece que ficam em atraso os seus trabalhos." João Carlos Pardal, em 1839, declarava estarem os trabalhos da Secretaria "em grande atraso". Em 1840, igualmente, estavam "muitos trabalhos atrasados" - atraso que ainda tentava ser eliminado em 1841. A respeito, ver: Relatório do presidente da província de Santa Catharina, José Mariano de Alburquerque, na abertura da 1a. Legislatura Provincial em 5 de abril de 1836. S.L.p., s.c.p., s.d.. p.1-2; Discurso pronunciado na abertura da Assemblea Legislativa da Província de Santa Catharina na segunda sessão ordinária da Segunda Legislatura Provincial, em 1839, pelo respectivo presidente, o brigadeiro João Carlos Pardal. Cidade do Desterro: Typ. Provincial, 1839. p.1; Discurso pronunciado pelo presidente da província de Santa Catharina, o marechal de campo Francisco Jozé de Souza Soares d'Andrea, na sessão ordinária do anno de 1840 aberta no primeiro dia do mez de março. Cidade do Desterro: Typ. Provincial, 1840. p.6; Falla que o presidente da Província de Santa Catharina, o brigadeiro Antero Jozé Ferreira de Brito dirigio á Assembléa legislativa da mesma província na abertura da sua sessão ordinária em o $\mathbf{1}^{\circ}$. de março de 1841 . Cidade do Desterro: Typographia Provincial, 1841. p.2.
} 
pelo tempo se vão deteriorando." 48

A fala de Coutinho visibiliza uma faceta do trabalho dos funcionários da Secretaria que, hoje, imersos em registros duplicados por uma infinidade de mecanismos tecnológicos, talvez tendamos a esquecer: a de produção e reprodução intensa dos documentos, manualmente. Os funcionários elaboravam os documentos a serem enviados pelo presidente da província (o "expediente"), registravam o material enviado, de forma integral, em livros copiadores ou em papéis avulsos posteriormente encadernados, e produziam novas cópias daquilo que não se encontrava em bom estado de conservação. Ocupados intensamente com essa produção, tinham, entre eles, até a década de 1860, apenas o porteiro-arquivista designado para as tarefas de arquivo. Daí que, em 1860, Francisco Carlos de Araújo Brusque entendesse ser "urgente a existência de um oficial arquivista", que ficaria incumbido do "importante trabalho de coordenar toda a correspondência, livros e papéis concernentes à administração."

A existência do "oficial arquivista" não impediu, contudo, que os presidentes continuassem a assinalar dificuldades na organização do arquivo da Secretaria: em 1864, Francisco José de Oliveira informava que "o trabalho de classificação e arranjo metódico do arquivo" seguia lentamente, em função de o oficial arquivista não ter substituto "nos seus impedimentos de moléstias, júri e outros.” No mesmo relatório, declarava faltarem

mesas, escrivaninhas e outros objetos de escrituração e arquivo, bem como encadernação da correspondência, mormente dos Avisos do Governo, e

\footnotetext{
${ }^{48}$ Quanto aos pronunciamentos dos presidentes, ver: Discurso pronunciado pelo presidente da província de Santa Catharina, o marechal de campo Francisco Jozé de Souza Soares d'Andrea..., op.cit, p.5; Falla que o presidente da provincia de Santa Catharina, o marechal de campo graduado Antero Jozé Ferreira de Brito, dirigio á Assemblea Legislativa da mesma provincia na abertura da sua sessão ordinaria em o 1.o de março de 1842. Cidade de Desterro, Typ. Provincial, 1842. p.4; Falla que o presidente da provincia de Santa Catharina, o marechal de campo Antero Jozé Ferreira de Brito, dirigio á Assemblea Legislativa da mesma provincia na abertura da sua sessão ordinaria, em o 1.o de março de 1843. Cidade do Desterro, Typ. Provincial, 1843. p.2; Falla que o presidente da provincia de Santa Catharina, o marechal de campo Antero Jozé Ferreira de Brito, dirigio á Assemblea Legislativa da mesma provincia na abertura da sua sessão ordinaria, em o $\mathbf{1}^{\mathbf{o}}$. de março de 1844. Cidade do Desterro, Typ. Provincial, 1844. p.3; Falla que o presidente da província de Santa Catharina, dr. João José Coutinho, dirigio á Assemblea Legislativa Provincial no acto da abertura de sua sessão ordinária em o $1^{\mathbf{0}}$. de março de 1857. Rio de Janeiro: Typ. Imp. e Const. de J. Villeneuve e C., 1857. p.6. Quanto aos períodos de governo: CABRAL, Oswaldo R. História de Santa Catarina. 4 ed. Apêndice de Celestino Sachet. Florianópolis: Lunardelli, 1994. p.383-385.

49 Relatório do presidente da província de Santa Catharina Francisco Carlos de Araújo Brusque, apresentado á Assemblea Legislativa Provincial na 1ª sessão da 10 ${ }^{\mathbf{a}}$. Legislatura. Rio de Janeiro: Typographia do Correio Mercantil, 1860. p.40. A figura do oficial arquivista apareceria efetivamente a partir de 1861.
} 
ofícios das principais Repartições da Província, não só para sua melhor conservação e bom arranjo, como para evitar o extravio de algum documento. $^{50}$

A falta de materiais próprios à escrituração e as condições inadequadas do prédio ocupado pela Secretaria são reafirmadas no ano seguinte, por Alexandre Rodrigues da Silva Chaves. Esse mesmo presidente também considerou que "os trabalhos do arranjo e escrituração do Arquivo da Secretaria" estavam, em 1865, "muito longe" de "chegar ao grau que se deseja". ${ }^{51}$ Uma idéia dessa distância é dada em relatório de janeiro de 1872, que marcou a transmissão do cargo de Joaquim Bandeira de Gouvêa para Guilherme Cordeiro Coelho Cintra: quando assumiu, havia "minutas para registro com mais de seis anos de atraso"; no momento do relatório, estava ainda atrasado o registro referente à Guarda Nacional, "em razão da moléstia do empregado que o tinha a seu cargo". Talvez por não estar apresentando o relatório aos deputados provinciais, mas a alguém que o substituiria, Bandeira de Gouvêa fez um dos poucos comentários a ferir a imagem de zelo, dedicação e laboriosidade conferida aos funcionários da Secretaria: a "saída mui freqüente de alguns empregados a tratar de interesses próprios, quando não alheios", teria sido uma das razões para deslocar a Secretaria "do pavimento térreo do Palácio da Presidência" para "o pavimento superior e contíguo ao Gabinete dos trabalhos do Presidente."

Dentre as várias tentativas de reorganizar a Secretaria, de modo a atender ao volume de trabalho e às diversas demandas administrativas, algumas delas, mencionadas em 1876 pelo presidente João Capistrano Bandeira de Mello Filho, envolviam procedimentos ligados à produção documental: desde agosto de 1875, teria cessado "o registro da correspondência oficial, exceto o da reservada"; "as ordens para pagamentos e fornecimentos" passaram a ser expedidas por despachos da Presidência "em vez de ofícios" e, "exceto em casos especiais ou de exigência legal", os atos administrativos deixaram de ser informados

\footnotetext{
50 Relatório do Vice-Presidente da Província de Santa Catharina, o commendador Francisco José d'Oliveira, apresentado á Assembléa Legislativa Provincial na $1^{a}$. Sessão da 12 ${ }^{\mathrm{a}}$. Legislatura. Santa Catharina: Typ. Catharinense de F.V.Avila \& C . $^{\text {. 1864. p.5. }}$

${ }^{51}$ Relatório do Presidente da Província de Santa Catharina o doutor Alexandre Rodrigues da Silva Chaves apresentado á Assemblea Legislativa Provincial na $2^{\mathrm{a}}$. sessão da $12^{\mathrm{a}}$. Legislatura em o $1^{\circ}$. de março de 1865. Santa Catharina: Typ. Catharinense de Ávila \& Rodrigues, 1865. p.43, 45.

${ }^{52}$ Relatório com que o Exm. Sr. Dr. Joaquim Bandeira de Gouvêa passou a administração da província de Santa Catharina ao Exm. Sr. Dr. Guilherme Cordeiro Coelho Cintra, $1^{\circ}$. Vice-presidente da mesma, em 7 de janeiro de 1872. Cidade do Desterro: Typ. De J. J. Lopes, 1872. p.14-15.
} 
por meio de comunicações (entendendo-se que seriam necessariamente conhecidos por outros meios, inclusive a necessária publicação impressa); além disso, as informações solicitadas às repartições deveriam passar a ser "escritas à margem dos requerimentos ou ofícios" despachados pela Presidência. ${ }^{53}$ As medidas, que buscaram reduzir a massa documental produzida e, conseqüentemente, o tempo despendido pelos empregados da Secretaria nessa produção, não parecem ter sido suficientes para garantir melhores condições para a organização da documentação. Indica isso a fala de João Rodrigues Chaves, em 1881: segundo ele, fazia-se necessária a "reorganização do arquivo da Repartição", uma vez que era então "difícil procurar-se qualquer documento"; sugeria ainda que "os papéis de uma Repartição de tanta importância" deveriam estar "cronologicamente arrumados." ${ }^{, 54}$ Em fins de 1887, o presidente Francisco José da Rocha informava à Assembléia o quadro desolador em que encontrara o arquivo da Secretaria:

O Arquivo estava em completa desordem e sem os necessários utensílios para a conservação e coordenação dos documentos. Por proposta do Dr. Secretário, mandei fazer quanto era preciso, e passar temporariamente para a Secretaria o Arquivista adido ao Tesouro a fim de auxiliar na sistematização do trabalho.

À Secretaria mandei também fornecer alguns móveis indispensáveis para os livros e papéis, e outros reparos foram feitos com o fim de a tornar mais higiênica. Os cômodos são acanhados e os empregados não têm ali o desejável conforto. ${ }^{55}$

Bem abrigar a Secretaria e encontrar meios para dar conta de um volumoso expediente parecem ter sido desafios permanentes dos presidentes da província de Santa Catarina. Quadros anexados a alguns relatórios das década de 1860 e 1870 permitem

\footnotetext{
${ }^{53}$ Falla com que o Exm. Sr. Dr. João Capistrano Bandeira de Mello Filho abrio a $1^{\text {a }}$. sessão da $21^{\mathrm{a}}$. Legislatura da Assembléa Legislativa da Província de Santa Catharina em $\mathbf{1}^{\circ}$. de março de 1876. Cidade do Desterro: Typ. de J.J. Lopes, 1876. p.121-122.

${ }^{54}$ Falla com que o Exmo. Snr. Doutor João Rodrigues Chaves abriu a segunda sessão da vigesima segunda Legislatura da Assembléa Provincial de Santa Catharina, em 2 de fevereiro de 1881. Cidade do Desterro: Typ. E Lith de Alex Margarida, 1881. p.43-44.

${ }^{55}$ Relatório apresentado á Assembléa Legislativa Provincial de Santa Catharina na 2a . sessão de sua 26a . legislatura pelo presidente Francisco José da Rocha, em 11 de outubro de 1887. Rio de Janeiro: Typ. da União de A.M. Coelho da Rocha \& C., 1888. p.406.
} 
vislumbrar, além do volume, os tipos documentais produzidos e acumulados pela Secretaria, que recobriam as várias áreas de atuação governamental (ver Apêndice II-16).

Não somente a Secretaria da Presidência, contudo, possuía arquivo. Documento anexado à fala de João Rodrigues Chaves na abertura da Assembléia Provincial, em 1881, informa sobre a documentação gerada pela Secretaria de Polícia da província, no ano anterior: ofícios, telegramas, portarias, passaportes (com exceção desses últimos, todos também possuindo as correspondentes minutas e registros). ${ }^{56}$ Tendo âmbito de atuação compreensivelmente mais restrito do que o da Secretaria da Presidência, a Secretaria de Polícia produziu, em 1880, volume documental bem menor do que aquela nos anos 1860 e $1870 .{ }^{57}$

A própria Assembléia Provincial tinha seu arquivo e suas peculiaridades: funcionando a Assembléia durante um curto período do ano, seus funcionários eram, nos meses seguintes, deslocados para outras funções (inclusive, para trabalhos na Secretaria da Presidência). A legislação pouco clara, na década de 1850, acerca das responsabilidades quanto ao arquivo, acarretaria, segundo o presidente João José Coutinho, problemas quanto à sua integridade. Na fala de 1857, Coutinho frisava a necessidade de "esclarecer esse negócio de maneira que se saiba quem é o responsável pelo arquivo, para que se não extraviem documentos importantes e que têm de servir para a história da Assembléia e da Província." E acrescentava, a respeito da situação gerada pelo término da reunião da Assembléia, quando de imediato os funcionários dirigiam-se a outras repartições:

Deixando imediatamente os empregados a secretaria, ficando, como é natural, confusos, fora dos respectivos maços, e talvez mesmo da casa, alguns documentos e papéis, não pode o arranjo e guarda do arquivo deixar de ressentir-se dessa precipitação. ${ }^{58}$

\footnotetext{
${ }^{56}$ Falla com que o exm. sñr. Doutor João Rodrigues Chaves abriu a segunda sessão da vigésima segunda legislatura da Assembléa Provincial de Santa Catharina em 2 de fevereiro de 1881. Cidade do Desterro: Typ. e Lith. de Alex. Margarida, 1881. (anexo: "Trabalhos da Secretaria", datado de 31 de dezembro de 1880 e elaborado pelo secretário José Aureliano Cidade).

${ }^{57}$ Foram 1.769 documentos elaborados e expedidos, envolvendo também 1.395 minutas, além de 1.395 registros, sem contar a correspondência reservada (61 ofícios elaborados e expedidos, além de 42 minutas e 42 registros).

${ }^{58}$ Falla que o presidente da província de Santa Catharina, dr. João José Coutinho..., op.cit., p.5-6. Na fala de Coutinho, cabe ressaltar a atribuição de valor histórico aos documentos da Assembléia.
} 
Os juízos emitidos pela maioria dos presidentes da província de Santa Catarina, em especial após 1859, devem ainda ser apreciados considerando-se o curto período em que permaneciam no cargo. Excetuando-se Francisco de Albuquerque Melo (1825-1830), Feliciano Nunes Pires (1831-1835), Antero José Ferreira de Brito (1840-1848), João José Coutinho (1850-1859) e Francisco José da Rocha (1885-1888), os demais presidentes desempenharam suas funções em menos de dois anos, e na sua maior parte, durante apenas alguns meses. ${ }^{59}$ A curta permanência no cargo, como demonstrou José Murilo de Carvalho, era uma característica do exercício dessa função - algo que, se causava prejuízos do ponto de vista da continuidade administrativa, trazia vantagens no plano político: "contribuía para fornecer experiência política a um grande número de pessoas, além de lhes dar oportunidade de conhecer melhor o país e desenvolver perspectiva menos provinciana", bem como "dar aos ministros a oportunidade de premiar os amigos. ${ }^{60} \mathrm{Na}$ lógica da administração imperial, contudo, Santa Catarina era uma província de pouca expressão, prestando-se ao treinamento de elementos da elite política, que posteriormente ocupariam a mesma função em províncias consideradas mais importantes, ou seguiriam carreira em cargos de maior projeção. ${ }^{61}$

Diferentemente do que ocorre com as falas e relatórios de presidentes da província, as mensagens que presidentes de estado e governadores ofereceram à Assembléia Legislativa, ou ao Congresso Representativo, não contêm, de forma geral, informações substanciais sobre o órgão que herdou a documentação da Secretaria da Presidência - em um primeiro momento, a Secretaria do Governo. Posteriormente, o arquivo passou à Secretaria de Estado do Interior e Justiça, à Secretaria Geral dos Negócios do Estado (à qual pertencia a Diretoria de Interior e Justiça), novamente à Secretaria de Estado do Interior e Justiça, à Secretaria de Administração e Justiça e, finalmente, à Secretaria da Administração (à qual encontra-se atualmente vinculado o Arquivo Público do Estado). Sintomaticamente, os governantes republicanos elaboraram peças de conteúdo mais estritamente político e com visão panorâmica das questões administrativas, remetendo, para mais detalhes, aos relatórios

\footnotetext{
${ }^{59}$ CABRAL, Oswaldo Rodrigues. op.cit., p.383-385.

${ }^{60}$ CARVAlHO, José Murilo de. A construção da ordem: a elite política imperial; Teatro de sombras: a política imperial. 2 ed. rev. Rio de Janeiro: Ed. da UFRJ, Relume-Dumará, 1996. p.110.

${ }^{61}$ Ibidem, p.109, 123. Informa o autor que projeto apresentado à Câmara de Deputados, em 1860, dividia as províncias em três blocos, segundo sua importância; Santa Catarina estava integrada ao terceiro bloco, juntamente com Paraná, Espírito Santo, Rio Grande do Norte, Amazonas e Piauí.
} 
parciais de seus subordinados. ${ }^{62}$ Para o que aqui nos interessa, mais significativos são os relatórios apresentados aos presidentes de estado, ou governadores, pelos secretários de governo.

Apesar disso, as mensagens, sobretudo nos inícios republicanos, contêm várias referências relevantes quanto à inadequação das repartições à nova ordem políticoinstitucional, e à necessidade de reforma ou reestruturação administrativa. Em meio a esse debate, que procedimentos teriam sido adotados em relação a toda a documentação gerada pelo governo? Qual o destino dado aos documentos acumulados pela antiga Secretaria da Presidência da Província?

Mensagem apresentada em agosto de 1893, por Eliseu Guilherme da Silva, apontava "a necessidade de uma nova reorganização dos serviços a cargo das diversas repartições públicas do Estado.” Segundo seu juízo,

Ainda modeladas pelo antigo sistema, as nossas repartições não correspondem às necessidades resultantes das novas instituições adotadas, e deixam muito a desejar no desempenho de seus múltiplos e variados encargos.

Há uma verdadeira anarquia em todos os serviços, força é confessá-lo, indispensável se torna uma reforma radical." ${ }^{\text {63 }}$

Contudo, as medidas de reorganização promovidas pelos primeiros governos republicanos, cheias de idas e vindas, não parecem ter sido mais felizes, ou menos confusas. Meses depois da apresentação da mensagem, a Lei estadual $n^{\circ}$. 109, de 30 de outubro de 1893, reformava o Serviço Administrativo do Estado, criando duas grandes secretarias - a dos Negócios da Fazenda e a dos Negócios do Interior -, ficando a elas vinculados os serviços e

\footnotetext{
${ }^{62}$ É o caso da mensagem do vice-governador Gustavo Richard, na abertura do Congresso Legislativo em 29 de setembro de 1891: "Quaisquer outros esclarecimentos de que precisardes, podereis requisitar da Secretaria do Governo do Estado, aonde se acham arquivados os relatórios dos chefes das repartições públicas." Mensagens lidas na abertura do Congresso Constituinte a 28 de abril de 1891 e na abertura do Primeiro Congresso Legislativo a 29 de setembro de 1891. Desterro: Typ. do Jornal do Commercio, 1892. p.19. Algo similar afirma Felipe Schmidt, na mensagem de 1917: "No relatório da Secretaria Geral encontrareis mais amplas informações sobre todos os serviços públicos, habilitando-vos ao conhecimento exato de nossa situação." Mensagem apresentada ao Congresso Representativo, em 14 de agosto de 1917, pelo Dr. Felippe Schmidt, Governador do Estado de Santa Catarina. S.1.p., s.c.p., s.d.. p.95.

${ }^{63}$ Mensagem apresentada á Assemblea Legislativa do Estado de Santa Catharina pelo cidadão tenentecoronel Elyseu Guilherme da Silva, 1'. Vice-presidente do Estado, em 7 de agosto de 1893. Desterro: Gabinete Sul-Americano, s.d. p.16.
} 
competências das antigas repartições (extintas nessa ocasião). Pelo que pode ser deduzido a partir da leitura da lei, as atribuições da Secretaria do Governo (que, em princípio, nos anos iniciais da República, substituíra, em suas funções, a Secretaria da Presidência da Província) seriam absorvidas por uma das diretorias da Secretaria do Interior. Cinco anos depois da reforma do Serviço Administrativo, foram novamente criadas duas secretarias, a "do Interior e Justiça" e a "das Obras Públicas e Finanças" (Lei estadual nº. 328, de 23 de setembro de 1898). Os funcionários da antiga Secretaria do Governo seriam aproveitados, pelo que indica o quadro funcional previsto, em uma das três diretorias da Secretaria do Interior e Justiça (justamente a Diretoria do Interior e Justiça).

A reorganização não foi aprovada pelo governador seguinte: para Felipe Schmidt, era urgente seu aperfeiçoamento, desfazendo-se "a confusão implantada nos seus diversos departamentos." ${ }^{\text {"64 }}$ Em 1899, nova lei reorganizou as Secretarias de Estado (Lei estadual n ${ }^{\circ}$. 445, de 13 de outubro de 1899), continuando a existir duas grandes secretarias, sendo agora a “dos Negócios do Interior" e a "dos Negócios da Fazenda”. À primeira ficariam ligados "todos os serviços da administração pública, excetuados os da arrecadação, fiscalização, contabilidade, escrituração da receita e despesa do Estado" (Art. $3^{\circ}$.). Nova modificação em 1901 (Lei estadual $\mathrm{n}^{\circ}$. 518, de 4 de setembro de 1901), sendo criada uma única grande Secretaria, a "Secretaria Geral dos Negócios do Estado", dividida em três diretorias: do Interior e Justiça; da Instrução Pública; de Viação, Terras e Obras Públicas. Foi restabelecido o Tesouro do Estado, em lugar da Secretaria da Fazenda, então extinta. O Secretário Geral seria o intermediário entre o governador e todos os demais chefes de repartição (Art. $8^{\circ}$.), centralizando todos os documentos a ele dirigidos, e encaminhando ao governador só aqueles que, como Secretário, não pudesse resolver diretamente (Art. $9^{\circ}$.).

Em meio às diversas propostas de reforma e reorganização administrativa das duas primeiras décadas republicanas, o Arquivo da Secretaria Geral foi mencionado uma vez, na mensagem lida por Gustavo Richard, em agosto de 1909. Dizia o então governador:

\footnotetext{
${ }^{64}$ Mensagem apresentada ao Congresso Representativo em 10 de agosto de 1899 pelo Dr. Felippe Schmidt, governador do Estado. Florianópolis: Typ. da Livraria Moderna, 1899. p.5.
} 
O Arquivo da Secretaria Geral está também passando por uma grande reforma, procedendo-se atualmente à encadernação de todos os documentos ali existentes. ${ }^{65}$

Estabelecida em 1901, a Secretaria Geral dos Negócios do Estado foi dividida em duas pela Lei estadual $\mathrm{n}^{\circ}$. 1.196, de 26 de setembro de 1918: a Secretaria do Interior e Justiça e a Secretaria da Fazenda, Viação, Obras Públicas e Agricultura.

Nas seguidas modificações da estrutura administrativa, nota-se sempre a manutenção de dois núcleos fundamentais: as questões entendidas como de Governo, ou de "Interior", e as questões relacionados à área de Fazenda; conforme as circunstâncias, os problemas relacionados à instrução pública, à saúde (ou "higiene") e às obras públicas ficam afetas a um ou outro núcleo. Pela lei de 1918, na Secretaria do Interior e Justiça haveria uma Diretoria de Interior e Justiça e uma Diretoria de Instrução Pública, além de entidades tão díspares quanto a Chefatura de Polícia, a Força Pública do Estado, a Inspetoria de Higiene, o Arquivo Público e a Biblioteca Pública. Com exceção das diretorias, todas as demais repartições estariam subordinadas ao Secretário. Foi a primeira lei que mencionou o "Arquivo Público", como entidade definida na estrutura administrativa.

É muito provável que, nessa tentativa de 1918 de institucionalização do Arquivo Público, considerações acerca do valor cultural ou histórico da documentação relativa ao governo da Capitania, da Província e do Estado estivessem presentes, dado que o Instituto Histórico e Geográfico de Santa Catarina estaria de alguma forma gerenciando-o: foi justamente uma das figuras de maior destaque do Instituto, um de seus fundadores - José Arthur Boiteux -, a pessoa então nomeada para assumir a Secretaria do Interior e Justiça (à

\footnotetext{
${ }^{65}$ Mensagem lida pelo Exmo. Sr. Coronel Gustavo Richard, Governador do Estado, na $2^{\text {a }}$. Sessão da $7^{\text {a }}$. Legislatura do Congresso Representativo em 2 de agosto d 1908. Joinville (SC): Typ. Boehm, 1908. p. 16. Um indício de identificação entre o Arquivo da Secretaria Geral e o que seria o "Arquivo Público" está presente em livro publicado por Lucas Boiteux, em 1912: nele afirma que, durante o governo de Gustavo Richard "a Biblioteca e o Arquivo foram também mais bem instalados.” BOITEUX, Lucas Alexandre. Notas para a história catharinense. Florianópolis: Typ. a vapor da Livraria Moderna, [1912]. p.430.
} 
qual ficaria subordinado o Arquivo, subordinação confirmada pelo Decreto estadual $\mathrm{n}^{\mathrm{o}} .1170$, de 28/09/1918). ${ }^{66}$

Distintas interpretações quanto ao valor administrativo ou histórico da documentação a ser abrigada pelo Arquivo Público e da importância de sua organização parecem ter caracterizado, porém, as relações entre o Poder Executivo e o Legislativo, naquele momento: veja-se que a lei orçamentária relativa ao exercício de 1919 (Lei estadual $n^{0}$. 1.235, de 01/11/1918) não previu dotação específica para o Arquivo Público do Estado (mas previu o pagamento de vencimentos de um "oficial arquivista", na Diretoria de Interior e Justiça). Nos anos seguintes, nas mensagens ao Congresso Representativo, o governador em exercício Hercílio Luz insistiu, sem sucesso, na necessidade de que fosse prevista verba na lei orçamentária para a organização do Arquivo do Estado. ${ }^{67}$

Onze anos depois, em fins de 1929, o Regulamento Geral da Administração Estadual previa que na Secretaria de Estado do Interior e Justiça estariam, entre outros, os serviços relativos “à estatística e ao arquivo” (Art. $2^{\circ}$.). No Capítulo III, no entanto, torna-se patente que uma parte da documentação arquivística estaria alheia à alçada da Secretaria do Interior e Justiça: os "arquivos da Presidência" do Estado, sob a guarda do Secretário da Presidência (Cap. III, Art. 11). O regulamento prevê procedimentos quanto ao controle da documentação administrativa: serviço de protocolo (Art. 111); registro e classificação de documentos (Art. 104, inciso IX); ordenação cronológica de vários deles (Art.15, inciso V);

\footnotetext{
${ }^{66}$ Para Walter Piazza, a criação do Arquivo Público seria uma das principais metas de José Arthur Boiteux, e a lei de 1918 teria o sentido de uma vitória pessoal: "Como homem público, intimamente ligado ao Partido Republicano Catarinense, desde antes da Proclamação da República, e aos seus líderes nas terras catarinenses, [José Arthur Boiteux] batalha pela criação do Arquivo Público do Estado. Atuante, não se descuida do valor da documentação. [...] não descansa enquanto não vê o ato de criação do Arquivo Público do Estado de Santa Catarina. A sua satisfação deve ter sido imensa ao ver promulgada, pelo Governador Felipe Schmidt, a Lei $\mathrm{n}^{\circ}$. 1.196, de 26 de setembro de 1918, criando em seu artigo $5^{\circ}$., diretamente subordinado ao Secretário do Interior e Justiça, o Arquivo Público do Estado. É uma vitória que lhe deve ter satisfeito parcialmente, porquanto significa, tão somente, o acumular de papéis no vetusto Palácio do Governo (à Praça Quinze de Novembro), em sua ala direita, onde funcionava aquela Secretaria de Estado." PIAZZA, Walter F. "Archivo Catharinense": um ideal proposto. Ágora, Florianópolis, n.12, dez. 1990, p.5-6.

${ }^{67} \mathrm{Na}$ mensagem apresentada em 22 de julho de 1919, Hercílio Luz, indicando que "a organização do Arquivo Público" era "necessidade aliás inadiável para que este ramo do serviço possa corresponder aos seus finns", apontava igualmente como necessária a inclusão de verba suficiente "na lei orçamentária futura". Na mensagem apresentada dois anos depois ao Congresso Representativo, o mesmo governador fazia solicitação de igual teor, acrescentando que a remodelação do Arquivo era "proveitosa e urgente." Mensagem apresentada ao Congresso Representativo, em 22 de julho de 1919, pelo Engenheiro Civil Hercílio Pedro da Luz, ViceGovernador, no exercício do cargo de Governador do Estado de Santa Catharina. S. 1. p., s.c.p., s.d. p.40; Mensagem apresentada ao Congresso Representativo, em 22 de julho de 1921, pelo Engenheiro Civil Hercílio Pedro da Luz, Vice-Governador, no exercício do cargo de Governador do Estado de Santa Catharina. S. 1. p., s.c.p., s.d. p.32.
} 
formação de processos, a partir dos documentos, de modo a evitar, entre outros aspectos, "a disposição tumultuária dos documentos" (Art.112); arquivamento (Art. 104, inciso X).

Pode-se considerar um desdobramento desse regulamento, apesar das importantes alterações político-administrativas que ocorreram na administração do Estado em decorrência da chamada Revolução de 1930, o decreto estadual publicado em março de 1931, que criou o serviço de protocolo nas repartições públicas do Estado. Nele é possível notar, além da ambição de maior controle dos documentos que entrassem e saíssem das repartições, o interesse na agilização das decisões ("Nenhuma autoridade ou funcionário poderá conservar em seu poder qualquer documento por espaço superior a 48 horas" - Decreto estadual $n^{\circ} .83$, de 6 de março de 1931, Art.1, inciso VI).

Em fins do mesmo ano de 1931, foi criado o Arquivo Público Estadual, pelo Decreto estadual $\mathrm{n}^{\circ}$. 186, de 28 de dezembro de 1931, subordinado à Secretaria do Interior e Justiça. É neste momento que aparece, em texto de caráter legal, a relevância histórica dos documentos abrigados neste órgão. Nos "considerandos" desse decreto, a criação do Arquivo Público Estadual era justificada, primeiramente, por seu caráter imprescindível, do ponto de vista administrativo e histórico:

[...] o serviço de Arquivo Público [...] é imprescindível não só para acautelar os legítimos interesses nas relações de direito privado e de direito administrativo, como também para manter uma fonte de seguras informações acerca dos acontecimentos que constituem a vida, tradição e história do Estado, nas diferentes épocas e em seus múltiplos aspectos.

Em segundo lugar, destacava-se que outros Estados da União já haviam criado serviço similar. ${ }^{68}$ Finalmente, salientava-se que o Arquivo Público constituiria "fonte de renda para o Estado". O último aspecto, algo vago nessas considerações iniciais, é aclarado no Artigo $3^{\circ}$., no qual se estabelece que o Juiz de Direito deveria providenciar para que fossem "imediatamente recolhidos ao Arquivo", logo que findos, "os autos de processos, os livros de notas, do registro civil e outros semelhantes" (alínea b). Subentende-se, assim, que o Arquivo

\footnotetext{
${ }^{68}$ No Império, tiveram arquivos institucionalizados as províncias do Amazonas (1852) e do Paraná (1855); nos inícios republicanos, a institucionalização de arquivos estaduais ocorre na Bahia (1890), em São Paulo (1892), no Pará (1894), em Minas Gerais (1895), no Mato Grosso (1896), no Rio Grande do Sul (1906) e em Sergipe (1923). Cf.: JARDIM, José Maria. Instituições arquivísticas: estrutura e organização; a situação dos arquivos estaduais. Revista do Patrimônio Histórico e Artístico Nacional. Rio de Janeiro, n. 21, 1986, p.39-42.
} 
Público seria fonte de renda uma vez que cobrasse pelas certidões emitidas a partir de documentos cartoriais. Em função da presença de tais documentos no Arquivo, o quadro de funcionários comportaria três "cartorários", além de dois datilógrafos, um porteiro, um contínuo-servente, um amanuense-conservador e um diretor (Art.6). ${ }^{69}$

Provavelmente devido à lei de criação do Arquivo, decreto publicado no ano seguinte extinguiu o cargo de "Oficial Arquivista", da Diretoria do Interior e Justiça (Decreto estadual $n^{\circ} .242$ de 18 de abril de 1932). No entanto, já em meados de 1933 o Arquivo Público também foi extinto, voltando seu serviço à "antiga organização" (Decreto estadual n . 349 de 10/05/1933, Art.2). No decreto, a extinção é justificada em função de o serviço criado - "destinado à guarda e conservação de documentos de natureza de ordem administrativa e judiciária" - não ser "de natureza inadiável”, além de sua manutenção significar "despesas incompatíveis com a situação financeira do Estado". Mas há ainda referência a outro fator, que talvez tenha sido o determinante: "a execução do Decreto que criou o Arquivo prejudicaria a serventuários de Justiça, com a diminuição de rendas, não tendo sido compensados, pecuniariamente, como em outros Estados."

\section{O acesso à documentação: entre os interesses do Estado e os do cidadão}

É por meio do regulamento da Secretaria da Presidência da Província datado de 2 de março de 1867 que temos mais clareza dos mecanismos de acesso então possíveis à documentação por ela reunida. ${ }^{70} \mathrm{O}$ oficial-arquivista, a quem caberia conservar o arquivo da repartição "na devida ordem, clareza e método" (Art. 31, parágrafo $1^{\circ}$.), não poderia franquear o arquivo “à pessoa alguma estranha à Repartição”, só fornecendo documentos, mesmo dentro da Repartição, ao Secretário e ao oficial-maior (e, mesmo assim, apenas "para o serviço dentro da Repartição", não sendo a entrega feita "sem responsabilidade escrita" - Art. 31, parágrafo $7^{\circ}$.). Ao mesmo tempo, caberia ao arquivista providenciar "as certidões, que forem requeridas, dos livros e documentos sob sua guarda, precedendo despacho do Presidente"

\footnotetext{
${ }^{69} \mathrm{O}$ mesmo decreto aprovava o regulamento do Arquivo (que, infelizmente, não foi localizado nem em versão impressa nem na legislação autógrafa existente no acervo do Arquivo Público do Estado de Santa Catarina).

${ }^{70}$ Regulamento que dá nova organisação á Secretaria da Presidência [datado de 2 de março de 1867]. [S.1.p., S.c.p., s.d.]. Acervo do Arquivo Público do Estado de Santa Catarina.
} 
(Art. 31, parágrafo $5^{\circ}$.). Portanto, em 1867, no tocante ao arquivo da Secretaria da Presidência da Província de Santa Catarina, o acesso era regulado de acordo com uma percepção, em relação à documentação, de valores eminentemente administrativos e jurídico-legais.

Um desdobramento importante, quanto ao acesso, diz respeito aos instrumentos de controle da documentação, também mencionados no regulamento: "um livro próprio para nele lançar diariamente a entrada de todos os papéis que se deverem arquivar, com resumida declaração do seu conteúdo" (Art. 31, parágrafo segundo) e "um catálogo completo e bem detalhado dos livros, mapas e documentos que houver no Arquivo" (sendo que uma "cópia autêntica" do catálogo deveria estar "em poder do Secretário" - Art. 31, parágrafo sexto). Supõe-se que, no catálogo, estariam indicados os locais de guarda dos documentos no depósito.

O mesmo regulamento de 1867 manifesta preocupação em relação à circulação de pessoas na repartição, que deveria ser restrita aos funcionários: cabia ao oficial-maior impedir que nela tivessem ingresso "as partes ou quaisquer outras pessoas", permitindo apenas a entrada no gabinete do Secretário, com a devida autorização prévia, "para objeto de serviço" (Art.28). Na prática, essa proibição era exercida diretamente pelo porteiro (Art. 32, parágrafo sétimo). A lógica do segredo em relação às questões de Estado é explicitada: oficiais, amanuenses e "todos os outros empregados" (portanto, também o porteiro e o contínuo) deveriam guardar "inviolável segredo de todos os negócios, e de quanto se passar na Repartição.” (Art. 30, parágrafo $3^{\circ}$.)

Cabe aqui um parêntese. Há que ter claro que, no tocante aos documentos produzidos no âmbito das estruturas estatais, foram historicamente produzidas diferenciações quanto aos tipos de documentos que deveriam ter ampla difusão, aqueles que poderiam ter difusão restrita e aqueles que não deveriam de nenhuma forma ser consultados (ou ainda, que poderiam ser consultados apenas por agentes do Estado). Mesmo nos mais fechados regimes políticos, documentos como leis e instrumentos jurídicos correlatos só têm sentido se amplamente difundidos e de conhecimento generalizado. $\mathrm{O}$ acesso pontual e restrito a documentos, como aquele feito por meio de certidões ou cópias de documentos públicos (principalmente aqueles com valor probatório de direitos a serem exercidos por particulares), pode ser localizado, por sua vez, em épocas bastante recuadas: estava previsto, por exemplo, 
no ordenamento jurídico do Império Romano. ${ }^{71}$ A questão do "segredo de Estado" esteve contudo fortemente presente na cultura política ocidental a partir da época moderna, mesmo sendo contestada ou relativizada em função dos interesses de determinados grupos (como os historiadores, mais fortemente a partir do século XIX). ${ }^{72}$

Os esforços dos historiadores para garantir acesso aos documentos públicos de arquivo, mesmo em países que, no século XIX, tinham papel destacado na ambição de tornar a História uma disciplina científica, nem sempre conseguiram superar a lógica do segredo que dominava as instituições públicas. O regulamento de 1856 do Arquivo Nacional francês previa que seu diretor impedisse a consulta de documentos caso a entendesse como prejudicial, do ponto de vista da administração; nos arquivos da Alemanha recém-unificada, segundo depoimento de Julius Ficker, em 1873, o segredo continuava a ser norma, e a abertura à pesquisa histórica, exceção. ${ }^{73}$

Tais considerações são relevantes, pois é comum se afirmar que, em alguns Estados, como o francês, o acesso de todo e qualquer cidadão aos documentos públicos foi garantido desde fins do século XVIII (citando-se a célebre Lei de 7 Messidor, ano II da Revolução Francesa - ou seja, de 25 de junho de 1794). Como salientou Elio Lodolini, apoiado em estudo de Robert-Henri Bautier, não só a consulta aí tornada possível foi bastante limitada, como não dizia respeito a documentos de "interesse histórico", dado que a mesma legislação republicana francesa determinava a transferência de documentos assim identificados para bibliotecas. Além disso, não se pode esquecer que o contexto revolucionário em que essa lei emergiu foi bastante transformado nos anos seguintes, o que ajuda a compreender, em parte, a sua frágil efetivação. Acrescente-se que uma consulta ampla e direta aos documentos seria apenas possível, naquele momento, com a instalação de salas de consulta nos arquivos, algo que, na Europa, de forma geral, ocorreria somente por volta da metade do século XIX, com as limitações já assinaladas. Bruno Galland esclarece que a Lei de 7 Messidor parte de uma compreensão própria do Antigo Regime para o que seriam "arquivos", e que englobaria apenas documentos de valor estritamente administrativo ou

\footnotetext{
${ }^{71}$ LODOLINI, Elio. Archivística: principios y problemas. Madrid: ANABAD, 1993. p. 247.

${ }^{72}$ Elio Lodolini fornece dados que alertam, no entanto, contra o equívoco de uma perspectiva linear no que se refere à questão do acesso aos arquivos públicos, lembrando a ampla liberdade de consulta que as comunas medievais, em especial aquelas constituídas no atual território italiano, concederam a seus membros. Ibidem, p.247-248.

${ }^{73}$ LODOLINI, Elio. op.cit., p.251.
} 
jurídico, como títulos, contratos, diplomas; a garantia de consulta ampla aos documentos estaria justamente em sua transferência para bibliotecas, então percebidas como o espaço privilegiado de pesquisa. $^{74} \mathrm{~A}$ abertura dos documentos arquivísticos governamentais à consulta pública envolverá, portanto, uma modificação no conceito de arquivo.

Os obstáculos encontrados pelos historiadores, quanto ao acesso aos documentos públicos de arquivo, fazem inclusive com que tenhamos uma outra perspectiva das várias iniciativas que, ao longo do século XIX, tratariam da reunião e publicação de grandes coleções de documentos, como os "Monumenta Germaniae Historica", a partir de 1826, a "Collection de documents inédits sur l'histoire de France", em 1835, os "Monumenta historiae patriae" italianos, em 1836, seguidos dos "Documenti di storia italiana", em 1867. ${ }^{75}$ Do mesmo modo, poderíamos repensar as iniciativas de publicação de documentos efetuadas pelo Instituto Histórico e Geográfico Brasileiro e pelos institutos históricos regionais, como o Instituto Histórico e Geográfico de Santa Catarina.

Célia Costa entendeu que a atuação do Instituto Histórico e Geográfico Brasileiro no levantamento e coleta de documentos colaborou para fragilizar o Arquivo Público imperial (futuro Arquivo Nacional), tornando-o mero "lugar de memória do próprio Estado". ${ }^{76}$ Mas não seriam os arquivos públicos, em cada instância do Estado, e em função de acumularem documentos produzidos por essas mesmas instâncias, em decorrência de suas atividades, seus "lugares de memória" por excelência? Não permitiriam eles o acesso a "outras" memórias apenas de forma enviesada, em leituras a contrapelo, e somente na medida em que os registros contemplem também as relações que os governos estabelecem com variados sujeitos sociais? Por outro lado, a mesma autora destacou que o Arquivo Público imperial - cuja existência estava prevista na Constituição de 1824, tendo sido criado somente em 1838 - "restringia o acesso aos seus documentos públicos à burocracia do Estado, perpetuando a política de sigilo oficial dos tempos coloniais". 77 É certo, porém, que a subordinação do acesso à lógica do segredo de Estado não era algo presente apenas no Estado brasileiro de então, como atestam os exemplos anteriores, relativos à Alemanha e à França do século XIX.

\footnotetext{
${ }^{74}$ Ibidem, p.250; SILVA, Armando Malheiro da, et al. op.cit., p.102. GALLAND, Bruno. Conserver pour 1'histoire: une nouvelle dimension pour les Archives Nationales de France. [Convegno Archivi e storia nell'Europa del XIX secolo, Archivio di Stato di Firenze]. Disponível em: <http://www.archiviodistato.firenze.it/atti/aes/galland.pdf>. Acesso em: 8 out. 2005.

${ }^{75}$ LE GOFF, Jacques. História e memória. Campinas (SP): Editora da UNICAMP, 1996. p.537-538.

${ }^{76}$ COSTA, Célia. O Arquivo Público do Império: o legado absolutista na construção da nacionalidade. Estudos históricos, Rio de Janeiro, v.14, n.26, 2000, p.224.

${ }^{77}$ Ibidem, p.226.
} 
A garantia de acesso aos documentos de caráter público pelos cidadãos em geral será significativamente afirmada, em vários países, a partir do fim da Segunda Guerra Mundial, uma vez que o reconhecimento do direito à informação como direito fundamental é consagrado pela Declaração Universal dos Direitos do Homem, de $1948 .^{78}$

O regulamento da Secretaria da Presidência da Província de Santa Catarina, de 1867, se inscreve, portanto, em um contexto jurídico em que as garantias amplas de acesso aos documentos públicos não estavam dadas, e no qual o trato dos arquivos significava, mais que tudo, a garantia do sigilo para a melhor condução dos negócios públicos, bem como da inviolabilidade das provas para assegurar direitos (direitos tanto da administração como dos cidadãos). Neste contexto, os valores atribuídos à documentação pública eram, fundamentalmente, valores administrativos e jurídico-legais (ou probatórios).

Mesmo a transição para a República não alteraria esse quadro geral: em regulamentos posteriores, pertinentes à Secretaria de Interior e Justiça e à Secretaria Geral dos Negócios do Estado, a manutenção de valores eminentemente administrativos e jurídicolegais para o arquivo, e a ausência de atribuição de outros pode ser facilmente constatada. Isso é visível, sobretudo, nas disposições que vedam "a entrada de pessoas estranhas no recinto da Secretaria", e obrigam os funcionários a "guardar o mais absoluto sigilo com relação aos negócios que correrem pela secretaria”; sentido análogo tem a proibição, aos funcionários, de serem "procuradores de partes" ou "processar papéis que representem interesses seus ou de parentes". Entre 1898 e 1902, os regulamentos determinam ainda como incumbência do arquivista "passar certidões mediante despacho do Secretário." 79

Os sinais de mudança são claros algumas décadas adiante, na Lei estadual $\mathrm{n}^{\circ}$. 2.378, de 28 de junho de 1960, que criou o Arquivo Público do Estado. A lei previa várias formas de acesso às informações registradas nos documentos de seu acervo: fornecimento de

${ }^{78}$ O "direito à informação governamental" foi assegurado em vários países a partir de então: em 1951, na Finlândia; em 1966, nos Estados Unidos; em 1970, na Dinamarca e Noruega; em 1978, na França, Holanda e Espanha; em 1982, na Austrália, Nova Zelândia e Canadá; em 1985, na Colômbia; em 1993, na Hungria. Cabe ressaltar que, antes mesmo da França, a Suécia, no bojo de preocupações com a liberdade de imprensa, teria garantido, em 1766, livre acesso aos documentos oficiais a todo cidadão sueco. DUCHEIN, Michel. Les obstacles à l'accés, à l'utilisation et au transfert de l'information contenue dans les archives: une étude RAMP. Paris: UNESCO, 1983. p.11; JARDIM, José Maria. Transparência e opacidade do Estado no Brasil: usos e desusos da informação governamental. Niterói (RJ): Editora da UFF, 1999. p.70-71.

${ }^{79}$ Regulamento para a Secretaria de Estado dos Negocios do Interior e da Justiça. Florianópolis: Typ. da Livraria Moderna, 1899; Regulamento para a Secretaria de Estado dos Negocios do Interior - 1900. Florianópolis: Typ. da "Republica", s.d.; Regulamento para a Secretaria Geral dos Negócios do Estado 1902. Florianópolis: Gab. Typ. de M. Callado, s.d. 
certidões, cópias autenticadas e fotocópias, mediante pagamento de custas; consulta direta sob fiscalização, quando motivada por questões entre partes; consulta direta autorizada pelo Secretário do Interior e Justiça, quando motivada por fins culturais; difusão por meio de publicação. ${ }^{80} \mathrm{Na}$ lei há nitidamente a atribuição, aos documentos públicos da administração estadual, de valores outros que não os meramente administrativos (visíveis em várias das finalidades do Arquivo, aqui não mencionadas) ou probatórios - são atribuídos, à documentação, valores culturais ou, mais propriamente, "históricos". Contudo, o intervalo entre a intenção de acesso mais amplo, contida na lei, e sua concretização, pode ser constatado nos relatórios da Secretaria dos Negócios do Interior e Justiça apresentados ao governador. Em relatório de março de 1962, por exemplo, o Secretário esclarece que o Arquivo, "não obstante preenchido o respectivo quadro de funcionários, teve de ser recolhido à Secretaria do Interior e Justiça, por ausência de boas condições das instalações que lhe haviam sido destinadas de início." ${ }^{81}$ Só em fins dos anos 1970, conforme já referido, o Arquivo passaria a funcionar, efetivamente, como instituição aberta à pesquisa. ${ }^{82}$

Em fins da década de 1980, os profissionais que trabalhavam no Arquivo Público do Estado ganharam, por força do Decreto estadual nº 1.444/1988, ao lado das atribuições já existentes quanto à organização da documentação de guarda permanente, outras competências, implicadas no Subsistema Estadual de Arquivos. Naquele momento, além de dizerem respeito à administração estadual, suas atividades passaram a estar voltadas para os arquivos municipais. O Arquivo Público empenhou-se em exercer, no estado de Santa Catarina, o papel de referência técnica quanto a questões arquivísticas, o que fica visível na

${ }^{80} \mathrm{Ou}$, conforme o texto da lei, no que se refere às finalidades do órgão: "facilitar, por todos os meios, as consultas pelas partes interessadas, em recinto apropriado, sob fiscalização e mediante o pagamento dos devidos emolumentos" (Art. $2^{\circ}$., inciso III); "fornecer certidões, cópias autenticadas e fotocópias a quem as requerer, de qualquer documento existente no Arquivo, mediante o pagamento das devidas custas" (Art. $2^{\circ}$., inciso IV); "publicar, quando for possível, os documentos que possam contribuir para vulgarização cultural, sobre assunto histórico, relacionado com a evolução política de Santa Catarina" (Art. $2^{\circ}$., inciso V). Determinava ainda a lei que teria "ingresso franqueado no Arquivo a pessoa que, para elaboração de obra de divulgação cultural e histórica de Santa Catarina", o requeresse "ao Secretário do Interior e Justiça, com o fim de realizar pesquisas e estudos na documentação ali existente" (Art. $4^{\mathrm{o}}$.).

${ }^{81}$ Relatório da Secretaria do Interior e Justiça, referente ao exercício de 1961, apresentado pelo Secretário Paulo Macarini ao governador do Estado Celso Ramos. Florianópolis, março de 1962; datilografado. Acervo do Arquivo Público do Estado de Santa Catarina (Relatórios de órgãos diversos, I.J., r, 1961, 38-4, cx.114).

${ }^{82}$ Essa é também a visão de Walter Piazza. Ver: PIAZZA, Walter Fernando. Arquivo Público: retrospectiva e prospectiva. In: Arquivo Público do Estado de Santa Catarina - 30 anos (1960-1990). Florianópolis: Secretaria de Estado da Administração, 1990. p.8. 
consulta aos boletins informativos da instituição. A sistematização dos dados, disponibilizados nos boletins, sobre as atividades de consultoria técnica a diversos órgãos públicos e, mesmo, a entidades privadas, embora relativas a um breve período (1998-2002), permite verificar a regular orientação técnica a órgãos da administração estadual, no que diz respeito a procedimentos de avaliação e organização de documentos arquivísticos (ver Apêndice II-17). Ao lado disso, houve o atendimento também regular a arquivos municipais já institucionalizados ou a prefeituras interessadas em criá-los. Estes - os arquivos municipais - eram outro desafio na constituição do campo arquivístico. Através dos encontros catarinenses de arquivos e da consultoria técnica disponibilizada às administrações municipais, o Arquivo Público do Estado procurou fazer a sua parte. Mas o que fizeram as administrações municipais? 


\section{Parte II}

\section{Capítulo 3}

\section{Arquivos públicos municipais: entre a memória-culto e a memória-direito}

Sendo um dos alvos principais das ações que visaram conformar o campo arquivístico em Santa Catarina (sobretudo a partir da década de 1980, com a atuação do Arquivo Público do Estado), os arquivos públicos municipais catarinenses tiveram sua trajetória de institucionalização marcada pela identificação com questões pertinentes à "memória" (no sentido de memória coletiva ou social). Mais precisamente, caracterizaram-se por um movimento pendular entre a memória identificada com o culto ao passado e a memória como direito contemplado no exercício da cidadania.

A este respeito, a análise da legislação de criação de tais instituições apresenta especial interesse, sobretudo se tentarmos estabelecer as conexões que os textos legais guardaram entre si, os elos que mantiveram com leis estaduais e federais correlatas e, simultaneamente, suas relações com debates, práticas e ações que incidiram sobre o campo arquivístico, dentro e fora do estado de Santa Catarina. Tal análise certamente poderia ganhar aprofundamento com o estudo pontual do contexto de produção dessas leis e decretos, no âmbito de cada município - o jogo de forças em causa, os debates então encaminhados etc. Afinal, toda lei ou decreto costuma ser fruto de negociações entre a esfera do Executivo e do Legislativo, bem como entre segmentos da sociedade civil e setores da administração pública. No entanto, considerações desse tipo ampliariam em muito o escopo do presente trabalho, e não serão aqui contempladas.

Pelos dados apurados na pesquisa, 25 foram os municípios catarinenses que formalizaram, por meio de legislação, a existência de uma instância administrativa responsável pelos documentos produzidos pela administração pública municipal. ${ }^{1}$ Estão sendo considerados, nesse cômputo, os arquivos efetivamente criados na esfera pública. O Museu e Arquivo Histórico do Vale do Itajaí-Mirim (conhecido como "Casa de Brusque"), por

\footnotetext{
${ }^{1}$ Ver Apêndice II-18.
} 
exemplo, não foi aqui incluído, embora abrigue documentação pública: é mantido, desde ao menos 1971, por entidade particular, a Sociedade Amigos de Brusque (criada em 1953 por Ayres Gevaerd). ${ }^{2}$ Também foi excluído o Museu Thiago de Castro, em Lages, apesar de dispor, igualmente, de documentos públicos referentes ao município (trata-se de instituição privada, mantida pelos familiares de Danilo Thiago de Castro, seu idealizador). ${ }^{3}$

Os primeiros arquivos públicos municipais criados por lei foram os de Jaraguá do Sul (1971), Joinville e Blumenau (1972) e Itajaí (1976). Com exceção dos arquivos municipais de São Bento do Sul e Indaial, criados respectivamente em 1983 e 1986, os demais surgiram a partir de 1988: Ipumirim (1988), Itaiópolis, Campos Novos e Porto União (1989), Tubarão (1990), Concórdia (1991), Pinheiro Preto, Biguaçu e São José (1992), Chapecó e Balneário Camboriú (1993), Florianópolis e Rio do Sul (1994), Serra Alta (1995), Canoinhas (1997), Nova Erechim, Criciúma e Ibirama (1998), Capivari de Baixo (2003). ${ }^{4}$

Em termos geográficos, tais arquivos municipais podem ser localizados em cinco áreas de distribuição: uma longa faixa ao norte (Joinville, Jaraguá do Sul, São Bento do Sul, Itaiópolis, Canoinhas e Porto União); uma área que segue do litoral para o vale do Itajaí (Balneário Camboriú, Itajaí, Blumenau, Indaial, Ibirama e Rio do Sul); uma faixa que se estende do meio-oeste para o oeste do Estado (Campos Novos, Pinheiro Preto, Concórdia, Ipumirim, Chapecó, Nova Erechim e Serra Alta); na área litorânea, um pequeno núcleo na Grande Florianópolis (Florianópolis, São José e Biguaçu); ao sul, um núcleo também integrado por apenas três arquivos (Tubarão, Criciúma e Capivari de Baixo).

\footnotetext{
${ }^{2}$ Ver: NUNES, Neusa Rosane D., TERTITCHNIJ, Maria Tereza (orgs.). Guia dos arquivos municipais. Florianópolis: Arquivo Público do Estado, 1992, p.23; STEIN, Letícia L. K. História e linguística de uma cidade [sobre Brusque]. Revista Voz das Letras [Universidade do Contestado], Concórdia (SC), n.2, 1º sem. 2005. Disponível em: <http://www.nead.uncnet.br/2004/revistas/letras/2/4.pdf >. Acesso em: 12 fev. 2006.

${ }^{3}$ Informação disponível em: <http://www.cidadelages.com.br/cidade/pontos_turisticos.php>. Acesso em: 29 out. 2005.

${ }^{4}$ Maria Lourdes Blatt Ohira e Priscila Martinez apontam datas distintas para a institucionalização dos arquivos de São Bento do Sul, Criciúma, Balneário Camboriú e Indaial, que teriam sido criados, respectivamente, em 1971, 1983, 1992 e 1994. No caso dos três primeiros arquivos, entretanto, os instrumentos legais de criação identificados pelas próprias autoras são posteriores a tais datas e coincidem com aqueles mencionados no Apêndice II-18. Cf.: OHIRA, M. L. B., MARTINEZ, P. A. Acessibilidade aos documentos nos arquivos públicos municipais do Estado de Santa Catarina - Brasil. 1'. Integrar: Congresso Internacional de Arquivos, Bibliotecas, Centros de documentação e Museus: textos. São Paulo: Imprensa Oficial do Estado, 2002. p. 344.
} 


\section{Os arquivos institucionalizados entre 1971 e 1986: o culto ao passado}

A análise da legislação de criação dos arquivos municipais catarinenses permitiu detectar concepções comuns e, mesmo, instrumentos legais que atuaram como base dos demais.

Em um primeiro momento (1971-1986), num cenário de poucos arquivos institucionalizados em Santa Catarina, as leis referentes aos de Blumenau e Joinville serviram como modelos, uma vez que a primeira lei de criação (do arquivo de Jaraguá do Sul, em 1971) é excessivamente curta (constituída apenas por dois artigos: um, criando o Arquivo e o Museu, e integrando-os à Biblioteca Pública Municipal; o outro, pondo a lei em vigor e revogando as disposições em contrário). Já a lei relativa ao Arquivo de Joinville, de 1972, é minuciosa, mas apenas quanto ao acervo que se pretendia abrigar na instituição (excetuado o Art. $1^{\circ}$., criando o Arquivo, e o $2^{\circ}$., vinculando-o à Biblioteca Pública, todos os demais, recheados de incisos e desdobramentos, referem-se ao acervo). Mesmo assim, o decreto que regulamentou a lei de criação do Arquivo de São Bento do Sul, datado de 1985, reproduz quase integralmente a lei do Arquivo de Joinville, limitando-se a pequenos cortes ou alterações e emendas (e à devida substituição da palavra "Joinville" por "São Bento do Sul"). A imitação não deixa de ser curiosa, uma vez que, treze anos depois de formalmente criado o Arquivo de Joinville, o decreto relativo ao Arquivo de São Bento do Sul instalava, ao menos no papel, uma situação de litígio, de "contencioso arquivístico", pois deveria abrigar praticamente a mesma documentação da entidade joinvilense.

Já a lei que, ao criar a Fundação "Casa Dr. Blumenau", ao menos mencionou o Arquivo do município, serviu simultaneamente como base para a elaboração do estatuto da Fundação Genésio Miranda Lins, à qual estava vinculado o Arquivo de Itajaí, e para a

\footnotetext{
5 Por contencioso arquivístico entende-se situação de "conflito de jurisdição arquivística", sendo a jurisdição arquivística, por sua vez, "competência legalmente atribuída a uma instituição quanto à entrada, custódia, propriedade, transferência, eliminação e recolhimento de arquivos.” BELLOTTO, Heloísa L., CAMARGO, Ana Maria de Almeida (coord.). Dicionário de Terminologia Arquivística. São Paulo: AAB-SP, 1996.
} 
Elaboração da lei de criação da Fundação Indaialense de Cultura. ${ }^{6}$ Os objetivos da Fundação Indaialense de Cultura (surgida apenas um ano depois de ter sido criado o "Centro de Cultura do Município de Indaial") seriam praticamente os mesmos da Fundação "Casa Dr. Blumenau".

$\mathrm{Na}$ legislação relativa a tais arquivos, sobressai a questão da História e da Memória. Assim, os arquivos de Blumenau e Itajaí seriam organizados e mantidos por fundações de caráter cultural que deveriam promover, entre outras ações: a "conservação do patrimônio histórico e cultural" de seus respectivos municípios; a "conservação e a divulgação das tradições culturais e folclore regional"; a "edição de livros e outras publicações" que estudassem e divulgassem "as tradições histórico-culturais do Município"; os "estudos e pesquisas sobre a história, as tradições, o folclore, a genealogia e outros aspectos de interesse cultural do Município". O decreto referente a Itajaí estabelece, ainda, caber à Fundação Genésio Miranda Lins: "realizar reuniões, conferências, encontros, círculos de estudo, debates, seminários, simpósios e congressos sobre história catarinense, especialmente do vale do Itajầ"; "promover, junto aos órgãos públicos competentes, a preservação dos monumentos históricos, artísticos e arquitetônicos do Município de Itajấ”; "congregar os historiadores, sociólogos, escritores, pesquisadores, folcloristas, geógrafos e professores interessados no cultivo das legítimas tradições culturais de Itajaí e do Estado de Santa Catarina"; despertar o interesse pela pesquisa histórica, valorizando o culto do passado". ${ }^{7}$

Tradições culturais articuladas a folclore, perspectiva não meramente municipalista, mas regionalista (Vale do Itajaí e Estado de Santa Catarina), história identificada a passado, passado a ser cultuado: alguns desses elos também estão claros na lei de criação do Arquivo de Joinville e no decreto que regulamenta o Arquivo de São Bento do Sul (que em sua maior parte, como já referido, segue a lei de Joinville). Veja-se, em especial,

\footnotetext{
${ }^{6} \mathrm{O}$ estatuto da Fundação Genésio Miranda Lins foi aprovado pelo Decreto municipal [Itajaí] no ${ }^{\circ} .1 .543$, de 27 de janeiro de 1977. Note-se, contudo, que a Fundação Genésio Miranda Lins era então identificada como "pessoa jurídica de direito público, com função técnica desvinculada da Administração Municipal e com a finalidade exclusivamente cultural." (Lei municipal [Itajaí] $\mathrm{n}^{\circ}$. 1.515, de 1 de dezembro de 1976, Art. $1^{\circ}$.). A Fundação "Casa Dr. Blumenau" estava claramente vinculada à administração municipal: o Art. 22 de seu estatuto previa que a Fundação manteria com a Prefeitura "relações de coordenação, devendo operar de tal sorte que não haja duplicidade de programas ou paralelismo de atividades entre as duas entidades." (Decreto municipal [Blumenau] $\mathrm{n}^{\mathrm{o}} .221$, de 20 jun. 1972).

${ }^{7}$ Lei municipal [Blumenau] no. 1.835, de 7 de abril de 1972, Art. 2 ${ }^{\circ}$.; Decreto municipal [Itajaí] no ${ }^{\circ} .1 .543$ de 27 de janeiro de 1977, Art. $3^{\circ}$. Grifos meus.
} 
o trecho do texto legal que dispõe sobre a possibilidade do Arquivo de Joinville coletar documentos dos demais municípios "da Região geo-econômica da qual Joinville forma o centro": o objetivo seria transformá-lo "em um centro de pesquisas históricas para toda a Região Norte-Nordeste do Estado de Santa Catarina”. Com isso, entendia-se dar cumprimento ao

$$
\begin{aligned}
& \text { "desideratum" que inspirou o "Compromisso de Brasília", quando } \\
& \text { recomenda que "o culto do Passado é o elemento básico para a formação da } \\
& \text { consciência nacional" e ainda aponta o interesse de se "transmitir às novas } \\
& \text { gerações e consciências o interesse do [sic] ambiente histórico-cultural." }
\end{aligned}
$$

O "Compromisso de Brasília" foi documento firmado em abril de 1970, como resultado de encontro entre governadores, secretários estaduais de cultura, prefeitos e representantes de instituições culturais. Promovido pelo Ministério de Educação e Cultura do então ministro Jarbas Passarinho, o encontro teve participação marcante da Diretoria do Patrimônio Histórico e Artístico Nacional (DPHAN) e do Conselho Federal de Cultura. Interessa salientar que o próprio documento deu destaque aos signatários de Santa Catarina:

Pelo Estado de Santa Catarina assinaram o documento os professores Jaldir Bhering Faustino da Silva, Secretário de Estado da Educação e Cultura, Carlos Humberto Pederneiras Corrêa, Diretor do Departamento de Cultura, e Oswaldo Rodrigues Cabral, representante da Universidade Federal de Santa Catarina e da comissão especial que estuda a organização do Conselho de Defesa do Patrimônio Histórico do Estado nomeada pelo Governador Ivo Silveira. ${ }^{9}$

Esse claro comprometimento de autoridades catarinenses com o documento (todas, aliás, ligadas também ao campo da produção histórica) permite ao menos em parte

\footnotetext{
${ }^{8}$ Lei municipal $n^{\circ} .1 .182$ [Joinville], 20 de março de 1972, Art. $7^{\circ}$., parágrafo único. No caso de São Bento do Sul, o texto sofreu pequenas alterações: além da substituição das referências a Joinville por "São Bento do Sul”, projetou-se o arquivo como centro de pesquisas históricas "para toda a Região Norte do Estado de Santa Catarina" (Decreto municipal [São Bento do Sul] nº. 246, de 1 de abril de 1985, Art. 11, parágrafo único). O culto ao passado e ao "antigo" seria revelado, de forma mais prosaica, nas atividades então previstas para a “Associação do Arquivo" de São Bento do Sul, entre elas: “auxiliar na publicação do jornalzinho 'O Passado'; preparar encontros de pessoas idosas com o intuito de fazê-las falar do passado; lembrar os aniversários das pessoas idosas, mandando-lhes um cartão e flores; visitar periodicamente estas pessoas." (Art. $7^{\circ}$.)

${ }^{9}$ Compromisso de Brasília. In: Cartas patrimoniais. Brasília: Ministério da Cultura, IPHAN, 1995. p.166. Nenhum representante de outra unidade da federação foi explicitamente mencionado no documento.
} 
compreender a especial relevância atribuída ao "Compromisso", na lei relativa ao Arquivo de Joinville.

O "Compromisso de Brasília" procurou integrar as várias instâncias administrativas em torno da preservação do patrimônio cultural: reconhecia-se "a inadiável necessidade de ação supletiva dos Estados e dos Municípios à atuação federal no que se refere à proteção dos bens culturais de valor nacional" (item 1). Indicou ainda uma tomada de posição oficial quanto ao significado de bens culturais que, tendo relevância em nível local ou regional, não ganhavam atenção do órgão de preservação federal. No documento anexo ao “Compromisso", datado também de 1970 e assinado por Lúcio Costa, afirmava-se:

[...] no acervo de cada região há obras significativas e valiosas cuja preservação escapa à alçada federal; é, pois, chegado o momento de cada Estado criar o seu próprio serviço de proteção vinculado à universidade local, às municipalidades e à DPHAN [...]. ${ }^{10}$

Assim, o encontro fixou, em seu documento final, ser competência dos estados e municípios, "com a orientação técnica da DPHAN, a proteção dos bens culturais de valor regional" (item 2). O mesmo documento, em seu item 9, entendeu ser "o culto do passado elemento básico da formação da consciência nacional" (passagem citada na lei de criação do Arquivo de Joinville). Quanto aos arquivos, recomendou, no item 11, a defesa de seu acervo, "de modo a ser evitada a destruição de documentos, ou tendo por fim preservá-los convenientemente", sendo para isso "apreciável a colaboração do Arquivo Nacional com as congêneres repartições estaduais e municipais."

Dois pontos do "Compromisso" são ainda significativos, no que tange às possíveis influências nas políticas culturais catarinenses. No item 10, entende-se caber "às universidades o entrosamento com bibliotecas e arquivos públicos nacionais, estaduais, municipais, bem assim os arquivos eclesiásticos e de instituições de alta cultura”, incentivando "a pesquisa quanto à melhor elucidação do passado e à avaliação de inventários dos bens regionais cuja defesa se propugna". No item 20, recomenda-se "utilização preferencial, para casas de cultura ou repartições de atividades culturais, dos imóveis de valor histórico e artístico cuja proteção incumbe ao poder público". ${ }^{11}$ Ecos da valorização do papel

\footnotetext{
${ }^{10}$ Ibidem, p. 167.

${ }^{11}$ Ibidem, p.163-165.
} 
das universidades e dos arquivos eclesiásticos são detectáveis nos encontros catarinenses de arquivos, em especial nos primeiros (ver Parte II, Capítulo 1). Quanto à escolha de "imóveis de valor histórico e artístico" para abrigar atividades culturais, a preocupação aparece nas leis que formalmente criam os arquivos municipais de Indaial, Campos Novos e Pinheiro Preto (ver Apêndice II-20).

Em 1971, encontro similar ao de 1970, desta vez realizado em Salvador, novamente enfatizou o papel das universidades, recomendando-se convênios com o órgão de preservação federal (então Instituto do Patrimônio Histórico e Artístico Nacional - IPHAN) para a elaboração de "inventário sistemático dos bens móveis de valor cultural, inclusive dos arquivos notariais", bem como para a criação de centros universitários de estudo voltados "à investigação do acervo natural e de valor cultural em suas respectivas áreas de influência". ${ }^{2}$

Nos primeiros anos da década de 1970, o "Compromisso de Brasília" foi uma das referências no planejamento de ações culturais no âmbito do governo estadual de Santa Catarina. O "programa cultural” para 1971-1972 tinha, entre seus quinze projetos, um deles especialmente dedicado à "dinamização para a execução do Compromisso de Brasília": abrangia "estudos e diretrizes para a criação do Serviço de Proteção aos Bens Culturais do Estado de Santa Catarina", "colaboração para a criação do Museu do Mar de Santa Catarina" e "estudo de criação e instalação do Museu Histórico de Santa Catarina". ${ }^{13}$ Apesar de nenhum daqueles projetos abordar especificamente a questão dos arquivos municipais, ela estava no horizonte das preocupações do Departamento de Cultura estadual: segundo Carlos Humberto Corrêa, seu então diretor (e signatário, cabe lembrar, do "Compromisso de Brasília"),

Câmaras municipais, prefeituras, paróquias, cartórios etc, órgãos que geralmente não dão importância a seus arquivos, quando os possuem, serviriam de elementos de pesquisa documental para levantamentos históricos inéditos ou correções de conceitos arcaicos, através de processos modernos de metodologia de pesquisa e de restauração de documentos antigos.

\footnotetext{
${ }^{12}$ Compromisso de Salvador. In: Cartas patrimoniais, op.cit., p.173 (respectivamente itens 16 e 19).

${ }^{13}$ Programa da política de assistência cultural do Departamento de Cultura da Secretaria de Governo do Estado de Santa Catarina. In: CABRAL, Oswaldo R., et al. Povo e tradição em Santa Catarina. Florianópolis: EDEME, [1971]. (Realidade Catarinense) p.128. Teriam contribuído significativamente para a elaboração do programa Jali Meirinho, Theobaldo Costa Jamundá e Augusto N. Souza, à época diretores de divisão do Departamento de Cultura (p.120).
} 
Corrêa assinalava, também, aspectos que coincidiam com algumas das linhasmestras da historiografia catarinense ligada ao IHGSC (entidade à qual seria admitido como sócio efetivo em 1973): de um lado, a perspectiva cívico-patriótica; de outro, a defesa da pesquisa histórica fundamentada em documentação (sobretudo arquivística). Considerou:

[...] o centro-oeste catarinense, principalmente, além de outras regiões, mostra provas da não-utilização de seus arquivos pela falta ou pela inexistência de uma séria pesquisa histórica, não só com o objetivo de desenvolver o amor pela própria terra, através de exemplos de homens que por ela passaram, mas principalmente encontrar os verdadeiros alicerces culturais e as relações existentes entre Santa Catarina e os Estados vizinhos. Assim, como elemento importante dos objetivos da programação cultural, devem ser incluídos direta ou indiretamente processos incentivadores à pesquisa histórica através da documentação municipal. ${ }^{14}$

Cabe ressalvar que, na década de 1970, a relação entre o "histórico" e o "antigo", embora forte, não era meramente sinonímica. É o que deixam entrever os textos legais aqui examinados, em passagens que discriminam os acervos dos arquivos municipais.

O Arquivo de Itajaí deveria "guardar e conservar" tanto documentos "antigos" como "recentes": era o caso, por exemplo, dos "mapas geográficos do Município de Itajaí, da cidade e de partes da área da cidade" (deveriam ser coletados "desde os mais antigos aos mais atualizados, mandados levantar pelo Governo Municipal ou particulares"). Percebe-se que a historicidade não é compreendida como necessariamente centenária, pois o acervo deveria ainda ser composto de "livros e documentos históricos, de interesse do Município, com mais de dez anos, que se encontram depositados nos arquivos das repartições públicas municipais". Por outro lado, o caráter histórico dos documentos poderia tanto ser, por suposto, claramente reconhecível (veja-se que deveriam integrar o Arquivo de Itajaí "documentos históricos de qualquer natureza") como existir de forma latente: no Arquivo deveriam estar guardados, segundo a lei de 1977, "documentos provenientes de repartições municipais ou de instituições privadas, e mesmo de particulares, que possam interessar à história ou ciências afins". ${ }^{15}$

\footnotetext{
${ }^{14}$ Citações extraídas de: CORRÊA, Carlos Humberto. A problemática da difusão e do planejamento cultural em Santa Catarina. In: CABRAL, Oswaldo R., et al. Povo e tradição..., op.cit., respectivamente p.116 e 117.

${ }^{15}$ Decreto municipal [Itajaí] nº. 1.543, de 27 de janeiro de 1977 , Art. $3^{\circ}$. Grifos meus.
} 
No caso do Arquivo de Joinville (e, por extensão, do de São Bento do Sul), a documentação "histórica" a ser abarcada pela entidade municipal conectava-se, antes de tudo, com a trajetória da administração do município (nele deveria estar "toda documentação ligada à administração de Joinville, desde a fundação"). ${ }^{16}$ Nota-se a preocupação com a documentação referente à Câmara Municipal, mas também, muito intensamente, com as estruturas administrativas a ela anteriores - em especial, aquelas ligadas a empreendimentos de colonização encetados no século XIX, ressaltando a forte presença de imigrantes de origem germânica e seus descendentes. Faz-se, neste sentido, detalhada discriminação de documentos a serem incorporados ao acervo do Arquivo de Joinville. A intenção era reunir (como originais ou reproduções) "toda" a documentação" referente:

- "ao extinto 'Colonisations Verein von 1849, zu Hamburg"”;

- "às diversas Diretorias da Colônia Francisca, com sede em Joinville";

- “à colonização geral” do Município, "seja do 'Domínio Dona Francisca', do 'Domínio Pirabeiraba' [...] e quaisquer outros empreendimentos de colonização, que tenham tido a sua sede nesta cidade, em qualquer época de sua História";

- “à extinta 'Vertreterschaft der Vereingten Grudeigenthumer von Joinville' (Associação representativa dos proprietários coligados de imóveis de Joinville)";

- "à Hanseatische Kolonisation Gesellschaft m.b.H”. ${ }^{17}$

A lei de criação do Arquivo de Joinville foi generosa na abrangência do acervo e, em princípio, não estava remetida exclusivamente a uma perspectiva "germanista": seriam reunidos documentos oficiais e particulares e, entre os primeiros, do Executivo, do Legislativo ou do Judiciário, produzidos em âmbito federal, estadual ou municipal. No Arquivo seriam abrigados documentos impressos ou manuscritos, textuais, iconográficos ou audiovisuais: toda documentação que atestasse a diversidade das práticas e relações sociais tecidas e entretecidas no âmbito do município - além dos registros governamentais, registros de atividades comerciais, industriais, agropecuárias, escolares, cartoriais, eclesiásticas, consulares, jornalísticas, associativas... Tudo aquilo que dissesse respeito ou fizesse alusão a

\footnotetext{
${ }^{16}$ Lei municipal [Joinville] $\mathrm{n}^{\mathrm{o}}$. 1.182, de 20 de março de 1972, Art. $3^{\circ}$., inciso I.

${ }^{17}$ Os mesmos documentos são citados no decreto que regulamentou a lei de criação do Arquivo de São Bento do Sul, com exceção dos referentes à associação de proprietários de imóveis de Joinville (ver Decreto municipal [São Bento do Sul] nº. 246 de 1 de abril de 1985, Art. $4^{\circ}$ ).
} 
Joinville: mapas, leis, jornais, monografias, textos literários, cartões postais, filmes, registros fotográficos... Enfim,

[...] qualquer documento, em qualquer língua, de qualquer época de sua História, impresso, manuscrito, fotocopiado ou filmado, que sirvam [sic] para elucidar qualquer fato ocorrido em qualquer época de sua História, ou também dos fatos que conduziram à sua Fundação. ${ }^{18}$

Vislumbra-se, na ânsia discriminativa, a preocupação com nada relegar, nada esquecer: tudo que de alguma forma pudesse estar associado a Joinville mereceria lugar, em seu Arquivo. ${ }^{19}$

A fúria colecionista joinvilense, espraiando-se infinitamente por espécies documentais e dimensões do cotidiano na sucessão dos anos, conhece, entretanto, eventos e personagens privilegiados que afloram dessa imensa superfície. No século XIX, a Guerra do Paraguai e sobretudo uma Joinville dos colonos germânicos e "dos príncipes" (destacada na alusão às "publicações, em qualquer língua, alusivas à Princesa Dona Francisca e ao seu esposo, o Almirante Príncipe de Joinville”, igualmente a serem coletadas). No século XX, a Joinville que participa de conflitos armados como a Revolução Federalista de 1893 e "quaisquer outras Revoluções", além da Segunda Guerra Mundial."20 A História dos "grandes acontecimentos" e dos "grandes homens", tantas vezes associada a uma "história tradicional", encontra também o seu lugar: além das "batalhas", além das figuras da nobreza ligadas ao que se considera primórdios da história local, "as famílias e os vultos mais notáveis do Passado de Joinville", cuja documentação deveria ser abrigada no Arquivo na forma de originais (quando doados) ou de reproduções. ${ }^{21}$

\footnotetext{
${ }^{18}$ Lei municipal [Joinville] $\mathrm{n}^{\circ}$. 1.182, de 20 de março de 1972, Art. $7^{\circ}$. O mesmo artigo, com pequenas alterações, aparece no decreto de São Bento do Sul anteriormente referido (Art. 11); a maior parte dos documentos que aparecem na lei de Joinville é também referida nesse decreto.

${ }^{19}$ Não foram esquecidos, por exemplo, listas telefônicas (Lei municipal [Joinville] n ${ }^{\circ}$. 1.182, de 20 de março de 1972, Art. $3^{\circ}$., inciso XVII), selos e estampas relativos a festas e eventos comemorativos (mesmo artigo, inciso XXI), manifestos e panfletos, "de caráter político ou não" (Art. $4^{\circ}$. , inciso II).

${ }^{20}$ Ibidem, Art. $3^{\circ}$., inciso III e Art. $4^{\circ}$., inciso III. No Decreto municipal [São Bento do Sul] n ${ }^{\circ}$. 246, de $1^{\circ}$. de abril de 1985, a Guerra do Paraguai foi excluída, mas incluída a Primeira Guerra Mundial (Art. $4^{\circ}$., inciso XVI).

${ }^{21}$ Lei municipal [Joinville] no. 1.182, de 20 de março de 1972, Art. $5^{\circ}$. Ainda uma vez, vale salientar a emulação, por parte de São Bento do Sul: seu Arquivo município aceitaria "também, para guarda e conservação, documentos ligados às famílias tradicionais sãobentenses, de qualquer origem [...] reunindo dessa forma uma documentação histórica, a mais completa possível, sobre as famílias e os vultos mais notáveis do passado de São Bento do Sul, seja no setor administrativo, econômico e também cultural" (Decreto municipal [São Bento do Sul] $\mathrm{n}^{\mathrm{o}}$. 246, de 1 de abril de 1985 , Art.5 ${ }^{\circ}$. Grifos meus).
} 
Nada é especificado acerca da composição do acervo do Arquivo de Blumenau na legislação de criação da Fundação "Casa Dr. Blumenau" - talvez, porque o Arquivo já existisse de fato há mais tempo, não só como conjunto documental, mas como espaço de consulta e pesquisa pública, já apresentando um determinado perfil.

Relatório do prefeito de Blumenau, Frederico Busch Jr., apresentado em 1949 à Câmara Municipal, discorria sobre a importância do arquivo para a administração e destacava os investimentos feitos na sua organização. Aos interesses da administração somavam-se os da população em geral, pois, em 1950, o mesmo prefeito informava sobre a intensa visitação de que era objeto o arquivo municipal:

Tem sido visitado por grande número de pessoas, principalmente o foi na época que precedeu os festejos do Centenário, contando-se, entre os visitantes ilustres, historiógrafos e jornalistas que vinham colher abundante material para publicações referentes à nossa Comuna, o que vem demonstrando a utilidade desta Repartição. ${ }^{22}$

Já aberto à consulta pública, portanto, no início dos anos 1950, no final daquela mesma década o Arquivo de Blumenau sofreria um revés que marcaria indelevelmente toda a sua trajetória posterior: em fins de 1958, incêndio destruiu a documentação, além de parte do edifício da Prefeitura Municipal (onde também estava abrigado o Fórum). Segundo relatório do prefeito municipal:

Manuscritos pessoais, do fundador da nossa Comuna, Dr. Hermann Bruno Otto Blumenau, bem como todo o documentário referente à vida social, política, econômica e administrativa de Blumenau, desde a sua fundação em 1850 até o ano de 1957, tudo ficou em cinzas, o que é realmente de lamentar. Foi uma perda irreparável para o Município. Esse mesmo Arquivo, por ocasião do Centenário de Blumenau, esteve aberto à visitação pública, tendo

${ }^{22}$ Relatório dos negócios administrativos do Município de Blumenau, referente ao ano de 1950, apresentado à Câmara Municipal pelo Prefeito Frederico Guilherme Busch Júnior. S.L.p.: s.c.p., s.d. s.p.. Também Relatório da gestão dos negócios administrativos do Município de Blumenau durante o ano de 1949, apresentado à Câmara Municipal pelo Prefeito Frederico Guilherme Busch Júnior. Blumenau (SC): Tipografia e Livraria Blumenauense, s.d. p.43-44. 
merecido unânime manifestação da Imprensa Brasileira, de que era o mais completo de todos quanto existiam no País.

Também a valiosa Biblioteca Jurídica, os arquivos dos Cartórios do Crime, do Cível e Comercial, dos vários Tabelionatos, do Cartório de Órfãos e do Cartório Eleitoral foram consumidos pelo fogo. ${ }^{23}$

Após o incêndio, parte do conteúdo dos materiais originais foi recuperada a partir de cópias anteriormente feitas por pesquisadores, como José Ferreira da Silva e Oswaldo Cabral, ganhando divulgação por meio do periódico Blumenau em Cadernos. ${ }^{24}$

Ainda quanto aos arquivos municipais institucionalizados na década de 1970, cabe destacar que o decreto que regulamenta o Arquivo de São Bento do Sul, em tantos pontos assemelhado à lei de criação do Arquivo de Joinville, apresenta, contudo, aspectos peculiares, e que parecem assinalar, por assim dizer, a transição para um outro momento das discussões que, no país, envolveram os arquivos. Elaborado em 1985, o decreto de São Bento do Sul antecipa em parte o Decreto estadual nº 1.444, de 23 de março de 1988. Assim:

\section{Quadro 1}

Similaridades entre o Decreto municipal (São Bento do Sul) $n^{o} .246 / 1985$

e o Decreto estadual $n^{\circ}$. $1.444 / 1988$

\begin{tabular}{|c|c|}
\hline $\begin{array}{l}\text { Decreto municipal (São Bento do Sul) } \\
n^{0} .246 \text {, de 01/04/1985 }\end{array}$ & $\begin{array}{l}\text { Decreto estadual } n^{0} .1 .444, \\
\text { de } 23 \text { de março de } 1988\end{array}$ \\
\hline $\begin{array}{l}\text { Art. } 1^{\circ} \text { - É dever do Poder Público a proteção } \\
\text { especial de documentos de arquivo como } \\
\text { elementos de prova e instrumentos de apoio à } \\
\text { administração, à cultura e ao desenvolvimento } \\
\text { científico. }\end{array}$ & $\begin{array}{l}\text { Considerando que é dever do Poder Público a } \\
\text { proteção especial de documentos de arquivo, } \\
\text { como elemento de prova e instrumento de apoio à } \\
\text { administração, à cultura e ao desenvolvimento } \\
\text { científico. }\end{array}$ \\
\hline
\end{tabular}

\footnotetext{
${ }^{23}$ Relatório dos negócios administrativos do Município de Blumenau referente ao ano de 1958, apresentado à Câmara Municipal pelo Prefeito Frederico Guilherme Busch Júnior. Blumenau (SC): Tipografia e Livraria Blumenauense, s.d. p.7.

${ }^{24}$ Relatório apresentado por José Ferreira da Silva ao Prefeito Municipal [de Blumenau], Dr. Carlos Zadrozny, sobre os setores culturais do governo municipal, 20 de janeiro de 1966. Cópia carbono, datilografada. Acervo: Arquivo Histórico José Ferreira da Silva. s.p. Também: Blumenau em Cadernos, Blumenau (SC): t.I, n.11, nov.1958, p.214-217; t.I, n.12, dez. 1958, p.221; t. II, n.8, ago.1959, p.155. No Blumenau em Cadernos de agosto de 1959, Frederico Kilian informou: "Por um feliz acaso, achamos entre os escombros e cinzas do prédio do "Fórum" e Arquivo de Blumenau, destruídos pelo incêndio do dia 8 de novembro de 1958, e salvamos, vários livros de atas da Câmara de Blumenau, que, embora carbonizados nas partes externas e nas margens, ainda permitem leitura, em grande parte, das atas neles lavradas." (p.155).
} 


\begin{tabular}{|c|c|}
\hline $\begin{array}{l}\text { Art. } 2^{\circ} \text {. - Consideram-se arquivos, para os fins do } \\
\text { presente Decreto, o conjunto de documentos, } \\
\text { organicamente acumulados, produzidos ou } \\
\text { recebidos por pessoa física e instituições públicas } \\
\text { ou privadas, em decorrência do exercício de } \\
\text { atividades específicas, qualquer que seja o suporte } \\
\text { da informação ou a natureza do documento. }\end{array}$ & $\begin{array}{l}\text { fins deste Decreto, o conjunto de documentos, } \\
\text { organicamente acumulados, produzidos ou } \\
\text { recebidos por pessoa física e instituições } \\
\text { públicas*, qualquer que seja o suporte da } \\
\text { informação ou a natureza do documento. } \\
\text { *não há menção, neste trecho, às instituições } \\
\text { privadas. }\end{array}$ \\
\hline $\begin{array}{l}\text { Art. } 9^{\circ} . \text { - O Arquivo Hi } \\
\text { Bento do Sul é inalienáv } \\
\text { que os documentos int } \\
\text { poderão, sob qualquer c } \\
\text { ser eliminados, destruído }\end{array}$ & $\begin{array}{l}\text { são inalienáveis e imprescritíveis. } \\
\text { Art. } 14 \text { - Os documentos integrantes de arquivos } \\
\text { permanentes [...] não poderão, sob qualquer } \\
\text { circunstância ou pretexto, ser eliminados ou } \\
\text { destruídos. }\end{array}$ \\
\hline $\begin{array}{l}\text { Art. } 10-\text { Aquele que desfigurar } \\
\text { documentos de valor permane } \\
\text { responsabilizado penal, civil e a }\end{array}$ & $\begin{array}{l}\text { Art. } 15 \text { - Aquele que desfigurar ou de } \\
\text { documentos de valor permanente } \\
\text { responsabilizado penal, civil e admini }\end{array}$ \\
\hline
\end{tabular}

Como já referido (Parte II, Capítulo 1), foi provavelmente o projeto de lei sobre a política nacional de arquivos elaborado na década de 1980 (que daria origem à Lei federal $\mathrm{n}^{\circ}$. 8.159/1991) a matriz do decreto estadual de 1988. O mesmo teria ocorrido, ao que tudo indica, no caso do decreto sãobentense. Cabe descartar, como possíveis referências, os decretos federais referentes ao Sistema de Serviços Gerais dos órgãos civis da administração federal e ao Sistema Nacional de Arquivos (SINAR) ${ }^{25}$ : neles há apenas dispositivos relativos ao funcionamento dos sistemas e à articulação entre seus órgãos, não havendo preocupação em conceituar arquivos, estabelecer deveres do Poder Público em relação a eles ou, ainda, dispor sobre a guarda e eliminação de documentos públicos. Um outro modelo possível seria o projeto "Arquivos", elaborado no âmbito da Associação Brasileira de Normas Técnicas, em 1982, e que teria tido "ampla circulação" no meio arquivístico brasileiro. ${ }^{26}$ Mais provável, porém, como base, é mesmo o Projeto de Lei $\mathrm{n}^{\circ} .4 .895-\mathrm{A} / 84$, relativo a uma política nacional

\footnotetext{
${ }^{25}$ Respectivamente, Decreto federal $\mathrm{n}^{\mathrm{o}}$. 75.657, de 24 de abril de 1975, e Decreto federal $\mathrm{n}^{\mathrm{o}}$. 82.308, de 25 de setembro de 1978. Textos legais disponíveis em: ASSOCIAÇÃO DOS ARQUIVISTAS BRASILEIROS. Arquivologia: textos e legislação. Rio de janeiro: 1979.p.28-38.

${ }^{26}$ Sobre o projeto e sua circulação, ver: BELLOTTO, Heloísa L., CAMARGO, Ana Maria de Almeida (coord.). Dicionário de Terminologia Arquivística, op.cit., p.IX (“Apresentação”). Trata-se do projeto 14:04-01, da ABNT.
} 
de arquivos, e que ficou alguns anos tramitando no Congresso $\mathrm{Nacional}^{27}$ : os pontos destacados no Quadro 1 estão igualmente presentes, com algumas modificações, na Lei federal no.8.159/1991 (a "lei de arquivos"). ${ }^{28}$

Em meados da década de 1980, os arquivos brasileiros, sem que fosse abandonado o elo com o "passado", passaram a ser mais freqüentemente atrelados à palavra-chave "cidadania" - o que é perceptível na legislação referente aos arquivos municipais catarinenses.

\section{Os arquivos institucionalizados após 1988: cidadania e direito à memória}

A partir de 1988, a institucionalização de arquivos municipais, antes restrita, em Santa Catarina, ao norte do estado e ao vale do Itajaí, expandiu-se por outras regiões. Além disso, assinalaram-se mudanças nas vinculações administrativas até então mais costumeiras.

Antes de 1988, os arquivos municipais catarinenses aparecem, na legislação, ligados à área da cultura: quer a fundações culturais (Blumenau, Itajaí) quer a equipamentos culturais específicos dos municípios. Neste último caso, ainda que apresentadas como soluções provisórias, estão as vinculações dos arquivos às bibliotecas públicas municipais (caso de Jaraguá do Sul, em 1971, e de Joinville, em 1972) ou a centros culturais (como o Centro de Cultura de Indaial, diretamente subordinado, aliás, ao Prefeito). ${ }^{29}$

A partir de 1988, talvez sob influência do Decreto estadual 1.444/1988, ou da Lei federal 8.159/1991, as vinculações foram estabelecidas tanto com a esfera cultural como com

27 COSTA, Célia Maria Leite, FRAIZ, Priscila Moraes V. Acesso à informação nos arquivos brasileiros. Estudos históricos, Rio de Janeiro, v.2, n.3, 1989, esp. p. 69-70.

${ }^{28}$ Ver, a este respeito, na lei federal de 1991: "É dever do poder público a gestão documental e a proteção especial a documentos de arquivos, como instrumento de apoio à administração, à cultura e ao desenvolvimento científico e como elemento de prova e informação." (Art. $1^{\circ}$ ); "Consideram-se arquivos, para os fins desta Lei, os conjuntos de documentos produzidos e recebidos por órgãos públicos, instituições de caráter público e entidades privadas, em decorrência de exercício de atividades específicas, bem como por uma pessoa física, qualquer que seja o suporte da informação ou a natureza dos documentos." (Art.2 $2^{\circ}$ ); "Os documentos de valor permanente são inalienáveis e imprescritíveis." (Art. 10); "Ficará sujeito à responsabilidade penal, civil e administrativa, na forma da legislação em vigor, aquele que desfigurar ou destruir documentos de valor permanente ou considerados de interesse público e social." (Art. 25). O texto completo da lei está disponível, entre outras publicações, em: JARDIM, José Maria. Transparência e opacidade do Estado no Brasil: usos e desusos da informação governamental. Niterói (RJ): Editora da Universidade Federal Fluminense, 1999. p.217221.

${ }^{29}$ A subordinação administrativa não é explicitada no caso do Arquivo de São Bento do Sul. Ver Apêndice II-19. 
a esfera mais propriamente administrativa do Executivo municipal. Neste último caso (marcadamente, no período 1991-1995), estão os arquivos dos municípios de Concórdia, São José, Chapecó, Balneário Camboriú, Florianópolis e Serra Alta, embora as respectivas leis dos dois primeiros não sejam, a este respeito, muito precisas (os demais aparecem claramente ligados a secretarias de administração). ${ }^{30}$ Outros arquivos foram subordinados diretamente aos gabinetes dos prefeitos (Pinheiro Preto, Biguaçu e Capivari de Baixo), mas, à exceção de Capivari de Baixo, apareceram associados também à esfera cultural, em função do local destinado ao seu funcionamento (uma sala anexa ao Museu Municipal, em Pinheiro Preto; a Biblioteca Municipal, em Biguaçu). ${ }^{31}$ Os elos privilegiados com a área da cultura foram mantidos mais diretamente nos demais, através das fundações culturais (Ipumirim, Rio do Sul, Criciúma) ou por meio da integração dos arquivos às secretarias de cultura (Campos Novos - no âmbito da "Casa de Cultura de Campos Novos" -, Jaraguá do Sul - em 1991 -, Tubarão, Nova Erechim, Ibirama). ${ }^{32}$ A vinculação/subordinação administrativa não é explicitada, porém, nos casos dos arquivos de Itaiópolis e Canoinhas. ${ }^{33}$

A articulação à área estritamente administrativa nem sempre descartou trabalho conjunto com a de cultura. Em Chapecó e Serra Alta, ambos os arquivos estariam vinculados a secretarias de Fazenda e Administração, sendo que, "no interesse da administração e sempre que oportuno", atuariam articuladamente com o Departamento de Patrimônio Histórico e Memória (no caso de Chapecó) e com a Biblioteca Pública Municipal (no caso de Serra Alta). O inverso aconteceria com o Arquivo de Nova Erechim, criado como órgão "integrante da estrutura da Secretaria Municipal da Educação, Cultura e Esporte”: tal secretaria deveria atuar "articuladamente" com a Secretaria Municipal da Administração e Finanças. ${ }^{34}$ De modo

\footnotetext{
${ }^{30}$ Ver Apêndice II-19. O Decreto municipal [Concórdia] nº. 2.892, de 19 de dezembro de 1991, previa a existência de um "Arquivo Central do Município", sendo que a Secretaria de Administração, por intermédio da Coordenadoria de Documentação e Publicações, definiria "as diretrizes da política arquivística do Município." (Art.18). A mesma incumbência, por intermédio de Coordenadoria similar, caberia à Secretaria de Administração de São José (Lei municipal no . 2.436, de 10 de dezembro de 1992, Art. 22). A menção a uma "Coordenadoria de Documentação e Publicações" aponta que, nos dois casos, o decreto estadual de 1988 serviu como referência.

${ }^{31}$ Ver Apêndice II-20.

${ }^{32}$ Ver Apêndice II-20. Na legislação em causa, a área da cultura, quando no âmbito das secretarias, geralmente estava integrada à de educação e à de esportes.

${ }^{33}$ Ver Apêndice II-20. Em Canoinhas, a lei apenas cria o arquivo, ficando prevista regulamentação pelo Executivo Municipal (Lei municipal n. 2.903, de 22 de outubro de 1997, Art.2 ${ }^{\circ}$.).

${ }^{34}$ Lei municipal [Chapecó] n ${ }^{\circ}$. 3.536, de 10 de agosto de 1993 (Art. 3 ${ }^{\text {o, }}$, parágrafo único); Lei municipal [Serra Alta] $n^{\circ} .314$, de 25 de outubro de 1995 (Art. 3 ${ }^{\text {o, }}$, parágrafo único); Lei municipal [Nova Erechim] n ${ }^{\circ} .890$, de 10 de março de 1998 (Arts. $1^{\circ}$. e $3^{\circ}$.).
} 
similar, o Arquivo de Criciúma, vinculado à Fundação Cultural de Criciúma, teria relações estreitas com a Secretaria de Administração, uma vez que esta última seria responsável pela elaboração do Plano de Destinação da Documentação Municipal e, em conjunto com a Fundação, pela confecção do regimento interno do Arquivo. ${ }^{35}$

A compreensão dos arquivos municipais como prioritariamente "culturais" ou "administrativos" teria correspondido a diferentes visões quanto ao acervo a ser por eles abarcado?

No que tange aos "culturais", a lei de institucionalização do Arquivo de Campos Novos (onde o Arquivo integrava uma das unidades da Casa de Cultura) indica a sua compreensão fundamentalmente como um centro de documentação, sem preocupação especial com os documentos gerados pela administração municipal. Assim, seria responsável pela guarda e organização de "documentos históricos, fotografias, filmes, vídeo-cassetes, fitas cassetes e objetos que demonstrem a evolução da história de Campos Novos ou que a ela se relacionem". ${ }^{36}$ Nos demais arquivos mais marcadamente situados na área cultural da administração municipal, a abrangência do acervo também deveria ser ampla:

\section{Quadro 2}

Composição dos acervos dos arquivos municipais catarinenses, segundo a legislação posterior a 1988: arquivos da esfera "cultural"

\begin{tabular}{|c|c|}
\hline Composição do acervo de cada arquivo municipal & Textos legais \\
\hline $\begin{array}{l}\text { Acervo composto por "qualquer documento escrito - } \\
\text { manuscrito ou impresso -, iconográfico, } \\
\text { fonofotográfico, pertencente a entidades públicas - } \\
\text { Executivo, Legislativo e Judiciário - e particulares, } \\
\text { culturais, religiosas, pessoas físicas, estabelecimentos } \\
\text { rurais, comerciais, industriais e outras", com o intuito } \\
\text { de "resguardar a memória do Município e sua gente". }\end{array}$ & $\begin{array}{l}\text { Lei municipal [Itaiópolis] } \mathrm{n}^{\circ} .16 \text {, de } 22 \text { de } \\
\text { fevereiro de } 1989 \text { (Art. } 2^{\circ} . \text {, a e b). } * \\
\text { Lei municipal [Tubarão] }{ }^{\circ} \text {. } 1.463 \text {, de } 17 \text { de } \\
\quad \text { julho de } 1990 \text { (Art. } 2^{\circ} \text {., a e b). } \\
\text { Lei municipal [Rio do Sul] n }{ }^{\circ} .2 .956 \text {, de } 16 \\
\text { de dezembro de } 1994\left(\text { Art. } 2^{\circ} \text {., a e b). }\right.\end{array}$ \\
\hline $\begin{array}{l}\text { Acervo composto por “documentos de qualquer } \\
\text { natureza e procedência, de natureza jurídica ou não, } \\
\text { privada, administrativa ou pessoal, documentários } \\
\text { fotográficos, fonográficos ou de vídeo e outros, } \\
\text { oriundos da administração municipal, de outros órgãos } \\
\text { públicos e de entidades privadas, } \\
\text { visando a preservação da memória histórico-documental } \\
\text { do Município e sua gente.” }\end{array}$ & $\begin{array}{l}\text { Lei municipal [Jaraguá do Sul] } \mathrm{n}^{\circ} .1 .464 \text {, } \\
\text { de } 10 \text { de maio de } 1991 \text { (Art. } 2^{\circ} \text {., a). }\end{array}$ \\
\hline
\end{tabular}

${ }^{35}$ Lei municipal [Criciúma] no ${ }^{\circ} .3 .670$, de 11 de setembro de 1998 (arts. $9^{\circ}$. e 10).

${ }^{36}$ Decreto municipal [Campos Novos] n'. 2.443, de 12 de abril de 1989, art.14, inciso I. Grifos meus. 


\begin{tabular}{|c|c|}
\hline $\begin{array}{l}\text { Acervo composto por “documentos produzidos ou } \\
\text { acumulados por Instituições Públicas Municipais em } \\
\text { decorrência de suas funções específicas", além de } \\
\text { documentos doados por "entidades ou pessoas físicas } \\
\text { particulares, cuja importância do teor histórico } \\
\text { contribua para o resgate da história do Município." }\end{array}$ & $\begin{array}{c}\text { Lei municipal [Criciúma] } \mathrm{n}^{\circ} .3 .670 \text {, de } 11 \\
\text { de setembro de } 1998 \text { (Art. } 5^{\circ} \text {.). } \\
\text { Lei municipal [Ibirama] } \mathrm{n}^{\mathrm{o}} .2 .301 \text {, de } 18 \text { de } \\
\text { dezembro de } 1998 \text { (Art. } 5^{\circ} \text {.).** }\end{array}$ \\
\hline $\begin{array}{l}\text { Acervo composto por "toda a documentação } \\
\text { permanente e intermediária da administração pública } \\
\text { municipal, legislativa, judiciária e privada quando } \\
\text { solicitada", incluindo "documentos manuscritos, } \\
\text { impressos, cartográficos, audiovisuais." }\end{array}$ & $\begin{array}{c}\text { Lei municipal [Pinheiro Preto] } \mathrm{n}^{\circ} .623 \text {, de } \\
20 \text { de maio de } 1992\left(\text { arts. } 3^{\circ} \text {. e } 4^{\circ} .\right) \\
\text { Lei municipal [Biguaçu] } \mathrm{n}^{\mathrm{o}} .714 \text {, de } 22 \text { de } \\
\text { maio de } 1992\left(\text { arts. } 3^{\circ} \text {. e } 4^{\circ} \text {.). }\right.\end{array}$ \\
\hline
\end{tabular}

Obs.:

* O Arquivo Público e Histórico de Itaiópolis estava subordinado ao "Executivo Municipal". ** Na lei de criação do Arquivo Público Municipal de Ibirama, o texto sofre pequena alteração na alusão às doações, referidas a documentos "de entes jurídicos ou de pessoas físicas, cujo teor contribua para o resgate da história do Município.”

No Quadro 2, observa-se a intenção de reunir uma documentação diversificada, quanto ao gênero e quanto a entidades produtoras/acumuladoras - o que, aliás, já havia sido observado na legislação referente aos arquivos institucionalizados antes de 1988, em especial os de Joinville e de São Bento do Sul. As leis de criação dos arquivos de Pinheiro Preto, Biguaçu, Criciúma e Ibirama, contudo, apresentaram nuances importantes neste universo documental, subentendendo-se a priorização dos documentos produzidos e acumulados propriamente pelas administrações dos municípios. Nestes casos, os documentos de caráter privado (de pessoas físicas ou jurídicas) comporiam o acervo de forma complementar, conforme interesse dessas mesmas entidades (manifestado por meio de doações) ou, supõe-se, do próprio arquivo municipal e, mais amplamente, da municipalidade (caso da documentação privada "solicitada"). De forma geral, foi mantida a perspectiva de guarda dos documentos (privados ou públicos) que fossem valiosos para a memória ou a história do município. ${ }^{37}$

Situado na área de cultura, mas com vínculos estreitos com a de administração, o Arquivo de Nova Erechim teve seu acervo definido da mesma forma que os acervos dos arquivos de Chapecó e Serra Alta (subordinados, por sua vez, a secretarias de administração, porém articulados à de cultura):

${ }^{37}$ Esse compromisso também está na lei que criou o Arquivo Histórico do Município de Florianópolis (Lei municipal [Florianópolis] $n^{\circ}$. 4.491, de 14 de setembro de 1994, Art. $5^{\circ}$.). O texto da lei referente à composição do acervo é rigorosamente o mesmo presente na lei de criação do Arquivo de Criciúma, de 1998. O Arquivo de Florianópolis, porém, estava vinculado à Secretaria Municipal de Administração. 


\section{Quadro 3}

Composição dos acervos dos arquivos municipais catarinenses, segundo a legislação posterior a 1988: arquivos entre as esferas "cultural" $e$ "administrativa"

\begin{tabular}{|c|c|}
\hline Composição do acervo de cada arquivo municipal & Textos legais \\
\hline $\begin{array}{c}\text { Acervo composto pelo "conjunto de documentos produzidos } \\
\text { ou recebidos por instituições governamentais de âmbito } \\
\text { municipal, em decorrência de suas funções administrativas, } \\
\text { legislativas e, no que couber, judiciárias." }\end{array}$ & $\begin{array}{c}\text { Lei municipal [Chapecó] } \mathrm{n}^{\circ} .3 .536, \mathrm{de} \\
10 \text { de agosto de } 1993 \text { (Art. } 2^{\circ} \text { ). } \\
\text { Lei municipal [Serra Alta] } \mathrm{n}^{\circ} .314 \text {, de } \\
25 \text { de outubro de 1995 (Art. } 2^{\circ} \text {.). } \\
\text { Lei municipal [Nova Erechim] } \mathrm{n}^{\circ} .890, \\
\text { de } 10 \text { de março de } 1998 \text { (Art. } 2^{\circ} . \text {.). }\end{array}$ \\
\hline
\end{tabular}

Nas leis desses três últimos arquivos, percebe-se a preocupação com a documentação pública de caráter propriamente municipal (daí a ressalva quanto aos documentos gerados por funções judiciárias). Os elos com a questão da memória, nesses textos legais, estiveram ausentes ou foram estabelecidos de forma indireta (vislumbrados nas alusões à política arquivística do município).

Pela lei do Arquivo de Chapecó, que parece ter servido de base às outras duas, as diretrizes da política arquivística municipal seriam definidas pelo Departamento de Serviços Gerais da Secretaria da Fazenda e Administração, em conjunto com o Departamento de Patrimônio Histórico e Memória da Secretaria da Educação e Cultura (Art. 12). O vínculo com o Departamento de Patrimônio Histórico e Memória remete, de imediato, à lei sobre proteção do patrimônio cultural do município, segundo a qual a "guarda, defesa e conservação dos documentos de interesse histórico" caberia ao Arquivo de Chapecó. ${ }^{38}$ Dispositivo legal que, a rigor, teve o poder de ampliar o escopo da atuação da instituição arquivística, e o universo de seu acervo, dado que os "documentos de interesse histórico" não seriam, necessariamente, apenas aqueles produzidos pela administração municipal.

Por outro lado, se em Serra Alta e Nova Erechim as áreas de administração e cultura também definiriam em conjunto a política arquivística municipal, diferentemente de Chapecó não haveria um órgão de preservação do patrimônio cultural incumbido do diálogo

${ }^{38}$ Lei municipal [Chapecó] no . 3.531, de 25 de junho de 1993 (Art. 22). 
com a Secretaria de Administração. Na lei de Serra Alta, inclusive, o lugar do Departamento de Patrimônio Histórico e Memória é ocupado pela Biblioteca Pública Municipal... ${ }^{39}$

Da consulta à legislação, conclui-se que a posição ocupada pelos arquivos na estrutura administrativa, a partir de 1988, não significou necessariamente o afrouxamento de preocupações com a memória ou a história do município (quando diretamente ligados a gabinetes de prefeitos ou a secretarias de administração) ${ }^{40}$ nem a ausência de procedimentos que envolvessem documentos administrativos em todas as suas fases (e não apenas os da chamada "fase permanente", habitualmente abrigados nos arquivos "históricos"). Entretanto, a abertura para atividades de gestão documental, nos arquivos institucionalizados após 1988, é rara nos casos em que os arquivos não apresentam alguma conexão com a Secretaria de Administração ou com o Gabinete do Prefeito. Exceção, neste sentido, é o Arquivo de Jaraguá do Sul que, recriado em 1991, estaria ligado à Secretaria Municipal de Cultura, Esporte e Turismo: caberia a ele recolher a documentação da chamada fase intermediária, tanto da Prefeitura como da Câmara Municipal, participando da seleção dos documentos a serem preservados. $^{41}$

Por outro lado, a freqüente articulação dos arquivos a mais de um órgão da administração (Fundação Cultural e Secretaria de Administração; Secretaria de Administração e Secretaria da Cultura; Gabinete do Prefeito e Secretaria da Cultura) põe em causa as dificuldades de expressar, nas leis, as complexas finalidades de tais instituições, não abarcáveis plenamente nem na dimensão "cultural" nem na "administrativa". Na década de 1990, os arquivos transitaram entre a memória como culto ao passado e a memória como exercício de cidadania, atrelando-se a esta última também os imperativos da racionalidade administrativa. É o que fica visível na lei de criação do Arquivo de Balneário Camboriú, que articula, na instituição arquivística, políticas de gestão documental e de proteção ao

\footnotetext{
${ }^{39}$ Lei municipal [Serra Alta] no. 314, de 25 de outubro de 1995 (Art. 12); Lei municipal [Nova Erechim] $n^{\circ}$. 890, de 10 de março de 1998 (Art. 10).

40 O Arquivo de Capivari de Baixo, diretamente vinculado ao Gabinete do Prefeito, teria, entre suas competências, "localizar, recolher, reunir, recuperar, organizar e preservar documentação pública e particular em geral, centralizando-a a fim de que possa ser utilizada, pesquisada e divulgada por qualquer forma, com o objetivo de resguardar a memória do município e de sua gente". Lei municipal [Capivari de Baixo] nº.892, de 1 de julho de 2003 (Art. $2^{\circ}$., item a). Nesse aspecto, a lei de Capivari de Baixo é bastante próxima das de Itaiópolis, Tubarão e Rio do Sul.

${ }^{41}$ Lei municipal [Jaraguá do Sul] no .1 .464 , de 10 de maio de 1991 (Art. $8^{\circ}$.).
} 
patrimônio documental arquivístico. ${ }^{42}$

\section{Eficiência e transparência: servir à administração e aos cidadãos}

A preocupação com a gestão documental e, sobretudo, com a avaliação de documentos públicos municipais, não foi exclusiva da lei de criação do Arquivo de Balneário Camboriú, embora não tenha sido predominante na legislação examinada. Os arquivos públicos municipais criados por lei, em Santa Catarina, foram essencialmente compreendidos como instituições arquivísticas voltadas para acervos de caráter permanente - daí, inclusive, a constância com que a palavra "histórico" apareceu em suas denominações. ${ }^{43}$ A má redação de leis e decretos, provavelmente em função do pouco domínio, por parte dos legisladores, das discussões próprias à área arquivística, por vezes até impediu a avaliação de documentos (já que esta envolve, também, a decisão de eliminação): veja-se que, na lei de criação do Arquivo de Ibirama, foram considerados documentos públicos municipais "todos os registros de informações geradas e acumuladas pelos órgãos que compõem a administração pública direta ou indireta da Prefeitura Municipal de Ibirama, no exercício de suas atribuições"; ao mesmo tempo, estabeleceu-se que "a destruição, descaracterização ou desfiguração de documentos públicos do município" seria punida "na forma da Lei”. 44

\footnotetext{
${ }^{42}$ Caberia ao Arquivo "desenvolver política de gestão de documentos adequados [sic] à realidade municipal [e] compatível com todas as necessidades de agilização da informação e eficiência administrativa"; "promover a integração das diferentes fases do ciclo de vida dos documentos"; "assegurar condições de conservação, proteção e acesso ao patrimônio documental". Lei municipal [Balneário Camboriú] no .1 .293 , de 29 de novembro de 1993 (Art. $2^{\circ}$.).

43 Arquivo Histórico de Jaraguá do Sul; Arquivo Histórico Municipal de Joinville; Arquivo Histórico do Município de Blumenau (mais tarde Arquivo Histórico José Ferreira da Silva); Arquivo Histórico do Município de Itajaí; Arquivo Histórico Municipal de São Bento do Sul; Arquivo Histórico do Município de Indaial (mais tarde Arquivo Histórico Municipal Theobaldo Costa Jamundá); Arquivo Histórico Municipal Ipumirense; Arquivo Público e Histórico de Itaiópolis; Arquivo Histórico de Campos Novos; Arquivo Público e Histórico de Porto União; Arquivo Público e Histórico de Tubarão; Arquivo Histórico de Concórdia; Arquivo Histórico Municipal de Pinheiro Preto; Arquivo Histórico Municipal de Biguaçu; Arquivo Histórico de São José; Arquivo Histórico do Município de Balneário Camboriú; Arquivo Histórico do Município de Florianópolis (mais tarde Arquivo Histórico do Município de Florianópolis Professor Osvaldo Rodrigues Cabral); Arquivo Público Histórico de Rio do Sul; Arquivo Histórico de Canoinhas; Arquivo Histórico do Município de Criciúma; Arquivo Público e Histórico do Município de Capivari de Baixo. As exceções: Arquivo Público Municipal de Chapecó; Arquivo Público Municipal de Serra Alta; Arquivo Público Municipal de Nova Erechim; Arquivo Público Municipal de Ibirama.

${ }^{44}$ Lei municipal [Ibirama] nº. 2.031, de 18 de dezembro de 1998 (Arts. $3^{\circ}$. e 4º.). Pelos critérios da Arquivística contemporânea, a punição seria cabível se os documentos não tivessem sido adequadamente avaliados ou se fossem considerados de caráter permanente.
} 
Na década de 1990, todavia, a legislação referente aos arquivos municipais catarinenses registrou preocupação em articulá-los à documentação produzida contemporaneamente, de modo a garantir a renovação dos acervos das instituições criadas. Daí as referências aos documentos municipais nas três fases clássicas de seu ciclo vital, de acordo com a chamada "teoria das três idades": a fase corrente, a intermediária e a permanente. ${ }^{45}$ Há também alusões aos procedimentos de avaliação de documentos municipais, mais freqüentes, aliás, do que à "gestão documental". 46

O decreto municipal que, em Concórdia, dispôs sobre a política municipal de arquivos, estabeleceu o Arquivo Central do Município: a ele caberia recolher documentos dos arquivos intermediários, em âmbito municipal; tais arquivos intermediários, por sua vez, seriam resultado de avaliação e seleção que os arquivos correntes tivessem sofrido. ${ }^{47} \mathrm{O}$ mesmo ocorreria em São José (apenas, na lei municipal, o lugar do Arquivo Central de Concórdia seria ocupado pelo do “Arquivo Histórico Municipal” de São José). ${ }^{48}$ Outros textos legais (leis de Pinheiro Preto, Biguaçu, Chapecó, Serra Alta e Nova Erechim) previram, juntamente com o arquivo de caráter permanente, um arquivo intermediário a ele integrado. ${ }^{49}$

\footnotetext{
${ }^{45} \mathrm{Na}$ área de arquivos, a "teoria das três idades" entende que os documentos de um conjunto documental arquivístico vivem momentos diferentes, de acordo com os valores primários e secundários neles percebidos. Tais valores não só podem ser diferentes, ao longo do tempo, como variar de intensidade. No caso de arquivos institucionais, quando os valores primários (ou seja, diretamente ligados às razões de produção dos documentos) são entendidos como altos, os documentos em geral mantêm sua vigência e possuem consulta freqüente, por isso permanecendo próximos aos órgãos de origem (considera-se estarem na fase "corrente"). Os valores primários e secundários (isto é, aqueles agregados aos primários) determinarão o tempo durante o qual os documentos serão conservados: reduzidos ou findos os valores primários, os valores secundários poderão garantir a guarda dos documentos, quer temporariamente (nos arquivos "intermediários") quer definitivamente (nos arquivos "permanentes"). Note-se que as três fases do ciclo documental estão referidas na Lei federal no. 8.159/91, Art. $8^{\circ}$. ${ }^{46}$ A gestão documental, a rigor, engloba a avaliação, além de outros procedimentos técnicos: seria um "conjunto de medidas e rotinas visando à racionalização e eficiência na criação, tramitação, classificação, uso primário e avaliação de arquivos.” BELLOTTO, Heloísa L., CAMARGO, Ana Maria de Almeida (coord.). Dicionário de Terminologia Arquivística. op.cit..

${ }^{47}$ Decreto municipal [Concórdia] $n^{\circ}$. 2.892, de 19 de dezembro de 1991 (Arts. $3^{\circ}$. , 4 ${ }^{\circ}$., 17). O Arquivo Histórico de Concórdia seria criado no Arquivo Central em 1996 - Decreto municipal [Concórdia] nº. 3.779, de 28 de novembro de 1996 (Art. $1^{\circ}$.).

${ }^{48}$ Lei municipal [São José] no. 2.436, de 10 de dezembro de 1992 (Art. $8^{\circ}$ ).

${ }^{49}$ Lei municipal [Pinheiro Preto] no .623 , de 20 de maio de 1992 (Art. $1^{\circ}, \S 1^{\text {o }}$.); Lei municipal [Biguaçu] n ${ }^{\circ} .714$, de 22 de maio de 1992 (Art. $1^{\circ}$., $\S 1^{\circ}$ ); Lei municipal [Chapecó] $\mathrm{n}^{\mathrm{o}}$. 3.536, de 10 de agosto de 1993; Lei municipal [Serra Alta] no. 314, de 25 de outubro de 1995; Lei municipal [Nova Erechim] nº. 890, de 10 de março de 1998. Em cada município, a função do arquivo intermediário seria receber a documentação municipal futuramente abrigada (em parte) no arquivo permanente. Sutilezas das discussões arquivísticas escaparam a certos legisladores, e a redação das leis às vezes torna imprecisos, ambígüos ou inadequados alguns dispositivos. Em Chapecó, estabeleceu-se que o Arquivo Público Municipal reuniria documentos municipais do Executivo, do Legislativo e, no que coubesse, do Judiciário (Art. $2^{\circ}$.), mas também que seria composto por arquivo corrente, intermediário e permanente (Art. $4^{\circ}$.); a redação do Art. $4^{\circ}$. sugere referência aos documentos acumulados pelo próprio Arquivo, em decorrência de suas funções, e não ao conjunto de documentos municipais. O mesmo problema está presente nas leis de Serra Alta e Nova Erechim.
} 
Neles foram mencionadas "operações de avaliação e seleção" de documentos, e às vezes até mesmo a elaboração de tabelas de temporalidade (Pinheiro Preto e Biguaçu), mas os critérios e procedimentos de avaliação não foram explicitados. ${ }^{50}$

Já as leis de criação dos arquivos de Florianópolis e Criciúma previram ao menos a elaboração, por "Comissão Interdisciplinar", de um "Plano de Destinação da Documentação Municipal". 51

Definir a destinação dos documentos significa, em linhas gerais, determinar sua guarda ou eliminação, e o momento ou período em que ocorrerá. É preciso, portanto, avaliar os documentos, a eles atribuir valores. Para a discussão em torno dos valores, e conseqüentemente da preservação ou não dos documentos, texto de Helena Corrêa Machado, publicado em 1991, recomendava equipes interdisciplinares. ${ }^{52}$ Como assinalou Rose Marie Inojosa, em texto contido na mesma publicação, o produtor do arquivo é o melhor avaliador do valor primário dos documentos, "mas para a avaliação de seus valores secundários e do provável interesse cultural que a documentação pode apresentar, é necessário somar ao julgamento do produtor a apreciação de outros profissionais." ${ }^{33}$ As comissões interdisciplinares previstas em Florianópolis e Criciúma estavam afinadas, portanto, com o debate brasileiro acerca da avaliação. Não está claro se o mesmo ocorreu em Jaraguá do Sul, pois a lei que, em 1991, recriou o arquivo municipal, entendeu que a "seleção da documentação a ser preservada no estágio intermediário" seria feita por equipe "composta por funcionários do Arquivo Histórico" e dos setores de origem dos documentos, "sob a supervisão do diretor do Arquivo",54, não havendo nenhuma referência ao seu caráter interdisciplinar.

\footnotetext{
50 Tanto na lei relativa a Pinheiro Preto (Art. $5^{\circ}$.) como na relativa a Biguaçu (Art. $5^{\circ}$.), seria o arquivo permanente o responsável pela elaboração de tabela de temporalidade (ou seja, pelo instrumento que definiria prazos de guarda - temporária ou definitiva - e eliminação dos documentos, bem como mecanismos de reprodução e eventuais restrições de acesso).

${ }^{51}$ Lei municipal [Florianópolis] $\mathrm{n}^{\mathrm{o}}$. 4.491, de 14 de setembro de 1994; Lei municipal [Criciúma] nº. 3.670, de 11 de setembro de 1998 (Art. 9.).

${ }^{52}$ MACHADO, Helena Corrêa. Contribuição ao estabelecimento de critérios para avaliação de documentos de arquivo. In: CASTILHO, Ataliba Teixeira de (org.). A sistematização de arquivos públicos. Campinas (SP): Editora da UNICAMP, 1991. p.75. O texto de Helena Corrêa Machado circulara, desde 1988, em forma de apostila de aula (cópia eletrostática a partir de original datilografado). Praticamente a mesma composição da equipe interdisciplinar é adotada em publicação técnica posterior, promovida pelo Arquivo Nacional: INDOLFO, Ana Celeste et al. Gestão de documentos: conceitos e procedimentos básicos. Rio de Janeiro: Arquivo Nacional, 1995. p.19.

53 INOJOSA, Rose Marie. Tabelas de temporalidade. In: CASTILHO, Ataliba Teixeira de (org.). A sistematização..., op.cit., p.91.

${ }^{54}$ Lei municipal [Jaraguá do Sul] nº 1.464 , de 10 de maio de 1991 (Art. 8º., § 2º).
} 
A interdisciplinaridade das comissões procuraria garantir uma avaliação atenta aos diversos valores atribuíveis à documentação. Pois, sendo públicos, os documentos não são de interesse apenas da administração, mas do conjunto dos cidadãos, servindo de prova para o exercício de direitos e prendendo-se à prestação de contas que os poderes instituídos devem fazer à coletividade. A avaliação arquivística, portanto, ao menos em sociedades que se pretendem democráticas, faz emergir a questão da transparência nas decisões e atividades realizadas no âmbito dos organismos estatais. Por outro lado, cidadãos e administração pública seriam, em princípio, beneficiados pelos resultados da avaliação: maior controle da massa documental, redução do nível de redundância informativa e garantia de preservação do que fosse significativo, além de racionalização de custos e recursos. ${ }^{55}$

Por serem públicos os documentos avaliados, as decisões tomadas no processo de avaliação deveriam ser divulgadas, proporcionando a manifestação dos cidadãos. $\mathrm{O}$ compromisso com a divulgação não está contido na legislação municipal analisada, mas foi afirmado nos anos 1990, em nível nacional, por meio de resoluções do Conselho Nacional de Arquivos - CONARQ. ${ }^{56}$

A década de 1990 também assinalou a tentativa de aproximar alguns dos arquivos municipais catarinenses criados nos anos 1970 (marcados pela concepção da memória-culto) à perspectiva da memória-direito: foi o que ocorreu com o Arquivo de Jaraguá do Sul, já mencionado, e com o Arquivo de Itajaí, que em 1998 estabeleceu, por lei, uma política de gestão documental (quase que exclusivamente voltada, porém, à avaliação). A lei de Itajaí, ao discriminar os documentos de valor mediato e imediato, estava muito próxima da Lei estadual nº 9.747, de 26 de novembro de 1994. Já as menções a uma "Comissão Central de Avaliação de Documentos - CCAD" (não explicitada, na lei estadual) e a comissões setoriais de

\footnotetext{
55 Segundo Helena Corrêa Machado, a avaliação de documentos de arquivo deveria ter como resultados: "redução, ao essencial, da massa documental dos arquivos"; "aumento do índice de recuperação da informação"; "garantia de condições de conservação da documentação de valor permanente"; "orientação para normalizar o processo de produção documental, bem como no emprego de suportes adequados para o registro de informação"; "conquista de espaço físico e redução de peso"; "melhor aproveitamento de recursos (pessoal e material)", "valorização dos arquivos correntes". MACHADO, Helena Corrêa. op.cit., p.71.

${ }^{56}$ Pela Resolução no. 5 (CONARQ), de 30 de setembro de 1996, os editais para eliminação de documentos, uma vez publicados, deveriam aguardar de 30 a 45 dias para aplicação, prazo dado para "possíveis manifestações" ou para "possibilitar às partes interessadas requererem, a suas expensas, o desentranhamento de documentos ou cópias de peças de processos." (Art. $2^{\circ}$.). A publicidade de editais de ciência de eliminação de documentos também foi prevista na Resolução nº 7 (CONARQ), de 20 de maio de 1997 (Art. 5.). Cf.: BERNARDES, Ieda Pimenta. Como avaliar documentos de arquivo. São Paulo: Associação de Arquivistas Brasileiros - Núcleo Regional de São Paulo, Arquivo do Estado, 1998. (Projeto Como fazer, 1). p.84-87.
} 
avaliação documental, bem como a um Arquivo Intermediário (então criado) ${ }^{57}$, remetem tanto aos decretos que, em Florianópolis, buscaram implantar uma política de gestão documental no município $^{58}$, como à provável matriz de todos esses textos legais - a saber, o Decreto municipal nº 29.745/1991 que, em São Paulo, estabeleceu normas de avaliação e destinação para os documentos públicos municipais (ver Parte II, Capítulo 1).

Em Florianópolis, a coordenação das atividades arquivísticas em âmbito municipal foi claramente concebida de forma sistêmica: objetivava-se a implantação de um "Sistema Único de Arquivos Municipais", e os esforços neste sentido seriam, no entender do então prefeito, Sérgio Grando, uma "conquista no direito da cidadania plena". ${ }^{59}$ Concórdia, por sua vez, transpondo para a realidade municipal o Decreto estadual $n^{\circ}$. 1.444/1988, concebeu, em 1991, um Subsistema Municipal de Arquivos, que teria como órgão central (com função de coordenação) a Coordenadoria de Documentação e Publicações, apoiada pela Comissão Municipal de Arquivos (órgão consultivo e de assessoramento técnico). ${ }^{60}$

Com ou sem sistema de arquivos, com ou sem avaliação de documentos, o certo é que a legislação referente aos arquivos municipais catarinenses buscou garantir o acesso dos cidadãos à documentação pública. Acesso nem sempre livre, nem sempre amplo, nem sempre gratuito: restrições foram feitas, conforme a categoria dos documentos ou o perfil do usuário.

A documentação de caráter sigiloso foi objeto de ressalvas: em Jaraguá do Sul, embora a consulta aos documentos reservados pudesse ser autorizada pelo diretor do Arquivo, as razões do interesse deveriam ser explicadas - curiosamente, não pelo próprio interessado, mas "pelo responsável pela instituição" à qual pertencesse o pesquisador (supondo-se, portanto, um pesquisador acadêmico ou profissional). ${ }^{61}$ Em Concórdia, São José, Chapecó, Serra Alta e Nova Erechim previa-se "o direito de livre acesso e pesquisa com referência a documentos de arquivos permanentes”, enquanto que também anunciavam-se normas para consulta "a documentos sigilosos" ou que, "por sua natureza e condições", impusessem

\footnotetext{
${ }^{57}$ Lei municipal [Itajaí] no $n^{\circ} .343$, de 27 de novembro de 1998 (Arts. 5º., $9^{\circ} ., 13$ e 14).

${ }^{58}$ Após a lei de criação do Arquivo de Florianópolis, os decretos municipais no ${ }^{\circ}$ 622/1995 e no ${ }^{\circ}$ 623/1995. Cf.: PREFEITURA MUNICIPAL DE FLORIANÓPOLIS. Arquivo Histórico do Município de Florianópolis. Plano de destinação e implantação da Política de Gestão e Administração da Documentação Municipal: para entendimento da Política de Gestão e Administração da Documentação Pública - desde a produção até o destino final. Florianópolis: 1995. Sobre a questão, ver também Parte III, Capítulo 3.

59 GRANDO, Sérgio. Apresentação. In: PREFEITURA MUNICIPAL DE FLORIANÓPOLIS. Arquivo Histórico do Município de Florianópolis. Plano de destinação..., op.cit. Sérgio Grando foi candidato eleito pela coligação "Frente Popular", tendo governado a capital entre 1993 e 1996.

${ }^{60}$ Decreto municipal [Concórdia] no ${ }^{\circ}$. 2.892, de 19 de dezembro de 1991 (Arts. 11 e 12).

${ }^{61}$ Lei municipal [Jaraguá do Sul] no .1 .464 , de 10 de maio de 1991 (Art. 8º., § 5., alínea b).
} 
restrições de consulta, mesmo em arquivos permanentes. ${ }^{62}$ Em Chapecó, Serra Alta e Nova Erechim, o "livre acesso" não significaria necessariamente gratuidade: o Secretário da Fazenda e Administração (ou outra autoridade competente) poderia franquear o ingresso ao Arquivo, possibilitando a consulta à documentação, à pessoa que tencionasse elaborar "obra de divulgação cultural e histórica do município". Teriam ainda "ingresso franqueado" estudantes da rede pública e particular de ensino, "quando da realização de pesquisas e estudos", e desde que tivessem "a devida permissão do titular da Secretaria da Fazenda e Administração" (ou do órgão responsável). ${ }^{63}$

Cabe notar que a cobrança pela consulta aos arquivos municipais foi prevista justamente em leis que buscaram priorizar, como acervo daquelas instituições arquivísticas, os documentos públicos produzidos no âmbito do município, que seriam tratados de forma integrada (fases corrente, intermediária e permanente). Isso sugere que a gestão documental, às vezes apenas entrevista nas leis, pode ter sido tomada mais como instrumento de racionalização administrativa do que como mecanismo facilitador do exercício da cidadania. No entanto, como já apontado, o tema da cidadania estava no horizonte dos debates gerais que, nos anos 1990, enfocaram a gestão documental. O mesmo acontecia com as discussões relacionadas à proteção ao patrimônio documental arquivístico, envolvendo procedimentos de constituição da memória social.

No início da década de 1990, um Congresso realizado na cidade de São Paulo, com o emblemático título de "Patrimônio Histórico e Cidadania - O direito à memória", incluiu, em seu documento final, a seguinte resolução:

O patrimônio arquivístico municipal, em todos os seus suportes, é importante não apenas como garantia de eficiência e clareza dos atos da administração, mas também como fonte inesgotável de conhecimento e garantia dos direitos dos cidadãos. Por isso recomenda-se que os municípios empreendam políticas de gestão de documentos, adotando sistemas municipais de arquivos e garantindo a sua organização, acesso público

\footnotetext{
${ }^{62}$ Decreto municipal [Concórdia] ${ }^{\circ} .2 .892$, de 19 de dezembro de 1991 (Art. $5^{\circ}$.); Lei municipal [São José] no ${ }^{\circ}$. 2.436, de 10 de dezembro de 1992 (Art. $9^{\circ}$.); Lei municipal [Chapecó] no . 3.536, de 10 de agosto de 1993 (Art. $6^{\circ}$.); Lei municipal [Serra Alta] ${ }^{\circ} .314$, de 25 de outubro de 1995 (Art. 6.); Lei municipal [Nova Erechim] n. 890, de 10 de março de 1998 (Art. $6^{\circ}$.). Ao invés de "sigilosos", as leis de Chapecó, Serra Alta e Nova Erechim usam o termo "especiais".

${ }^{63}$ Lei municipal [Chapecó] no ${ }^{\circ}$. 3.536, de 10 de agosto de 1993 (Art. 8.); Lei municipal [Serra Alta] no .314 , de 25 de outubro de 1995 (Art. $8^{\circ}$.); Lei municipal [Nova Erechim] no .890 , de 10 de março de 1998 (Art. $8^{\circ}$.).
} 
imediato aos seus acervos, conforme preceito constitucional, sem qualquer cláusula de impedimento à circulação das informações. ${ }^{64}$

Se o direito à informação fundamentava a resolução do Congresso quanto ao patrimônio arquivístico municipal, o "direito à memória" deveria orientar, mais amplamente, as práticas de preservação, com atenção “às diferentes modalidades que compõem os registros da memória social, em sua diversidade". ${ }^{65}$ Promovido pela Prefeitura Municipal de São Paulo durante a gestão de Luiza Erundina (então ligada ao Partido dos Trabalhadores), o Congresso tomava o direito à memória - ou, nas palavras de Maria Célia Paoli, o "direito ao passado" como "possibilidade de recriar a memória dos que perderam não só o poder, mas também a visibilidade de suas ações, resistências e projetos." Segundo Maria Célia Paoli, o "direito ao passado" deveria ser exercido como "crítica e subversão constantes das versões instituídas." 66

Essa memória que do passado faz saltar conflitos, permitindo aos sujeitos sociais posicionarem-se em relação a eles, distancia-se de uma memória que é culto ao passado. Sendo memória-direito, seria exercida no "espaço da cidadania", trabalhando "em torno da disputa pela memória social". Envolveria, necessariamente, "a construção de um outro horizonte historiográfico", 67

A pluralidade de versões sobre o passado também está relacionada à diversidade de registros acerca dele. Não permitiria a síndrome colecionista de vários arquivos municipais catarinenses (ao menos, como é detectável em suas leis de criação) a abertura para a pluralidade de interpretações?

Mais do que sentido crítico, o colecionismo voraz, que deu a muitos desses arquivos feição de centros de documentação, parece estar em parte relacionado às especificidades de tais instituições no contexto brasileiro. Pois o município não se reduz a uma célula estatal: remete a uma coletividade marcada pela singularidade de sua trajetória

\footnotetext{
${ }^{64}$ Resoluções da sessão plenária de encerramento do Congresso "Patrimônio Histórico e Cidadania - O direito à Memória”, São Paulo, 16 de agosto de 1991. São Paulo: Secretaria Municipal de Cultura, Departamento do Patrimônio Histórico, 1991. p.3 (Resolução 15).

${ }^{65}$ Ibidem, p.1 (Resolução 1).

${ }^{66}$ PAOLI, Maria Célia. Memória, história e cidadania: o direito ao passado. In: PREFEITURA DO MUNICÍPIO DE SÃO PAULO. Secretaria Municipal de Cultura. Departamento do Patrimônio Histórico. O direito à memória: patrimônio histórico e cidadania. São Paulo: 1992. p.27. À época do Congresso, Maria Célia Paoli trabalhava junto ao Departamento do Patrimônio Histórico - DPH - da Prefeitura Municipal de São Paulo.

${ }^{67}$ Ibidem.
} 
histórica e de seus contornos territoriais - integrando, portanto, dimensões da experiência histórica tanto públicas como privadas. ${ }^{68}$ Assim,

[...] os arquivos públicos brasileiros vivenciam na base, ou seja, no âmbito dos arquivos municipais, uma situação sui-genesis quanto à área de jurisdição: não se limitam à guarda dos documentos produzidos pelos órgãos que exercem, a nível local, o chamado imperium; estendem por vezes sua proteção não só aos produtos de funcionamento de entidades que, embora atuem em seu território, pertencem ao Estado ou à União, como também aos documentos de natureza privada. ${ }^{69}$

Quanto à incorporação de documentos de outras esferas administrativas à do município, é compreensível pela prática de delegação de funções, que, no caso brasileiro, nasce com o processo de constituição do Estado nacional, como resposta às dificuldades de governar um território de tão grandes dimensões e tantos contrastes. ${ }^{70}$ No que diz respeito à coleta de documentos de caráter privado, é feita a partir da percepção alargada da própria noção de público, não apenas relacionada ao domínio do estatal, mas também àquilo que possa ser partilhado coletivamente, que tenha "interesse público". ${ }^{71} \mathrm{O}$ arquivo municipal é, assim, o arquivo da "cidade", enquanto configuração de espaços onde "instauram-se possibilidades de ação pela presença coletiva dos atores sociais e pelo registro dessa presença dramatizada em espetáculo., 72

Por outro lado, o impulso colecionista se faz numa época de obsessão pela memória, tal como vêm sendo caracterizados os últimos vinte e cinco anos. Estaríamos vivendo sob o império de um "dever de memória" que tudo pretende englobar e que tornaria

\footnotetext{
${ }^{68}$ MACHADO, Helena Corrêa; CAMARGO, Ana Maria de Almeida. Roteiro para implantação de arquivos municipais. São Paulo: Porto Calendário, 1996. p.16.

${ }^{69}$ Ibidem, p.13-14. Ver também: CAMARGO, Ana Maria de Almeida. Metropolitan Archives in Federative Countries: the Case of Brazil. In: ROBERTS, M.V. (ed.). Archives and the Metropolis. London: Corporation of London, Guildhall Library Publications, 1998. p.169-170.

${ }^{70}$ CAMARGO, Ana Maria de Almeida. Metropolitan Archives..., op.cit., p.169-170; CAMARGO, Ana Maria de Almeida. Arquivos municipais: problemas de jurisdição. Boletim do Centro de Memória UNICAMP, Campinas (SP), v.1, n.2, jul-dez. 1989. p.18-19.

${ }^{71}$ Sobre a questão, ver: CAMARGO, Ana Maria de Almeida. O público e o privado: contribuição para o debate em torno da caracterização de documentos e arquivos. Arquivo: boletim histórico e informativo, São Paulo, v,9, n.2, jul-dez. 1988, p.57-64.

${ }^{72}$ BRESCIANI, Maria Stella. Cidade e história. In: OLIVEIRA, Lúcia Lippi (org.). Cidade: história e desafios. Rio de Janeiro: Editora FGV, 2002. p.30.
} 
"cada um o historiador de si mesmo", como quis Pierre Nora ${ }^{73}$. Uma "cultura da memória", como a denominou Andréas Huyssen ${ }^{74}$, verdadeira "maquinaria patrimonial” que, para HenriPierre Jeudy, deseja eliminar o acaso na transmissão cultural: "não há espaço para escolha, tudo deve ser transmitido graças a uma operação prévia de conservação." ${ }^{, 75} \mathrm{Ou}$, ainda, o que Michel Melot, com humor, caracterizou como "alucinação da conservação absoluta da História protegida". 76

Não à toa, a própria arquivística foi alcançada pela onda memorialística, com questionamentos bastante contundentes às práticas de avaliação consolidadas a partir do século XIX. Especialmente nos EUA, no Canadá e na Austrália, vários arquivistas têm defendido a idéia de que os arquivos devem "documentar" os múltiplos aspectos da ordem social. Para o canadense Terry Cook, por exemplo, não caberia apenas estudar, no processo de avaliação, as grandes funções que condicionam a existência das instituições e o perfil dos conjuntos documentais arquivísticos, mas compreendê-las como referenciais de processos sociais mais amplos. Entende que o arquivista-avaliador (e certamente tem como referência o arquivista à frente de uma instituição pública) precisa detectar "quais funções estão pobremente documentadas nos arquivos institucionais e devem ser complementadas ou suplementadas por manuscritos privados, outras mídias arquivísticas, projetos de história oral e documentação não-arquivística [...]"77.

A intenção de acentuar a relação dos arquivos com a memória, dando-lhes a função de documentar a "sociedade" ("representá-la"), talvez consiga torná-los gigantescos, mas não impedirá que sejam necessariamente incompletos nem eliminará a arbitrariedade das “complementações". Põe de lado, ao mesmo tempo, a especificidade dos arquivos, e atribui ao Estado o papel de organizador da memória social. Uma tal orientação, em relação aos

\footnotetext{
${ }^{73}$ NORA, Pierre. Entre memória e história: a problemática dos lugares. Projeto História, São Paulo, n.10, dez.1993. p.17.

${ }^{74}$ HUYSSEN, Andréas. Seduzidos pela memória: arquitetura, monumentos, mídia. Rio de Janeiro: Aeroplano, 2000. p.14-15.

${ }^{75}$ JEUDY, Henri-Pierre. Espelho das cidades. Rio de Janeiro: Casa da Palavra, 2005. p.16.

${ }^{76}$ MELOT, Michel. Des archives considerées comme une substance hallucinogène. Traverses, Paris, v. 36, janvier 1986, p.15.

${ }^{77}$ COOK, Terry. Archival appraisal and collection: issues, challenges, new approaches [Special Lecture Series, University of Maryland and NARA Staff, 21-22 April 1999]. Disponível em: <http://www.mybestdocs.com/cookt-nara-990421-2.htm>. Acesso em: 24 de março de 2005. Para uma abordagem crítica de tais posições, ver: MENNE-HARITZ, Angelika. Appraisal or documentation: can we appraise archives by selecting content? The American Archivist, Chicago, v.57, 1994, p.528-542.
} 
arquivos públicos (inclusive, claro, os arquivos municipais), corre o risco de relegar a segundo plano os documentos governamentais que, em princípio, deveriam privilegiar.

Nos capítulos seguintes, pretende-se analisar, mais detidamente, as trajetórias de quatro instituições arquivísticas municipais de Santa Catarina: os arquivos de Joinville, Blumenau, Itajaí e Florianópolis. Para além das considerações gerais aqui tecidas acerca do debate arquivístico e dos pressupostos que embasaram a legislação de criação dos arquivos municipais catarinenses, busca-se verificar, nesses casos, as diferenças e distâncias entre o modelo de arquivo proposto nas respectivas leis de criação e os arquivos efetivamente instituídos.

Três desses arquivos (Joinville, Blumenau e Itajaí) foram criados por lei antes da década de 1980 (período de grande concentração de esforços na constituição do campo arquivístico em Santa Catarina). Já o Arquivo de Florianópolis surgiu na década de 1990, momento caracterizado por legislação protetora e reguladora, em relação aos arquivos, e também por intensa remodelação de práticas administrativas e reconfigurações no trato de documentos e informações. Ao mesmo tempo, tais arquivos estão situados em municípios onde existem cursos de graduação em História, com variadas demandas de pesquisa da parte de seus alunos e professores. A intenção é, portanto, compreender em que medida a interação específica entre o campo arquivístico e o historiográfico, em tais localidades, condicionou as atividades cotidianas daquelas instituições arquivísticas, contribuindo para sua visibilidade social. 


\section{PARTE III:}

\section{PRODUZIR}

Evitem dizer que algumas vezes cidades diferentes sucedem-se no mesmo solo e com o mesmo nome, nascem e morrem sem se conhecer, incomunicáveis entre si.

Às vezes, os nomes dos habitantes permanecem iguais, e o sotaque das vozes, e até mesmo os traços dos rostos; mas os deuses que vivem com os nomes e nos solos foram embora sem avisar

e em seus lugares acomodaram-se deuses estranhos."

Ítalo Calvino (As cidades invisíveis) 


\title{
Parte III
}

\section{Capítulo 1}

\section{Arquivos: depositários de heranças}

\author{
A nós cabe - exatamente hoje, nesta época turbulenta \\ de transformações e radicalizações - preservar os valores autênticos \\ a nós legados, lutar por eles e transmiti-los, sempre imbuídos \\ da sábia expressão do mestre Goethe: \\ "O que herdaste de teus ancestrais, \\ Conquista-o, para o possuíres!”.
}

Elly Herkenhoff, 1985.

Em meio a uma atmosfera tumultuária que tudo parece querer arrastar para a mudança, há quem persista, insista, preserve. Nas tensões entre ruptura e continuidade, teima aquele que se coloca ao lado da permanência. Preservar é, então, uma prova de resistência. Não à toa, vários órgãos de preservação do patrimônio cultural se intitulam "de defesa": tratase de opor forças ao que é lido como ameaça de destruição e perda. Nessa clave, Elly Herkenhoff alude, em 1985, à preservação de "valores autênticos", preservação que é simultaneamente luta e transmissão. Mas que valores autênticos estariam em causa? De onde falava Elly Herkenhoff? E a quem se dirigia?

O trecho que serve de epígrafe a esse capítulo foi extraído de texto relativamente longo sobre a trajetória do Arquivo Histórico de Joinville, publicado no boletim daquela instituição. Elly Herkenhoff, joinvilense então com 79 anos, ocupava no Arquivo de Joinville, desde fins da década de 1970, o cargo de historiadora. As razões do texto ligam-se a momento particularmente importante: a construção de um prédio próprio para o Arquivo. As expectativas eram as melhores: tratava-se de, em breve, desocupar "uma sala há muito superlotada", que não oferecia "a mínima segurança contra os múltiplos perigos, como roubo, incêndio e inundações", e passar a "moderno edifício, seguro contra incêndio e enchente".

\footnotetext{
${ }^{1}$ HERKENHOFF, Elly. O Arquivo Histórico de Joinville: seus tesouros - suas deficiências - suas possibilidades. Arquivo Histórico Municipal de Joinville - AHMJ, Joinville (SC), v.2, n.6, set.1985, p.10. O mesmo texto foi inserido entre os documentos da "urna" agregada, em 1985, às fundações do prédio atualmente ocupado pelo Arquivo.
} 
No novo prédio, portanto, preservar - no sentido de dar guarda adequada - seria realmente possível. Qual o alvo de preservação? Segundo Elly Herkenhoff, um "tesouro imensamente precioso, como não o possui, por certo, nenhuma outra comunidade fundada por imigrantes alemães no Brasil" (p.1). Tesouro que incluía: "a coleção das listas de passageiros dos barcos de imigrantes, a começar pelo Colón, até quase o final do século"; uma coleção de mapas, alguns deles elaborados pelos engenheiros agrimensores que trabalharam nas fases iniciais da colonização; relatórios de diretores da Colônia; "escrituras de compra e venda, a partir das primeiras vendas de terras da Sociedade Colonizadora"; uma coleção de jornais publicados em Joinville e outros editados, no Brasil, em alemão ou português; "velhas revistas alemãs"; livros de literatura, em alemão, ou sobre Joinville, do século XIX e do século XX; "numerosos livros de canto, livros de reza e bíblias", assim como antigos anuários, dicionários e enciclopédias, também predominantemente em alemão; "numerosas músicas"; "modelos para bordados"; "livros de cozinha"; "cartões com vistas"; milhares de imagens fotográficas; passaportes, boletins escolares, diplomas, cartões de felicitações e de pêsames, convites e programas para eventos os mais variados. ${ }^{2}$

Põe em destaque, portanto, antes de tudo, o legado dos "fundadores" (os imigrantes alemães), bem como de seus descendentes, traduzido em "extremamente rico e diversificado [...] documentário que testemunha a vida social outrora florescente em Joinville" (p.6). Registros que remetiam tanto ao âmbito do público como do privado. Um legado, aliás, não de todo protegido:

[...] é certo também que ainda existem incontáveis preciosidades, inúmeros tesouros - muitas vezes ignorados, abandonados em caixotes carcomidos pelo cupim e em caixas bolorentas, em cantos úmidos talvez, ou nos sótãos de velhas casas, ali há anos depositados e esquecidos... (p.10)

\footnotetext{
2 Ibidem, p.4-9. Ressalte-se que a autora também menciona, embora com menor ênfase, documentos relacionados às funções da Câmara Municipal (ou a ela delegadas), a partir de 1870: livros de atas, livros copiadores, relatórios, bem como estatísticas e listas de eleitores. Ainda, documentos de núcleos de colonização que antes integravam o Domínio Dona Francisca e que hoje correspondem a áreas de outros municípios (como São Bento do Sul, Guaramirim, Jaraguá do Sul e Corupá). Igualmente, como previa a lei de criação do Arquivo, documentos relativos a conflitos ou revoltas que extrapolaram as fronteiras do município, mas dos quais Joinville de alguma forma participou: a guerra contra o Paraguai, a chamada "Revolução Federalista", o movimento de 1930 .
} 
Nem todos reconheciam os "tesouros" enquanto tais. Do abandono e do esquecimento, porém, eles freqüentemente saltavam para o abrigo valorizador do Arquivo Histórico de Joinville, como assinalavam

[...] as doações mais ou menos volumosas, ofertadas em maior ou menor intervalo de tempo, como por exemplo, em caso de falecimento ou de mudança de residência - muitas vezes, porque não se sabe 'o que fazer com este traste' - um 'traste', que inúmeras vezes se acaba revelando verdadeira preciosidade, que vem enriquecer extraordinariamente o nosso Arquivo! (p.10)

O Arquivo de Joinville guardava, assim, as "preciosidades" daqueles que, tendo vivido em Joinville, deixaram no município as marcas de sua passagem. Afirmava ainda Elly Herkenhoff: "Cabe a nós colher tão preciosa herança, restaurá-la, microfilmá-la, quando possível, preservando-a para gerações futuras em ambiente adequado" (p.10). "Nós" - os funcionários do Arquivo, a instituição em seu todo. "Nós" - autora e, também, leitores do boletim. "Nós" - joinvilenses, munícipes, que, no limite, sustentavam o próprio Arquivo.

A lei de criação do Arquivo de Joinville dá especial relevância à documentação relacionada ao empreendimento de colonização e à presença germânica na região hoje ocupada pelo município, mas não se refere apenas a ela (ver, a respeito, Parte II, Capítulo 3). No entanto, uma obsessão pelo século XIX e pelos imigrantes alemães está presente na trajetória do Arquivo de Joinville, tal como pode ser acompanhada através de seu boletim, entre os anos de 1983 e $1998^{3}$. Referências à coleção de Carlos Ficker, divulgação regular de trechos traduzidos do Kolonie Zeitung, preocupação reiterada com as listas de passageiros de navios em que viajaram os imigrantes, tradução e publicação de documentos encontrados na urna enterrada, em 1857, com a pedra fundamental da Igreja da Paz, projetos de intercâmbio com o Arquivo de Hamburgo - tudo levava a entender o Arquivo Histórico de Joinville

\footnotetext{
3 O boletim do Arquivo Municipal de Joinville, editado entre 1983 e 1998, é uma importante fonte de informação sobre suas atividades, inclusive publicando relatórios da instituição. A publicação foi iniciada em outubro de 1983, sendo bimestral até 1985, passando a trimestral entre 1985 e 1988; não foi editada em 1989 , sendo retomada em 1990, semestralmente, até 1992. Após nova interrupção (o boletim não foi publicado nem em 1993 nem em 1994), teve três números (semestrais) entre 1995 e 1996; depois disso, apenas um número em 1998 (do qual, aliás, estão completamente ausentes referências ao Arquivo, pois trata apenas do Festival de Dança de Joinville).
} 
“como importante centro de documentação histórica sobre a imigração alemã em todo o país". 4

\section{Espólios}

Em Joinville, os relatos referentes aos documentos reunidos para custódia pelo Arquivo Histórico põem em destaque dois personagens: Adolfo Bernardo Schneider e Carlos Ficker.

Quanto ao primeiro, estaria muito estreitamente vinculado à própria
institucionalização do Arquivo, em 1972. ${ }^{5}$ Assim estabeleceu (e consagrou) Apolinário Ternes, em cerimônia que, por ocasião dos 20 anos do Arquivo Histórico de Joinville, em março de 1992, homenageou Schneider (primeiro diretor do Arquivo) e Harald Karmann (prefeito, em 1972). A luta de Schneider pela criação do Arquivo de Joinville seria, aliás, muito anterior à década de 1970: para Ternes, então diretor do Arquivo, “a inspiração [...] daquele ato administrativo retrocede em anos e tem no nome [sic] do historiador Adolfo Bernardo Schneider o seu principal protagonista." 6

Quatro anos depois desse discurso, o próprio Adolfo Schneider, no mesmo boletim do Arquivo, apresentou sua versão: nomeado diretor da Biblioteca Municipal, teria

\footnotetext{
${ }^{4}$ TERNES, Apolinário. Breve história do Arquivo. Boletim do Arquivo Histórico Municipal de Joinville AHMJ, Joinville (SC), n.10, jun.1992. p.4-5). Modificando ligeiramente - mas de forma decisiva - o previsto na lei de criação do Arquivo (a saber, que fosse um "centro de pesquisas históricas para toda a região"), em abril de 1984 a diretora da instituição, Sarah Gomes, afirmou o "intuito de montar no Arquivo Histórico de Joinville um Centro de Documentação da História de Joinville e Região da Antiga Colônia Dona Francisca." (grifos meus). Cf. GOMES, Sarah. Editorial. Arquivo Histórico Municipal de Joinville - AHMJ, Joinville (SC), v.1, n.4, abr.1984. p.1.

${ }^{5}$ Note-se que iniciativa anterior, não concretizada, teria ocorrido nos anos 1930, segundo Elly Herkenhoff, "conforme se verifica por um convite nas colunas do Kolonie Zeitung daquela época". A autora não esclarece de quem era a iniciativa, mas o alvo principal parece ter sido, também, a documentação vinculada aos antigos colonos de origem germânica. O projeto, "por motivos ignorados, não pôde ser concretizado." Cf. HERKENHOFF, Elly. O Arquivo Histórico de Joinville: seus tesouros..., op.cit., p.7.

${ }^{6}$ Arquivo comemora 20 anos e presta homenagem aos dois principais idealizadores [discurso de Apolinário Ternes]. Boletim do Arquivo Histórico Municipal de Joinville - AHMJ, Joinville (SC), n.10, jun.1992, p.13. No mesmo número do boletim (p.3), em texto intitulado "Breve história do Arquivo", Ternes destaca Schneider como "o principal responsável pelo surgimento da Instituição, como resultado de anos de intenso 'lobby' junto ao poder público municipal, mostrando a dramática necessidade e importância do surgimento de um órgão destinado a criar mecanismos de preservação da memória histórica do município.” Note-se que, já no primeiro número do boletim do Arquivo (quando ainda não tinha o nome de boletim), Adolfo Bernardo Schneider é identificado como "escritor e historiador de Joinville, sempre à frente de iniciativas culturais de vulto". Cf.: GOMES, Sarah M.I. Apresentação. Arquivo Histórico Municipal de Joinville - AHMJ, Joinville (SC), v.1, n.1, out.1983, p.I.
} 
procurado dar destino adequado a documentos postos de lado pelas bibliotecárias, tidos como sem interesse, e geralmente reservados em um armário - “jornais de Joinville, os Diários Oficiais da União e do Estado e outras coisas mais" -, além de "coleções de jornais joinvilenses" que, com autorização do prefeito, adquirira da viúva D. Rola Schwartz, e que estavam guardados, por sua vez, no sótão. ${ }^{7}$ Mas sua preocupação fundamental estava ligada aos documentos sob a guarda de Carlos Ficker. Segundo Schneider, Ficker, quando presidente da Comissão do Museu Nacional de Colonização e Imigração, teria transferido para "sua casa particular, localizada no Morro Fritz Alt”, a documentação relativa à Colônia Dona Francisca, antes "guardada no chalé existente ao lado do Palácio dos Príncipes". Discordando dessa apropriação, e entendendo que a documentação deveria estar disponível para consulta pública, Schneider teria proposto a criação do Arquivo de Joinville, inclusive elaborando a lei posteriormente aprovada pela Câmara Municipal, "sem qualquer emenda". 8

Os embates em torno da posse da documentação do Domínio Dona Francisca ajudariam a compreender, portanto, porque tais documentos foram tão enfática e detalhadamente relacionados como integrantes do acervo do Arquivo Histórico de Joinville, na lei que o criou (ver, a respeito, Parte II, capítulo 3). A circunstância de ser Adolfo Schneider, em 1972, diretor da Biblioteca Municipal, esclareceria, ainda, as razões de instalação do arquivo recém-criado em uma das salas daquele órgão. Em um primeiro momento, entretanto, a documentação abrigada no Arquivo Histórico de Joinville não teria ido muito além daquela que já estava, inicialmente, no prédio da Biblioteca. Segundo Schneider, "faltava o motivo real da criação do Arquivo: a documentação histórica guardada no chalé do "Domínio Dona Francisca"'. Mas relações pessoais particularmente tensas entre Schneider e Ficker não facilitariam negociações no sentido de preencher essa lacuna. ${ }^{9}$

\footnotetext{
${ }^{7}$ SCHNEIDER, Adolfo Bernardo. A criação do Arquivo Histórico Municipal de Joinville. Boletim do Arquivo Histórico Municipal de Joinville - AHMJ, Joinville (SC), n.14, jun.1996, p.8.

${ }^{8}$ SCHNEIDER, Adolfo Bernardo. op. cit., p.8. Elly Herkenhoff destacou ser a criação do Arquivo de Joinville "o primeiro passo decisivo da parte de nossas autoridades, em concordância com o 'Compromisso de Brasília' de 03 de abril de 1970", para a preservação do "tesouro" documental da imigração alemã em Joinville. Cf. HERKENHOFF, Elly. O Arquivo Histórico de Joinville: seus tesouros..., Op.cit., p.1.

${ }^{9}$ As "divergências com o referido senhor [Carlos Ficker] já duravam perto de 20 anos e aparentemente não se vislumbrava alguma solução." SCHNEIDER, Adolfo Bernardo. op. cit., p.9. Além disso, Ficker também teria a coleção completa do Kolonie Zeitung, aparentemente obtida de Max Boehm, último sócio da editora daquele jornal. Quando Prefeito de Joinville, e supostamente por insistência de Schneider, Pedro Ivo Campos teria declarado a coleção como sendo de utilidade pública, "mas o processo de desapropriação ficou encalhado." (p.910)
} 
Contudo, um relatório do prefeito Helmut Fallgatter, relativo ao período de 19611965, apresenta informações diferentes acerca da questão. Em 1961 foi firmado convênio entre a prefeitura e o Ministério da Educação e Cultura para dar concretização à lei federal que, em 1957, criou o Museu Nacional de Imigração e Colonização. O antigo "Palácio dos Príncipes" foi reformado e inaugurado ainda durante a administração de Fallgatter, que designou uma comissão para dirigi-lo, formada por Carlos Ficker (presidente), Hilda Krisch (tesoureira), Ingo Jordan (secretário) e Helga Schmidt, Edith Weizel, K. Rosenberger, João dos Santos Neves e J.J.Puls. ${ }^{10}$ Carlos Ficker teria sido incumbido de organizar, como parte integrante do Museu, "uma biblioteca especializada com arquivo histórico, contendo todos os documentos, mapas, livros e publicações sobre a imigração e colonização na antiga Colônia Dona Francisca, hoje Joinville.” Acrescenta o prefeito:

Os entendimentos havidos com o Ministério da Educação e Cultura e o Patrimônio Histórico e Artístico Nacional confirmaram definitivamente a absoluta necessidade da organização do Arquivo Histórico e sua instalação, à prova de incêndio e fogo, numa dependência da Biblioteca Municipal de Joinville. ${ }^{11}$

O que foi, à época, denominado de "Arquivo Histórico", era uma solução para organizar as numerosas "doações de documentos e publicações relativas a Joinville" encaminhadas ao Museu. Daí a idéia de que reunisse um conjunto bastante amplo de documentos (e a relação de materiais colecionáveis assemelha-se a um rascunho da lei de criação do Arquivo, de 1972). ${ }^{12}$ Complemento do acervo do Museu, o "Arquivo Histórico" teria, neste sentido, um tema como elemento organizador, e não uma entidade produtora (como a administração municipal), nem uma forma de acumulação específica (orgânica, em termos propriamente arquivísticos). Criado por lei municipal em 1972, o Arquivo Histórico de

\footnotetext{
${ }^{10}$ Prefeito Helmut Fallgater presta contas de seus 5 anos de administração - 1961-1965. Joinville (SC): s.c.p., s.d. p.116.

${ }^{11}$ Ibidem, p. 296.

12 "Dentro desse Arquivo Histórico deverão ser colecionados: 1) Livros sobre imigração e colonização, especialmente quando é citada Joinville ou feita descrição da Colônia Dona Francisca; 2) Periódicos, jornais e revistas de interesse histórico; 3) Relatórios e publicações oficiais sobre a colonização, especialmente sobre a Colônia Dona Francisca e Joinville; 4) Manuscritos, cartas e papéis escritos à mão, com referência a Joinville; 5) Mapas e plantas originais ou litografados do tempo da colonização, mostrando o desenvolvimento da cidade; 6) Iconografia de Joinville, quadros e fotografias de todas as épocas; 7) Diversos, como filmes, notas e contas antigas de firmas comerciais, rótulos de fábricas, clichês, etc. etc.” Ibidem.
} 
Joinville manteve o caráter colecionista da instituição concebida na década de 1960, embora desvinculado do Museu Nacional de Imigração e Colonização.

De toda forma, somente quando Adolfo Schneider não mais ocupava o cargo de diretor do Arquivo e Carlos Ficker já havia morrido, a documentação que teria determinado a própria existência do Arquivo Histórico de Joinville seria a ele incorporada. Com a morte de Ficker, aliás, os documentos do Domínio Dona Francisca passaram a integrar seu espólio, tendo inclusive deixado Santa Catarina, levados para São Paulo e Minas Gerais. Vendidos à Prefeitura, foram finalmente integrados ao Arquivo de Joinville no final da década de $1970 .{ }^{13}$

Qual a importância da aquisição da coleção Ficker, para o Arquivo Histórico de Joinville?

Fazendo, em 1992, um balanço da trajetória da instituição, Apolinário Ternes considerou-a um dos seus dois grandes momentos (o segundo teria sido a inauguração e ocupação do prédio próprio, em 1986). ${ }^{14}$ Ao menos em relação ao acervo do Arquivo, haveria um "antes" e um "depois" da coleção Ficker. Assim, até a aquisição,

Livros, jornais, revistas, fotografias, mapas, relatórios, listas telefônicas e até prosaicos cartões postais foram regular e eficientemente colecionados. Estava sendo construído um patrimônio precioso, mas o conjunto documental mais importante, este ainda se encontrava longe do Arquivo. ${ }^{15}$

Ternes, jornalista e historiador, ocupava a direção do Arquivo à época da aquisição da coleção. Ainda segundo ele, a importância da documentação reunida por Carlos Ficker - que não se resumia ao material colhido no Museu Nacional de Imigração e Colonização - poderia ser traduzida também numericamente: estimava, em 1992, que ela representasse cerca de $80 \%$ do acervo de todo o Arquivo Histórico de Joinville. ${ }^{16}$ Quatro anos depois, essa avaliação seria por ele corrigida, de modo a valorizar ainda mais tais documentos:

\footnotetext{
${ }^{13}$ SCHNEIDER, Adolfo Bernardo. op. cit., p.10; TERNES, Apolinário. Patrimônio arquivístico. Boletim do Arquivo Histórico Municipal de Joinville - AHMJ, Joinville (SC), n.14, jun.1996, p.14. Segundo Ternes, a decisão de adquirir o acervo Ficker teria sido tomada em 1977 pelo então prefeito Luiz Henrique da Silveira. Texto de Sarah Gomes e Maria Thereza Böbel ("Levantamento inicial do acervo"), contido no boletim de fevereiro de 1984, informa ter a aquisição ocorrido em 1979. Cf. Arquivo Histórico Municipal de Joinville AHMJ, Joinville (SC), v.1, n.3, fev.1984. p.2.

${ }^{14}$ TERNES, Apolinário. Breve história do Arquivo. op.cit. p.4.

15 Arquivo comemora 20 anos..., op.cit., p.14-15.

16 TERNES, Apolinário. Breve história do Arquivo. op.cit., p.4.
} 
Preservada por polêmica ação do historiador Carlos Ficker, a documentação primária da fundação e colonização de Joinville hoje existente no Arquivo, no que considero $90 \%$ do material realmente documental, ainda carece de tratamento adequado. Sua classificação e catalogação permanece a mesma feita pelo citado historiador, que se autorizou 'proprietário' daquela vasta documentação. ${ }^{17}$

Outros documentos relacionados ao Domínio Dona Francisca, relativos ao período inicial do empreendimento de colonização, continuaram, no entanto, em mãos de particulares, mas o interesse em sua proteção e abertura à consulta pública foi explicitado em 1988, por decreto municipal. ${ }^{18}$

Destacados pelo seu primeiro diretor (Schneider), bem como pelo seu diretor recorrente (Ternes) $)^{19}$, os documentos colecionados por Carlos Ficker não foram, contudo, alvo privilegiado das ações de organização do acervo promovidas no Arquivo Histórico de Joinville, nem mesmo de divulgação destacada em seu boletim. Este papel coube sobretudo ao jornal Kolonie Zeitung e às listas de imigrantes.

O Kolonie Zeitung foi o primeiro jornal publicado no que é hoje o município de Joinville, caracterizando-se pela longa trajetória (1862-1942). Ganhou primeiramente destaque, nos boletins do Arquivo Histórico de Joinville, por ter sido microfilmado, no início da década de 1980, no âmbito do Plano Nacional de Microfilmagem de Periódicos Brasileiros, promovido pela Biblioteca Nacional. A importância atribuída à participação de Joinville naquele projeto está indicada no gesto solene de entrega dos microfilmes, feita ao Arquivo, em $1^{\circ}$. de março de 1984, por Ernani Bayer, reitor da Universidade Federal de Santa Catarina (instituição envolvida na execução do Plano, no âmbito catarinense), e por Valmor Bonifácio

\footnotetext{
${ }^{17}$ TERNES, Apolinário. Patrimônio arquivístico. op.cit., p.14. Grifos meus. Não fica claro o que entende o autor por "material realmente documental". Talvez fizesse referência a documentos de caráter propriamente arquivístico.

${ }^{18}$ Decreto municipal [Joinville] $n^{\circ}$. 5.994, de 14 de novembro de 1988: declara de interesse público documentos históricos relacionados com as atividades da Colônia Dona Francisca. Em seu Artigo $1^{\circ}$., o decreto classifica "como arquivos privados de interesse público os documentos históricos relacionados com as atividades da Colônia Dona Francisca, atualmente de propriedade de Aldo Franzoi, titular do Domínio Dona Francisca Ltda.”, remetendo às disposições a isso relativas do Decreto Estadual no .1 .444 de 23 de março de 1988. Publicado no jornal A Notícia, de Joinville, de 15 de novembro de 1988; cópia gentilmente fornecida por Ilanil Coelho.

${ }^{19}$ Apolinário Ternes foi diretor do Arquivo Histórico de Joinville ao menos em duas ocasiões, entre 1977 e 2000 (ver Apêndice III-1).
} 
Senna, professor da UFSC e diretor regional do Plano. ${ }^{20}$ Trechos do Kolonie Zeitung foram publicados regularmente no boletim do Arquivo, quer com tradução de Maria Thereza Böbel (as "Curiosidades traduzidas do Kolonie Zeitung", ou apenas "Curiosidades do Kolonie Zeitung"), quer por Rosa Herkenhoff (textos reunidos sob a rubrica "Subsídios históricos”). O editorial da primeira edição, de 20 de dezembro de 1862, foi igualmente traduzido e publicado no boletim de abril de 1984 .

A valorização do "Jornal da Colônia" contribuiu para estabelecer uma forte identificação entre o Arquivo e a história dos primeiros imigrantes que formaram a Colônia Dona Francisca, instalada em terras do Príncipe de Joinville. A partir de abril de 1985, esse esforço de identificação foi reforçado, pois o boletim do Arquivo, apesar de continuar a ser mimeografado, ganhou uma capa impressa - e que reproduzia, justamente, a primeira página do número inicial do Kolonie Zeitung, contendo o editorial (na área interna da capa, lia-se sua tradução). ${ }^{21}$

Mencionadas como parte do acervo, nos primeiros números do boletim do Arquivo, as chamadas "listas de imigrantes" (ou seja, listas de passageiros de navios que embarcaram de Hamburgo para a Colônia Dona Francisca) foram objeto de atividades institucionais de caráter permanente. Eram, aliás, documentos de difícil leitura e transcrição (por estarem escritos em letra gótica). As listas chegaram a dar corpo, mais tarde, a um dos setores da instituição (o "Setor de Imigração"), bastante consultado não só por estudiosos de genealogia como por interessados em obter a cidadania alemã. ${ }^{22} \mathrm{Na}$ instituição, o trabalho de tradução, transcrição e organização das listas ficou em geral a cargo da funcionária Maria Thereza Böbel, cuja trajetória profissional esteve profundamente marcada pela proximidade

\footnotetext{
${ }^{20}$ Relatório semestral de atividades [jan.-jun.1984]. Arquivo Histórico Municipal de Joinville - AHMJ, Joinville (SC), v.1, n.5, jun.1984. p.1. Também o Joinvillenser Zeitung (1895-1938) foi objeto de microfilmagem, no mesmo Plano. Cf. GOMES, Sarah M.I. Apresentação. Arquivo Histórico Municipal de Joinville - AHMJ, Joinville (SC), v.1, n.1, out.1983. p.II.

${ }^{21}$ A capa continuou a acompanhar o boletim, mimeografado, até dezembro de 1988. Note-se que as edições posteriores a 1988 passaram a ser impressas tipograficamente.

${ }^{22}$ Ver, a respeito, o relatório do quadriênio 1989-1992, publicado no Boletim do Arquivo Histórico Municipal de Joinville - AHMJ, Joinville (SC), n.11, dez.1992, p.9-23. O Setor de Imigração elaborava fichas de imigrantes, com base não somente nas listas de imigrantes desembarcados como em outros documentos (tais como registros de óbitos, em especial do "Cemitério dos Imigrantes"). Ver, a respeito: Arquivo Histórico Municipal de Joinville - AHMJ, Joinville (SC), v.5-6, n.3-5, abr.-dez.1988. p.13.
} 
com esses documentos. ${ }^{23}$

Além disso, houve esforço no sentido de levantar, na Alemanha, documentos de interesse para a história de Joinville - e, obviamente, relacionados à fase de implantação da Colônia Dona Francisca. A preocupação principal foi estabelecer elos com o Arquivo de Hamburgo, uma vez que o empreendimento de colonização foi assumido por sociedade colonizadora criada naquela cidade alemã.

O intercâmbio com o Arquivo de Hamburgo já era mencionado no primeiro boletim do Arquivo Histórico de Joinville, de outubro de 1983. No entanto, projeto formal de "Intercâmbio de informações entre o Arquivo Histórico de Joinville e a República Federal da Alemanha" teria sido encaminhado à embaixada alemã em Brasília apenas no final de 1987, e aprovado em Bonn em 1988. No bojo deste projeto, a funcionária Maria Thereza Böbel viajou à então Alemanha Ocidental e ali visitou várias cidades, selecionando material e solicitando microfilmes. Por sua vez, Klaus Richter, ligado ao Arquivo de Hamburgo, teria procedido a levantamentos em Joinville. ${ }^{24}$

Em meados da década de 1990, observa-se uma inflexão na extrema valorização dos documentos da fase inicial da Colônia Dona Francisca, mudança que poderia ser interpretada como sinal da "modernização" da instituição, vislumbrada por Raquel S.Thiago, ex-diretora do Arquivo, em texto publicado em junho de 1996:

\footnotetext{
${ }^{23}$ Maria Thereza Böbel publicou vários textos, no boletim do Arquivo, relacionados às listas. No boletim n. 5, de 1984, "Lista de imigrantes - metodologia de pesquisa" (em co-autoria com Sarah Gomes); nos boletins de setembro e dezembro de 1987, a "Relação das listas de navios de imigrantes existentes no nosso acervo", por ela organizada; em novembro de 1990, novo texto sobre as listas de imigrantes, bem como no de junho de 1996 ("O potencial arquivístico do Arquivo Histórico de Joinville", em que ressalta "a crescente procura por dados ali contidos, tanto para fins de genealogia quanto para dar entrada no processo para obtenção da cidadania alemã", daí ter surgido "muito cedo a necessidade de se traduzir estas listas." - p.21). As listas também tiveram destaque nas poucas apresentações feitas pelo Arquivo Histórico de Joinville em encontros catarinenses de arquivos: Maria Thereza Böbel apresentou o trabalho "Histórias que nos contam as listas de imigrantes", em 1988. Cf.: PIAZZA, Walter F. (org.). Anais do III Encontro de Arquivos Catarinenses; I Painel de Arquivos SulBrasileiros. Florianópolis: Secretaria de Estado da Administração, Coordenadoria de Documentação e Publicações, Arquivo Público, 1986. p.25. Em conjunto com Raquel S.Thiago, Maria Thereza Böbel ainda elaborou o livro Joinville - os pioneiros: Documento e História, lançado em 2001, e que tem por base as "listas de imigrantes". Cf.: GROTH, Marlise. Livro resgata a vida dos pioneiros. A Notícia, Joinville (SC), 11 de junho de 2001.

${ }^{24}$ Sobre o intercâmbio com o Arquivo de Hamburgo, ver: GOMES, Sarah M.I. Apresentação. Arquivo Histórico Municipal de Joinville - AHMJ, Joinville (SC), v.1, n.1, out.1983, p.I-II; BÖBEL, Maria Thereza. Projeto "Intercâmbio de informações entre o Arquivo Histórico de Joinville e a República Federal da Alemanha." Boletim do Arquivo Histórico Municipal de Joinville - AHMJ, Joinville (SC), n.7, nov.1990. p.3-6. Maria Thereza Böbel, no texto de 1990, informa também que Richter, historiador pela Universidade de Hamburgo e Arquivista "pela Escola Superior de Marburgo", teria prestado ainda "valioso auxílio" ao Arquivo Histórico de Joinville, orientando quanto ao "arranjo dos nossos cinco principais fundos, quatro dos quais ligados ao processo de imigração e colonização de Joinville e região.” (p.3)
} 
O Arquivo Histórico moderniza-se, seja através da sua informatização e conexão na INTERNET, ou da forma de organização do acervo, seja, ainda, na valorização de novas fontes no sentido de abrir-se campo para novas abordagens da História, principalmente no âmbito social e cultural. Prepara-se, pouco a pouco, um acervo mais democrático, vale dizer, composto de testemunhos não apenas oficiais, mas também do homem comum, daquele que também constrói a história. ${ }^{25}$

O comentário de Raquel S. Thiago é significativo para mapear algumas das questões que passaram então a ser dirigidas ao Arquivo, e que articularam modernização, documentos, historiografia, memória social, identidade, cidadania, democracia. Todo esse boletim de junho de 1996 é, aliás, a este respeito, bastante significativo. ${ }^{26}$

Também em junho de 1996, Ilanil Coelho, então diretora do Arquivo, tece um discurso que, em certo sentido, é complementar ao de Raquel S.Thiago:

Entendendo que o patrimônio arquivístico municipal é fundamental para o fortalecimento da identidade social e ainda, levando em conta o 'cosmopolitismo' de Joinville, advindo das mudanças do cenário econômico que propiciou a fixação e a convivência de vários grupos e sujeitos sociais, buscou-se estabelecer para o AHJ ações que refletissem essas mudanças, no sentido de democratizar o seu acervo e os registros da memória social. ${ }^{27}$

A democratização do acervo é aí destacada, portanto, como ampliação do universo de documentos abrigados pelo Arquivo. Neste sentido, houve a criação de "um Conselho Técnico-Científico, com representantes de diversas áreas do conhecimento”, para estudar “possibilidades concretas do estabelecimento de uma política de acervo." 28

25 S.THIAGO, Raquel. AHJ - um testemunho. Boletim do Arquivo Histórico Municipal de Joinville AHMJ, Joinville (SC), n.14, jun.1996, p.20. Grifos meus.

${ }^{26} \mathrm{O}$ tema da identidade, por exemplo, aparece, embora com tonalidades distintas, nos textos de Ilanil Coelho, Apolinário Ternes, Heloísa Bellotto e João Klug.

${ }^{27}$ COELHO, Ilanil. Uma experiência em curso... Boletim do Arquivo Histórico Municipal de Joinville AHMJ, Joinville (SC), n.14, jun.1996, p.28. Grifos meus.

28 Ibidem. Problemas relacionados ao corpo técnico ("falta de um quadro efetivo de pessoal técnico, de atualização técnico-científica") e aos recursos financeiros disponíveis (escassos) dificultariam a "modernização". 
Pode-se questionar se o Arquivo Histórico de Joinville, à altura de 1996, e apesar de vinculado ao governo municipal, investira a tal ponto no recolhimento, tratamento técnico e difusão da documentação de caráter "oficial” que pudesse ser com ela prioritariamente identificado. Como apontou Elly Herkenhoff, uma década antes, a documentação oficial era apenas uma parte dos "tesouros" do Arquivo, que incluíam uma miríade de registros do cotidiano dos habitantes de Joinville, até mesmo em âmbito doméstico (livros de reza, modelos para bordados, livros de cozinha...). Isso coadunava-se, como já visto, com a legislação de criação do Arquivo Histórico de Joinville: o acervo da instituição não deveria abarcar apenas documentos governamentais. E, pelo que se depreende da leitura dos boletins do Arquivo Histórico de Joinville, de forma alguma a instituição procurara se apresentar ou se firmar como arquivo contendo, prioritariamente, documentos da administração pública municipal. Desde o início, procurou forjar uma vocação mais próxima da de centro de documentação, voltado para registros da história do município e de seus moradores, embora privilegiando os registros gerados por um grupo social específico (os imigrantes de origem germânica e seus descendentes). Daí que seja possível detectar, na alusão de Ilanil Coelho aos "vários grupos e sujeitos sociais" que construíram historicamente Joinville, um alerta (implícito) contra a perspectiva "germanista" (tendente, dados sua força e poder de inscrição social, a invisibilizar outras perspectivas e experiências sociais). Ao mesmo tempo, a forma cuidadosa com que a então diretora trata a questão, sem aludir claramente à intensa identificação da instituição com uma memória "étnica" (germânica) e "épica" (dos valorosos pioneiros e seus descendentes), deixa entrever o quão delicada e difícil era uma mudança de orientação nas atividades do Arquivo. ${ }^{29}$

$\mathrm{O}$ anseio de mudança aponta para a necessidade de buscar novos espólios aqueles até então recolhidos não dariam conta, supostamente, da diversidade de memórias ligadas a Joinville. Conseqüentemente, nem todos os "grupos e sujeitos sociais" poderiam se perceber como legatários do espólio até então recolhido. Quem seriam, de fato, os herdeiros?

\footnotetext{
${ }^{29}$ No mesmo texto em que alude à modernização do Arquivo Histórico de Joinville, Raquel S. Thiago comenta, aliás, que o intercâmbio com a Alemanha estava "em vias de reatamento": surgiam "possibilidades concretas de microfilmagem da documentação a que, em 1989, não tínhamos acesso" (a saber, os documentos existentes em cidades da então Alemanha Oriental). S.THIAGO, Raquel. AHJ - um testemunho. op.cit., p.19.
} 


\section{Heranças e herdeiros}

Pensar as ações de criação de instituições custodiadoras de acervos na Joinville do pós-Segunda Guerra Mundial implica destacar a atuação de alguns personagens reconhecidos por sua ascendência alemã. Significa pensar, igualmente, a imposição da nacionalização, durante o período Vargas - ela é, a este respeito, uma questão incontornável.

Como desconhecer que essas pessoas, afinal, haviam recorrido com unhas e dentes, no pós-guerra, à memória de seu povo, prejudicada pelos exageros da campanha de nacionalização? Como, na condição de historiadora, ignorar seu receio de perderem, nos descaminhos da história, a memória da saga de seus antepassados? E foi dessa reação que nasceu, também, já na década de 1950, o Museu Nacional de Imigração e Colonização. ${ }^{30}$

Lembrando de seus primeiros tempos como diretora do Arquivo Histórico de Joinville, Raquel S. Thiago tentou situar e compreender, em 2001, a maneira, entre reticente e decepcionada, com que sua nomeação foi recebida por Elly Herkenhoff e Adolfo Bernardo Schneider. Salientou, porém, não demorarem ambos "a aceitar, como diretora, a caboclinha que nada sabia de alemão e, portanto, não saberia dirigir o AHJ." 31

O próprio Adolfo Bernardo Schneider estabeleceu relação entre os efeitos da nacionalização imposta e a preocupação com a preservação dos registros da memória dos imigrantes e seus descendentes. Pois foi assim que decidiu iniciar o texto no qual comentaria "A criação do Arquivo Histórico Municipal de Joinville":

Joinville e todo o Brasil Meridional estavam passando por um longo período de estagnação cultural, que teve início com os decretos do Presidente Getúlio Vargas, em 1934, fechando cerca de 2.000 escolas, onde se lecionava em alemão, de 1936, quando foi proibida a imprensa brasileira em alemão, que atingiu em Joinville dois jornais editados desde 1862 e 1895, e afinal a proibição completa de tudo o que era impresso em alemão, seja importado ou não, e também qualquer comunicação em alemão, seja verbal ou por

30 S.THiago, Raquel. Um menino de dez anos. A Notícia, 27 de julho de 2001. Disponível em: <http://www.an.com.br/2001/jul/27/0opi.htm>. Acesso em 8 de maio de 2004.

${ }^{31}$ Ibidem. 
escrito. O esquema cultural montado aqui pelos imigrantes alemães, de cultura destacada, desde 1850, simplesmente parou [...]. Realmente, por longo tempo, tudo parou. ${ }^{32}$

No pós-1945, os que percebiam, tal como Schneider, a estagnação das atividades culturais, buscaram a elas imprimir movimento. Nesse processo, Adolfo Bernardo Schneider, joinvilense nascido em 1906, filho de imigrantes alemães, teve seu nome ligado à criação ou direção de várias instituições culturais de Joinville: além da Biblioteca Pública Rolf Colin e do Arquivo Histórico de Joinville, já mencionados, o Museu Nacional de Imigração e Colonização, o Museu do Sambaqui e o Museu Fritz Alt. ${ }^{33} \mathrm{Na}$ juventude, estudou em Florianópolis e, posteriormente, na década de 1920, na Alemanha, em Hamburgo. Retornou a Joinville já casado, em fins daquela mesma década. Em depoimento concedido ao jornal $A$ Notícia, em 2001, relatou o grande sofrimento no período da guerra: "Sofri muito naqueles tempos [...]."34

Por sua vez, Elly Herkenhoff, nascida em Joinville em 1906, transferiu residência para o Espírito Santo em 1928 e posteriormente para o Rio de Janeiro; morou em São Paulo entre 1955 e 1972, então retornando a Joinville. Não viveu diretamente, portanto, os efeitos da campanha de nacionalização em Santa Catarina. Os elos com o município eram, entretanto, fortes: seus pais, segundo o sobrinho João Baptista, estavam entre os "fundadores da cidade". É, aliás, “à memória dos imigrantes” Mathias e Emma Herkenhoff (seus pais), Franz e Bertha Kohlbach (seus avós) e Rudolph e Alwin Kohlbach (seus tios) que Elly Herkenhoff dedica o livro Joinville - nosso teatro amador. ${ }^{35}$

\footnotetext{
${ }^{32}$ SCHNEIDER, Adolfo Bernardo. A criação do Arquivo Histórico Municipal de Joinville. op.cit. p.7.

${ }^{33}$ Ibidem, p.11-12; Boletim [IHGSC], Florianópolis (SC), n.52, jul.2002, p.8. O Museu Nacional de Imigração e Colonização foi criado em 1957, por lei federal. Anos mais tarde - mais precisamente, em novembro de 1962 - o "Cemitério dos Imigrantes" seria tombado pelo IPHAN. Cf.: SILVA, Janine Gomes da. Tempo de lembrar, tempo de esquecer...: as vibrações do Centenário e o período da Nacionalização: histórias e memórias sobre a cidade de Joinville. 295 p. Florianópolis, 2004. Tese (Doutorado em História). Universidade Federal de Santa Catarina; p.119, 134.

${ }^{34}$ SILVA, João Francisco da. Uma testemunha da história e suas recordações. A Notícia, Joinville (SC), 2001. Neste depoimento e no texto publicado no boletim do Arquivo de 1986, Schneider entende que a perseguição aos alemães e as proibições que lhes foram impostas, no período Vargas, geraram uma situação pior que o "apartheid" sul-africano.

${ }^{35}$ HERKENHOFF, Elly. Joinville - nosso teatro amador (1858-1938). Joinville (SC): Arquivo Histórico de Joinville, 1989; ANACLETO, Antônio. Historiadora recebe título. A Notícia, Joinville (SC), 29 de setembro de 1999; WEBER, Betina. Morre, aos 98 anos, Elly Herkenhoff. A Notícia, Joinville (SC), 19 de setembro de 2004; HERKENHOFF, João Baptista. Uma existência dedicada à imigração alemã. A Notícia, Joinville (SC), 23 de setembro de 2004.
} 
A grande questão parecia ser não só revalorizar o papel dos imigrantes alemães, como tornar deles inseparável a imagem de Joinville e dos joinvilenses. Identificar toda uma coletividade, portanto, a um grupo específico. Daí a necessidade de estabelecer elos entre passado e presente, inventariar permanências, detectar tradições. As comemorações do centenário da colonização foram, neste sentido, um momento-chave.

O Centenário - que aconteceria em 1951 - começou a ter comemorações planejadas ao menos cinco anos antes, tendo à frente a Sociedade Amigos de Joinville, fundada em março de 1946. Analisando os materiais produzidos acerca do centenário, neste período, Janine Gomes da Silva neles detectou uma tentativa de contrabalançar a contribuição de origem germânica e a de origem lusitana, "abafando memórias de dores recentes e revigorando antigos personagens". ${ }^{36}$ Nessa reacomodação, ainda como destacou a autora, o ponto de equilíbrio era a ética do trabalho (uma das chaves, afinal, do discurso da nacionalização - p.88-89). Veja-se, a este respeito, o prefácio do álbum do centenário:

Cultuar a memória dos pioneiros da civilização de Joinville, enaltecer o trabalho ordeiro e pacífico dos seus filhos e glorificar as tradições de cultura de um povo, foi o objetivo primordial da presente publicação, em suas páginas singelas e expressivas, toda a magnitude e a pujança do civismo e do patriotismo de uma comuna que pontifica entre os maiores centros culturais de Santa Catarina e do Brasil. ${ }^{37}$

O prefácio não só rendia "tributo de homenagem aos fundadores de Joinville", como enaltecia "a obra grandiosa e patriótica dos que mourejam nas oficinas de trabalho, onde têm alicerçado os fundamentos do grande edifício do nosso progresso material e econômico, consagrando o seu esforço em forjar a grandeza da sua pátria." Trabalho, civismo, patriotismo: era talvez a esses valores, tidos como "autênticos", que se referia Elly Herkenhoff no texto de 1985 com que abrimos esse capítulo.

\footnotetext{
${ }^{36}$ SILVA, Janine Gomes da. Tempo de lembrar, tempo de esquecer..., Op.cit. p.21-22.

${ }^{37}$ SCHULZ, Albano [presidente da Sociedade Amigos de Joinville]. Prefácio. Álbum histórico do Centenário de Joinville. Joinville (SC): [Sociedade Amigos de Joinville], 1951. p.7.
} 


\section{Honrar a herança e dela dispor}

Ao herdeiro cabe receber a herança, mas como dispor dela? Como garantir que possa ser transmitida?

No caso das heranças em causa, não só a conservação, mas também a organização dos registros documentais eram pressupostos de sua transmissão, no presente e no futuro. Na trajetória do Arquivo Histórico de Joinville, tal como pode ser acompanhada principalmente por meio de seus boletins, são perceptíveis, no entanto, as dificuldades em lidar com a diversidade de materiais do acervo e atender às suas especificidades - sobretudo, a dos documentos arquivísticos.

Veja-se que, em 1980, o acervo estaria dividido em seis "seções": Leis, Imprensa, Biblioteca, Fototeca, Mapoteca e Documentação. ${ }^{38}$ Ou seja, havia uma tentativa de diferenciar os documentos segundo seu gênero - basicamente, textual ou iconográfico - e, no interior desse primeiro recorte, efetuar diferenciações que levassem em conta as espécies documentais (mapas ou cartas geográficas, por exemplo) e as técnicas de registro (documentos impressos tipograficamente ou obtidos por meio de processo fotográfico). Estariam reunidos, sob a rubrica "documentação", documentos manuscritos de caráter arquivístico? Se a organização do acervo, em 1980, parece autorizar essa conclusão, o mesmo não ocorre com a reorganização promovida em 1983. Naquele ano, a documentação teria sido distribuída por quatorze diferentes categorias: "livros, legislação, periódicos, diários oficiais, jornais, manuscritos, mapas, microfilmes, fotografias, filmes, fitas-cassete, quadros, músicas e documentos." ${ }^{39}$ Embora a classificação aí presente não seja propriamente, nos moldes cartesianos, um modelo de clareza e distinção (como indicam as sobreposições, por exemplo, no caso de "periódicos", "jornais" e “diários oficiais"), é particularmente obscura quanto à categoria "documentos": o que, afinal, abarcaria? Simplesmente todos os documentos que não pertencessem às demais categorias? Ou os documentos propriamente arquivísticos, organicamente acumulados, cabendo, às demais categorias, coleções, artificialmente reunidas?

Embora a última hipótese pareça relativamente razoável, é pouco provável. Como esperar que os documentos arquivísticos fossem então compreendidos em suas

\footnotetext{
${ }^{38}$ TERNES, Apolinário. Breve história do Arquivo. op.cit., p.5.

${ }^{39}$ Ibidem, p.7.
} 
especificidades, se em outubro de 1983 o boletim do Arquivo Histórico de Joinville deixava claro que os critérios de organização do acervo seguiam uma lógica biblioteconômica? "Documentos", "recortes de jornais", "personalidades ilustres" (dossiês?) e "fotografias" recebiam uma

classificação alfa-numérica, em que a letra é D, R, P, F, respectivamente, seguida da letra do assunto e do número dado ao assunto; a numeração é decimal, de 10 em 10 números, com remissivas. A classificação obedece à Organização de Arquivos. [sic]

Assim temos C-300 = Casas Enxaimel, C-310 = Casas típicas $\mathrm{xx}$ Casas Enxaimel. RC - 300 é um Recorte de jornal, DC-300 é um Documento, PC300 Personalidade ilustre, FC-300 Fotografia, todos referentes a Casas Enxaimel. ${ }^{40}$

Informava-se ainda que os demais documentos - mapas, plantas, livros, leis, diários oficiais... - haviam sido ordenados cronologicamente e por assunto. $\mathrm{O}$ investimento na classificação temática da documentação é atestado alguns meses depois, quando se informa, com base em relatórios anteriores a 1983, que a "documentação" e os "recortes de jornal" estavam contidos em "508 caixas de papelão, contendo 485 assuntos diferentes", bem como "2 arquivos de aço com 4 gavetas contendo documentos relativos às Personalidades Ilustres de Joinville e de Santa Catarina" e "64 gavetas do arquivo horizontal adquirido com a Coleção Carlos Ficker em 1979 pela Prefeitura Municipal de Joinville, insuficientes para arquivar o acervo." ${ }^{41}$ Não fica claro se documentos acumulados por organismos diferentes (por exemplo: a Câmara Municipal, o Conselho Municipal, a Sociedade Colonizadora de Hamburgo) foram então desmembrados e reunidos sob a rubrica de diferentes temas, o que, do ponto de vista arquivístico, levando-se em conta o princípio de proveniência, seria inadequado. Acentuando a perspectiva biblioteconômica de organização do acervo, dá-se

\footnotetext{
${ }^{40}$ GOMES, Sarah M.I. Apresentação. Arquivo Histórico Municipal de Joinville - AHMJ, Joinville (SC), v.1, n.1, out.1983. p.II. Significativamente, o assunto utilizado como exemplo destaca justamente um dos elementoschave de identificação da herança germânica, em Santa Catarina: as casas "enxaimel". A este respeito, Paul Keller, nas comemorações do centenário de Joinville (em 1951), afirmou ser a "casa de "enchamel" um tipo arquitetônico "predominante nas construções joinvilenses, tipo esse que nos vem desde os primeiros tempos de fundação da cidade.” KELLER, Paul Hellmuth. Álbum histórico do Centenário de Joinville. Joinville (SC): [Sociedade Amigos de Joinville], 1951. p.67.

${ }^{41}$ Arquivo Histórico Municipal de Joinville - AHMJ, Joinville (SC), v.1, n.3, fev.1984. p.2.
} 
destaque para curso de atualização realizado pela diretora da instituição, em julho de 1984, referente à AACR2 (segunda edição das Anglo American Cataloging Rules), curso este visto como "imprescindível para os trabalhos de catalogação em [sic] documentos que precisam ser preservados para que estudiosos façam pesquisas e planos de organização, para gerações atuais e futuras". 42

Deixando o Arquivo de ocupar uma das salas da Biblioteca Municipal, passando a prédio especialmente construído para abrigar seu acervo, bem como as atividades que lhe dissessem respeito, a organização do acervo também ganhou novo impulso. Os problemas de compreensão do que seria próprio do tratamento técnico arquivístico, entretanto, parecem ter persistido: informes sobre o processo de organização dão conta, em dezembro de 1986, de atividades relativas à "arquivística", sendo a este respeito mencionadas "a confecção de listagem de periódicos" e a "remontagem dos jornais encadernados". ${ }^{43}$ Aparentemente, por "arquivística" entendia-se o conjunto de atividades de controle, conservação e organização dos documentos, independentemente da forma como tivessem sido acumulados. Há indícios de que essa perspectiva permanecia em meados de 1987, mesmo havendo, naquele período, assessoria do Pró-Documento na organização dos "Documentos manuscritos e datilografados". ${ }^{44}$ Pelas informações disponíveis nos boletins do Arquivo Histórico de Joinville, a assessoria do Pró-Documento no desenvolvimento das atividades técnicas da instituição continuou ao menos até inícios de $1988{ }^{45}$

Resultado ou não das orientações técnicas recebidas daquele órgão federal, é certo que termos próprios à área de arquivos, como "fundos", estão presentes nos boletins do Arquivo de 1988 - nas referências às atividades de "Arquivística", são mencionados o "Fundo Administração Municipal" e o "Fundo Dona Francisca". Em 1990, são também mencionados os fundos "Direção da Colônia" e "Cartório Eleitoral" (o último definido a partir de doação feita pelo Fórum no ano anterior). De forma geral, estariam no âmbito das preocupações

\footnotetext{
${ }^{42}$ Arquivo Histórico Municipal de Joinville - AHMJ, Joinville (SC), v.1, n.6, ago.1984. p.7.

${ }^{43}$ Arquivo Histórico Municipal de Joinville - AHMJ, Joinville (SC), v.4, n.1, dez.1986, p.16.

${ }^{44}$ Em junho de 1987, na parte do relatório de atividades do Arquivo referente à "Arquivística", menciona-se a organização, nas estantes, dos diários oficiais, além da identificação de fotografias e do início da organização dos documentos manuscritos e datilografados. Cf.: Arquivo Histórico Municipal de Joinville - AHMJ, Joinville (SC), v.4, n.3, jun.1987, p.22. A assessoria do Pró-Documento era feita, inicialmente, por intermédio da arquivista Mônica Medrado. p.16. Cf. Arquivo Histórico Municipal de Joinville - AHMJ, Joinville (SC), v.4, n.2, mar.1987, p.16.

${ }^{45}$ Técnicos do Pró-Documento visitaram o Arquivo Histórico de Joinville em 27 de novembro de 1987 e em fevereiro de 1988 (coordenador de informática). Ver: Arquivo Histórico Municipal de Joinville - AHMJ, Joinville (SC): v.5, n.1, dez.1987, p.17; v.5, n.2, mar.1988, p.18.
} 
"arquivísticas", juntamente com os "documentos manuscritos e datilografados", fotografias e mapas. Em 1990, a organização dos materiais - "identificação, catalogação e arquivamento" estaria sendo feita a partir de "instruções recebidas do Pró-Preserv (Centro de Preservação e Conservação), do Rio de Janeiro."46 No que tange aos conjuntos documentais arquivísticos, os anos iniciais da década de 1990 assinalam atividades de arranjo e descrição (com elaboração de inventário) de processos do Fórum, dos documentos do "Fundo Dona Francisca", além dos documentos reunidos por Carlos Ficker (já que agora identificados nos relatórios de atividades como "Fundo Ficker", e não como "coleção" Ficker) e do arquivo pessoal de Carlos Gomes de Oliveira, doado ao Arquivo. ${ }^{47}$

A questão das assessorias efetuadas por órgãos federais, cujos técnicos vez por outra se deslocavam a Joinville para prestar serviços de forma mais direta, põe em causa o problema da capacitação do corpo de funcionários ou, em outro enfoque, da reestruturação do quadro de pessoal. Ou seja, tratava-se de preparar os funcionários já integrantes do quadro para exercer determinadas funções técnicas no Arquivo ou prever, na instituição, um conjunto de cargos de perfil técnico, pressupondo, portanto, a incorporação de novos profissionais. Se a primeira possibilidade tentava ser suprida com cursos de curta ou média duração, mais especificamente voltados para as questões de interesse do Arquivo, ${ }^{48}$ a segunda buscou ser equacionada ao menos a partir de 1995, em meio às discussões acerca do regimento da instituição. Com o regimento, esperava-se imprimir "maior dinamismo às atividades técnicocientíficas", inclusive criando "um quadro de lotação de funcionários especializados com atribuições de deveres e direitos." ${ }^{49}$ Em meados de 1996, a Fundação Cultural de Joinville, à qual o Arquivo estava vinculado, realizou "concurso público para provimento de cargos da

\footnotetext{
46 Arquivo Histórico Municipal de Joinville - AHMJ, Joinville (SC), v.5-6, n.3-5, abr.-dez.1988. p.13; Boletim do Arquivo Histórico de Joinville, Joinville (SC), n.6, mar.1990, p.22. Em 1988, livros e periódicos aparecem como pertinentes ao setor de "Biblioteca"; em março de 1990, os mapas já não aparecem no rol de documentos da parte "Arquivística".

${ }^{47}$ Boletim do Arquivo Histórico Municipal de Joinville - AHMJ, Joinville (SC): n.7, nov.1990, p.23; n.9, dez.1991, p.17. Também CORRÊA, Roseana Maria. O acervo particular do ex-senador Carlos Gomes de Oliveira. Boletim do Arquivo Histórico Municipal de Joinville - AHMJ, Joinville (SC), n.10, jun.1992, p.23. Note-se a inconstância de caracterização do acervo Ficker, como coleção ou arquivo: em 1984, foi identificado como "Arquivo Ficker" (Arquivo Histórico Municipal de Joinville - AHMJ, Joinville (SC), v.2, n.1-2, outdez. 1984. p.4).

${ }^{48}$ Ver, por exemplo, no primeiro semestre de 1996, a conclusão, por parte da funcionária Terezinha Fernandes da Rosa, do Curso de Especialização em "Organização e Administração em Arquivos”, promovido pela UFSC. Boletim do Arquivo Histórico Municipal de Joinville - AHMJ, Joinville (SC), n. 14, jun.1996. p.56.

${ }^{49}$ Boletim do Arquivo Histórico Municipal de Joinville - AHMJ, Joinville (SC), n.12, jul.1995. p.50.
} 
área cultural."50 Raquel S. Thiago, em texto publicado em boletim de junho daquele ano, pronunciou-se a respeito do pessoal técnico do Arquivo da seguinte forma:

Em 1986, quando da inauguração do prédio, escrevi, para um encarte comemorativo, no jornal "A Notícia", um artigo intitulado "Um sonho realizado'. Referia-me às novas instalações [do Arquivo Histórico de Joinville], necessidade mais imediata. Um ano depois, em julho de 1987, quando completou-se o primeiro ano de funcionamento, publiquei outro artigo, "O sonho não acabou", que refletia minha angústia e as de colegas pela carência de profissionais qualificados que possibilitassem ao Arquivo o cumprimento da sua missão... [...] Após dez anos, vale a pena festejar: procura-se fornecer, pelo menos em parte, resposta ao problema, com a criação de cargos de Historiador, Arquivologista [sic], Encadernador, Tradutor e Restaurador de Documentos, o que significa a garantia de funcionários qualificados para desenvolverem projetos que correspondam às necessidades de Joinville e Região. ${ }^{51}$

Raquel S. Thiago, ex-diretora do Arquivo e à época integrada à área cultural da Prefeitura, também participava do Grupo Técnico-Científico do Arquivo Histórico de Joinville, empossado em julho de 1995. O Grupo, integrado por três funcionárias, além de "cientistas" e "professores", tinha como finalidade "conferir maior visibilidade à preservação do patrimônio arquivístico da cidade”, basicamente dando suporte aos projetos da instituição, por meio de "discussões e pareceres". 52 Deve-se concluir, pelos objetivos do Grupo Técnico, que as ações envolvendo a preservação do patrimônio arquivístico, em Joinville, não tinham até então alcançado grande visibilidade? A construção e a ocupação de um prédio próprio não teriam, neste sentido, sido suficientes?

\footnotetext{
${ }^{50}$ Boletim do Arquivo Histórico Municipal de Joinville - AHMJ, Joinville (SC), n.14, jun.1996. p.55.

${ }^{51}$ S.THIAGO, Raquel. AHJ - um testemunho. Boletim do Arquivo Histórico Municipal de Joinville AHMJ, Joinville (SC), n.14, jun.1996. p.20.

${ }^{52}$ Tomaram posse em 1995, como integrantes do Grupo: Raquel S.Thiago, Sandra P.L.C.Guedes e Iara Andrade Costa (historiadoras), Paulo Unger (geógrafo), Maria Nazaré Fabel (bibliotecária), Antônio Nascimento (advogado), Sueli Cagneti ("literata") e as funcionárias Ilanil Coelho (diretora), Terezinha Fernandes da Rosa e Dietlinde Clara Rothert. Boletim do Arquivo Histórico Municipal de Joinville - AHMJ, Joinville (SC), n.12, jul.1995. p.49.
} 


\section{A arca dos tesouros}

Reconciliado com o desejo de Adolfo Schneider de que abrigasse os documentos do Domínio Dona Francisca, recolhidos por Carlos Ficker, o Arquivo Histórico de Joinville encontra, no início dos anos 1980, uma nova meta: sua sede exclusiva.

Alojado, desde a sua criação, em sala da Biblioteca Pública Rolf Colin, de aproximadamente $100 \mathrm{~m}^{2}$, o Arquivo àquela altura não tinha mais como abrigar adequadamente todos os documentos sob sua guarda. Já em 1981 teria havido, segundo Apolinário Ternes, “intenso debate na comunidade sobre a urgência em se dotar o Arquivo de uma sede própria, e o arquiteto Helmuth Keller, acionado pela Prefeitura, chega a elaborar um projeto para a futura sede do Arquivo."53 Em 1983, o boletim do Arquivo Histórico de Joinville registra, por meio de Sarah Gomes, sua então diretora, a aprovação da planta do futuro prédio, e a definição do local de construção. ${ }^{54}$ Em 1984, a diretora obtém cópia da planta do Arquivo Geral da Cidade do Rio de Janeiro, de modo que pudesse "ser estudada pelos engenheiros encarregados da construção da sede do AHJ."

Estando naquele momento já bastante identificado com a memória dos imigrantes germânicos do século XIX, o Arquivo Histórico volta-se para o país de origem dos primeiros colonos, estabelecendo contatos com representantes do governo alemão no Brasil: um dossiê sobre o acervo e as instalações físicas que ocupava é encaminhado ao Cônsul Honorário da República Federal da Alemanha, no primeiro semestre de 1984. O governo da RFA compromete-se a dar apoio financeiro ao projeto de construção do edifício, o que é informado em visita ao Arquivo feita pelo embaixador alemão, Walter Gorenflos, em 30 de agosto de 1984. O prédio seria construído, em princípio, "ao lado da Casa da Cultura.",56

\footnotetext{
53 TERNES, Apolinário. Breve história do Arquivo. op.cit. p.6. Sobre as dimensões da sala ocupada na Biblioteca Pública, há informações ligeiramente divergentes: $100 \mathrm{~m}^{2}$ (HERKENHOFF, Elly. O Arquivo Histórico de Joinville: seus tesouros..., op.cit., p.1) ou 120m² (GOMES, Sarah M.I. Apresentação. op.cit., p.I).

${ }_{55}^{54}$ GOMES, Sarah M.I. Apresentação. Op.cit., p.I.

${ }_{55}$ Arquivo Histórico Municipal de Joinville - AHMJ, Joinville (SC), v.1, n.6, ago.1984. p.6. José Antonio Vieira era o engenheiro responsável pela execução da obra, segundo o boletim de out-dez. de 1984 (Arquivo Histórico Municipal de Joinville - AHMJ, Joinville (SC), v.2, n.1-2, out-dez.1984. p.6.).

${ }^{56}$ Arquivo Histórico Municipal de Joinville - AHMJ, Joinville (SC), v.1, n.5, jun.1984. p.1; Arquivo Histórico Municipal de Joinville - AHMJ, Joinville (SC), v.2, n.1-2, out-dez.1984. p.1-2. A informação acerca do local de construção é confirmada no boletim de abril de 1985 ("ao lado da Casa da Cultura, à Av. Brasil, antes do DNOS" - Arquivo Histórico Municipal de Joinville - AHMJ, Joinville (SC), v.2, n.4, abr.1985. p.3) e no de setembro de 1985 ("no terreno ao lado da Casa da Cultura, margeando o Rio Cachoeira" - Arquivo Histórico Municipal de Joinville - AHMJ, Joinville (SC), v.2, n.6, set.1985. p.14).
} 
Como a reforçar a necessidade de dar abrigo seguro e digno ao acervo, e a comprovar que as dificuldades vivenciadas não eram meramente retóricas, duas inundações, no primeiro semestre de 1984, acentuaram a precariedade da situação do Arquivo Histórico: a primeira, em 7 de agosto, deveu-se ao acúmulo de águas pluviais no telhado da Biblioteca, resultando em prejuízo para "grande número de jornais encadernados e livros", submetidos a processo de secagem ao longo de duas semanas; a segunda, em 17 de outubro, foi provocada durante a madrugada por problema interno ("o engate da torneira da pia que se encontra no interior do Arquivo arrebentou"), afetando muitos materiais:

[...] toda uma coleção de livros de Medicina, pilhas de jornais do século passado, documentos do Arquivo Ficker, recortes de jornais, documentos diversos guardados em caixas de camisa, mais de 30 quadros - alguns bordados a mão, com fios dourados e enfeitados com flores secas - material para encadernação, tudo, enfim encharcado. ${ }^{57}$

O trabalho de recuperação dos documentos afetados pela água, em outubro, obrigou o Arquivo a suspender a consulta pública por uma semana.

Entre a elaboração do projeto da nova sede e sua inauguração, ocorrida em julho de 1986, uma cerimônia especial promoveu a nova inscrição do Arquivo Histórico de Joinville no tecido da cidade: o lançamento da pedra fundamental, realizado em 29 de julho de 1985, na presença de diversas autoridades, em especial as da administração municipal (com destaque para Wittich Freitag, Prefeito Municipal, e Miraci Deretti, presidente da Fundação Cultural de Joinville) e do governo da República Federal da Alemanha (Hasso Freiher von Maltzahn, Cônsul Geral da República Federal da Alemanha, e Wolfgang Voigt, Cônsul Honorário em Joinville). Na cerimônia, uma urna foi integrada às bases do futuro edifício. Era, claramente, uma "cápsula do tempo", contendo registros contemporâneos relativos a outras localidades (jornais "do país") e de Joinville (documentos que apresentassem "seus aspectos culturais, sociais, políticos, econômicos, físicos", além de "fotografias, moedas e cédulas" e "jornais locais). Registros, sobretudo, do próprio Arquivo: relatórios de atividades, boletins, fotografias, uma cópia da lei de criação. Foram igualmente

\footnotetext{
57 Arquivo Histórico Municipal de Joinville - AHMJ, Joinville (SC), v.2, n.1-2, out-dez.1984. p.3-4. Os equipamentos utilizados na secagem foram secadores de cabelo e ventiladores (os últimos, emprestados de vários órgãos municipais).
} 
incluídos na urna, muito significativamente, textos "da historiadora Elly Herkenhoff, funcionária do Arquivo": os livros Joinville - ontem e hoje e Joinville - nossos prefeitos, 1869/1903, além do artigo "O Arquivo Histórico de Joinville - seus tesouros - suas deficiências - suas possibilidades". Ao lado dos textos da historiadora, uma cópia do discurso então pronunciado pelo Prefeito Freitag. ${ }^{58}$ Elly Herkenhoff, a autoridade sobre o passado; Freitag, a autoridade do presente.

Nas instituições arquivísticas brasileiras de caráter permanente, é freqüente que a articulação entre passado e presente tente ser claramente visualizada por meio da arquitetura. Escolhem-se, então, como sedes, antigos edifícios, às vezes protegidos por tombamento, considerados, em algum nível governamental, integrantes do patrimônio edificado. ${ }^{59}$ Essa praxe (seguida inclusive em Santa Catarina, como já destacado no Capítulo 3, Parte II) não foi adotada no caso do Arquivo Histórico de Joinville. O vínculo estreito entre presente e passado é perceptível, sim, na persistência da presença germânica - os alemães de hoje prestando homenagem aos alemães de outrora. O governo da República Federal da Alemanha apoiou de fato a construção da nova sede, colaborando com 100 mil marcos em uma obra orçada em Cr\$1,2 bilhões. Com ela, o espaço disponível para o Arquivo decuplicaria: previa-se uma área total de $1.024 .71 \mathrm{~m}^{2}$, permitindo ampliações; as áreas internas seriam totalmente climatizadas ("temperatura interior constante de 18 graus" e "funcionamento de ar condicionado durante 24 horas por dia"), havendo ainda sistema de detecção de fumaça e de variação de temperatura. No prédio novo, nenhuma alusão, mesmo que fantasmática, ao que era lido como "tipicamente alemão", em termos arquitetônicos (ou seja, o enxaimel): “o padrão arquitetônico é moderno". ${ }^{6}$

\footnotetext{
${ }^{58}$ Arquivo Histórico Municipal de Joinville - AHMJ, Joinville (SC), v.2, n.6, set.1985. p.13. A seu modo, a urna do Arquivo, além de entregar o presente ao futuro, de alguma forma estabelecia pontes com o passado: pois também os primeiros imigrantes deixaram sua "cápsula do tempo". Os documentos da urna da pedra fundamental da Igreja da Paz, lançada a $1^{\circ}$. de junho de 1857, e encontrados em 1960, durante a reforma da Igreja, foram microfilmados e os microfilmes incorporados ao acervo do Arquivo Histórico de Joinville. Alguns desses documentos foram publicados no boletim do Arquivo (Arquivo Histórico Municipal de Joinville AHMJ, Joinville (SC): v.3, n.2, mar.1986, p.9; v.4, n.1, dez.1986, p.9-11).

${ }^{59}$ Em comentário acerca da sede própria do Arquivo Histórico de Joinville, esse aspecto é destacado por Sandra P.L. de Camargo Guedes, que o estende também a museus e bibliotecas "de grandes capitais como São Paulo e Rio de Janeiro". GUEDES, Sandra P.L. de Camargo. Considerações sobre a História Nova e o Arquivo Histórico de Joinville. Boletim do Arquivo Histórico Municipal de Joinville - AHMJ, Joinville (SC), n.14, jun.1996, p.40.

${ }^{60}$ Ibidem, p.14-15.
} 
Finalizado o prédio e realizada a árdua mudança, a diretora da nova fase, Raquel S. Thiago, comemorava:

Podemos aquilatar a dimensão extraordinária da construção de um prédio apropriado para guardar nosso acervo histórico, primeiro porque temos em Joinville uma faculdade de História, com opção pelo bacharelado. Como professora daquela Instituição, partilhei das frustrações decorrentes da falta de um acervo organizado. [...]

Por outro lado, respiramos aliviados, pois está garantida a preservação do acervo. Temos documentos das mais variadas origens e ainda estamos por descobrir outros tantos deles, agora com sua organização. Daí o valor da obra inaugurada: a possibilidade de realizar melhor e mais completa conservação dos documentos com os laboratórios de restauração e encadernação, além de condições para preservarmos as novas fontes de informação que a técnica contemporânea põe à nossa disposição: fotografias, microfilmes e fitas magnéticas, através dos laboratórios de microfilmagem, fotografia e história oral. ${ }^{61}$

Quanto prometia o novo prédio! Novos horizontes poderiam ser abertos para a pesquisa histórica em Joinville, com documentos melhor conservados e organizados, além de mais diversificados. Tamanha era a importância atribuída a ele que um número inteiro do boletim foi dedicado a comemorar os dez anos de sua ocupação. Segundo a diretora de então, Ilanil Coelho,

A construção do atual prédio, equipado com sistema central de ar condicionado, climatização ambiente e alarmes contra incêndio e roubo, colocou o AHJ, desde a inauguração, em 1986, em posição de destaque no contexto nacional, já que poucas cidades do país possuem instalações e prédios adequados a abrigar o seu patrimônio arquivístico. Porém, o mais importante é que este prédio, enquanto produção cultural, foi e continua

\footnotetext{
${ }^{61}$ S.THIAGO, Raquel. O Novo Arquivo Histórico: um sonho realizado. Arquivo Histórico Municipal de Joinville - AHMJ, Joinville (SC), v.3, n.4, set.1986, p.5.
} 
sendo expressão de um desejo social de apropriação do passado e do presente. A cidade, portanto, orgulha-se de tê-lo como referência. ${ }^{62}$.

O Arquivo de Joinville conseguiu, enfim, o prédio próprio que permitiria estar à altura das heranças a preservar: moderno, no sentido das tecnologias implantadas a serviço dos imperativos de conservação; modernista, em seu desenho contemporâneo, que remete às obras de Frank Loyd Wright. Ao lado da climatização, para zelar pela recuperação dos documentos já danificados, ou controlar os danos, foi montado laboratório de conservação, restauro e encadernação de documentos; para atender às demandas contemporâneas de rapidez na disponibilização de dados, teve início a informatização das atividades de descrição dos documentos. Mas, seria o sonho maior que Joinville?

Não bastou o prédio, não bastaram laboratórios, não bastaram equipamentos; não bastou, nem mesmo, concurso público para profissionais especializados. Afinal, prédios e equipamentos precisam ser mantidos, setores e funcionários animados por atividades pertinentes ao perfil da instituição, para as quais existam recursos financeiros. Em meio ao caminho a trilhar, no pós-sede própria, vê-se que o laboratório não pode restaurar, por falta de papel especial, nem encadernar, por falta de encadernador; que o setor de informática tem mais dados do que os computadores disponíveis podem processar e armazenar, e também apresenta falta de funcionários especializados. Os pequenos obstáculos sofrem adiante uma transformação espetaculosa, desvio para o trágico: a peste. Dois anos depois da quebra do sistema de ventilação que deveria funcionar ininterruptamente, detecta-se a contaminação dos documentos de dois setores do Arquivo por inseticidas organoclorados, utilizados no trato com os documentos nos inícios da organização da instituição. O risco à saúde dos funcionários faz com que a Vigilância Sanitária interdite, em setembro de 2002, os dois setores, justamente os que contêm "as coleções mais antigas", o que passa a impedir sua consulta. ${ }^{63}$ Cerca de um ano depois, o Arquivo Histórico de Joinville suspende toda e

\footnotetext{
${ }^{62}$ COELHO, Ilanil. Apresentação. Boletim do Arquivo Histórico Municipal de Joinville - AHMJ, Joinville (SC), n.14, jun.1996, p.5.

${ }^{63}$ GROTH, Marlise. Na enfermaria. A Notícia, Joinville (SC), 10 de agosto de 2003. A reportagem informa, ainda: "Com o sistema de ventilação quebrado, alguns técnicos tiveram irritação nos olhos, náuseas, tontura, dores de cabeça e problemas estomacais. De acordo com o presidente da Fundação Cultural de Joinville, a variação de temperatura provocou a proliferação de fungos no local. Isso, associado ao pesticida em suspensão e à falta de equipamentos adequados para o manuseio do material, causou os problemas nos funcionários."
} 
qualquer consulta ao acervo, para intensificar a desinfecção dos documentos. O trabalho no depósito A exige grande aparato:

Para trabalhar nesse ambiente, os técnicos usam roupas pesadas, feitas de tecido especial, capuz com respirador motorizado, botas de borracha e luvas. Além de passar por uma mesa especial de higienização, limpeza com pincel, aspirador de pó e, dependendo da fragilidade, por pó de borracha, tudo ocorre dentro de uma cabine de fluxo laminar, equipamento que garante mais segurança ao técnico e ao ambiente. ${ }^{64}$

No depósito A, esclarece o jornal A Notícia, estavam "as preciosidades do Arquivo: todo o conjunto denominado 'domínio da Colônia Dona Francisca' [sic], listas de imigração, diários, fotografias, livros de óbitos, casamentos e batismos, mapas e gravuras." Uma das mais antigas funcionárias do Arquivo, Maria Thereza Böbel, leitora e tradutora assídua dos documentos em alemão do século XIX, adoece, com câncer, suspeitando-se que as causas da doença tenham relação com a presença dos organoclorados na documentação por ela manipulada ao longo de anos; morre em outubro de $2005 .^{65}$

Reaberto em março de 2006, mas apenas para consulta parcial do acervo, o Arquivo mantinha justamente seus "tesouros" do século XIX inacessíveis. ${ }^{66}$ Um espólio sob interdição, desconhecido para possíveis novos herdeiros.

\section{Variações sobre os mesmos temas}

A percepção de serem depositários de heranças - e, mais especificamente, de heranças ligadas a tradições germânicas, disseminadas a partir dos empreendimentos de

\footnotetext{
${ }^{64}$ GROTH, Marlise. Arquivo Histórico de Joinville fecha portas por quatro meses. A Notícia, Joinville (SC), 30 de agosto de 2004.

${ }^{65}$ CIA, André Luís. Arquivo Histórico reabre na segunda. A Notícia, Joinville (SC), 18 de março de 2006, caderno "Cidade". Nota assinada pelo advogado Rogério Zuel Gomes, publicada no mesmo jornal em 25 de março de 2006 ("Contestação", na seção "Opinião"), questiona pontos da reportagem de 18 de março, e assinala que Maria Thereza Böbel entrara com ação indenizatória contra a municipalidade em função da doença.

${ }^{66}$ ARGOLO, Carla. Limpeza no tesouro do passado. Diário Catarinense, Florianópolis, 19 de janeiro de 2006, caderno "Variedades", p.3; Arquivo Histórico é reaberto. Diário Catarinense, Florianópolis, 21 de março de 2006. Reaberto Arquivo Histórico de Joinville, após 4 anos. A Notícia, Joinville (SC), 21 de março de 2006, caderno "Geral".
} 
colonização aos quais se prendem os inícios da vida municipal - articula significativamente o Arquivo Histórico de Joinville e o Arquivo Histórico de Blumenau, ambos criados como “arquivos históricos”, por lei, em 1972.

Tal como o Arquivo de Joinville, Blumenau valorizou determinados conjuntos documentais produzidos na segunda metade do século XIX, muito semelhantes, aliás, em sua tipologia: coleções de jornais (o Urwaldsbot e o Blumenauer Zeitung), registros fotográficos, relatórios de diretores da colônia, listas de imigrantes. Uma compreensão da História como passado a ser cultuado (e que valorizou "fundadores" e "pioneiros") também se aliou à necessidade de superação dos traumas deixados pela campanha de nacionalização, entre descendentes de imigrantes alemães. Os investimentos de ambas as instituições foram significativos quanto à reunião, conservação, reprodução, transcrição e tradução de documentos originais (manuscritos ou impressos) produzidos na língua alemã e ligados aos primeiros tempos das colônias, inclusive procedendo-se, para tanto, a levantamentos na Alemanha. No caso específico de Blumenau, o incêndio que atingiu o acervo documental da administração municipal, em fins da década de 1950, deu margem a que essa enorme lacuna causada pelo fogo fosse, de algum modo, preenchida com documentos doados por munícipes (uma documentação em grande medida contemporânea - ou referente - aos momentos iniciais da vida da colônia, com ênfase na presença alemã).

Simultaneamente, a preservação de uma dada memória forjou um fazer historiográfico, tendo os arquivos como abrigos e vetores. Convém examinar mais detidamente esse fazer. 


\section{Parte III}

\section{Capítulo 2}

\section{Arquivos: laboratórios de História}

Enquanto conjuntos documentais, os arquivos são resultado da ação continuada de entidades (pessoas físicas ou jurídicas), ao registrarem as trajetórias de suas existências e acumularem tais registros. Enquanto instituições, os arquivos dispõem acerca da documentação produzida, organizando-a, eliminando-a, preservando-a. Se públicas, as instituições arquivísticas devem tornar os documentos acessíveis e divulgá-los, com isso abrindo caminho para a geração de novos documentos. As próprias instituições produzirão instrumentos de pesquisa, publicações, exposições. Os usuários, por sua vez, recolherão, nos arquivos, provas de direitos (que formarão, possivelmente, processos) e informações várias, que permitirão desde a elaboração de árvores genealógicas a reportagens e documentários, monografias, dissertações e teses.

Se não podem ser vistos simplesmente como "celeiros de fatos", como apontou incisivamente Lucien Febvre, há cerca de 60 anos, ${ }^{1}$ constituem-se os arquivos como laboratórios de História. São locais para os quais dirigem-se os usuários, munidos de perguntas, lápis e papel (além de, hoje, muitas vezes, laptop e câmera digital) e, no contato com os registros, buscam provar - no sentido de validar e de experimentar, como apontou Ginzburg. ${ }^{2}$ Realizam o labor de colher materiais, examiná-los, dar-lhes forma e sentido. Entre os usuários, os historiadores.

\footnotetext{
${ }^{1}$ Sur une forme d'histoire qui n'est pas la nôtre: l'histoire historisante - texto traduzido em: MOTA, Carlos Guilherme (org.). Lucien Febvre: História. 2 ed. São Paulo: Ática, 1992. p.103-107 (a alusão aos "celeiros de fatos" encontra-se na p.107).

2 Mesmo longa, vale a citação: “[Em italiano] Provare significa, por um lado, 'validar' e, por outro, 'experimentar', como observou Montaigne falando de seus próprios Ensaios. A linguagem da prova é a de quem submete os materiais da pesquisa a uma aferição permanente: 'provando e confirmando', como rezava a famosa divisa da Academia [científica florentina] del Cimento. A fórmula correspondente em inglês moderno - trial and error - evoca na palavra trial a verificação (test) e a tentativa (attempt), o tribunal e a Casa da Moeda. Quem controla as ligas metálicas é o saggiatore (em inglês the assayer): a palavra que agradou a Galileu. Caminhamos às apalpadelas, como o luthier que bate delicadamente, com os nós dos dedos, na madeira do violino: uma imagem que Marc Bloch contrapôs à perfeição mecânica do torno, para sublinhar o inextirpável componente artesanal do trabalho do historiador." GINZBURG, Carlo. Relações de força: história, retórica, prova. São Paulo: Companhia das Letras, 2002. p.11-12.
} 
Em arquivos como os de Blumenau, Itajaí e Joinville, desde a década de 1970 claramente incumbidos, por lei, de disponibilizar seus acervos ao público, quais teriam sido seus usuários, o que teriam consultado? Abertos os acervos, feito o convite à pesquisa e à produção de História, como os pesquisadores teriam respondido a isso?

\section{A História buscada}

Ao longo do tempo, os arquivos de Blumenau, Itajaí e Joinville nem sempre adotaram os mesmos critérios para o controle de atendimento ao público, mudando ainda a maneira de divulgar tais dados, o que impõe vários limites à análise. Tendo-se como referência um período para o qual foram obtidos dados sobre o atendimento relativos a todas as três instituições - a saber, o período de 1987 a 1992 -, essas limitações tornam-se visíveis.

Neste período, os relatórios de atividades do Arquivo Histórico de Blumenau indicam o número de pesquisadores, de alunos (ou "escolares") e de visitantes (tanto os "ilustres" como os representantes de municípios à procura de orientação técnica). Não são fornecidos, contudo, dados quanto ao tipo de pesquisas, nem especificados os materiais consultados (ver Apêndice III-7). Com isso, não é possível saber em que medida os "escolares" apenas visitaram o Arquivo, em turmas, ou procederam a pesquisas. Note-se que, em anos anteriores $(1983,1984)$, os relatórios diferenciaram as pesquisas "escolares" (do ensino fundamental e médio) das pesquisas de pós-graduação, distintas, por sua vez, das voltadas para reportagens jornalísticas e das genealógicas.

Isso não significa afirmar que o controle mais detalhado do atendimento e das demandas de pesquisa não fosse feito pela instituição. Em 1987, a responsável pelo Arquivo Histórico de Blumenau, Sueli Petry, publicou artigo em que apresentava uma classificação das demandas de pesquisa e seus respectivos percentuais, além de dados sobre a ocupação profissional dos pesquisadores e vínculos institucionais. ${ }^{3}$ Embora algo imperfeita, por dividir o mesmo conjunto de demandas ora por um critério (área de interesse) ora por outro (materiais consultados), a classificação é relevante: entre agosto de 1986 e junho de 1987, 208 pesquisadores teriam freqüentado o Arquivo Histórico de Blumenau, 37,3\% deles

\footnotetext{
3 PETRY, Sueli Maria Vanzuita. O perfil do pesquisador do Arquivo Histórico "José Ferreira da Silva". Blumenau em Cadernos, Blumenau (SC), t. XXVIII, n.10, out. 1987, p.327.
} 
interessados em temas ligados à história regional, 15,94\% em genealogia, 14,18\% em "assuntos diversos", 11,22\% em "História Social", 9,13\% em fotografia, 5,77\% em arquitetura, 5,76\% em cartografia. A freqüência de jornalistas (19,34\%) superava a de estudantes $(18,11 \%)$, historiadores $(17,3 \%)$ e “professores" $(12,42 \%)$, além de um conjunto de usuários das mais variadas profissões. ${ }^{4}$

Levando-se em conta os dados de atendimento divulgados regularmente pelas instituições, em relatórios de atividades e boletins, verifica-se que o Arquivo de Joinville, entre 1987 e 1992, apenas destacou o número de pesquisas, sem quantificação de pesquisadores, além de especificar, entre as consultas, as de caráter genealógico (Apêndice III-6). Como o número de pesquisas não coincide necessariamente com o de pesquisadores, a comparação dos dados das instituições arquivísticas de Blumenau e Joinville fica prejudicada. No entanto, observa-se que o número de pesquisas (em Joinville) e de pesquisadores (em Blumenau) cresceu continuamente, com exceção do ano de 1990. Nos dois arquivos houve um salto significativo entre 1991 e 1992: em Joinville, o número de pesquisas teve um aumento de aproximadamente $65 \%$ em relação ao ano anterior, e em Blumenau o número de pesquisadores cresceu em torno de 53\%. No caso de Itajaí, os índices de pesquisa são bastante inferiores aos de Blumenau e Joinville, e inconstante o fluxo de pesquisadores, sobretudo entre 1987 e 1989 (Apêndice III-8). Contudo, aí é igualmente observável uma ampliação entre 1991 e 1992 (crescimento de 46\% na freqüência de pesquisadores). São dados que sugerem uma transformação marcante nas necessidades de consulta e pesquisa, a partir de 1992, causada por fatores não meramente locais, e que mereceriam investigação aprofundada. Muito provavelmente, a transformação relaciona-se à expansão dos cursos universitários, nas várias áreas, tanto em nível de Pós-Graduação (incluindo as especializações, comportando elaboração de monografias) como de Graduação (devido principalmente às exigências de trabalhos de conclusão de curso).

Pelos dados relativos ao período anterior a 1987, é possível verificar, em Joinville e, principalmente, em Blumenau, um grande número de pesquisas "escolares". O interesse na pesquisa genealógica também esteve presente entre os usuários de ambas as instituições. Um

\footnotetext{
${ }^{4}$ Não é possível saber, a partir da classificação das atividades dos usuários, se nas categorias "estudantes" e "professores" estavam incluídos apenas os de ensino fundamental e médio ou também os de graduação e pósgraduação; não fica claro o critério de classificação dos "historiadores" (formação universitária em História? produção historiográfica publicada?).
} 
dado que só é possível detectar no Arquivo Histórico de Joinville, em relação ao período 1983-1986, refere-se aos materiais consultados: as consultas a periódicos foram bastante expressivas, inclusive a diários oficiais, e provavelmente incluíram muitos usuários sem motivações acadêmicas.

Como explicar índices de pesquisa tão menores, no mesmo período, em Itajaí?

Criado por lei na década de 1970, o Arquivo Histórico de Itajaí foi implantado apenas na década seguinte: sua organização teve início em 1985, nos dois primeiros anos com equipe coordenada por Maria Bernardete Ramos Flores, então professora dos cursos de graduação da FEPEVI (posteriormente, UNIVALI), em Itajaí, e posteriormente por Edison d'Ávila. ${ }^{5}$ Foi inicialmente instalado no Palácio Marcos Konder, já sede do Museu Histórico e da própria Fundação Genésio Miranda Lins (entidade à qual estavam vinculados o museu e o arquivo), com parte significativa da documentação alojada no sótão, em condições inadequadas. Em 1998 foi decidida a transferência provisória do Arquivo Histórico para a Casa Konder (efetivada em dezembro) e planejada sua sede definitiva na Casa Lins. ${ }^{6}$ A instalação na Casa Lins ocorreria no primeiro semestre de 2001, passando o Arquivo Histórico a integrar o que foi chamado de Centro de Documentação e Memória Histórica Genésio Miranda Lins. ${ }^{7}$

Tudo indica que as instalações físicas ocupadas foram fator determinante no atendimento a usuários do Arquivo de Itajaí: o número de pesquisadores cresceu significativamente, entre 1986 e 1996, mas foi muito mais acentuado após 1998 (ver Apêndice III-8). Para o período 1999-2002, foi feita a discriminação dos materiais consultados, notando-se o predomínio da consulta a coleções e, em especial, a jornais. O item "documentos", que talvez indique os materiais integrantes de conjuntos documentais arquivísticos, ultrapassou duas mil unidades consultadas, entre 1999 e 2002; uma consulta baixa, porém, em relação à totalidade de materiais pesquisados pelos usuários (os

\footnotetext{
${ }^{5}$ Relatório de atividades relativo ao ano de 1986, apresentado pelo presidente da Fundação Genésio Miranda Lins, Edison d'Ávila. Itajaí (SC), janeiro de 1987; Relatório de atividades relativo ao ano de 1987, apresentado pelo presidente do Conselho Curador, Edison d’Ávila. Itajaí (SC), janeiro de 1988. Acervo: Centro de Documentação e Memória Histórica/Arquivo Público de Itajaí.

${ }^{6}$ Relatório de atividades da Fundação Genésio Miranda Lins, relativo ao ano de 1996. Itajaí (SC), [1997]; Relatório de atividades da Fundação Genésio Miranda Lins, relativo ao ano de 1998. Itajaí (SC), [1999]. Acervo: Centro de Documentação e Memória Histórica/Arquivo Público de Itajaí.

${ }^{7}$ Relatório de atividades da Fundação Genésio Miranda Lins, relativo ao ano de 2001 Itajaí (SC), [2002]. Acervo: Centro de Documentação e Memória Histórica/Arquivo Público de Itajaí.
} 
"documentos", em 1999 e 2001, foram cerca de 19\% de toda a documentação consultada, e $13 \%$ em 2002).

Visitados e consultados, os arquivos mostraram-se conhecidos - até que ponto, contudo, o público usuário teria conseguido diferenciá-los de bibliotecas e centros de documentação? Em que medida o interesse pela documentação pública municipal teria sido significativo?

Deve-se considerar que, na organização dos acervos, as prioridades eleitas por diretores e técnicos das instituições serão determinantes para induzir a consulta a este ou aquele conjunto documental (inclusive por não ser costumeira a disponibilização de documentos ainda não organizados). Os materiais já tratados tecnicamente, para os quais há instrumentos de pesquisa, tenderão, portanto, a ser alvo mais freqüente de busca e uso. No entanto, novas demandas de pesquisa, uma vez detectadas, poderão sinalizar a necessidade de reformulação dos projetos de organização arquivística, com a concentração de esforços no tratamento de documentação antes considerada não-prioritária. O jogo de influências recíprocas, nascido da relação entre instituições e usuários, é, conseqüentemente, um fator de relevo nos quesitos disponibilização e consulta. Daí que, visando oferecer o número mais amplo possível de opções aos usuários, recomende-se, na área arquivística, a adoção de programas de descrição cuja etapa inicial esteja voltada para a confecção de instrumentos de pesquisa mais genéricos. Tal como destacado por Heloísa Bellotto,

Dada a necessidade de se fornecer, antes de qualquer particularidade, uma visão geral dos fundos do arquivo, seus serviços e possibilidades de acesso, o primeiro instrumento a ser elaborado deve ser o guia. Os instrumentos parciais (referentes a fundos determinados ou a parte deles), como inventários e catálogos, podem ser feitos concomitante ou sucessivamente. Já os catálogos seletivos e as edições de fontes, em virtude de suas especificidades, podem ser elaborados paralelamente, fora do ritmo normal do trabalho descritivo. ${ }^{8}$

Embora o Arquivo Histórico de Blumenau buscasse desde logo controlar o seu acervo de forma minuciosa, e fosse prevista, em 1983, a publicação de "um manual do

\footnotetext{
8 BELlotTo, Heloísa L. Política de descrição documental. In: -. Arquivos permanentes: tratamento documental. 2 ed. rev. ampl. Rio de Janeiro: Ed. FGV, 2004. p.220.
} 
inventário analítico dos documentos do acervo nos anos de 1839 a 1883", 9 o primeiro instrumento de pesquisa publicado, no início de 1989, foi justamente um guia. Esperava-se que os 300 exemplares do Guia do Arquivo possibilitassem ao pesquisador ter "conhecimento e orientação do acervo documental do arquivo."10 Atualmente, procura-se fornecer informações sobre o acervo através da Internet - na perspectiva da diretora de Patrimônio Histórico-Museológico, Sueli Petry, que mantém-se responsável pelo Arquivo Histórico, o ideal a perseguir é o da disponibilização de todos os instrumentos de pesquisa (que hoje são muitos) no website da Fundação Cultural de Blumenau, de modo a agilizar o atendimento aos pesquisadores. $^{11}$

As informações constantes do website da Fundação Cultural de Blumenau sobre os instrumentos de pesquisa apontam a preocupação em dar acesso à documentação do século XIX mais diretamente relacionada a imigrantes e seus descendentes. Atende-se, assim, tanto a pesquisas acadêmicas de caráter histórico sobre imigração e colonização como a pesquisas de caráter genealógico: há "listas de imigrantes", cobrindo o período 1851-1922, lista de moradores da Colônia Blumenau (1869), listas de membros da Comunidade Evangélica (1857-1896), relação de casamentos celebrados pela Igreja Evangélica (1857-1879), além de um guia dos lotes e linhas coloniais (1887-1934) e de um catálogo de documentos referentes à colonização (1850-1884). Há também um guia de todos os dossiês temáticos, integrados pelos documentos doados à instituição ao longo dos anos (conjunto que recebeu o nome de "Fundo Memória da Cidade”), além de guia do fundo Prefeitura Municipal de Blumenau e catálogos das diversas coleções (periódicos, fotografias, mapas, documentos áudio-visuais, livros). O volume de documentos públicos municipais é menor em relação aos documentos doados e colecionados, em função do incêndio do arquivo da Prefeitura, na década de 1950, e de enchentes subseqüentes, além do envolvimento continuado de parcela dos moradores sobretudo, os de ascendência alemã - na constituição do acervo. Segundo Sueli Petry,

\footnotetext{
${ }^{9}$ Relatório anual do Arquivo Histórico Prof. José Ferreira da Silva - 1983. Blumenau (SC), [1984]. Acervo: Arquivo Histórico Prof. José Ferreira da Silva.

${ }^{10}$ Relatório trimestral das atividades desenvolvidas pelo Arquivo Histórico Prof. José Ferreira da Silva jan.-fev. 1989. Blumenau, [1984]. Ver também: Relatório das atividades do Arquivo Histórico Prof. José Ferreira da Silva - 1988. Blumenau (SC), dez. 1988. Acervo: Arquivo Histórico Prof. José Ferreira da Silva.

${ }^{11}$ Depoimento de Sueli Petry, em 17 de novembro de 2005 - versão transcrita. Fl. 24. Arquivo pessoal de Janice Gonçalves. Ao menos até julho de 2006, os instrumentos de pesquisa estavam apenas relacionados no website (http://www.fcblu.com.br/arquivo/arquivoh/index.asp).
} 
[...] esse Arquivo é todo atípico, acredito eu, porque ele é uma mescla de vários documentos reunidos por temas. Ele não está seguindo um fundo. A questão do fundo só vai aparecer mais tarde, que é o que nós estamos coletando, o que vem da Prefeitura, de forma aleatória [...]; não está seguindo, assim, uma fluidez, como deveria ser, uma gestão documental.

[..] Na realidade, nós fomos reunindo aquilo que a comunidade nos deu. Então, é uma documentação que me parece que dá uma direção para famílias. A intenção não era essa. [...] Hoje, existem no acervo mais de 75 mil fotografias, do século XIX aos tempos atuais. E essa documentação foi doada por quem? Pelas famílias. Elas querem se ver. E qual é o tipo de pesquisa que mais domina aqui conosco? Genealogia. E você vê que a comunidade está ajudando a construir esse Arquivo a tal ponto, que nós temos pessoas que nos ajudam a traduzir gratuitamente livros de registro da Igreja, digitam, e vão cruzando as informações de óbito, nascimento e casamento. ${ }^{12}$

As famílias "querem se ver". Sueli Petry indica um outro elemento determinante na constituição e organização do acervo: os investimentos de memória feitos por certos segmentos sociais, buscando inscrever-se como sujeitos da história blumenauense através do Arquivo.

O doador em pouco tempo quer ver a documentação já trabalhada, processada, classificada, e o nome dele, que ele doou. Então isso deixa claro, para mim pelo menos, a personificação, que eles estão em busca de marcar a presença deles. ${ }^{13}$

Embora não tenham sido localizadas informações neste sentido, é muito possível que as pressões dos doadores tenham em parte orientado a organização de materiais do acervo de Joinville, definindo prioridades.

No Arquivo Histórico de Itajaí, diferentemente, desde o início de sua organização foram priorizados o conjunto documental referente à administração pública municipal e a coleção de fotografias. Primeiramente identificada e ordenada cronologicamente, a documentação municipal foi dividida em três grandes fundos - Prefeitura Municipal, Câmara

\footnotetext{
${ }^{12}$ Depoimento de Sueli Petry..., op.cit., fl. 3-5.

${ }^{13}$ Ibidem, fl. 5.
} 
Municipal e "Judiciário". Em 1992, o arranjo dos "fundos administrativos" foi considerado prioridade. Até mesmo a documentação de caráter intermediário da Prefeitura foi objeto de ações do Arquivo, desde ao menos $1989 .{ }^{14}$ Isso se deve, em parte, à inexistência de uma identificação "étnica", na constituição do acervo e da instituição, embora seja perceptível a valorização da "açorianidade", especialmente, em Itajaí, a partir da festa da "Marejada", iniciada em $1987 .{ }^{15} \mathrm{O}$ aprofundamento em estudos na área de arquivos, por dois funcionários responsáveis por orientar a linha de trabalho do Arquivo Histórico de Itajaí - Edison d'Ávila e Vera Lúcia Pecego Estork - provavelmente contribuiu para a atenção cotidiana aos documentos públicos municipais. ${ }^{16}$

Elegendo o que deve ser primeiramente organizado e disponibilizado, as instituições arquivísticas influenciam, em variados graus, a pesquisa de caráter histórico e,

${ }^{14}$ Relatório de atividades relativo ao ano de 1986, apresentado pelo presidente da Fundação Genésio Miranda Lins, Edison d'Ávila. op.cit.; Relatório de atividades relativo ao ano de 1987, apresentado pelo presidente do Conselho Curador, Edison d'Ávila. op.cit.; Relatório de atividades relativo ao ano de 1988, encaminhado ao Prefeito Municipal, João Omar Macagnan, pelo Conselho Curador da Fundação Genésio Miranda Lins. Itajaí (SC), maio de 1989; Relatório de atividades relativo ao ano de 1989, encaminhado ao Prefeito Municipal, João Omar Macagnan, pelo presidente da Fundação Genésio Miranda Lins, Edison d'Ávila. Itajaí (SC), julho de 1990; Relatório de atividades da Fundação Genésio Miranda Lins referente ao ano de 1990. Itajaí (SC), janeiro de 1991; Relatório de atividades da Fundação Genésio Miranda Lins referente ao ano de 1991. Itajaí (SC), janeiro de 1992; Relatório de atividades da Fundação Genésio Miranda Lins referente ao ano de 1992. Itajaí (SC), janeiro de 1993; Relatório de atividades da Fundação Genésio Miranda Lins referente ao ano de 1993. Itajaí (SC), janeiro de 1994; Relatório de atividades da Fundação Genésio Miranda Lins referente ao ano de 1994. Itajaí (SC), [1995]; Relatório de atividades da Fundação Genésio Miranda Lins referente ao ano de 1995. Itajaí (SC), [1996]; Relatório de atividades da Fundação Genésio Miranda Lins, relativo ao ano de 1996. op.cit; Relatório de atividades da Fundação Genésio Miranda Lins, relativo ao ano de 1998. op.cit. Acervo: Centro de Documentação e Memória Histórica/Arquivo Público de Itajaí.

${ }^{15} \mathrm{Na}$ década de 1990, esse viés açoriano - emprestado, em alguma medida, às atividades do Arquivo Histórico e, mais amplamente, da Fundação Genésio Miranda Lins - torna-se mais visível. Em abril de 1992, o Arquivo Histórico de Itajaí, representado por Edison d’Ávila, participou da III Semana de Estudos Açorianos (D’Ávila apresentou a comunicação "Manoel Antonio Fontes - um açoriano tardio na história de Itajấ”). Também nos anos 1990 a Fundação participou da AÇOR - Festa Açoriana de Santa Catarina, tal como o Arquivo Público do Estado. Cf.: Relatório de atividades da Fundação Genésio Miranda Lins referente ao ano de 1992. op.cit; Relatório de atividades da Fundação Genésio Miranda Lins referente ao ano de 1995. op.cit; Relatório de atividades da Fundação Genésio Miranda Lins referente ao ano de 1998. op.cit. Note-se que uma pequena publicação da Fundação Genésio Miranda Lins (Festas e tradições populares de Itajaí), feita em 1994, e de autoria de Edison d'Ávila e Márcia d'Ávila, procurou destacar a herança lusitana, quando não especificamente açoriana, nas manifestações de cultura popular em Itajaí. Sobre a Marejada no contexto das "tradições inventadas" das festas de outubro catarinenses, ver: SEVERINO, José Roberto. Itajaí e a identidade açoriana: a maquiagem possível. Itajaí (SC): Editora da UNIVALI, 1999.

${ }^{16}$ Edison d'Ávila freqüentou em 1990 o Curso de Especialização em “Organização de Arquivos”, promovido pela Universidade de São Paulo, através do Instituto de Estudos Brasileiros. Vera Estork, "bibliotecária e arquivista", passou a atuar no Arquivo Histórico de Itajaí a partir de 1991. Cf.: Relatório de atividades da Fundação Genésio Miranda Lins referente ao ano de 1990, op.cit.; Relatório de atividades da Fundação Genésio Miranda Lins referente ao ano de 1991, op.cit.; Relatório de atividades da Fundação Genésio Miranda Lins referente ao ano de 1992. op.cit. 
conseqüentemente, a produção historiográfica. Mas essa influência não está remetida apenas aos efeitos que a organização do acervo acarreta à consulta. Os arquivos (e a referência principal aqui são as instituições arquivísticas de caráter permanente, sobretudo as públicas) podem contribuir para dar relevo a certos períodos, personagens e interpretações históricas também através de atividades de difusão cultural, como exposições, edições de livros e periódicos, palestras, cursos, seminários. ${ }^{17}$

\section{A História exposta}

Em texto seminal sobre a relação entre a exposição museológica e o conhecimento histórico, Ulpiano Toledo Bezerra de Meneses salientou que a História, enquanto forma do conhecimento, "não pode ser visualizada". E isso porque

A História não é algo que possa ser apreendido sensorialmente - modo padrão de estímulo na exposição. Exclui-se, portanto, da responsabilidade do museu histórico preservar ou restituir o passado - quaisquer que sejam as motivações. Tudo que se fizer nessa direção estará, inelutavelmente, permeado de ideologia e mascaramentos. ${ }^{18}$

Caberia à exposição museológica, uma vez que pretendesse abordar aspectos históricos (ou, mais propriamente, problemas históricos), lidar com os objetos de modo a estimular reflexões sobre determinados processos sociais aos quais estejam mais diretamente relacionados. E escapar à atitude fetichista, pensando uma história nos objetos, e não dos objetos. $^{19}$

No caso dos arquivos ditos "históricos", as exposições buscam em geral apresentar os documentos de seu acervo - os originais ou suas reproduções -, destacando o

\footnotetext{
${ }^{17}$ Certamente outras atividades não estão descartadas. Veja-se que o Arquivo Histórico de Joinville, ao longo de 1990, e por meio de seu Laboratório de História Oral, preparou dezenas de "boletins com curiosidades [sic] da história de Joinville, de Santa Catarina e do Brasil", além de "algumas notas sobre os trabalhos desenvolvidos no Arquivo Histórico", para divulgação mensal na Rádio Cultura/FM. Boletim do Arquivo Histórico Municipal de Joinville - AHMJ, Joinville (SC), n.7, nov.1990, p.24.

${ }^{18}$ MENESES, Ulpiano Toledo Bezerra de. Do teatro da memória ao laboratório da História: a exposição museológica e o conhecimento histórico. Anais do Museu Paulista, São Paulo, Nova Série, v.2, jan.-dez.1994, p.38.

${ }^{19}$ Ibidem, p.27.
} 
quanto podem ser relevantes para a compreensão de variados temas e questões de interesse coletivo. Ao valorizarem a documentação, igualmente promovem a valorização da instituição arquivística. Mas não só isso: como apontou Susanna Vela,

[...] também são uma possibilidade de enriquecer os fundos com a entrada de novos fundos privados, de projetar e fazer avançar linhas de trabalho e de demonstrar a utilidade da investigação nos arquivos. ${ }^{20}$

Assim, como já observado em relação ao Arquivo Público do Estado de Santa Catarina (Parte II, Capítulo 2), as exposições são momentos em que as instituições procuram estabelecer, fortalecer ou modificar os nexos com o meio social no qual estão inseridas, ensaiando aproximações em relação a determinados grupos, negociando expectativas de distinção, reafirmando, legitimando ou questionando discursos e práticas de memória.

Tomando-se como referência as exposições promovidas pelo Arquivo Histórico de Blumenau entre 1983 e 1992, tal como discriminadas nos relatórios de atividades da instituição (ver Apêndice III-10), observa-se que as exposições tiveram o município como mote principal (o que não chega a surpreender). As exceções foram as exposições aludindo a grandes efemérides, uma de âmbito internacional (os "500 anos da América"), a outra, nacional (os cem anos da "Abolição da escravidão"). Mesmo as duas exposições que tiveram como recorte geográfico o vale do Itajaí (“O Vale em Cartaz”, "Indígenas do Vale do Itajấ”) provavelmente levaram em conta a configuração territorial do município de Blumenau antes de $1893 .^{21}$

A Blumenau exposta é, antes de tudo, a cidade fotografada: uma mostra fotográfica sobre a "história de Blumenau", duas vezes apresentada em 1985, parece ter sido retomada e renovada dois anos depois, em "Imagens de Blumenau Antiga", bem como em 1988, em "Imagens de Blumenau". Por vezes, foram enfatizados certos aspectos dessa história: as enchentes (1983), a "evolução cultural" (1985), o "militarismo" (1992). Em outros momentos, marcos referenciais: a rua XV de Novembro, a ponte metálica, a Estrada de Ferro

\footnotetext{
${ }^{20}$ VELA, Susanna. La organización de exposiciones. In: ALBERCH, Ramon et al. Archivos y cultura: manual de dinamización. Gijón (Espana): Trea, 2001. p.85.

${ }^{21}$ Em 1893, no transcurso da Revolução Federalista, os distritos de Gaspar e de Indaial foram desmembrados de Blumenau; em 1930, houve o desmembramento dos distritos de Bela Aliança e Taió, que formaram o município de Rio do Sul; em fevereiro de 1934, foram desmembrados os distritos de Hamônia e Gaspar, seguidos de Indaial e Timbó. Cf.: SILVA, José Ferreira da. História de Blumenau. 2 ed. Blumenau (SC): Fundação Casa Dr. Blumenau, 1988. p.139, 162-163, 167.
} 
Santa Catarina (todas destacadas em exposições de 1992) ou instituições e entidades, como a Sociedade Recreativa Ipiranga, a Escola Básica Estadual Luís Delfino (em 1983) e a Fraternidade Blumenauense (1992). Enfim, personagens: quer coletivos (os “indígenas”), quer individuais (padre José Jacobs, Edith Gaertner, José Ferreira da Silva). Ferreira da Silva foi, aliás, claramente identificado com o Arquivo, tendo sido seu nome incorporado ao da instituição, em 1983, ano em que foi ainda realizada exposição em sua homenagem (retomada em fins de 1987 e inícios de 1988). O próprio Arquivo Histórico de Blumenau foi objeto de uma das exposições, em 1992. Além disso, os títulos indicam que determinados conjuntos documentais foram especialmente enfocados: a coleção de cartazes ("Blumenau em cartaz", 1987), por exemplo, ou a coleção de "Kalendere", os calendários ou almanaques editados em língua alemã que circularam em Blumenau e região, no século XIX e nas primeiras décadas do XX (“O calendário através dos tempos”).

Supõe-se que a ausência de menção, nos relatórios de atividades do Arquivo Histórico de Blumenau, a exposições nos anos de 1984, 1989, 1990 e 1991, corresponda de fato à sua não-realização. De toda forma, e ressalvadas as lacunas informativas, os dados levantados apontam para uma média de 3 a 4 exposições anuais, entre 1983 e 1988 (aí considerados os diferentes locais de exposição, e não necessariamente o conteúdo das exposições, que às vezes se repetia). Já em 1992, o número de exposições foi significativamente maior (12, em todo o ano). As exposições voltaram-se tanto para o "grande público" quanto para públicos específicos. Algumas parecem ter sido solicitadas, em função de datas comemorativas: a exposição sobre a "Sociedade Recreativa Ipiranga", na própria sede da entidade; a exposição sobre a Escola Básica Estadual Luís Delfino, montada na escola; a exposição sobre a "Fraternidade Blumenauense", na própria entidade.

Uma característica marcante das exposições do Arquivo Histórico de Blumenau aqui destacadas: com exceção de uma, foram todas externas. Assim, não chamaram o público à instituição: foram até ele, em escolas, entidades associativas, igrejas, restaurantes, na universidade, no calçadão. Lançou-se mão, também, do Museu da Família Colonial, a partir de 1987 fisicamente próximo da sede do Arquivo (mesmo quando a exposição não tivesse com ele estreita afinidade temática, como no caso da exposição relativa à Abolição). Em parte, porém, o recurso a ambientes externos se deve às limitações físicas do prédio ocupado 
pelo Arquivo. $^{22}$

Se comparadas às exposições promovidas pelo Arquivo Histórico de Joinville, entre 1984 e 1992, as exposições do Arquivo Histórico de Blumenau revelam estratégias institucionais de divulgação algo distintas.

Há convergência, claro, na eleição do município como tema recorrente: veja-se, em Joinville, uma primeira exposição, em 1984, sobre a "História de Joinville", além do recurso freqüente à grande exposição preparada em 1986, quando da inauguração do prédio especialmente construído para o Arquivo. Foi grande, aliás, o investimento nessa exposição "Joinville - seus tempos, seus lugares, sua gente", inclusive com deslocamentos da funcionária Maria Thereza Böbel para o Rio de Janeiro (objetivando a compra de materiais) e de funcionário do Pró-Documento, do Rio de Janeiro para Joinville, apenas para a sua montagem. ${ }^{23}$ Essa exposição de antigas fotografias de Joinville foi, no todo ou em parte, exibida ao menos onze vezes, entre 1986 e 1991 (e ainda uma vez em 1995 - ver Apêndice III-9).

Outras exposições foram retomadas mais de uma vez, como "Nossos compositores - 1900-1940" (duas vezes em 1987 e uma vez em 1988) e "Nossas escolas" (quatro vezes, entre 1988 e 1989), além de "Retratos de Joinville hoje" (três vezes, em 1989). ${ }^{24}$ "Nossos compositores" procurou divulgar a coleção de partituras do Arquivo de Joinville, sobretudo aquelas que registravam composições de músicos locais. Foi inaugurada, em março de 1987, com apresentação musical em que foram executadas algumas das composições cujas partituras estavam expostas. ${ }^{25}$ "Nossas escolas", por sua vez, favoreceu o

\footnotetext{
${ }^{22}$ Em 1983, o Arquivo Histórico de Blumenau foi transferido para a "antiga sede da Câmara Municipal de Vereadores", em caráter provisório (Relatório anual do Arquivo Histórico Prof. José Ferreira da Silva 1983. Blumenau, [1984]). Em 1985, começou a ser construído o prédio que abrigaria "as dependências do Arquivo Histórico, Administração e Biblioteca Pública". O projeto do prédio foi elaborado sem participação "de especialistas na área da Arquivística e Biblioteconomia" (Relatório anual das atividades do Arquivo Histórico durante o ano de 1985. Blumenau, janeiro de 1986. Acervo do Arquivo Histórico Prof. José Ferreira da Silva). O prédio, planejado logo após as enchentes de 1983-1984, e inaugurado em 1987, foi construído com recursos de várias empresas, conforme Sueli Petry (Depoimento de Sueli Petry..., op.cit., fl.7).

${ }^{23}$ Maria Thereza Böbel viajou para o Rio, entre 25 e 27 de junho de 1986; Luís Alberto Zúñiga foi o funcionário do Pró-Documento incumbido de sua organização e montagem. Arquivo Histórico Municipal de Joinville AHMJ, Joinville (SC), v.3, n.3, jun.1986, p.14. A "nova etapa", no prédio próprio, seria marcada pelas visitas técnicas: Sérgio Burgi, do InFoto, esteve em Joinville para orientar montagem de Laboratório Fotográfico; Raquel S.Thiago, por sua vez, visitou o Arquivo do Município de Rio Claro (com Maria Thereza Böbel), em São Paulo, e a UFSC, em Florianópolis (neste último caso, interessada em informações sobre Laboratório de História Oral). Arquivo Histórico Municipal de Joinville - AHMJ, Joinville (SC), v.3, n.4, set.1986, p.19.

24 "Joinville - seus tempos, seus lugares, sua gente", "Nossos compositores - 1900-1940" e "Nossas escolas" também foram previstas na programação do Arquivo Histórico de Joinville para 1995.

${ }^{25}$ Arquivo Histórico de Joinville, Joinville (SC), v.4, n.2, mar.1987, p.17.
} 
deslocamento temporário da exposição, do Arquivo para instituições de ensino (o que ocorreu em 1989). Um diferencial, portanto, em relação a Blumenau: no prédio inaugurado em 1986, havia espaço destinado a exposições, daí terem elas se concentrado no próprio Arquivo. ${ }^{26}$ Embora menos freqüentes do que em Blumenau, em Joinville as exposições externas aconteceram, e não só em escolas de ensino fundamental e médio: na Universidade Regional de Joinville, na área reservada à "Festa das Flores" ou à realização do projeto "Mutirão Cultural", e até mesmo em Florianópolis ("Retratos de Joinville hoje" foi exibida no Palácio Cruz e Sousa, em 1989).

A ênfase na palavra "retrato" ("Auto-retrato de Santa Catarina", "Retrato dos anos vinte", "Retratos de Joinville hoje"), se sugere uma tendência à personificação dos temas abordados (Joinville, Santa Catarina, os “anos 20", remetendo, novamente, aos comentários de Ulpiano Toledo Bezerra de Meneses acerca da impossibilidade de "visualizar" a História, ou de "exibir" relações e práticas), indica, principalmente, o recurso freqüente, nas exposições joinvilenses, aos registros fotográficos. Os registros iconográficos são os mais costumeiros, nas exposições: além das fotografias, selos ("Joinville através da filatelia", "Vamos salvar nosso ambiente"), caricaturas ("Cidade como caricatura"), xilogravuras ("A gravura em madeira ao longo dos séculos"), cartazes ("Fotografias e cartazes da Festa das Flores do passado", "Cartazes escolares sobre o meio ambiente"), cartões natalinos ("Cartões antigos de Natal”) e até mesmo grafites (“Grafites do muro de Berlim”). Por que, aliás, uma exposição sobre os grafites do muro de Berlim patrocinada por arquivo público municipal?

Diferentemente do observado em Blumenau, no mesmo período, as exposições do Arquivo de Joinville abriram-se freqüentemente a temas que não estivessem centrados na trajetória histórica do município ou em seu acervo. Assim, foram feitas exposições tratando mais amplamente de Santa Catarina ("Auto-retrato de Santa Catarina", "Patrimônio cultural de Santa Catarina - sua arquitetura"), da história do Brasil ("E assim se proclamou a República") e, de forma acentuada, da Alemanha ou de questões que de alguma forma

\footnotetext{
${ }^{26}$ O prédio parece ter atraído visitantes de fora de Joinville: em 1984, mencionam-se turistas "de várias procedências, inclusive de Buenos Aires", interessados em "conhecer o Arquivo"(Arquivo Histórico Municipal de Joinville - AHMJ, Joinville (SC), v.1, n.5, jun.1984, p.2), bem como "turistas do país e do exterior", sempre "surpresos e encantados com nossas preciosidades, e muito interessados na nossa história." (Arquivo Histórico Municipal de Joinville - AHMJ, Joinville (SC), v.2, n.1-2, out-dez.1984, p.6-7); em 1986 há referências aos meses de férias, em que o Arquivo recebia "várias visitas de turistas, brasileiros como estrangeiros, que mostravam interesse e curiosidade em conhecer a nossa história, a origem de nossos imigrantes etc." (Arquivo Histórico Municipal de Joinville - AHMJ, Joinville (SC), v.3, n.2, mar.1986, p.15).
} 
pudessem ser associadas à cultura germânica (“August Sander e Erich Salomon, dois precursores da fotografia alemã", "Franz Kafka", "De Gutenberg à eletrônica", "Cartilha da guerra - Bertolt Brecht", "Ciências naturais e técnicas - a Alemanha no século XIX", “Grafites do muro de Berlim”, “Mozart - 1756-1791”).

Quanto ao último ponto, convém salientar que algumas dessas exposições não foram concebidas e elaboradas diretamente pelo Arquivo Histórico de Joinville (outra diferença em relação a Blumenau): ao menos duas delas foram organizadas pelo Instituto Goethe de Curitiba, e uma pelo Instituto Cultural Brasil-Alemanha. Essa abertura a parcerias e a uma maior amplitude temática das exposições emprestou à instituição uma imagem mais genericamente "cultural", e para além da de instituição custodiadora e divulgadora de acervos. É importante salientar, entretanto, que algumas das exposições organizadas por outras entidades serviram para que o Arquivo Histórico de Joinville marcasse apoio institucional a iniciativas de identificação do município à "germanidade". ${ }^{27}$

Identificação reforçada em 1992, nas comemorações dos vinte anos de institucionalização do Arquivo Histórico de Joinville. Para a ocasião, uma grande exposição foi organizada, reunindo, segundo seu então diretor, Apolinário Ternes, "as preciosidades, as raridades, os documentos originais e únicos dos nossos diferentes acervos". Com isso, teria sido possível aos joinvilenses, "pela primeira vez", "ver documentos de excepcional raridade e intraduzível importância histórica." ${ }^{28}$ Raridade, preciosidade e importância histórica - assim saberiam os visitantes da exposição -, entendidas à maneira dos colecionadores, geralmente apegados ao que é visto como "antigo", a tudo aquilo que pode ser tido como "primeiro", aos rastros dos proprietários, aos pertences dos ilustres e de seus familiares (entre eles, os de origem germânica). Assim, foram postos em exposição, entre outros documentos: o primeiro livro tratando sobre a Colônia Dona Francisca (o de Rodowicz, de 1853); um livro de autoria da mãe do filósofo Schopenhauer, de 1831; uma carta do príncipe de Joinville a seu cunhado, D.Pedro II; uma carta da princesa Dona Francisca a seu irmão Pedro; uma caderneta de campo do engenheiro August Wunderwald, de 1868; o diploma de farmacêutico de Hugo

\footnotetext{
${ }^{27}$ Como abordado anteriormente (Parte III, Capítulo 1), o Arquivo Histórico de Joinville manteve estreitos laços com a Alemanha, que foram decisivos não só para a construção do prédio próprio como para o apoio a projetos, inclusive de intercâmbio. O "Intercâmbio Joinville-Langenhagen" foi objeto de exposição em 1996.

28 Discurso de Apolinário Ternes em 7 de março de 1992. Boletim do Arquivo Histórico Municipal de Joinville - AHMJ, Joinville (SC), n.10, jun.1992, p.13-14.
} 
Delitsch, de 1849; o diploma do primeiro advogado joinvilense, Carlos Gomes de Oliveira. ${ }^{29}$ Presente, na exposição de 1992, não só uma certa maneira de interpretar a história de Joinville, mas de compreender a própria História - característica talvez reincidente nas demais exposições.

É impossível, porém, a partir dos dados levantados acerca da maior parte das exposições (praticamente apenas títulos, períodos e locais de realização, além do número de visitantes, se tanto) comentar as abordagens e interpretações adotadas. Isso só seria factível por meio da visitação das exposições e de sua análise minuciosa. Algo similar ocorre quanto à recepção, pelo público - faltam dados e estudos a respeito, uma preocupação que mereceria estar no horizonte das instituições, e mesmo no do meio acadêmico. ${ }^{30}$

Entre os dados disponibilizados sobre as exposições, aqueles que dizem respeito ao público, quando existem, dão conta apenas da freqüência de visitação. No período em foco, não constam dos relatórios de atividades do Arquivo Histórico de Blumenau. Já quanto ao Arquivo Histórico de Joinville, foram fornecidos para a maior parte das exposições entre 1986 e 1989. Com duração bastante variável, mas em geral mantidas pelo período de duas semanas a um mês, algumas exposições joinvilenses superaram o número de 300 visitantes (apenas cinco, entre as que tiveram freqüência de público assinalada), a mais visitada de todas sendo a que inaugurou o prédio próprio, em 1986: 1.918 visitantes, ao longo de seis semanas, mobilizaram-se para conhecer a exposição e, certamente, as novas instalações do Arquivo.

Mesmo levando em conta as limitações da análise frente aos dados obtidos, podese considerar, de toda forma, que as exposições promovidas pelos arquivos de Joinville e Blumenau contribuíram, em maior ou menor grau, para afirmá-los como lugares de História: espaços possíveis de reflexão acerca das trajetórias que variados sujeitos inscreveram nos dois municípios, "através dos tempos" (como em expressão contida nos títulos de duas exposições do Arquivo Histórico de Blumenau) ou de "seus tempos", nas relações com o "passado" e o "hoje" (termos que também integraram títulos de exposições, em Joinville). Em linhas gerais, e em correspondência com o tratamento dispensado aos acervos institucionais, reforçaram a

\footnotetext{
${ }^{29}$ Ibidem, p. 14.

${ }^{30}$ Néstor Garcia Canclini, tendo como referencial os museus, tem acentuado a necessidade de estudos sobre o público, ou ainda, sobre os "consumidores culturais". Ver: GARCIA CANCLINI, Nestor. O patrimônio cultural e a construção imaginária do nacional. Revista do Patrimônio Histórico e Artístico Nacional, Rio de Janeiro, n.23, 1994. p.105-106; GARCIA CANCLINI, Nestor. Culturas híbridas: estratégias para entrar e sair da modernidade. São Paulo: EDUSP, 1997. esp.p.144-157.
} 
perspectiva acentuadamente "germânica" da história desses municípios, valorizadora dos empreendimentos de colonização e das figuras consideradas proeminentes neste processo, bem como do legado cultural dos imigrantes.

No caso de um arquivo como o de Itajaí, as exposições não parecem ter cumprido o mesmo papel, pois, promovidas pela Fundação Genésio Miranda Lins, foram em geral sediadas no Museu Histórico, com isso reduzindo sua contribuição para a disseminação da instituição arquivística junto à população. Quanto ao Arquivo Histórico de Florianópolis, é provável que tenha realizado uma única exposição, justamente na inauguração de suas instalações físicas, em 1995. ${ }^{31}$

\section{A História editada}

Os arquivos municipais podem ainda dar seu aval a determinadas interpretações históricas por meio da promoção de publicações. As publicações periódicas, caso existam, têm, neste sentido, particular relevância.

Entre 1983 e 1995, o boletim do Arquivo Histórico de Joinville foi importante instrumento de divulgação de suas atividades e de seu acervo, apesar das interrupções na publicação, em 1989 e 1993-1994. ${ }^{32}$ No boletim foram divulgados, com regularidade, vários textos da funcionária-historiadora Elly Herkenhoff (ver Parte III, Capítulo 1), que teve igualmente trabalhos publicados na forma de livro. ${ }^{33} \mathrm{O}$ Arquivo Histórico de Florianópolis,

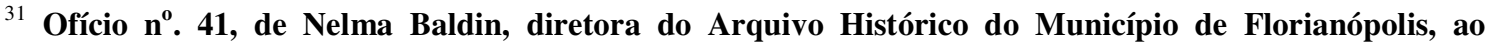
presidente do Instituto Histórico e Geográfico de Santa Catarina. Florianópolis, 29 de novembro de 1995. Nelma Baldin solicitou permissão para reproduzir fotografias do acervo do IHGSC, para atender "à necessidade que tem o Arquivo Histórico do Município de Florianópolis, para a sua inauguração e montagem do seu próprio acervo documental fotográfico em sua sede, sita a rua General Bittencourt, 223, Centro de Florianópolis." Arquivo corrente do Arquivo Histórico de Florianópolis, Ofícios expedidos - 1995.

32 O conteúdo do número publicado em julho de 1998 não tinha nenhuma relação com o Arquivo e foi utilizado como mero veículo de propaganda do Festival de Dança de Joinville.

${ }^{33}$ O Arquivo Histórico de Joinville publicou, de Elly Herkenhoff: Nossos Prefeitos, 1869-1903 (1984); Era uma vez um simples caminho (1987), Joinville - nosso teatro amador - 1858-1938 (1989). A História da imprensa de Joinville (1998) foi, a rigor, publicada pela Fundação Cultural de Joinville, em parceria com a UFSC. Também foram publicados pelo Arquivo vários outros trabalhos, no formato de livros ou opúsculos: de Cyro Ehlke, $A$ maçonaria no passado histórico joinvilense - a loja maçônica 'Deustche Freundschaft zum südlichen Kreuze', Amizade alemã ao Cruzeiro Sul (1990); de Hilda Krisch, História do Cemitério dos Imigrantes e da Casa da Memória do Imigrante (1991); de Creso Coimbra, François d'Orleans, Principe de Joinville: o coronel Lutherod e o homem do chapéu grande (1991); de Sílvia Heinzelmann, Fritz Alt (1991); de Rodowicz, Colônia Dona Francisca (1992); sob a coordenação de Roseana Maria Corrêa e Terezinha Fernandes da Rosa, História dos bairros de Joinville (1992). Em 1981, o Arquivo Histórico de Joinville publicou a tradução, feita por Elly Herkenhoff, de uma carta de Ottokar Doerffel (Joinville - ontem e hoje). 
por seu turno, publicaria breves boletins (informações contidas em folder), embora apenas a partir dos anos 2000, e de forma irregular. ${ }^{34} \mathrm{O}$ Arquivo Histórico de Itajaí nunca teve boletim próprio, e o periódico associado à Fundação Genésio Miranda Lins - o Anuário de Itajaí, com publicação iniciada em 1998 - não serviu como veículo regular de divulgação de suas atividades. ${ }^{35}$ Quanto ao Arquivo Histórico de Blumenau, sua principal publicação tem sido a revista Blumenau em Cadernos.

Blumenau em Cadernos teve José Ferreira da Silva como fundador. Professor, jornalista, prefeito nomeado de Blumenau entre 1938 e 1941, historiador especialmente dedicado à história da região do vale do Itajaí, Ferreira da Silva também dirigiu, nos anos 1960, a Biblioteca Pública Municipal, sendo mais tarde diretor executivo da Fundação Casa Dr. Blumenau (à qual estava vinculado o Arquivo Histórico de Blumenau). Mas é mais freqüentemente lembrado pelos anos de dedicação a Blumenau em Cadernos, revista cujo primeiro número circulou em novembro de 1957, e que Ferreira da Silva dirigiu até sua morte, em dezembro de 1973, quando contava 76 anos. ${ }^{36}$ O número duplo da revista relativo a janeiro e fevereiro de 1974, subseqüente à sua morte, prestou homenagem ao fundador e exdiretor, firmando o compromisso de dar continuidade à publicação. No número seguinte, de março de 1974, a revista, dirigida por Federico Carlos Allende, já aparecia como "propriedade da Fundação Casa Dr. Blumenau". ${ }^{37}$ Daí em diante, seria assumida pela Prefeitura Municipal de Blumenau, através da Fundação Casa Dr. Blumenau (e, posteriormente, da Fundação Cultural de Blumenau). O Arquivo Histórico de Blumenau, vinculado à Fundação, responsabilizou-se pela edição. ${ }^{38}$

No primeiro número, Blumenau em Cadernos, definido como "mensário dedicado à história e aos interesses do vale do Itajấ”, apresentava suas intenções:

\footnotetext{
${ }^{34}$ No acervo da Biblioteca Pública do Estado de Santa Catarina foi encontrado um exemplar do boletim informativo do Arquivo Histórico de Florianópolis publicado em abril de 2001 (era o número 4); em 2005 passaram a ser publicados boletins trimestrais.

${ }^{35}$ Um único artigo referiu-se ao Arquivo Histórico de Itajaí: de autoria de Vera Lúcia de Nóbrega Pecego Estork, então coordenadora do Arquivo, consta do Anuário de Itajaí de 2000. Note-se que o periódico, ao adotar o nome de "Anuário de Itajấ" homenageou publicações de mesmo título editadas em 1924, em 1949 e em 1959-1960. Cf.: Anuário de Itajaí - 1998 [Fundação Genésio Miranda Lins]. Itajaí (SC), n.1, 1998, p.7.

${ }^{36}$ Note-se, contudo, que a revista sugere seu afastamento em 1960, quando passou a residir em Curitiba - referese a ele como "colaborador". Cf.: Um apelo. Blumenau em Cadernos, Blumenau (SC), t.III, n.11, nov. 1960, p. 212 .

37 Cf.: Não podemos parar. Blumenau em Cadernos, Blumenau (SC), t.XV, n.1-2, jan.-fev.1974, p.1; Blumenau em Cadernos, Blumenau (SC), t.XV, n.3, mar.1974.

${ }^{38}$ Cabe informar que, em dezembro de 1972, a Lei municipal $\mathrm{n}^{\circ} .1 .895$ tornara a revista Blumenau em Cadernos de utilidade pública. Cf.: Blumenau em Cadernos, Blumenau (SC), t.XIV, n.1, jan. 1973, p.2.
} 
Traremos o passado e o presente de Blumenau, contados e registrados em cadernos mensais, [...] para tornar mais conhecida a história do município, mais estimada e venerada a memória dos homens que fizeram a sua grandeza atual e para que o exemplo desses pioneiros sirva de orientação e de estímulo aos que, na hora que passa, trabalham por que o nosso futuro não seja menos glorioso que o nosso passado.

Mas não nos limitaremos a rebuscar arquivos, a contar casos dos tempos idos. Procuraremos, também, apontar aos que, na atualidade, concorrem com o seu trabalho para o engrandecimento comum, o caminho a seguir. O bom caminho." ${ }^{39}$

Objetivos, portanto, perfeitamente afinados com perspectivas esposadas pelos historiadores ligados ao Instituto Histórico e Geográfico de Santa Catarina: divulgar a história de Santa Catarina (neste caso, através da perspectiva local e da região do vale do Itajaí), destacar aqueles que a engrandeceram, contribuir para decisões acerca de questões do presente. José Ferreira da Silva seria, aliás, mais tarde, membro do IHGSC, bem como da Academia Catarinense de Letras.

Na sua primeira década, Blumenau em Cadernos abrigou artigos de alguns dos principais historiadores do Instituto, como Lucas Alexandre Boiteux, Carlos da Costa Pereira e Oswaldo Rodrigues Cabral. Cabral teria ainda vários artigos publicados na década de 1970, inclusive um especialmente dedicado a José Ferreira da Silva, logo após a morte deste, e no qual o comparou a Carlos da Costa Pereira:

[...] Não se lhe pedia uma informação que ele não se afanasse em fornecê-la da maneira mais completa que lhe era possível; não se lhe pedia uma opinião, que ele não a externasse com sinceridade, embora com simplicidade e com a modéstia que foram o apanágio da sua autoridade. Neste como em muitos pontos a sua afinidade espiritual com Carlos da Costa Pereira - um outro grande historiador, um conteúdo de capacidade, de honestidade e de competência num oceano de modéstia -, a sua afinidade espiritual, dizia eu,

${ }^{39}$ A que viemos. Blumenau em Cadernos, Blumenau (SC), t.I, n.1, nov. 1957, p.1. 
foi a mais completa possível, tornando-os seres humanos talhados num mesmo e invejável padrão e feitio. ${ }^{40}$

Outro historiador destacado do IHGSC a colaborar com a revista foi Walter Fernando Piazza, e isso desde 1968. Entretanto, a revista reuniu principalmente a produção de historiadores de Blumenau e de cidades relativamente próximas. Entre os autores mais dedicados à história de Blumenau, Christiana Deeke Barreto (que esteve inclusive encarregada do Arquivo de Blumenau, em 1950), ${ }^{41}$ Edith Kormann, Frederico Kilian e o próprio José Ferreira da Silva. Entre os estudiosos da história de Joinville, Adolfo Bernardo Schneider, Carlos Ficker, Elly Herkenhoff e Rosa Herkenhoff (ambas, Elly e Rosa, publicando vários textos contidos no boletim do Arquivo Histórico de Joinville; Rosa, basicamente, traduzindo trechos do Kolonie Zeitung). Ainda: o padre Victor Vincenzi, mais voltado à história de Rio dos Cedros; Atílio Zonta, à história de Ascurra; Ayres Gevaerd, à história de Brusque; Aluisius Carlos Lauth, à história de Azambuja. Bastante regulares nas colaborações, autores como Maria do Carmo Krieger Goulart, que publicou vários artigos sobre a presença polonesa em Santa Catarina, e Antonio Roberto Nascimento, com diversos estudos biográficos e genealógicos. ${ }^{42}$

A revista publicou, além de estudos, documentos de interesse para a história de Blumenau e região - nos primeiros anos, sobretudo através de Frederico Kilian, em textos intitulados "Vasculhando velhos arquivos". Essa preocupação perdurou ao longo dos anos, pois ganhou particular importância após o incêndio que destruiu o arquivo municipal, em novembro de 1958:

Os dados históricos, as transcrições de interessantes documentos antigos, que estes 'Cadernos' já publicaram nesta primeira série, encerrada com esta edição [de dezembro de 1958], ficam, assim, resguardados para a posteridade. Centenares de outros, cujas cópias havíamos ajuntado, no

\footnotetext{
${ }^{40}$ CABRAl, Oswaldo R. Em memória de um amigo. Blumenau em Cadernos, Blumenau (SC), t.XV, n.3, mar. 1974, p.4.

${ }^{41}$ Relatório dos negócios administrativos do município de Blumenau, referente ao ano de 1950, apresentado à Câmara Municipal pelo Prefeito Frederico Guiherme Busch Junior. S.l.p., s.c.p., s.d.

${ }^{42}$ José Gonçalves, Sueli Petry e Cristina Ferreira, devido ao envolvimento direto com a produção da revista, também tiveram diversos textos publicados. Para um levantamento sistemático dos artigos publicados, até 1995, ver: FIORI, Neide Almeida; PETRY, Sueli Maria V. (orgs.). Índice da revista Blumenau em Cadernos 1957-1995: referências de autores e títulos. Blumenau (SC): Arquivo Histórico Prof. José Ferreira da Silva, Florianópolis: Editora da UFSC, 1996.
} 
propósito mesmo de, um dia, concretizarmos a idéia que há muito estava em nossas cogitações, serão registrados em novos tomos, ficando assim, em parte mínima embora, amenizados os efeitos da verdadeira catástrofe. ${ }^{43}$

Dois anos mais tarde, Ferreira da Silva, residindo em Curitiba, divulgava na revista o seu projeto de levantamento e reprodução sistemática de documentos relativos a Blumenau no século XIX e inícios do XX, para tanto solicitando a colaboração dos leitores:

[...] J. Ferreira da Silva solicita, por nosso intermédio, a todos quantos possuam retratos de pessoas e de acontecimentos do passado blumenauense, ou prospectos, rótulos ou reclames de produtos que aqui se fabricavam no século passado, ou nos começos deste, ou ainda qualquer outro documento que diga respeito ao comércio e às indústrias daquela época, queiram fazer o favor de enviá-los, por empréstimo, àquele nosso amigo [...]. Todos os documentos e fotografias que lhe forem enviados para exame e clichês serão, em seguida, devolvidos aos remetentes. ${ }^{44}$

Em 1966, quando dirigia a Biblioteca Municipal de Blumenau, Ferreira da Silva organizava anotações e transcrições de documentos, visando doar o material ao arquivo municipal:

Quando no exercício do cargo de Prefeito Municipal (1938/1941), mandei copiar as principais peças existentes no Arquivo Municipal, como os Relatórios do Dr. Blumenau, seus requerimentos ao governo imperial etc. [...] Estou preparando essa documentação para doá-la ao Município, juntamente com o fichário-enciclopédia e a biblioteca especializada de literatura do Vale do Itajaí, de minha propriedade. [...] E é um trabalho necessário, indispensável mesmo à própria administração municipal. Sem ele, o governo do Município não poderá responder às indagações a respeito do passado de Blumenau, seja no que concerne ao seu desenvolvimento

\footnotetext{
${ }^{43}$ Blumenau em Cadernos, Blumenau (SC), t.I, n.12, dez. 1958, p.221.

${ }^{44}$ Um apelo, op.cit.
} 
demográfico, seja no que diz respeito à sua vida econômica, social, política e cultural. $^{45}$

Ex-prefeito de Blumenau, José Ferreira da Silva valorizou os documentos públicos municipais também por sua importância administrativa. Pesquisador, compulsou e reuniu documentos, disponibilizando-os e oferecendo sua própria interpretação acerca da história de Blumenau. ${ }^{46}$ Fundador e diretor de Blumenau em Cadernos, durante mais de duas décadas mobilizou estudiosos da história do vale do Itajaí e, disseminando-a, buscou atrair leitores. Diretor executivo da Fundação Casa Dr. Blumenau, tentou fortalecer a biblioteca pública e o arquivo histórico municipais. Ao assumir seu nome e sua revista, o Arquivo Histórico de Blumenau encampou sua herança intelectual.

A influência da perspectiva de Ferreira da Silva insinuou-se igualmente nas publicações avulsas promovidas pela Fundação Casa Dr. Blumenau, mesmo após sua morte: foram editadas três de suas obras ( $O d r$. Blumenau, Entre a enxada e o microscópio, Cronografia do Dr. Blumenau, todas em 1978) e obras de alguns de seus colaboradores em Blumenau em Cadernos, como Frederico Kilian (Genealogia da família Hering, em 1980), Nemésio Heusi (História romanceada de Blumenau e seu fundador, 1981), Maria do Carmo R. Krieger Goulart (Brusque - essas ruas que eu amo, em 1982), Victor Vincenzi (História e imigração italiana de Rio dos Cedros, 1985), embora houvesse lugar para mestres em História pela Universidade Federal de Santa Catarina (foram publicadas as dissertações de Beatriz Pelizzetti - Um banco de imigrantes em Santa Catarina, em 1986 - e Sueli Petry - Os clubes de caça e tiro da região de Blumenau, em 1982). Mesmo mais recentemente, duas figuras caras a José Ferreira da Silva, e por ele biografadas - Fritz Müller e Hermann

\footnotetext{
${ }^{45}$ Relatório apresentado por José Ferreira da Silva ao Prefeito Municipal [de Blumenau], Dr. Carlos Zadrozny, sobre os setores culturais do governo municipal. Blumenau, 20 de janeiro de 1966. Cópia carbono, datilografada. Acervo: Arquivo Histórico José Ferreira da Silva. O comentário está contido na rubrica "Arquivo Histórico". No mesmo relatório, Ferreira da Silva informava estar trabalhando em uma história de Blumenau voltada para o público escolar. Sua História de Blumenau foi publicada primeiramente em 1972 - conforme esclarece o autor, na própria obra, "por conta dos cofres municipais". SILVA, José Ferreira da. História de Blumenau..., op.cit., p.5.

${ }^{46}$ Entre suas obras: O padre Jacobs (1928); A colonização do vale do Itajaí (1931); Fritz Müller (1931); Entre a enxada e o microscópio: o colono Fritz Müller (1971); O dr. Blumenau (1933); História do município da Penha (1959); As terras do Itajaí e Vasconcellos Drummond (1963); Itajaí, a fundação e o fundador (1967); Cronografia do dr. Blumenau (1964); A bandeira do Brasil (1967); Blumenau - pequeno guia turístico (1971); História de Blumenau (1972); A imprensa em Blumenau (publicação póstuma, 1977). Cf.: SACHET, Celestino. A literatura catarinense. Florianópolis: Lunardelli, 1985. p.318-319.
} 
Blumenau - foram objeto de cuidadas publicações: Müller, no centenário de nascimento; Blumenau, nas comemorações dos 150 anos do município. ${ }^{47}$

Hoje bimestral, a revista Blumenau em Cadernos, muito embora não tenha se voltado prioritariamente para a divulgação das atividades do Arquivo Histórico de Blumenau, tem sido decisiva para garantir visibilidade à instituição. Além disso, mantém-se como espaço aberto aos pesquisadores da história de Santa Catarina (em especial, a do vale de Itajaí), independentemente de suas formações, posicionamentos políticos e opções teóricometodológicas, o que lhe confere lugar peculiar no cenário mais recente de embates historiográficos entre "novos" e "velhos".

\section{Historiadores nas repartições}

A presença de pesquisadores de História no interior das instituições arquivísticas em questão (Joinville, Itajaí, Blumenau, Florianópolis), quer na função de diretores, quer ocupando cargos de historiadores, é outro ponto a considerar.

O Arquivo Histórico de Blumenau, além de marcado de várias maneiras pela atuação de José Ferreira da Silva, tem à sua frente, desde a segunda metade da década de 1970, a historiadora Sueli Petry, e na década de 1990 teve em seus quadros a historiadora Cristina Ferreira (que, entre outras atividades, trabalhou na edição de Blumenau em Cadernos e participou da organização de várias outras publicações).

Em Joinville, há fortes indícios de que a institucionalização do Arquivo Histórico esteve relacionada a embates entre dois historiadores locais, Adolfo Bernardo Schneider e Carlos Ficker (ver Parte III, Capítulo 1). No confronto entre ambos, envolvendo documentos relacionados à história de Joinville, é possível vislumbrar divergências quanto à publicização

\footnotetext{
${ }^{47}$ ZILLIG, Cezar. Dear Mr. Darwin: a intimidade da correspondência entre Fritz Müller e Charles Darwin. Blumenau (SC): 43 Gráfica e Ed., 1997. 241p.; BLUMENAU, Hermann. Um alemão nos trópicos. Org. Cristina Ferreira e Sueli M. V. Petry. Blumenau (SC): Instituto Blumenau 150 anos, Cultura em Movimento, 1999. 280 p. (edição bilíngüe); BLUMENAU, Hermann. A colônia alemã Blumenau na Província de Santa Catarina no sul do Brasil. Org. Cristina Ferreira. Blumenau (SC): Instituto Blumenau 150 anos, Cultura em Movimento, 1999. Note-se que, em 1996, foi publicado livro em homenagem a José Ferreira da Silva: PETRY, Sueli M.V.; FERREIRA, Cristina (org.). José Ferreira da Silva: centenário de nascimento. Blumenau: Fundação Cultural de Blumenau, 1996. O Arquivo Histórico de Blumenau teve envolvimento em todas essas publicações.
} 
do que fosse de interesse público (mesmo que, na origem, privado) frente à privatização do que fosse originalmente público. Certamente pode-se detectar aí uma disputa de autoridade acerca da história de Joinville. Disputa que se fez sentir, por exemplo, em Blumenau em Cadernos: tendo Adolfo Bernardo Schneider publicado texto acerca da data de fundação de Joinville, em março de 1962, Carlos Ficker contestou-o no mês de maio, destacando uma série de equívocos e imprecisões. ${ }^{48}$ Segundo Ficker, Schneider teria se baseado "na tradição", adotando "versões e teorias de outros autores, sem antes verificar-lhes a exatidão, sem ir-lhes [sic] 'ÀS FONTES', como convém proceda todo pesquisador." "49 Suas críticas foram feitas, conseqüentemente, "a bem da verdade histórica". 50

Carlos Ficker baseava a autoridade de seu trabalho na pesquisa empírica, no recurso à documentação. Teria, aliás, em vários acervos, deixado rastros de seu trabalho de “verificação das fontes”. Na revista Ágora, Klaus Richter, em 1989, informou ter detectado, na chamada "Coleção Ficker" do Arquivo Histórico de Joinville, "livros de contabilidade e documentos mais significativos sobretudo quanto à Colônia Dona Francisca na Sociedade Colonizadora de Hamburgo, de 1849 a 1897”, e que estavam anteriormente guardados na administração do Domínio Dona Francisca. Igualmente, localizou, naquela coleção, sete dos doze "livros copiadores da Hanseática", e que faltavam ao acervo do Museu Eduardo de Lima e Silva Hoerhan. ${ }^{51}$ Na mesma revista, mas em dezembro de 1990, Beat Meier indicou ter encontrado, também em pesquisas na Coleção Ficker, vários documentos públicos:

Todos estes documentos faltam no Arquivo Público de Santa Catarina e já fizeram falta a muitos pesquisadores!

Não quero saber como estes documentos saíram do acervo do Arquivo Público e quem é o responsável por isso, já que Carlos Ficker comprou vários documentos, como me informou uma funcionária do Arquivo

\footnotetext{
${ }^{48}$ SCHNEIDER, Adolfo Bernardo. A data da fundação de Joinville. Blumenau em Cadernos, Blumenau (SC), t. V, n.3, mar.1962, p.54-55; FICKER, Carlos. A data da fundação de Joinville. Blumenau em Cadernos, Blumenau (SC), t.V, n.5, maio 1962, p.86-90.

${ }^{49}$ FICKER, Carlos. A data..., op.cit., p.86.

${ }^{50}$ Ibidem, p.90.

${ }^{51}$ RICHTER, Klaus. Recuperação de fontes para a colonização alemã no norte de Santa Catarina. Ágora, Florianópolis, n.9, jan.1989, p.17.
} 
Histórico de Joinville. O que me interessa é que o Arquivo Público receba de volta o que a ele pertence. ${ }^{52}$

$\mathrm{O}$ artigo de Meier questiona, de forma geral, a atitude de pesquisadores que, pensando apenas em seus próprios interesses, privam outros pesquisadores da consulta a documentos públicos. Questão que, por sua vez, movimenta outras, plenas de ambigüidades.

Pois os historiadores, no exercício de seu ofício, não somente costumam compulsar documentos em variados acervos, como produzir seus próprios acervos de anotações, transcrições, reproduções do material compulsado. Em caso de perdas documentais sofridas pelas instituições, como a causada ao arquivo municipal de Blumenau pelo incêndio de 1958, esses acervos pessoais podem até ser mobilizados e, em parte, suprir lacunas. Em Blumenau, há notícia de que estudiosos como Ferreira da Silva, Cabral e Kilian colaboraram neste sentido.

Mas em situações nas quais o acesso aos arquivos de instituições públicas não está formalizado e garantido por lei, ou que não é possível em decorrência da desordem dos documentos ou, ainda, quando o acesso é restrito em função de sua classificação como sigilosos, a consulta fica restrita às permissões especiais, concedidas ou não, conforme a vontade do funcionário ou da autoridade responsável. Sonia Combe demonstrou que, na França, mesmo em situações de garantia legal de acesso, documentos foram considerados sigilosos e postos à margem da pesquisa para a maioria dos interessados, havendo, contudo, o acesso privilegiado por parte de algumas pessoas - historiadores que, para garantir seus privilégios, compactuaram com a lógica do segredo de Estado. ${ }^{53}$

Por outro lado, a concessão de privilégio de acesso à documentação envolve um compromisso de confiança recíproca, que pode eventualmente liberar aquilo que em circunstâncias normais não seria permitido - como, por exemplo, a consulta sem acompanhamento ou o empréstimo de documentos (o que abriria a possibilidade de desfalque dos acervos). O prestígio dos pesquisadores envolvidos é um componente potencialmente ampliador do rol de facilidades.

\footnotetext{
${ }^{52}$ MEIER, Beat Richard. Duas descobertas de documentos primários do século passado a respeito de várias colônias alemãs hoje meio esquecidas como "Santa Isabel", "Piedade", "São Pedro de Alcântara" e “Teresópolis”. Ágora, Florianópolis, n.12, dez. 1990, p.24-25.

${ }_{53}$ COMBE, Sonia. Archives interdites: les peurs françaises face à l'Histoire contemporaine. Paris: Albin Michel, 1994. esp. p.145-165 (“L'autorisation exceptionelle de consultation”).
} 
Além disso, a percepção reiterada da "insensibilidade" das autoridades públicas frente à preservação de documentos pode servir como fator estimulador de ações individuais de "proteção" - nulos para a administração pública, e sujeitos à destruição, os documentos estariam "a salvo" nos escritórios dos estudiosos.

Uma combinação peculiar, portanto, de sinistros, descaso, descuidos e privilégios relacionados ao trato da documentação pública talvez seja responsável pela migração indevida de muitos documentos para a esfera do privado. Neste contexto, os historiadores, no papel de usuários, ocupam sem dúvida uma posição ambígüa.

Mas há que lembrar: os historiadores podem ainda estar do outro lado do balcão de atendimento, como no caso dos arquivos aqui em questão. Entre os historiadoresfuncionários: em Joinville, Elly Herkenhoff, mais tarde, Roseana Corrêa e Terezinha Fernandes da Rosa, e hoje também Janine Gomes da Silva; em Blumenau, Cristina Ferreira; em Itajaí, Rogério Marcos Lenzi e Edison d'Ávila (que além de atuar como historiador foi diretor do Arquivo, conselheiro do Conselho Curador e presidente da Fundação Genésio Miranda Lins) ${ }^{54}$. Além deles, os historiadores que exerceram cargos ou funções de direção. ${ }^{55}$

O historiador que dirige uma instituição arquivística não necessita solicitar a ninguém permissão de acesso, pois, a rigor, tem a possibilidade de consulta a qualquer documento sob sua alçada (embora, não necessariamente, permissão de uso). Sendo historiador-diretor, conseguirá limitar-se a trabalhar apenas no sentido de preservar, disponibilizar e divulgar a documentação? Ou aproveitará o cargo e os encargos para, à maneira de Michelet, alimentar sua produção historiográfica?

Sueli Petry, refletindo sobre a questão e sobre seu próprio percurso profissional, comentou:

A minha preocupação foi organizar, organizar, organizar, atender, atender, deixar isso aí exposto... e no fim eu me anulei, no meu lado de historiadora. Mas, por outro lado, eu tenho consciência muito clara disso, foi uma opção. [...] O que eu tinha que fazer era mais urgente. Então, as prioridades foram

\footnotetext{
${ }^{54} \mathrm{O}$ Arquivo Histórico de Florianópolis não tem historiadores em seu quadro funcional (sua lei de criação prevê apenas diretor e assistente, o que até hoje não foi alterado). Isso, entretanto, não impediu (nem impede) que nele atuem estagiários da área de História ou funcionários que, deslocados de outros setores para atuar no Arquivo, tenham formação na área de História.

${ }^{55}$ Quanto aos diretores e responsáveis pelos arquivos aqui estudados, ver os Apêndices III-1, III-2, III-4 e IIII-5.
} 
outras e o lado historiadora foi ficando para trás. Hoje eu quero correr atrás do tempo perdido, fazendo as leituras que eu não fiz, procurando recuperar. ${ }^{56}$

Sua permanência na instituição, porém, tem sido excepcionalmente longa se comparada a de outros diretores de arquivos municipais, e que não costumam ir além do período de uma gestão. Entre os diretores dos arquivos aqui examinados: Nelma Baldin, em Florianópolis; Adolfo Bernardo Schneider, Raquel S. Thiago e Ilanil Coelho, em Joinville (Apolinário Ternes foi diretor mais de uma vez). Historiadores cuja atuação na instituição não foi certamente marcada pela publicação de seus próprios estudos. No entanto, certamente contribuíram para confirmar ou alterar políticas adotadas nas instituições que dirigiram - em relação ao acesso, por exemplo. Na perspectiva de Raquel S.Thiago, a atuação de historiadores, nos arquivos, tende a favorecer o acesso mais amplo à documentação:

[...] o técnico vai se especializando tanto, que o documento acaba sendo um fim em si mesmo. Para preservar o documento, por ele, ninguém olha. [...] Quanto menos você pegar, quanto menos você olhar... Porque aquilo ali é uma relíquia, não pode pegar. Claro que os historiadores sabem os cuidados que têm que tomar, sabem como acondicionar, como isso, como aquilo. Mas não cheguemos aos exageros! Eu vejo com muito bons olhos aqueles [arquivos] que são dirigidos por historiadores. $\mathrm{O}$ historiador tem essa visão um pouco mais desprendida. ${ }^{57}$

Em Itajaí, Edison d’Ávila, apesar de ter ocupado o cargo de diretor do Arquivo, a rigor, por um período relativamente breve, esteve muito próximo da instituição durante praticamente vinte anos, levando-se em conta sua participação no Conselho Curador da Fundação Genésio Miranda Lins, entre 1986 e 2006 (ver Apêndice III-3). No rol de publicações da Fundação, algumas são de autoria de Edison d'Ávila. ${ }^{58}$ Mais recentemente (em

\footnotetext{
${ }^{56}$ Depoimento de Sueli Petry..., op.cit., fl.12.

${ }^{57}$ Depoimento de Raquel S.Thiago, em 18 de novembro de 2005 - versão transcrita. Fl. 12. Arquivo pessoal de Janice Gonçalves.

58 D’ÁVILA, Edison. Pequena história de Itajai. Itajaí (SC): Fundação Genésio Miranda Lins, 1982; D’ÁVILA, Edison. A revolução federalista de 1893 em Itajaí. Itajaí (SC): Fundação Genésio Miranda Lins, Arquivo Histórico de Itajaí, 1993; D’ÁVILA, Edison. Itajaí - breve notícia histórica do aglomerado urbano. Itajaí (SC): Arquivo Histórico de Itajaí, 1993; D’ÁVILA, Edison; D’ÁVILA, Márcia. Festas e tradições populares de Itajaí. Itajaí: Fundação Genésio Miranda Lins, 1994; D’ÁVILA, Edison. Nossa Senhora dos Navegantes: festa e história. Itajaí (SC): Fundação Genésio Miranda Lins, 1996.
} 
2005), José Bento Rosa da Silva assumiu a coordenação do atual Centro de Documentação e Memória Histórica de Itajaí/Arquivo Público, buscando imprimir um novo sentido para a instituição, uma outra perspectiva histórica:

[...] Itajaí é uma cidade politicamente muito conservadora, e eu penso que tanto o Museu como o Arquivo [ligados à Fundação Genésio Miranda Lins] são fontes de preservação desse conservadorismo. A memória oficial da cidade está no Museu e está no Arquivo. E são essas histórias que são veiculadas nos meios de comunicação, nas escolas, em tudo que é parte. Então nós vamos aproveitar esse lugar oficial de memória para trazer as outras memórias.

[...] aqui deve ser um lugar de história viva. A gente está relacionando sempre a documentação escrita, as fontes, também com aquilo que está se fazendo na contemporaneidade. [...] E é nesse sentido que estamos investindo prioritariamente, neste momento, na memória dos bairros. [...] Trata-se de contar a história de Itajaí a partir dos olhares que vêm dos bairros. [...] Todas as pessoas que quisessem contar o que elas soubessem sobre o bairro, sobre a cidade, sobre a história, a partir da ótica delas e da memória delas, independente da faixa etária, independente do segmento social, nós listamos, e agora estamos executando essas entrevistas. ${ }^{59}$

Nos arquivos históricos de Blumenau e Joinville também foram desenvolvidos projetos de História Oral. A articulação passado e presente, portanto, neles se fez (e faz) com ênfases distintas nos dois termos - ora pesa mais o vestígio do passado, representado pelos documentos, ora a lembrança, sempre feita a partir do presente, colhida em depoimentos.

Mas quem escolhe os depoentes? Em Itajaí, há a intenção de “descentrar” a feitura da História: a escolha desloca-se do historiador para o depoente. Que se faça ouvir, assim, em regime de auto-escolha, quem está fora do "centro" - da cidade e da fabricação da História. Na Itajaí de 2005, “Memória dos Bairros”, na Joinville de 1992, a "História dos Bairros": em Joinville pesava mais o que era narrado, em Itajaí, vale mais quem narra. Reencontra-se em Itajaí o tema do direito à memória, que é direito de lembrar, de registrar e de difundir o

\footnotetext{
${ }^{59}$ Depoimento de José Bento Rosa da Silva, em 6 de outubro de 2005 - versão transcrita. Fl. 1 e 4. Arquivo pessoal de Janice Gonçalves.
} 
lembrado. ${ }^{60}$ Não à toa, o direito à memória encontra abrigo nessa instituição híbrida: Centro de Documentação e Memória Histórica de Itajaí/Arquivo Público. Pende, no entanto, mais para o primeiro do que para o segundo. Residiria aqui o limite dos arquivos enquanto laboratórios de História?

\footnotetext{
${ }^{60}$ No folder relativo ao projeto "Memória dos Bairros", lê-se: "A cidade não é feita apenas de matéria concreta. As trajetórias da cidade residem também em nossas memórias. É por isso que a Fundação Genésio Miranda Lins desenvolve este projeto: para que as lembranças, fazeres e saberes dos grupos sociais não se percam no tempo, não se afastem da vida. A memória é um direitos de todos."
} 


\section{Parte III}

\section{Capítulo 3}

\section{Arquivos: instrumento e espelho da razão administrativa}

Na inauguração do Centro Cultural de Florianópolis, anteontem à noite,

a professora e historiadora Sara Regina Poyares dos Reis

fez a doação ao Arquivo Histórico Municipal de uma surpreendente preciosidade.

Nada mais nada menos do que a certidão de nascimento da cidade,

'um documento que ninguém conhece', disse ela, muito trêmula

pela importância do objeto. Era o decreto imperial de 24 de fevereiro de 1823,

assinado de próprio punho pelo imperador dom Pedro 2 [sic],

elevando a antiga vila de Desterro à categoria de cidade.

O documento original havia sido resgatado e mantido por Oswaldo Rodrigues Cabral,

seu tio, que foi praticamente seu pai, e de quem herdou todo seu trabalho de pesquisa sobre a história de Santa Catarina.

Raul Sartori (A Notícia, 27 de novembro de 2004).

A inauguração do centro cultural aconteceu, portanto, em 25 de novembro. Meses antes, em março, havia sido inaugurada a "Casa da Memória", em prédio protegido por tombamento municipal e estadual, no qual funcionara o Partido Republicano Catarinense, o Tribunal Regional Eleitoral e a OAB de Santa Catarina. A "Casa da Memória” reuniu os acervos que já estavam sob a responsabilidade da Fundação Franklin Cascaes, órgão da administração municipal indireta - coleções e arquivos pessoais "relativos à história, à memória, à identidade e à produção cultural da cidade"1. Na concepção original, a Casa também deveria incorporar o Arquivo Histórico do Município. Os encaminhamentos administrativos dados ao projeto, contudo, fizeram com que o Arquivo fosse desmembrado da "Casa da Memória”, mantendo-se subordinado à Secretaria Municipal da Administração.

\footnotetext{
${ }^{1}$ Disponível em: <http://www.pmf.sc.gov.br/franklincascaes/index.php?link=institucional\&sublink=patrimônio> Acesso em 12 jun.2005. O acervo enfatiza registros documentais de manifestações artísticas. Também a respeito da inauguração da Casa da Memória, ver: A Notícia, Joinville (SC), 1º. de abril de 2004 (coluna de Moacir Benevenutti).
} 
Tal como a "Casa da Memória", o Centro de Memória Cultural foi instalado na área central de Florianópolis, mas em local de maior visibilidade: em frente à praça XV de Novembro, com sua figueira centenária, o monumento aos mortos na Guerra do Paraguai, os bustos e estátuas de "catarinenses ilustres", além de outros marcos edificados ao seu redor - a antiga Casa de Câmara e Cadeia, a catedral, o Museu Histórico de Santa Catarina.

$\mathrm{Na}$ esquina da rua Tiradentes, o prédio do Centro de Memória Cultural foi construído nos anos 1930 e integra conjunto tombado pelo município (Decreto municipal $n^{\circ}$. 270/86), tendo sido ocupado primeiramente pelo Banco do Brasil e, em seguida, pelo Serviço do Patrimônio da União. Com a inauguração do Centro, passou a abrigar o Arquivo Histórico do Município de Florianópolis, a Associação Literária Florianopolitana, a Galeria Municipal de Arte Pedro Paulo Vecchietti e o Memorial Meyer Filho. ${ }^{2}$ E o Arquivo, que desde a lei de criação, de 1994, era “Arquivo Histórico do Município de Florianópolis”, ganhou um patrono: Oswaldo Rodrigues Cabral.

Ao atribuir o nome de Cabral ao Arquivo (que, vale salientar, era "Histórico"), a municipalidade privilegiou o historiador, mais do que o médico, o jornalista, o professor e o político que ele, Oswaldo Cabral, também soube ser em Florianópolis. Sobretudo, o historiador que escreveu a obra Nossa Senhora do Desterro, dedicada à cidade no período colonial e imperial, e baseada, em parte, nos documentos arquivísticos municipais. ${ }^{3}$ A homenagem do poder público municipal, que parecia significar reconhecimento e gratidão, foi então retribuída pela sobrinha de Cabral, Sara, ela também historiadora e, portanto, representando com ainda maior legitimidade o homenageado: em troca do "presente" dado pelo município, um "presente" para o município, cumprindo uma regra geral de reciprocidade. ${ }^{4}$ Não um presente qualquer: uma "preciosidade", cuja transmissão, frisa o

\footnotetext{
${ }^{2}$ Informações disponíveis em: <http://belasantacatarina.com.br/noticias.asp?id=1094>. Acesso em 12 jun. 2005.

${ }^{3}$ Escreveu Cabral, na abertura da obra: "Andei guardando, durante uns trinta anos, uma vintena de cadernos com apontamentos colhidos nos Arquivos do Palácio e da Prefeitura, bem como na coleção dos jornais da segunda metade do século passado que, embora desfalcada, constitui ainda o mais precioso manancial de informações de todo o gênero sobre a cidade do Desterro e sua vida. Andei guardando porque sempre pensei em escrever esta obra - NOSSA SENHORA DO DESTERRO - e não outras, com as quais contribuí para as letras históricas de Santa Catarina e para adquirir um modesto renome, maior do que o merecido, de estudioso da nossa História." CABRAL, Oswaldo R. Nossa Senhora do Desterro: notícia. Florianópolis: Lunardelli, 1979. v.1, p.13.

4 "Uma parte considerável de nossa moral e de nossa própria vida permanece estacionada nessa mesma atmosfera em que dádiva, obrigação e liberdade se misturam. [...] A dádiva não retribuída ainda torna inferior quem a aceitou, sobretudo quando é recebida sem espírito de reciprocidade." MAUSS, Marcel. Ensaio sobre a dádiva. In: Sociologia e antropologia. São Paulo: Cosac \& Naify, 2003. p. 294. (publicado originalmente em 1925).
} 
colunista social que publica a nota, emocionou a doadora a ponto de fazê-la tremer. Como se traduz o valor do presente? Na sua pertinência: trata-se de documento intimamente associado à história do município - marca a passagem de vila a cidade. Sem aprofundar-se no significado político-administrativo dessa passagem, o colunista esclarece aos leitores: trata-se da "certidão de nascimento da cidade". O valor reside também na autoridade emprestada ao documento por quem o assina: o imperador (mesmo que o colunista, ou talvez o responsável final pela impressão do texto, tenha confundido o pai com o filho). Sim, "assinado de próprio punho pelo imperador"! Por ser documento do século XIX, período predileto de Cabral em seus estudos, certamente seria particularmente valioso para o historiador, o que eleva mais um pouco a generosidade do gesto de doação. Além disso, havia o fator surpresa: se o decreto imperial não era, obviamente, desconhecido, aquele documento, manuscrito, original autêntico, enfim - "ninguém" conhecia. E por que? Fecho da narrativa: o documento fora salvo ("resgatado") e conservado até os nossos dias porque posto sob a proteção de Cabral (e, posteriormente, da herdeira de seu acervo). Caberia agora à Prefeitura (naquele ato representada pela prefeita, Ângela Amin), mas em especial ao Arquivo Histórico de Florianópolis, a guarda e preservação do precioso bem.

Convém, contudo, examinar mais atentamente essa troca de presentes: trata-se, então, de uma devolução, mal disfarçada em doação. A posse privada de documento público foi positivada, pois fruto de "resgate". Mas por que Oswaldo Cabral teria "resgatado" o documento? A nota "Raridade", inserida na coluna de Moacir Pereira, n'A Notícia de 27 de novembro, acrescenta mais elementos ao enredo:

O documento integrava o acervo do professor Oswaldo Cabral, homenageado com o nome do centro [sic]. Seria queimado por ordem do prefeito de Florianópolis na década de 40.

No gesto de Sara Regina Poyares dos Reis, talvez, a indicação de que, se prefeito anterior já quisera eliminar documentos cujo valor não sabia reconhecer, o mesmo não acontecia com a então prefeita, então concedendo lugar digno para as atividades do Arquivo Histórico de Florianópolis.

As condições do "resgate" ficaram por esclarecer. Mas o pouco apreço pela documentação municipal (ou ainda, a ausência de percepção de seu valor para a própria 
administração, passados alguns anos da produção dos documentos) fora manifestado ao menos em outro momento.

\section{Caminhos e descaminhos dos documentos públicos municipais}

Em meados de 1960, uma portaria do prefeito de Florianópolis, Oswaldo Machado, cedeu os documentos mais antigos da Prefeitura - 327 livros, cobrindo o período de 1715 a 1909 - à Faculdade de Filosofia. ${ }^{5}$ Em funcionamento a partir de 1955, a Faculdade havia sido concebida como passo inicial para a implantação da primeira universidade de Santa Catarina e, em 1960, esse projeto estava em vias de se concretizar: em 18 de dezembro daquele ano, a Lei federal $n^{\circ}$. 3.849 criou a Universidade de Santa Catarina ${ }^{6}$.

A partir da portaria do prefeito, os documentos seriam abrigados no Departamento de Documentação Histórica da Faculdade de Filosofia, sendo possível vislumbrar, portanto, que seriam objeto de organização, além de base das pesquisas ali realizadas, quer por professores, quer pelos alunos. O corpo docente da Faculdade tinha inicialmente a forte presença de religiosos, tendo sido necessário ainda buscar outros professores fora de Santa Catarina. Oswaldo Cabral integrava o grupo dos docentes leigos e "locais", sendo inicialmente incumbido da disciplina "História da Antigüidade e da Idade Média". Em 1955, entre os alunos da primeira turma do Curso de Geografia e História estavam Marly Anna Fortes Bustamante e Walter Fernando Piazza. ${ }^{7}$

Como já destacado, o jornalista Moacir Pereira indicou, em sua coluna n’ A Notícia de 27 de novembro de 2004, que o "salvamento" daquele decreto imperial ocorreu na

\footnotetext{
${ }^{5}$ AMBONI, Narcisa de Fátima. Biblioteca Universitária, Setor de Santa Catarina: organização e funcionamento. In: SOARES, Iaponan (org.). Arquivos \& Documentos em Santa Catarina. Florianópolis: Secretaria da Justiça, Arquivo Público do Estado, 1985. p.103. Aparentemente transcrevendo a portaria, Narcisa Amboni informou, no I Encontro de Arquivos Catarinenses: "Em 4 de julho de 1960 o Prefeito Municipal Oswaldo Machado, através da Portaria $\mathrm{n}^{\circ}$. 51, resolve: no uso de suas atribuições, fazer cessão ao Departamento de Documentação Histórica da Faculdade Catarinense de Filosofia, do Arquivo Histórico do Município, ou seja, do Arquivo da Câmara Municipal." A portaria não foi localizada em nenhum dos acervos consultados no processo de pesquisa.

${ }^{6}$ SILVA, Elizabeth Farias da. Ontogenia de uma universidade: a Universidade Federal de Santa Catarina (1962-1980). 291p. São Paulo, 2000. Tese (Doutorado em Educação) - Faculdade de Educação, USP. p.11; FONTES, Henrique da Silva. Pensamentos, palavras e obras: Primeiro caderno - Da Faculdade de Filosofia. Florianópolis: [Edição do Autor], 1960. p.5-21.

${ }^{7}$ FONTES, Henrique da Silva. Pensamentos..., op.cit., p.19-21.
} 
década de 1940. Contudo, uma hipótese que tornaria compreensível a presença do documento no acervo de Oswaldo Cabral seria justamente o fato de ter sido abrigado na Faculdade em que era professor. Ficando no Departamento de Documentação Histórica os documentos municipais cedidos pela Prefeitura de Florianópolis, pode-se supor a grande proximidade que os pesquisadores ligados à Faculdade teriam com eles, sem os obstáculos que, em instituições arquivísticas, costumam ser impostos à sua manipulação, cópia ou empréstimo (este último, aliás, costumeiramente vedado). Não é difícil imaginar que, utilizados para atividades com os alunos ou para pesquisas dos docentes, os documentos pudessem com certa freqüência "migrar" do Departamento de Documentação Histórica para os escritórios dos professores em suas residências. Afinal, o gesto que envolveu a sua cessão à Faculdade de Filosofia indica terem sido considerados em seu valor puramente cultural, isentos de valor administrativo ou, mesmo, jurídico. E quem poderia duvidar do apreço e do cuidado que seriam dedicados aos documentos por pesquisadores reconhecidamente voltados para a história de Santa Catarina?

Com a implantação da Universidade Federal de Santa Catarina, a Faculdade de Filosofia deixaria de existir de forma autônoma, integrando-se à nova instituição. E os documentos públicos municipais foram posteriormente transferidos para a Biblioteca Universitária, criada em $1976 .^{8}$ Referida com freqüência nas dissertações em História relativas a Santa Catarina (em especial as defendidas no Programa de Pós-Graduação em História da Universidade Federal de Santa Catarina), a Biblioteca Universitária certamente teve parte das consultas regulares devidas à presença daqueles documentos em seu acervo.

Tais documentos teriam permanecido na Universidade Federal até meados da década de 1990, com exceção de 36 pastas com tipos documentais diversos da Câmara Municipal de Desterro, que em junho de 1986 teriam sido enviadas ao Arquivo Público do Estado. ${ }^{9}$ Atingidos por enchente que afetou parte do acervo da Biblioteca Universitária, em 1995, os documentos retornaram à guarda do Executivo municipal, uma vez que poderiam ser abrigados no Arquivo Histórico de Florianópolis. ${ }^{10}$

\footnotetext{
${ }^{8}$ AMBONI, Narcisa de Fátima. op.cit., p.103.

${ }^{9}$ RIBEIRO, Marilene Filomeno Machado. Arquivo Histórico do Município de Florianópolis. In: Anais do VI, VII e VIII Encontro Catarinense de Arquivos. Florianópolis: Secretaria de Estado da Administração, Associação de Amigos do Arquivo Público do Estado, 2000. p.202.

${ }^{10}$ Apresentação. In: QUINTEIRO, Suely Veiga (org.). Catálogo de conjuntos documentais do município de Florianópolis (Câmara de Desterro; Cemitérios Públicos). Florianópolis: Arquivo Histórico do Município de Florianópolis, 2004. p.3.
} 
O Arquivo de Florianópolis foi inaugurado apenas em dezembro de 1995, apesar de criado por lei em setembro de $1994 .{ }^{11}$ A iniciativa de institucionalização de um arquivo municipal na capital teria sido de Nelma Baldin, mestre em História pela UFSC e doutora em Educação pela PUC-SP que, à época, exercia, na Prefeitura, o cargo de assessora. Para elaboração do projeto que resultaria na lei de criação do Arquivo, contou, segundo seu depoimento, com a colaboração de Neusa Rosane Damiani Nunes e Talita Telemberg Soares, funcionárias do Arquivo Público do Estado de Santa Catarina. ${ }^{12}$ Ainda em 1994, em dezembro, Nelma Baldin foi nomeada diretora do Arquivo Histórico de Florianópolis. ${ }^{13}$

Para se constituir como espaço de pesquisa, e assim dar cumprimento a uma de suas atribuições legais - a saber, "facilitar, por todos os meios", "pelas partes interessadas", as consultas do acervo sob sua guarda, "em recinto apropriado e sob fiscalização" (Lei municipal $\mathrm{n}^{\mathrm{o}}$. 4.491/1994, Art. $6^{\mathrm{o}}$., inciso II), o Arquivo Histórico de Florianópolis precisava existir concretamente. Necessitava, de um lado, de espaço físico e, de outro, de acervo.

Pela lei de criação, o Arquivo deveria funcionar "na área central da cidade, em prédio específico, com adequadas condições de segurança para armazenar os documentos públicos municipais que constituem o patrimônio documental dos florianopolitanos" (Art.2 ${ }^{\circ}$.). Segundo Nelma Baldin, após a sua nomeação e a alocação de funcionárias para a instituição, procurou local onde instalar o Arquivo:

Encontrei, numa rua bem próxima do Instituto Estadual de Educação - Rua General Bittencourt -, uma casa antiga que tinha ali. Mandamos pintar a casa, reformamos, e entrei em contato com o Banco do Brasil (que estava mudando os móveis das agências) e solicitei a doação dos móveis usados para o Arquivo. Recebemos escrivaninhas, cadeiras, armários, estantes de aço, e aí começamos a coletar documentos. ${ }^{14}$

\footnotetext{
${ }^{11}$ RIBEIRO, Marilene Filomeno Machado. op.cit., p.201-202. No mesmo texto (provavelmente por problemas de editoração) há duas datas distintas para a inauguração: $1^{\circ}$. de dezembro (p.201) e 19 de dezembro (p. 202) de 2005.

${ }^{12}$ As funcionárias do Arquivo Público do Estado teriam auxiliado ainda na elaboração do regimento do Arquivo e no Plano de Destinação de Documentos. Depoimento de Nelma Baldin, em 15 de novembro de 2005 versão transcrita. Fls. 10 e 12 . Arquivo pessoal de Janice Gonçalves.

${ }^{13}$ Relatório de atividades referente a 1994, elaborado por Nelma Baldin, diretora do Arquivo Histórico do Município de Florianópolis. Florianópolis, s.d. [janeiro de 1995?].Arquivo corrente do Arquivo Histórico Municipal de Florianópolis "Oswaldo Rodrigues Cabral” - AHMF, Ofícios expedidos, 1995.

${ }^{14}$ Depoimento de Nelma Baldin, op.cit., fl. 10.
} 
A casa no número 223 da rua General Bittencourt foi alugada pouco antes da inauguração do Arquivo. Antes disso, outras alternativas foram buscadas, enquanto o Arquivo funcionava, formalmente, em uma sala do Gabinete do Prefeito. ${ }^{15}$

A intenção inicial parece ter sido ocupar o "prédio da antiga Portobrás, sito à rua Almirante Lamego - Centro", tendo sido feitas consultas ao Instituto de Planejamento Urbano de Florianópolis - IPUF, quanto à viabilidade de ocupação, antes mesmo de aprovada a lei de criação do Arquivo, e novamente em fevereiro de $1995 .{ }^{16}$ Poucos meses depois, em agosto de 1995, tinha-se já outro prédio em vista: aquele então ocupado pela sede da OAB/SC, "no centro da cidade". Nelma Baldin solicitou ao IPUF que fosse feito estudo no sentido de verificar a possibilidade de ocupação do prédio para "sede do Arquivo Histórico do Município de Florianópolis e, também, de parte das atividades da Fundação Franklin Cascaes: a Casa da Memória de Florianópolis." 17

O insucesso em ocupar prédio que, sendo tombado, pudesse conferir ao Arquivo a legitimidade de seu caráter "histórico", provavelmente levou a opções mais pragmáticas. Assim, em setembro de 1995, houve ainda a tentativa de alugar parte de imóvel situado na rua Arcipreste Paiva, que contaria com $120 \mathrm{~m}^{2}$ para o Arquivo, além de $46 \mathrm{~m}^{2}$ de área comum ${ }^{18}$ o que também não se efetivou. A opção pelo imóvel da rua General Bittencourt - em área de menor movimento e possivelmente de aluguel inferior ao do outro prédio - parece ter se dado

\footnotetext{
${ }^{15}$ Ofício circular s/n, da diretora do Arquivo Histórico do Município de Florianópolis, Nelma Baldin. Florianópolis, 29 de setembro de 1995. Arquivo corrente do AHMF, Ofícios expedidos, 1995. O ofício consultado foi enviado a funcionária do IPUF, e mencionava "a sala onde atualmente funciona a sede do Arquivo Histórico do Município de Florianópolis, nas instalações do Gabinete do Prefeito (na bilheteria do Art 7)." O website da Prefeitura Municipal de Florianópolis, na página relativa ao Arquivo Histórico, informa que o funcionamento inicial da instituição se deu "em uma pequena sala no antigo prédio da Prefeitura, na rua Almirante Alvim”. Disponível em: http://www.pmf.sc.gov.br/arquivo_historico. Acesso em: 17 out. 2005.

${ }^{16}$ Ofício da diretora do Arquivo Histórico do Município de Florianópolis, Nelma Baldin, ao diretorpresidente do IPUF, José Lúcio de Arruda Gomes. Florianópolis, 23 de fevereiro de 1995. Arquivo corrente do AHMF, Ofícios expedidos, 1995. Ofício anterior teria sido enviado em $1^{\circ}$. de agosto de 1994 . A consulta ao IPUF se fez em função do órgão estar incumbido da preservação do patrimônio edificado, uma vez que o prédio em questão - antiga Inspetoria de Rios e Portos - havia sido tombado pelo município em 1992. Informação disponível em: http://www.ipuf.sc.gov.br. Acesso em: 13 ago.2005.

${ }^{17}$ Ofício no ${ }^{\mathbf{0}}$ 15, da diretora do Arquivo Histórico do Município de Florianópolis, Nelma Baldin, ao diretorpresidente em exercício do IPUF, Luiz Antonio M. Maciel Dantas. Florianópolis, $1^{\circ}$. de agosto de 1995. Arquivo corrente do AHMF, Ofícios expedidos, 1995. O prédio em questão seria, portanto, aquele efetivamente ocupado pela Casa da Memória, a partir de março de 2004, na esquina da rua Padre Miguelinho com a rua Anita Garibaldi, e tombado em nível municipal e estadual.

${ }^{18}$ Contrato de locação de imóvel proposto para o Arquivo Histórico do Município [encaminhado com comunicação interna da diretora do Arquivo Histórico do Município de Florianópolis, de Nelma Baldin, para funcionário da Secretaria Municipal da Administração, Carlos Alberto da Silva]. Florianópolis, 28 de setembro de 1995. Arquivo corrente do AHMF, Documentos recebidos, 1994-1996.
} 
entre setembro e novembro de 1995, pois em 29 de novembro preparava-se a inauguração do Arquivo Histórico de Florianópolis. ${ }^{19}$

Inaugurado o Arquivo, era preciso constituir o acervo. Na própria inauguração, teriam sido entregues os documentos da Câmara Municipal de Desterro que desde 1986 encontravam-se no Arquivo Público do Estado. ${ }^{20}$ No final de dezembro foram enviados ofícios a vários órgãos municipais, solicitando a transferência de documentos anteriores a 1975. Nos ofícios, circulares e relatórios que registram a própria existência do Arquivo Histórico de Florianópolis, não foi possível apurar com precisão o grau de sucesso dessa iniciativa - em processo de organização, os documentos disponibilizados para consulta encontram-se bastante lacunares.

À Câmara Municipal, por exemplo, a diretora havia indicado: "documentos do século passado e da Antiga Desterro deverão ser transferidos ao Arquivo Histórico.” O apelo era feito ao presidente da Câmara "considerando-se a sua sensibilidade às causas históricas da nossa cidade." ${ }^{21}$ Da parte da Câmara Municipal, a resposta à solicitação foi negativa, e bastante emblemática do que seria usualmente compreendido como "histórico":

[...] no Arquivo desta Câmara Municipal não contém [sic] nenhum documento referente à história deste Legislativo.

Outrossim, possuímos somente em nossos arquivos, documentos pertinentes às atividades desenvolvidas por este Poder. ${ }^{22}$

Apesar de a diretora do Arquivo Histórico do Município ter se referido, em sua solicitação, aos documentos de um determinado período (fundamentalmente, o período anterior ao republicano), a resposta do presidente da Câmara Municipal sugere a compreensão dos documentos da Câmara como possuidores apenas de valor administrativo (portanto, de interesse apenas para as atividades cotidianas da própria Câmara).

\footnotetext{
${ }^{19}$ Ofício no. 41 da diretora do Arquivo Histórico do Município de Florianópolis, Nelma Baldin, ao presidente do IHGSC, Prof. Walter F. Piazza. Florianópolis, 29 de novembro de 1995. Arquivo corrente do AHMF, Ofícios expedidos, 1995.

${ }^{20}$ RIBEIRO, Marilene Filomeno Machado. op.cit., p.202.

${ }^{21}$ Ofício da diretora do Arquivo Histórico do Município de Florianópolis, Nelma Baldin, ao presidente da Câmara Municipal de Florianópolis. Florianópolis, 26 de dezembro de 1995. Arquivo corrente do AHMF, Ofícios expedidos, 1995.

${ }^{22}$ Ofício $\mathbf{n}^{\mathbf{0}}$. 10/96, do presidente da Câmara Municipal, Demósthenes José Machado, à diretora do Arquivo Histórico do Município de Florianópolis, Nelma Baldin. Florianópolis, de 10 de janeiro de 1996. Arquivo corrente do AHMF, Documentos recebidos, 1994-96.
} 
Ainda segundo Nelma Baldin, alguns dos primeiros documentos a integrarem o acervo do Arquivo foram coletados junto ao Cemitério:

A primeira coisa que a gente fez foi ir ao Cemitério Público [...]. Fomos coletar os antigos livros de registros do cemitério - imagine como estavam, desde que o cemitério existia... Encontramos os documentos em péssimo estado de conservação. Não tínhamos tecnologia, levamos todos aqueles livros encharcados de mofo, colocamos tudo no sol para secar. Mas secaram e aí, com lupa, tentamos reconstruir. Depois fomos nas secretarias da Prefeitura, coletamos todos os documentos, registramos, catalogamos, fizemos o trabalho de construção, de criação do Arquivo. E a cidade ganhou um Arquivo Histórico. ${ }^{23}$

Entre a definição da sede, a coleta dos primeiros conjuntos documentais e a exoneração, a pedido, da primeira diretora do Arquivo, houve o intervalo de poucos meses: Nelma Baldin deixou o cargo no início de fevereiro de $1996 .{ }^{24}$ Substituiu-a a bibliotecária Marilene Filomeno Machado Ribeiro, que no mesmo ano, no "Painel de Arquivos Municipais" do VII Encontro Catarinense de Arquivos, realizado em setembro, apresentou comunicação sobre a instituição. Pela comunicação, verifica-se que a Universidade Federal já enviara ao Arquivo Histórico de Florianópolis o material sob sua guarda durante mais de três décadas: segunda a então diretora, "385 livros da época do Desterro/Câmara Municipal, anos de 1715 a 1943", bem como "28 caixas-arquivo com documentos relativos aos anos de 18091955”. Além destes documentos e daqueles entregues pelo Arquivo Público do Estado, na inauguração do Arquivo Histórico de Florianópolis, "40 livros do Antigo Cemitério da Ponte/Desterro, recebidos da SUSP, dos anos de 1841-1925", e "446 pastas em 128 caixasarquivo, transferidas pelo IPUF em 1982". ${ }^{25}$ Catálogos estariam em elaboração, possibilitando a consulta da documentação por pesquisadores. ${ }^{26}$

Mesmo não localizados, na documentação consultada, relatórios de atividades referentes aos anos de 1995 e 1996, as informações obtidas de forma esparsa em meio à

\footnotetext{
${ }^{23}$ Depoimento de Nelma Baldin, op.cit., fls. 10-11.

${ }^{24}$ Decreto $n^{0}$. 053/96 - resolve exonerar, a pedido, Nelma Baldin, do cargo em comissão de Diretora do Arquivo Histórico do Município de Florianópolis, a partir de 01/02/1996. Florianópolis, 7 de fevereiro de 1996. Arquivo corrente do AHMF, Outros documentos de funcionários - vários anos.

${ }^{25}$ RIBEIRO, Marilene Filomeno Machado. op.cit., p.202-203.

${ }^{26}$ Ibidem, p.202.
} 
correspondência da instituição parecem ser suficientes para indicar a fragilidade do Arquivo Histórico de Florianópolis, em termos técnicos e gerenciais. A correspondência expedida pelo Arquivo, em 1996, registra basicamente agradecimentos por publicações recebidas e solicitações de doações de equipamentos. Não foi encontrada nenhuma referência às atividades que, já na lei de criação, tentaram traçar uma segunda vocação para o "Arquivo Histórico".

\section{Uma dupla vocação}

A inauguração do novo espaço físico para o Arquivo Histórico de Florianópolis, em 2004, compartilhado com outras instituições e órgãos, pôs momentaneamente em segundo plano uma vocação que, desde a institucionalização do Arquivo, procurara ser forjada para ele. Dez anos antes, o Arquivo fora, sim, criado para preservar aquilo que fosse significativo do ponto de vista histórico, mas também para cumprir papel importante em processos tecnicamente adequados de avaliação dos documentos municipais. Se, escorado na importância da preservação dos documentos "históricos", o Arquivo teria que sair em busca dos documentos municipais mais antigos (que recuavam ao século XVIII), não deveria descurar dos documentos que estavam sendo produzidos no presente. Em textos legais posteriores à lei de criação do Arquivo de Florianópolis, a instituição ganharia relevância nas atividades que, desenvolvidas pelos órgãos da administração municipal, procurariam instituir e consolidar uma "política de gestão e administração da documentação municipal”.

A institucionalização do Arquivo Histórico de Florianópolis foi concebida e concretizada no governo de Sérgio Grando (1993-1996), o governo da "Frente Popular" que, na campanha eleitoral, articulou o apoio de oito partidos, à época considerados de esquerda ou centro-esquerda: PPS, PT, PDT, PSB, PSDB, PCB, PC do B, PV. ${ }^{27}$ Neste contexto, a iniciativa foi apresentada como elemento importante para o exercício da cidadania:

A contribuição que os Arquivos têm dado para a formação da identidade $e$ cidadania de um povo levou a Administração Popular a investir na

\footnotetext{
${ }^{27}$ Teria contado com o apoio, também, do Movimento Socialista Revolucionário (MSR). Cf.: FONTANA, Remy. Introdução: uma novidade política. In: GRANDO, Sérgio (org.). Florianópolis de todos. Florianópolis: Insular, 2000. p.11 e 31 .
} 
preservação da memória e na recuperação da história das gentes e da Administração Pública, implantando, em Florianópolis, o Arquivo Histórico do Município de Florianópolis, criado através da Lei Municipal nº 4.491 de 14 de setembro de $1994 .^{28}$

Como derivados da Lei municipal $\mathrm{n}^{\mathrm{o}}$. 4.491/1994, dois decretos foram publicados no ano seguinte: o Decreto municipal $\mathrm{n}^{\circ}$. 622, de 22 de agosto de 1995, que aprovou o "Plano de Destinação e Implantação da Política de Gestão e Administração da Documentação Municipal", e o Decreto municipal $n^{\circ}$. 623, da mesma data, que estabeleceu "normas de avaliação e destinação para os documentos da administração pública do Município de Florianópolis". A partir deles, todo o processo de avaliação seria orientado pelo Arquivo Histórico do Município, e conduzido pela Comissão Central de Avaliação de Documentos CCAD, havendo ainda comissões setoriais de avaliação - CSA. Arquivo Histórico e CCAD trabalhariam de forma articulada, e as tabelas de temporalidade seriam o principal produto deste processo, elaboradas a partir dos dados levantados pelos diversos órgãos municipais, através das comissões setoriais de avaliação. ${ }^{29}$

Estariam sujeitos à avaliação apenas os documentos produzidos após 1930: os anteriores seriam considerados de caráter permanente e "encaminhados indiscriminadamente para o Arquivo Permanente (Arquivo Histórico), para serem guardados. ${ }^{, 30}$ Embora orientando o processo, o Arquivo Histórico não lidaria diretamente com a documentação de caráter intermediário: isso estaria a cargo dos próprios órgãos municipais. Assim, os documentos de caráter corrente ficariam nos arquivos setoriais, sendo posteriormente transferidos para os arquivos centrais de cada órgão. Ao Arquivo Histórico caberia apenas receber os documentos de caráter permanente enviados pelos vários arquivos centrais. Com isso, o Arquivo Histórico, os arquivos centrais e os arquivos setoriais constituiriam o "Sistema Único de Arquivos".

\footnotetext{
${ }^{28}$ GRANDO, Sérgio José. Apresentação. In: PREFEITURA MUNICIPAL DE FLORIANÓPOLIS. Arquivo Histórico do Município de Florianópolis. Plano de destinação e implantação da Política de Gestão e Administração da Documentação Municipal: para entendimento da Política de Gestão e Administração da Documentação Pública - desde a produção até o destino final. Florianópolis: 1995. Grifos meus. Na introdução à mesma publicação, Nelma Baldin ressaltou que o acervo administrativo deveria ser organizado para "melhor servir à municipalidade e ao cidadão."

${ }^{29}$ PREFEITURA MUNICIPAL DE FLORIANÓPOLIS. Arquivo Histórico do Município de Florianópolis. Plano de destinação..., op.cit..

${ }^{30}$ Ibidem.
} 
No processo de montagem formal do "Sistema Único de Arquivos" - ou seja, por meio de textos legais - foram feitos contatos com algumas instituições e seus respectivos funcionários. Além do Arquivo Público do Estado de Santa Catarina, houve consulta ao Arquivo Municipal de São Paulo e, em Santa Catarina, aos arquivos municipais de Blumenau, Joinville e Itajaí. A visita ao Arquivo de São Paulo, em abril de 1995, foi justificada por Nelma Baldin em função do interesse em "observar a técnica de implantação de um sistema de arquivos municipal moderno e eficiente (modelo no Brasil)". ${ }^{31} \mathrm{O}$ relatório da viagem confirma, aliás, a filiação entre os decretos florianopolitanos e o decreto paulistano referente à avaliação e destinação de documentos. ${ }^{32}$ A visita aos arquivos catarinenses, prevista para o mesmo mês de abril, teria por objetivo "a observação de Sistemas de Arquivos Municipais considerados 'modelos' no Estado de Santa Catarina."33 Vê-se que os "sistemas de arquivos" catarinenses eram tomados como uma referência vaga às próprias instituições arquivísticas, dado que, naquele momento, nenhuma delas estava integrada à administração municipal de forma sistêmica.

O esforço para efetivar o Sistema Único de Arquivos e dar início à avaliação dos documentos arquivísticos municipais é visível nas ações realizadas antes mesmo do Arquivo Histórico de Florianópolis ganhar sua sede. No início de abril de 1995, o "Plano de Destinação da Documentação Municipal" já estava elaborado, sendo enviado a vários setores da Prefeitura com o intuito de que fosse "lido, estudado e praticado". ${ }^{34}$ Entre outubro e dezembro de 1995, por exemplo, ao menos três órgãos municipais indicaram representantes para as comissões setoriais de avaliação: a Fundação Municipal de Esportes, a Secretaria

\footnotetext{
${ }^{31}$ Ofício da diretora do Arquivo Histórico do Município de Florianópolis, Nelma Baldin, ao Secretário Municipal da Administração. Florianópolis, 12 de abril de 1995. Arquivo corrente do AHMF, Ofícios expedidos, 1995.

32 No relatório, Nelma Baldin informa terem sido a ela disponibilizados alguns documentos, entre eles o Decreto municipal [São Paulo] $n^{\circ}$. 29.745/1991. Relatório de viagem de trabalho apresentado pela diretora do Arquivo Histórico do Município de Florianópolis, Nelma Baldin. Florianópolis, s.d. [abril de 1995]. Arquivo corrente do AHMF, Ofícios expedidos, 1995.

${ }^{33}$ Plano de viagem de trabalho, prevista para 27 e 28 de abril de 1995, para Itajaí, Blumenau e Joinville, elaborado pela diretora do Arquivo Histórico do Município de Florianópolis, Nelma Baldin. Florianópolis, s.d. Arquivo corrente do AHMF, Ofícios expedidos, 1995.

${ }^{34}$ Ofício circular da diretora do Arquivo Histórico do Município de Florianópolis, Nelma Baldin, a vários setores da administração municipal, enviando cópia do Plano de Destinação da Documentação Municipal. Florianópolis, 10 de abril de 1995. Arquivo corrente do AHMF, Ofícios expedidos - 1995.
} 
Municipal de Educação e a Secretaria de Saúde e Desenvolvimento Social. ${ }^{35}$

Com a saída de Nelma Baldin da direção do Arquivo, é clara a solução de continuidade nas atividades relativas à implantação do processo de avaliação. Tal situação parece ter sido agravada com a mudança de governo, ao menos em seus primeiros momentos - os documentos do próprio Arquivo que puderam ser consultados sugerem o seu não-lugar em relação aos demais órgãos e às diretrizes da nova administração. Uma nova diretora, Leda Vieira, assumiu a instituição e, em inícios de 1997, tentou dar seguimento às atividades do Sistema: ao menos, é o que se depreende de autorização dada a ela pela Prefeita Ângela Amin, através da qual pôde "manter contato com todos os órgãos da Prefeitura Municipal com vistas à avaliação e ao resgate de material histórico porventura existente."36

É pouco provável que os contatos da diretora do Arquivo com as várias repartições da Prefeitura tenham sido bem-sucedidos, pois, ao completar-se o primeiro ano daquela gestão, Leda Vieira sugeriu ao Secretário Municipal de Administração “o repensamento [sic] na criação da tabela de temporalidade para os arquivos setoriais".37 Atestam as dificuldades encontradas na compreensão do "Sistema Único de Arquivos", por parte dos órgãos municipais, alguns registros presentes na correspondência passiva do Arquivo: a "doação" de documentos, em nome da preservação da história do município ("51 plantas de quadras do Plano Diretor do Município”, enviadas pela Secretaria Municipal de Urbanismo e Serviços Públicos) ${ }^{38}$, ou o envio, sem prévia avaliação, de documentos de valor permanente duvidoso (como uma caixa de "Controle de fax - ano 97/98", encaminhada pela

\footnotetext{
35 A Portaria n ${ }^{\circ}$. 23/95, de 9 de outubro de 1995, da Fundação Municipal de Esportes, constitui a Comissão Setorial de Avaliação, composta por Janete Ely, Rosana dos Santos e Zenir Terezinha Guesser; Ofício GS $\mathrm{n}^{\circ} .540 / 95$, de 30 de novembro de 1995, da Secretaria Municipal de Educação, indica os funcionários Neusa Grotto, Nilzomar da Silva e Maria Madalena Decker; Ofício GAB/481/95, de 12 de dezembro de 1995, da Secretaria de Saúde e Desenvolvimento Social, indica os funcionários Aída Aurora Belzer Martins e Ilso Adenor Godinho. Arquivo corrente do AHMF, Documentos recebidos, 1994-96.

${ }^{36}$ Autorização da Prefeita Municipal, Ângela Amin, para a diretora do Arquivo Histórico do Município de Florianópolis, Leda Rosa Cardoso Vieira. Florianópolis, 14 de março de 1997. Arquivo corrente do AHMF, Circulares recebidas, 1997 e 1998.

${ }^{37}$ Relatório de atividades de 1997, assinado por Leda Rosa Cardoso Vieira. Florianópolis, 22 de janeiro de 1998. Arquivo corrente do AHMF, Ofícios expedidos em 1998 para o Secretário da Administração.

${ }^{38}$ Ofício no . 433/07 - GS/SUSP, do Secretário Municipal de Urbanismo e Serviços Públicos à diretora do Arquivo Histórico do Município de Florianópolis, Leda Rosa Cardoso Vieira. Florianópolis, 3 de julho de 1997. Arquivo corrente do AHMF, Ofícios recebidos/expedidos, 1997.
} 
Secretaria Municipal de Educação). ${ }^{39}$

Uma conjuntura mais favorável à gestão documental se esboça ainda em 1998, pois um novo decreto estabelecendo "normas de avaliação e destinação de documentos da administração pública municipal" foi publicado (Decreto municipal $\mathrm{n}^{\circ}$. 489, de 10 de dezembro de 1998). Houve a tentativa de reconstituir as comissões de avaliação, marcando o Arquivo Histórico uma reunião, para 13 de abril, com servidores indicados como representantes dos órgãos municipais nas comissões de avaliação. ${ }^{40}$ A primeira reunião da CCAD seria realizada em 24 de junho de 1999; outra reunião aconteceria um mês depois, em 20 de julho. ${ }^{41}$ Tudo indica que o Arquivo Histórico de Florianópolis encontrara seu lugar na nova gestão - é nítido o maior engajamento da Secretaria Municipal da Administração na avaliação de documentos, positivada na perspectiva da racionalização administrativa.

Para que o "Sistema Único de Arquivos" funcionasse, era preciso, entretanto, o envolvimento de todos os órgãos municipais. Assinalando dificuldades encontradas, o Secretário Municipal da Administração, em ofício-circular de dezembro de 1999, cobrou participação efetiva dos funcionários da Prefeitura na Comissão Central de Avaliação de Documentos, pois alguns órgãos estariam "comprometendo o andamento dos trabalhos pela ausência de seus representantes". ${ }^{42}$ As ausências seriam um problema persistente: mesmo em abril de 2002, quando já existia uma versão de tabela de temporalidade, alerta-se para a circunstância de os documentos da Secretaria Municipal de Transportes e Obras não terem sido incluídos, em virtude da ausência de seus representantes em reuniões "onde seriam avaliados os documentos da SMTO". 43 No segundo semestre de 2004, Suely Quinteiro, diretora do Arquivo Histórico do Município de Florianópolis desde 2002, repetia a

\footnotetext{
${ }^{39}$ Em conjunto com outros documentos do período 1993-1997, foram encaminhados para serem colocados "em guarda permanente do arquivo histórico." Ofício G.S nº 1119/99, da Secretária Municipal de Administração ao Chefe da Unidade de Apoio da Secretaria Municipal de Administração. Florianópolis, 27 de dezembro de 1999. Arquivo corrente do AHMF, Ofícios recebidos - diversos - 1999.

${ }^{40}$ Ofícios de $\mathbf{n}^{\mathbf{0}}$. 15/99 a 28/99, encaminhados pelo Arquivo Histórico do Município de Florianópolis a vários órgãos municipais. Florianópolis, 30 de março a 7 de abril de 1999. Arquivo corrente do AHMF, Membros da CCAD/ Tabela de temporalidade - 1999.

${ }^{41}$ Ofícios $n^{0} .41$ a 56/99, de junho de 1999, e ofícios $n^{0} .60$ a 74/99, de julho de 1999, da diretoria do Arquivo Histórico do Município de Florianópolis a vários órgãos municipais, convocando para reuniões. Arquivo corrente do AHMF, Membros da CCAD/ Tabela de temporalidade - 1999.

${ }^{42}$ Ofício circular no. 38/99, do Secretário Municipal de Administração a vários órgãos municipais. Florianópolis, 27 de dezembro de 1999. Arquivo corrente do AHMF, Membros da CCAD/Tabela de Temporalidade - 1999.

${ }^{43}$ Ofício no . 26/02, da diretora do Arquivo Histórico do Município de Florianópolis, Suely V. Quinteiro, ao Secretário Municipal de Transportes e Obras. Florianópolis, de 18 de abril de 2002. Arquivo corrente do AHMF, Ofícios enviados - 2002.
} 
constatação: "a falta de comparecimento às reuniões dos representantes de algumas unidades [...] inviabilizou a análise dos documentos das mesmas." ${ }^{44}$

A aprovação de uma tabela de temporalidade, mesmo lacunar, para a documentação municipal, possibilitou a eliminação regular de documentos. Mas, contrariando a concepção inicial do Sistema Único de Arquivos, não coube ao Arquivo Histórico de Florianópolis apenas receber, dos vários órgãos municipais, a documentação de caráter permanente. Suely Quinteiro, em abril de 2003, queixou-se de estarem "os trabalhos de seleção, descarte e fragmentação de documentos [...] sobrecarregando o Arquivo Histórico."45 Toda a parte operacional da aplicação da tabela de temporalidade estava a cargo do Arquivo, portanto, fazendo com que a sua diretora sugerisse, ao Secretário da Administração,

[...] a transferência dos serviços de fragmentação para a Unidade de Apoio, passando todos os órgãos da Prefeitura a fazerem a seleção dos seus documentos, encaminhando os descartáveis para a fragmentação e enviando ao Arquivo somente os documentos destinados à guarda temporária ou permanente, previamente selecionados.

Todos podem fazer uso da tabela de temporalidade em vigor, consultando o Arquivo para qualquer dúvida. ${ }^{46}$

Cabe esclarecer que, em meio à primeira gestão da prefeita Ângela Amin (19972000), a situação do Arquivo Histórico de Florianópolis mudara também em termos de instalações físicas, o que parece apontar para uma percepção diferenciada do Arquivo, em relação à gestão anterior. Com o Arquivo na casa da rua General Bittencourt, o governo Sérgio Grando tentava dar efetividade a uma instituição arquivística compreendida como instrumento do exercício de direitos (como o direito à memória e o direito à informação, ambos convergindo para o exercício da cidadania); era preciso, portanto, garantir espaço para a consulta pública dos documentos. A consulta, porém, levando-se em conta os números

\footnotetext{
${ }^{44}$ Comunicação interna no. 113/04, da diretora do Arquivo Histórico do Município de Florianópolis, Suely V. Quinteiro, ao Secretário Municipal de Administração. Florianópolis, s.d. Arquivo corrente do AHMF, Comunicação interna enviada - 2004. Embora a comunicação interna não esteja datada, deduz-se que seja do segundo semestre, em função da alusão ao pouco tempo para conclusão de certas atividades antes do "encerramento da atual gestão".

${ }^{45}$ Ofício no ${ }^{\mathbf{0}}$ 17/03, da diretora do Arquivo Histórico do Município de Florianópolis, Suely V. Quinteiro, ao Secretário Municipal de Administração. Florianópolis, 30 de abril de 2003. Arquivo corrente do AHMF, Ofícios enviados - 2003.

${ }^{46}$ Ibidem.
} 
apresentados pela diretora Leda Vieira, relativamente a 1997 e 1998, era mínima: ao longo de 1997, 46 pesquisadores, consultando 182 documentos; em 1998, 38 pesquisadores e 191 documentos consultados. ${ }^{47}$ Motivo talvez suficiente para deslocar o Arquivo Histórico de Florianópolis para prédio onde estivessem concentrados diversos órgãos municipais, inclusive o Gabinete da Prefeita. Assim, no final de 1998, decidiu-se instalar o Arquivo em prédio na rua Conselheiro Mafra, então transformado em principal endereço da Prefeitura Municipal. ${ }^{48}$ O espaço a ocupar seria, contudo, reduzido e pouco adequado: Leda Vieira, em janeiro de 1999, destacou ser insuficiente até mesmo para o material do Arquivo, além de úmido e afetado por luz intensa. ${ }^{49}$ Pequeno para o acervo, ele também abrigaria, com dificuldade, pesquisadores. Com isso, o Arquivo Histórico de Florianópolis passaria a estar fundamentalmente a serviço da administração. ${ }^{50}$

A vocação do Arquivo para a pesquisa histórica seria reafirmada, todavia, em meados da segunda gestão Ângela Amin, juntamente com a recuperação da idéia de uma "Casa da Memória". 51 A atuação da diretora Suely Quinteiro, neste sentido, teve relevância em especial sua iniciativa de encaminhar projeto voltado para a "conservação preventiva de documentos históricos da Prefeitura Municipal de Florianópolis" ao programa ADAI (“Apoyo al Desarrollo de Archivos Iberoamericanos"), sustentado pelo Ministério da Educação, Cultura e Desporto da Espanha. Aprovado no âmbito do programa, o projeto obteve, em 2003,

\footnotetext{
${ }^{47}$ Relatório de atividades, 1997-1998, encaminhado por Leda Rosa Cardoso Vieira. Florianópolis, 27 de novembro de 1998. Arquivo corrente do AHMF, Ofícios expedidos em 1998 para o Secretário da Administração. ${ }^{48}$ Ofício circular n⿳0. 30/98, do Secretário Municipal da Administração. Florianópolis, 9 de outubro de 1998. Arquivo corrente do AHMF, Ofícios recebidos - 1998.

${ }^{49}$ Ofício no ${ }^{\mathbf{0}}$ 03/99, da diretora do Arquivo Histórico do Município de Florianópolis, Leda Rosa C. Vieira, ao Secretário Municipal de Administração. Florianópolis, 26 de janeiro de 1999. Arquivo corrente do AHMF, Ofícios expedidos - 1999.

${ }^{50}$ Nota pessoal: em 2000, visitei o Arquivo Histórico do Município de Florianópolis, no andar térreo da rua Conselheiro Mafra $\mathrm{n}^{\circ}$. 656, e conversei com sua diretora, Leda Rosa Cardoso Vieira. O Arquivo possuía duas escrivaninhas, para a diretora e para sua assistente (todo o quadro de pessoal da instituição) e uma mesa de tampo redondo, com duas cadeiras, para os usuários; havia também uma pequena área de depósito e uma saleta para higienização. Documentos da Prefeitura de produção mais recente estavam localizados no subsolo. Inexistiam instrumentos de pesquisa. O Arquivo contava ainda com seis estagiários (graduandos das áreas de História, Administração, Biblioteconomia e Direito) e, para os serviços de limpeza, era atendido por duas serventes da Prefeitura.

51 “....] há também um estudo de instalação da Casa da Memória, fazendo com que o espaço físico hoje ocupado, que é inadequado, seja remanejado para outro local [sic], tornando o Arquivo mais amplo, de maneira que possa atender suas necessidades e objetivos reais.” QUINTEIRO, Suely Veiga. Arquivo Histórico do Município de Florianópolis. In: Caderno de resumos do X Encontro Catarinense de Arquivos e V Painel de Arquivos Municipais - 2 a 4 de setembro de 2002. Florianópolis: 2002. p.26-27.
} 
recursos no montante aproximado de cinco mil e quinhentos dólares, ${ }^{52}$ o que provavelmente contribuiu para alterar a percepção da administração municipal em relação ao Arquivo. Um dos resultados do projeto foi o primeiro instrumento de pesquisa publicado do Arquivo: um catálogo cujo núcleo documental principal é justamente aquele formado pelos documentos da Câmara de Desterro anteriormente abrigados na Universidade Federal. ${ }^{53}$

Não à toa, o final da gestão contemplou o Arquivo Histórico de Florianópolis com instalações mais adequadas - a decisão, importante para pesquisadores, também decorria de demandas da administração municipal. Vale salientar que o andamento dos trabalhos de avaliação, seleção e eliminação de documentos envolvia o recolhimento da documentação de caráter permanente ao Arquivo, cuja capacidade de armazenamento, segundo a diretora Suely Quinteiro, estava esgotada desde setembro de $2002 .{ }^{54}$ A situação tornara-se ainda pior no início de 2004, com remanejamentos efetuados no prédio da Prefeitura na Rua Conselheiro Mafra, de modo a ali instalar uma agência do Banco do Brasil. Com isso, o Arquivo "perdeu $22 \mathrm{~m}^{2}$ do seu já exíguo espaço físico" e, de imediato, teve praticamente que paralisar suas atividades, pois ficou

sem condições de atender aos pesquisadores, sem espaço até para colocar algumas mesas e cadeiras e acomodar servidores e estagiários, com os trabalhos de seleção e descarte interrompidos e com o atendimento ao público prejudicado. ${ }^{55}$

Acrescente-se que, como a mudança para o prédio atualmente ocupado praticamente coincidiu com a transição de governo, várias atividades tiveram que aguardar a reacomodação dos órgãos aos novos ocupantes de cargos e a orientações político-

\footnotetext{
${ }^{52}$ Ofício no ${ }^{\mathbf{3}}$ 36/03, da diretora do Arquivo Histórico do Município de Florianópolis, Suely V. Quinteiro, ao Secretário Municipal de Administração. Florianópolis, 22 de julho de 2003. Arquivo corrente do AHMF, Ofícios enviados - 2003. Comunicação sobre o projeto financiado pelo Programa ADAI foi apresentada no XI Encontro Catarinense de Arquivos: QUINTEIRO, Suely Veiga. Arquivo Histórico [de Florianópolis] e o Programa ADAI. In: Programa do XI Encontro Catarinense de Arquivos - 13 a 15 de setembro de 2004. [2004]. Folder.

${ }^{53}$ Apresentação. In: QUINTEIRO, Suely Veiga (org.). Catálogo de conjuntos documentais..., op.cit, p.3.

${ }^{54}$ Ofício n ${ }^{\mathbf{3}}$. 71/02, da diretora do Arquivo Histórico do Município de Florianópolis, Suely V. Quinteiro, para o Secretário Municipal de Administração. Florianópolis, 11 de setembro de 2002. Arquivo corrente do AHMF, Ofícios expedidos - 2001/2002; Ata de reunião do Colegiado da Secretaria de Administração. Florianópolis, 8 de janeiro de 2004. Arquivo corrente do AHMF, Atas de reuniões do Colegiado da Secretaria de Administração - 2003/2004.

${ }^{55}$ Relatório da diretora do Arquivo Histórico do Município de Florianópolis, Suely V. Quinteiro, sobre a transferência provisória do Arquivo Histórico, realizada em 13 de fevereiro de 2004. Florianópolis, 19 de fevereiro de 2004. Arquivo corrente do AHMF, Ofícios enviados - 2003 [sic].
} 
administrativas possivelmente diferenciadas. O compromisso com a gestão documental foi, contudo, reafirmado, como pode ser observado no boletim do Arquivo Histórico de Florianópolis editado no segundo semestre de 2005:

Uma das primeiras ações desenvolvidas pela nova administração do Arquivo Histórico do Município (AHM) foi a de iniciar a reestruturação do processo de gestão documental da Prefeitura Municipal de Florianópolis (PMF). ${ }^{56}$

O atual diretor, Antonio Dario Neves, aponta a intenção de valorizar as duas vocações do Arquivo Histórico de Florianópolis:

[o Arquivo Histórico do Município de Florianópolis] tem a função de coordenar os outros arquivos das secretarias da Prefeitura. Quer dizer, ao mesmo tempo que se pensa na importância da conservação desse acervo, pensando que gerações futuras possam ter acesso a uma informação de alto nível, que remonta aos tempos anteriores [...].

Numa palavra, nós queremos, dentro desse projeto que nós ansiamos por ele, de relação com a prefeitura, com as secretarias, criar oportunidades de fazermos com que funcione um projeto da Prefeitura que se chama Sistema Único de Arquivos. Quer dizer, que os arquivos deixem de ser ilhas [...]. ${ }^{57}$

No prédio atualmente ocupado, os pesquisadores encontram uma pequena sala para eles especialmente reservada, e um acervo a ser organizado. Muitos dos documentos dos séculos XVIII e XIX, como já indicava o catálogo publicado em 2004, estão deteriorados e interditados para consulta. A interdição motivou, inclusive, nota na coluna diária de Cacau Menezes, publicada no Diário Catarinense em 3 de dezembro de 2005:

O Arquivo Municipal de Florianópolis, que, para quem não sabe, está entre os mais bem instalados e equipados do Brasil, ironicamente está dificultando quem mais precisa dele, os pesquisadores. A maioria dos documentos

\footnotetext{
${ }^{56}$ Boletim informativo do Arquivo Histórico Municipal de Florianópolis. Florianópolis, jul-set. 2005. Folder. ${ }^{57}$ Depoimento de Antonio Dario Neves e Fábio Andréas Richter, em 11 de novembro de 2005 - versão transcrita. Fls. 1 e 3. Arquivo pessoal de Janice Gonçalves.
} 
primários (manuscritos) está interditada por não ter tratamento adequado. Enquanto se aguarda restauração, ninguém pode manuseá-los. ${ }^{58}$

Ingresso midiático do Arquivo Histórico de Florianópolis nas disputas políticas locais: os documentos estariam interditados pela falta de tratamento adequado (subtexto: a atual administração não trata adequadamente dos documentos); o Arquivo é um dos "mais bem instalados e equipados do Brasil" (subtexto: a instalação e os equipamentos foram realizações da administração anterior); o prejuízo é de "quem mais precisa" do Arquivo: o usuário, o pesquisador (subtexto: o Arquivo não cumpre sua função fundamental).

Promover o encontro dos pesquisadores com o acervo do Arquivo de Florianópolis não é, porém, tarefa simples. Os documentos que se encontram sumariamente descritos, no catálogo publicado, referem-se a períodos históricos que têm atraído, na última década, um número menos significativo de pesquisadores, se tomarmos como referência dissertações e teses sobre Santa Catarina (ver Parte I, Capítulo 1). Grande número de documentos diz respeito à administração financeira municipal (controle contábil e da arrecadação), e os estudos na área de história econômica também sofreram um refluxo, a partir da década de 1980, não só em Santa Catarina. ${ }^{59} \mathrm{Na}$ sua maioria exigindo ao menos alguns conhecimentos de paleografia, vários são de leitura ainda mais difícil em função do estado de conservação em que se encontram. E existem também as lacunas, provavelmente provocadas nos últimos cinquienta anos, em meio aos vários deslocamentos da documentação municipal, talvez ainda anteriores.

Vale lembrar que foram justamente os documentos de arquivo do município que motivaram Lucas Alexandre Boiteux a utilizar a imagem dos "sombrios umbrais" dos arquivos catarinenses, em meio à polêmica travada em 1918, na Revista do IHGSC, acerca da data de criação da freguesia de Desterro (ver Parte I, Capítulo 2). Contestado acerca da informação que a respeito constava em seu livro Notas para a história catarinense, Lucas Boiteux informou que, no processo de elaboração da obra, não pôde consultar o arquivo de Florianópolis, não tendo sido a isso autorizado. ${ }^{60} \mathrm{E}$, como também anteriormente mencionado (Parte I, Capítulo 2), Henrique Fontes, anos antes, em 1913, e na mesma revista, apontara para

\footnotetext{
${ }^{58}$ MENEZES, Cacau. Interditado. Diário Catarinense, Florianópolis, 3 dez. 2005.

${ }^{59}$ Ver: FRAGOSO, João; FLORENTINO, Manolo. História econômica. In: CARDOSO, Ciro F.; VAINFAS, Ronaldo (orgs.). Domínios da história: ensaios de teoria e metodologia. Rio de Janeiro: Campus, 1997. esp. p.27-30 e 36-39.
} 
a desorganização desses documentos ("a montoeira dos livros do arquivo municipal") e para os indícios de perdas significativas, por descuido ou descaso (na busca do primeiro livro de vereanças de Desterro, "o volume desejado não apareceu", podendo talvez ter sido "queimado ou despedaçado por velho e inútil”, destruído por traças ou pela umidade) ${ }^{61}$

Em grande medida, o Arquivo Histórico de Florianópolis está por descobrir. É pouco conhecido do público em geral, apesar de seus mais de dez anos de funcionamento talvez, pelas peculiaridades de sua trajetória, que não assinalou iniciativas de difusão cultural, permitindo à instituição maior visibilidade. Também os pesquisadores ainda pouco o freqüentam. Cabe lembrar que documentos públicos da Câmara Municipal de Desterro, do Conselho Municipal e da Prefeitura, em função das relações entre os órgãos governamentais, podem ser consultados em outros locais, como o Arquivo Público do Estado, o arquivo da Assembléia Legislativa e o arquivo do Fórum da capital (cujos documentos arquivísticos mais antigos estão hoje sob a guarda do Tribunal de Justiça do Estado). Parte dos documentos do acervo esteve, como aqui apontado, disponível para consulta na Biblioteca Universitária (hoje, Biblioteca Central) da Universidade Federal de Santa Catarina, bem como no Arquivo Público do Estado, e isso mesmo antes da institucionalização do Arquivo Histórico de Florianópolis - situação que talvez tenha contribuído para que o Arquivo não fosse percebido como necessário. Além disso, o pesquisador interessado na história de Desterro/Florianópolis pode ainda recorrer aos periódicos da Biblioteca Pública do Estado, ou aos materiais do acervo do Instituto Histórico e Geográfico de Santa Catarina, ambas as instituições sediadas na capital. Talvez não haja clareza acerca da singularidade dos documentos reunidos no arquivo do município.

Diferentemente dos casos de Joinville e Blumenau, o Arquivo Histórico de Florianópolis não buscou reunir coleções identificadas com determinadas memórias, que mobilizassem certos grupos sociais. Manteve-se centrado nos documentos municipais.

Os esforços da atual direção buscam garantir uma estrutura técnico-administrativa para o Arquivo, dado que, formalmente, seu quadro de pessoal é constituído somente por

\footnotetext{
${ }^{60}$ BOITEUX, Lucas Alexandre. Commentarios á Historia Catharineta. RTIHGSC, 1918, $3^{\text {o }}$. trim., p. 329.

${ }^{61}$ Discurso proferido pelo sr. Bacharel Henrique da Silva Fontes na sessão commemorativa do $187^{\circ}$. anniversario da creação da villa de $\mathrm{N}^{\mathrm{a}}$. $\mathrm{S}^{\mathrm{a}}$. do Desterro, sessão realizada a 26 de março de 1913 . RTIHGSC, $1913,1^{\circ}$. $-2^{\circ}$. trim., p.117.
} 
diretor e assistente. ${ }^{62} \mathrm{E}$, ao lado disso, reforçar seu papel como instrumento e espelho da razão administrativa: nas palavras do atual diretor, Antonio Dario Neves,

[...] não há um Arquivo distante da Prefeitura. Nós somos um Arquivo dentro de uma Secretaria Administrativa. A Secretaria Administrativa há de ser uma Secretaria de peso dentro da administração da Prefeitura. E ela há de reconhecer que o Arquivo não pode ser um peso morto, um lugar de jogar documentos fora." $" 63$

\section{Razão administrativa ou histórica?}

Além do Arquivo de Florianópolis, o Arquivo de Itajaí também buscou assumir funções mais relevantes junto à administração municipal, para além da de mero receptáculo de documentos sem valor administrativo. Desde a década de 1980, o Arquivo Histórico de Itajaí colaborava com a Prefeitura Municipal nas questões referentes ao arquivo intermediário: entre as atividades realizadas em 1989, por exemplo, estavam as de "recuperação e organização do acervo do arquivo intermediário municipal, na etapa preliminar de sua organização por décadas". ${ }^{64}$ Aprovada lei municipal relativa a uma política de gestão documental, em $1998^{65}$, os relatórios de atividades da Fundação Genésio Miranda Lins passaram a registrar deslocamentos de funcionários à "Casa de Cabeçudas", onde estava o arquivo intermediário, para localização de documentos (provavelmente em função de solicitações de órgãos da Prefeitura Municipal). ${ }^{66}$ Entre setembro e dezembro de 1999, teria sido iniciada a "organização dos acervos documentais depositados na Casa de Cabeçudas", mais especificamente o Fundo Prefeitura Municipal e o Fundo Câmara Municipal (documentos do período 1950-1983). ${ }^{67}$ Tratando-se de arquivo intermediário, e tendo em vista

\footnotetext{
${ }^{62}$ Depoimento de Antonio Dario Neves..., op.cit., fls. 1-2, 7-8.

${ }^{63}$ Ibidem, fl. 10.

${ }^{64}$ Relatório de atividades relativo ao ano de 1989, encaminhado ao Prefeito Municipal, João Omar Macagnan, pelo presidente da Fundação Genésio Miranda Lins, Edison d'Ávila. Itajaí (SC), julho de 1990. Acervo: Centro de Documentação e Memória Histórica/Arquivo Público de Itajaí.

${ }^{65}$ Lei municipal [Itajaí] n ${ }^{\circ} .3 .343$, de 27 de novembro de 1998.

${ }^{66}$ Relatório de atividades da Fundação Genésio Miranda Lins, relativo ao ano de 1998. Itajaí (SC), [1999]; Relatório de atividades da Fundação Genésio Miranda Lins, relativo ao ano de 1999 Itajaí (SC), [2000], p.10. Acervo: Centro de Documentação e Memória Histórica/Arquivo Público de Itajaí.

${ }^{67}$ Relatório de atividades da Fundação Genésio Miranda Lins, relativo ao ano de 1999, op.cit., p.12.
} 
a lei de 1998, pode-se supor que a organização desses conjuntos documentais consistisse em identificação para posterior avaliação. O Arquivo de Itajaí também recebeu, provenientes do arquivo intermediário da Prefeitura, documentos fotográficos e áudio-visuais. ${ }^{68}$ Prestou ainda assessoria técnica a órgãos da administração municipal (como a Secretaria de Educação e a Secretaria de Administração) quanto à organização de documentos arquivísticos. ${ }^{69}$

Foi talvez a intenção de firmar o Arquivo Histórico de Itajaí como instância vinculada a todas as fases da documentação arquivística municipal que fez com que, na virada para o século XXI, passasse a ser denominado de "Arquivo Público". ${ }^{70} \mathrm{Na}$ condição de Arquivo Público de Itajaí, a instituição assessorou e acompanhou, em 2002, o processo de construção da sede do Arquivo Intermediário da Prefeitura, inaugurado em outubro daquele ano. Durante a realização da obra, o Arquivo Público de Itajaí recebeu temporariamente a documentação de caráter intermediário, responsabilizando-se pelo atendimento às solicitações de documentos feitas por secretarias e demais órgãos municipais. ${ }^{71}$ Em 2003, prosseguiu com o assessoramento técnico na organização do Arquivo Intermediário da Prefeitura, e em 2004, ficou responsável pelo seu gerenciamento. ${ }^{72}$

A vitória do candidato do Partido dos Trabalhadores para o cargo de prefeito de Itajaí, nas últimas eleições municipais, acarretaria, iniciado o governo, uma série de alterações na Fundação Genésio Miranda Lins. De um lado, na sua estrutura, resultando na extinção do Conselho Curador e na criação de um Conselho Deliberativo, bem como de uma Superintendência e de diretores para cada unidade da Fundação. Pelo novo estatuto, o Arquivo, a rigor, deixou de existir, pois, além dos museus, foi apenas mencionado o Centro de

\footnotetext{
${ }^{68}$ Relatório de atividades da Fundação Genésio Miranda Lins, relativo ao ano de 1999, op.cit., p.14.

${ }^{69}$ Relatório de atividades da Fundação Genésio Miranda Lins, relativo ao ano de 2001. Itajaí (SC), [2002], p.13, 15-16. Acervo: Centro de Documentação e Memória Histórica/Arquivo Público de Itajaí.

${ }^{70}$ Relatório de atividades da Fundação Genésio Miranda Lins, relativo ao ano de 1999, op.cit.; Relatório de atividades da Fundação Genésio Miranda Lins, relativo ao ano de 2001. op.cit.; Relatório de atividades da Fundação Genésio Miranda Lins, relativo ao ano de 2002 Itajaí (SC), [2003]. Acervo: Centro de Documentação e Memória Histórica/Arquivo Público de Itajaí. No relatório referente às atividades de 2002, um trecho do "Histórico da Fundação Genésio Miranda Lins" assinala: "O Arquivo Histórico, hoje Arquivo Público [...]". Tudo indica que a mudança de denominação ocorreu em 2001, em função da ocupação da "Casa Lins"; o relatório de atividades relativo ao ano de 2000 não foi localizado.

${ }^{71}$ Relatório de atividades da Fundação Genésio Miranda Lins, relativo ao ano de 2002. op.cit., p.20 e 22.

${ }^{72}$ Relatório de atividades da Fundação Genésio Miranda Lins, relativo ao ano de 2003. Itajaí (SC), [2004], p.5. Relatório de atividades da Fundação Genésio Miranda Lins, relativo ao ano de 2004. Itajaí (SC), [2005]. p.40. Acervo: Centro de Documentação e Memória Histórica/Arquivo Público de Itajaí.
} 
Documentação e Memória Histórica "Genésio Miranda Lins". 73 Figuras intimamente associadas à trajetória da entidade, como Edison d’Ávila, foram afastadas.

Interessa notar que o Centro de Documentação e Memória Histórica "Genésio Miranda Lins" não era uma novidade: segundo os relatórios de atividades da Fundação, foi concebido no contexto da reforma da "Casa Lins", que envolvia também a construção de um anexo, no qual estariam instalados o Arquivo Histórico, a Biblioteca de Apoio e o Gabinete de Arte. O projeto foi aprovado pelo Ministério da Cultura para que pudesse captar recursos pela chamada Lei Rouanet, e projeto complementar, também aprovado, objetivava a elaboração de livro sobre Genésio Miranda Lins. ${ }^{74}$ Tudo indica que os projetos foram a maneira encontrada para ocupar a "Casa Lins" (doada pela família Lins à Fundação), atendendo a necessidades da Fundação (como a de uma sede apropriada para o Arquivo). Estratégia, portanto, para simultaneamente captar recursos para a reforma do prédio, "retribuir" a doação feita pela família (com a homenagem a Genésio Miranda Lins, no livro elaborado e na denominação do Centro) e reunir, sob uma denominação suficientemente abrangente, órgãos tão distintos como um arquivo, uma biblioteca e um "gabinete de arte".

Inaugurado em maio de 2001, o Centro de Documentação e Memória Histórica “Genésio Miranda Lins”, pelo que pode ser inferido dos relatórios de atividades da Fundação, designava apenas um espaço físico (o conjunto edificado formado pela "Casa Lins" e seu anexo), e não uma nova instituição custodiadora de documentos. Não se vislumbra, nos relatórios de atividades, nenhuma intenção de dissolver as fronteiras entre Arquivo Público, Biblioteca de Apoio e Gabinete de Arte. Mas a apropriação da idéia original, pela gestão municipal instalada a partir de 2005, indica o aproveitamento de uma "brecha" para a mudança de perspectiva quanto ao papel dessas instituições na produção da memória social (ver Parte III, Capítulo 2).

A partir de 2001, na "Casa Lins" transmutada em Centro de Documentação e Memória Histórica, o Arquivo Histórico de Itajaí pudera se tornar Arquivo Público - com instalações apropriadas, em princípio, para atuar como espaço de pesquisa e para coordenar a gestão documental do município, recolhendo regularmente a documentação avaliada como de

\footnotetext{
${ }^{73}$ Lei municipal [Itajaí] n ${ }^{\circ}$. 4.263, de 16 de março de 2005; Decreto municipal [Itajaí] no ${ }^{\circ} .7 .575$, de 19 de julho de 2005. O Centro de Documentação é citado no Art. $8^{\circ}$. do decreto.

${ }_{74}$ Relatório de atividades da Fundação Genésio Miranda Lins, relativo ao ano de 1999, op.cit., p.5; Relatório de atividades da Fundação Genésio Miranda Lins, relativo ao ano de 2001. op.cit., p.12; Relatório de atividades da Fundação Genésio Miranda Lins, relativo ao ano de 2002. op.cit., p.5.
} 
valor permanente. Compreendido como articulado a um centro de documentação e memória, tende a ter suas especificidades institucionais apagadas ou mal compreendidas, e sua visibilidade reduzida. No difícil equilíbrio entre a razão administrativa e a histórica, o Arquivo Público de Itajaí parece ter pendido, mais recentemente, para esta última. ${ }^{75}$

Em Joinville e Blumenau, a gestão documental há vários anos foi lançada como meta a ser perseguida. Em Joinville, na cerimônia de comemoração dos vinte anos do Arquivo Histórico, Apolinário Ternes, seu diretor, declarou:

Agora é tempo da instituição ampliar as suas funções, deixando a característica de Arquivo Histórico, para se transformar num Arquivo Público. Precisamos incorporar, com urgência, os conjuntos documentais da prefeitura e da Câmara, assim como já incorporamos os arquivos do Poder Judiciário. O Arquivo precisa se transformar no gestor de toda a documentação da administração pública e, para isto, deve mudar sua filosofia operacional. Precisamos de especialistas em arquivística. Precisamos de técnicos em gestão documental. Precisamos de mais espaço, também. É o desafio para os próximos anos e só com isto o Arquivo terá cumprido com suas finalidades e responsabilidades. ${ }^{76}$

Segundo Sueli Petry, responsável pelo Arquivo Histórico de Blumenau,

Cada gestão que chega, nós vamos lá, conversamos, pedimos, falamos da necessidade de manter essa documentação [municipal]. [...] não se concebe mais um município do porte de Blumenau não estar com a sua gestão documental.

[...] [Na Prefeitura Municipal de Blumenau] não existe uma política de classificação, seleção, tabela de temporalidade... não existe nada. E não é por falta de orientação: nós temos conversado com as secretarias, [...] alguns

\footnotetext{
75 Isso não significa que as atividades relacionadas à gestão documental tenham sido interrompidas: em abril de 2006, teve início o curso "Gestão de documentos: da classificação à destinação", promovido pela Fundação Genésio Miranda Lins e pela Fundação de Educação Profissional e Administração Pública de Itajaí, voltado para os servidores municipais. Foi ministrado até maio do mesmo ano por Euclides José da Cruz e Vera Lúcia Estork, funcionários da Fundação Genésio Miranda Lins. Disponível em: http://fgml.itajai.sc.gov.br/noticiasp_det.php? id_noticia=3522. Acesso em: 19 jun. 2006.

${ }^{76}$ Boletim do Arquivo Histórico Municipal de Joinville - AHMJ, Joinville (SC), n.10, jun.1992, p.17.
} 
departamentos da Prefeitura nos procuraram. Já é um bom começo. Principalmente o setor da Administração. Existe vontade, sim. ${ }^{77}$

Apesar das metas de uns e da vontade de outros, os Arquivos de Blumenau e Joinville continuam a pender para a razão histórica, talvez sob o peso do perfil forjado para ambas as instituições.

${ }^{77}$ Depoimento de Sueli Petry, em 17 de novembro de 2005 - versão transcrita. Fl. 3, 14, 15. Arquivo pessoal de Janice Gonçalves. 


\section{Conclusão:}

À moda de coda

Ao abordar a historiografia sobre Santa Catarina, não foi minha intenção negar a "novidade" da "nova geração". As diferenças existem. Como existem, aliás, entre os historiadores anteriores. A "história tradicional", tal como representada contemporaneamente, não é muito mais do que um lugar-comum. Neste sentido, sua caracterização usual contribui pouco para a compreensão das razões de certas opções historiográficas. Mais preocupante: ao fixar, para os estudos históricos, uma linha evolutiva, faz parecer que apenas as discussões e escolhas mais recentes merecem ser levadas em conta em nossas reflexões cotidianas. E não seria contra a visão de um tempo linear, vazio e homogêneo que gostaria de se erguer também a "nova geração"?

Do ponto de vista do ofício do historiador, que exige atenção às complexidades daquilo que é estudado, não é menos inadequado tratar em bloco (mesmo que implicitamente) uma produção historiográfica que recobre quase um século (se levarmos em conta a idéia de ruptura em fins da década de 1980). Estilos, visões, abordagens, períodos e temas preferencialmente estudados mudaram - de historiador para historiador, também em variados graus. Se Lucas Boiteux, Oswaldo Cabral e Walter Piazza podem ser aproximados por muitas razões (as obras de "história geral" sobre Santa Catarina e seu viés didático, por exemplo, ou a sua farta produção), distanciam-se de outras tantas maneiras: na escrita, nas influências recebidas, na consistência das pesquisas, na força dos argumentos. Pense-se em Oswaldo Cabral e Carlos da Costa Pereira, historiadores que compartilharam experiências e amizade: um, quase o negativo do outro, se levado em conta o volume da produção. Costa Pereira, signo da concisão e precisão, tinha o costume de revisitar velhas polêmicas históricas para tentar reencaminhá-las, corrigi-las, como se concebesse o historiador antes de tudo como revisor. E as imagens se desdobram: em Cabral, o historiador-cronista, em Lucas Boiteux, o historiador-escavador.

Cabe ainda indicar aquilo que, por parecer evidente, talvez seja mais facilmente esquecido: o mesmo historiador, em sua trajetória, pode conhecer diferentes fases, e as motivações que fizeram com que escrevesse certos trabalhos podem também significar 
flutuações ou mudanças expressivas em sua obra. Convém dar aos historiadores, como apontou Joana Pedro, o direito à temporalidade, o direito à historicidade.

Embora a indicação de uma dimensão patriótica na história construída pelo IHGSC não seja propriamente original, entendi que deveria ser posta em relevo, por estabelecer um elo fundamental entre os inúmeros trabalhos ligados à entidade. E é preciso lembrar que esses historiadores foram (e talvez ainda sejam), antes de tudo, homens de ação inclusive em decorrência de seu devotamento à "pequena pátria".

"Homens de ação", "homens de letras" - as mulheres começaram a inscrever-se na história da historiografia em Santa Catarina há poucas décadas (eis aí uma das vertentes de investigação que emergiram do processo de pesquisa).

Mas o que fizeram, então, os "homens de ação"? Investigaram a história de Santa Catarina, e também forjaram instituições, aglutinaram pessoas em torno de projetos, coordenaram equipes, participaram da grande e da pequena política, engajaram-se em lutas de defesa do patrimônio cultural catarinense. E ocuparam-se de arquivos.

Com trajetória de institucionalização bastante acidentada, o Arquivo Público do Estado de Santa Catarina foi objeto das preocupações dos historiadores quando ainda era "Arquivo do Palácio" - documentos se perdiam, segundo eles, por descuido, por descaso, por desleixo. O que fazer? Na primeira metade do século XX, a saída parecia ser copiá-los, e divulgá-los através da Revista do IHGSC. Na década de 1980, as preocupações transformaram-se em ações capazes de alterar o estatuto do velho depósito, tornado espaço de pesquisa e de exercício da cidadania. A reestruturação do Arquivo Público do Estado, nos anos 1980, a criação de um Subsistema Estadual de Arquivos, a promoção dos encontros catarinenses de arquivos: todas essas ações, encaminhadas em grande medida por membros do IHGSC, contribuíram para colocar Santa Catarina no mapa da Arquivística brasileira.

Mas, se o campo historiográfico, em Santa Catarina, dá sinais de crescimento e consolidação, o mesmo não pode ser dito do campo arquivístico. Nas universidades, continua muito ligado à esfera da Biblioteconomia, inexistindo curso específico de graduação; os encontros catarinenses de arquivos, até 2004 realizados a cada dois anos, tiveram, mais recentemente, pouca participação de instituições arquivísticas catarinenses, principalmente no que se refere aos arquivos públicos municipais. Estes, aliás, continuam a ser poucos, e a onda de leis de criação dos anos 1980-1990 não foi renovada. 
Os percursos de instituições como os arquivos de Joinville, Blumenau, Itajaí e Florianópolis, e até mesmo do Arquivo Público do Estado, sugerem que a fragilidade do campo arquivístico tentou ser contrabalançada com uma aproximação em relação ao campo historiográfico. Os primeiros pós-graduados em História, em Santa Catarina (aqueles que realizaram suas defesas, junto ao Programa de Pós-Graduação em História da UFSC, entre fins da década de 1970 e inícios da de 1980) também se engajaram nos arquivos municipais: Sueli Petry, Nelma Baldin, Raquel S. Thiago, Maria Bernardete Ramos Flores. Com freqüência, porém, a presença dos historiadores nos arquivos tendeu a fortalecer apenas uma de suas vocações - a de locus de produção e disseminação do conhecimento histórico através da própria constituição dos acervos, de sua organização, de sua disseminação por meio de exposições, publicações e outras atividades de "difusão cultural".

Mas a valorização da história, nos arquivos, pode levar também ao privilegiamento de determinadas experiências históricas (como demonstram os arquivos municipais de Blumenau e Joinville), e não apenas pela força da vontade dos historiadores que eventualmente trabalhem nas instituições: o caso de Blumenau mostra o poder dos agentes sociais na produção e sustentação de memórias que lhes sejam caras. Mudanças vividas pelas instituições, quanto à história a ser valorizada, podem gerar verdadeiras "batalhas de memória" (como as recentemente anunciadas em Itajaí).

A especificidade dos arquivos públicos - que os aproxima, em alguma medida, da área de preservação do patrimônio cultural, mas não permite nela abarcá-los completamente faz pensar no papel dos historiadores. É certamente importante que ajam como historiadores, em instituições como essas. Se agirem percebendo-se também como cidadãos, em integração com as variadas demandas de acesso aos documentos e de transparência administrativa, contribuirão para articular, nos arquivos públicos, vocação político-administrativa e vocação para a pesquisa histórica, que são, em princípio, contemporaneamente, indissociáveis. 


\section{Referências}

\section{Documentos de arquivo gerados pelas próprias instituições}

Academia Catarinense de Letras (Florianópolis, SC).

Dossiês de acadêmicos: Carlos da Costa Pereira, Carlos Humberto P. Corrêa, Henrique Boiteux, Henrique Fontes, Iaponan Soares de Araújo, Jaldyr B..F. da Silva, Jali Meirinho, José A. Boiteux, José Johanny, Lucas Alexandre Boiteux, Oswaldo R. Cabral, Walter F. Piazza.

Arquivo Histórico Municipal Prof. José Ferreira da Silva (Blumenau, SC).

Relatórios anuais e parciais, entre 1983 e 1992 (com exceção de relatório de 1986, não localizado).

Arquivo Histórico Municipal Prof. Oswaldo Rodrigues Cabral (Florianópolis, SC).

Arquivo corrente (conjuntos documentais discriminados tal como identificados pela instituição):

Atas de reuniões do Colegiado da Secretaria de Administração - 2003/2004.

Circulares recebidas, 1997 e 1998.

Comunicação interna enviada - 2004.

Documentos recebidos, 1994-1996.

Membros da CCAD/ Tabela de temporalidade - 1999.

Ofícios enviados - 2002; 2003.

Ofícios expedidos - 1995.

Ofícios expedidos - 1995; 1999; 2001/2002.

Ofícios expedidos - 1998 (para o Secretário da Administração).

Ofícios recebidos - 1998.

Ofícios recebidos - diversos - 1999.

Ofícios recebidos/expedidos - 1997.

Outros documentos de funcionários - vários anos.

Arquivo Público do Estado de Santa Catarina (Florianópolis, SC).

Ata da conferência de Frederico Michel Litto. [Florianópolis], 20 de setembro de 1984; documento manuscrito. Acervo do Arquivo Público do Estado de Santa Catarina, Fundo Arquivo Público, G IV, SG IV.1, 60-1984-1996, s.7. f.21.

Ata do Painel realizado durante o segundo encontro de arquivos catarinenses. Florianópolis, 19 de setembro de 1986; documento datilografado. Acervo do Arquivo Público do Estado de Santa Catarina, Fundo Arquivo Público, GIV, SG IV.1, 60-1984-1996, s.7. 
Relatório do relator do segundo dia de sessões do I Encontro Catarinense de Arquivos (relator identificado, a lápis, como o Prof. Jali Meirinho). [Florianópolis], 21 de setembro de 1984; datilografado. Acervo do Arquivo Público do Estado de Santa Catarina, Fundo Arquivo Público, G IV, SG IV.1, 60-1984-1996, s.10.

Associação de Amigos do Arquivo Público do Estado de Santa Catarina (Florianópolis, SC).

Estatuto 2000. [Florianópolis]: [2001].

Centro de Documentação e Memória Histórica/Arquivo Municipal (Itajaí, SC).

Relatórios anuais de atividades da Fundação Genésio Miranda Lins, relativos aos anos de 1986 a 2004 (excetuados os de 1997 e 2000, não localizados).

\section{Museu Paulista}

Arquivo permanente, Fundo Museu Paulista, Grupo Direção e Administração, Subgrupo Comunicação e Intercâmbio*:

Bilhete de José Boiteux a Afonso de Taunay, encaminhando bandeira do movimento do Contestado. Florianópolis, 5 de abril de 1926.

Carta de Afonso de Taunay a Lucas Boiteux. 24 de fevereiro de 1931.

Carta de Afonso de Taunay ao desembargador Boiteux. 13 de maio de 1932.

* Agradeço a Karine Anhezini pela colaboração, enviando cópia digital de material consultado durante suas pesquisas.

\section{Instrumentos de pesquisa (publicados) e prospectos de divulgação de instituições arquivísticas catarinenses}

GOVERNO DO ESTADO DE SANTA CATARINA. Secretaria de Estado da Administração. Diretoria de Administração Patrimonial e Documentação. Gerência do Arquivo Público do Estado. Regulamento de Consulta - Setor de Pesquisa e Consulta. Florianópolis: 2000. Folder.

QUINTEIRO, Suely Veiga (org.). Catálogo de conjuntos documentais do município de Florianópolis (Câmara de Desterro; Cemitérios Públicos). Florianópolis: Arquivo Histórico do Município de Florianópolis, 2004.

SOARES, Ana Maria, NUNES, Neusa Rosane Damiani. Catálogo dos instrumentos de pesquisa [do Arquivo Público do Estado de Santa Catarina]. Florianópolis: Gerência do Arquivo Público do Estado, 2000.

TERTITCHNIJ, Maria Tereza, NUNES, Neusa Rosane D.(orgs.). Guia dos arquivos municipais de Santa Catarina. Florianópolis: Arquivo Público do Estado de Santa Catarina, 1992. 
Publicações periódicas de instituições arquivísticas catarinenses relativas à sua atuação e ao seu acervo

Arquivo Histórico Municipal de Joinville - AHMJ / Arquivo Histórico de Joinville - AHJ: Joinville (SC), out.1983-dez. 1988.

Blumenau em Cadernos, [Arquivo Histórico José Ferreira da Silva/Fundação Cultural de Blumenau], Blumenau (SC) - 1958-1962; 1973-1974, 1987.*

Boletim do Arquivo Histórico de Joinville - AHMJ, Joinville (SC), mar.1990- jun.1996.

Boletim informativo [Arquivo Público do Estado de Santa Catarina / Associação de Amigos do Arquivo Público do Estado de Santa Catarina], Florianópolis, 1993-2005.

Boletim informativo do Arquivo Histórico Municipal de Florianópolis. Florianópolis, jul-set. 2005.

Revista Ágora - Revista da Associação de Amigos do Arquivo Público do Estado de Santa Catarina, Florianópolis, 1985-2004.

*assumida pela Prefeitura, através da Fundação Cultural, a partir de 1974.

Anais, programas e cadernos de resumos de encontros de arquivos em Santa Catarina

Arquivos \& Documentos em Santa Catarina [Anais do I Encontro de Arquivos Catarinenses Florianópolis, 20 a 21 de setembro de 1984]. Florianópolis: IOESC, 1985. (Coleção José Gonçalves dos Santos Silva, 1) 127p.

PIAZZA, Walter F. (org.). Anais do III Encontro de Arquivos Catarinenses/I Painel de Arquivos Sul-Brasileiros - 15 e 16 de setembro de 1988. Florianópolis: Arquivo Público do Estado de Santa Catarina, CNPq, 1988. 125p.

Anais do IV Encontro de Arquivos Catarinense/II Painel de Arquivos Sul-Brasileiro - Joaçaba, 3 a 5 de julho de 1990. Florianópolis: Secretaria de Estado da Administração/Arquivo Público do Estado de Santa Catarina, 1990. 84p.

Anais do $5^{\circ}$. Encontro Catarinense de Arquivos - Itajaí, 23 a 25 de setembro de 1992. Florianópolis: Fundação Catarinense de Cultura, Arquivo Público do Estado de Santa Catarina, Associação de Amigos do Arquivo Público do Estado de Santa Catarina, 1994.

Anais do VI, VII e VIII Encontro Catarinense de Arquivos - Blumenau [1994], Florianópolis [1996], Jaraguá do Sul [1998]. Florianópolis: Secretaria de Estado da Administração/Gerência do Arquivo Público do Estado de Santa Catarina, Associação de Amigos do Arquivo Público do Estado de Santa Catarina, 2000.

Caderno de resumos do IX Encontro Catarinense de Arquivos e IV Painel de Arquivos Municipais - 6 a 8 de novembro de 2000. Blumenau (SC): 2000.

Caderno de resumos do X Encontro Catarinense de Arquivos e V Painel de Arquivos Municipais - 2 a 4 de setembro de 2002. Florianópolis: 2002. p.26-27.

Programa do XI Encontro Catarinense de Arquivos - 13 a 15 de setembro de 2004. [2004]. Folder. 
Publicações periódicas na forma de anuários ou almanaques

Annuario catharinense para 1904, com a biographia do almirante José Marques Guimarães - 10. anno. Florianópolis: Typ. da Livraria Moderna de Paschoal Simone, [1904].

Annuario de Santa Catharina para 1901- segundo anno. Florianópolis: Typographia do Gabinete Sul-Americano.

Anuário Catarinense. [Florianópolis], 1948-1956.

Anuário de Itajaí [Fundação Genésio Miranda Lins]. Itajaí (SC), 1998-2004.

Publicações periódicas catarinenses na área de História

Archivo Catharinense - revista mensal illustrada, Rio de Janeiro, n.1-6, 1908.

Cadernos de Joinville - boletim informativo do Círculo Joinvilense de Pesquisas Históricas. Joinville (SC), n.4/5, abril de 1964.

Revista Catarinense de História. Florianópolis, 1990-2006. [a partir de 1999, denominada "Fronteiras: Revista Catarinense de História"]

Revista Catharinense, Laguna (SC), 1911-1912, 1912-1913, 1914.

Revista Trimensal do Instituto Historico e Geographico de Santa Catharina/ Revista do Instituto Histórico e Geográfico de Santa Catarina, Florianópolis, 1902, 1913-1920, 1943-1944, 1979-2004.

Anais de encontros na área de História realizados em Santa Catarina

Anais do I Encontro Estadual de História - Florianópolis, 1986. Florianópolis: Imprensa Universitária, 1987. 226p.

Anais do III Encontro Estadual de História - Florianópolis, 1990. Florianópolis: Imprensa Universitária, 1990. 173p.

Dissertações e teses sobre Santa Catarina produzidas no âmbito de Programas de PósGraduação em História

As dissertações e teses consultadas foram discriminadas no Apêndice I-1 (última coluna à direita, indicação “cs"). 
Estudos sobre a história e sobre historiadores de Santa Catarina (excetuadas as dissertações e teses em História)

ARAÚJO, Camilo Buss. A sociedade sem exclusão do padre Vilson Groh: a construção dos movimentos sociais na comunidade do Mont Serrat. Florianópolis: Insular, 2004.

BOITEUX, Lucas Alexandre. Figuras do passado catarinense: o capitão-mór Domingos de Brito Peixoto, senhor da Laguna - sua prole e seus serviços. Florianópolis: 1954.

Moderna, [1912].

Notas para a história catharinense. Florianópolis: Typ. a vapor da Livraria Paulistas em Santa Catharina seiscentista - Dias Velho, o colonizador. Annaes do Museu Paulista, São Paulo, tomo IV, 1931, p.429-479.

Pequena historia catharinense (adoptada oficialmente). Florianópolis: Officinas a elect. da "Imprensa Official", 1920.

BRANCHER, Ana (org.). História de Santa Catarina: estudos contemporâneos. Florianópolis: Letras Contemporâneas, 1999.

BRANCHER, Ana, AREND, Sílvia Maria Fávero (orgs). História de Santa Catarina no século XIX. Florianópolis: Editora da UFSC, 2001.

BRANCHER, Ana; AREND, Sílvia Maria Fávero (orgs.). História de Santa Catarina: séculos XVI a XIX. Florianópolis: Ed da UFSC, 2004.

CABRAL, Oswaldo R. A História da Política em Santa Catarina durante o Império. Florianópolis: Ed. da UFSC, Assembléia Legislativa do Estado de Santa Catarina, 2004. 4v.

A vitória da colonização açoriana em Santa Catarina (Separata da revista

"Cultura Política", do Rio de Janeiro). Florianópolis: Imprensa Oficial do Estado, [1941].

História de Santa Catarina. 4 ed. Florianópolis: Lunardelli, 1994.

Introdução: Carlos da Costa Pereira; sua vida - sua obra. In: PEREIRA, Carlos da

Costa. A Revolução Federalista de 1893 em Santa Catarina. Florianópolis: Governo do Estado de Santa Catarina, 1976. p.5-24.

Nossa Senhora do Desterro: notícia. Florianópolis: Lunardelli, 1979. v.1.

Os açorianos (Separata do volume II dos Anais do I Congresso de História Catarinense). Florianópolis: Imprensa Oficial, 1950.

Santa Catharina (História - Evolução). São Paulo: Companhia Editora Nacional, 1937. (Brasiliana - Biblioteca Pedagógica Brasileira, 80).

CABRAL, Oswaldo R. et al. Povo e tradição em Santa Catarina. Florianópolis: EDEME, [1971]. (Realidade Catarinense)

CARDOSO, Fernando Henrique. Negros em Florianópolis: relações sociais e econômicas. Florianópolis: Insular, 2000.

CORREAA, Carlos Humberto P. Diálogo com Clio: ensaios de história política e cultural. Florianópolis: Insular, 2003.

História da cultura catarinense - v. 1: O Estado e as Idéias. Florianópolis: Editora da UFSC, Diário Catarinense, 1997. 
Lições de política e cultura: a Academia Catarinense de Letras, sua criação e relações com o poder. Florianópolis: Edições ACL, 1996.

Um Estado entre duas Repúblicas: a Revolução de 30 e a política de Santa Catarina até 35. Florianópolis: Editora da UFSC, Assembléia do Estado de Santa Catarina, 1984.

DALLABRIDA, Norberto. A historiografia catarinense e a obra de Américo da Costa Souto. Revista Catarinense de História, Florianópolis, n.4, 1996, p.9-19.

FALCÃO, Luiz Felipe. Entre ontem e amanhã: diferença cultural, tensões sociais e separatismo em Santa Catarina no século XX. Itajaí (SC): Editora da UNIVALI, 2000.

FÁVERI, Marlene de. Memórias de uma (outra) guerra: cotidiano e medo durante a Segunda Guerra em Santa Catarina. Florianópolis: Ed. da UFSC, Itajaí (SC): Ed. da UNIVALI, 2004.

FERREIRA, Cristina, FRÓTSCHER, Méri (orgs.). Visões do Vale: perspectivas historiográficas recentes. Blumenau (SC): Nova Letra, 2000.

FLORES, Maria Bernardete Ramos. A farra do boi: palavras, sentidos, ficções. Florianópolis: Ed. da UFSC, 1997.

da UFSC, 2004.

Os espanhóis conquistam a Ilha de Santa Catarina - 1777. Florianópolis: Ed.

FLORES, Maria Bernardete Ramos, et al. (orgs.). A casa do baile: estética e modernidade em Santa Catarina. Florianópolis: Fundação Boiteux, 2006.

HERKENHOFF, Elly. Joinville - nosso teatro amador (1858-1938). Joinville (SC): Arquivo Histórico de Joinville, 1989.

JAMUNDÁ, Theobaldo Costa. Catarinenses ilustres. In: História de Santa Catarina. Curitiba: Grafipar, 1970. v. 2.

Catarinensismos. Florianópolis: UDESC, EDEME, 1974.

LEITE, Ilka B. (org.). Negros no sul do Brasil: invisibilidade e territorialidade. Florianópolis: Letras Contemporâneas, 1996.

MEIRINHO, Jali. República e oligarquias: subsídios para a história catarinense - 1889-1930. Florianópolis: Insular, 1997.

MORGA, Antonio (org.). História das mulheres de Santa Catarina. Florianópolis: Letras contemporâneas, Chapecó (SC): Argos, 2001.

PEDRO, Joana Maria (org.). Práticas proibidas: práticas costumeiras de aborto e infanticídio no século XX. Florianópolis: Cidade Futura, 2003.

PEDRO, Joana Maria, et al. Negro em terra de branco: escravidão e preconceito em Santa Catarina no século XIX. Porto Alegre: Mercado Aberto, 1988.

PELUSO JR., Victor A. A identidade catarinense. RIHGSC, Florianópolis, $3^{\mathrm{a}}$. fase, n.5, 1984, p.259280.

PEREIRA, Carlos da Costa. Minhas memórias. Florianópolis: Ed. da UFSC, FCC Edições, 1996.

PIAZZA, Walter F. Catarinensismo. In: Aspectos da vida e da obra de Lucas Alexandre Boiteux. Florianópolis: Conselho Estadual de Cultura, 1981. p.

PIAZZA, Walter F. Dois historiadores catarinenses: Afonso d'E. Taunay e Lucas A. Boiteux. RIHGSC, Florianópolis, $3^{\mathrm{a}}$. fase, n.6, 1985. p.

Elementos básicos da história catarinense. In: SILVA, Jaldyr B. Faustino da et al.

Fundamentos da cultura catarinense. Rio de Janeiro: Laudes, 1970. p.21-48. 
Florianópolis: Editora da UFSC, Lunardelli, 1983.

1981, p.57-75.

Historiografia de Santa Catarina. Revista do IHGSC, Florianópolis, $3^{\mathrm{a}}$. fase, n.3,

Instituto Histórico e Geográfico de Santa Catarina: estudo histórico-analítico (1896-1996). Florianópolis: Editora da UDESC, 1996.

O Instituto Histórico e a sua Revista. In: SOARES, Iaponan, PRAZERES, Lêda Maria d'Ávila da Silva (orgs.). Índice analítico da Revista do Instituto Histórico e Geográfico de Santa Catarina: 1902-1987. Florianópolis: IHGSC, 1988.

PÍTSICA, Paschoal A. Henrique Fontes: o historiador. RIHGSC, $3^{a}$. fase, n.6, 1985. p.85-93.

RAMPINELLI, Waldir José (org.). História e poder: a reprodução das elites em Santa Catarina. Florianópolis: Insular, 2003.

SACHET, Celestino. A literatura catarinense. Florianópolis: Lunardelli, 1985.

As transformações estético-literárias dos anos 20 em Santa Catarina. Florianópolis: UDESC, Edeme, 1974.

SERPA, Élio Cantalício. A identidade catarinense nos discursos do Instituto Histórico e Geográfico de Santa Catarina. Revista de Ciências Humanas, Florianópolis, v.14, n.20, 1996, p.63-79.

SEVERINO, José Roberto. Itajaí e a identidade açoriana: a maquiagem possível. Itajaí (SC): Editora da UNIVALI, 1999.

SILVA, Elizabeth Farias da. Ontogenia de uma universidade: a Universidade Federal de Santa Catarina (1962-1980). 291p. São Paulo, 2000. Tese (Doutorado em Educação) - Faculdade de Educação, USP.

SILVA, Jaldyr B. Faustino da, et al. Fundamentos da cultura catarinense. Rio de Janeiro: Laudes, 1970.

SILVA, José Ferreira da. História de Blumenau. 2 ed. Blumenau (SC): Fundação Casa Dr. Blumenau, 1988.

SOUZA, Sara Regina Silveira de. Oswaldo R. Cabral: páginas de um livro de memórias. Florianópolis: Ed. da UFSC, UDESC, 1993.

WOLFF, Cristina Scheibe. Historiografia catarinense: uma introdução ao debate. Revista Catarinense de História, Florianópolis, n.2, 1994, p.5-15.

Depoimentos orais concedidos por historiadores e profissionais de arquivo

Depoimentos de Antonio Dario Neves e Fábio Andreas Richter, em 11 de novembro de 2005. Local: Arquivo Histórico do Município Prof. Oswaldo Rodrigues Cabral, Florianópolis.

Depoimento de Carlos Humberto Pederneiras Corrêa, em 4 de novembro de 2005. Local: IHGSC, Florianópolis.

Depoimento de Jali Meirinho, em 10 de novembro de 2005.

Local: IHGSC, Florianópolis. 
Depoimento de Joana Maria Pedro, em 19 de abril de 2006.

Local: CFH - UFSC, Florianópolis.

Depoimento de José Bento Rosa da Silva, em 6 de outubro de 2005.

Local: Centro de Documentação e Memória História/Arquivo Municipal, Itajaí.

Depoimento de Maria Bernardete Ramos Flores, em 19 de abril de 2006.

Local: CFH - UFSC, Florianópolis.

Depoimento de Nelma Baldin, em 15 de novembro de 2005.

Local: residência da entrevistada, Florianópolis.

Depoimento de Neusa Rosane Damiani Nunes, em 15 de dezembro de 2005.

Local: Arquivo Público do Estado de Santa Catarina, Florianópolis.

Depoimento de Raquel S.Thiago, em 18 de novembro de 2005.

Local: UNIVILLE, Joinville.

Depoimento de Sueli Petry, em 17 de novembro de 2005.

Local: Arquivo Histórico Municipal Prof. José Ferreira da Silva, Florianópolis.

Mensagens, falas, discursos e relatórios referentes ao governo provincial ou estadual

Discurso pronunciado na abertura da Assembléa Legislativa da Província de Santa Catharina na segunda sessão ordinária da Segunda Legislatura Provincial, em 1839, pelo respectivo presidente, o brigadeiro João Carlos Pardal. Cidade do Desterro: Typ. Provincial, 1839.

Discurso pronunciado pelo presidente da província de Santa Catharina, o marechal de campo Francisco Jozé de Souza Soares d'Andrea, na sessão ordinária do anno de 1840 aberta no primeiro dia do mez de março. Cidade do Desterro: Typ. Provincial, 1840.

Falla com que o exm. sñr. Doutor João Rodrigues Chaves abriu a segunda sessão da vigésima segunda legislatura da Assembléa Provincial de Santa Catharina em 2 de fevereiro de 1881. Cidade do Desterro: Typ. e Lith. de Alex. Margarida, 1881. (anexo: "Trabalhos da Secretaria", datado de 31 de dezembro de 1880 e elaborado pelo secretário José Aureliano Cidade).

Falla com que o Exm. Sr. Dr. João Capistrano Bandeira de Mello Filho abrio a $1^{\mathrm{a}}$. sessão da $21^{\mathrm{a}}$. Legislatura da Assembléa Legislativa da Província de Santa Catharina em $1^{\circ}$. de março de 1876. Cidade do Desterro: Typ. de J.J. Lopes, 1876.

Falla com que o Exmo. Snr. Doutor João Rodrigues Chaves abriu a segunda sessão da vigesima segunda Legislatura da Assembléa Provincial de Santa Catharina, em 2 de fevereiro de 1881. Cidade do Desterro: Typ. E Lith de Alex Margarida, 1881.

Falla que o presidente da província de Santa Catharina, dr. João José Coutinho, dirigio á Assemblea Legislativa Provincial no acto da abertura de sua sessão ordinária em o $1^{\circ}$. de março de 1857. Rio de Janeiro: Typ. Imp. e Const. de J. Villeneuve e C., 1857.

Falla que o presidente da Província de Santa Catharina, o brigadeiro Antero Jozé Ferreira de Brito dirigio á Assembléa legislativa da mesma província na abertura da sua sessão ordinária em o 1․ de março de 1841. Cidade do Desterro: Typographia Provincial, 1841. 
Falla que o presidente da provincia de Santa Catharina, o marechal de campo graduado Antero Jozé Ferreira de Brito, dirigio á Assemblea Legislativa da mesma provincia na abertura da sua sessão ordinaria em o 1.o de março de 1842. Cidade de Desterro, Typ. Provincial, 1842.

Falla que o presidente da provincia de Santa Catharina, o marechal de campo Antero Jozé Ferreira de Brito, dirigio á Assemblea Legislativa da mesma provincia na abertura da sua sessão ordinaria, em o 1.o de março de 1843. Cidade do Desterro, Typ. Provincial, 1843.

Falla que o presidente da provincia de Santa Catharina, o marechal de campo Antero Jozé Ferreira de Brito, dirigio á Asssemblea Legislativa da mesma provincia na abertura da sua sessão ordinaria, em o $1^{\circ}$. de março de 1844. Cidade do Desterro, Typ. Provincial, 1844.

Mensagem apresentada á Assemblea Legislativa do Estado de Santa Catharina pelo cidadão tenente-coronel Elyseu Guilherme da Silva, $1^{\circ}$. Vice-presidente do Estado, em 7 de agosto de 1893. Desterro: Gabinete Sul-Americano, s.d.

Mensagem apresentada ao Congresso Representativo em 10 de agosto de 1899 pelo Dr. Felippe Schmidt, governador do Estado. Florianópolis: Typ. da Livraria Moderna, 1899.

Mensagem apresentada ao Congresso Representativo, em 14 de agosto de 1917, pelo Dr. Felippe Schmidt, Governador do Estado de Santa Catarina. S.l.p., s.c.p., s.d..

Mensagem apresentada ao Congresso Representativo, em 22 de julho de 1919, pelo Engenheiro Civil Hercílio Pedro da Luz, Vice-Governador, no exercício do cargo de Governador do Estado de Santa Catharina. S. 1. p., s.c.p., s.d.

Mensagem apresentada ao Congresso Representativo, em 22 de julho de 1921, pelo Engenheiro Civil Hercílio Pedro da Luz, Vice-Governador, no exercício do cargo de Governador do Estado de Santa Catharina. S. 1. p., s.c.p., s.d..

Mensagem lida pelo Exmo. Sr. Coronel Gustavo Richard, Governador do Estado, na 2a . Sessão da $7^{\text {a }}$. Legislatura do Congresso Representativo em 2 de agosto de 1908. Joinville (SC): Typ. Boehm, 1908.

Mensagens lidas na abertura do Congresso Constituinte a 28 de abril de 1891 e na abertura do Primeiro Congresso Legislativo a 29 de setembro de 1891. Desterro: Typ. do Jornal do Commercio, 1892.

Relatório apresentado á Assembléa Legislativa Provincial de Santa Catharina na $2^{\mathrm{a}}$. sessão de sua 26 . legislatura pelo presidente Francisco José da Rocha, em 11 de outubro de 1887. Rio de Janeiro: Typ. da União de A.M. Coelho da Rocha \& C., 1888.

Relatório com que o Exm. Snr. Doutor Theodoreto Carlos de Faria Souto abriu a sessão da vigessima quarta legislatura da Assembléa Provincial de Santa Catharina em 25 de março de 1883. Cidade do Desterro: Typographia do Caixeiro, 1883.

Relatório com que o Exm. Sr. Cônego Joaquim Eloy de Medeiros, $2^{\circ}$. Vice-presidente passou a administração da província ao Exm. Sr. Dr. Abdon Baptista, $1^{\circ}$. Vice-presidente, em 26 de junho de 1889. Desterro: Typographia da Republica, 1890.

Relatório com que o Exm. Sr. Dr. Joaquim Bandeira de Gouvêa passou a administração da província de Santa Catharina ao Exm. Sr. Dr. Guilherme Cordeiro Coelho Cintra, $\mathbf{1}^{\mathbf{c}}$. Vicepresidente da mesma, em 7 de janeiro de 1872. Cidade do Desterro: Typ. De J. J. Lopes, 1872.

Relatório da Secretaria do Interior e Justiça, referente ao exercício de 1961, apresentado pelo Secretário Paulo Macarini ao governador do Estado Celso Ramos. Florianópolis, março de 1962; datilografado. Acervo do Arquivo Público do Estado de Santa Catarina (Relatórios de órgãos diversos, I.J., r, 1961, 38-4, cx.114). 
Relatório do presidente da província de Santa Catharina Francisco Carlos de Araújo Brusque, apresentado á Assemblea Legislativa Provincial na $1^{a}$. sessão da 10 ${ }^{\text {a }}$. Legislatura. Rio de Janeiro: Typographia do Correio Mercantil, 1860.

Relatório do Presidente da Província de Santa Catharina o doutor Alexandre Rodrigues da Silva Chaves apresentado á Assemblea Legislativa Provincial na 2a ${ }^{\mathrm{a}}$. sessão da 12 ${ }^{\mathrm{a}}$. Legislatura em o $1^{\circ}$. de março de 1865. Santa Catharina: Typ. Catharinense de Ávila \& Rodrigues, 1865.

Relatório do presidente da província de Santa Catharina, José Mariano de Alburquerque, na abertura da 1a. Legislatura Provincial em 5 de abril de 1836. S.l.p., s.c.p., s.d.. p.1-2;

Relatório do Vice-Presidente da Província de Santa Catharina, o commendador Francisco José d'Oliveira, apresentado á Assembléa Legislativa Provincial na $1^{\mathrm{a}}$. Sessão da $\mathbf{1 2}^{\mathrm{a}}$. Legislatura. Santa Catharina: Typ. Catharinense de F.V.Avila \& C ${ }^{\mathrm{a}}$, 1864.

Relatórios referentes a governos municipais

Acervo do Arquivo Histórico Prof. José Ferreira da Silva (Blumenau):

Relatório apresentado por José Ferreira da Silva ao Prefeito Municipal [de Blumenau], Dr. Carlos Zadrozny, sobre os setores culturais do governo municipal, 20 de janeiro de 1966. Cópia carbono, datilografada. Acervo: Arquivo Histórico José Ferreira da Silva. s.p.

Relatório da gestão dos negócios administrativos do Município de Blumenau durante o ano de 1949, apresentado à Câmara Municipal pelo Prefeito Frederico Guilherme Busch Júnior. Blumenau (SC): Tipografia e Livraria Blumenauense, s.d..

Relatório dos negócios administrativos do Município de Blumenau referente ao ano de 1958, apresentado à Câmara Municipal pelo Prefeito Frederico Guilherme Busch Júnior. Blumenau (SC): Tipografia e Livraria Blumenauense, s.d..

Relatório dos negócios administrativos do Município de Blumenau, referente ao ano de 1950, apresentado à Câmara Municipal pelo Prefeito Frederico Guilherme Busch Júnior. S.l.p.: s.c.p..

Acervo da Biblioteca Pública do Estado de Santa Catarina (Florianópolis, SC):

Prefeito Helmut Fallgater presta contas de seus 5 anos de administração - 1961-1965. Joinville (SC): s.d. p.116.

\section{Legislação}

ASSOCIAÇÃO DOS ARQUIVISTAS BRASILEIROS. Arquivologia: textos e legislação. Rio de Janeiro: 1979.

Constituição do Estado de Santa Catarina de 1892. In: Collecção de leis do Estado de Santa Catharina - 1892. Florianópolis: Gab. Typ. d'O Dia, 1914.

Decreto estadual $\mathrm{n}^{\circ} .21$ de 19 de agosto de 1890. In: ESTADO DE SANTA CATHARINA. Decretos e resoluções de 17 de novembro de 1889 a 31 de dezembro de 1890. Florianópolis: Typ.; da Escola [de] Artífices, 1915. 
Decreto estadual $n^{\circ}$. 1.444, de 23 de março de 1988. In: SANTA CATARINA. Legislação estadual 1988. Florianópolis: Secretaria de Estado da Administração, Coordenadoria de Documentação e Publicações, 1989.

Decreto estadual $\mathrm{n}^{\circ}$. 1170, de 28 de setembro de 1918. In: ESTADO DE SANTA CATARINA. Collecção de leis, decretos e resoluções de 1918. Florianópolis: Officina da Imprensa Official, 1919.

Decreto Estadual $n^{\circ} .186$, de 28 de dezembro de 1931. In: ESTADO DE SANTA CATARINA. Colleção de decretos, resoluções e portarias de 1931. Florianópolis: Gab.Tip.Brasil, 1932.

Decreto estadual nº 225 de 28 de dezembro de 1898. In: Decretos e Actos de 1895 a 1899. Florianópolis: Officinas da Imprensa Official, 1919.

Decreto estadual n ${ }^{\circ} .228$ de 28 de dezembro de 1898. In: Decretos e Actos de 1895 a 1899. Florianópolis: Officinas da Imprensa Official, 1919.

Decreto estadual $n^{\circ} .232$ de 29 de dezembro de 1898. In: Decretos e Actos de 1895 a 1899. Florianópolis: Officinas da Imprensa Official, 1919.

Decreto estadual $n^{\circ} .242$ de 18 de abril de 1932. In: ESTADO DE SANTA CATARINA. Colleção de decretos, resoluções e portarias de 1932. Florianópolis: Livraria Central, 1933.

Decreto estadual $n^{\circ}$. 29.745, de 14 de maio de 1991. Revista do Arquivo Municipal, São Paulo, n. 199, 1991, p.153-158.

Decreto estadual $n^{\circ}$. 3.575, de 7 de outubro de 2005. Disponível em:<www.pge.sc.gov.br/Legislação>. Acesso em: 25 maio 2006.

Decreto estadual $\mathrm{n}^{\mathrm{o}}$. 3.585, de 7 de outubro de 2005. Disponível em: <www.pge.sc.gov.br/Legislação>. Acesso em: 25 maio 2006.

Decreto estadual $n^{\circ} .349$, de 10 de maio de 1933. In: ESTADO DE SANTA CATARINA. Colleção de decretos, resoluções e portarias de 1933. Florianópolis: Gab.Tip.Brasil, 1934.

Decreto estadual $n^{\circ} .83$, de 06 de março de 1931. In: ESTADO DE SANTA CATARINA. Colleção de decretos, resoluções e portarias de 1931. Florianópolis: Gab.Tip.Brasil, 1932.

Decreto estadual [São Paulo] nº.22.789, de 19 de outubro de 1984. In: Arquivo: boletim histórico e informativo, São Paulo, v. 5, n. 4, out-dez. 1984, p.133-139.

Decreto municipal [Blumenau] nº 221, de 20 jun. 1972. [Cópia eletrostática disponível no Arquivo Público do Estado de Santa Catarina].

Decreto municipal [Campos Novos] no $n^{\circ}$.443, de 12 de abril de 1989. [Cópia eletrostática disponível no Arquivo Público do Estado de Santa Catarina].

Decreto municipal [Concórdia] nº. 2.892, de 19 de dezembro de 1991. [Cópia eletrostática disponível no Arquivo Público do Estado de Santa Catarina].

Decreto municipal [Concórdia] nº 3.779, de 28 de novembro de 1996.*

Decreto municipal [Itajaí] $\mathrm{n}^{\circ}$. 1.543, de 27 de janeiro de 1977. [Cópia eletrostática disponível no Arquivo Público do Estado de Santa Catarina].

Decreto municipal [Itajaí] n ${ }^{\circ}$. 7.575, de 19 de julho de 2005. [Cópia eletrostática disponível no Centro de Documentação e Memória Histórica/Arquivo Municipal de Itajaí].

Decreto municipal [Joinville] nº. 5.994, de 14 de novembro de 1988. A Notícia, de Joinville, de 15 de novembro de 1988.

Decreto municipal [São Bento do Sul] n ${ }^{\circ}$. 246, de $1^{\circ}$. de abril de 1985. [Cópia eletrostática disponível no Arquivo Público do Estado de Santa Catarina]. 
Lei estadual $n{ }^{\circ} .445$ de 13 de outubro de 1899. In: Collecção das leis do Estado de S. Catharina promulgadas no anno de 1899. Florianópolis: Typ. da "República", s.d.

Lei estadual $\mathrm{n}^{\circ} .518$ de 4 de setembro de 1901. In: Collecção de leis de 1901. Florianópolis: [s.c.p.], 1920.

Lei estadual $n^{\circ} .109$ de 30 de outubro de 1893. In: In: Collecção das leis promulgadas em 1893. Desterro [sic]: Typ. da Republica, s.d.

Lei estadual n ${ }^{\circ} .112$, de 4 de outubro de 1894. In: Collecção de leis do Estado de Santa Catharina 1892. Florianópolis: Gab. Typ. d'O Dia, 1914.

Lei estadual $n^{\circ} .1196$, de 26 de setembro de 1918. In: Collecção de leis, decretos e resoluções de 1918. Florianópolis: Officina da Imprensa Official, 1919.

Lei estadual $\mathrm{n}^{\circ} .1235$ de 01 de novembro de 1918. In: Collecção de leis, decretos e resoluções de 1918. Florianópolis: Officina da Imprensa Official, 1919.

Lei estadual no. 328 de 23 de setembro de 1898. In: Colleção de leis do Estado de Santa Catharina promulgadas no anno de 1898. Florianópolis: gab. Typ. D’O Dia, 1913.

Lei federal $n^{\circ} .8 .159$, de 8 de janeiro de 1991. In: JARDIM, José Maria. Sistemas e políticas públicas de arquivos no Brasil. Niterói (RJ): EdUFF, 1995. p.183-188.

Lei municipal [Balneário Camboriú] $\mathrm{n}^{\circ}$. 1.293, de 29 de novembro de 1993. [Cópia eletrostática disponível no Arquivo Público do Estado de Santa Catarina].

Lei municipal [Biguaçu] ño. 714, de 22 de maio de 1992.*

Lei municipal [Blumenau] no . 1.835, de 7 de abril de 1972. [Cópia eletrostática disponível no Arquivo Público do Estado de Santa Catarina].

Lei municipal [Chapecó] no . 3.531, de 25 de junho de 1993.*

Lei municipal [Chapecó] n ${ }^{\circ}$. 3.536, de 10 de agosto de 1993.*

Lei municipal [Criciúma] nº 3.670, de 11 de setembro de 1998.*

Lei municipal [Florianópolis] nº 4.491, de 14 de setembro de 1994.*

Lei municipal [Ibirama] ${ }^{\circ}$. 2.031, de 18 de dezembro de 1998.*

Lei municipal [Itajaí] no ${ }^{\circ}$ 1.515, de 1 de dezembro de 1976. [Cópia eletrostática disponível no Arquivo Público do Estado de Santa Catarina].

Lei municipal [Itajaí] n ${ }^{\circ}$. 4.263, de 16 de março de 2005. [Cópia eletrostática disponível no Centro de Documentação e Memória Histórica/Arquivo Municipal de Itajaí].

Lei municipal [Itajaí] nº.3.343, de 27 de novembro de 1998. [Cópia eletrostática disponível no Centro de Documentação e Memória Histórica/Arquivo Municipal de Itajaí].

Lei municipal [Jaraguá do Sul] $n^{\circ}$. 1.464, de 10 de maio de 1991. [Cópia eletrostática disponível no Arquivo Público do Estado de Santa Catarina].

Lei municipal [Joinville] $\mathrm{n}^{\circ}$. 1.182, de 20 de março de 1972. [Cópia eletrostática disponível no Arquivo Público do Estado de Santa Catarina].

Lei municipal [Nova Erechim] nº. 890, de 10 de março de 1998.*

Lei municipal [Pinheiro Preto] nº. 623, de 20 de maio de 1992.*

Lei municipal [São José] nº. 2.436, de 10 de dezembro de 1992 .*

Lei municipal [Serra Alta] no. 314, de 25 de outubro de 1995.* 
Regulamento para a Secretaria de Estado dos Negocios do Interior e da Justiça. Florianópolis: Typ. da Livraria Moderna, 1899.

Regulamento para a Secretaria de Estado dos Negocios do Interior - 1900. Florianópolis: Typ. da "Republica", s.d..

Regulamento para a Secretaria Geral dos Negócios do Estado - 1902. Florianópolis: Gab. Typ. de M. Callado, s.d.

Regulamento que dá nova organisação á Secretaria da Presidência [datado de 2 de março de 1867]. [S.1.p., S.c.p., s.d.]. Acervo do Arquivo Público do Estado de Santa Catarina.

*Obs.: as leis sem referência de publicação foram obtidas no website www.leismunicipais.br (acesso entre maio de 2005 e junho de 2006)

\section{Noticiário de imprensa}

(excluídos os materiais contidos em dossiês de acadêmicos da Academia Catarinense de Letras)

A história sob um novo olhar. Diário Catarinense, Florianópolis, 9 nov. 2004 (capa do caderno "Variedades").

A Imprensa, a Política e os Partidos em SC [entrevista concedida por Oswaldo Rodrigues Cabral a Moacir Pereira, em 15 de setembro de 1976]. A Ponte, Florianópolis, maio de 1981 (1ª semana), p.5.

ANACLETO, Antônio. Historiadora recebe título. A Notícia, Joinville (SC), 29 de setembro de 1999.

ARGOLO, Carla. Limpeza no tesouro do passado. Diário Catarinense, Florianópolis, 19 de janeiro de 2006, caderno "Variedades", p.3.

Arquivo Histórico é reaberto. Diário Catarinense, Florianópolis, 21 de março de 2006.

Arquivo Público guarda três séculos de história de SC. Gestão em foco, Florianópolis, n.2, ago.2001, p.7.

Arquivo Público, ainda pobre, mas digno, atrai a pesquisa. O Estado, Florianópolis, 27 nov. 1983.

BIANCHINI, Fábio. Uma outra sede para a Academia. Diário Catarinense, Florianópolis, 20 out.2005.

BRANCHER, Ana; AREND, Sílvia Maria Fávero. Leviandade e ressentimento. Diário Catarinense, Florianópolis, 4 dez. 2004 (Caderno "Cultura", p.13).

CIA, André Luís. Arquivo Histórico reabre na segunda. A Notícia, Joinville (SC), 18 de março de 2006, caderno "Cidade".

Entrevista de Walter Piazza [concedida a Jeferson Lima]. A Notícia, Joinville (SC), 15 jan. 2004 (Anexo, capa).

GROTH, Marlise. Arquivo Histórico de Joinville fecha portas por quatro meses. A Notícia, Joinville (SC), 30 de agosto de 2004.

GROTH, Marlise. Livro resgata a vida dos pioneiros. A Notícia, Joinville (SC), 11 de junho de 2001).

GROTH, Marlise. Na enfermaria. A Notícia, Joinville (SC), 10 de agosto de 2003.

HERKENHOFF, João Baptista. Uma existência dedicada à imigração alemã. A Notícia, Joinville (SC), 23 de setembro de 2004.

História. Diário Catarinense, Florianópolis, 5 dez. 2005. 
LIMA, Jéferson. Mudança conturbada. A Notícia, Joinville (SC), 6 jun.2006.

MENEZES, Cacau. Interditado. Diário Catarinense, Florianópolis, 3 dez. 2005.

MOSIMANN, João Carlos. Academicismo e engodo. Diário Catarinense, Florianópolis, 20 nov. 2004 (Caderno "Cultura", p.15).

MOSIMANN, João Carlos. De polêmicas e medievais carapuças: uma tréplica a respeito de História de Santa Catarina - séculos XVI a XIX. Diário Catarinense, Florianópolis, 11 dez. 2004 (Caderno "Cultura", p.16).

MOSIMANN, João Carlos. O duplo assassinato de Dias Velho. Diário Catarinense, Florianópolis, 26 nov. 2005 (Caderno "Cultura", capa).

MOSIMANN, João Carlos. Uma história mal contada. Diário Catarinense, Florianópolis, 29 jan. 2005 (Caderno "Cultura").

Não foi bem assim: livro reúne ensaios de nova geração de historiadores. A Notícia, Joinville (SC), 3 maio 1999 (caderno "Anexo").

Nova geração de historiadores: grupo lança "História de Santa Catarina no século 19". A Notícia, Joinville (SC), 12 dez.2001 (caderno "Anexo").

Reaberto Arquivo Histórico de Joinville, após 4 anos. A Notícia, Joinville (SC), 21 de março de 2006, caderno "Geral".

S.THIAGO, Raquel. Um menino de dez anos. A Notícia, 27 de julho de 2001. Disponível em: $<$ http://www.an.com.br/2001/jul/27/0opi.htm> . Acesso em 8 de maio de 2004.

SILVA, João Francisco da. Uma testemunha da história e suas recordações. A Notícia, Joinville (SC), 2001.

TERNES, Apolinário. Walter F. Piazza, historiador [entrevista]. A Notícia, Joinville (SC), 25 nov. 1996, p.E2, (A Notícia Especial, "Grandes entrevistas").

WEBER, Betina. Morre, aos 98 anos, Elly Herkenhoff. A Notícia, Joinville (SC), 19 de setembro de 2004.

\section{Bibliografia complementar}

ABREU, João Capistrano de. Ensaios e estudos: Crítica e História (4 ${ }^{\mathrm{a}}$. série). Rio de Janeiro: Civilização Brasileira, Brasília: INL, 1976.

ABUD, Kátia Maria. O sangue intimorato e as nobilíssimas tradições: a construção de um símbolo paulista - o bandeirante. São Paulo, 1985. Tese (Doutorado em História). FFLCH-USP.

Álbum histórico do Centenário de Joinville. Joinville (SC): [Sociedade Amigos de Joinville], 1951.

AMIN, Esperidião, FONTANA, Victor. Carta dos Catarinenses: Santa Catarina - um compromisso com o futuro. [Florianópolis]: S.c.p., [1982].

ANHEZINI, Karina. Fundamentos da escrita da história de Afonso de Taunay ou como se escrevia a história nas primeiras décadas do século XX. In: ASSOCIAÇÃO Nacional de História - ANPUH, XXIII Simpósio Nacional de História - História: Guerra e Paz, 17 a 22 de julho de 2005 - Anais suplementares. Disponível em: <http://www.anpuh.uepg.br/xxiii-simposio/anais/textos/KARINA\% 20\%20ANHEZINI.pdf > Acesso em 20 de outubro de 2005. 
Museu Paulista e trocas intelectuais na escrita da História de Afonso de Taunay. Anais do Museu Paulista, São Paulo, N. Sér., v.10/11, 2002-2003, p.37-60.

Arquivo Público do Estado de Santa Catarina - 30 anos (1960-1980). Florianópolis: Secretaria de Estado da Administração, 1990.

ARRUDA, José Jobson A.; TENGARRINHA, José Manuel. Historiografia luso-brasileira contemporânea. Bauru (SP): EDUSC, 1999.

BARÇANTE, L.C. Qualidade Total: uma visão brasileira - o impacto estratégico na Universidade e na Empresa. Rio de Janeiro: Campus, 1998.

BELLOTTO, Heloísa L. Arquivos permanentes: tratamento documental. 2 ed. rev. ampl. Rio de Janeiro: Ed. FGV, 2004.

BELlOTTO, Heloísa L., CAMARGO, Ana Maria de Almeida (coord.). Dicionário de Terminologia Arquivística. São Paulo: AAB-SP, 1996.

BERNARDES, Ieda Pimenta. Como avaliar documentos de arquivo. São Paulo: Associação de Arquivistas Brasileiros - Núcleo Regional de São Paulo, Arquivo do Estado, 1998. (Projeto Como fazer, 1).

Boletim da Associação dos Amigos do Arquivo Público [do Paraná]. Curitiba, n.6, 2001. p.1.

BOURDIEU, Pierre. A economia das trocas lingüísticas: o que falar quer dizer. S.Paulo: EDUSP, 1998.

Os usos sociais da ciência: por uma sociologia clínica do campo científico. São Paulo: Ed. da UNESP, 2004.

BOUTIER, Jean, JULIA, Dominique (org.). Passados recompostos: cantos e canteiros da História. Rio de Janeiro: Ed. da UFRJ, Ed. FGV, 1998.

BREFE, Ana Cláudia Fonseca. O Museu Paulista: Affonso de Taunay e a memória nacional, 19171945. São Paulo: Ed. da UNESP, Museu Paulista, 2005.

BRESCIANI, Maria Stella. Cidade e história. In: OLIVEIRA, Lúcia Lippi (org.). Cidade: história e desafios. Rio de Janeiro: Editora FGV, 2002.

BURKE, Peter (org.). A escrita da História: novas perspectivas. S.Paulo: Editora da UNESP, 1992. (Biblioteca básica)

CAIRE-JABINET, Marie-Paule. Introdução à historiografia. Bauru (SC): Edusc, 2003.

CAMARGO, Ana Maria de Almeida. Arquivos municipais: problemas de jurisdição. Boletim do Centro de Memória UNICAMP, Campinas (SP), v.1, n.2, jul-dez. 1989. p.18-19.

Metropolitan Archives in Federative Countries: the Case of Brazil. In: ROBERTS, M.V. (ed.). Archives and the Metropolis. London: Corporation of London, Guildhall Library Publications, 1998. p.169-170.

O público e o privado: contribuição para o debate em torno da caracterização de

documentos e arquivos. Arquivo: boletim histórico e informativo, São Paulo, v,9, n.2, jul-dez. 1988, p.57-64.

CANDIDO, Antonio. O significado de Raízes do Brasil [datado de dezembro de 1967]. In: HOLANDA, Sérgio Buarque de. Raízes do Brasil. Rio de Janeiro: José Olympio, 1986.

CARDOSO, Ciro F.; VAINFAS, Ronaldo (orgs.). Domínios da História: ensaios de teoria e metodologia. Rio de Janeiro: Campus, 1997.

Cartas patrimoniais. Brasília: Ministério da Cultura, IPHAN, 1995. 
CARVAlHO, José Murilo de. A construção da ordem: a elite política imperial; Teatro de sombras: a política imperial. 2 ed. rev. Rio de Janeiro: Ed. da UFRJ, Relume-Dumará, 1996.

CASTILHO, Ataliba Teixeira de (org.). A sistematização de arquivos públicos. Campinas (SP): Editora da UNICAMP, 1991.

CATTANI, Antonio David (org.). Trabalho e tecnologia: dicionário crítico. 2 ed. Petrópolis: Vozes, Porto Alegre: Ed. da UFRGS, 1999.

COMBE, Sonia. Archives interdites: les peurs françaises face à l'Histoire contemporaine. Paris: Albin Michel, 1994.

COOK, Terry. Archival appraisal and collection: issues, challenges, new approaches [Special Lecture Series, University of Maryland and NARA Staff, 21-22 April 1999]. Disponível em: <http://www.mybestdocs.com/cookt-nara-990421-2.htm>. Acesso em: 24 de março de 2005.

Archival science and postmodernism: new formulations for the old concepts. Archival Science, Dordrecht, v.1, n.1, 2001, p.3-24.

Arquivos pessoais e arquivos institucionais: para um entendimento arquivístico comum da formação da memória em um mundo pós-moderno. Estudos Históricos, Rio de Janeiro, v.11, n.21, 1998, p.129-149.

What is past is prologue: a history of archival ideas since 1898, and the future paradigm shift. Archivaria, n.43, 1997. Disponível em: <http://www.mybestdocs.com/cooktpastprologue-ar43fnl.hm>. Acesso em: 24 jan. 2006.

COSTA, Célia Maria Leite, FRAIZ, Priscila Moraes V. Acesso à informação nos arquivos brasileiros. Estudos históricos, Rio de Janeiro, v.2, n.3, 1989, esp. p. 69-70.

COSTA, Célia. O Arquivo Público do Império: o legado absolutista na construção da nacionalidade. Estudos históricos, Rio de Janeiro, v.14, n.26, 2000.

DIAS, Maria Odila Leite da Silva. A interiorização da metrópole (1808-1853). In: MOTA, Carlos Guilherme (org.). 1822: dimensões. São Paulo: Perspectiva, 1972. p.160-184.

DIEHL, Astor Antônio. A cultura historiográfica brasileira nos anos 1980: experiências e horizontes. 2 ed. rev. ampl. Passo Fundo (RS): Universidade de Passo Fundo, 2004.

A cultura historiográfica brasileira: do IHGB aos anos 1930. Passo Fundo (RS): Universidade de Passo Fundo, 1998.

DUCHEIN, Michel. Les obstacles à l'accés, à l'utilisation et au transfert de l'information contenue dans les archives: une étude RAMP. Paris: UNESCO, 1983.

DURANTI, Luciana. Registros documentais contemporâneos como provas de ação. Estudos Históricos, Rio de Janeiro, v.7, n.13, 1994, p.49-64.

The impact of digital technology on archival science. Archival Science, Dordrecht, v.1, n.1, 2001, p.25-37.

ESPOSEL, José Pedro. Arquivos: uma questão de ordem. Niterói (RJ): Muiraquitã, 1994.

FARGE, Arlette. Le goût de l'archive. Paris: Éditions du Seuil, 1989. (La Librairie du XX $X^{\mathrm{e}}$ Siècle).

FEBVRE, Lucien. Honra e pátria. Rio de Janeiro: Civilização Brasileira, 1998.

FERREIRA, Antonio Celso. A epopéia bandeirante: letrados, instituições, invenção histórica (18701940). São Paulo: Ed. da UNESP, 2002. 
FICO, Carlos, POLITO, Ronald. A historiografia brasileira nos últimos 20 anos: tentativa de avaliação crítica. In: MALERBA, Jurandir (org.). A velha história: teoria, método e historiografia. Campinas (SP): Papirus, 1996. p.189-208.

FIORI, Neide Almeida; PETRY, Sueli Maria V. (orgs.). Índice da revista Blumenau em Cadernos 1957-1995: referências de autores e títulos. Blumenau (SC): Arquivo Histórico Prof. José Ferreira da Silva, Florianópolis: Editora da UFSC, 1996.

FONSECA, Maria Odila. Arquivologia e ciência da informação. Rio de Janeiro: Editora FGV, 2005. Informação, arquivos e instituições arquivísticas. Arquivo \& Administração, Rio de Janeiro, v.1, n.1, jan-jul.1998.

FONTES, Henrique da Silva. Pensamentos, palavras e obras: Primeiro caderno - Da Faculdade de Filosofia. Florianópolis: [Edição do Autor], 1960.

FRANCO, Celina do A.P. M. Uma proposta radical de trabalho. Revista do Patrimônio Histórico e Artístico Nacional, Rio de Janeiro, n.21, 1986, p.33-38.

FREYRE, Gilberto. O mundo que o português criou: aspectos das relações sociaes e de cultura do Brasil com Portugal e as colônias portuguesas. Pref. António Sérgio. Rio de Janeiro: José Olympio, 1940 (Documentos brasileiros, 28).

GALLAND, Bruno. Conserver pour l'histoire: une nouvelle dimension pour les Archives Nationales de France. [Convegno Archivi e storia nell'Europa del XIX secolo, Archivio di Stato di Firenze]. Disponível em: <http://www.archiviodistato.firenze.it/atti/aes/galland.pdf>. Acesso em: 8 out. 2005.

GARCIA CANCLINI, Nestor. Culturas híbridas: estratégias para entrar e sair da modernidade. São Paulo: EDUSP, 1997.

O patrimônio cultural e a construção imaginária do nacional. Revista do Patrimônio Histórico e Artístico Nacional, Rio de Janeiro, n.23, 1994, p.94-115.

GINZBURG, Carlo. Relações de força: história, retórica, prova. São Paulo: Companhia das Letras, 2002.

GOMES, Angela de Castro. História e historiadores: a política cultural do Estado Novo. Rio de Janeiro: Editora da Fundação Getúlio Vargas, 1996.

GRANDO, Sérgio (org.). Florianópolis de todos. Florianópolis: Insular, 2000.

GUIMARÃES, Manoel Luís Salgado. Nação e Civilização nos Trópicos: o Instituto Histórico e Geográfico Brasileiro e o projeto de uma história nacional. Estudos Históricos, Rio de Janeiro, n.1, 1988.

HALL, Stuart. A identidade cultural na pós-modernidade. 10 ed. Rio de Janeiro: DP\&A, 2005.

HARTOG, François. O século XIX e a História: o caso Fustel de Coulanges. Rio de Janeiro: Editora da UFRJ, 2003.

O tempo desorientado - Tempo e História: "Como escrever a história da França". Anos 90, Porto Alegre, n.7, jul.1997. p.

Seuil, 2003.

Regimes d'historicité: présentisme et experiénces du temps. Paris: Éditions du

HARVEY, David. Condição pós-moderna: uma pesquisa sobre as origens da mudança cultural. 8 ed. São Paulo: Loyola, 1999.

HUYSSEN, Andréas. Seduzidos pela memória: arquitetura, monumentos, mídia. Rio de Janeiro: Aeroplano, 2000. 
IGLÉSIAS, Francisco. Historiadores do Brasil: capítulos de historiografia brasileira. 2. impr. Rio de Janeiro: Nova Fronteira, Belo Horizonte: Ed. da UFMG, 2000.

n.2. José Honório Rodrigues e a historiografia brasileira. Acervo, Rio de Janeiro, v.2,

INDOLFO, Ana Celeste et al. Gestão de documentos: conceitos e procedimentos básicos. Rio de Janeiro: Arquivo Nacional, 1995.

JARDIM, José Maria, FONSECA, Maria Odila (orgs.). A formação do arquivista no Brasil: I Reunião Brasileira de Ensino de Arquivologia (REBRARQ). Niterói (RJ): EdUFF, 1999.

JARDIM, José Maria. As novas tecnologias da informação e o futuro dos arquivos. Estudos Históricos, Rio de Janeiro, v.5, n.1, p.251-60, 1992.

Instituições arquivísticas: estrutura e organização; a situação dos arquivos estaduais. Revista do Patrimônio Histórico e Artístico Nacional. Rio de Janeiro, n. 21, 1986, p.3942.

Sistemas e políticas públicas de arquivos no Brasil. Niterói (RJ): EdUFF, 1995.

Transparência e opacidade do Estado no Brasil: usos e desusos da informação governamental. Niterói (RJ): Editora da Universidade Federal Fluminense, 1999.

JEUDY, Henri-Pierre. Espelho das cidades. Rio de Janeiro: Casa da Palavra, 2005.

LE GOFF, Jacques (org.). A história nova. São Paulo: Martins Fontes, 1998.

História e memória. Campinas (SP): Editora da UNICAMP, 1996.

LODOLINI, Elio. Archivística: principios y problemas. Madrid: ANABAD, 1993.

LOWENTHAL, David. Como conhecemos o passado. Projeto História, S.Paulo, n.17, nov.1998, p.63-201. [tradução de capítulo do livro The past is a foreign country]

MACHADO, Helena Corrêa; CAMARGO, Ana Maria de Almeida. Roteiro para implantação de arquivos municipais. São Paulo: Porto Calendário, 1996.

MATTOS, Selma Rinaldi de. O Brasil em lições. Rio de Janeiro: Access, 2000.

MAUSS, Marcel. Sociologia e antropologia. São Paulo: Cosac \& Naify, 2003.

MELOT, Michel. Des archives considerées comme une substance hallucinogène. Traverses, Paris, v.36, janvier 1986, p.14-19.

MENESES, Ulpiano Toledo Bezerra de. Do teatro da memória ao laboratório da História: a exposição museológica e o conhecimento histórico. Anais do Museu Paulista, São Paulo, Nova Série, v.2, jan.dez.1994.

MENNE-HARITZ, Angelika. Access: the reformulation of an archival paradigm. Archival Science, Dordrecht, v.1, n.1, 2001, p.57-82.

MENNE-HARITZ, Angelika. Appraisal or documentation: can we appraise archives by selecting content? The American Archivist, Chicago, v.57, 1994, p.528-542

What can be achieved with archives? In: The concept of record: report from the Second Stockholm Conference on Archival Science and the Concept of Record, 30-31 May 1996. Stockholm: Riksarkivet, 1998. p.11-24.

MOTA, Carlos Guilherme (org.). Lucien Febvre: História. 2 ed. São Paulo: Ática, 1992.

NADER, Pedro Eduardo Portilho de. Histórias adversas: a confrontação entre a história dos Annales e a chamada história positivista. Revista USP, São Paulo, n.23, set.-nov.1994, p.63-67. 
NORA, Pierre. Entre memória e história: a problemática dos lugares. Projeto História, São Paulo, n.10, dez.1993. p. n.2-3, 2003, p.47-49.

Missions et enjeux des archives dans les sociétés contemporaines. Comma, Paris,

OHIRA, M. L. B., MARTINEZ, P. A. Acessibilidade aos documentos nos arquivos públicos municipais do Estado de Santa Catarina - Brasil. 1 ${ }^{\mathbf{0}}$. Integrar: Congresso Internacional de Arquivos, Bibliotecas, Centros de documentação e Museus: textos. São Paulo: Imprensa Oficial do Estado, 2002. p.

OSADA, Takashi. Housekeeping 5 S's: Seiri, Seiton, Seiso, Seiketsu, Shitsuke - cinco pontos-chave para o ambiente da Qualidade Total. São Paulo: IMAM, 1992.

PIAZZA, Walter F., SOARES, Iaponan. O Arquivo Público do Estado de Santa Catarina (fundos referentes ao Poder Legislativo Estadual). Memória da V Semana da História - 3 a 7 [de] outubro [de] 1983, campus de Franca. Franca (SP): Universidade Estadual Paulista, Instituto de História e Serviço Social, 1984. p.395-398.

PREFEITURA DO MUNICÍPIO DE SÃO PAULO. Secretaria Municipal de Cultura. Departamento do Patrimônio Histórico. O direito à memória: patrimônio histórico e cidadania. São Paulo: 1992.

RAGO, Margareth. A “nova” historiografia brasileira. Anos 90, Porto Alegre, n.11, jul. 1999, p.73-96.

Regulamento do Archivo Publico [11 de julho de 1855]. Boletim do Arquivo do Paraná. Curitiba, Ano 2, n.1, 1977.

REIS, José Carlos. A história, entre a filosofia e a ciência. 2 ed. São Paulo: Ática, 1999.

Resoluções da sessão plenária de encerramento do Congresso "Patrimônio Histórico e Cidadania - O direito à Memória", São Paulo, 16 de agosto de 1991. São Paulo: Secretaria Municipal de Cultura, Departamento do Patrimônio Histórico, 1991. p.3 (Resolução 15).

REVEL, Jacques. História e Ciências Sociais: o paradigma dos Annales. In: -. A invenção da sociedade. Lisboa: Difel, Rio de Janeiro: Bertrand Brasil, s.d. (Memória e sociedade). [1a. ed. em francês: 1989] p.13-41.

Revista USP, São Paulo, n.38, jun.-ago.1998 (Dossiê “Intérpretes do Brasil”)

RICARDO, Cassiano. O Estado Novo e o seu sentido bandeirante. Cultura Política, Rio de Janeiro, v.1, n.1, março de 1941.

ROUSSO, Henry. O arquivo ou o indício de uma falta. Estudos históricos, Rio de Janeiro, v.9, n.17, 1996, p.85-91.

SALGADO, Graça (coord.). Fiscais e meirinhos: a administração no Brasil Colonial. Rio de Janeiro: Nova Fronteira, Brasília, INL, 1985.

SCHWARCZ, Lilia M. O espetáculo das raças: cientistas, instituições e questão racial no Brasil, 1870-1930. São Paulo: Companhia das Letras, 1995.

SCHWARTZ, Joan M, COOK, Terry. Arquivos, documentos e poder: a construção da memória moderna. Registro, Indaiatuba (SP), n.3, jul.2004, p.18-33.

SILVA, Armando Malheiro da, et al. Arquivística: teoria e prática de uma ciência da informação v.1. Porto: Afrontamento, 1999.

SILVA, Rogério Forastieri da. História da historiografia: capítulos para uma história das histórias dahistoriografia. Bauru (SC): Edusc, 2001. 
SOARES, Iaponan. Arquivo Público do Estado de Santa Catarina (1983-1986): uma experiência de ação co-participativa. Anais da VII Reunião da Sociedade Brasileira de Pesquisa Histórica. São Paulo: 1988.

STEEDMAN, Carolyn. Dust: the archive and cultural history. New Brunswick: Rutgers University Press, 2002.

STEIN, Letícia L. K. História e lingüística de uma cidade [sobre Brusque]. Revista Voz das Letras [Universidade do Contestado], Concórdia (SC), n.2, $1^{\circ}$. sem. 2005. Disponível em: <http://www.nead.uncnet.br/2004/revistas/letras/2/4.pdf >. Acesso em: 12 fev. 2006.

UNIVERSIDADE FEDERAL DE SANTA CATARINA. Centro de Filosofia e Ciências Humanas. Departamento de História Programa de Pós-Graduação em História Catálogo de dissertações: área de concentração - História Cultural. Florianópolis: 1998.

VELA, Susanna. La organización de exposiciones. In: ALBERCH, Ramon et al. Archivos y cultura: manual de dinamización. Gijón (Espana): Trea, 2001. p.85.

ZOTZ, Werner; KAISER, Jakzam. Santa Catarina - retratos: gente e paisagens. Florianópolis: Letras brasileiras, 2004.

\section{Websites}

Website da "Enciclopédia Simpozio": <www.simpozio.ufsc.br/Port/1-enc/y-mega/RevFilosofia/ 7460y004.htm.> Acesso em: 16 jan. 2006.

Website da Associação Brasiliense de Arquivologia: <abarq.blospot.com>.. Acesso em: 19 maio 2006.

Website da Associação de Arquivistas da Bahia. Acesso em: <www.arquivistasbahia.org>. 19 maio 2006.

Website da Associação de Arquivistas de São Paulo: <www.arqsp.org.br>. Acesso em: 19 maio 2006.

Website da Associação de Arquivistas do Estado do Rio de Janeiro. <www.aaerj.org.br>. Acesso em: 19 maio 2006.

Website da Associação dos Arquivistas do Estado do Rio Grande do Sul: <www.aargs.com.br>. Acesso em: 19 maio 2006.

Website da Fundação Cultural de Blumenau: <www.fcblu.com.br/arquivo/arquivoh/indesx.asp.> Acesso entre ago.2005 e jun.2006.

Website da Fundação Genésio Miranda Lins:<fgml.itajai.sc.gov.br/noticiasp_det.php? id_noticia=3522>. Acesso entre ago.2005 e jun. 2006.

Website da Prefeitura Municipal de Florianópolis, página relativa ao Arquivo Histórico: <www.pmf.sc.gov.br/arquivo_historico $>$. Acesso entre out. 2005 e jun.2006.

Website do Instituto de Planejamento Urbano de Florianópolis//IPUF: <www.ipuf.sc.gov.br>. Acesso em: 13 ago. 2005.

Website do Instituto Histórico e Geográfico de Santa Catarina: <www.ihgsc.org.br/eméritos.htm>. Acesso entre set. 2005 e maio 2006v b.

Website: <www.cidadelages.com.br/cidade/pontos_turisticos.php>. Acesso em: 29 out. 2005. 


\section{Apêndices}

\section{Parte I}

Apêndice I-1: Dissertações de mestrado e teses de doutorado (em História) sobre Santa Catarina (1974-2005)

Apêndice I-2: Instituições em que foram defendidas dissertações e teses (em História) sobre Santa Catarina (1974-2005)

Apêndice I-3: Orientadores das dissertações e teses (em História) relativas a Santa Catarina defendidas na UFSC (1977-2005)

Apêndice I-4: Publicações em livro de dissertações de mestrado e teses de doutorado (em História) sobre Santa Catarina

\section{Parte II}

Apêndice II-1: Edições dos encontros catarinenses de arquivos

Apêndice II-2: Entidades promotoras e apoiadoras dos encontros catarinenses de arquivos

Apêndice II-3: Objetivos dos encontros catarinenses de arquivos

Apêndice II-4: Principais atividades dos encontros catarinenses de arquivos

Apêndice II-5: Participantes que integraram a programação dos encontros catarinenses de arquivos

Apêndice II-6: Proposições e recomendações dos encontros catarinenses de arquivos

Apêndice II-7: Diretores/ gerentes do Arquivo Público do Estado de Santa Catarina

Apêndice II-8: Associação de Amigos do Arquivo Público do Estado de Santa Catarina: pessoas que assumiram cargos na Diretoria e Conselhos Fiscal e Editorial (1985-2007)

Apêndice II-9: Artigos, manuais, instrumentos de pesquisa e documentos do acervo publicados na revista Ágora (por ordem de autor)

Apêndice II-10: Publicações do Arquivo Público do Estado de Santa Catarina e da Associação de Amigos do Arquivo Público

Apêndice II-11: Arquivo Público do Estado de Santa Catarina - exposições promovidas

Apêndice II-12: Arquivo Público do Estado de Santa Catarina - presença de representantes da instituição em eventos (1998-2005) 
Apêndice II-13: Arquivo Público do Estado de Santa Catarina - visitas de grupos/ turmas de estudantes (1998-2002)

Apêndice II-14: Arquivo Público do Estado de Santa Catarina - estatística de atendimento ao público (1998-2003)

\section{Parte III}

Apêndice III-1: Arquivo Histórico de Joinville: diretores, coordenadores e responsáveis. 
Apêndice I-1

Dissertações de mestrado e teses de doutorado (em História) sobre Santa Catarina (1974-2005)

\begin{tabular}{|c|c|c|c|c|c|c|}
\hline $\operatorname{Autor}(a)$ & Título & $\begin{array}{l}\text { Ano de } \\
\text { defesa }\end{array}$ & Modalidade & Instituição & Orientador $(a)$ & Obs \\
\hline BLASCHKE, Helga. & A Fundição Tupy S. A. - uma indústria pioneira em Santa Catarina & 1974 & Dissertação & UFPR & Cecília Maria Westphalen & cs. \\
\hline $\begin{array}{l}\text { EDUARDO, Rosemari } \\
\text { Pozzi. }\end{array}$ & A madeira em Santa Catarina & 1974 & Dissertação & UFPR & Cecília Maria Westphalen & cs. \\
\hline PELLIZZETTI, Beatriz. & $\begin{array}{l}\text { O Banco de Crédito Popular e Agrícola de Bella Aliança } \\
\text { na conjuntura da emancipação municipal de Rio do Sul, SC }\end{array}$ & 1974 & Dissertação & UFPR & Brasil Pinheiro Machado & cs. \\
\hline KROETZ, Lando Rogério & As estradas de ferro de Santa Catarina: $1910-1960$ & 1975 & Dissertação & UFPR & Cecília Maria Westphalen & cs. \\
\hline $\begin{array}{l}\text { ANDRADE, Djanira Maria } \\
\text { Martins de }\end{array}$ & $\begin{array}{l}\text { A influência da Ponte Hercílio Luz no desenvolvimento } \\
\text { da Ilha de Santa Catarina }\end{array}$ & 1978 & Dissertação & UFSC & Lawrence James Nielsen & cs. \\
\hline LOCH, Cenilde & $\begin{array}{l}\text { A ação colonizadora de Joaquim Caetano Pinto Júnior } \\
\text { e a Colônia Grão-Pará }\end{array}$ & 1978 & Dissertação & PUC-RS & Olívio Manfroi & \\
\hline $\begin{array}{l}\text { PIAZZA, Maria de Fátima } \\
\text { Fontes }\end{array}$ & A invasão espanhola na Ilha de Santa Catarina & 1978 & Dissertação & UnB & Amado Luiz Cervo & cs. \\
\hline ALMEIDA, Rufino Porfírio & $\begin{array}{c}\text { Um aspecto da economia de Santa Catarina - a indústria ervateira: } \\
\text { o estudo da Companhia Industrial }\end{array}$ & 1979 & Dissertação & UFSC & Roger Frank Colson & cs. \\
\hline BALDIN, Nelma & $\begin{array}{l}\text { A Intendência de Marinha de Santa Catarina e seu papel } \\
\text { na ocupação da Província Cisplatina (1817-1832) }\end{array}$ & 1979 & Dissertação & UFSC & Walter Fernando Piazza & cs. \\
\hline $\begin{array}{l}\text { BARRETO, Maria } \\
\text { Theresinha Sobierajski }\end{array}$ & $\begin{array}{c}\text { Os poloneses do Alto Vale do Rio Tijucas: um estudo de história } \\
\text { demográfica }(1880-1950)\end{array}$ & 1979 & Dissertação & UFSC & Marly Anna F. B. Mira & cs. \\
\hline $\begin{array}{l}\text { BARROS, Edy Álvares } \\
\text { Cabral de }\end{array}$ & $\begin{array}{l}\text { A freguesia de Nossa Senhora das Necessidades e Santo Antônio: } \\
\qquad 1841 \text { a } 1910 \text { - a sua transição demográfica }\end{array}$ & 1979 & Dissertação & UFSC & Lawrence James Nielsen & cs. \\
\hline BOSSLE, Ondina Pereira & Henrique Lage e o desenvolvimento sul-catarinense & 1979 & Dissertação & UFSC & Roger Frank Colson & cs. \\
\hline COLOMBI, Luiz Vendelino & $\begin{array}{c}\text { Industrialização de Blumenau: } \\
\text { o desenvolvimento da Gebrüder Hering, 1880-1915 }\end{array}$ & 1979 & Dissertação & UFSC & George Philip Browne & cs. \\
\hline $\begin{array}{l}\text { FLORES, Maria Bernardete } \\
\text { Ramos }\end{array}$ & História demográfica de Itajaí - uma população em transição, 1866-1930 & 1979 & Dissertação & UFSC & Marly Anna F. B. Mira & cs. \\
\hline HACK, Osvaldo Henrique & A história da Igreja Presbiteriana em Florianópolis, 1898-1930 & 1979 & Dissertação & UFSC & Lawrence James Nielsen & cs. \\
\hline $\begin{array}{l}\text { HILLESHEIM, Anselmo } \\
\text { Antonio }\end{array}$ & $\begin{array}{l}\text { O crescimento do mercado interno numa colônia do Império: } \\
\text { o caso de Blumenau, 1850-1880 }\end{array}$ & 1979 & Dissertação & UFSC & Roger Frank Colson & \\
\hline HÜBENER, Laura & $\begin{array}{l}\text { O movimento comercial do porto de Nossa Senhora do Desterro } \\
\text { no século XIX }\end{array}$ & 1979 & Dissertação & UFSC & Roger Frank Colson & cs. \\
\hline
\end{tabular}




\begin{tabular}{|c|c|c|c|c|c|c|}
\hline Autor(a) & Título & $\begin{array}{l}\text { Ano de } \\
\text { defesa }\end{array}$ & Modalidade & Instituição & Orientador(a) & Obs \\
\hline MARTINS, Valmir & $\begin{array}{l}\text { A contribuição do imigrante para o desenvolvimento das relações } \\
\text { capitalistas de produção no sul do Estado de Santa Catarina }\end{array}$ & 1979 & Dissertação & UFSC & Roger Frank Colson & cs. \\
\hline MEIRINHO, Jali & A república em Santa Catarina (1889-1900) & 1979 & Dissertação & UFSC & Walter Fernando Piazza & cs. \\
\hline MONTEIRO, Jaecyr & Nacionalização do ensino em Santa Catarina (1930-1940) & 1979 & Dissertação & UFSC & Errol Dean Jones & cs. \\
\hline PACHECO, Darcy & $\begin{array}{l}\text { Um estudo sobre a Junta da Real Fazenda de Santa Catarina, } \\
\text { período } 1817-1831\end{array}$ & 1979 & Dissertação & UFSC & George Philip Browne & cs. \\
\hline $\begin{array}{l}\text { PEDRO, Joana Maria/ } \\
\text { [Joana Maria Pedro } \\
\text { Machado] }\end{array}$ & $\begin{array}{l}\text { O desenvolvimento da construção naval em Itajaí, SC: } \\
\text { uma resposta ao mercado local - 1900-1950 }\end{array}$ & 1979 & Dissertação & UFSC & Roger Frank Colson & \\
\hline $\begin{array}{l}\text { PETRY, Sueli Maria } \\
\text { Vanzuita }\end{array}$ & Os clubes de caça e tiro em Blumenau & 1979 & Dissertação & UFSC & George Philip Browne & cs. \\
\hline PICK, Reinaldo João & $\begin{array}{l}\text { O Colégio Catarinense, um marco na história } \\
\text { da educação em Santa Catarina }\end{array}$ & 1979 & Dissertação & UFSC & Errol Dean Jones & cs. \\
\hline $\begin{array}{l}\text { SANTOS, Roselys Izabel } \\
\text { Corrêa dos }\end{array}$ & Colonização italiana no Vale do Itajaí-Mirim & 1979 & Dissertação & UFSC & Paulo Fernando Araújo Lago & cs. \\
\hline $\begin{array}{l}\text { VIEIRA, Amazile de } \\
\text { Hollanda }\end{array}$ & O Instituto Polytechnico no contexto sócio-cultural de Florianópolis & 1979 & Dissertação & UFSC & Paulo Fernando Araújo Lago & cs. \\
\hline $\begin{array}{l}\text { CZESNAT, Lígia de } \\
\text { Oliveira }\end{array}$ & $\begin{array}{l}\text { As estruturas das atividades comerciais da empresa } \\
\text { de Carl Hoepcke \& Cia. no contexto catarinense }\end{array}$ & 1980 & Dissertação & UFSC & Kendall Walker Brown & cs. \\
\hline FARIAS, Vilson Francisco & $\begin{array}{c}\text { A Freguesia da Enseada de Brito: } \\
\text { evolução histórica-demográfica de } 1778 \text { a } 1907\end{array}$ & 1980 & Dissertação & UFSC & Lawrence James Nielsen & cs. \\
\hline SCHAPPO, Vera Lúcia & $\begin{array}{l}\text { A contabilidade provincial: análise histórica dos orçamentos } \\
\text { da Província de Santa Catarina, } 1835-1889\end{array}$ & 1980 & Dissertação & UFPR & Carlos Roberto A. dos Santos & cs. \\
\hline $\begin{array}{l}\text { SENA, Walmor Bonifácio } \\
\text { de }\end{array}$ & $\begin{array}{c}\text { A política do cooperativismo de eletrificação rural em Santa Catarina: } \\
\text { o caso da Cooperativa de Eletrificação Rural em Santa Maria }\end{array}$ & 1980 & Dissertação & UFSC & Ernesto Aníbal Ruiz & cs. \\
\hline $\begin{array}{l}\text { SOUZA, Sara Regina } \\
\text { Silveira de }\end{array}$ & $\begin{array}{c}\text { A presença portuguesa na arquitetura da ilha de Santa Catarina, } \\
\text { séculos XVIII e XIX }\end{array}$ & 1980 & Dissertação & UFSC & Nereu do Vale Pereira & cs. \\
\hline $\begin{array}{l}\text { HEIDEMANN, Eugênia } \\
\text { Exterkoetter }\end{array}$ & O carvão em Santa Catarina: 1918-1954 & 1981 & Dissertação & UFPR & Cecília Maria Westphalen & cs. \\
\hline $\begin{array}{l}\text { PRATES, Arlete Maria } \\
\text { Maykot }\end{array}$ & $\begin{array}{l}\text { Atuação estatal no cooperativismo agrícola catarinense: } \\
\text { o caso da Cooperativa Regional Alfa (1957-1979) }\end{array}$ & 1981 & Dissertação & UFSC & Ernesto Aníbal Ruiz & cs. \\
\hline $\begin{array}{l}\text { SILVEIRA, Adélia dos } \\
\text { Santos }\end{array}$ & $\begin{array}{c}\text { Catálogo analítico descritivo dos jornais do Desterro (1850-1894): } \\
\text { o jornal como fonte histórica }\end{array}$ & 1981 & Dissertação & UFSC & Aníbal Abadie-Aicardi & cs. \\
\hline
\end{tabular}




\begin{tabular}{|c|c|c|c|c|c|c|}
\hline Autor (a) & Título & $\begin{array}{l}\text { Ano de } \\
\text { defesa }\end{array}$ & Modalidade & Instituição & Orientador $(a)$ & Obs \\
\hline $\begin{array}{l}\text { COELHO, Pedro Paulo } \\
\text { Waltrick }\end{array}$ & O desenvolvimento da pecuária bovina de Lages & 1982 & Dissertação & UFSC & Ernesto Aníbal Ruiz & cs. \\
\hline $\begin{array}{l}\text { CORRÊA, Carlos Humberto } \\
\text { Pederneiras }\end{array}$ & $\begin{array}{c}\text { Santa Catarina: um Estado entre duas repúblicas (a luta política num } \\
\text { período de mudanças ideológicas, 1930-1935) }\end{array}$ & 1982 & Tese & USP & $\begin{array}{l}\text { Antônia Fernanda Pacca de } \\
\text { Almeida Wright }\end{array}$ & cs. \\
\hline $\begin{array}{l}\text { CUNHA, Maria Teresa } \\
\text { Santos }\end{array}$ & $\begin{array}{c}\text { A contribuição historiográfica de Lucas Alexandre Boiteux no Jornal do } \\
\text { Commercio do Rio de Janeiro (1911-1957) }\end{array}$ & 1982 & Dissertação & UFSC & Aníbal Abadie-Aicardi & cs. \\
\hline BOPPRÉ, Maria Regina & $\begin{array}{l}\text { Regime eleitoral e realidade político-social no Império: o caso do } \\
\text { Altiplano Catarinense nas primeiras eleições diretas (1881-1889) }\end{array}$ & 1983 & Dissertação & UFSC & Carlos Humberto P. Corrêa & cs. \\
\hline $\begin{array}{l}\text { S. THIAGO, Eneida Raquel } \\
\text { de }\end{array}$ & $\begin{array}{l}\text { Um caso de liderança luso-brasileira na região de Joinville: } \\
\text { Abdon Baptista, 1884-1922 }\end{array}$ & 1983 & Dissertação & UFSC & Walter Fernando Piazza & cs. \\
\hline ALMEIDA, Rufino Porfírio & $\begin{array}{l}\text { A Empresa Comercial e Industrial Germano Stein S.A. (1883-1983): } \\
\text { estudo histórico-econômico-financeiro de uma empresa centenária }\end{array}$ & 1985 & Tese & USP & José Jobson de A. Arruda & cs. \\
\hline BOSSLE, Ondina Pereira & $\begin{array}{l}\text { A industrialização de Santa Catarina: um estudo } \\
\text { de história econômica regional (1880-1945) }\end{array}$ & 1985 & Tese & USP & $\begin{array}{l}\text { Antônia Fernanda Pacca de } \\
\text { Almeida Wright }\end{array}$ & cs. \\
\hline $\begin{array}{l}\text { DIAS, Maria de Fátima } \\
\text { Sabino }\end{array}$ & $\begin{array}{c}\text { Sindicalismo e Estado corporativista: } \\
\text { o caso do Sindicato dos Trabalhadores nas Indústrias de Fiação e } \\
\text { Tecelagem de Blumenau, 1941-1950 }\end{array}$ & 1985 & Dissertação & UFSC & Ernesto Aníbal Ruiz & cs. \\
\hline GOMES, Valter Manoel & Formas do pensamento historiográfico catarinense & 1985 & Dissertação & UFSC & Walter Fernando Piazza & cs. \\
\hline LAUS, Sônia Pereira & $\begin{array}{c}\text { A UDN em Santa Catarina: } \\
\text { uma oligarquia em luta pelo poder (1945-1960) }\end{array}$ & 1985 & Dissertação & UFSC & Carlos Humberto P. Corrêa & cs. \\
\hline $\begin{array}{l}\text { MORAES, Laura do } \\
\text { Nascimento Rótolo }\end{array}$ & $\begin{array}{c}\text { Catálogo analítico descritivo dos jornais de Florianópolis, } \\
\text { 1894-1914: o jornal como fonte histórica }\end{array}$ & 1985 & Dissertação & UFSC & Aníbal Abadie-Aicardi & cs. \\
\hline $\begin{array}{l}\text { RENAUX-HERING, Maria } \\
\text { Luiza }\end{array}$ & $\begin{array}{l}\text { A industrialização no Vale do Itajaí, 1880-1945: } \\
\text { contribuição ao estudo do modelo catarinense de desenvolvimento }\end{array}$ & 1985 & Tese & USP & Laima Mesgravis & cs. \\
\hline VEGINI, Edmundo & $\begin{array}{l}\text { A personalidade histórica de Crispim Mira e a regeneração nacional pela } \\
\text { ética germânica do trabalho, 1880-1927 }\end{array}$ & 1985 & Dissertação & UFSC & Aníbal Abadie-Aicardi & cs. \\
\hline COLAÇO, Thaís Luzia & O carnaval no Desterro - século XIX & 1988 & Dissertação & UFSC & Carlos Humberto P. Corrêa & cs. \\
\hline $\begin{array}{l}\text { CORREIA, Ana Maria } \\
\text { Martins Coelho }\end{array}$ & $\begin{array}{c}\text { A expansão da Igreja em Santa Catarina: a reação anti-clerical } \\
\text { e a questão do clero nacional (1892-1920) }\end{array}$ & 1988 & Dissertação & UFSC & Aníbal Abadie-Aicardi & cs. \\
\hline $\begin{array}{l}\text { MORAES, Maria Luíza de } \\
\text { Paiva Melo }\end{array}$ & $\begin{array}{l}\text { Atuação da firma Theodor Wille \& Cia. } \\
\text { no mercado cafeeiro do Brasil, 1844-1918 }\end{array}$ & 1988 & Tese & USP & Emanuel Soares de V. Garcia & \\
\hline ARAÚJO, Hermetes Reis & $\begin{array}{c}\text { A invenção do litoral: reformas urbanas e reajustamento social } \\
\text { em Florianópolis na Primeira República }\end{array}$ & 1989 & Dissertação & PUC-SP & Elias Thomé Saliba & cs. \\
\hline
\end{tabular}




\begin{tabular}{|c|c|c|c|c|c|c|}
\hline Autor(a) & Título & $\begin{array}{l}\text { Ano de } \\
\text { defesa }\end{array}$ & Modalidade & Instituição & Orientador(a) & Obs \\
\hline $\begin{array}{l}\text { MEDRANO, Lília Inês } \\
\text { Zanotti de }\end{array}$ & $\begin{array}{c}\text { Livre navegação dos rios Paraná e Uruguay: uma análise do comércio } \\
\text { entre o Império brasileiro e a Argentina, 1852-1889 }\end{array}$ & 1989 & Tese & USP & Emanuel Soares da V. Garcia & \\
\hline $\begin{array}{l}\text { RODERJAN, Roselys } \\
\text { Vellozo }\end{array}$ & $\begin{array}{l}\text { A formação de comunidades campeiras nos planaltos paranaenses } \\
\text { e sua expansão para o sul - séculos XVI a XIX }\end{array}$ & 1989 & Dissertação & UFSC & Carlos Humberto P. Corrêa & cs. \\
\hline SCHLICHTING, Aida Melo & $\begin{array}{c}\text { Catálogo analítico-descritivo dos jornais de Florianópolis } \\
\text { (1914-1930): o jornal como fonte histórica }\end{array}$ & 1989 & Dissertação & UFSC & Aníbal Abadie-Aicardi & cs. \\
\hline SERPA, Élio Cantalício & Igreja e catolicismo popular no planalto serrano catarinense, 1891-1930 & 1989 & Dissertação & UFSC & Rufino Porfírio Almeida & cs. \\
\hline $\begin{array}{l}\text { MASI, Marco Aurélio } \\
\text { Nadal de }\end{array}$ & $\begin{array}{c}\text { Escavações arqueológicas do Pe. João Alfredo Rohr. S.J.: } \\
\text { o assentamento da Armação do Sul, SC/Brasil }\end{array}$ & 1990 & Dissertação & UNISINOS & Pedro Ignácio Schmitz & \\
\hline $\begin{array}{l}\text { OLIVEIRA, Henrique Luiz } \\
\text { Pereira }\end{array}$ & $\begin{array}{l}\text { Os filhos da falha: assistência aos expostos } \\
\text { e remodelações das condutas em Desterro (1828-1887) }\end{array}$ & 1990 & Dissertação & PUC-SP & $\begin{array}{c}\text { Estefania Knotz Canguçu } \\
\text { Fraga } \\
\end{array}$ & cs. \\
\hline $\begin{array}{l}\text { PERARDT, Joaquim } \\
\text { Francisco }\end{array}$ & História demográfica de Angelina (1860/1950) & 1990 & Dissertação & UFSC & Marly Anna F. B. Mira & cs. \\
\hline VEIGA, Eliane Veras da & $\begin{array}{l}\text { Processo histórico de mutação da paisagem urbana } \\
\text { da área central de Florianópolis (1850-1930) }\end{array}$ & 1990 & Dissertação & UFSC & Aníbal Abadie-Aicardi & cs. \\
\hline BELLANI, Eli Maria & $\begin{array}{l}\text { Madeira, balsas e balseiros no rio Uruguai: } \\
\text { o processo de colonização do velho município de Chapecó, 1917-1950 }\end{array}$ & 1991 & Dissertação & UFSC & Rufino Porfírio Almeida & cs. \\
\hline CARDOSO, Maria Zilene & $\begin{array}{l}\text { Gaspar, século XIX: as dificuldades para o seu povoamento inicial } \\
\text { e a desmistificação de uma dependência }\end{array}$ & 1991 & Dissertação & UFSC & Carlos Humberto P. Corrêa & cs. \\
\hline $\begin{array}{l}\text { FLORES, Maria Bernardete } \\
\text { Ramos }\end{array}$ & $\begin{array}{c}\text { Teatros da vida, cenários da história: a Farra do Boi e outras festas na } \\
\text { Ilha de Santa Catarina - leitura e interpretação }\end{array}$ & 1991 & Tese & PUC-SP & Holien Gonçalves Bezerra & cs. \\
\hline JESUS, Samir Ribeiro de & $\begin{array}{l}\text { Formação do trabalhador catarinense: } \\
\text { o caso do caboclo do Planalto Serrano }\end{array}$ & 1991 & Dissertação & UFSC & Carlos Humberto P. Corrêa & cs. \\
\hline KLUG, João & $\begin{array}{c}\text { Consciência germânica e luteranismo na comunidade alemã de } \\
\text { Florianópolis (1868-1938) }\end{array}$ & 1991 & Dissertação & UFSC & Aníbal Abadie-Aicardi & cs. \\
\hline SCHMITZ, Sérgio & $\begin{array}{c}\text { Bancos privados públicos em Santa Catarina: a trajetória do BDE - } \\
\text { contribuição à história bancária catarinense }\end{array}$ & 1991 & Tese & USP & José Jobson de A. Arruda & cs. \\
\hline $\begin{array}{l}\text { SCHWAB, Aparecida } \\
\text { Beduschi }\end{array}$ & $\begin{array}{l}\text { O movimento operário: evolução do Sindicato dos Trabalhadores nas } \\
\text { Indústrias de Fiação e Tecelagem de Blumenau - 1950/1988 }\end{array}$ & 1991 & Dissertação & UFSC & Rufino Porfírio Almeida & cs. \\
\hline TEIXEIRA, Arilton & $\begin{array}{l}\text { Catálogo analítico-descritivo dos jornais lagunenses } \\
\text { (1864-1900) - o jornal como fonte histórica }\end{array}$ & 1991 & Dissertação & UFSC & Aníbal Abadie-Aicardi & cs. \\
\hline WOLFF, Cristina Scheibe & As mulheres da colônia de Blumenau: cotidiano e trabalho, 1850-1900 & 1991 & Dissertação & PUC-SP & Déa Ribeiro Fenelon & \\
\hline $\begin{array}{l}\text { BRANCHER, Helga Maria } \\
\text { Siviero }\end{array}$ & História sócio-econômica de Capinzal (SC), 1910-1980 & 1992 & Dissertação & PUC-RS & Dorivaldo Walmor Poletto & \\
\hline
\end{tabular}




\begin{tabular}{|c|c|c|c|c|c|c|}
\hline Autor $(a)$ & Título & $\begin{array}{l}\text { Ano de } \\
\text { defesa }\end{array}$ & Modalidade & Instituição & Orientador $(a)$ & Obs \\
\hline $\begin{array}{l}\text { CAMPOS, Cynthia } \\
\text { Machado }\end{array}$ & Controle e normatização das condutas em Santa Catarina (1930-1945) & 1992 & Dissertação & PUC-SP & Maria Antonieta M. Antonacci & cs. \\
\hline D’ACAMPORA, Márcia & $\begin{array}{l}\text { A construção da imagem do inimigo: o papel dos jornais durante a } \\
\text { Segunda Guerra Mundial em Florianópolis (1939-1945) }\end{array}$ & 1992 & Dissertação & UFSC & Ernesto Aníbal Ruiz & cs. \\
\hline FERNANDES, Maria Luiza & $\begin{array}{l}\text { Partidos e Sindicatos - um estudo de caso: o Sindicato dos Trabalhadores } \\
\text { na Indústria de Extração de Carvão de Criciúma }\end{array}$ & 1992 & Dissertação & UFSC & Rufino Porfírio Almeida & cs. \\
\hline $\begin{array}{l}\text { GALLO, Ivone Cecília } \\
\text { D'Avila }\end{array}$ & O Contestado: o sonho do milênio igualitário & 1992 & Dissertação & UNICAMP & Edgar Salvadori De Decca & \\
\hline $\begin{array}{l}\text { GUEDES, Sandra Paschoal } \\
\text { Leite de Camargo }\end{array}$ & O exercício da arte de curar: o Hospital São José de Joinville, 1852-1952 & 1992 & Tese & USP & Nanci Leonzo & cs. \\
\hline HEERDT, Moacir & As escolas paroquiais em Santa Catarina (1890-1930) & 1992 & Dissertação & UFSC & Rufino Porfírio Almeida & cs. \\
\hline PEDRO, Joana Maria & $\begin{array}{l}\text { Mulheres honestas, mulheres faladas: uma questão de classe - papéis } \\
\text { sociais femininos na sociedade de Desterro/Florianópolis }(1880-1920)\end{array}$ & 1992 & Tese & USP & Maria Odila L. da Silva Dias & cs. \\
\hline RAUH, Rachel Cavalcanti & $\begin{array}{l}\text { Blumenau em imagens: fotógrafos e fotografias como fonte do estudo da } \\
\text { história da colônia de Blumenau (1850-1930) }\end{array}$ & 1992 & Dissertação & UFSC & Ernesto Aníbal Ruiz & cs. \\
\hline $\begin{array}{l}\text { RIBAS, Janete Jane Goulart } \\
\text { Taborda }\end{array}$ & A instrução pública elementar na Província de Santa Catarina, 1834-1889 & 1992 & Dissertação & UFSC & Marly Anna F. B. Mira & cs. \\
\hline WERLANG, Alceu Antônio & $\begin{array}{c}\text { A colonização às margens do rio Uruguai no extremo oeste catarinense: } \\
\text { atuação da Cia. Territorial Sul Brasil (1925-1954) }\end{array}$ & 1992 & Dissertação & UFSC & Carlos Humberto P. Corrêa & cs. \\
\hline $\begin{array}{l}\text { ARECO, Neide de Souza } \\
\text { Moreira }\end{array}$ & O Instituto Maria Auxiliadora (1928-1992) & 1993 & Dissertação & UFSC & Rufino Porfírio Almeida & cs. \\
\hline $\begin{array}{l}\text { DALLA COSTA, Armando } \\
\text { João }\end{array}$ & $\begin{array}{l}\text { O grupo Sadia e a produção integrada: } \\
\text { o lugar do agricultor no complexo agroindustrial. }\end{array}$ & 1993 & Dissertação & UFPR & Lando Rogério Kroetz & cs. \\
\hline DALLABRIDA, Norberto & $\begin{array}{l}\text { À sombra do campanário: o catolicismo romanizado na área de } \\
\text { colonização italiana do Médio Vale do Itajaí-Açu (1892-1918) }\end{array}$ & 1993 & Dissertação & UFSC & Carlos Humberto P. Corrêa & cs. \\
\hline LAZZARINI, Sérgio & $\begin{array}{c}\text { História demográfica da paróquia de } \\
\text { São João Batista de Campos Novos (1876-1940) }\end{array}$ & 1993 & Dissertação & UFSC & Marly Anna F. B. Mira & cs. \\
\hline MEURER, Bellini & Entre flores e manguezais: a construção do real em Joinville / SC & 1993 & Dissertação & PUC-SP & Leda Maria Pereira Rodrigues & \\
\hline $\begin{array}{l}\text { NECKEL, Roselane } \\
\text { [Roselane Neckel Kupka] }\end{array}$ & Tensões e imagens do viver urbano em Florianópolis (1910-1930) & 1993 & Dissertação & PUC-SP & Maria Antonieta M. Antonacci & cs. \\
\hline $\begin{array}{l}\text { SANTOS, Nelvio Paulo } \\
\text { Dutra }\end{array}$ & $\begin{array}{c}\text { Trentinos em Santa Catarina: a evolução econômica } \\
\text { de Nova Trento (1875-1960) }\end{array}$ & 1993 & Dissertação & UFSC & Rufino Porfírio Almeida & cs. \\
\hline
\end{tabular}




\begin{tabular}{|c|c|c|c|c|c|c|}
\hline Autor $(a)$ & Título & $\begin{array}{l}\text { Ano de } \\
\text { defesa }\end{array}$ & Modalidade & Instituição & Orientador $(a)$ & Obs \\
\hline SERPA, Élio Cantalício & $\begin{array}{c}\text { Igreja, elites dirigentes e catolicismo popular em Desterro/Florianópolis, } \\
\text { Laguna e Lages (1889-1920) }\end{array}$ & 1993 & Tese & USP & Augustin Wernet & \\
\hline BAHIA, Eliana Maria & Perfil de José Arthur Boiteux, um construtor da cultura catarinense & 1994 & Dissertação & UFSC & Carlos Humberto P. Corrêa & cs. \\
\hline $\begin{array}{l}\text { CAMPOS, Marília } \\
\text { Hafermann Netto }\end{array}$ & $\begin{array}{l}\text { Marisol S.A.- Indústria do vestuário: sua evolução (1964-1992) - } \\
\text { estudo histórico-econômico-financeiro }\end{array}$ & 1994 & Dissertação & UFSC & Rufino Porfírio Almeida & cs. \\
\hline $\begin{array}{l}\text { CHEREM, Rosângela } \\
\text { Miranda }\end{array}$ & Caminhos para muitos possíveis: Desterro no final do Império & 1994 & Dissertação & USP & Maria de Lourdes M. Janotti & cs. \\
\hline DUTRA, Ricardo Aldo & $\begin{array}{c}\text { Florianópolis: a organização político-administrativa - } \\
\text { a Intendência Distrital (1889-1932) }\end{array}$ & 1994 & Dissertação & UFSC & Carlos Humberto P. Corrêa & cs. \\
\hline FERREIRA, Sérgio Luiz & O banho de mar na Ilha de Santa Catarina - 1900-1970 & 1994 & Dissertação & UFSC & Joana Maria Pedro & cs. \\
\hline GÜTLER, Antônio Carlos & $\begin{array}{c}\text { A colonização do Saí (1842-1844): esperança de falansterianos, } \\
\text { expectativa de um governo }\end{array}$ & 1994 & Dissertação & UFSC & Valberto Dirksen & cs. \\
\hline HEINSFELD, Adelar & $\begin{array}{l}\text { A formação das fronteiras entre o Brasil e a Argentina: a Questão de } \\
\text { Palmas e a colonização germânica no Baixo Vale do Rio do Peixe - SC } \\
(1913-1949)\end{array}$ & 1994 & Dissertação & PUC-RS & René E. Gertz & \\
\hline LAVINA, Rodrigo & $\begin{array}{c}\text { Os Xokleng de Santa Catarina: } \\
\text { uma etnohistória e sugestões para os arqueólogos }\end{array}$ & 1994 & Dissertação & UNISINOS & Pedro Ignácio Schmitz & \\
\hline LUZ, Sérgio Ribeiro da & Nossa Senhora da Lapa do Ribeirão da Ilha e sua população: 1810-1930 & 1994 & Dissertação & UFSC & Marly Anna F. B. Mira & cs. \\
\hline SILVA, José Bento Rosa da & $\begin{array}{c}\text { Festa de preto em terra de branco: } \\
\text { história oral, memória e identidade em Santa Catarina }\end{array}$ & 1994 & Dissertação & PUC-SP & Márcia B. Mansor D’Alessio & \\
\hline VIEIRA, Jaci Guilherme & $\begin{array}{c}\text { História do PCB em Santa Catarina: } \\
\text { da sua gênese até a Operação Barriga Verde (1922/1975) }\end{array}$ & 1994 & Dissertação & UFSC & Carlos Humberto P. Corrêa & cs. \\
\hline $\begin{array}{l}\text { AMARAL, Maria Madalena } \\
\text { Velho do }\end{array}$ & As oficinas líticas de polimentos da ilha de Santa Catarina & 1995 & Dissertação & PUC-RS & Klaus Hilbert & \\
\hline D’ÁVILA, Edison & $\begin{array}{c}\text { O público e o privado na Fundação do Ensino Superior } \\
\text { em Itajaí (1962-1970) }\end{array}$ & 1995 & Dissertação & UFSC & Valberto Dirksen & cs. \\
\hline MARQUES, Ana Maria & $\begin{array}{l}\text { Cotidiano e religião: a construção } \\
\text { de uma cultura religiosa em Nova Trento }\end{array}$ & 1995 & Dissertação & UFSC & Maria Bernardete R. Flores & cs. \\
\hline MORGA, Antonio Emílio & Práticas afetivas femininas em Nossa Senhora do Desterro no século XIX & 1995 & Dissertação & USP & Eni de Mesquita Samara & cs. \\
\hline RADIN, José Carlos & Ítalo-brasileiros em Joaçaba & 1995 & Dissertação & UFSC & Valberto Dirksen & cs. \\
\hline ROCHA, Sandra Vieira da & Presbiterianismo independente em Santa Catarina & 1995 & Dissertação & UFSC & Rufino Porfírio Almeida & cs. \\
\hline $\begin{array}{l}\text { SANTOS, Roselys Izabel } \\
\text { Corrêa dos }\end{array}$ & $\begin{array}{c}\text { Terra prometida: teses e antítese; os jornais do norte da Itália e a } \\
\text { emigração para o Brasil (1875-1899) }\end{array}$ & 1995 & Tese & USP & Maria Thereza S. Petrone & \\
\hline
\end{tabular}




\begin{tabular}{|c|c|c|c|c|c|c|}
\hline Autor(a) & Título & $\begin{array}{l}\text { Ano de } \\
\text { defesa }\end{array}$ & Modalidade & Instituição & Orientador(a) & Obs \\
\hline SIEBERT, Itamar & $\begin{array}{c}\text { Um biênio de provações e entusiasmos nas origens do jornalismo } \\
\text { catarinense }(1855-1856) \text { : } \\
\text { entre a polêmica política e o processo civilizador }\end{array}$ & 1995 & Dissertação & UFSC & Aníbal Abadie-Aicardi & cs. \\
\hline $\begin{array}{l}\text { ANDERMANN, Adriane } \\
\text { Schroeder }\end{array}$ & $\begin{array}{l}\text { Histórias de engenho - os engenhos de farinha de mandioca em } \\
\text { Florianópolis: economia, cuidados com a produção, imagens (1917-1920) }\end{array}$ & 1996 & Dissertação & UFSC & Fernando Dias de Ávila Pires & cs. \\
\hline $\begin{array}{l}\text { CAMPIGOTO, José } \\
\text { Adilçon }\end{array}$ & $\begin{array}{l}\text { Roças, empresas e sonhos: jogos e discursos } \\
\text { (a CPT em Santa Catarina) }\end{array}$ & 1996 & Dissertação & UFSC & Élio Cantalício Serpa & cs. \\
\hline COSTA, Iara Andrade. & A cidade da ordem: tensões sociais e controle - Joinville: 1917-1943 & 1996 & Dissertação & UFPR & Euclides Marchi & cs. \\
\hline FÁVERI, Marlene de & $\begin{array}{l}\text { Moços e moças para um bom partido: } \\
\text { a construção das elites - Itajaí, 1929-1960 }\end{array}$ & 1996 & Dissertação & UFSC & Joana Maria Pedro & cs. \\
\hline FREITAS, Dúnia Anjos de & O olhar do Historiador garimpando no léxico na prosa de Cruz e Souza & 1996 & Dissertação & UFPR & Ana Maria Burmester & cs. \\
\hline LEHMKUHL, Luciene & $\begin{array}{c}\text { Imagens além do círculo: o Grupo de Artistas Plásticos de Florianópolis e } \\
\text { a positivação de uma cultura nos anos } 50\end{array}$ & 1996 & Dissertação & UFSC & Maria Bernardete R. Flores & cs. \\
\hline $\begin{array}{l}\text { MATA, Maria Margarete } \\
\text { Sell da }\end{array}$ & Jornal O Estado: uma história em construção (1915-1931) & 1996 & Dissertação & UFSC & Valberto Dirksen & cs. \\
\hline PAIM, Elison Antonio & Fala professor(a): o ensino de História em Chapecó - 1970-1990 & 1996 & Dissertação & PUC-SP & Maria Antonieta M. Antonacci & \\
\hline PEREIRA, Ivonete & As decaídas: mulheres no cotidiano de Florianópolis (1900-1940) & 1996 & Dissertação & UFSC & Joana Maria Pedro & cs. \\
\hline SANTANNA, Mara Rúbia & O velho no espelho: um cidadão que envelheceu & 1996 & Dissertação & UFSC & Maria Bernardete R. Flores & cs. \\
\hline $\begin{array}{l}\text { SANTOS, Joaquim } \\
\text { Gonçalves dos }\end{array}$ & $\begin{array}{l}\text { A Freguesia de São Miguel da Terra Firme: } \\
\text { aspectos históricos e demográficos, 1750-1894 }\end{array}$ & 1996 & Dissertação & UFSC & Marly Anna F. B. Mira & cs. \\
\hline SILVA, Osvaldo Paulino da & Arqueologia dos engenhos da ilha de Santa Catarina - parte sul & 1996 & Dissertação & PUC-RS & Arno Alvarez Kern & \\
\hline SOUZA, Rogério Luiz de & $\begin{array}{l}\text { A construção de uma nova ordem: } \\
\text { catolicismo e ideal nacional em Santa Catarina (1930-1945) }\end{array}$ & 1996 & Dissertação & UFSC & Artur César Isaia & cs. \\
\hline $\begin{array}{l}\text { VALERIM, Vera Regina } \\
\text { Alves }\end{array}$ & $\begin{array}{l}\text { A cura das almas: padre João Reitz e a comunidade da paróquia de } \\
\text { Sombrio }(1938-1963)\end{array}$ & 1996 & Dissertação & UFSC & Carlos Humberto P. Corrêa & cs. \\
\hline VOIGT, Márcio Roberto & $\begin{array}{l}\text { Imigração e cultura alemã no Vale do Itajaí: educação, religião e } \\
\text { sociedade na história de Timbó/SC (1869-1939) }\end{array}$ & 1996 & Dissertação & UFSC & Valberto Dirksen & cs. \\
\hline ZIMMERMANN, Joseane & Ao sul, os desejos: a cidade transfigurada na poesia de Eglê Malheiros & 1996 & Dissertação & UFSC & Maria Bernardete R. Flores & cs. \\
\hline $\begin{array}{l}\text { BARRETO, Cristiane } \\
\text { Manique }\end{array}$ & $\begin{array}{l}\text { Entre laços e nós: formação e atuação das elites no Vale do Itajaí } \\
\qquad(1889-1930)\end{array}$ & 1997 & Dissertação & UFRGS & René E. Gertz & \\
\hline $\begin{array}{l}\text { BITENCOURT, João } \\
\text { Batista }\end{array}$ & Clio positivada: a artesania da cidade histórica de Laguna & 1997 & Dissertação & UFSC & Sérgio Schmitz & cs. \\
\hline BRUHNS, Katianne & $\begin{array}{l}\text { Espaços de sociabilidade e o idioma: } \\
\text { a campanha de nacionalização em Joinville }\end{array}$ & 1997 & Dissertação & UFSC & Maria Bernardete R. Flores & cs. \\
\hline
\end{tabular}




\begin{tabular}{|c|c|c|c|c|c|c|}
\hline Autor $(a)$ & Título & $\begin{array}{l}\text { Ano de } \\
\text { defesa }\end{array}$ & Modalidade & Instituição & Orientador $(a)$ & Obs \\
\hline CAROLA, Carlos Renato & $\begin{array}{c}\text { Dos subterrâneos da história: as trabalhadoras das minas de carvão de } \\
\text { Santa Catarina (1937-1964) }\end{array}$ & 1997 & Dissertação & UFSC & Joana Maria Pedro & cs. \\
\hline COELHO, Mário César & Moderna ponte velha: imagens \& memória da ponte Hercílio Luz & 1997 & Dissertação & UFSC & Maria Bernardete R. Flores & cs. \\
\hline $\begin{array}{l}\text { FONTOURA, Arselle de } \\
\text { Andrade da }\end{array}$ & $\begin{array}{l}\text { Por entre luzes e sombras... Hospital Colônia Santana: (re)significando } \\
\text { um espaço da loucura }\end{array}$ & 1997 & Dissertação & UFSC & Maria Bernardete R. Flores & cs. \\
\hline FREITAS, Patrícia de & $\begin{array}{c}\text { Margem da palavra, silêncio do número: } \\
\text { o negro na historiografia de Santa Catarina }\end{array}$ & 1997 & Dissertação & UFSC & Élio Cantalício Serpa & cs. \\
\hline KLUG, João & $\begin{array}{l}\text { A escola teuto-brasileira e o processo de modernização em Santa } \\
\text { Catarina: ação da Igreja Luterana através das escolas (1871-1938) }\end{array}$ & 1997 & Tese & USP & Augustin Wernet & cs. \\
\hline LOHN, Reinaldo Lindolfo & $\begin{array}{c}\text { Campos do atraso, campos modernos: análise dos discursos da extensão } \\
\text { rural em Santa Catarina (1956-1975) }\end{array}$ & 1997 & Dissertação & UFSC & Sérgio Schmitz & cs. \\
\hline MARIA, Maria das Graças & $\begin{array}{c}\text { Imagens invisíveis de Áfricas presentes: experiências negras no cotidiano } \\
\text { da cidade de Florianópolis }(1930-1940)\end{array}$ & 1997 & Dissertação & UFSC & Joana Maria Pedro & cs. \\
\hline NIEBUHR, Marlus & $\begin{array}{l}\text { Memória e cotidiano do operário têxtil } \\
\text { na cidade de Brusque/SC: a greve de } 1952\end{array}$ & 1997 & Dissertação & UFSC & Joana Maria Pedro & cs. \\
\hline OSTETTO, Lucy Cristina & $\begin{array}{l}\text { Vozes que recitam, lembranças que se refazem: narrativas de } \\
\text { descendentes de italianos(as) - Nova Veneza, 1920-1950 }\end{array}$ & 1997 & Dissertação & UFSC & Maria Bernardete R. Flores & cs. \\
\hline $\begin{array}{l}\text { SANTOS, Paulete Maria } \\
\text { Cunha dos }\end{array}$ & $\begin{array}{l}\text { Protocolo do bom cidadão - Série Fontes: lições de moral e civismo na } \\
\text { organização da educação em Santa Catarina }(1920-1950)\end{array}$ & 1997 & Dissertação & UFSC & $\begin{array}{l}\text { Maria Teresa Santos Cunha; } \\
\text { Maria Bernardete R. Flores } \\
\text { (co-orientadora) }\end{array}$ & cs. \\
\hline SANTOS, Paulo César dos & $\begin{array}{l}\text { Espaço e memória: o aterro da Baía Sul } \\
\text { e o desencontro marítimo de Florianópolis }\end{array}$ & 1997 & Dissertação & UFSC & $\begin{array}{l}\text { Maria Bernardete R. Flores; } \\
\text { Henrique Luiz Pereira Oliveira } \\
\text { (co-orientador) }\end{array}$ & cs. \\
\hline $\begin{array}{l}\text { SCHROEDER, Rosa Maria } \\
\text { Steiner }\end{array}$ & Uma mulher além do seu tempo: Maura de Senna Pereira & 1997 & Dissertação & UFSC & Maria Teresa Santos Cunha & cs. \\
\hline SILVA, Janine Gomes da & $\begin{array}{l}\text { Tensões, trabalho e sociabilidades: histórias de mulheres } \\
\text { em Joinville no século XIX }\end{array}$ & 1997 & Dissertação & UFSC & $\begin{array}{l}\text { Valberto Dirksen; } \\
\text { Joana Maria Pedro } \\
\text { (co-orientadora) }\end{array}$ & cs. \\
\hline VALENTINI, Delmir José & $\begin{array}{c}\text { Da cidade santa à corte celeste: } \\
\text { memórias de sertanejos e a Guerra do Contestado }\end{array}$ & 1997 & Dissertação & PUC-RS & Núncia S. de Constantino & \\
\hline WOLF, Juçara Nair & $\begin{array}{c}\text { Espaços de sobrevivência e sociabilidades: uma análise do cotidiano em } \\
\text { São Carlos, SC (1930-1945) }\end{array}$ & 1997 & Dissertação & UFSC & Élio Cantalício Serpa & \\
\hline ZIMMER, Roseli & $\begin{array}{l}\text { Pomerode, a cidade mais alemã do Brasil: as manifestações de } \\
\text { germanidade de uma festa teuto-brasileira }\end{array}$ & 1997 & Dissertação & UFSC & $\begin{array}{c}\text { Valberto Dirksen; } \\
\text { João Klug (co-orientador) }\end{array}$ & cs. \\
\hline
\end{tabular}




\begin{tabular}{|c|c|c|c|c|c|c|}
\hline Autor $(a)$ & Título & $\begin{array}{l}\text { Ano de } \\
\text { defesa }\end{array}$ & Modalidade & Instituição & Orientador $(a)$ & Obs \\
\hline ALVES, Elza Daufenbach & $\begin{array}{c}\text { Discurso religioso católico e normatização de comportamentos } \\
\text { (São Ludgero-SC, 1900-1980) }\end{array}$ & 1998 & Dissertação & UFSC & Artur César Isaia & cs. \\
\hline $\begin{array}{l}\text { BASTOS, Maria do Carmo } \\
\text { dos Santos }\end{array}$ & Luzes e sombras: a história da Empresa Força e Luz Santa Catarina S.A. & 1998 & Dissertação & UFSC & Sérgio Schmitz & cs. \\
\hline $\begin{array}{l}\text { CAMPOS, Cynthia } \\
\text { Machado }\end{array}$ & $\begin{array}{c}\text { A política da língua na era Vargas: proibição do falar alemão e } \\
\text { resistências no sul do Brasil }\end{array}$ & 1998 & Tese & UNICAMP & Maria Stella Martins Bresciani & cs. \\
\hline $\begin{array}{l}\text { CAVALETT, Laucí } \\
\text { Aparecida }\end{array}$ & O integralismo e o teuto-brasileiro: Joinville, 1930-1938 & 1998 & Dissertação & UFSC & João Klug & cs. \\
\hline $\begin{array}{l}\text { CHEREM, Rosângela } \\
\text { Miranda }\end{array}$ & $\begin{array}{c}\text { Os faróis do tempo novo: } \\
\text { política e cultura no amanhecer republicano da capital catarinense }\end{array}$ & 1998 & Tese & USP & Maria de Lourdes M. Janotti & cs. \\
\hline COMERLATO, Fabiana & $\begin{array}{l}\text { Análise espacial das armações catarinenses e suas estruturas } \\
\text { remanescentes: um estudo através da Arqueologia Histórica }\end{array}$ & 1998 & Dissertação & PUC-RS & Arno Alvarez Kern & cs. \\
\hline ESPIG, Márcia Janete & A presença da gesta carolíngea no movimento do Contestado & 1998 & Dissertação & UFRGS & José Rivair Macedo & \\
\hline FALCÃO, Luiz Felipe & $\begin{array}{c}\text { Entre ontem e amanhã: diversidade cultural, tensões sociais e separatismo } \\
\text { em Santa Catarina no século XX }\end{array}$ & 1998 & Tese & USP & Zilda Márcia Grícoli Iokoi & \\
\hline FERREIRA, Cristina & $\begin{array}{c}\text { Cidadania e identidade na sociedade teuto-brasileira: José Deeke e os } \\
\text { embates interétnicos no Vale do Itajaí }\end{array}$ & 1998 & Dissertação & UFSC & João Klug & cs. \\
\hline FROTSCHER, Méri & $\begin{array}{l}\text { Etnicidade e trabalho alemão: } \\
\text { outros usos e outros produtos do labor humano }\end{array}$ & 1998 & Dissertação & UFSC & Maria Bernardete R. Flores & cs. \\
\hline GASCHO, Maria de Lurdes & $\begin{array}{c}\text { Catequistas franciscanas: uma antecipação do "aggiornamento" } \\
\text { em Santa Catarina (1915-1965) }\end{array}$ & 1998 & Dissertação & UFSC & Artur César Isaia & cs. \\
\hline GROSSELLI, Renzo & Noi tirolesi, sudditi felici di Don Pedro II & 1998 & Tese & PUC-RS & Núncia S. de Constantino & \\
\hline LIMA, Maria Aparecida de & A plasticidade dos artefatos de barro: olarias de São José & 1998 & Dissertação & UFSC & Joana Maria Pedro & cs. \\
\hline MARCON, Frank Nilton & Visibilidade e resistência negra em Lages & 1998 & Dissertação & UNISINOS & Heloísa Jochim Reichel & \\
\hline $\begin{array}{l}\text { MAY, Patrícia Zumblick } \\
\text { Santos }\end{array}$ & Redes político-empresariais de Santa Catarina: 1961-1970 & 1998 & Dissertação & UFSC & Joana Maria Pedro & cs. \\
\hline MIRANDA, Antônio Luiz & $\begin{array}{l}\text { A Penitenciária de Florianópolis: de um instrumento da modernidade à } \\
\text { utilização por um Estado totalitário }\end{array}$ & 1998 & Dissertação & UFSC & Sérgio Schmitz & cs. \\
\hline RÉCHIA, Karen Christine & $\begin{array}{c}\text { Lembranças íntimas de minha avó: partos, parteiras e outras histórias em } \\
\text { Treze de Maio, SC }\end{array}$ & 1998 & Dissertação & UFSC & Cristina Scheibe Wolff & cs. \\
\hline $\begin{array}{l}\text { SANTANGELO, Beatriz } \\
\text { Koneski }\end{array}$ & Sobre Itajaí: uma discussão historiográfica & 1998 & Dissertação & UFSC & Joana Maria Pedro & cs. \\
\hline SERPA, Ivan Carlos & $\begin{array}{l}\text { Os engenhos de Limeira: } \\
\text { história e memória da imigração italiana no Vale do Itajaí-Mirim }\end{array}$ & 1998 & Dissertação & UFSC & Sérgio Schmitz & cs. \\
\hline
\end{tabular}




\begin{tabular}{|c|c|c|c|c|c|c|}
\hline Autor $(a)$ & Título & $\begin{array}{l}\text { Ano de } \\
\text { defesa }\end{array}$ & Modalidade & Instituição & Orientador $(a)$ & Obs \\
\hline SEVERINO, José Roberto & Itajaí e a identidade açoriana: a maquiagem possível & 1998 & Dissertação & UFSC & Maria Bernardete R. Flores & cs. \\
\hline SOUZA, Sirlei de & $\begin{array}{l}\text { Ecos de resistência na desconstrução da ordem: uma análise da } \\
\text { "Revolução de 64" em Joinville }\end{array}$ & 1998 & Dissertação & UFSC & Élio Cantalício Serpa & cs. \\
\hline TESSEROLLI, Mirian & $\begin{array}{l}\text { Passeio pela vida breve do poeta Sezefredo das Neves: entretecendo } \\
\text { história e literatura }\end{array}$ & 1998 & Dissertação & UFSC & Maria Bernardete R. Flores & cs. \\
\hline $\begin{array}{l}\text { VENDANA, Léa Maria } \\
\text { Ferreira }\end{array}$ & $\begin{array}{c}\text { Aprender para desenvolver: diferentes visões da política educacional } \\
\text { durante o regime militar em Santa Catarina }\end{array}$ & 1998 & Dissertação & UFSC & Artur César Isaia & \\
\hline $\begin{array}{l}\text { VERÍSSIMO, Marise da } \\
\text { Silveira }\end{array}$ & Marias do Socorro: mulheres presas, mulheres torturadas & 1998 & Dissertação & UFSC & Élio Cantalício Serpa & cs. \\
\hline $\begin{array}{l}\text { ZANELATTO, João } \\
\text { Henrique }\end{array}$ & $\begin{array}{c}\text { Homens do barro: experiências de trabalhadores da cerâmica vermelha } \\
\text { (olarias) em Morro da Fumaça }\end{array}$ & 1998 & Dissertação & UFSC & Élio Cantalício Serpa & cs. \\
\hline ALVES, Márcia & $\begin{array}{l}\text { Entre a folia e a sacristia: as (re)significações e intervenções da elite } \\
\text { clerical e civil na Festa do Divino em Florianópolis (1896-1925) }\end{array}$ & 1999 & Dissertação & UFSC & Artur César Isaia & cs. \\
\hline $\begin{array}{l}\text { CAMPOS, Emerson César } \\
\text { de }\end{array}$ & $\begin{array}{c}\text { O catarinense de bombacha: movimento tradicionalista gaúcho } \\
\text { em Santa Catarina (1959-1997) }\end{array}$ & 1999 & Dissertação & UFSC & Maria Bernardete R. Flores & cs. \\
\hline COSTA, Marli de Oliveira & $\begin{array}{l}\text { Artes de viver: recriando e reinventando espaços - memórias das famílias } \\
\text { da vila operária mineira Próspera Criciúma (1945-1961) }\end{array}$ & 1999 & Dissertação & UFSC & Maria Bernardete R. Flores & cs. \\
\hline FERNANDES, Maria Luiza & Trabalhadores catarinenses: estudo de caso entre têxteis e mineiros & 1999 & Tese & USP & Nanci Leonzo & cs. \\
\hline KROTH, Sirlei Antoninha & $\begin{array}{l}\text { Atalhos da luta: trajetórias e experiências das mulheres agricultoras em } \\
\text { Santa Catarina (1983-1998) }\end{array}$ & 1999 & Dissertação & PUC-SP & Denise Bernuzzi Sant'Anna & \\
\hline MACHADO, Aldonei & $\begin{array}{l}\text { A cidade no dial: Florianópolis nas ondas médias e curtas do rádio } \\
\text { (décadas de } 40 \text { e 50) }\end{array}$ & 1999 & Dissertação & UFSC & Maria Teresa Santos Cunha & cs. \\
\hline MACHADO, Vanderlei & $\begin{array}{c}\text { O espaço público como palco de atuação masculina: a construção de um } \\
\text { modelo burguês de masculinidade em Desterro }(1850-1884)\end{array}$ & 1999 & Dissertação & UFSC & Joana Maria Pedro & cs. \\
\hline MARCON, Telmo & Memória e cultura: modos de vida dos caboclos do Goi-En, SC & 1999 & Tese & PUC-SP & Maria Antonieta M. Antonacci & \\
\hline $\begin{array}{l}\text { MORAES, Laura do } \\
\text { Nascimento Rótolo }\end{array}$ & $\begin{array}{l}\text { Cães, vento sul e urubus: higienização e cura em Desterro/ Florianópolis } \\
\qquad(1830-1918)\end{array}$ & 1999 & Tese & PUC-RS & Margaret Marchiori Bakos & cs. \\
\hline NODARI, Eunice Sueli & A renegociação da etnicidade no Oeste de Santa Catarina (1917-1954) & 1999 & Tese & PUC-RS & Margaret Marchiori Bakos & cs. \\
\hline $\begin{array}{l}\text { PIRES, José Henrique } \\
\text { Nunes }\end{array}$ & $\begin{array}{c}\text { Cinema e História: José Julianelli e Alfredo Baumgarten, pioneiros do } \\
\text { cinema catarinense }\end{array}$ & 1999 & Dissertação & UFSC & Ernesto Aníbal Ruiz & cs. \\
\hline VOIGT, André Fabiano & $\begin{array}{l}\text { Imigrantes entre a cruz e a espada: imigração alemã, confissão religiosa e } \\
\text { cidadania no Vale do Itajaí (1847-1863) }\end{array}$ & 1999 & Dissertação & UFSC & João Klug & cs. \\
\hline ZANELA, Claudia Cristina & $\begin{array}{l}\text { Atrás da porta: o discurso sobre o turismo na Ilha de Santa Catarina } \\
\qquad(1983-1998)\end{array}$ & 1999 & Dissertação & UFSC & Sérgio Schmitz & cs. \\
\hline
\end{tabular}




\begin{tabular}{|c|c|c|c|c|c|c|}
\hline Autor(a) & Título & $\begin{array}{l}\text { Ano de } \\
\text { defesa }\end{array}$ & Modalidade & Instituição & Orientador $(a)$ & Obs \\
\hline ALVES, Rosilene Maria & $\begin{array}{l}\text { Se mostram de novo os bugres: abordagens da } \\
\text { imprensa catarinense sobre o indígena (1900-1914) }\end{array}$ & 2000 & Dissertação & UFSC & João Klug & cs. \\
\hline ANDRADE Jr., Lourival & $\begin{array}{l}\text { Mascates de sonhos: as experiências dos artistas de circo-teatro } \\
\text { em Santa Catarina - Circo-Teatro Nh'Ana }\end{array}$ & 2000 & Dissertação & UFSC & Maria Bernardete R. Flores & cs. \\
\hline ANDRADE, Santino & $\begin{array}{l}\text { Os alemães estão chegando: discursos sobre o imigrante alemão } \\
\text { em Santa Catarina (1850-1890) }\end{array}$ & 2000 & Dissertação & UFSC & Sérgio Schmitz & cs. \\
\hline ASSIS, Leonora Portela de & $\begin{array}{l}\text { Planos, ações e experiências na transformação da "pacata" } \\
\text { Florianópolis em capital turística }\end{array}$ & 2000 & Dissertação & UFSC & Cristina Scheibe Wolff & cs. \\
\hline $\begin{array}{l}\text { CURTA, Domingos Luiz } \\
\text { Costa }\end{array}$ & $\begin{array}{l}\text { Laços da terra: experiências dos grupos de } \\
\text { cooperação agrícola em Quilombo, SC }\end{array}$ & 2000 & Dissertação & PUC-SP & Estefânia Knotz Canguçu & \\
\hline $\begin{array}{l}\text { ELÍBIO Jr., Antônio } \\
\text { Manoel }\end{array}$ & Uma heroína na História: representações sobre Anita Garibaldi & 2000 & Dissertação & UFSC & Sérgio Schmitz & cs. \\
\hline GERBER, Diana Mara & Saneamento urbano e estratégia de poder & 2000 & Dissertação & UFSC & Artur César Isaia & \\
\hline LUZ, Rogério Silva & $\begin{array}{l}\text { Futebol e Política: um estudo do clientelismo político } \\
\text { em Florianópolis - SC (1946-1964) }\end{array}$ & 2000 & Dissertação & UFSC & Ernesto Aníbal Ruiz & cs. \\
\hline MORTARI, Cláudia & $\begin{array}{l}\text { Os homens pretos do Desterro: um estudo sobre a Irmandade } \\
\text { de Nossa Senhora do Rosário }(1841-1860)\end{array}$ & 2000 & Dissertação & PUC-RS & Margaret Marchiori Bakos & \\
\hline $\begin{array}{l}\text { NIEHUES, Valdete } \\
\text { Daufenback }\end{array}$ & De agricultor a operário: lembranças de migrantes & 2000 & Dissertação & UFSC & Valmir Francisco Muraro & cs. \\
\hline $\begin{array}{l}\text { OLIVEIRA, Josiane Roza } \\
\text { de }\end{array}$ & $\begin{array}{c}\text { Nos meandros da cidade: testemunhos e memórias atravessados pela } \\
\text { vivência religiosa - Assembléia de Deus em Chapecó }\end{array}$ & 2000 & Dissertação & PUC-SP & Fernando Torres Londoño & \\
\hline $\begin{array}{l}\text { PEREIRA, Karen } \\
\text { Parmigiani }\end{array}$ & $\begin{array}{c}\text { Mulheres em terra de homens do mar: cotidiano e sobrevivência em uma } \\
\text { colônia pesqueira - Barra da Lagoa (1940-1980) }\end{array}$ & 2000 & Dissertação & UFSC & Joana Maria Pedro & \\
\hline POYER, Viviani & $\begin{array}{l}\text { Penitenciária Estadual da Pedra Grande: um estudo sobre a política de } \\
\text { combate à criminalidade em Florianópolis entre 1935-1945 }\end{array}$ & 2000 & Dissertação & UFSC & Sérgio Schmitz & cs. \\
\hline SOUZA, Evandro André de & Franklin Cascaes: uma cultura em transe & 2000 & Dissertação & UFSC & Cristina Scheibe Wolff & cs. \\
\hline VIEIRA, Alexandre Sardá & A educação formal no velho município de Chapecó (1929-1945) & 2000 & Dissertação & UFSC & Eunice Sueli Nodari & cs. \\
\hline ALBINO, José Francisco & $\begin{array}{c}\text { A nacionalização no Estado Novo e a ameaça alemã: um olhar em São } \\
\text { Pedro de Alcântara (1937-1945) }\end{array}$ & 2001 & Dissertação & UFSC & Valberto Dirksen & cs. \\
\hline BEHS, Edelberto & O processo de abrasileiramento da igreja dos alemães & 2001 & Dissertação & UFSC & João Klug & cs. \\
\hline $\begin{array}{l}\text { BRANCO, Juçara de Souza } \\
\text { Castello }\end{array}$ & $\begin{array}{l}\text { Alemães em Lages: uma história de conflitos e alianças } \\
\text { guardadas pela memória }\end{array}$ & 2001 & Dissertação & UFSC & Valberto Dirksen & cs. \\
\hline
\end{tabular}




\begin{tabular}{|c|c|c|c|c|c|c|}
\hline Autor(a) & Título & $\begin{array}{l}\text { Ano de } \\
\text { defesa }\end{array}$ & Modalidade & Instituição & Orientador $(a)$ & Obs \\
\hline $\begin{array}{l}\text { BRAUN Neto, Francisco } \\
\text { Alfredo }\end{array}$ & $\begin{array}{l}\text { Artefatos do corpo: os desejos de produzir corpos perfeitos } \\
\text { em Itajaí na década de } 20\end{array}$ & 2001 & Dissertação & UFSC & Maria Bernardete R. Flores & cs. \\
\hline $\begin{array}{l}\text { CRUZ, Ecleides de Fátima } \\
\text { Bleichuvel }\end{array}$ & $\begin{array}{c}\text { Duas instituições e um projeto: Igreja, Escola e Nacionalização } \\
\text { no Vale do Rio do Peixe em Santa Catarina (1917-1945) }\end{array}$ & 2001 & Dissertação & PUC-RS & René E. Gertz & \\
\hline DALLABRIDA, Norberto & $\begin{array}{l}\text { Virtus et Sciencia: o Ginásio Catarinense e a (re) produção } \\
\text { das elites catarinenses na Primeira República }\end{array}$ & 2001 & Tese & USP & Augustin Wernet & cs. \\
\hline $\begin{array}{l}\text { FARIAS, Deisi Scunderlick } \\
\text { Elói de }\end{array}$ & $\begin{array}{c}\text { Arqueologia e educação: uma proposta de preservação para os sambaquis } \\
\text { do sul de Santa Catarina (Jaguaruna, Laguna e Tubarão) }\end{array}$ & 2001 & Dissertação & PUC-RS & Klaus Hilbert & \\
\hline $\begin{array}{l}\text { FORNAZARI, Luciana } \\
\text { Rosar }\end{array}$ & $\begin{array}{l}\text { Gênero em revista: imagens modernas de homens e mulheres na revista } \\
\qquad \text { O Cruzeiro do segundo pós-guerra }\end{array}$ & 2001 & Dissertação & UFSC & Maria Bernardete R. Flores & cs. \\
\hline IZIDRO, Juliane Maria & O jazigo funerário de Içara no contexto litorâneo catarinense & 2001 & Dissertação & UNISINOS & Pedro Ignácio Schmitz & \\
\hline $\begin{array}{l}\text { MACHADO, Paulo } \\
\text { Pinheiro }\end{array}$ & $\begin{array}{l}\text { Um estudo sobre as origens sociais e a formação política das lideranças } \\
\text { sertanejas do Contestado: } 1912-1916\end{array}$ & 2001 & Tese & UNICAMP & Cláudio H. de M. Batalha & cs. \\
\hline $\begin{array}{l}\text { MIRANDA, Silmara } \\
\text { Luciane }\end{array}$ & Lages, 1940: discursos e remodelações urbanas & 2001 & Dissertação & UFSC & Élio Cantalício Serpa & \\
\hline $\begin{array}{l}\text { NUNES, Karla Leonora } \\
\text { Dahse }\end{array}$ & Antonieta de Barros: uma história & 2001 & Dissertação & UFSC & Élio Cantalício Serpa & cs. \\
\hline $\begin{array}{l}\text { OLIVEIRA, Eveli Souza } \\
\text { D'Avila de }\end{array}$ & $\begin{array}{l}\text { Mais além da vitória: ritos de instituição do movimento de } 30 \\
\text { em Florianópolis: imprensa, governo e memória }\end{array}$ & 2001 & Dissertação & UFSC & Luiz Felipe Falcão & cs. \\
\hline $\begin{array}{l}\text { OLIVEIRA, Núcia } \\
\text { Alexandra Silva de }\end{array}$ & $\begin{array}{l}\text { As páginas da beleza: as representações sobre a beleza feminina } \\
\text { na imprensa (1960-1980) }\end{array}$ & 2001 & Dissertação & UFSC & Joana Maria Pedro & cs. \\
\hline PEREIRA, Lucésia & $\begin{array}{c}\text { Florianópolis, década de 30: ruas, rimas e desencantos } \\
\text { na poesia dissonante de Trajano Margarida }\end{array}$ & 2001 & Dissertação & UFSC & Luiz Felipe Falcão & \\
\hline $\begin{array}{l}\text { RODRIGUES, Rogério } \\
\text { Rosa }\end{array}$ & $\begin{array}{l}\text { Os sertões catarinenses: embates e conflitos envolvendo a atuação militar } \\
\text { na Guerra do Contestado }\end{array}$ & 2001 & Dissertação & UFSC & Sérgio Scmitz & cs. \\
\hline $\begin{array}{l}\text { SCHMITT, Jaqueline } \\
\text { Aparecida Martins Zarbato }\end{array}$ & $\begin{array}{c}\text { Trabalhando em Florianópolis: as práticas de trabalho e as memórias de } \\
\text { trabalhadores e trabalhadoras, } 1900-1920\end{array}$ & 2001 & Dissertação & UFSC & Cristina Scheibe Wolff & cs. \\
\hline SILVA, José Bento Rosa da & $\begin{array}{l}\text { Do porão ao convés: estivadores de Itajaí (SC): } \\
\text { entre a memória e a história }\end{array}$ & 2001 & Tese & UFPE & Antonio Torres Montenegro & \\
\hline SILVA, Maurício Higino da & $\begin{array}{c}\text { Olhos, mãos e rostos: a produção pictórica de Eduardo Dias } \\
\text { na Florianópolis de } 1890 \text { a } 1940\end{array}$ & 2001 & Dissertação & UFSC & Cynthia Machado Campos & cs. \\
\hline SOUZA, Rogério Luiz de & A reforma social católica e o novo limiar capitalista (1945-1965) & 2001 & Tese & UFPR & Euclides Marchi & cs. \\
\hline WERLE, André Carlos & $\begin{array}{l}\text { O reino jesuítico germânico nas margens do rio Uruguai: aspectos da } \\
\text { formação da colônia Porto Novo (Itapiranga) }\end{array}$ & 2001 & Dissertação & UFSC & Valberto Dirksen & cs. \\
\hline
\end{tabular}




\begin{tabular}{|c|c|c|c|c|c|c|}
\hline Autor(a) & Título & $\begin{array}{l}\text { Ano de } \\
\text { defesa }\end{array}$ & Modalidade & Instituição & Orientador $(a)$ & Obs \\
\hline $\begin{array}{l}\text { ACKERMANN, Sílvia } \\
\text { Regina }\end{array}$ & $\begin{array}{l}\text { Um espaço e muitas vidas: Abrigo de Menores do Estado de Santa } \\
\text { Catarina em Florianópolis na década de } 1940\end{array}$ & 2002 & Dissertação & UFSC & Luiz Felipe Falcão & cs. \\
\hline $\begin{array}{l}\text { AMORIM, Christiano } \\
\text { Schaufert }\end{array}$ & $\begin{array}{l}\text { Arquitetura do silêncio: o indígena na escrita, } \\
\text { relações de civilização e extermínio }\end{array}$ & 2002 & Dissertação & UFSC & Ana Lúcia Vulfe Nötzold & cs. \\
\hline $\begin{array}{l}\text { BITENCOURT, João } \\
\text { Batista }\end{array}$ & Estado Novo, Cidade Velha: o Governo Vargas desde Laguna & 2002 & Tese & UFRGS & Sandra Jatahy Pesavento & cs. \\
\hline BRANCO, Mirian Adriano & $\begin{array}{c}\text { Corpos nefastos - cidadania incerta: em Lages, Centro Cívico Cruz e } \\
\text { Souza e a invenção da Nação }\end{array}$ & 2002 & Dissertação & UFSC & Maria Bernardete R. Flores & cs. \\
\hline $\begin{array}{l}\text { CARESIA, Roberto } \\
\text { Marcelo }\end{array}$ & $\begin{array}{c}\text { Ícones da vida moderna: tecnologia e saúde nos anúncios publicitários } \\
\text { veiculados em Blumenau (1935-1955) }\end{array}$ & 2002 & Dissertação & UFSC & João Klug & cs. \\
\hline $\begin{array}{l}\text { CARVALHO, Liliane Edira } \\
\text { Ferreira }\end{array}$ & $\begin{array}{l}\text { Do balcão à mesa: imigrantes e descendentes de sírios e libaneses na } \\
\text { construção de uma identidade na Grande Florianópolis (1910-1950) }\end{array}$ & 2002 & Dissertação & UFSC & Cristina Scheibe Wolff & cs. \\
\hline $\begin{array}{l}\text { CASTRO, Eloah Rocha } \\
\text { Monteiro }\end{array}$ & $\begin{array}{l}\text { Jogo de formas híbridas: arquitetura e modernidade } \\
\text { em Florianópolis na década de } 50\end{array}$ & 2002 & Tese & UFSC & Maria Bernardete R. Flores & cs. \\
\hline COSTA, Sandro da Silveira & $\begin{array}{l}\text { Ponte Hercílio Luz: mutações urbanas em uma cidade insular } \\
\qquad(1890-1960)\end{array}$ & 2002 & Dissertação & UFSC & Valmir Francisco Muraro & cs. \\
\hline $\begin{array}{l}\text { CRISTOFOLINI, Nilton } \\
\text { José }\end{array}$ & $\begin{array}{l}\text { Nacionalização do ensino: estratégia para } \\
\text { a construção da nacionalidade e sua contextualização em Joinville }\end{array}$ & 2002 & Dissertação & UFSC & Valberto Dirksen & cs. \\
\hline FÁVERI, Marlene de & $\begin{array}{l}\text { Memórias de uma (outra) guerra: cotidiano e medo } \\
\text { durante a Segunda Guerra em Santa Catarina }\end{array}$ & 2002 & Tese & UFSC & Joana Maria Pedro & cs. \\
\hline $\begin{array}{l}\text { GALLO, Ivone Cecília } \\
\text { D'Avila }\end{array}$ & A aurora do socialismo: fourierismo e o Falanstério do Saí (1839-1850) & 2002 & Tese & UNICAMP & Edgar Salvadori De Decca & \\
\hline GARCIA Jr., Edgar & Práticas regionalizadoras e o "mosaico cultural catarinense" & 2002 & Dissertação & UFSC & Cynthia Machado Campos & \\
\hline GAVRON, Eva Lúcia & $\begin{array}{l}\text { Seduções e defloramentos: o controle normativo das práticas sexuais } \\
\text { em Florianópolis (1930-1940) }\end{array}$ & 2002 & Dissertação & UFSC & Joana Maria Pedro & \\
\hline GRUNER, Clóvis & $\begin{array}{l}\text { Leituras matutinas: modernidade, utopias e heterotopias na imprensa } \\
\text { joinvilense (1951-1980) }\end{array}$ & 2002 & Dissertação & UFPR & $\begin{array}{c}\text { Sérgio Nadalin; } \\
\text { Ana Maria Burmester } \\
\text { (co-orientadora) }\end{array}$ & \\
\hline IUNKOVSKI, Roberto & $\begin{array}{l}\text { Migrantes caboclos em Florianópolis: } \\
\text { trajetória de uma experiência religiosa }\end{array}$ & 2002 & Dissertação & UFSC & Valmir Francisco Muraro & cs. \\
\hline JOCHEM, Toni Vidal & $\begin{array}{l}\text { A formação da Colônia alemã Teresópolis } \\
\text { e a atuação da Igreja Católica (1860-1910) }\end{array}$ & 2002 & Dissertação & UFSC & Eunice Sueli Nodari & \\
\hline
\end{tabular}




\begin{tabular}{|c|c|c|c|c|c|c|}
\hline Autor(a) & Título & $\begin{array}{l}\text { Ano de } \\
\text { defesa }\end{array}$ & Modalidade & Instituição & Orientador $(a)$ & Obs \\
\hline KASPARY, Alceu & $\begin{array}{c}\text { O discurso católico em Santa Catarina no período de 1960-1964 } \\
\text { e sua relação com a legitimação do Golpe de Estado }\end{array}$ & 2002 & Dissertação & UFSC & Artur César Isaia & cs. \\
\hline LOHN, Reinaldo Lindolfo & $\begin{array}{l}\text { Pontes para o futuro: relações de poder e cultura urbana } \\
\text { (Florianópolis, 1950-1970) }\end{array}$ & 2002 & Tese & UFRGS & Sandra Jatahy Pesavento & cs. \\
\hline MATTOS, Débora Michels. & $\begin{array}{c}\text { Fora do arraial: lepra e instituições asilares } \\
\text { em Santa Catarina (1940-1950) }\end{array}$ & 2002 & Dissertação & USP & Maria Helena P. T. Machado & cs. \\
\hline $\begin{array}{l}\text { NONNENMACHER, } \\
\text { Marilange }\end{array}$ & "Um lugar de memória": Rua Conselheiro Mafra no século XX & 2002 & Dissertação & UFSC & Cynthia Machado Campos & cs. \\
\hline SALOMON, Marlon Jeison & $\begin{array}{c}\text { O saber do espaço: ensaio sobre a geografização do espaço } \\
\text { em Santa Catarina no século XIX }\end{array}$ & 2002 & Tese & UFSC & Maria Bernardete R. Flores & cs. \\
\hline $\begin{array}{l}\text { SANTOS, Maurício Aurélio } \\
\text { dos }\end{array}$ & $\begin{array}{l}\text { Acumulação, geração de emprego e diversificação de economia no sul de } \\
\text { Santa Catarina: carvão, cerâmica e a indústria de plásticos }\end{array}$ & 2002 & Tese & USP & José Jobson de A. Arruda & cs. \\
\hline $\begin{array}{l}\text { SCHWENGBER, Valdir } \\
\text { Luiz }\end{array}$ & $\begin{array}{l}\text { Arqueologia e Informática: uma proposta de educação patrimonial sobre } \\
\text { os sambaquis do Sul de Santa Catarina }\end{array}$ & 2002 & Dissertação & PUC-RS & Klaus Hilbert & \\
\hline SILVA, Clailton Márcio da & $\begin{array}{l}\text { Saber, sentir, servir e saúde: a construção do novo jovem rural } \\
\text { dos Clubes 4-S, SC (1970-1985) }\end{array}$ & 2002 & Dissertação & UFSC & Cristina Scheibe Wolff & cs. \\
\hline $\begin{array}{l}\text { SORATTO, Delotide } \\
\text { Cristina Flores }\end{array}$ & Poderes locais e a implantação da Diocese de Tubarão (1940-1960) & 2002 & Dissertação & UFSC & Eunice Sueli Nodari & cs. \\
\hline WAGNER, Ana Paula & $\begin{array}{c}\text { Diante da liberdade: um estudo sobre libertos da Ilha de Santa Catarina, } \\
\text { na segunda metade do século XIX }\end{array}$ & 2002 & Dissertação & UFPR & Luiz Geraldo Santos da Silva & \\
\hline BERNARDI, Paulo & $\begin{array}{l}\text { Canção do imigrante italiano: uma leitura a partir } \\
\text { de uma localidade rural catarinense (1996-1999) }\end{array}$ & 2003 & Tese & UFSC & Cynthia Machado Campos & \\
\hline BRIGNOL, Juliani Moreira & $\begin{array}{c}\text { Bordados do destino: saberes das mulheres afrodescendentes } \\
\text { na passagem do século XIX ao XX }\end{array}$ & 2003 & Dissertação & UFSC & Rosângela M. Cherem & cs. \\
\hline $\begin{array}{l}\text { CAMPOS, Emerson César } \\
\text { de }\end{array}$ & $\begin{array}{c}\text { Territórios deslizantes: recortes, miscelâneas e exibições na cidade } \\
\text { contemporânea - Criciúma (SC), 1980-2002 }\end{array}$ & 2003 & Tese & UFSC & Maria Bernardete R. Flores & cs. \\
\hline $\begin{array}{l}\text { CARVALHO, Maristela } \\
\text { Moreira de }\end{array}$ & $\begin{array}{c}\text { As vontades de saber e as relações de poder na "pastoral da sexualidade" } \\
\text { da arquidiocese de Florianópolis: continuidades e rupturas no discurso da } \\
\text { oficialidade católica (1960-1980) }\end{array}$ & 2003 & Dissertação & UFSC & $\begin{array}{l}\text { Joana Maria Pedro } \\
\text { Rogério Luiz de Sousa } \\
\text { (co-orientador) }\end{array}$ & cs. \\
\hline DOLZAN, Janiane Cinara & A (re)invenção da italianidade em Rodeio - SC & 2003 & Dissertação & UFSC & Joana Maria Pedro & cs. \\
\hline $\begin{array}{l}\text { FERREIRA, Giovana } \\
\text { Callado }\end{array}$ & $\begin{array}{c}\text { Corpos que dançam: elementos para uma história das práticas corporais } \\
\text { elaboradas por homens e mulheres em Florianópolis } \\
\text { no início do século XX (1900-1930) }\end{array}$ & 2003 & Dissertação & UFSC & Luiz Felipe Falcão & \\
\hline
\end{tabular}




\begin{tabular}{|c|c|c|c|c|c|c|}
\hline Autor (a) & Título & $\begin{array}{l}\text { Ano de } \\
\text { defesa }\end{array}$ & Modalidade & Instituição & Orientador(a) & Obs \\
\hline FROTSCHER, Méri & $\begin{array}{l}\text { Da celebração da etnicidade teuto-brasileira à afirmação da brasilidade: } \\
\text { ações e discursos das elites na esfera pública de Blumenau (1929-1950) }\end{array}$ & 2003 & Tese & UFSC & Maria Bernardete R. Flores & cs. \\
\hline MACHADO, Fabiana Ferret & Expressões Rupestres da Ilha do Campeche/SC & 2003 & Dissertação & PUC-RS & Arno Alvarez Kern & \\
\hline $\begin{array}{l}\text { MENEGOL, Dilene } \\
\text { Magalhães Pinto }\end{array}$ & $\begin{array}{c}\text { Inferências sobre o modo de vida dos caçadores-pescadores-coletores dos } \\
\text { sambaquis do norte do Estado de Santa Catarina e sul do Estado do } \\
\text { Paraná, através da análise das mandíbulas e dos dentes }\end{array}$ & 2003 & Dissertação & PUC-RS & Klaus Hilbert & \\
\hline SILVA, Cristiani Bereta da. & $\begin{array}{l}\text { As fissuras na construção do "novo homem" e da "nova mulher" - } \\
\text { relações de gênero e subjetividades no devir MST - 1979-2000 }\end{array}$ & 2003 & Tese & UFSC & Joana Maria Pedro & \\
\hline SIMONI, Karine & Além da enxada, a utopia: a colonização italiana no Oeste Catarinense & 2003 & Dissertação & UFSC & Valmir Francisco Muraro & cs. \\
\hline SPRÍCIGO, Antônio César & $\begin{array}{l}\text { Sujeitos esquecidos, sujeitos lembrados: entre fatos e números a } \\
\text { escravidão registrada na freguesia do Araranguá no século XIX }\end{array}$ & 2003 & Dissertação & UFSC & Eunice Sueli Nodari & cs. \\
\hline $\begin{array}{l}\text { VENERA, Raquel } \\
\text { Alvarenga Sena }\end{array}$ & $\begin{array}{l}\text { Cortina de ferro: quando o estereótipo é a lei e a transgressão feminina } \\
\text { (processos crime de mulheres em Itajaí - décadas de 1960-1990) }\end{array}$ & 2003 & Dissertação & UFSC & Joana Maria Pedro & cs. \\
\hline $\begin{array}{l}\text { BANDEIRA, Dione da } \\
\text { Rocha }\end{array}$ & $\begin{array}{c}\text { Ceramistas pré-coloniais da Baía da Babitonga, SC: } \\
\text { arqueologia e etnicidade }\end{array}$ & 2004 & Tese & UNICAMP & Pedro Paulo Abreu Funari & \\
\hline $\begin{array}{l}\text { CARDOSO, Paulino de } \\
\text { Jesus Francisco }\end{array}$ & $\begin{array}{l}\text { Negros em Desterro: experiências de populações de origem africana } \\
\text { em Florianópolis, } 1860-1888\end{array}$ & 2004 & Tese & PUC-SP & Maria Odila L. da Silva Dias & \\
\hline CAROLA, Carlos Renato & $\begin{array}{c}\text { Assistência médica, saúde pública e o processo modernizador } \\
\text { da região carbonífera de Santa Catarina (1930-1964) }\end{array}$ & 2004 & Tese & USP & Vera Lúcia do Amaral Ferlini & \\
\hline $\begin{array}{l}\text { COLLAÇO, Vera Regina } \\
\text { Martins }\end{array}$ & $\begin{array}{l}\text { O Teatro da União Operária: } \\
\text { um palco em sintonia com a modernidade brasileira }\end{array}$ & 2004 & Tese & UFSC & Maria Bernardete R. Flores & cs. \\
\hline COSTA, Glaucia Dias da & $\begin{array}{l}\text { Vida noturna e cultura urbana em Florianópolis, } \\
\text { décadas } 50,60 \text { e } 70 \text { do século XX }\end{array}$ & 2004 & Dissertação & UFSC & Maria Bernardete R. Flores & \\
\hline $\begin{array}{l}\text { DIAS, Haylor Delambre } \\
\text { Jacques }\end{array}$ & A arte de Nilo Dias no cenário cultural florianopolitano & 2004 & Dissertação & UFSC & Maria de Fátima Fontes Piazza & cs. \\
\hline HEUER, Johanna Wolfram & $\begin{array}{l}\text { A norrmatização dos sepultamentos em Nossa Senhora do Desterro: } \\
\text { uma história funerária }\end{array}$ & 2004 & Dissertação & UFSC & Maria Bernardete R. Flores & \\
\hline $\begin{array}{l}\text { LUNA, Gloria Alejandra } \\
\text { Guarnizo }\end{array}$ & $\begin{array}{l}\text { As ondas e o tempo: uma análise sobre a transformação de um território - } \\
\text { Praia Brava, Itajaí, SC }\end{array}$ & 2004 & Dissertação & UFSC & Cristina Scheibe Wolff & \\
\hline MORGA, Antonio Emílio & $\begin{array}{l}\text { Masculinidade, economia e sociabilidade: } \\
\text { Nossa Senhora do Desterro no século XIX }\end{array}$ & 2004 & Tese & USP & Eni de Mesquita Samara & cs. \\
\hline
\end{tabular}




\begin{tabular}{|c|c|c|c|c|c|c|}
\hline Autor (a) & Título & $\begin{array}{l}\text { Ano de } \\
\text { defesa }\end{array}$ & Modalidade & Instituição & Orientador $(a)$ & Obs \\
\hline $\begin{array}{l}\text { SANTOS, Johanna Steiner } \\
\text { dos }\end{array}$ & $\begin{array}{l}\text { Escolhas e vivências dos colonos no processo de modernização do campo } \\
\text { - Forquilhinhas, década de } 60 \text { e } 70\end{array}$ & 2004 & Dissertação & UFSC & Cristina Scheibe Wolff & \\
\hline $\begin{array}{l}\text { SANTOS, Manoel P.R. } \\
\text { Teixeira dos }\end{array}$ & $\begin{array}{c}\text { "Vida e trabalho nas floresta": uma análise da interação entre imigrantes e } \\
\text { a floresta nas colônias do Vale do Itajaí e norte de Santa Catarina durante } \\
\text { a segunda metade do século XIX }\end{array}$ & 2004 & Dissertação & UFSC & João Klug & cs. \\
\hline SAYÃO, Thiago Juliano & $\begin{array}{l}\text { Nas veredas do folclore: leituras sobre política cultural e identidade em } \\
\text { Santa Catarina (1948-1975) }\end{array}$ & 2004 & Dissertação & UFSC & Luiz Felipe Falcão & cs. \\
\hline SCHUH, Marcos Batista & $\begin{array}{l}\text { Palavras de fé em mãos que trabalham, ou: caminhos para a organização } \\
\text { da Paróquia São Carlos Barromeu - São Carlos, SC }\end{array}$ & 2004 & Dissertação & UFSC & Maria Bernardete R. Flores & \\
\hline SEVERINO, José Roberto & $\begin{array}{l}\text { Noi oriundi: cultura, identidade e representações } \\
\text { da imigração italiana em Santa Catarina }\end{array}$ & 2004 & Tese & USP & Zilda Márcia Grícoli Iokoi & \\
\hline $\begin{array}{l}\text { SILVA, Adriano Larentes } \\
\text { da }\end{array}$ & Fazendo cidade: a construção do urbano em São Miguel do Oeste - SC & 2004 & Dissertação & UFSC & Cristina Scheibe Wolff & \\
\hline SILVA, Janine Gomes da & $\begin{array}{c}\text { Tempo de lembrar, tempo de esquecer... as vibrações do Centenário e o } \\
\text { período de nacionalização: } \\
\text { histórias e memórias sobre a cidade de Joinville }\end{array}$ & 2004 & Tese & UFSC & Joana Maria Pedro & \\
\hline VIEIRA, Edna Elza & Simbolismo e reelaboração na cultura material xokleng & 2004 & Dissertação & UFSC & Ana Lúcia Vulfe Nötzold & cs. \\
\hline VOJNIAK, Fernando & $\begin{array}{l}\text { Iluminar a inteligência e educar a afetividade: uma história do gênero } \\
\text { masculino no Oeste Catarinense - 1950-1970 }\end{array}$ & 2004 & Dissertação & UFSC & Cristina Scheibe Wolff & \\
\hline ALVES, Elza Daufenbach & $\begin{array}{c}\text { Nos bastidores da Cúria: desobediências e conflitos relacionais } \\
\text { no intra-clero catarinense (1892-1955) }\end{array}$ & 2005 & Tese & UFSC & João Klug & \\
\hline $\begin{array}{l}\text { ANGELO, Elis Regina } \\
\text { Barbosa }\end{array}$ & $\begin{array}{c}\text { Tecendo rendas: } \\
\text { gênero, cotidiano e geração - Lagoa da Conceição, Florianópolis, SC }\end{array}$ & 2005 & Dissertação & PUC-SP & Maria Izilda Santos de Matos & \\
\hline ANNUSECK, Ellen & $\begin{array}{c}\text { Nos bastidores da festa: outras histórias, memórias e sociabilidades em } \\
\text { um bairro operário de Blumenau (1940-1950) }\end{array}$ & 2005 & Dissertação & UFSC & Adriano Luiz Duarte & \\
\hline $\begin{array}{l}\text { AREND, Sílvia Maria } \\
\text { Fávero }\end{array}$ & $\begin{array}{l}\text { Filhos de criação: uma história dos menores abandonados no Brasil } \\
\text { (década de 1930) }\end{array}$ & 2005 & Tese & UFRGS & Sandra Jatahy Pesavento & \\
\hline BEM, Fernanda & $\begin{array}{l}\text { Trabalhadores da indústria frigorífica: trabalho, política e protesto } \\
\text { (Chapecó, SC - 1967-1982) }\end{array}$ & 2005 & Dissertação & UFSC & Adriano Luiz Duarte & \\
\hline $\begin{array}{l}\text { BORGES, Nilsen Christiani } \\
\text { Oliveira }\end{array}$ & $\begin{array}{l}\text { Terra, gado e trabalho: sociedade e economia escravista em Lages, SC } \\
\qquad(1840-1865)\end{array}$ & 2005 & Dissertação & UFSC & Beatriz Gallotti Mamigonian & \\
\hline CESCO, Susana & $\begin{array}{l}\text { Desmatamento e migração no Alto Vale do Rio do Peixe: discussões } \\
\text { sobre "progresso" e transformação ambiental }\end{array}$ & 2005 & Dissertação & UFSC & Eunice Sueli Nodari & \\
\hline
\end{tabular}




\begin{tabular}{|c|c|c|c|c|c|c|}
\hline $\operatorname{Autor}(a)$ & Título & $\begin{array}{l}\text { Ano de } \\
\text { defesa }\end{array}$ & Modalidade & Instituição & Orientador $(a)$ & Obs \\
\hline COMERLATO, Fabiana & As representações rupestres do litoral de Santa Catarina & 2005 & Tese & PUC-RS & Denis Paul Vialou & \\
\hline $\begin{array}{l}\text { FARIAS, Deisi Scunderlick } \\
\text { Eloy de }\end{array}$ & $\begin{array}{c}\text { Distribuição e padrão de assentamento - propostas para sítios de tradição } \\
\text { umbu na encosta de Santa Catarina }\end{array}$ & 2005 & Tese & PUC-RS & Pedro Ignácio Schmitz & \\
\hline LAZARIN, Katiuscia Maria & $\begin{array}{c}\text { Fanáticos, rebeldes e caboclos: discursos e invenções sobre diferentes } \\
\text { sujeitos na historiografia do Contestado (1916-2003) }\end{array}$ & 2005 & Dissertação & UFSC & Paulo Pinheiro Machado & \\
\hline $\begin{array}{l}\text { MEDEIROS, Rangel de } \\
\text { Oliveira }\end{array}$ & $\begin{array}{l}\text { Igreja Universal do Reino de Deus: a construção discursiva da inclusão e } \\
\text { da exclusão (1977-2004) }\end{array}$ & 2005 & Dissertação & UFSC & Maria de Fátima Fontes Piazza & \\
\hline $\begin{array}{l}\text { NUNES, Eduardo Silveira } \\
\text { Netto }\end{array}$ & $\begin{array}{l}\text { Das ruas ao internato: experiências infantis - Abrigo de Menores do } \\
\text { Estado de Santa Catarina em Florianópolis (1950-1972) }\end{array}$ & 2005 & Dissertação & PUC-SP & Olga Brites & \\
\hline OTTO, Clarícia & $\begin{array}{l}\text { Catolicidades e italianidades: jogos de poder no Médio Vale do Itajaí- } \\
\text { Açu e no sul de Santa Catarina }\end{array}$ & 2005 & Tese & UFSC & Artur César Isaia & \\
\hline PENA, Clemente Gentil & $\begin{array}{c}\text { Escravidão, liberdade e os arranjos de trabalho na Ilha de Santa Catarina } \\
\text { nas últimas décadas de escravidão }(1850-1888)\end{array}$ & 2005 & Dissertação & UFSC & Beatriz Gallotti Mamigonian & \\
\hline ROSSATO, Luciana & $\begin{array}{c}\text { A lupa e o diário: história natural, viagens científicas e relatos sobre a } \\
\text { capitania de Santa Catarina (1763-1822) }\end{array}$ & 2005 & Tese & UFRGS & Susana Bleil de Souza & \\
\hline SANT’ANNA, Mara Rúbia & $\begin{array}{l}\text { Aparência e poder: novas sociabilidades urbanas } \\
\text { em Florianópolis, } 1950-1970\end{array}$ & 2005 & Tese & UFRGS & Francisco Marshall & \\
\hline SARDÁ, Juliana & $\begin{array}{l}\text { Na contra-mão da lei: a repressão policial e os desviantes da ordem em } \\
\text { Florianópolis nas primeiras décadas do século XX }\end{array}$ & 2005 & Dissertação & UFSC & Renata Palandri Sigolo Sell & \\
\hline $\begin{array}{l}\text { SCHMITT, Jaqueline } \\
\text { Aparecida Martins Zarbato }\end{array}$ & $\begin{array}{l}\text { O Lar dos Velhinhos Irmão Erasto: muitas histórias para contar } \\
\text { (o cotidiano da entidade espírita - Florianópolis, 1956-2000) }\end{array}$ & 2005 & Tese & UFSC & Joana Maria Pedro & \\
\hline TÉO, Marcelo Robson & $\begin{array}{c}\text { A vitrola nostálgica: música e constituição cultural em Florianópolis } \\
\text { (décadas de } 1930 \text { e 40) }\end{array}$ & 2005 & Dissertação & UFRGS & Carla Simone Rodeghero & \\
\hline $\begin{array}{l}\text { WITTMANN, Luísa } \\
\text { Tombini }\end{array}$ & $\begin{array}{l}\text { Atos do contato: histórias do povo indígena no Vale do Itajaí } \\
\qquad(1850-1926)\end{array}$ & 2005 & Dissertação & UNICAMP & John Manuel Monteiro & \\
\hline
\end{tabular}

Onde: cs = consultada

Fontes:

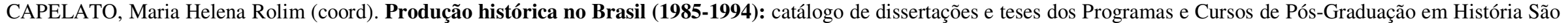
Paulo: Xamã, 1995. v. 1-3.

CORRÊA, Carlos Humberto P. Catálogo das dissertações e teses dos cursos de pós-graduação em História, 1973-1985. Florianópolis: Editora da UFSC, 1987.

FICO, Carlos, POLITO, Ronald. A História no Brasil (1980-1989): séries de dados. Ouro Preto: Editora UFOP, 1994. 


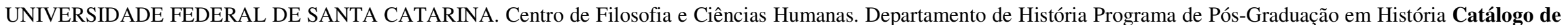
dissertações: área de concentração - História Cultural. Florianópolis: 1998.

Website da CAPES (http://www.capes.gov.br; acessos em set. 2003, fev.2004, jul. 2005, mar. 2006).

Website da PUC-RS (http://www.pucrs.br; catálogo on-line do sistema integrado de bibliotecas; acessos em 03 set.2003, 8 maio 2004,5 ago.2005, 9 jul.2006)

Website da PUC-SP (http://www.pucsp.br; catálogo on-line do sistema integrado de bibliotecas; acessos em 03 set.2003, 8 maio 2004, 5 ago.2005, 9 jul.2006)

Website da UFPR (http://www.ufpr.br; catálogo on-line do sistema integrado de bibliotecas; acessos em 03 set.2003, 8 maio 2004,5 ago.2005, 9 jul.2006)

Website da UFRGS (http://www.ufrgs.br; catálogo on-line do sistema integrado de bibliotecas; acessos em 03 set.2003, 8 maio 2004, 5 ago.2005, 9 jul.2006)

Website da UFSC (http://www.ufsc.br; catálogo on-line do sistema integrado de bibliotecas; acessos em 03 set.2003, 8 maio 2004,5 ago.2005, 9 jul.2006)

Website da UNICAMP (http://www.unicamp.br; catálogo on-line do sistema integrado de bibliotecas; acessos em 03 set.2003, 8 maio 2004,5 ago.2005, 9 jul.2006)

Website da UNISINOS (http://www.unisinos.br; catálogo on-line do sistema integrado de bibliotecas; acessos em 03 set.2003, 8 maio 2004,5 ago.2005, 9 jul.2006)

Website da USP (http://www.usp.br; catálogo on-line do sistema integrado de bibliotecas; acessos em 03 set.2003, 8 maio 2004, 5 ago.2005, 9 jul.2006)

Website do Banco de teses da USP (http://www.teses.usp.br; Acessos em 9 ago. 2002; 03 dez.2003, 8 maio 2004, 5 ago.2005, 9 jul.2006) 
Apêndice I-2

Instituições em que foram defendidas dissertações e teses (em História) sobre Santa Catarina (1974-2005)

\begin{tabular}{|c|c|c|c|c|c|c|c|c|c|c|c|c|c|c|c|c|c|c|c|c|c|c|c|c|c|c|c|c|c|c|c|c|c|}
\hline & 74 & 75 & 76 & 77 & 78 & 79 & 80 & 81 & 82 & 83 & 84 & 85 & 86 & 87 & 88 & 89 & 90 & 91 & 92 & 93 & 94 & 95 & 96 & 97 & 98 & 99 & 00 & 01 & 02 & 03 & 04 & 05 & Total \\
\hline PUC-RS & & & & & 1D & & & & & & & & & & & & & & $1 \mathrm{D}$ & & $1 \mathrm{D}$ & 1D & $1 \mathrm{D}$ & $1 \mathrm{D}$ & $\begin{array}{l}1 \mathrm{D} \\
1 \mathrm{~T}\end{array}$ & $2 \mathrm{~T}$ & 1D & $2 \mathrm{D}$ & $1 \mathrm{D}$ & $2 \mathrm{D}$ & & $2 \mathrm{~T}$ & $\begin{array}{c}13 \mathrm{D} \\
5 \mathrm{~T}\end{array}$ \\
\hline PUC-SP & & & & & & & & & & & & & & & & $1 \mathrm{D}$ & $1 \mathrm{D}$ & $\begin{array}{l}1 \mathrm{D} \\
1 \mathrm{~T}\end{array}$ & $1 \mathrm{D}$ & $2 \mathrm{D}$ & $1 \mathrm{D}$ & & 1D & & & \begin{tabular}{l|}
$1 \mathrm{D}$ \\
$1 \mathrm{~T}$
\end{tabular} & $2 \mathrm{D}$ & & & & $1 \mathrm{~T}$ & $2 \mathrm{D}$ & $\begin{array}{c}13 \mathrm{D} \\
3 \mathrm{~T}\end{array}$ \\
\hline UFPE & & & & & & & & & & & & & & & & & & & & & & & & & & & & $1 \mathrm{~T}$ & & & & & $1 \mathrm{~T}$ \\
\hline UFPR & $3 \mathrm{D}$ & $1 \mathrm{D}$ & & & & & 1D & 1D & & & & & & & & & & & & $1 \mathrm{D}$ & & & $2 \mathrm{D}$ & & & & & $1 \mathrm{~T}$ & $2 \mathrm{D}$ & & & & $\begin{array}{c}11 \mathrm{D} \\
1 \mathrm{~T}\end{array}$ \\
\hline UFRGS & & & & & & & & & & & & & & & & & & & & & & & & $1 \mathrm{D}$ & $1 \mathrm{D}$ & & & & $2 \mathrm{~T}$ & & & $\begin{array}{l}\mathrm{D} \\
3 \mathrm{~T}\end{array}$ & $\begin{array}{l}3 \mathrm{D} \\
5 \mathrm{~T}\end{array}$ \\
\hline UFSC & & & & & $1 \mathrm{D}$ & 19D & $4 \mathrm{D}$ & $2 \mathrm{D}$ & $2 \mathrm{D}$ & $2 \mathrm{D}$ & & $5 \mathrm{D}$ & & & $2 \mathrm{D}$ & $3 \mathrm{D}$ & $2 \mathrm{D}$ & $6 \mathrm{D}$ & $6 \mathrm{D}$ & $4 \mathrm{D}$ & $7 \mathrm{D}$ & 5D & $12 \mathrm{D}$ & $16 \mathrm{D}$ & $18 \mathrm{D}$ & $8 \mathrm{D}$ & $12 \mathrm{D}$ & 14D & $\begin{array}{c}15 \mathrm{D} \\
3 \mathrm{~T}\end{array}$ & \begin{tabular}{|l|}
$7 \mathrm{D}$ \\
$4 \mathrm{~T}$ \\
\end{tabular} & \begin{tabular}{c|}
$11 \mathrm{D}$ \\
$2 \mathrm{~T}$ \\
\end{tabular} & $\begin{array}{l}8 \mathrm{D} \\
3 \mathrm{~T} \\
\end{array}$ & $\begin{array}{c}191 \mathrm{D} \\
12 \mathrm{~T}\end{array}$ \\
\hline UnB & & & & & 1D & & & & & & & & & & & & & & & & & & & & & & & & & & & & 1D \\
\hline UNICAMP & & & & & & & & & & & & & & & & & & & $1 \mathrm{D}$ & & & & & & $1 \mathrm{~T}$ & & & $1 \mathrm{~T}$ & $1 \mathrm{~T}$ & & $1 \mathrm{~T}$ & 1D & $\begin{array}{l}2 \mathrm{D} \\
4 \mathrm{~T}\end{array}$ \\
\hline UNISINOS & & & & & & & & & & & & & & & & & $1 \mathrm{D}$ & & & & $1 \mathrm{D}$ & & & & $1 \mathrm{D}$ & & & $1 \mathrm{D}$ & & & & & $4 \mathrm{D}$ \\
\hline USP & & & & & & & & & $1 \mathrm{~T}$ & & & $3 \mathrm{~T}$ & & & $1 \mathrm{~T}$ & $1 \mathrm{~T}$ & & $1 \mathrm{~T}$ & $2 \mathrm{~T}$ & $1 \mathrm{~T}$ & $1 \mathrm{D}$ & $\begin{array}{l}1 \mathrm{D} \\
1 \mathrm{~T}\end{array}$ & & $1 \mathrm{~T}$ & $2 \mathrm{~T}$ & $1 \mathrm{~T}$ & & $1 \mathrm{~T}$ & $\begin{array}{l}1 \mathrm{D} \\
1 \mathrm{~T} \\
\end{array}$ & & $3 \mathrm{~T}$ & & $\begin{array}{c}3 \mathrm{D} \\
20 \mathrm{~T}\end{array}$ \\
\hline Total & $3 \mathrm{D}$ & $1 \mathrm{D}$ & - & - & $3 \mathrm{D}$ & 19D & $5 \mathrm{D}$ & $3 \mathrm{D}$ & $\begin{array}{l}2 \mathrm{D} \\
1 \mathrm{~T}\end{array}$ & $2 \mathrm{D}$ & - & $\begin{array}{l}5 \mathrm{D} \\
3 \mathrm{~T} \\
\end{array}$ & - & - & $\begin{array}{l}2 \mathrm{D} \\
1 \mathrm{~T}\end{array}$ & $\begin{array}{l}4 \mathrm{D} \\
1 \mathrm{~T}\end{array}$ & $4 \mathrm{D}$ & $\begin{array}{l}7 \mathrm{D} \\
2 \mathrm{~T}\end{array}$ & $\begin{array}{l}9 \mathrm{D} \\
2 \mathrm{~T}\end{array}$ & $\begin{array}{l}7 \mathrm{D} \\
1 \mathrm{~T}\end{array}$ & $11 \mathrm{D}$ & $\begin{array}{l}7 \mathrm{D} \\
1 \mathrm{~T}\end{array}$ & $16 \mathrm{D}$ & $\begin{array}{c}18 \mathrm{D} \\
1 \mathrm{~T}\end{array}$ & $\begin{array}{c}21 \mathrm{D} \\
4 \mathrm{~T}\end{array}$ & $\begin{array}{l}9 \mathrm{D} \\
4 \mathrm{~T}\end{array}$ & $15 \mathrm{D}$ & $\begin{array}{c}17 \mathrm{D} \\
4 \mathrm{~T}\end{array}$ & $\begin{array}{c}19 \mathrm{D} \\
7 \mathrm{~T}\end{array}$ & $\begin{array}{l}9 \mathrm{D} \\
4 \mathrm{~T}\end{array}$ & $\begin{array}{c}11 \mathrm{D} \\
7 \mathrm{~T}\end{array}$ & $\begin{array}{c}12 \mathrm{D} \\
8 \mathrm{~T}\end{array}$ & $\begin{array}{c}241 D \\
51 T\end{array}$ \\
\hline
\end{tabular}

Onde: $\mathrm{D}=$ dissertação de mestrado; $\mathrm{T}=$ tese de doutorado.

Fontes: as mesmas já relacionadas no Apêndice I-1. 
Apêndice I-3

Orientadores das dissertações e teses (em História) relativas a Santa Catarina defendidas na UFSC (1977-2005)

\begin{tabular}{|c|c|c|c|c|c|c|c|c|c|c|c|c|c|c|c|c|c|c|c|c|c|c|c|c|c|c|c|c|c|c|}
\hline & 77 & 78 & 79 & 80 & 81 & 82 & 83 & 84 & 85 & 86 & 87 & 88 & 89 & 90 & 91 & 92 & 93 & 94 & 95 & 96 & 97 & 98 & 99 & 00 & 01 & 02 & 03 & 04 & 05 & Total \\
\hline Adriano Luiz Duarte & & & & & & & & & & & & & & & & & & & & & & & & & & & & & 2 & 2 \\
\hline Ana Lúcia Vulfe Nötzold & & & & & & & & & & & & & & & & & & & & & & & & & & 1 & & 1 & & 2 \\
\hline Aníbal Abadie-Aicardi & & & & & 1 & 1 & & & 2 & & & 1 & 1 & 1 & 2 & & & & 1 & & & & & & & & & & & 10 \\
\hline Artur César Isaia & & & & & & & & & & & & & & & & & & & & 1 & & 3 & 1 & 1 & & 1 & & & 1 & 8 \\
\hline Beatriz Gallotti Mamigonian & & & & & & & & & & & & & & & & & & & & & & & & & & & & & 2 & 2 \\
\hline Carlos Humberto P.Corrêa & & & & & & & 1 & & 1 & & & 1 & 1 & & 2 & 1 & 1 & 3 & & 1 & & & & & & & & & & 12 \\
\hline Cristina Scheibe Wolff & & & & & & & & & & & & & & & & & & & & & & 1 & & 2 & 1 & 2 & & 4 & & 10 \\
\hline Cynthia Machado Campos & & & & & & & & & & & & & & & & & & & & & & & & & 1 & 2 & 1 & & & 4 \\
\hline Élio Cantalício Serpa & & & & & & & & & & & & & & & & & & & & 1 & 2 & 3 & & & 2 & & & & & 8 \\
\hline Ernesto Anibal Ruiz & & & & 1 & 1 & 1 & & & 1 & & & & & & & 2 & & & & & & & 1 & 1 & & & & & & 8 \\
\hline Errol Dean Jones & & & 2 & & & & & & & & & & & & & & & & & & & & & & & & & & & 2 \\
\hline Eunice Sueli Nodari & & & & & & & & & & & & & & & & & & & & & & & & 1 & & 2 & 1 & & 1 & 5 \\
\hline Fernando Dias de Ávila Pires & & & & & & & & & & & & & & & & & & & & 1 & & & & & & & & & & 1 \\
\hline George Philip Browne & & & 3 & & & & & & & & & & & & & & & & & & & & & & & & & & & 3 \\
\hline Joana Maria Pedro & & & & & & & & & & & & & & & & & & 1 & & 2 & 3 & 3 & 1 & 1 & 1 & 2 & 4 & 1 & 1 & 20 \\
\hline João Klug & & & & & & & & & & & & & & & & & & & & & & 2 & 1 & 1 & 1 & 1 & & 1 & 1 & 8 \\
\hline Kendall Walker Brown & & & & 1 & & & & & & & & & & & & & & & & & & & & & & & & & & 1 \\
\hline Henrique Luiz Pereira Oliveira & & & & & & & & & & & & & & & & & & & & & $*$ & & & & & & & & & $1 *$ \\
\hline Lawrence James Nielsen & & 1 & 2 & 1 & & & & & & & & & & & & & & & & & & & & & & & & & & 4 \\
\hline Luiz Felipe Falcão & & & & & & & & & & & & & & & & & & & & & & & & & 2 & 1 & 1 & 1 & & 5 \\
\hline Maria Bernardete R. Flores & & & & & & & & & & & & & & & & & & & 1 & 3 & 5 & 3 & 2 & 1 & 2 & 3 & 2 & 4 & & 26 \\
\hline Maria de Fátima Fontes Piazza & & & & & & & & & & & & & & & & & & & & & & & & & & & & 1 & 1 & 2 \\
\hline Maria Teresa Santos Cunha & & & & & & & & & & & & & & & & & & & & & 2 & & 1 & & & & & & & 3 \\
\hline Marly Anna F.B. Mira & & & 2 & & & & & & & & & & & 1 & & 1 & 1 & 1 & & 1 & & & & & & & & & & 7 \\
\hline Nereu do Vale Pereira & & & & 1 & & & & & & & & & & & & & & & & & & & & & & & & & & 1 \\
\hline Paulo Fernando Araújo Lago & & & 2 & & & & & & & & & & & & & & & & & & & & & & & & & & & 2 \\
\hline Paulo Pinheiro Machado & & & & & & & & & & & & & & & & & & & & & & & & & & & & & 1 & 1 \\
\hline Renata Palandri Sigolo Sell & & & & & & & & & & & & & & & & & & & & & & & & & & & & & 1 & 1 \\
\hline Roger Frank Colson & & & 6 & & & & & & & & & & & & & & & & & & & & & & & & & & & 6 \\
\hline Rogério Luiz de Sousa & & & & & & & & & & & & & & & & & & & & & & & & & & & $*$ & & & $1 *$ \\
\hline Rosângela Miranda Cherem & & & & & & & & & & & & & & & & & & & & & & & & & & & 1 & & & 1 \\
\hline
\end{tabular}




\begin{tabular}{|c|c|c|c|c|c|c|c|c|c|c|c|c|c|c|c|c|c|c|c|c|c|c|c|c|c|c|c|c|c|c|}
\hline & 77 & 78 & 79 & 80 & 81 & 82 & 83 & 84 & 85 & 86 & 87 & 88 & 89 & 90 & 91 & 92 & 93 & 94 & 95 & 96 & 97 & 98 & 99 & 00 & 01 & 02 & 03 & 04 & 05 & Total \\
\hline Rufino Porfírio Almeida & & & & & & & & & & & & & 1 & & 2 & 2 & 2 & 1 & 1 & & & & & & & & & & & 9 \\
\hline Sérgio Schmitz & & & & & & & & & & & & & & & & & & & & & 2 & 3 & 1 & 3 & 1 & & & & & 10 \\
\hline Valberto Dirksen & & & & & & & & & & & & & & & & & & 1 & 2 & 2 & 2 & & & & 3 & 1 & & & & 11 \\
\hline Valmir Francisco Muraro & & & & & & & & & & & & & & & & & & & & & & & & 1 & & 2 & 1 & & & 4 \\
\hline Walter Fernando Piazza & & & 2 & & & & 1 & & 1 & & & & & & & & & & & & & & & & & & & & & 4 \\
\hline
\end{tabular}

Onde $*$ = co-orientação

Obs.: além de atuarem como orientadores, também co-orientaram trabalhos sobre Santa Catarina:

- Joana Maria Pedro (uma dissertação, em 1997).

- João Klug (uma dissertação, em 1997).

- Maria Bernardete Ramos Flores (uma dissertação, em 1997).

Fontes: as mesmas já relacionadas no Apêndice I-1. 
Apêndice I-4

Publicações em livro de dissertações de mestrado e teses de doutorado (em História) sobre Santa Catarina

\section{Publicação}

BALDIN, Nelma. A Intendência da Marinha de Santa Catarina e a Questão da Cisplatina. Florianópolis: Fundação Catarinense de Cultura, 1980.

BOPPRÉ, Maria Regina. Eleições diretas e primórdios do coronelismo catarinense (1881-1889). Florianópolis: Secretaria de Estado da Administração, 1989. (Memória pública de Santa Catarina - Historiografia, 2).

BOSSLE, Ondina Pereira. História da industrialização catarinense: das origens à integração no desenvolvimento brasileiro. [Florianópolis]: CNI-FIESC, 1988.

CAROLA, Carlos Renato. Dos subterrâneos da história: as trabalhadoras das minas de carvão de Santa Catarina (1937-1964). Florianópolis: Editora da UFSC, 2002.

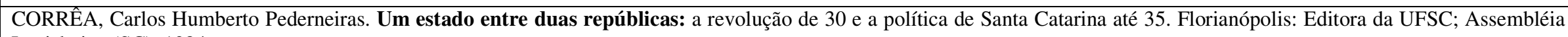
Legislativa (SC), 1984.

DALLABRIDA, Norberto. A fabricação escolar das elites: o Ginásio Catarinense na Primeira República. Florianópolis: Cidade Futura, 2001.

ESPIG, Márcia Janete. A presença da gesta carolíngea no movimento do Contestado. Canoas (RS): Editora da ULBRA, 2002.

FALCÃO, Luiz Felipe. Entre ontem e amanhã: diversidade cultural, tensões sociais e separatismo em Santa Catarina no século XX. Itajaí (SC): Editora da UNIVALI, 2000.

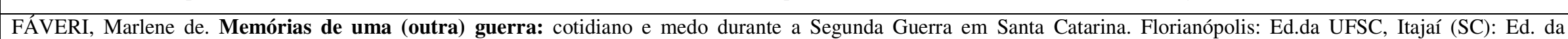
UNIVALI, 2004.

FÁVERI, Marlene de. Moços e moças para um bom partido: a construção das elites (Itajaí, 1929-1960). 2 ed. Itajaí (SC): Editora da UNIVALI, 1999.

FLORES, Maria Bernardete Ramos. A farra do boi: palavras, sentidos, ficções. Florianópolis: Editora da UFSC, 1997.

GALLO, Ivone Cecília D'Ávila. O Contestado: o sonho do milênio igualitário. Campinas (SP): Editora da UNICAMP, 1999. (Pesquisas)

GRUNER, Clóvis. Leituras matutinas: utopias e heterotopias da modernidade na imprensa joinvilense (1951-1980). Curitiba: Aos Quatro Ventos, 2003.

KLUG, João. Imigração e luteranismo em Santa Catarina. Florianópolis: Papa-Livro, 1994.

MACHADO, Paulo Pinheiro. Lideranças do Contestado: a formação e a atuação das chefias caboclas (1912-1916). Campinas (SP): Editora da UNICAMP, 2004.

MARCON, Telmo. Memória, história e cultura. Chapecó (SC): Argos, 2003.

NIEBUHR, Marlus. Ecos e sombras: memória operária em Brusque - SC na década de 50. Itajaí (SC): Editora da UNIVALI, 1999.

OTTO, Clarícia. Catolicidades e italianidades: tramas e poder em Santa Catarina (1875-1930. Florianópolis: Insular, 2006. 
PEDRO, Joana Maria. Mulheres honestas e mulheres faladas: uma questão de classe . Florianópolis: Editora da UFSC, 1994.

PEREIRA, Ivonete. “As decaídas”: prostituição em Florianópolis (1900-1940). Florianópolis: Ed. da UFSC, 2004.

PETRY, Sueli Maria Vanzuita. Os clubes de caça e tiro na região de Blumenau (1859-1981). Blumenau (SC): Fundação Casa Dr. Blumenau, 1982.

RENAUX-HERING, Maria Luiza. Colonização e indústria no Vale do Itajaí. Blumenau (SC): Editora da FURB, 1987.

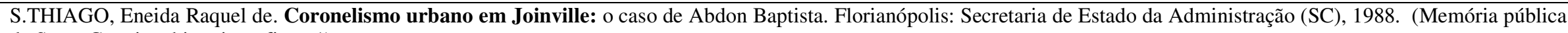
de Santa Catarina, historiografia, n.1)

SANTOS, Roselys Izabel Corrêa dos. A terra prometida: migração italiana, mito e realidade. 2 ed. Itajaí (SC): Editora da UNIVALI, 1999.

SEVERINO, José Roberto. Itajaí e a identidade açoriana: a maquiagem possível. Itajaí (SC): Editora da UNIVALI, 1999.

SILVA, Janine Gomes da. Tensões, trabalho e sociabilidades: histórias de mulheres em Joinville no século XIX. Joinville (SC): Editora da UNIVILLE, 2004.

SILVA, José Bento Rosa da. Estiva papa-siri: mãos e pés do Porto de Itajaí. Itajaí (SC): Ed. do autor, 2004.

SOUZA, Sara Regina Silveira de. A presença portuguesa na arquitetura da ilha de SC: séculos XVIII e XIX. Florianópolis: Fundação Catarinense de Cultura, 1981.

ZIMMER, Roseli. Pomerode: manifestações de germanidade em uma festa teuto-brasileira. [Santa Maria, RS]: Gráfica Palotti, 2002. 
Apêndice I-5

IHGSC: Sócios que assumiram cargos na Diretoria e em algumas comissões e conselhos

\section{Período 1896-1935}

\begin{tabular}{|c|c|c|}
\hline Sócio & Cargo/função & Período \\
\hline Afonso Cavalcanti Livramento & Tesoureiro & 1896 \\
\hline Afonso Wanderley Jr. & Orador & $1929-30$ \\
\hline Altino Corsino da Silva Flores & Membro da Comissão da Revista & 1935 \\
\hline Álvaro Tolentino de Souza & Tesoureiro & $1929-1930$ \\
\hline Antonio Lopes de Mesquita & Membro da Comissão de Sindicância & 1913 \\
\hline Antônio Maria Barroso Pereira & Membro da Comissão de Sindicância & 1913 \\
\hline Aristides de Mello & Membro da Comissão de Redação & 1902 \\
\hline Artur M. de Barros Oliveira Lima & Tesoureiro & 1902-1919 (1902, 1907, 1913-1919) \\
\hline \multirow[t]{4}{*}{ Augusto Fausto de Souza } & $2^{\text {o. }}$ Secretário & 1896 \\
\hline & $1^{\circ}$. Vice-Presidente & 1902 \\
\hline & Membro da Comissão de Sindicância & $1914-1915$ \\
\hline & Tesoureiro & $1919-1920$ \\
\hline Belarmino Correia & Membro da Comissão de Redação & 1913 \\
\hline Carlos da Mota Azevedo Corrêa & $1^{\circ}$. Secretário & 1935 \\
\hline Elpídio Fragoso & Tesoureiro & 1935 \\
\hline Euphrasio Cunha & Membro da Comissão de Redação & 1913 \\
\hline Felipe Schmidt & $1^{\circ}$. Vice-Presidente & 1896 \\
\hline \multirow[t]{2}{*}{ Fernando Machado Vieira } & $2^{\circ}$. Secretário & 1902 \\
\hline & $1^{\circ}$. Secretário & 1907, 1913-20, 1929-30 (1907, 1913-20, 1926-27, 1929-30) \\
\hline Francisco Barreiros Filho & Membro da Comissão da Revista & $1926-1927$ \\
\hline Francisco da Cunha Machado Beltrão & Presidente & 1896 \\
\hline Francisco Topp [Monsenhor] & Membro da Comissão de Sindicância & 1913-1915 \\
\hline Francisco X. Rodrigues de Souza & $2^{\circ}$. Secretário & $1919-1920$ \\
\hline \multirow[t]{2}{*}{ Gustavo Adolfo da Silveira } & $2^{\circ}$. Secretário & 1914-1919 \\
\hline & Tesoureiro & $1926-1927$ \\
\hline \multirow[t]{2}{*}{ Gustavo Lebon Regis } & Presidente & 1907 \\
\hline & $2^{\circ}$. Vice-Presidente & 1913,1913 \\
\hline Heitor Blum & Orador & 1935 \\
\hline Heitor Luz & $2^{\circ}$. Secretário & 1907 \\
\hline
\end{tabular}




\begin{tabular}{|c|c|c|}
\hline \multirow[t]{3}{*}{ Henrique da Silva Fontes } & Membro da Comissão de Redação & 1913-1915 \\
\hline & $1^{\circ}$. Vice-Presidente & 1914-1930 (1914-20, 1926-27, 1929-30) \\
\hline & Presidente & 1935 \\
\hline \multirow[t]{2}{*}{ Henrique Valgas } & $2^{\circ}$ Vice-Presidente & 1902 \\
\hline & Membro da Comissão de Redação & 1902 \\
\hline Heráclito Carneiro Ribeiro & $2^{\circ}$ Vice-Presidente & 1926-1927, 1929-1930 \\
\hline \multirow[t]{2}{*}{ Horácio Serapião de Carvalho } & $2^{\circ}$. Secretário & 1913,1913 \\
\hline & Secretário & 1921 \\
\hline Ivo d'Aquino Fonseca & Orador & $1919-1920$ \\
\hline João Manfredo Leite & Membro da Comissão de Redação & 1902 \\
\hline Joaquim David Ferreira Lima & $2^{\circ}$. Vice-Presidente & 1914-1920 \\
\hline \multirow[t]{2}{*}{ Joaquim Thiago da Fonseca } & Orador & 1896-1919 (1896, 1902, 1907, 1913-19) \\
\hline & Membro da Comissão de Redação & 1902 \\
\hline \multirow[t]{3}{*}{ José Artur Boiteux } & $1^{\circ}$. Secretário & 1896,1902 \\
\hline & Membro da Comissão de Redação & 1902 \\
\hline & Presidente & $1921,1926-30(1921,1926-27,1929-30)$ \\
\hline José Bonifácio da Cunha & $1^{\circ}$. Vice-Presidente & 1913 \\
\hline \multirow[t]{2}{*}{ José Lupércio Lopes } & $2^{\circ}$. Secretário & 1926-1927, 1929-1930 \\
\hline & $1^{\circ}$. Vice-Presidente & 1935 \\
\hline José Vieira da Rosa & Membro da Comissão de Redação & 1913 \\
\hline Laércio Caldeira de Andrada & Membro da Comissão da Revista & 1926-1935 (1926-27, 1929-30, 1935) \\
\hline \multirow{3}{*}{ Lucas Alexandre Boiteux } & Diretor da Revista & 1907 \\
\hline & Presidente & $1914-1920$ \\
\hline & Membro da Comissão da Revista & 1935 \\
\hline \multirow[t]{2}{*}{ Luiz Cavalcanti de Campos Melo } & $2^{\circ}$. Vice-Presidente & 1896 \\
\hline & Presidente & 1902 \\
\hline Luiz Gualberto & Membro da Comissão da Revista & 1926-1930 (1926-27, 1929-30) \\
\hline \multirow{2}{*}{ Manoel dos Santos Lostada } & $1^{\circ}$. Vice-Presidente & 1907 \\
\hline & Membro da Comissão de Redação & 1913-1915 \\
\hline Manoel C. de Arruda Câmara & Membro da Comissão de Redação & 1913-1915 \\
\hline Nereu Ramos & Membro da Comissão de Sindicância & 1914-1915 \\
\hline Odilon Fernandes & Membro da Comissão de Redação & $1929-1930$ \\
\hline Vidal José de Oliveira Ramos & Presidente & 1913 \\
\hline
\end{tabular}




\section{Período 1939-1968}

\begin{tabular}{|c|c|c|}
\hline Afonso Guilhermino Wanderley Jr. & Membro da Comissão da Revista & 1938-1939 \\
\hline Altino Corsino da Silva Flores & Membro da Comissão de Redação da Revista & $1959-1961$ \\
\hline Altino Flores & Membro da Comissão da Revista & 1938-1939 \\
\hline \multirow[t]{2}{*}{ Álvaro Tolentino de Sousa } & 2o. Secretário & 1941-1943 \\
\hline & 10. Secretário & 1943-1954 \\
\hline \multirow{3}{*}{ Andrelino Natividade da Costa } & 2o. Secretário & $1957-1965$ \\
\hline & Membro da Comissão de Redação da Revista & $1959-1961$ \\
\hline & 2o. Vice-Presidente & $1965-1967$ \\
\hline \multirow[t]{3}{*}{ Carlos da Costa Pereira } & 10. Secretário & $\begin{array}{l}1938-1943 \\
(1938-40 ; 1941-43)\end{array}$ \\
\hline & 1o. Vice-Presidente & $1947-1952 ; 1955-1957$ \\
\hline & 2o. Vice-Presidente & $1953-1955 ; 1957-1959$ \\
\hline Carlos da Mota Azevedo Corrêa & Tesoureiro & 1938-1939 \\
\hline Carlos Gomes de Oliveira & Orador & 1947-1951 \\
\hline Clementino Fausto Barcellos de Brito & 2o. Secretário & $1938-1940$ \\
\hline Custódio Francisco de Campos & 2o. Secretário & $1965-1967$ \\
\hline Eliezer dos Santos Saraiva & Tesoureiro & $1943-1944$ \\
\hline Elpídio Barbosa & Orador & $1945-1947$ \\
\hline Gil Costa & Orador & 1941-1943 \\
\hline Gustavo Neves & 2o. Secretário & 1947-1949 \\
\hline \multirow[t]{2}{*}{ Heitor Blum } & Orador & 1938-1939 \\
\hline & 10. Secretário & 1947-1949 \\
\hline Henrique da Silva Fontes & Presidente & 1938-1940; 1941-1967 \\
\hline João dos Santos Areão & Tesoureiro & $1947-1967$ \\
\hline José de Diniz & Membro da Comissão da Revista & 1938-1939 \\
\hline \multirow[t]{2}{*}{ José Lupércio Lopes } & 10. Vice-Presidente & 1938-1940; 1941-1945; 1953-1955; 1957-1967 \\
\hline & 2o. Vice-Presidente & $1945-1952 ; 1955-1957$ \\
\hline José Nicolau Born & Tesoureiro & 1944-1947 \\
\hline Lothario Paulo Rathfuchs & 2o. Secretário & 1943-1945 \\
\hline Luís Sanches Bezerra de Trindade & 2o. Secretário & $1949-1957$ \\
\hline Luís Sanches Bezerra de Trindade & 1o. Secretário & $1957-1967$ \\
\hline Manoel Ferreira de Melo & 2o. Secretário & $1945-1947$ \\
\hline Oswaldo Bulcão Vianna & Orador & $1943-1945 ; 1951-1967$ \\
\hline
\end{tabular}




\begin{tabular}{|l|l|l|}
\hline Oswaldo Rodrigues Cabral & 2o. Vice-Presidente & $1938-1940 ; 1941-1943 ; 1959-1965$ \\
\cline { 2 - 3 } & 1o. Secretário & $1954-1957$ \\
\cline { 2 - 3 } & Membro da Comissão de Redação da Revista & $1959-1961$ \\
\hline Othon da Gama d'Eça & 2o. Vice-Presidente & $1947-1949$ \\
\hline Renato de Medeiros Barbosa & Orador & $1939-1940$ \\
\hline Sílvio Elvídio Carneiro da Cunha & Tesoureiro & $1939-1940 ; 1941-43$ \\
\cline { 2 - 3 } & 2o. Vice-Presidente & $1943-1945$ \\
\cline { 2 - 3 } & 1o. Vice-Presidente & $1945-1947$ \\
\hline
\end{tabular}

\section{Período 1968-2005}

\begin{tabular}{|c|c|c|}
\hline \multirow[t]{2}{*}{ Aluízio Blasi } & Membro do Conselho Consultivo e Fiscal & 1990-1991 \\
\hline & $2^{\circ}$. Vice-Presidente & 1991-1993 \\
\hline Antonio Adolfo Lisboa & Membro do Conselho Fiscal & $1985-1987$ \\
\hline \multirow{2}{*}{ Augusto César Zeferino } & $1^{\circ}$. Vice-Presidente & $1999-2003$ \\
\hline & Membro do Conselho Editorial da Revista do IHGSC & $2001-2003$ \\
\hline Ayres Melchiades Ulysséa & Membro do Conselho Fiscal & 1983-1985 \\
\hline Carlos Alberto Silveira Lenzi & Orador & 1993-1997; 2001-2003 \\
\hline \multirow[t]{4}{*}{ Carlos Humberto Pederneiras Corrêa } & Membro do Conselho Fiscal/ Consultivo e Fiscal & $1975-1980 ; 1981-1983 ; 1985-1990$ \\
\hline & Redator da Revista do IHGSC & $1979-1990$ \\
\hline & Membro do Conselho Editorial da Revista do IHGSC & 1991-1992; 2001-2003 \\
\hline & Presidente do IHGSC & $2001-2003$ \\
\hline Dante Martorano & Membro do Conselho Fiscal & 1983-1985 \\
\hline \multirow[t]{3}{*}{ Eliana Maria Bahia } & $1^{\circ}$. Secretário & 1987-1989 \\
\hline & $2^{\circ}$. Secretário & 1989-1991; 1995-1997; 2001-2003 \\
\hline & Membro do Conselho Editorial da Revista do IHGSC & 1991-1992 \\
\hline \multirow[t]{3}{*}{ Evaldo Pauli } & Tesoureiro & $1971-1975$ \\
\hline & 2o. Tesoureiro & $1985-1989$ \\
\hline & $1^{\circ}$. Tesoureiro & 1988-1989 \\
\hline Geraldo Gama Salles & Membro suplente do Conselho Fiscal & $2001-2003$ \\
\hline \multirow[t]{2}{*}{ Hélio Teixeira da Rosa } & Membro suplente do Conselho Consultivo e Fiscal & $1995-1997$ \\
\hline & $2^{\circ}$. Tesoureiro & $1989-1991$ \\
\hline \multirow[t]{2}{*}{ Hoyêdo de Gouvêa Lins } & Membro titular do Conselho Fiscal & $2001-2003$ \\
\hline & Membro suplente do Conselho Consultivo e Fiscal & $1995-1997$ \\
\hline
\end{tabular}




\begin{tabular}{|c|c|c|}
\hline Iaponan Soares de Araújo & Membro do Conselho Fiscal/ Consultivo e Fiscal & $1985-1990$ \\
\hline Idaulo José Cunha & $1^{\circ}$. Tesoureiro & $1991-1997$ \\
\hline Iza Vieira da Rosa Grisard & $1^{\circ}$. Tesoureiro & $2001-2003$ \\
\hline \multirow[t]{5}{*}{ Jali Meirinho } & 2o. Vice-Presidente & 1994-1995 \\
\hline & Secretário & $1975-1980 ; 1981-1985$ \\
\hline & Diretor da Revista do IHGSC & 1979-1990 \\
\hline & Secretário Geral & 1985-1991; 1995-1997; 2001-2003 \\
\hline & Membro do Conselho Editorial da Revista do IHGSC & $1991-1992 ; 2001-2003$ \\
\hline José Cordeiro da Silva & Membro do Conselho Fiscal & 1971-1975; \\
\hline José Isaac Pilati & $2^{\circ}$. Tesoureiro & $2001-2003$ \\
\hline Lêda Maria D'Ávila da Silva Prazeres & Membro do Conselho Editorial da Revista do IHGSC & 1991-1992 \\
\hline Lélia Pereira da Silva Nunes & $1^{\circ}$. Secretário & 1991-1997 \\
\hline \multirow[t]{2}{*}{ Licurgo Ramos da Costa } & $2^{\circ}$. Vice-Presidente & 1985-1989; 1988-1991 \\
\hline & $1^{\circ}$. Vice-Presidente & 1991-1993 \\
\hline Marcelo Vieira Nascimento & Membro suplente do Conselho Fiscal & $2001-2003$ \\
\hline \multirow[t]{3}{*}{ Maria Regina Boppré } & $2^{\circ}$. Secretário & 1987-1989; 1988-1991 \\
\hline & $1^{\circ}$. Secretário & $1989-1991$ \\
\hline & Secretário Geral & 1991-1995 \\
\hline Maria Theresinha Sobiejaski Barreto & 2a. Secretária & $1985-1987$ \\
\hline Mário Fernandes Dias & Membro do Conselho Consultivo e Fiscal & $1991-1997$ \\
\hline \multirow[t]{3}{*}{ Marly Ana Fortes Bustamante Mira } & Membro do Conselho Consultivo e Fiscal & $1993-1997$ \\
\hline & Membro do Conselho Editorial da Revista do IHGSC & $2001-2003$ \\
\hline & Membro titular do Conselho Fiscal & $2001-2003$ \\
\hline Martinho Callado Jr. & Membro do Conselho Fiscal & 1971-1975; \\
\hline Maura Soares & $1^{\circ}$. Secretário & 1995-1997; 2001-2003 \\
\hline Nélvio Paulo Dutra Santos & 2o. Secretário & 1993-1994 \\
\hline \multirow[t]{2}{*}{ Nereu do Vale Pereira } & Membro titular do Conselho Fiscal & $2001-2003$ \\
\hline & Membro suplente do Conselho Consultivo e Fiscal & $1995-1997$ \\
\hline \multirow[t]{4}{*}{ Osvaldo Ferreira de Melo } & Membro do Conselho Consultivo e Fiscal & $1987-1990$ \\
\hline & Membro do Conselho Editorial da Revista do IHGSC & 1991-1992; 2001-2003 \\
\hline & $2^{\circ}$. Vice-Presidente & $2001-2003$ \\
\hline & $1^{\circ}$. Vice-Presidente & 1993-1997 \\
\hline \multirow[t]{2}{*}{ Paschoal Apóstolo Pítsica } & Membro do Conselho Fiscal & $1983-1985$ \\
\hline & Orador & $1985-1993$ \\
\hline Roselys Isabel Correa dos Santos & Membro do Conselho Fiscal & $1975-1979$ \\
\hline Rufino Porfírio Almeida & $2^{\circ}$. Tesoureiro & 1991-1997 \\
\hline
\end{tabular}




\begin{tabular}{|c|c|c|}
\hline Saulo Varella de Carvalho & 10. Secretário & $1985-1987$ \\
\hline Stella Vieira da Rosa Fernandes & Membro do Conselho Consultivo e Fiscal & 1990-1993 \\
\hline \multirow[t]{4}{*}{ Sylvia Amélia Carneiro da Cunha } & Secretária & 1971-1975; \\
\hline & Tesoureiro & 1975-1980; 1981-1985; 1988-1991 \\
\hline & 1a. Tesoureira & $1985-1991$ \\
\hline & Membro do Conselho Consultivo e Fiscal & 1991-1997 \\
\hline Telmo Viana Ribeiro & Membro do Conselho Fiscal & 1971-1975 \\
\hline Teófilo Matos & Membro do Conselho Consultivo e Fiscal & $1990-1991$ \\
\hline Theobaldo Costa Jamundá & Secretário & 1968 \\
\hline Valmor Bonifácio Sena & Membro do Conselho Fiscal & 1975-1980; 1981-1983 \\
\hline \multirow[t]{2}{*}{ Valter Manoel Gomes } & Membro do Conselho Fiscal & 1979-1980; 1981-1983 \\
\hline & Membro suplente do Conselho Fiscal & $2001-2003$ \\
\hline Vanderlei Rouver & $2^{\circ}$. Secretário & 1991-1993 \\
\hline \multirow[t]{2}{*}{ Victor Antonio Peluso Jr. } & Presidente do IHGSC & 1971-1980; 1981-1991 \\
\hline & Presidente perpétuo do IHGSC & 1991-1993 \\
\hline \multirow[t]{4}{*}{ Walter Fernando Piazza } & Presidente & 1968; 1991-1997 \\
\hline & Vice-Presidente & $1971-1980 ; 1981-1985$ \\
\hline & Redator da Revista do IHGSC & $1979-1990$ \\
\hline & $1^{\circ}$. Vice-Presidente & 1985-1991 \\
\hline Zedar Perfeito da Silva & Tesoureiro & 1968 \\
\hline
\end{tabular}

Fontes:

- RTIHGSC (1902, 1913-1920) e RIHGSC (1943-1944, 1979-2004);

- PIAZZA, Walter Fernando. Instituto Histórico e Geográfico de Santa Catarina: estudo histórico-analítico (1896-1996). Florianópolis: Editora da UDESC, 1996. 
Apêndice II-1

Edições dos encontros catarinenses de arquivos

\begin{tabular}{|c|c|c|c|}
\hline Edição do encontro & Data & Local & Publicação dos anais \\
\hline I Encontro de Arquivos Catarinenses & 20-21 set. 1984 & Florianópolis & $\begin{array}{l}\text { SOARES, Iaponan (org.). Arquivos \& Documentos em Santa Catarina. } \\
\text { Florianópolis: Secretaria da Justiça, Arquivo Público do Estado, 1985. 127p. }\end{array}$ \\
\hline II Encontro de Arquivos Catarinenses & $\begin{array}{c}\text { 19-20 set. } 1986 \\
\text { [de acordo com os Anais } \\
\text { do III Encontro] }\end{array}$ & Florianópolis & Publicação não efetuada. \\
\hline $\begin{array}{l}\text { III Encontro de Arquivos Catarinenses; } \\
\text { I Painel de Arquivos Sul-Brasileiros }\end{array}$ & 15-16 set. 1988 & Florianópolis & $\begin{array}{l}\text { PIAZZA, Walter F. (org.). Anais do III Encontro de Arquivos Catarinenses; I } \\
\text { Painel de Arquivos Sul-Brasileiros. Florianópolis: Secretaria de Estado da } \\
\text { Administração, Coordenadoria de Documentação e Publicações, Arquivo Público, } \\
\text { 1988. 125p. }\end{array}$ \\
\hline $\begin{array}{l}\text { IV Encontro de Arquivos Catarinense [sic]; } \\
\text { II Painel de Arquivos Sul-Brasileiro [sic] }\end{array}$ & 3-5 jul. 1990 & Joaçaba & $\begin{array}{l}\text { Anais [do] IV Encontro de Arquivos Catarinense; II Painel de Arquivos Sul- } \\
\text { Brasileiro - [Joaçaba], } 3 \text { a } 5 \text { de julho de 1990. Florianópolis: Secretaria de } \\
\text { Estado da Administração, 1990. 84p. [cópia eletrostática a partir de original } \\
\text { datilografado] }\end{array}$ \\
\hline $\begin{array}{l}\text { V Encontro Catarinense } \\
\text { de Arquivos }\end{array}$ & 23-25 set. 1992 & Itajaí & $\begin{array}{l}\text { Anais do } \mathbf{5}^{\mathbf{0}} \text {. Encontro Catarinense de Arquivos. Florianópolis: Fundação } \\
\text { Catarinense de Cultura, Associação de Amigos do Arquivo Público, 1992. 86p. }\end{array}$ \\
\hline $\begin{array}{l}\text { VI Encontro Catarinense de Arquivos; } \\
\text { I Painel de Arquivos Municipais }\end{array}$ & 14-16 set. 1994 & Blumenau & \multirow{3}{*}{$\begin{array}{l}\text { Anais do VI, VII e VIII Encontro Catarinense de Arquivos. Florianópolis: } \\
\text { Secretaria de Estado da Administração, Associação de Amigos do Arquivo Público } \\
\text { do Estado, 2000. 413p. }\end{array}$} \\
\hline $\begin{array}{l}\text { VII Encontro Catarinense de Arquivos; } \\
\text { II Painel de Arquivos Municipais }\end{array}$ & 18-20 set. 1996 & Florianópolis & \\
\hline $\begin{array}{l}\text { VIII Encontro Catarinense de Arquivos; } \\
\text { III Painel de Arquivos Municipais }\end{array}$ & $14-16$ set. 1998 & Jaraguá do Sul & \\
\hline $\begin{array}{l}\text { IX Encontro Catarinense de Arquivos; } \\
\text { IV Painel de Arquivos Municipais }\end{array}$ & $6-8$ nov. 2000 & Blumenau & Publicação ainda não efetuada. \\
\hline $\begin{array}{l}\text { X Encontro Catarinense de Arquivos; } \\
\text { V Painel de Arquivos Municipais de SC }\end{array}$ & $2-4$ set. 2002 & Florianópolis & Publicação ainda não efetuada. \\
\hline $\begin{array}{l}\text { XI Encontro Catarinense de Arquivos; } \\
\text { VI Painel de Arquivos Municipais de SC }\end{array}$ & $13-15$ set. 2004 & Florianópolis & Publicação ainda não efetuada. \\
\hline
\end{tabular}

Fontes:

- Caderno de resumos do IX Encontro Catarinense de Arquivos e IV Painel de Arquivos Municipais - 6 a 8 de novembro de 2000 . Blumenau (SC): 2000. p.33.

- Programa do X Encontro Catarinense de Arquivos e V Painel de Arquivos Municipais - 2 a 4 de setembro de 2002. [2002]. Folder.

- Programa do XI Encontro Catarinense de Arquivos - 13 a 15 de setembro de 2004. [2004]. Folder.

- Os próprios anais publicados. 
Apêndice II-2

Entidades promotoras e apoiadoras dos encontros catarinenses de arquivos

\begin{tabular}{|c|c|}
\hline Edição do encontro & Entidades promotoras / apoiadoras \\
\hline $\begin{array}{l}\text { I Encontro de Arquivos Catarinenses } \\
(1984)\end{array}$ & $\begin{array}{l}\text { Secretaria de Estado da Justiça, por meio do Arquivo Público do Estado de Santa Catarina. } \\
\text { A coordenadora executiva do encontro foi Ana Lúcia Coutinho Locks e o organizador dos anais, Iaponan Soares. }\end{array}$ \\
\hline $\begin{array}{l}\text { II Encontro de Arquivos Catarinenses } \\
\text { (1986) }\end{array}$ & Secretaria de Estado da Justiça; Arquivo Público do Estado de Santa Catarina. \\
\hline $\begin{array}{l}\text { III Encontro de Arquivos Catarinenses; } \\
\text { I Painel de Arquivos Sul-Brasileiros } \\
\text { (1988) }\end{array}$ & $\begin{array}{c}\text { Secretaria de Estado da Administração, por meio da Coordenadoria de Documentação e Publicações, à qual passara a estar subordinado o } \\
\text { Arquivo Público do Estado de Santa Catarina; contou com o apoio do CNPq. } \\
\text { Walter Piazza organizou os Anais. }\end{array}$ \\
\hline $\begin{array}{l}\text { IV Encontro de Arquivos Catarinense; } \\
\text { II Painel de Arquivos Sul-Brasileiro } \\
\text { (1990) }\end{array}$ & $\begin{array}{r}\text { Secretaria de Estado da Administração, por meio da Coordenadoria de Documentação e Publicações e, dentro desta, pelo Arquivo Público } \\
\text { do Estado de Santa Catarina, além da Prefeitura Municipal de Joaçaba. } \\
\text { Contou com o apoio da Associação de Amigos do Arquivo Público e da Secretaria de Estado da Cultura e do Esporte. }\end{array}$ \\
\hline $\begin{array}{l}\text { V Encontro Catarinense } \\
\text { de Arquivos (1992) }\end{array}$ & $\begin{array}{c}\text { Secretaria de Estado da Justiça e Administração, por meio do Arquivo Público do Estado. } \\
\text { Apoio: UNIVALI - Universidade do Vale do Itajaí, Arquivo Histórico de Itajaí, Associação de Amigos do Arquivo Público, Associação } \\
\text { Catarinense de Conservadores e Restauradores, Gabinete de Comunicação Social do Governo do Estado, SANTUR - Santa Catarina } \\
\text { Turismo, Imprensa Oficial do Estado, Caixa Econômica Federal. Os respectivos anais foram organizados pelo Arquivo Público do Estado e } \\
\text { pela Associação de Amigos do Arquivo Público, com o apoio da Fundação Catarinense de Cultura (então dirigida por Iaponan Soares de } \\
\text { Araújo). }\end{array}$ \\
\hline $\begin{array}{l}\text { VI Encontro Catarinense de Arquivos; } \\
\text { I Painel de Arquivos Municipais } \\
\text { (1994) }\end{array}$ & $\begin{array}{l}\text { Secretaria de Estado da Justiça e Administração, por meio da Diretoria de Administração Organizacional e Patrimonial / Arquivo Público } \\
\text { do Estado de Santa Catarina; Associação de Amigos do Arquivo Público do Estado de Santa Catarina; Prefeitura Municipal de Blumenau e } \\
\text { Fundação Casa Dr. Blumenau, por meio do Arquivo Histórico José Ferreira da Silva. } \\
\text { Colaboração da Fundação Universidade Regional de Blumenau (por meio do Departamento de História e Geografia), da Associação } \\
\text { Catarinense de Conservadores e Restauradores de Bens Culturais e da Imprensa Oficial do Estado de SC. }\end{array}$ \\
\hline $\begin{array}{c}\text { VII Encontro Catarinense de Arquivos; } \\
\text { II Painel de Arquivos Municipais } \\
\text { (1996) }\end{array}$ & $\begin{array}{c}\text { Secretaria de Estado da Administração / Diretoria de Administração Patrimonial e Documentação, } \\
\text { por meio da Gerência do Arquivo Público do Estado de Santa Catarina; Associação de Amigos do Arquivo Público do Estado de Santa } \\
\text { Catarina; Prefeitura Municipal de Florianópolis (em especial por meio da Secretaria Municipal de Turismo e da Secretaria de } \\
\text { Administração Municipal); Secretaria de Estado do Governo; Centro Integrado de Cultura. } \\
\text { Colaboração da SANTUR - Santa Catarina Turismo, da Associação Catarinense de Conservadores e Restauradores de Bens Culturais, do } \\
\text { Banco do Estado de Santa Catarina e da Imprensa Oficial do Estado de SC. }\end{array}$ \\
\hline
\end{tabular}




\begin{tabular}{|c|c|}
\hline $\begin{array}{l}\text { VIII Encontro Catarinense de } \\
\text { Arquivos; III Painel de Arquivos } \\
\text { Municipais (1998) }\end{array}$ & $\begin{array}{c}\text { Secretaria de Estado da Administração / Diretoria de Administração Patrimonial e Documentação, } \\
\text { por meio da Gerência do Arquivo Público do Estado de Santa Catarina; Associação de Amigos do Arquivo Público do Estado de Santa } \\
\text { Catarina; Prefeitura Municipal de Jaraguá do Sul, em especial por meio do Arquivo Histórico Victor Schmöckel. } \\
\text { Colaboração da Associação Catarinense de Conservadores e Restauradores de Bens Culturais, da Secretaria Municipal de Cultura, Esporte } \\
\text { e Lazer de Jaraguá do Sul, da Secretaria Municipal de Desenvolvimento Econômico de Jaraguá do Sul e do Sindicato dos Trabalhadores na } \\
\text { Indústria do Vestuário de Jaraguá do Sul. }\end{array}$ \\
\hline $\begin{array}{l}\text { IX Encontro Catarinense de Arquivos; } \\
\text { IV Painel de Arquivos Municipais } \\
\text { (2000) }\end{array}$ & $\begin{array}{l}\text { Secretaria de Estado da Administração / Diretoria de Administração Patrimonial e Documentação, por meio da Gerência do Arquivo } \\
\text { Público do Estado de Santa Catarina; Associação de Amigos do Arquivo Público do Estado de Santa Catarina; Prefeitura Municipal de } \\
\text { Blumenau / Fundação Cultural de Blumenau, por meio do Arquivo Histórico José Ferreira da Silva. } \\
\text { Apoio: Secretaria de Estado de Governo, Secretaria de Estado da Casa Civil, Imprensa Oficial do Estado de SC. }\end{array}$ \\
\hline $\begin{array}{l}\text { X Encontro Catarinense de Arquivos; } \\
\text { V Painel de Arquivos Municipais de } \\
\text { SC (2002) }\end{array}$ & $\begin{array}{l}\text { Secretaria de Estado da Administração / Diretoria de Administração Patrimonial e Documentação, por meio da Gerência do Arquivo } \\
\text { Público do Estado de Santa Catarina; Associação de Amigos do Arquivo Público do Estado de Santa Catarina. } \\
\text { Apoio: Prefeitura Municipal de Florianópolis, Secretaria de Estado de Governo, Secretaria de Estado da Casa Civil, } \\
\text { Imprensa Oficial do Estado de SC e empresa ACECO - Soluções completas em Arquivamento. }\end{array}$ \\
\hline $\begin{array}{l}\text { XI Encontro Catarinense de Arquivos; } \\
\text { VI Painel de Arquivos Municipais de } \\
\text { SC (2004) }\end{array}$ & $\begin{array}{l}\text { Secretaria de Estado da Administração, por meio da Diretoria de Arquivo Público; } \\
\text { Associação de Amigos do Arquivo Público do Estado de Santa Catarina. } \\
\text { Colaboração: Associação Catarinense de Conservadores e Restauradores de Bens Culturais; } \\
\text { empresa ACECO - Soluções completas em Arquivamento. }\end{array}$ \\
\hline
\end{tabular}

Fontes:

- Anais do $5^{\circ}$. Encontro Catarinense de Arquivos. Florianópolis: Fundação Catarinense de Cultura, Associação de Amigos do Arquivo Público, 1992.

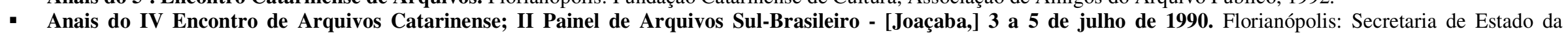
Administração, 1990.

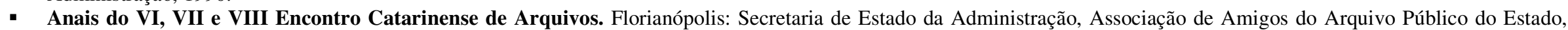
2000 .

- Caderno de resumos do IX Encontro Catarinense de Arquivos e IV Painel de Arquivos Municipais - 6 a 8 de novembro de 2000. Blumenau (SC): 2000.

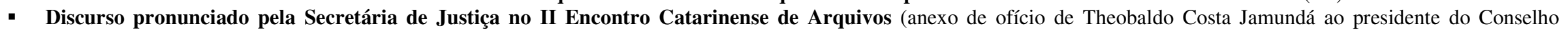
Estadual de Cultura, 24 de setembro de 1986). Acervo do Arquivo Público do Estado de Santa Catarina, Fundo Arquivo Público, GIV, SGIV.1, 60-1984-1996.

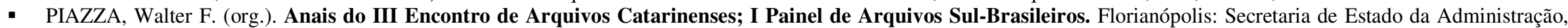
Coordenadoria de Documentação e Publicações, Arquivo Público, 1988.

- Programa do X Encontro Catarinense de Arquivos e V Painel de Arquivos Municipais - 2 a 4 de setembro de 2002. [2002]. Folder

- Programa do XI Encontro Catarinense de Arquivos - 13 a 15 de setembro de 2004. [2004]. Folder.

- SOARES, Iaponan (org.). Arquivos \& Documentos em Santa Catarina. Florianópolis: Secretaria da Justiça, Arquivo Público do Estado, 1985. 
Apêndice II-3

Objetivos dos encontros catarinenses de arquivos

\begin{tabular}{|c|c|}
\hline Edição do encontro & Objetivos \\
\hline $\begin{array}{l}\text { I Encontro de Arquivos } \\
\text { Catarinenses (1984) }\end{array}$ & $\begin{array}{l}\text { Segundo discurso da Secretária Estadual de Justiça, Heliete Marly Filomeno Leal, contido nos anais do I Encontro de Arquivos Catarinenses, o } \\
\text { evento manifestou "o propósito da Secretaria da Justiça e Arquivo Público em pretender organizar e inovar a dinâmica arquivística em nosso } \\
\text { Estado, tendo como ponto fundamental, preservar a memória catarinense e estimular a comunicação entre instituições congêneres." } \\
\text { Iaponan Soares, então diretor do Arquivo Público do Estado de Santa Catarina, inseriu o encontro nas metas do governo estadual de Esperidião } \\
\text { Amin, traduzido na "Carta dos Catarinenses", especificamente o que entendeu ser a meta de "preservação da identidade catarinense", } \\
\text { compreendendo ainda ser o documento "parcela importante dessa identidade", sendo que "preservá-lo significa assegurar seus traços culturais e } \\
\text { garantir os direitos e privilégios [sic] nas relações entre o cidadão e o Estado." (1) } \\
\text { Segundo a coordenadora executiva do encontro, Ana Lúcia Coutinho Locks, o evento "constituiu um esforço no sentido de compreender a } \\
\text { realidade atual dos Arquivos Catarinenses e suas perspectivas globais de transformações", podendo seus objetivos serem sintetizados em quatro: } \\
\text { "discutir e identificar as dificuldades do setor"; "estimular o intercâmbio de experiências profissionais, tendo em vista as dificuldades comuns"; } \\
\text { "sugerir uma política de divulgação do Arquivo junto à comunidade"; "possibilitar um maior aperfeiçoamento na organização do acervo arquival, } \\
\text { através do questionamento dos diferentes métodos e técnicas possíveis de adequação." (2) }\end{array}$ \\
\hline $\begin{array}{l}\text { II Encontro de Arquivos } \\
\text { Catarinenses (1986) }\end{array}$ & Não foram localizadas informações a este respeito. \\
\hline $\begin{array}{l}\text { III Encontro de Arquivos } \\
\text { Catarinenses; I Painel de } \\
\text { Arquivos Sul-Brasileiros (1988) }\end{array}$ & $\begin{array}{l}\text { Para o então Secretário Estadual de Administração, Antônio Niccolló Grillo, o evento teve sua organização relacionada à necessidade de "uma } \\
\text { melhor coordenação dos trabalhos" de implantação do Subsistema Estadual de Arquivos. (3) }\end{array}$ \\
\hline $\begin{array}{l}\text { IV Encontro de Arquivos } \\
\text { Catarinense [sic]; } \\
\text { II Painel de Arquivos Sul- } \\
\text { Brasileiro (1990) }\end{array}$ & $\begin{array}{l}\text { Nos anais do IV Encontro, os objetivos não são explicitados, mas os trabalhos publicados sugerem a continuidade da preocupação com a } \\
\text { implantação e consolidação do Subsistema Estadual de Arquivos de Santa Catarina. }\end{array}$ \\
\hline $\begin{array}{l}\text { V Encontro Catarinense } \\
\text { de Arquivos (1992) }\end{array}$ & $\begin{array}{l}\text { Nos anais do V Encontro, no discurso do Secretário de Estado da Justiça e Administração, Rainoldo Uessler, assinala-se que o evento objetivava } \\
\text { "contribuir para a preservação do patrimônio documental, e, conseqüentemente, o engrandecimento cultural do nosso povo." Mais adiante, } \\
\text { ressalta "a importância da preservação e divulgação do patrimônio documental para o resgate da memória de um povo." (4) }\end{array}$ \\
\hline $\begin{array}{c}\text { VI Encontro Catarinense de } \\
\text { Arquivos; I Painel de Arquivos } \\
\text { Municipais (1994) }\end{array}$ & Os objetivos não foram explicitados nos anais. \\
\hline $\begin{array}{c}\text { VII Encontro Catarinense de } \\
\text { Arquivos; II Painel de Arquivos } \\
\text { Municipais (1996) }\end{array}$ & Os objetivos não foram explicitados nos anais. \\
\hline $\begin{array}{l}\text { VIII Encontro Catarinense de } \\
\text { Arquivos; III Painel de } \\
\text { Arquivos Municipais (1998) }\end{array}$ & Os objetivos não foram explicitados nos anais. \\
\hline
\end{tabular}




\begin{tabular}{|c|c|}
\hline $\begin{array}{l}\text { IX Encontro Catarinense de } \\
\text { Arquivos; } \\
\text { IV Painel de Arquivos } \\
\text { Municipais (2000) }\end{array}$ & $\begin{array}{l}\text { "Reunir profissionais de arquivos e áreas afins, visando o aprimoramento técnico dos conhecimentos arquivísticos, proporcionando-lhes a } \\
\text { oportunidade de troca de experiências e vivências municipais e regionais." (5) }\end{array}$ \\
\hline $\begin{array}{l}\text { X Encontro Catarinense de } \\
\text { Arquivos; } \\
\text { V Painel de Arquivos } \\
\text { Municipais de SC (2002) }\end{array}$ & $\begin{array}{l}\text { "Reunir profissionais de arquivos e de áreas afins, visando o aprimoramento técnico dos conhecimentos arquivísticos, proporcionando-lhes a } \\
\text { oportunidade de troca de experiências e vivências"; "proporcionar condições para uma reflexão sobre os novos rumos da arquivística, condição } \\
\text { indispensável para a evolução das metodologias"; "sugerir uma política de gestão documental com vistas à preservação da história } \\
\text { contemporânea, cujos acervos se encontram depositados em locais impróprios"; "discutir políticas arquivísticas, incentivando os responsáveis pela } \\
\text { administração dos arquivos para uma atividade mais dinâmica e melhorias no atendimento ao cidadão"; "ressaltar os aspectos legais e } \\
\text { constitucionais sobre a necessidade da preservação da memória documental". (6) }\end{array}$ \\
\hline $\begin{array}{l}\text { XI Encontro Catarinense de } \\
\text { Arquivos; } \\
\text { VI Painel de Arquivos } \\
\text { Municipais de SC (2004) }\end{array}$ & $\begin{array}{l}\text { O evento objetivava "o aprimoramento técnico dos conhecimentos arquivísticos", proporcionado a "profissionais de arquivo, de modo geral } \\
\text { (públicos, privados, culturais, escolares...), profissionais de história, sociologia, biblioteconomia, museologia, entre outros, bem como alunos e } \\
\text { professores dos diversos cursos ligados de alguma maneira a questões de arquivos e pessoas preocupadas e envolvidas com a preservação da } \\
\text { memória das comunidades", a "oportunidade de troca de experiências e vivências." (7) }\end{array}$ \\
\hline
\end{tabular}

Fontes:

1. SOARES, Iaponan (org.). Arquivos \& Documentos em Santa Catarina. Florianópolis: Secretaria da Justiça, Arquivo Público do Estado, 1985. Respectivamente p.10 e 7.

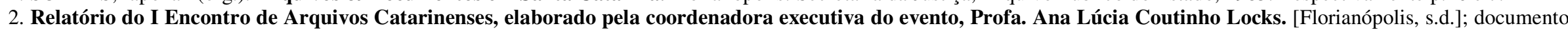
datilografado. Acervo do Arquivo Público do Estado de Santa Catarina, Fundo Arquivo Público, G IV, SG IV.1, 60-1984-1996, s.10.

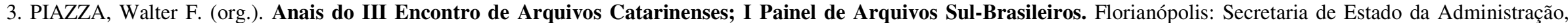
Coordenadoria de Documentação e Publicações, Arquivo Público, 1988. p.3.

4. Anais do 50 Encontro Catarinense de Arquivos. Florianópolis: Fundação Catarinense de Cultura, Associação de Amigos do Arquivo Público, 1992. p.13-14.

5. Segunda circular do IX Encontro Catarinense de Arquivos. Agosto de 2000. Arquivo pessoal (Janice Gonçalves).

6. Programa do X Encontro Catarinense de Arquivos e V Painel de Arquivos Municipais - 2 a 4 de setembro de 2002. Folder.

7. Programa do XI Encontro Catarinense de Arquivos - 13 a 15 de setembro de 2004. Folder.

Também consultados:

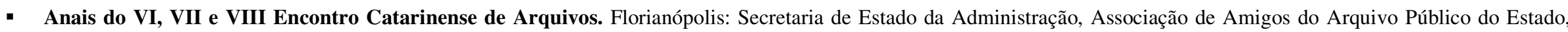
2000.

- Anotações realizadas durante o VIII, IX, o X e o XI Encontro Catarinense de Arquivos (1998 a 2004). Arquivo pessoal (Janice Gonçalves).

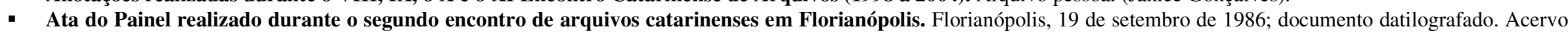
do Arquivo Público do Estado de Santa Catarina, Fundo Arquivo Público, GIV, SG IV.1, 60-1984-1996, s.7.

- Caderno de resumos do IX Encontro Catarinense de Arquivos e IV Painel de Arquivos Municipais - 6 a 8 de novembro de 2000 . Blumenau (SC): 2000. p.33.

- Caderno de resumos do VIII Encontro Catarinense de Arquivos e III Painel de Arquivos Municipais - 14 a 16 de setembro de 1998. Jaraguá do Sul (SC): 1998.

- Programa do VIII Encontro Catarinense de Arquivos e III Painel de Arquivos Municipais - 14 a 16 de setembro de 1998. Folder. 
Apêndice II-4

Principais atividades dos encontros catarinenses de arquivos

\begin{tabular}{|c|c|}
\hline Edição do encontro & Principais atividades dos encontros \\
\hline $\begin{array}{c}\text { I Encontro de } \\
\text { Arquivos } \\
\text { Catarinenses (1984) }\end{array}$ & $\begin{array}{l}\text { - } 1 \text { conferência de representante do Arquivo Nacional; } \\
\text { - } 1 \text { conferência de representante da Associação dos Arquivistas Brasileiros; } \\
\text { - } 1 \text { conferência de professora de pós-graduação em Arquivologia (PUC-RS) e arquivista/historiógrafa do Arquivo Histórico do RS; } \\
\text { - } 1 \text { conferência de especialista em microfilmagem (USP); } \\
\text { - } 3 \text { comunicações de pesquisadores de arquivos atuantes em SC; } \\
\text { - } 1 \text { comunicação de representantes do Arquivo Público do Estado; } \\
\text { - } 2 \text { comunicações de arquivos municipais (Arquivo de Blumenau, Arquivo de São Bento do Sul); } \\
\text { - } 4 \text { comunicações de representantes de arquivos eclesiásticos catarinenses (Arquivo Histórico Eclesiástico de SC, Arquivo Histórico da Sociedade das Irmãs } \\
\text { da Divina Providência, Arquivo Provincial Padre Lux, Arquivo da Diocese de Joinville - Província Eclesiástica de Florianópolis); } \\
\text { - } 4 \text { comunicações de representantes de setores da Universidade Federal de Santa Catarina (Biblioteca Universitária da UFSC, Laboratório de História Oral, } \\
\text { Laboratório de História Demográfica, Coordenação do Plano Nacional de Microfilmagem de Periódicos Brasileiros em SC). } \\
\text { - } 3 \text { comunicações apresentadas por representantes de órgãos públicos ligados à administração estadual de Santa Catarina na esfera do Poder Judiciário } \\
\text { (PRODASC, Tribunal de Justiça, Tribunal Regional Eleitoral), esta última não sendo apresentada (mas tendo o texto sido fornecido para publicação). } \\
\text { - } 1 \text { comunicação de representante do Arquivo Histórico do RS. }\end{array}$ \\
\hline $\begin{array}{c}\text { II Encontro de } \\
\text { Arquivos } \\
\text { Catarinenses (1986) }\end{array}$ & $\begin{array}{l}\text { Foram localizadas apenas informações referentes à realização, no encerramento do evento, de um painel onde "representantes das várias entidades públicas e } \\
\text { particulares do Estado tomaram a palavra durante cinco minutos para expor a situação dos arquivos catarinenses", a saber: } \\
\text { - Arquivo da Sociedade da Divina Providência; } \\
\text { - Arquivo de Azambuja; } \\
\text { - Arquivo Diocesano de Joinville; } \\
\text { - Centro Cultural de São Joaquim; } \\
\text { - Centro Regional de Pesquisa Histórica Criciumense; } \\
\text { - Museu Histórico Antônio Granemann de Souza (Curitibanos); } \\
\text { - Museu Histórico Thiago de Castro; } \\
\text { - Seção de Coleções Especiais da Biblioteca Central da UFSC; } \\
\text { - Universidade para o Desenvolvimento do Estado de SC (UDESC). }\end{array}$ \\
\hline $\begin{array}{c}\text { III Encontro de } \\
\text { Arquivos } \\
\text { Catarinenses; } \\
\text { I Painel de Arquivos } \\
\text { Sul-Brasileiros } \\
\text { (1988) }\end{array}$ & $\begin{array}{l}\text { - } 3 \text { comunicações de representantes do Arquivo Público do Estado; } \\
\text { - } 7 \text { comunicações de representantes de órgãos públicos ligados à administração estadual, nas esferas do Poder Executivo, Legislativo e Judiciário } \\
\text { (Coordenadoria de Documentação e Publicações da Secretaria de Estado da Administração, Secretaria de Estado da Educação, Fundação Hospitalar de Santa } \\
\text { Catarina, Assembléia Legislativa do Estado de Santa Catarina, Tribunal de Justiça do Estado, FATMA, CELESC); } \\
\text { - } 1 \text { comunicação de representante de órgão público ligado à administração federal (ELETROSUL); } \\
\text { - } 4 \text { comunicações/trabalhos de arquivos e centros de documentação de outros estados (Santa Casa de Misericórdia de Porto Alegre, Arquivo Histórico do Rio } \\
\text { Grande do Sul, Centro de Lógica, Epistemologia e História da Ciência- UNICAMP e Centro de Memória-UNICAMP); } \\
\text { - } 4 \text { comunicações de representantes de arquivos municipais catarinenses (Blumenau, Itajaí, Joinville - 2). }\end{array}$ \\
\hline
\end{tabular}




\begin{tabular}{|c|c|}
\hline \begin{tabular}{|c} 
IV Encontro de \\
Arquivos \\
Catarinense [sic]; \\
II Painel de Arquivos \\
Sul-Brasileiro (1990)
\end{tabular} & $\begin{array}{l}\text { - } 1 \text { conferência de representante do Arquivo Nacional; } \\
\text { - } 1 \text { comunicação de pesquisador de arquivo (historiador) catarinense; } \\
-6 \text { comunicações de representantes do Arquivo Público do Estado de SC; } \\
\text { - } 6 \text { comunicações de representantes de arquivos municipais catarinenses ou de interessados na implantação de determinados arquivos (Campos Novos, } \\
\text { Curitibanos, Imaruí, Itajaí, Joaçaba, Joinville); } \\
\text { - } 1 \text { comunicação de representante de sistema de arquivos universitário (UFSC); } \\
\text { - } 2 \text { comunicações de representantes de arquivos públicos estaduais (PR e RS). }\end{array}$ \\
\hline $\begin{array}{c}\text { V Encontro } \\
\text { Catarinense } \\
\text { de Arquivos (1992) }\end{array}$ & $\begin{array}{l}\text { - } 1 \text { conferência de representante do Arquivo Nacional;* } \\
\text { - } 4 \text { conferências de arquivistas com atuação destacada fora de SC (professora de Graduação em Arquivologia - UnB, representante do arquivo de Rio Claro- } \\
\text { SP, representante do arquivo de São Paulo-SP, representante do arquivo de Uberaba-MG); } \\
\text { - } 1 \text { comunicação de representante do Arquivo Público do Estado de SC; } \\
\text { - } 5 \text { comunicações de representantes de arquivos municipais catarinenses ou de interessados na implantação de determinados arquivos (Balneário Camboriú, } \\
\text { Blumenau, Ipumirim, Itajaí, São José); } \\
\text { - } 1 \text { comunicação de representante de órgão do Poder Executivo estadual (TRE-SC); } \\
\text { - } 1 \text { comunicação de representante de sistema de arquivos universitário (UFSC*); } \\
\text { - } 1 \text { comunicação de pesquisadora de arquivo (arquiteta) atuante em SC; } \\
\text { - } 2 \text { comunicações de representantes de instituições arquivísticas de outros Estados (Arquivo da Câmara de Curitiba***, Arquivo da Santa Casa de } \\
\text { Misericórdia de Porto Alegre*); } \\
\text { - } 3 \text { oficinas. }\end{array}$ \\
\hline $\begin{array}{r}\text { VI En } \\
\text { Catarin } \\
\text { Arqu } \\
\text { I Painel de } \\
\text { Municipa }\end{array}$ & $\begin{array}{l}\text { - } 3 \text { conferências de arquivistas com atuação destacada fora de SC (duas professoras da USP** e uma da UFRGS); } \\
\text { - } 1 \text { comunicação de representantes do Arquivo Público do Estado de SC; } \\
\text { - } 14 \text { comunicações de representantes de arquivos e fundações culturais municipais catarinenses (Balneário Camboriú*, Blumenau, Campos Novos*, } \\
\text { Chapecó*, Criciúma*, Indaial, Itaiópolis, Itajaí - 3, Jaraguá do Sul*, Joinville*, Tubarão, São José*); } \\
\text { - } 1 \text { comunicação de representante de empresa catarinense (Cia. Hering Têxtil - Blumenau*); } \\
\text { - } 1 \text { comunicação de representante de órgão de preservação (IBPC); } \\
\text { - } 1 \text { comunicação de representantes de curso universitário (UFPR); } \\
\text { - } 2 \text { comunicações de representantes de entidades de pesquisa (SBPH e IHGSC*); } \\
\text { - } 3 \text { comunicações de representantes de instituições arquivísticas de outros estados (Arquivo de Uberaba*, Santa Casa de Misericórdia de Porto Alegre - 2**); } \\
\text { - } 2 \text { oficinas. }\end{array}$ \\
\hline $\begin{array}{c}\text { VII Encontro } \\
\text { Catarinense de } \\
\text { Arquivos; } \\
\text { II Painel de Arquivos } \\
\text { Municipais (1996) }\end{array}$ & $\begin{array}{l}\text { - } 2 \text { conferências de representante do Arquivo Nacional;** } \\
\text { - } 2 \text { conferências de arquivistas com atuação destacada fora de SC (uma professora da USP e a presidente do Fórum Nacional de Dirigentes de Arquivos } \\
\text { Municipais); } \\
\text { - } 1 \text { conferência de consultor de empresa catarinense da área de processamento de imagem;* } \\
\text { - } 1 \text { conferência de especialista em conservação da Fundação Catarinense de Cultura;* } \\
\text { - } 1 \text { conferência de empresária na área de organização de documentos de arquivo (empresa Documentar - MG);* } \\
\text { - } 1 \text { comunicação de consultora de organização de documentos de empresa catarinense (Portobello); } \\
\text { - } 1 \text { comunicação de representante do Arquivo Público do Estado de SC; } \\
\text { - } 4 \text { comunicações de representantes de arquivos municipais catarinenses (Blumenau*, Florianópolis, Itajaí, Jaraguá do Sul); }\end{array}$ \\
\hline
\end{tabular}




\begin{tabular}{|c|c|}
\hline & $\begin{array}{l}\text { - } 1 \text { comunicação de representante de arquivo de Núcleo de Documentação universitário (UFF); } \\
\text { - } 4 \text { comunicações de representantes de entidade de pesquisa (Núcleo de Estudos Portugueses/UFSC - 3; Centro de Documentação e Pesquisa da Irmandade } \\
\text { Santa Casa de Misericórdia de Porto Alegre); } \\
\text { - } 2 \text { comunicações de representantes de cursos universitários (UnB, UFRGS*); } \\
\text { - } 1 \text { comunicação de representantes de órgão público municipal de outro Estado (Departamento de Água e Esgotos da Prefeitura de Porto Alegre). }\end{array}$ \\
\hline $\begin{array}{c}\text { VIII Encontro } \\
\text { Catarinense de } \\
\text { Arquivos; } \\
\text { III Painel de } \\
\text { Arquivos Municipais } \\
\text { (1998) }\end{array}$ & $\begin{array}{l}\text { - } 1 \text { conferência de representante do Arquivo Nacional/CONARQ; } \\
\text { - } 1 \text { conferência de arquivista com atuação destacada fora de SC (presidente do Fórum Nacional de Dirigentes de Arquivos Municipais*); } \\
\text { - } 1 \text { comunicação de representante do Arquivo Público do Estado de SC; } \\
\text { - } 7 \text { comunicações de representantes de arquivos e fundações culturais municipais catarinenses (Blumenau*, Brusque*, Campos Novos, Itajaí*, Rio do Sul*, } \\
\text { São José, Tubarão); } \\
\text { - } 4 \text { comunicações de representantes de instituições custodiadoras de documentos/de preservação do patrimônio arquivístico de outros Estados (Arquivo } \\
\text { Central da FGV-RJ; Fundação Pró-Memória de Indaiatuba - SP; Fundação Patrimônio Histórico da Energia de São Paulo*; Biblioteca Pública Álvares de } \\
\text { Azevedo - SP); } \\
\text { - } 1 \text { comunicação de representante de entidade de pesquisa (IHGEPR*); } \\
\text { - } 1 \text { comunicação de representante de projeto nacional de levantamento e reprodução de documentos (Projeto Resgate); } \\
\text { - } 2 \text { comunicações de representantes de arquivo universitário (UFSM/Hospital universitário, arquivo do Núcleo de Documentação da UFF*); } \\
\text { - } 4 \text { comunicações de representantes de cursos universitários (graduação e pós-graduação) (UFPR, UFSM, UFSC*, UDESC); } \\
\text { - } 1 \text { comunicação de pesquisadora da área de História (UNESP); } \\
\text { - } 1 \text { projeção de vídeo (sobre o rádio em Jaraguá do Sul); } \\
\text { - } 5 \text { cursos. }\end{array}$ \\
\hline $\begin{array}{c}\text { IX Encontro } \\
\text { Catarinense de } \\
\text { Arquivos; } \\
\text { IV Painel de } \\
\text { Arquivos Municipais } \\
\text { (2000) }\end{array}$ & $\begin{array}{l}\text { - } 1 \text { conferência de representante do Arquivo Nacional/CONARQ; } \\
\text { - } 1 \text { conferência de especialista em recursos humanos; } \\
\text { - } 4 \text { conferências de arquivistas/profissionais da área de preservação com atuação destacada fora de Santa Catarina (Arquivo do Estado de São Paulo/ SAESP; } \\
\text { Fórum Nacional de Dirigentes de Arquivos Municipais; Centro de Conservação e Restauração de Bens Culturais/UFMG*; Ministério da Cultura); } \\
\text { - } 7 \text { comunicações de representantes de arquivos e fundações culturais municipais de SC (Blumenau, Campos Novos*, Itajaí, Jaraguá do Sul, São José); } \\
\text { - } 2 \text { comunicações de representantes de órgãos públicos estaduais (Secretaria de Estado da Administração, Tribunal de Contas do Estado); } \\
\text { - } 2 \text { comunicações de representante de sistema de arquivos universitários (UFSC, UFPA); } \\
\text { - } 8 \text { comunicações de representantes de cursos universitários (graduação e pós-graduação) (FURB, UDESC - 2, UFSM - 2, UEL, UFPR, UNI-Rio*); } \\
\text { - } 2 \text { comunicações de representante de arquivo de instituição de pesquisa (Fundação Casa de Rui Barbosa-RJ, Arquivo Edgar Leuenroth/UNICAMP); } \\
\text { - } 1 \text { comunicação de representante de instituições arquivísticas de outros estados (Arquivo Público do RS). }\end{array}$ \\
\hline $\begin{array}{c}\text { X Encontro } \\
\text { Catarinense de } \\
\text { Arquivos; } \\
\text { V Painel de Arquivos } \\
\text { Municipais de SC } \\
\text { (2002) }\end{array}$ & $\begin{array}{l}\text { - } 3 \text { conferências de arquivistas / profissionais da área de preservação do patrimônio cultural com atuação destacada fora de SC (presidente do Fórum } \\
\text { Nacional de Dirigentes de Arquivos Municipais; IPHAN; UNI-Rio); } \\
\text { - } 1 \text { conferência de especialista em motivação; } \\
\text { - } 1 \text { conferência de pesquisador do folclore catarinense; } \\
\text { - } 2 \text { comunicações de representantes de órgãos públicos estaduais catarinenses (Secretarias de Estado da Fazenda e da Administração); } \\
\text { - } 8 \text { comunicações de representantes de instituições de pesquisa/custodiadoras de acervos (FIOCRUZ*, CEDAE/Campinas; CEDIC/PUC-SP - 2, Centro de } \\
\text { Documentação e Museus do Oeste de Santa Catarina*; Centro de Memória/UNICAMP*, Museu de Arte Contemporânea -USP, Fundação Pró-Memória de } \\
\text { Indaiatuba***); } \\
\text { - } 4 \text { comunicações de representantes de cursos universitários (UDESC - 2, UFPR, Universidade de Caxias do Sul*); }\end{array}$ \\
\hline
\end{tabular}




\begin{tabular}{|c|c|}
\hline & $\begin{array}{l}\text { - } 4 \text { comunicações/trabalhos de representantes de arquivos municipais catarinenses (Florianópolis, Itajaí, Jaraguá do Sul, Timbó); } \\
\text { - } 2 \text { comunicações de representantes de prefeituras municipais (Indaiatuba e Florianópolis); } \\
\text { - } 1 \text { comunicação de representante do GT Arquivos do Poder Judiciário - DF; } \\
\text { - } 4 \text { oficinas. }\end{array}$ \\
\hline $\begin{array}{c}\text { XI Encontro } \\
\text { Catarinense de } \\
\text { Arquivos; } \\
\text { VI Painel de } \\
\text { Arquivos Municipais } \\
\text { de SC (2004) }\end{array}$ & $\begin{array}{l}\text { - } 1 \text { conferência de representante do Arquivo Nacional/CONARQ; } \\
\text { - } 2 \text { conferências de arquivistas com atuação destacada fora de SC (professora da USP; presidente do Fórum Nacional de Dirigentes de Arquivos Municipais); } \\
\text { - } 1 \text { conferência de especialista na área de preservação do patrimônio cultural (IPHAN); } \\
\text { - } 1 \text { conferência de especialista em administração pública; } \\
\text { - } 1 \text { conferência de pesquisador do folclore catarinense; } \\
\text { - } 1 \text { conferência e } 2 \text { comunicações de representantes de cursos universitários (UDESC, Faculdade Assis Gurcacz - PR); } \\
\text { - } 1 \text { comunicação de pesquisador catarinense da área de História; } \\
\text { - } 1 \text { comunicação de representante da Associação de Amigos do Arquivo Público do Estado de Santa Catarina; } \\
\text { - } 1 \text { comunicação de representante de arquivo de empresa (Cooperativa Agrária Mista Entre Rios); } \\
\text { - } 2 \text { comunicações de representante do Fórum de Arquivos do RS; } \\
\text { - } 7 \text { comunicações de representantes de arquivos municipais catarinenses (Biguaçu, Blumenau, Brusque, Florianópolis, Itajaí, Joinville, São José). }\end{array}$ \\
\hline
\end{tabular}

* consta do programa mas não dos anais / não apresentada; ** uma apresentação consta do programa mas não dos anais; *** consta dos anais mas não do programa / inclusão durante o evento;

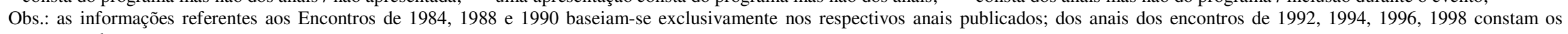
programas dos eventos.

Fontes:

- Anais do 50. Encontro Catarinense de Arquivos. Florianópolis: Fundação Catarinense de Cultura, Associação de Amigos do Arquivo Público, 1992.

- Anais do IV Encontro de Arquivos Catarinense; II Painel de Arquivos Sul-Brasileiro - [Joaçaba,] 3 a 5 de julho de 1990. Florianópolis: Secretaria de Estado da Administração, 1990.

- Anais do VI, VII e VIII Encontro Catarinense de Arquivos. Florianópolis: Secretaria de Estado da Administração, Associação de Amigos do Arquivo Público do Estado, 2000.

- Anotações realizadas durante o VIII, o IX, o X e o XI Encontro Catarinenses de Arquivos (1998 a 2004). Arquivo pessoal (Janice Gonçalves).

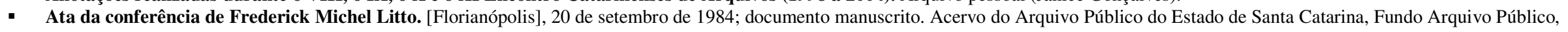
G IV, SG IV.1, 60-1984-1996, s.7.

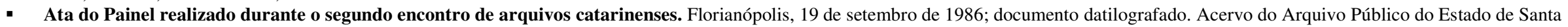
Catarina, Fundo Arquivo Público, GIV, SG IV.1, 60-1984-1996, s.7.

- Caderno de resumos do IX Encontro Catarinense de Arquivos e IV Painel de Arquivos Municipais - 6 a 8 de novembro de 2000. Blumenau (SC): 2000. p.33.

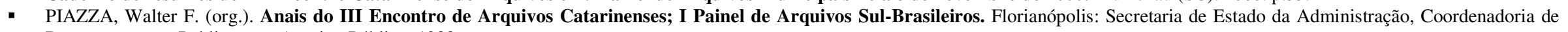
Documentação e Publicações, Arquivo Público, 1988.

- Programa do X Encontro Catarinense de Arquivos e V Painel de Arquivos Municipais - 2 a 4 de setembro de 2002. [2002]. Folder

- Programa do XI Encontro Catarinense de Arquivos - 13 a 15 de setembro de 2004. [2004]. Folder.

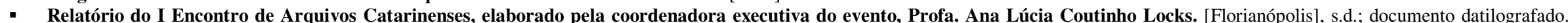
Acervo do Arquivo Público do Estado de Santa Catarina, Fundo Arquivo Público, G IV, SG IV.1, 60-1984-1996, s.10.

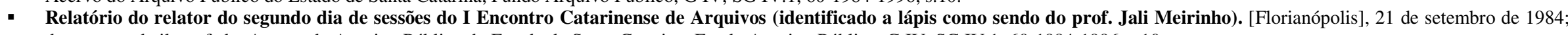
documento datilografado. Acervo do Arquivo Público do Estado de Santa Catarina, Fundo Arquivo Público, G IV, SG IV.1, 60-1984-1996, s.10.

- SOARES, Iaponan (org.). Arquivos \& Documentos em Santa Catarina. Florianópolis: Secretaria da Justiça, Arquivo Público do Estado, 1985. 
Apêndice II-5

Participantes que integraram a programação dos encontros catarinenses de arquivos*

* entre os apresentadores de comunicação foram considerados apenas os que participaram de mais de um encontro.

\begin{tabular}{|c|c|c|c|c|c|c|c|c|c|c|c|c|}
\hline \multirow[t]{2}{*}{ Participantes } & \multicolumn{11}{|c|}{ Modalidade de participação /Ano } & \multirow[t]{2}{*}{ Obs. } \\
\hline & 1984 & 1986 & 1988 & 1990 & 1992 & 1994 & 1996 & 1998 & 2000 & 2002 & 2004 & \\
\hline Adélia dos Santos Silveira & & & & & & & $\mathrm{CdM}$ & & & & & \\
\hline Álvaro Jorge Loro & & & & & & & & & & $\mathrm{Cf}$ & & \\
\hline Amadio Vetoretti & & & & & & Com & & Com & & & & \\
\hline Ana Lúcia C. Locks & Rel & & Com & & & & & & & & & \\
\hline Ana Maria de Almeida Camargo & & & & & & $\mathrm{Cf}$ & & & & & & \\
\hline Ana Maria Penha Mena Pagnocca & & & & & $\mathrm{Cf}$ & & & & & & & \\
\hline Ana Maria Soares M.de Araújo & Com & & & & Com & & & & $\mathrm{CdM}$ & $\mathrm{CdO}$ & & \\
\hline Ana Regina Berwanger & & & & & & Of; Cf & Com & & & Of & & \\
\hline Angelo Ricardo Christoffoli & & & & & Com & Com & & & & & & \\
\hline Anna Martha Rabuscke & Com & Com & & & & & & & & & & \\
\hline Carlos Augusto Ditadi & & & & & & & $\mathrm{Cf}$ & & & & & \\
\hline Carlos Osvaldo de Farias & & & & & & & & & & & $2 \mathrm{CdM}$ & \\
\hline Clarisse Leal & & & & & & & & & $\mathrm{Cf}$ & & & \\
\hline Cristina Ferreira & & & & & & Com & & Com & $\begin{array}{l}\text { Com; } \\
\text { CdM }\end{array}$ & & & \\
\hline Daíse Apparecida Oliveira & & & & & Of; $\mathrm{Cf}$ & Of & $\mathrm{Cf}$ & $\mathrm{Cf}$ & $\begin{array}{l}\mathrm{Cf} \\
\mathrm{CdM}\end{array}$ & Of; $\mathrm{Cf}$ & $\mathrm{Cf}$ & $\begin{array}{l}\text { Em 1996, texto em co-autoria (Ieda } \\
\text { Pimenta Bernardes). }\end{array}$ \\
\hline Daniel Flores & & & & & & & & Com & 2 Com & & & \\
\hline Denise Magda Thomasi & & & & & Of & & $\mathrm{Cf}$ & Cur & & & & \\
\hline Denise Molon Castanho & & & & & & & & Com & Com & & & Não compareceu em 1998. \\
\hline Dirlei Maria Kafer Gonçalves & & & & & & & & & & & $\mathrm{CdM}$ & \\
\hline Édison d'Ávila & & & Com & Com & & $\begin{array}{l}\mathrm{CdM} \\
\text { Com }\end{array}$ & $\mathrm{CdM}$ & $\mathrm{CdM}$ & $\mathrm{CdM}$ & CdM & & \\
\hline Egon Lotário Jagnow & & & & & & Com & Com & $\mathrm{CdM}$ & Com & & & \\
\hline Eliane Veras da Veiga & & & & & Com & & & & & Com & & \\
\hline Eloiza Maria Baggio & & & & Com & & Com & & & & & & \\
\hline Enedy Fátima Padilha da Rosa & & & & & & & & Com & Com & & Com & Não compareceu em 2000. \\
\hline Eneida Raquel S.Thiago & & Com & Com & & & & & & & & & \\
\hline Eni Barbosa & $\mathrm{Cf}$ & & & & & & & & & & & \\
\hline Esther Caldas Bertolletti & & & & & & & & & $\mathrm{Cf}$ & & & \\
\hline
\end{tabular}




\begin{tabular}{|c|c|c|c|c|c|c|c|c|c|c|c|c|}
\hline \multirow[t]{2}{*}{ Participantes } & \multicolumn{11}{|c|}{ Modalidade de participação /Ano } & \multirow[t]{2}{*}{ Obs. } \\
\hline & 1984 & 1986 & 1988 & 1990 & 1992 & 1994 & 1996 & 1998 & 2000 & 2002 & 2004 & \\
\hline Frederick Michel Litto & $\mathrm{Cf}$ & & & & & & & & & & & \\
\hline Gelci José Coelho & & & & & & & & & & $\mathrm{Cf}$ & $\mathrm{Cf}$ & \\
\hline Gilberto José Salvato & & & Com & & Com & & & & & & & \\
\hline Gilmar Antônio Moretti & & & & & & & & $\mathrm{ExV}$ & & & & \\
\hline Gilson Cruz de Oliveira & & & & & & & Com & Cur & & & & \\
\hline Helena de Fátima Nunes Silva & & & & & Com & Com & & & & & & \\
\hline Heloísa Liberalli Bellotto & & Cf? & & & Cf; Of & $\mathrm{Cf}$ & $\mathrm{Cf}$ & & & & $\begin{array}{c}\text { Cf; } \\
\text { LçL }\end{array}$ & \\
\hline Ieda Pimenta Bernardes & & & & & & & & & $\mathrm{Cf}$ & & & \\
\hline Jali Meirinho & Rel & & & & & & & & & & & \\
\hline Jaime Antunes da Silva & & & & & $\mathrm{Cf}$ & & $\mathrm{Cf}$ & & & & $\mathrm{Cf}$ & Não compareceu em 1992. \\
\hline Janice Gonçalves & & & & & & & & Com & $\begin{array}{c}\mathrm{CdM} \\
\text { Com }\end{array}$ & $\begin{array}{l}\text { Of; } \\
\text { Com }\end{array}$ & Com & \\
\hline Jeferson Antonio Martins & & & & Com & Of & & & & & $\mathrm{CdO}$ & & \\
\hline João Eurípedes Franklin Leal & & & & & & & & Com & Com & & & Não compareceu em 2000. \\
\hline José Chafi Francisco & Com & Com & & & & & & & & & & \\
\hline José Maria Jardim & $\mathrm{Cf}$ & & & & & & & & & & & \\
\hline Josiane Roza de Oliveira & & & & & & & & & & Com & CdM & Não compareceu em 2002. \\
\hline Lia Temporal Malcher & $\mathrm{Cf}$ & & & & & & & & & & & \\
\hline Luiz Antônio Cruz Souza & & & & & & & & & $\mathrm{Cf}$ & & & Não compareceu. \\
\hline Lygia Guimarães & & & & & & & & & & & $\mathrm{Cf}$ & \\
\hline Maria Aparecida de Lima & & & & & & Com & & Com & Com & & & \\
\hline Maria Aparecida Rodrigues Manzan & & & & & $\mathrm{Cf}$ & Com & & & & & & \\
\hline Maria Izabel de Oliveira & & & & $\mathrm{Cf}$ & & & & & & & & \\
\hline Maria Lourdes Blatt Ohira & & & & & & & & Com & $2 \mathrm{Com}$ & Com & $\mathrm{Cf}$ & \\
\hline Maria Thereza Böbel & & & Com & & & Com & & & & & & \\
\hline Maria Zilene Cardoso & & & & & & $\mathrm{CdM}$ & $\mathrm{CdP}$ & & & & & \\
\hline Marilena Leite Paes & & & & & & & & $\begin{array}{l}\text { Cf; } \\
\text { Cur }\end{array}$ & $\mathrm{Cf}$ & & & \\
\hline Marilene Filomeno Machado Ribeiro & & & & & & & Com & & & $\mathrm{CdM}$ & & \\
\hline Narcisa de Fátima Amboni & Com & Com & & & & & & & & & & \\
\hline Neusa Maria Schmitz & & & & & & & & & & $\mathrm{CdO}$ & & \\
\hline Neusa Maria Tribeck Ferreira & & & & & & & & & Com & Com & & \\
\hline Neusa Rosane Damiani Nunes & Com & & Com & 2 Com & Com & & & & $\begin{array}{c}\mathrm{CdM} \\
\text { Com }\end{array}$ & $\mathrm{CdO}$ & & \\
\hline
\end{tabular}




\begin{tabular}{|c|c|c|c|c|c|c|c|c|c|c|c|c|}
\hline \multirow{2}{*}{ Participantes } & \multicolumn{11}{|c|}{ Modalidade de participação /Ano } & \multirow{2}{*}{ Obs. } \\
\hline & 1984 & 1986 & 1988 & 1990 & 1992 & 1994 & 1996 & 1998 & 2000 & 2002 & 2004 & \\
\hline Priscila Amorim Martinez & & & & & & & & & 2 Com & Com & & \\
\hline Rogério Brasiliense Machado & & & & & & & $\mathrm{Cf}$ & & & & & \\
\hline Rosali Demboski de Souza & & & & & & & & & & & $\mathrm{Cf}$ & \\
\hline Sebastiana Vieira & & & & & & & & Cur & & & & \\
\hline Sérgio Conde de Albite Silva & & & & & & & & & & $\mathrm{Cf}$ & & \\
\hline Sílvia Regina Toassi Kita & & & & & & & & $\mathrm{CdM}$ & $\mathrm{CdM}$ & $\begin{array}{c}\text { CdM; } \\
\text { Com }\end{array}$ & $\mathrm{CdM}$ & \\
\hline Solange Rocha & & & & & & & & & & Of & & \\
\hline Sônia Maria Breda & & & & & & Com & & & Com & Com & & \\
\hline Sueli Maria Vanzuita Petry & Com & & Com & & $\begin{array}{l}\text { Com; } \\
\text { CdD }\end{array}$ & $\mathrm{CdP}$ & $\begin{array}{c}\mathrm{CdM} ; \\
\text { Com }\end{array}$ & Com & $\mathrm{CdM}$ & & Com & \\
\hline Suely Veiga Quinteiro & & & & & & & & & & Com & Com & \\
\hline Susana A. Cardoso & & & & & Of & & & & & & & \\
\hline Susana Cardoso Fernandez & & & & & & & & Cur & & & & \\
\hline Talita de A. Telemberg Soares & & & & $\begin{array}{l}\text { Com; } \\
\text { Rel }\end{array}$ & & & Com & Com & $\mathrm{CdM}$ & & Com & \\
\hline Thaís Luzia Colaço & & & & & $\mathrm{CdD}$ & & $\mathrm{CdM}$ & & & & & \\
\hline Valéria Gouvêa Ghanem & & & Com & 2 Com & $\mathrm{CdM}$ & & Com & & Com & $\mathrm{CdM}$ & $\mathrm{CdM}$ & \\
\hline Vera Lúcia de Nóbrega Pecego Estork & & & & & Com & $2 \mathrm{Com}$ & Com & Com & Com & Com & $\begin{array}{c}\text { CdM; } \\
\text { Com }\end{array}$ & \\
\hline Vera Lúcia M. Barroso & & & Com & & Com & & & & & & & \\
\hline Virgínia Anna Zimmermann & & & & & & & & & $\mathrm{CdM}$ & $\mathrm{CdM}$ & Com & \\
\hline Walter Fernando Piazza & Com & $\mathrm{CdP}$ & Com & Com & & $\mathrm{Cf}$ & & & & & & \\
\hline $\begin{array}{l}\text { Onde: } \\
\mathrm{CdD}=\text { Coordenação de debates } \\
\mathrm{CdM}=\text { Coordenação de mesa }\end{array}$ & $\begin{array}{l}\mathrm{CdO}= \\
\mathrm{CdP}=\end{array}$ & $\begin{array}{l}\text { oorden } \\
\text { pordena }\end{array}$ & $\begin{array}{l}\text { ão de c } \\
\text { ão de } \mathrm{p}\end{array}$ & $\begin{array}{l}\text { icina } \\
\text { inel }\end{array}$ & $\begin{array}{l}\mathrm{Cf}= \\
\mathrm{Com}\end{array}$ & $\begin{array}{l}\text { Conferên } \\
=\text { Comul }\end{array}$ & $\begin{array}{l}\text { cia } \\
\text { icação }\end{array}$ & & $\begin{array}{l}\text { Cur }=\mathrm{Cu} \\
\text { Of }=\text { Ofi }\end{array}$ & & & $\begin{array}{l}\text { Rel = Relatório de sessão/encontro } \\
\text { ExV = Exibição de vídeo } \\
\mathrm{LçL}=\text { Lançamento de livro }\end{array}$ \\
\hline
\end{tabular}

- A indicação de não-comparecimento foi feita apenas nos casos em que a informação pôde ser levantada.

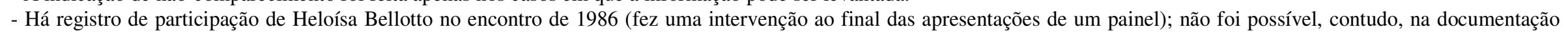
consultada, verificar a condição na qual participou do evento (muito provavelmente, como conferencista).

Fontes:

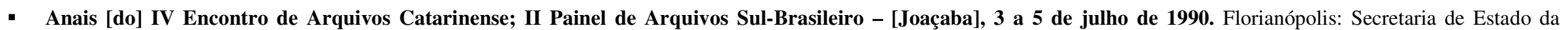
Administração, 1990. 
- Anais do $5^{\circ}$. Encontro Catarinense de Arquivos. Florianópolis: Fundação Catarinense de Cultura, Associação de Amigos do Arquivo Público, 1992.

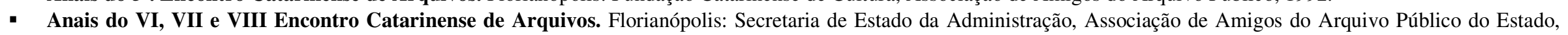
2000.

- Anotações realizadas durante o VIII, o IX, o X e o XI Encontros Catarinenses de Arquivos (1998 a 2004). Arquivo pessoal (Janice Gonçalves).

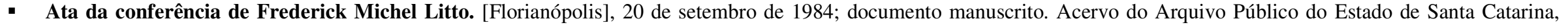
Fundo Arquivo Público, G IV, SG IV.1, 60-1984-1996, s.7.

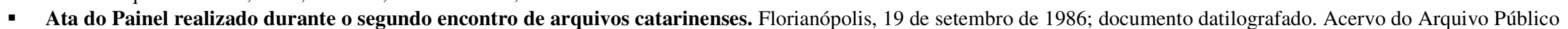
do Estado de Santa Catarina, Fundo Arquivo Público, GIV, SG IV.1, 60-1984-1996, s.7.

- Caderno de resumos do IX Encontro Catarinense de Arquivos e IV Painel de Arquivos Municipais - 6 a 8 de novembro de 2000. Blumenau (SC): 2000.

- Caderno de resumos do VIII Encontro Catarinense de Arquivos e III Painel de Arquivos Municipais - 14 a 16 de setembro de 1998. Jaraguá do Sul (SC): 1998.

- Caderno de resumos do X Encontro Catarinense de Arquivos e V Painel de Arquivos Municipais - 2 a 4 de setembro de 2002. Florianópolis: 2002.

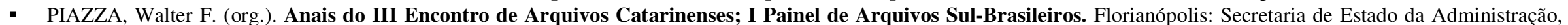
Coordenadoria de Documentação e Publicações, Arquivo Público, 1988.

- Programa do VIII Encontro Catarinense de Arquivos e III Painel de Arquivos Municipais - 14 a 16 de setembro de 1998 . Folder.

- Programa do XI Encontro Catarinense de Arquivos - 13 a 15 de setembro de 2004. Folder.

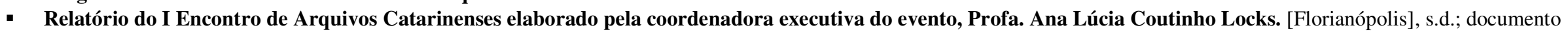
datilografado. Acervo do Arquivo Público do Estado de Santa Catarina, Fundo Arquivo Público, G IV, SG IV.1, 60-1984-1996, s.10.

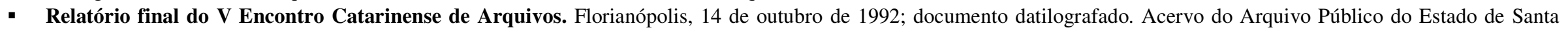
Catarina, Fundo Arquivo Público, G IV, SG IV.1, 60-1984-1996, s.10.

- SOARES, Iaponan (org.). Arquivos \& Documentos em Santa Catarina. Florianópolis: Secretaria da Justiça, Arquivo Público do Estado, 1985. 
Apêndice II-6

Proposições e recomendações dos encontros catarinenses de arquivos

\begin{tabular}{|c|c|c|}
\hline Tema & Proposições e recomendações & $\operatorname{Ano}(s)$ \\
\hline \multirow{15}{*}{$\begin{array}{l}\text { Arquivos públicos } \\
\text { municipais }\end{array}$} & Que as prefeituras municipais "dediquem especial atenção aos arquivos.” & 1984 \\
\hline & $\begin{array}{l}\text { "Que o Poder Público promova a criação e o desenvolvimento de arquivos municipais com a função de recolher, preservar e garantir acesso } \\
\text { aos documentos públicos municipais". }\end{array}$ & 1986 \\
\hline & $\begin{array}{l}\text { "Que o Poder Público promova o mapeamento dos acervos públicos localizados nos municípios, em convênio com as Prefeituras, visando o } \\
\text { recolhimento, a preservação e o acesso a estes acervos pelos arquivos públicos municipais." }\end{array}$ & 1986 \\
\hline & Que "sejam asseguradas instalações físicas adequadas e equipamentos necessários à devida conservação dos arquivos públicos municipais." & 1988 \\
\hline & $\begin{array}{l}\text { Que "os poderes públicos municipais promovam a criação e a implantação de arquivos municipais, com a finalidade de integrar as } \\
\text { municipalidades ao Sistema Estadual de Arquivos." }\end{array}$ & 1988 \\
\hline & $\begin{array}{l}\text { "Que os Prefeitos eleitos em } 03 \text { de outubro de } 1992 \text { para administrarem os } 43 \text { [sic] municípios de Santa Catarina criem na estrutura básica } \\
\text { da Prefeitura Municipal um órgão que tenha a competência de controlar a produção e o arquivamento da documentação, visando a criação } \\
\text { do Arquivo Público Municipal." }\end{array}$ & 1992 \\
\hline & "Que no Município de Florianópolis seja criado o Arquivo Público Municipal.” & 1992 \\
\hline & "Que seja criado no Arquivo Público do Estado de Santa Catarina o Fórum de Diretores de Arquivos Municipais.” & 1992 \\
\hline & $\begin{array}{l}\text { Que "as Prefeituras do Estado de Santa Catarina, com o apoio das Câmaras Municipais, envidem esforços no sentido de criar Arquivos } \\
\text { Públicos Municipais com estrutura e funções definidas de acordo com a moderna Arquivologia." }\end{array}$ & 1992 \\
\hline & $\begin{array}{l}\text { Que "as Prefeituras dos Municípios do Estado de Santa Catarina [...] criem seus Arquivos Municipais com a finalidade de preservar e } \\
\text { divulgar seu patrimônio documental, de acordo com o que está determinado no Artigo } 9^{\circ} \text {. da Constituição do Estado de Santa Catarina." } \\
\text { [Direção e funcionários do APESC] }\end{array}$ & 1994 \\
\hline & $\begin{array}{l}\text { Que sejam assegurados, aos arquivos municipais de Santa Catarina, "recursos humanos e financeiros com a finalidade de aparelhá-los para } \\
\text { que possam desempenhar as funções que lhes competem, de preservar, organizar e divulgar o patrimônio documental, visando ao resgate da } \\
\text { memória das comunidades." [Direção e funcionários do APESC] }\end{array}$ & 1994 \\
\hline & $\begin{array}{l}\text { "Que seja criado o Arquivo Histórico de Ibirama, tendo em vista a importante documentação pertencente ao patrimônio de Ibirama (sobre } \\
\text { colonização alemã e italiana, reserva indígenas e florestais, Estrada de Ferro do Vale do Itajaí) e pela proximidade do centenário do } \\
\text { município." [Izabel Mir Brandt] }\end{array}$ & 1994 \\
\hline & $\begin{array}{l}\text { "Que seja criado o Arquivo Histórico do Município de Laguna, um dos mais antigos de Santa Catarina, e considerado pelo SPHAN como } \\
\text { Patrimônio Histórico, cujos documentos são fontes importantíssimas para o resgate da história de Santa Catarina e que se encontram sem } \\
\text { nenhuma proteção e organização." [Amadio Vetoretti] }\end{array}$ & 1994 \\
\hline & $\begin{array}{l}\text { "Que os Arquivos Públicos e Históricos Municipais se cadastrem junto ao Fórum Nacional de [Dirigentes de] Arquivos Municipais, que é a } \\
\text { entidade que legitimamente os representa junto aos prefeitos." [Daíse Aparecida Oliveira] }\end{array}$ & 1996 \\
\hline & $\begin{array}{l}\text { Que haja ampla divulgação "aos Prefeitos Municipais de Santa Catarina sobre a obrigatoriedade legal das Prefeituras Municipais } \\
\text { preservarem os documentos que constituem a memória da sua comunidade, criando os Arquivos Municipais e implementando os já } \\
\text { existentes." [Talita de A. T. Soares e demais participantes] }\end{array}$ & 1996 \\
\hline
\end{tabular}




\begin{tabular}{|c|c|c|}
\hline & $\begin{array}{l}\text { Que os "municípios que já possuem arquivos" estimulem "as cidades vizinhas a criarem os seus Arquivos Municipais, considerando que os } \\
\text { arquivos constituem-se em instrumentos imprescindíveis para o bom funcionamento das instituições públicas, facilitando o acesso à } \\
\text { informação e garantindo o direito à cidadania." [Daíse Aparecida Oliveira] }\end{array}$ & 1998 \\
\hline & $\begin{array}{l}\text { "Que o Poder Público Municipal promova a criação e implantação de Arquivos Públicos Municipais com a finalidade de integrar os seus } \\
\text { Municípios ao Sistema Estadual de Arquivos." [Neusa Rosane Damiani Nunes] }\end{array}$ & 1998 \\
\hline & $\begin{array}{l}\text { "Que os organizadores do evento encaminhem aos prefeitos municipais as recomendações deste IX Encontro, ressaltando a importância da } \\
\text { criação dos arquivos municipais e da implantação de políticas de gestão documental." [Fórum Nacional de Dirigentes de Arquivos } \\
\text { Municipais] }\end{array}$ & 2000 \\
\hline & $\begin{array}{l}\text { "Que os prefeitos dos municípios catarinenses sejam informados dos resultados desse evento e que sejam estimulados a criarem o Arquivo } \\
\text { Público de sua cidade e a se inscreverem no Projeto do CIA/SAM - Conselho Internacional de Arquivos - Seção de Arquivos Municipais." } \\
\text { [Fórum Nacional de Dirigentes de Arquivos Públicos Municipais] }\end{array}$ & 2002 \\
\hline \multirow[t]{8}{*}{$\begin{array}{l}\text { Arquivos públicos } \\
\quad \text { estaduais }\end{array}$} & $\begin{array}{l}\text { "Que o Poder Público Estadual [de SC] promova a construção de um prédio próprio para o Arquivo Público do Estado, garantindo-lhe } \\
\text { instalações físicas adequadas para a preservação e ampliação do seu patrimônio arquivístico". }\end{array}$ & 1986 \\
\hline & $\begin{array}{l}\text { Que sejam reavivadas as "relações Arquivo Nacional, SINAR, Universidades e Arquivos Estaduais, com vistas a projetos que viabilizem } \\
\text { estudos para padronização de métodos e técnicas arquivísticas, como também, o incentivo à criação de Sistemas Estaduais de Arquivos." } \\
\text { [Adolpho Mariano da Costa] }\end{array}$ & 1990 \\
\hline & $\begin{array}{l}\text { Que nos levantamentos para o Guia Nacional de Arquivos cada Arquivo Estadual atue como "normatizador e órgão monitor do projeto, } \\
\text { para um efetivo aproveitamento das informações colhidas no decorrer do projeto." [Adolpho Mariano da Costa] }\end{array}$ & 1990 \\
\hline & $\begin{array}{l}\text { Que o Governo do Estado de Santa Catarina aprove o projeto de "criação da Diretoria do Arquivo Público, na estrutura administrativa do } \\
\text { Estado, em nível hierárquico compatível com a responsabilidade de custodiar o patrimônio documental." }\end{array}$ & 1992 \\
\hline & "Que seja criado o Arquivo Geral do Poder Judiciário no Estado de Santa Catarina.” [Arquivo Público do Estado de Santa Catarina] & 2000 \\
\hline & $\begin{array}{l}\text { "Que seja encaminhada recomendação ao governador do Estado de Santa Catarina alertando sobre a necessidade da criação da Diretoria do } \\
\text { Arquivo Público do Estado, na atual estrutura administrativa." [Marilena Leite Paes] }\end{array}$ & 2000 \\
\hline & $\begin{array}{l}\text { "Que o Governo do Estado, por meio da Secretaria de Estado da Administração e a Associação de Amigos do Arquivo Público se } \\
\text { empenhem em destinar e adequar o prédio localizado na Rua Dom Joaquim, no centro de Florianópolis, para a sede própria do Arquivo } \\
\text { Público do Estado." [Geraldo Gama Salles] }\end{array}$ & 2000 \\
\hline & $\begin{array}{l}\text { Que o Arquivo Público do Estado de Santa Catarina seja instalado "em uma sede própria e adequada, de acordo com as normas } \\
\text { arquivísticas." [funcionários do Arquivo Público do Estado] }\end{array}$ & 2004 \\
\hline \multirow{5}{*}{$\begin{array}{l}\text { Encontros de } \\
\text { arquivos }\end{array}$} & "Que seja assegurada, no próximo Governo, a continuação bienal do Encontro de Arquivos Catarinenses”. & 1986 \\
\hline & $\begin{array}{l}\text { Que "sejam realizados encontros regionais de arquivos, com vistas ao intercâmbio dos arquivos públicos e privados, ao patrimônio } \\
\text { arquivístico estadual [sic] com o apoio das instituições a eles subordinadas." }\end{array}$ & 1988 \\
\hline & $\begin{array}{l}\text { Que "sejam realizados, em 1990, pelo Arquivo Público do Estado de Santa Catarina, o IV Encontro de Arquivos Catarinenses e o II Painel } \\
\text { de Arquivos Sul-Brasileiros." }\end{array}$ & 1988 \\
\hline & $\begin{array}{l}\text { Que "nos próximos Encontros [de Arquivos Catarinenses] sejam realizadas paralelamente oficinas de Arquivologia, que elejam temas } \\
\text { ligados às diversas técnicas arquivísticas e que preparem melhor o pessoal que atua nos Arquivos Municipais, Históricos e Privados no } \\
\text { Estado de Santa Catarina." }\end{array}$ & 1990 \\
\hline & $\begin{array}{l}\text { "Que os próximos Encontros Catarinenses de Arquivos tenham o apoio da Prefeitura do município-sede e da Associação dos Municípios da } \\
\text { região." }\end{array}$ & 1992 \\
\hline
\end{tabular}




\begin{tabular}{|c|c|c|}
\hline & $\begin{array}{l}\text { Que a "Gerência de Monitoramento de Documentos Oficiais do Estado de Santa Catarina e o Arquivo Público do Estado" estimulem "a } \\
\text { realização de Encontros Regionais, dedicados ao aperfeiçoamento de técnicas arquivísticas adotadas, que são diferentes das dos centros de } \\
\text { documentação." }\end{array}$ & 1992 \\
\hline & $\begin{array}{l}\text { "Que o próximo Encontro Catarinense de Arquivos seja realizado no Município de Blumenau, com a condição de que, se dentro de seis } \\
\text { meses, a contar desta data, não obtiver o apoio da Prefeitura Municipal, ficará a cargo do Arquivo Público do Estado e da Associação de } \\
\text { Amigos do Arquivo Público a definição de um outro município." }\end{array}$ & 1992 \\
\hline & Que seja realizado em 1995, em Brasília, o “I Encontro de Arquivos do Centro-Oeste”. [Vânia Caldas Saraiva, do APDF] & 1994 \\
\hline & Que sejam criados “espaços maiores para relatos e troca de experiências nos eventos da área de Arquivologia.” [Ana Regina Berwanger] & 1994 \\
\hline & $\begin{array}{l}\text { "Que haja mais interesse das Assessorias de Comunicações dos órgãos da Administração Direta do Estado na divulgação de eventos } \\
\text { ligados às áreas de arquivo e documentação." [Neusa Rosane Damiani Nunes] }\end{array}$ & 1996 \\
\hline & $\begin{array}{l}\text { "Que haja mais participação dos Arquivos Públicos Municipais de Santa Catarina no Painel de Arquivos Municipais realizado nos } \\
\text { Encontros Catarinenses de Arquivos." [Neusa Rosane Damiani Nunes] }\end{array}$ & 1996 \\
\hline & $\begin{array}{l}\text { "Que os dirigentes dos arquivos municipais catarinenses se comprometam, espontaneamente [sic], em participar dos Encontros de } \\
\text { Arquivos, com a finalidade de divulgar o trabalho que está sendo desenvolvido em seu município, mostrando ao prefeito a importância de } \\
\text { sua participação." [Arquivo Público do Estado de Santa Catarina] }\end{array}$ & 2000 \\
\hline \multirow{7}{*}{$\begin{array}{l}\text { Legislação } \\
\text { relacionada aos } \\
\text { arquivos }\end{array}$} & $\begin{array}{l}\text { Que seja estabelecida "legislação com sanções aplicáveis àqueles que deixarem de observar as normas protetoras [d]o patrimônio } \\
\text { documental." }\end{array}$ & 1984 \\
\hline & $\begin{array}{l}\text { Que sejam instituídas [em SC] "uma lei estadual sobre arquivos e leis municipais sobre arquivos, estabelecendo no Arquivo Público do } \\
\text { Estado e nos arquivos públicos municipais as competências de recolhimento dos documentos produzidos e acumulados pelas } \\
\text { administrações públicas nas quais se inserem". }\end{array}$ & 1986 \\
\hline & $\begin{array}{l}\text { "Que a legislação arquivística impeça a eliminação de qualquer documento público sem a autorização prévia do Arquivo Público do } \\
\text { Estado, a nível de administração estadual, e dos arquivos públicos municipais, a nível das administrações municipais." }\end{array}$ & 1986 \\
\hline & $\begin{array}{l}\text { "Que na nova Constituição brasileira sejam incluídos dispositivos expressos sobre os procedimentos de proteção e acesso ao patrimônio } \\
\text { arquivístico do país". }\end{array}$ & 1986 \\
\hline & $\begin{array}{l}\text { Que "sejam definidas e legalmente garantidas as competências dos arquivos públicos quanto às atividades de recolhimento, preservação e } \\
\text { acesso aos documentos produzidos e acumulados pela administração pública." }\end{array}$ & 1988 \\
\hline & $\begin{array}{l}\text { Que "seja garantido, na próxima Constituição Federal, o direito do cidadão ao acesso às informações produzidas e acumuladas pelas } \\
\text { entidades públicas cujo destino final são os arquivos públicos, bem como as informações produzidas e acumuladas pelas entidades } \\
\text { privadas, principalmente impedindo-se a evasão de arquivos privados, de interesse da cultura regional." }\end{array}$ & 1988 \\
\hline & $\begin{array}{l}\text { Que "seja alterada a orientação constitucional de proteção a documentos de valor cultural, substituindo-se [sic] por todo e qualquer } \\
\text { documento de valor corrente, intermediário e permanente." }\end{array}$ & 1988 \\
\hline \multirow[t]{2}{*}{$\begin{array}{c}\text { Sistemas de } \\
\text { arquivos em SC }\end{array}$} & $\begin{array}{l}\text { Que seja estabelecido "um sistema estadual de arquivos, com uma política voltada ao intercâmbio de informações e experiências entre } \\
\text { todos os arquivos existentes no Estado de Santa Catarina." }\end{array}$ & 1984 \\
\hline & $\begin{array}{l}\text { "Que sejam instituídos o Sistema de Arquivos do Estado de Santa Catarina, tendo como órgão central o Arquivo Público do Estado, e } \\
\text { sistemas municipais de arquivos, tendo como órgãos centrais os arquivos públicos municipais." }\end{array}$ & 1986 \\
\hline
\end{tabular}




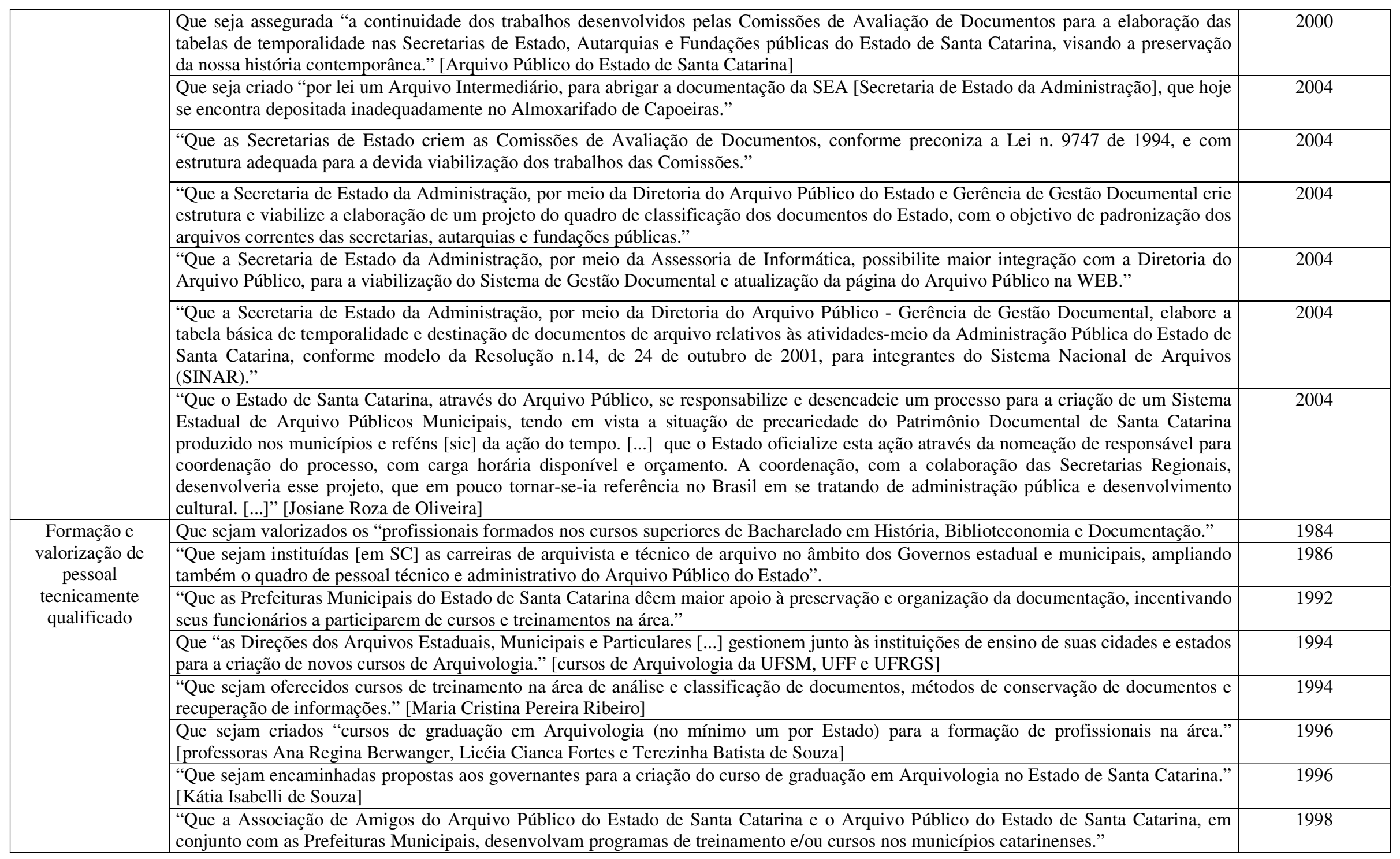




\begin{tabular}{|c|c|c|}
\hline \multirow{5}{*}{$\begin{array}{l}\text { Divulgação do } \\
\text { papel dos arquivos } \\
\text { e de seus acervos }\end{array}$} & Que sejam conscientizados "autoridades e segmentos da sociedade do papel a desempenhar na preservação do acervo documental." & 1984 \\
\hline & Que se desperte "para a realidade de que só as fontes históricas facultarão o conhecimento da identidade catarinense, tão discutida." & 1984 \\
\hline & $\begin{array}{l}\text { Que "seja mais divulgada, no âmbito do poder público e na sociedade, a função dos arquivos públicos na proteção ao patrimônio } \\
\text { documental arquivístico." }\end{array}$ & 1988 \\
\hline & $\begin{array}{l}\text { "Que os Arquivos Públicos divulguem mais seus acervos junto aos alunos de } 1^{\circ} \text {. e } 2^{\circ} \text {. graus das escolas públicas e particulares." [Kátia } \\
\text { Isabelli de Souza] }\end{array}$ & 1996 \\
\hline & $\begin{array}{l}\text { "Que haja a implantação de sites pelos Arquivos Públicos Municipais e Estaduais, tendo como parâmetros as diretrizes propostas pelo } \\
\text { CONARQ - Conselho Nacional de Arquivos." [Maria Lourdes Blatt Ohira] }\end{array}$ & 2004 \\
\hline \multirow{6}{*}{$\begin{array}{l}\text { Sensibilização e } \\
\text { apoio de } \\
\text { autoridades } \\
\text { públicas }\end{array}$} & $\begin{array}{l}\text { "Que os arquivos públicos estadual e municipais recebam condições técnica[s] e administrativas para fazerem face às funções de } \\
\text { recolhimento, preservação e acesso ao patrimônio arquivístico". }\end{array}$ & 1986 \\
\hline & $\begin{array}{l}\text { "Que as recomendações deste Encontro sejam enviadas pelo Arquivo Público do Estado a todas as Secretarias de Estado, às prefeituras } \\
\text { municipais, à Universidade Federal de Santa Catarina, à Universidade para o Desenvolvimento do Estado de Santa Catarina, aos diversos } \\
\text { órgãos privados voltados para o desenvolvimento cultural do Estado, ao Arquivo Nacional e aos demais arquivos públicos estaduais do } \\
\text { país." }\end{array}$ & 1986 \\
\hline & $\begin{array}{l}\text { Que sejam procurados "meios eficazes de sensibilização dos Governos Estaduais para os problemas crônicos dos arquivos (recursos } \\
\text { humanos e financeiros) e da própria valorização dos Arquivos Públicos." [Adolpho Mariano da Costa] }\end{array}$ & 1990 \\
\hline & $\begin{array}{l}\text { "Que sejam amplamente divulgados junto aos governantes dos Estados e Municípios os resultados obtidos no tratamento técnico dos } \\
\text { acervos arquivísticos catarinenses." [Kátia Isabelli de Souza] }\end{array}$ & 1996 \\
\hline & $\begin{array}{l}\text { "Que seja programado um encontro com dirigentes municipais, estaduais, de instituições privadas não-governamentais, com a finalidade de } \\
\text { conscientizar e sensibilizar os mesmos em relação ao trabalho que os profissionais da área de arquivística estão desenvolvendo." [Laura } \\
\text { Marques] }\end{array}$ & 1996 \\
\hline & $\begin{array}{l}\text { "Que os governantes eleitos no próximo dia } 6 \text { de outubro sejam informados pelos responsáveis - autoridades competentes - sobre a } \\
\text { situação em que se encontra o patrimônio documental de seu Estado e que dêem continuidade aos projetos em andamento neta área." } \\
\text { [Arquivo Público do Estado de Santa Catarina] }\end{array}$ & 2002 \\
\hline \multirow[t]{2}{*}{$\begin{array}{c}\text { Associações de } \\
\text { arquivistas }\end{array}$} & $\begin{array}{l}\text { Que seja repensado "o papel da Associação dos Arquivistas Brasileiros, como entidade reguladora e incentivadora das necessidades } \\
\text { arquivísticas do país, criando-se a mentalidade de um arquivismo atuante, oferecendo subsídios técnico-informativos aos Arquivos } \\
\text { Estaduais para que consolidem uma posição de destaque e importância frente aos Governos dos Estados, às Secretarias às quais pertençam, } \\
\text { e à própria comunidade." [Adolpho Mariano da Costa] }\end{array}$ & 1990 \\
\hline & "Que se formem Associações a nível regional para dar assistência técnica aos arquivos." & 1992 \\
\hline $\begin{array}{l}\text { Cursos de } \\
\text { Graduação } \\
\text { em História }\end{array}$ & $\begin{array}{l}\text { Que "a Direção do Arquivo Público do Estado [de SC] e a Associação dos Amigos do Arquivo entrem em contato com os cursos de } \\
\text { História e de Estudos Sociais, a nível de graduação, existentes no Estado de Santa Catarina, enfatizando a necessidade de uma ação } \\
\text { conjunta visando a preservação documental, tendo em vista a importância dos Arquivos para a elaboração da História." [Walter F. Piazza] }\end{array}$ & 1990 \\
\hline \multirow{3}{*}{$\begin{array}{l}\text { Procedimentos } \\
\text { técnicos }\end{array}$} & Que haja "modernização das técnicas arquivísticas", tendo em vista os "novos métodos provocados pelo avanço da informática." & 1984 \\
\hline & $\begin{array}{l}\text { "Que sejam divulgados os planos de codificação e classificação de documentos de arquivos, para que sejam aplicados pelas instituições } \\
\text { arquivísticas do país, visando a uniformidade." [Neusa Rosane Damiani Nunes] }\end{array}$ & 1994 \\
\hline & $\begin{array}{l}\text { "Que as instituições, ao contratarem serviços de digitalização de acervos documentais, consultem o Arquivo Público de seu estado, ou } \\
\text { outras instituições arquivísticas, no sentido de receberem orientação quanto à preservação e ao acesso às informações digitalizadas ou } \\
\text { digitais." [Arquivo Público do Estado de Santa Catarina] }\end{array}$ & 2002 \\
\hline
\end{tabular}




\begin{tabular}{|c|c|c|}
\hline & $\begin{array}{l}\text { "Que as instituições invistam na gestão documental, avaliando, classificando e organizando a sua documentação com vistas à eficácia do } \\
\text { serviço público ou privado e a preservação do patrimônio documental." [Arquivo Público do Estado de Santa Catarina] }\end{array}$ & 2002 \\
\hline \multirow{5}{*}{$\begin{array}{l}\text { Proteção a } \\
\text { conjuntos } \\
\text { documentais } \\
\text { específicos }\end{array}$} & Que haja "promoção e apoio técnico para implantação de arquivos de empresas e particulares." & 1984 \\
\hline & $\begin{array}{l}\text { "Que todos os projetos voltados para a preservação do patrimônio arquivístico privado envolva[m] sempre representantes dos arquivos } \\
\text { públicos, sejam do Estado ou dos municípios". }\end{array}$ & 1986 \\
\hline & $\begin{array}{l}\text { "Que o Arquivo Público do Estado, em colaboração com os arquivos municipais, realize o mapeamento dos acervos arquivísticos privados } \\
\text { existentes no Estado de Santa Catarina." }\end{array}$ & 1986 \\
\hline & $\begin{array}{l}\text { "Que seja valorizada a preservação do acervo documental da antiga Inspetoria de Rios e Portos pertencente ao Município de Florianópolis, } \\
\text { e que este acervo seja organizado e divulgado à comunidade de pesquisadores." }\end{array}$ & 1992 \\
\hline & $\begin{array}{l}\text { "Que as Dioceses e Cartórios se associem aos esforços dos arquivos municipais e dos Estado na ação de preservação e conservação e } \\
\text { acesso ao público de seus acervos documentais." [Esther Caldas Bertoletti] }\end{array}$ & 2000 \\
\hline $\begin{array}{c}\text { Produção } \\
\text { bibliográfica na } \\
\text { área arquivística }\end{array}$ & $\begin{array}{l}\text { "Que toda a produção bibliográfica na área de arquivo em formato eletrônico produzida a partir de encontros e/ou cursos de graduação e } \\
\text { pós-graduação sejam disponibilizados [sic] em link a ser criado na página do Arquivo do Público do Estado." [Maria Lourdes Blatt Ohira] }\end{array}$ & 2004 \\
\hline
\end{tabular}

Obs.:

- Foram excluídas as moções de agradecimento e parabenização.

- As recomendações de 1984 aparecem como “conclusões” no relatório das sessões do dia 21 de setembro de 1984, bem como no relatório geral do evento (são idênticas).

Fontes:

- Anais do $5^{\circ}$. Encontro Catarinense de Arquivos. Florianópolis: Fundação Catarinense de Cultura, Associação de Amigos do Arquivo Público, 1992. p.80-82.

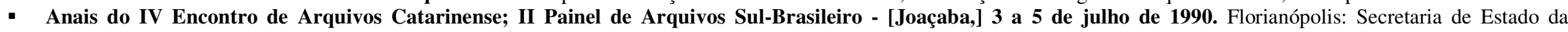
Administração, 1990. p.71-72.

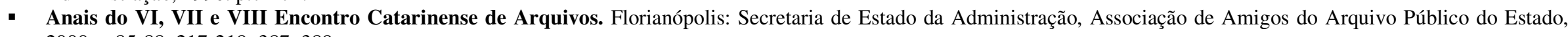
2000, p.85-88, 217-219, 387, 389.

- Boletim informativo [Arquivo Público do Estado de Santa Catarina/ Associação de Amigos do Arquivo Público], Florianópolis, n.32-33, jul-dez.2000. p.6-7.

- Boletim informativo [Arquivo Público do Estado de Santa Catarina/ Associação de Amigos do Arquivo Público], Florianópolis, n.40-41, jul-dez.2002. p.15.

- Boletim informativo [Arquivo Público do Estado de Santa Catarina/ Associação de Amigos do Arquivo Público], Florianópolis, n.49, out.-dez.2004.

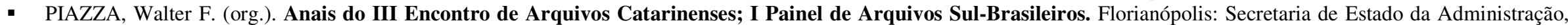
Coordenadoria de Documentação e Publicações, Arquivo Público, 1988. p.94-95.

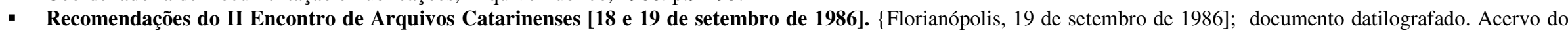
Arquivo Público do Estado de Santa Catarina, Fundo Arquivo Público, GIV, SG IV.1, 60-1984-1996, s.9.

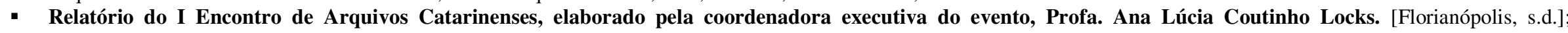
documento datilografado. Acervo do Arquivo Público do Estado de Santa Catarina, Fundo Arquivo Público, G IV, SG IV.1, 60-1984-1996, s.10.

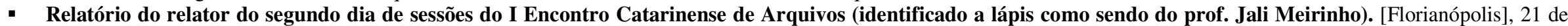
setembro de 1984; datilografado. Acervo do Arquivo Público do Estado de Santa Catarina, Fundo Arquivo Público, G IV, SG IV.1, 60-1984-1996, s.10. 
Apêndice II-7

Diretores/ gerentes do Arquivo Público do Estado de Santa Catarina

\begin{tabular}{|c|c|c|c|}
\hline Cargo /função & Período & Diretor / gerente & Obs.: \\
\hline Diretor & 1960 (out.) - 1961 (jan.) & Francisco Mascarenhas & \\
\hline Diretor & 1961 (jun.) - 1971 (jun.) & Djalma Coelho de Souza & \\
\hline Diretor & 1971 (jun.) - 1976 (abr.) & Santos Verani & \\
\hline Diretor & 1976 (abr.) - 1982 (fev.) & Wilmar Pacheco & \\
\hline Diretor & 1982 (maio) - 1983 (mar.) & Ewaldo Vilela & \\
\hline Diretor & 1983 (mar.) - 1988 (dez.) & Iaponan Soares & \\
\hline Diretora & 1988 (dez.) - 1991 (mar.) & Lêda Maria d'Ávila da Silva Prazeres & Funcionária do Arquivo Público do Estado de Santa Catarina. \\
\hline Gerente & 1991 (mar.) - 1995 (jan.) & Talita de Almeida Telemberg Soares & Funcionária do Arquivo Público do Estado de Santa Catarina. \\
\hline Gerente & 1995 (fev.) - 1998 (dez.) & Neusa Rosane Damiani Nunes & Funcionária do Arquivo Público do Estado de Santa Catarina. \\
\hline Gerente & 1999 (jan.)- 2002 (dez.) & Talita de Almeida Telemberg Soares & Funcionária do Arquivo Público do Estado de Santa Catarina. \\
\hline Diretor & 2003 (mar.) - 2005 (jan.) & Carlos Osvaldo de Farias & \\
\hline Diretor & 2005 (fev.) - jan. 2006 & Moacir Montibeller & \\
\hline Diretora & Desde fev. 2006 & Dirlei Maria Kafer Gonçalves & $\begin{array}{l}\text { Ocupava o cargo de Gerente de Gestão Documental desde o primeiro } \\
\text { semestre de } 2003 \text {. }\end{array}$ \\
\hline
\end{tabular}

Fontes:

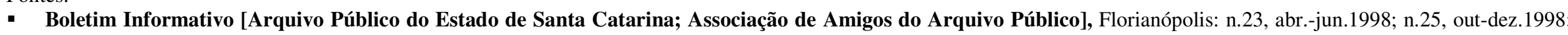
n.26, jan-mar.1999; n.28, jul-set.1999; n.29, out-dez. 1999; n.30, jan.-mar.2000; n.31, abr.-jun.2000; n.32-33, jul.-dez.2000; n.34, jan.-mar. 2001; n.35, abr.-jun.2001; n.36, jul.set.2001; n.37, out.-dez.2001; n.38, jan.-mar.2002; n.39, abr.-jun.2002; n.40-41, jul-dez.2002; n.42-43, jan.-jun.2003; n.44. jul-set.2003; n.54, jan.-mar.2006.

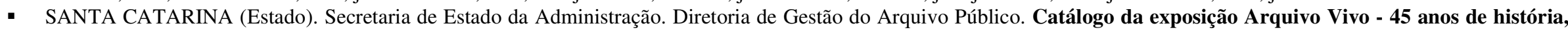
de 29 de junho a 28 de setembro de 2005. Florianópolis: 2005 . p.7.

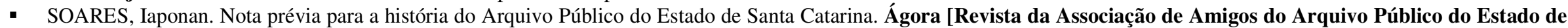
Santa Catarina], Florianópolis, ano I, n.1, junho de 1985, p.5-9. 
Apêndice II-8

Associação de Amigos do Arquivo Público do Estado de Santa Catarina:

pessoas que assumiram cargos na Diretoria e Conselhos Fiscal e Editorial (1985-2007)

\begin{tabular}{|c|c|c|c|c|c|c|c|c|c|c|c|c|}
\hline & $1985-86$ & 1987-88 & $1989-90$ & 1991-92 & 1993-95 & 1995-97 & 1997-99 & 1999-01 & 2001-03 & 2003-05 & 2005-07 & Obs. \\
\hline Adalberto Ribeiro da Silva & & & & & & & & & & & mCEd & Funcionário do APESC. \\
\hline Adélia dos Santos Silveira & & & $\mathrm{mCE} / \mathrm{C}$ & & & & & & & & & \\
\hline Ana Lúcia Bérgamo & & & & & & & & & & & $\mathrm{mCF}$ & \\
\hline Ana Lúcia Coutinho Locks & & & & $\mathrm{mCF}$ & & & & & & & & Foi funcionária do APESC. \\
\hline Ana Maria Soares [Martins de Araújo] & $2^{\circ} . \mathrm{VP}$ & $2^{\circ} . \mathrm{VP}$ & $\mathrm{mCF}$ & & & $2^{\circ} . \mathrm{S}$ & $2^{\circ} . \mathrm{S}$ & $\mathrm{mCEd}$ & $2^{\circ} . S$ & $2^{\circ} . \mathrm{T}$ & $2^{\circ} . \mathrm{T}$ & Funcionária do APESC. \\
\hline Ana Silva Borges & & & & $2^{\circ} . \mathrm{S}$ & $\mathrm{mCF}$ & & $\mathrm{mCF}$ & & & & & Foi funcionária do APESC. \\
\hline Carlos Alberto Machado de Souza & $2^{\circ} . \mathrm{T}$ & $2^{\circ} . \mathrm{T}$ & $1^{\circ} . \mathrm{T}$ & & & & & & & & & Foi funcionário do APESC. \\
\hline Carlos Osvaldo de Farias & & & & & & & & & & $\mathrm{VP}$ & $\mathrm{P}$ & Foi diretor do APESC. \\
\hline Cleuza Regina Costa Martins & & & $2^{\circ} . S$ & $2^{\circ} . \mathrm{T}$ & $\mathrm{mCF}$ & $2^{\circ} . \mathrm{T}$ & mCEd & $\mathrm{mCEd}$ & $\mathrm{mCEd}$ & & & Funcionária do APESC. \\
\hline Dirlei Maria Kafer Gonçalves & & & & & & & & & & $\mathrm{mCEd}$ & $\mathrm{mCEd}$ & Diretora do APESC. \\
\hline Edison d'Ávila & & & & $\mathrm{P}$ & & & & $1^{\circ} . \mathrm{S}$ & & & & \\
\hline Edmundo Vegini & & & $\mathrm{mCE} / \mathrm{C}$ & & & & & & & & & \\
\hline Eliana Maria Bahia & & $1^{\circ} . \mathrm{S}$ & $2^{\circ} . \mathrm{VP}$ & & & & & & & & & \\
\hline Eroildes de Melo Damas & & & & $\mathrm{mCE} / \mathrm{C}$ & & & & & & & & Foi funcionária do APESC. \\
\hline Geraldo Gama Salles & & & & & & $\mathrm{P}$ & $\mathrm{P}$ & $\mathrm{P}$ & $\mathrm{P}$ & $\mathrm{P}$ & & \\
\hline Helena Maria Correia de Souza Pessi & & & & & $2^{\circ} . \mathrm{T}$ & $1^{\circ} . \mathrm{S}$ & $1^{\circ} . \mathrm{S}$ & $2^{\circ} . \mathrm{S}$ & & & & Foi funcionária do APESC. \\
\hline Heleno Pagliario Mendonça & $1^{\circ} . \mathrm{T}$ & $1^{\circ} . \mathrm{T}$ & & & & & & & & & & Foi funcionário do APESC. \\
\hline Iaponan Soares de Araújo & $1^{\circ} . \mathrm{VP}$ & $1^{\circ} . \mathrm{VP}$ & & & & & & & & & & Foi diretor do APESC. \\
\hline \begin{tabular}{|l|} 
Ivan Ramos \\
\end{tabular} & & & & & $2^{\circ} . \mathrm{VP}$ & & & & & & & \\
\hline Jali Meirinho & & & $\mathrm{mCE} / \mathrm{C}$ & & & & & & & & & \\
\hline Janice Gonçalves & & & & & & & & $\mathrm{mCEd}$ & & & mCEd & \\
\hline Janir Brandt & & & & & & & & & & mCEd & & \\
\hline Jeferson Antonio Martins & & & & & $\mathrm{mCE} / \mathrm{C}$ & $\mathrm{mCEd}$ & mCEd & $\mathrm{mCEd}$ & $\mathrm{mCEd}$ & mCEd & $1^{\circ} . \mathrm{S}$ & Foi estagiário no APESC. \\
\hline Jorge Abouhatem & $2^{\circ} . \mathrm{T}$ & & & & & & & & & & & Foi funcionário do APESC. \\
\hline Juvêncio Bráulio Lopes & & & & & & & & $1^{\mathrm{o}} . \mathrm{T}$ & $1^{\circ} . \mathrm{T}$ & $1^{\mathrm{o}} . \mathrm{T}$ & & \\
\hline Laura M. Hübener & & & $\mathrm{mCE} / \mathrm{C}$ & & & & & & & & & \\
\hline Léa dos Santos Sousa & & & & & & & mCEd & & & & & \\
\hline Lêda Maria d'Ávila da Silva Prazeres & $2^{\circ} . S$ & $2^{\circ} . \mathrm{S}$ & $1^{\circ} . \mathrm{VP}$ & & & $\mathrm{mCF}$ & mCEd & mCEd & mCEd & mCEd & $\mathrm{mCEd}$ & Funcionária do APESC. \\
\hline Leonor Salles Quaresma & & & & $\mathrm{mCE} / \mathrm{C}$ & $\mathrm{mCE} / \mathrm{C}$ & mCEd & $1^{\mathrm{o}} . \mathrm{T}$ & mCEd & $\mathrm{mCF}$ & mCEd & $1^{\mathrm{o}} . \mathrm{T}$ & \\
\hline Luci Maria da Luz & & & & $\mathrm{mCE} / \mathrm{C}$ & $\mathrm{mCE} / \mathrm{C}$ & $\mathrm{mCEd}$ & & & & & & Foi funcionária do APESC. \\
\hline Márcia Regina Fantini da Silva & $2^{\circ} . S$ & & $1^{\circ} . \mathrm{S}$ & & & & & & & & & Foi funcionária do APESC. \\
\hline
\end{tabular}




\begin{tabular}{|c|c|c|c|c|c|c|c|c|c|c|c|c|}
\hline & $1985-86$ & 1987-88 & $1989-90$ & 1991-92 & $1993-95$ & 1995-97 & $1997-99$ & 1999-01 & 2001-03 & 2003-05 & 2005-07 & Obs. \\
\hline Maria Cristina d'Eça Luz da Conceição & & & & & $1^{\circ} . \mathrm{T}$ & $1^{\circ} . \mathrm{T}$ & & & & & & Foi funcionária do APESC. \\
\hline Maria de Fátima Campos & & & & & & & & & & $\mathrm{mCEd}$ & & \\
\hline Maria Regina Boppré & & $\mathrm{mCF}$ & $\mathrm{P}$ & $\mathrm{mCE} / \mathrm{C}$ & & & & & & & & \\
\hline Marilene Filomeno Machado Ribeiro & & & & & & & $\mathrm{mCF}$ & $\mathrm{mCF}$ & $\mathrm{mCF}$ & $\mathrm{mCF}$ & $\mathrm{mCEd}$ & \\
\hline Marli Antônia Pires & & & & & & $\mathrm{mCF}$ & & & & & & Foi funcionária do APESC. \\
\hline Moacir Montibeller & & & & & & & & & & & VP & Foi diretor do APESC. \\
\hline Nazir Rodrigues Laureano & & & & & & & & & $2^{\circ} . \mathrm{T}$ & & & \\
\hline Nélvio Paulo Dutra Santos & & & $2^{\mathrm{o}} . \mathrm{T}$ & $\mathrm{mCF}$ & $\mathrm{mCE} / \mathrm{C}$ & & & & & & & \\
\hline Neusa Maria Schmitz & & & & & & & $2^{\circ} . \mathrm{T}$ & $\mathrm{mCF}$ & $\mathrm{mCF}$ & $\mathrm{mCF}$ & mCEd & Funcionária do APESC. \\
\hline Neusa Rosane Damiani Nunes & & $\mathrm{mCF}$ & $\mathrm{mCF}$ & $1^{\circ} . \mathrm{VP}$ & $1^{\circ} . \mathrm{S}$ & VP & VP & $2^{\circ} . \mathrm{T}$ & mCEd & mCEd & $\mathrm{mCF}$ & Funcionária do APESC. \\
\hline Ninarosa Manfroi & & & & & & & & & & & mCEd & \\
\hline Noêmia Kühnen Lopes & & & & $1^{\circ} . \mathrm{T}$ & $\mathrm{mCF}$ & $\mathrm{mCF}$ & $\mathrm{mCF}$ & $\mathrm{mCF}$ & $\mathrm{mCEd}$ & $\mathrm{mCF}$ & & Foi funcionária do APESC. \\
\hline Norberto Ulysséa Ungaretti & & & & & $\mathrm{P}$ & & & & & & & \\
\hline Paschoal Apóstolo Pítsica & & $\mathrm{mCF}$ & $\mathrm{mCF}$ & $\mathrm{mCF}$ & & & & & & & & \\
\hline Paulo Clóvis Schmitz & & & & & & & & & & & $\mathrm{mCEd}$ & \\
\hline Rose Mari Lobo Goulart & & & & & $\mathrm{mCE} / \mathrm{C}$ & $\mathrm{mCEd}$ & & & & & & Foi funcionária do APESC. \\
\hline Rosiani Pereira Soares & & & & & & & & & $1^{\circ} . \mathrm{S}$ & & & \\
\hline Talita de Almeida Telemberg Soares & & & & $2^{\circ} . \mathrm{VP}$ & $1^{\circ} . \mathrm{VP}$ & $\mathrm{mCEd}$ & mCEd & $\mathrm{VP}$ & $\mathrm{VP}$ & $2^{\circ} . S$ & $2^{\circ} . S$ & Funcionária do APESC. \\
\hline Valéria Gouvêa Ghanem & $1^{\circ} . \mathrm{S}$ & & & $1^{\circ} . \mathrm{S}$ & $2^{\circ} . S$ & & & & & & & Foi funcionária do APESC. \\
\hline Virgínia Anna Zimmermann & & & & & & & & & & $1^{\circ} . \mathrm{S}$ & $\mathrm{mCF}$ & \\
\hline Walter F. Piazza & $\mathrm{P}$ & $\mathrm{P}$ & $\mathrm{mCE} / \mathrm{C}$ & $\mathrm{mCE} / \mathrm{C}$ & & & & & & & & \\
\hline
\end{tabular}

\section{Onde:}

$\begin{array}{ll}\text { APESC }=\text { Arquivo Público do Estado de Santa Catarina } & \mathrm{P}=\text { Presidente } \\ \mathrm{VP}=\text { Vice-Presic }\end{array}$

$\mathrm{VP}=$ Vice-Presidente $\left(1^{\mathrm{o}} . \mathrm{VP}=1^{\mathrm{o}}\right.$. Vice-Presidente $\mathrm{e}$ $2^{\circ}$. VP $=2^{\circ}$. Vice-Presidente)

$1^{\circ} . S=1^{\circ}$. Secretário $\left(2^{\circ} . S=2^{\circ}\right.$. Secretário $)$

$1^{\circ} . \mathrm{T}=1^{\circ}$. Tesoureiro $\left(2^{\circ} . \mathrm{T}=2^{\circ}\right.$. Tesoureiro $)$
$\mathrm{mCE} / \mathrm{C}=$ Membro do Conselho Editorial/Consultivo $\mathrm{mCEd}=$ Membro do Conselho Editorial $\mathrm{mCF}=$ membro do Conselho Fiscal

Fontes:

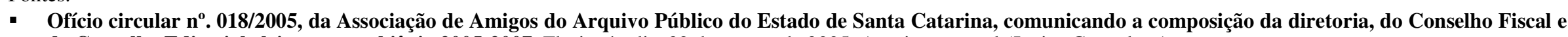
do Conselho Editorial eleitos para o biênio 2005-2007. Florianópolis, 29 de agosto de 2005. Arquivo pessoal (Janice Gonçalves).

- Revista Ágora, Florianópolis, n.1-38, 1985-2003.

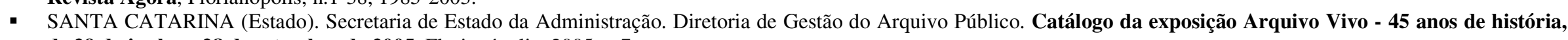
de 29 de junho a 28 de setembro de 2005. Florianópolis: 2005. p.7. 
Apêndice II-9:

Artigos, manuais, instrumentos de pesquisa e documentos do acervo publicados na revista Ágora (por ordem de autor)

\begin{tabular}{|c|c|c|c|c|}
\hline Autor(es) & Título & $N^{o}$. & Período & Obs. \\
\hline $\begin{array}{ll}-- \\
\end{array}$ & $\begin{array}{l}\text { Conservação preventiva } \\
\text { [texto publicado na revista Conservation / The Getty Institute, 1992] }\end{array}$ & 25 & 1997 (1º. Sem.) & $\begin{array}{l}\text { Tradução de Helena Maria C. de } \\
\text { Souza Pessi. }\end{array}$ \\
\hline--- & $\begin{array}{l}\text { Documentos selecionados do conjunto documental Grupos Escolares } \\
\text { (transcritos). }\end{array}$ & 37 & 2003 (1 $1^{\circ}$. Sem. $)$ & \\
\hline Adriane Schroeder Andermann & $\begin{array}{l}\text { "A gente comia farinha do engenho....": o engenho como espaço de } \\
\text { memória - tradição, folclore, imagens. }\end{array}$ & 25 & 1997 (1 $1^{\circ}$. Sem.) & \\
\hline Aloisius Carlos Lauth & Um museu religioso & 3 & 1986 (jul.) & \\
\hline \multirow[t]{2}{*}{ Amadio Vettoretti } & A história e os arquivos. & 19 & 1994 (jul.) & \\
\hline & Os italianos no sul catarinense. & $33 / 34$ & $\begin{array}{c}2001 \\
\left(1^{\circ} . / 2^{\circ} . \text { Sem. }\right) \\
\end{array}$ & \\
\hline \multirow[t]{2}{*}{ Ana Lúcia Coutinho Locks } & Os cartórios como fontes de pesquisa. & 2 & 1985 (dez.) & \\
\hline & Arranjos em arquivo público. & 4 & 1986 (dez.) & $\begin{array}{l}\text { Co-autora: } \\
\text { Valéria Gouvêa Ghanem }\end{array}$ \\
\hline \multirow[t]{2}{*}{ Ana Lúcia Vulfe Nötzold } & $\begin{array}{l}\text { Encontros e desencontros: colonos e indígenas no povoamento de Santa } \\
\text { Catarina. }\end{array}$ & 29 & 1999 (1º. Sem.) & $\begin{array}{l}\text { Co-autora: } \\
\text { Andréia Mendes de Souza }\end{array}$ \\
\hline & Rituais de sepultamento Kaingáng & 35 & $2002\left(1^{\circ}\right.$. Sem. $)$ & $\begin{array}{l}\text { Co-autora: } \\
\text { Ninarosa M.da Silva Manfroi }\end{array}$ \\
\hline Ana Maria Soares M. de Araújo & Nossa experiência no Arquivo Público. & 1 & 1985 (jun.) & $\begin{array}{l}\text { Co-autora: } \\
\text { Neusa Rosane D. Nunes }\end{array}$ \\
\hline André Fabiano Voigt & $\begin{array}{l}\text { Conflitos religiosos entre a Colônia Blumenau e a Paróquia de Gaspar no } \\
\text { século XIX: a questão dos cemitérios católico e evangélico-luterano. }\end{array}$ & 31 & $2000\left(1^{\circ}\right.$. Sem. $)$ & \\
\hline \multicolumn{4}{|l|}{ Andréia Mendes de Souza } & Ver: Ana Lúcia V.Nötzold. \\
\hline Antonieta de Barros & Falando às mestras. & 23 & 1996 (1 $1^{\circ}$. Sem.) & \\
\hline Antônio Luiz Miranda & $\begin{array}{l}\text { Instituição penal e controle social - a construção da Penitenciária e um } \\
\text { novo tratamento da criminalidade em Florianópolis. }\end{array}$ & 30 & 1999 (2º. Sem.) & \\
\hline \multirow[t]{2}{*}{ Antônio Roberto Nascimento } & Antigos moradores do Desterro: subsídios genealógicos. & 14 & 1991 (dez.) & \\
\hline & Gustave Luiz Lebon. & 18 & 1993 (dez.) & \\
\hline \multirow[t]{2}{*}{ Beat Richard Méier } & $\begin{array}{l}\text { Paróquia Evangélica de Santa Isabel: os primeiros pastores e os livros } \\
\text { eclesiásticos mais antigos. }\end{array}$ & 7 & 1988 (jun.) & \\
\hline & $\begin{array}{l}\text { Duas descobertas de documentos primários do século passado a respeito } \\
\text { de várias colônias alemãs hoje meio esquecidas (como "Santa Isabel", } \\
\text { "Piedade", "São Pedro de Alcântara" e "Teresópolis"). }\end{array}$ & 12 & 1990 (dez.) & \\
\hline
\end{tabular}




\begin{tabular}{|c|c|c|c|c|}
\hline Autor(es) & Título & $N^{o}$. & Período & Obs. \\
\hline Cátia Dagnoni & Ensino, educação e cultura material: desafios e possibilidades. & $33 / 34$ & $\begin{array}{c}2001 \\
\left(1^{\circ} . / 2^{\circ} . \text { Sem. }\right) \\
\end{array}$ & \\
\hline Celso Ramos & Discurso do governador. & 23 & $1996\left(1^{\circ}\right.$. Sem. $)$ & \\
\hline Cláudia de Araújo Grillo & Nota preliminar sobre o projeto "Evolução administrativa do Estado". & 9 & 1989 (jun.) & \\
\hline \multicolumn{4}{|l|}{ Cláudia Gonçalves de Souza } & $\begin{array}{l}\text { Ver: Maria Lourdes Blatt Ohira } \\
\text { (trabalho conjunto) }\end{array}$ \\
\hline \multirow[t]{3}{*}{ Cleuza Regina Costa Martins } & $\begin{array}{l}\text { Indexação e análise da documentação administrativa municipal de } \\
\text { Florianópolis e Blumenau no período compreendido entre 1941e } 1950 .\end{array}$ & 19 & 1994 (jul.) & \\
\hline & $\begin{array}{l}\text { Catálogo do Fundo Cartorial do Arquivo Público do Estado de Santa } \\
\text { Catarina. }\end{array}$ & 22 & 1995 (dez.) & $\begin{array}{l}\text { Co-autoras: Maria Cristina d'Eça } \\
\text { Neves Luz da Conceição e Neusa } \\
\text { Schmitz. }\end{array}$ \\
\hline & Manual de procedimentos para a organização de acervos fotográficos. & 28 & 1998 (2º. Sem.) & \\
\hline Cynthia Machado Campos & $\begin{array}{l}\text { Do controle social à produção da verdade: uma investigação em Foucault } \\
\text { e no pensamento marxista. }\end{array}$ & 15 & 1992 (jul.) & \\
\hline \multirow[t]{2}{*}{ Daniela Francescutti Martins } & $\begin{array}{l}\text { As relações entre o usuário e o guia de fundos na era digital: um relato de } \\
\text { experiências. }\end{array}$ & 24 & 1996 (2º. Sem.) & \\
\hline & $\begin{array}{l}\text { Os desafios da Arquivologia frente à tecnologia de informação - uma } \\
\text { revisão de literatura. }\end{array}$ & 26 & $1997\left(2^{\circ}\right.$. Sem. $)$ & \\
\hline Edison d'Ávila & A importância dos arquivos como fonte de pesquisa. & 15 & 1992 (jul.) & \\
\hline \multirow[t]{4}{*}{ Edison Mueller } & A bandeira do Município de Blumenau. & 1 & 1985 (jun.) & \\
\hline & Afonso de Taunay e a heráldica municipal catarinense. & 3 & 1986 (jul.) & \\
\hline & Afonso de Taunay e a heráldica municipal catarinense -2 . & 4 & 1986 (dez.) & \\
\hline & A heráldica - ontem e hoje. & 7 & 1988 (jun.) & \\
\hline Edmundo Vegini & O pensamento político de Crispim Mira. & 5 & 1987 (jun.) & \\
\hline Eliana Bahia & Em busca de uma casa para a cultura. & 10 & 1989 (dez.) & \\
\hline \multirow[t]{2}{*}{ Eliane Veras da Veiga } & $\begin{array}{l}\text { Correspondência dos engenheiros aos presidentes da província de Santa } \\
\text { Catarina: sua importância como fonte histórica. }\end{array}$ & 7 & 1988 (jun.) & \\
\hline & $\begin{array}{l}\text { O conjunto arquitetônico do Ribeirão da Ilha - importância da sua } \\
\text { preservação. }\end{array}$ & 8 & 1988 (dez.) & \\
\hline Eloíza Rocha Pereira & Resgate dos arquivos municipais goianos: uma proposta de ação. & 19 & 1994 (jul.) & \\
\hline Fábia Liliã Luciano Carminatti & $\begin{array}{l}\text { Gênese e expansão da educação na província de Santa Catarina: um } \\
\text { estudo do surgimento e desenvolvimento do magistério público, } 1835 \text { - } \\
1889 \text {. }\end{array}$ & 27 & 1998 (1º. Sem.) & \\
\hline Fernando Chiquio Boppré & Por uma pedagogia adequada. & 38 & $2003\left(2^{\circ}\right.$. Sem. $)$ & \\
\hline H.Rey & Contribuições à geografia médica: a Ilha de Santa Catarina & 39 & 2004 (1 $1^{\circ}$. Sem.) & $\begin{array}{l}\text { Tradução de Romilda Brisighelli } \\
\text { Salles. }\end{array}$ \\
\hline
\end{tabular}




\begin{tabular}{|c|c|c|c|c|}
\hline Autor(es) & Título & $N^{o}$. & Período & Obs. \\
\hline Haroldo Pacheco da Silveira Santos & Colonização açoriana. & 19 & 1994 (jul.) & \\
\hline Helenita Caldeira da Silva & $\begin{array}{l}\text { Uma apresentação resumida de alguns museus de Florianópolis: Museu de } \\
\text { Arte e Museu Histórico de Santa Catarina, Museu Vitor Meirelles, Museu } \\
\text { Universitário e Ecomuseu do Ribeirão da Ilha. }\end{array}$ & 31 & $2000\left(1^{\circ}\right.$. Sem. $)$ & \\
\hline Heloísa Liberalli Bellotto & Arquivos para a administração e para a história. & 3 & 1986 (jul.) & \\
\hline Hermetes Reis de Araújo & $\begin{array}{l}\text { A Saúde Pública como fonte de pesquisa para a histórica social em Santa } \\
\text { Catarina. }\end{array}$ & 8 & 1988 (dez.) & \\
\hline \multirow[t]{6}{*}{ Iaponan Soares } & $\begin{array}{l}\text { Nota prévia para a história do Arquivo Público do Estado de Santa } \\
\text { Catarina. }\end{array}$ & 1 & 1985 (jun.) & \\
\hline & Viajantes catarinenses: roteiro para uma bibliografia. & 2 & 1985 (dez.) & \\
\hline & Cidadania, preservação de documentos e Constituição. & 3 & 1986 (jul.) & \\
\hline & Organização e administração de arquivos & 5 & 1987 (jun.) & \\
\hline & José Honório Rodrigues e o desenvolvimento da arquivística brasileira. & 6 & 1987 (dez.) & \\
\hline & $\begin{array}{l}\text { Historiografia e documentação sobre escravos em Santa Catarina - as } \\
\text { fontes do Arquivo Público do Estado. }\end{array}$ & 8 & 1988 (dez.) & \\
\hline Ilka Boaventura & Viagem aos relatos de viagem. & 4 & 1986 (dez.) & \\
\hline Ilse Scherer Warren & Associativismo civil em Florianópolis - evolução e tendências. & 27 & $1998\left(1^{\circ}\right.$. Sem. $)$ & \\
\hline \multicolumn{4}{|l|}{ Ilson Luiz Coelho } & Ver: Orivalda Lima Silva. \\
\hline Izabel Cristina Knoll & Um ensaio sobre a criação do Teatro Santa Izabel na Vila do Desterro. & $20 / 21$ & $\begin{array}{l}1994 \text { (dez.) a } \\
1995 \text { (jul.) }\end{array}$ & \\
\hline Jali Meirinho & $\begin{array}{l}\text { Documento dá nova interpretação à Revolução Federalista em Santa } \\
\text { Catarina. }\end{array}$ & 2 & 1985 (dez.) & \\
\hline \multirow[t]{2}{*}{ Jeferson Antonio Martins } & Manual de conservação e restauração. & 13 & 1991 (jul.) & $\begin{array}{l}\text { Co-autora: Talita de Almeida } \\
\text { Telemberg Soares. }\end{array}$ \\
\hline & O papel: aspectos de sua história e de sua fabricação. & 14 & 1991 (dez.) & $\begin{array}{l}\text { Co-autora: Talita de Almeida } \\
\text { Telemberg Soares. }\end{array}$ \\
\hline João Klug & $\begin{array}{l}\text { Contribuição das fontes luteranas de Florianópolis à história cultural } \\
\text { catarinense. }\end{array}$ & 12 & 1990 (dez.) & \\
\hline $\begin{array}{l}\text { José Mariano de Albuquerque } \\
\text { Cavalcante }\end{array}$ & $\begin{array}{l}\text { Relatório de José Mariano de Albuquerque Cavalcante, presidente da } \\
\text { província de Santa Catarina (transcrição paleográfica). }\end{array}$ & 32 & $2000\left(2^{\circ}\right.$. Sem. $)$ & $\begin{array}{l}\text { Transcrição de Neusa Maria } \\
\text { Schmitz. }\end{array}$ \\
\hline José Octávio & José Honório Rodrigues e a Paraíba - correspondência e análise crítica. & 6 & 1987 (dez.) & \\
\hline José Sebastião Witter & José Honório Rodrigues: historiador combatente. & 6 & 1987 (dez.) & \\
\hline \multirow[t]{2}{*}{ Karine Simoni } & $\begin{array}{l}\text { Entre a cruz e a espada: ensaio sobre o extermínio dos carijó na Ilha de } \\
\text { Santa Catarina. }\end{array}$ & 30 & $1999\left(2^{\circ}\right.$. Sem. $)$ & \\
\hline & Oeste catarinense: a bússola. & 38 & $2003\left(2^{\circ}\right.$. Sem. $)$ & \\
\hline
\end{tabular}




\begin{tabular}{|c|c|c|c|c|}
\hline Autor(es) & Título & $N^{o}$. & Período & Obs. \\
\hline Klaus Richter & $\begin{array}{l}\text { Recuperação de fontes sobre a colonização alemã no norte de Santa } \\
\text { Catarina. }\end{array}$ & 9 & 1989 (jun.) & \\
\hline Laura Machado Hübener & Documentos do século XIX sobre Santa Catarina. & 2 & 1985 (dez.) & \\
\hline Lauro Junkes & Raízes italianas do Brasil. & 24 & $1996\left(2^{\circ}\right.$. Sem. $)$ & \\
\hline Leatrice Moellmann & As migrações dos séculos XIX e XX - parte I: os alemães & 35 & $2002\left(1^{\circ}\right.$. Sem. $)$ & \\
\hline Luci Maria da Luz & Avaliação - Fundos - Arranjo. & 16 & 1992 (dez.) & \\
\hline \multirow[t]{2}{*}{ Lucy Woellner dos Santos } & $\begin{array}{l}\text { A pesquisa agrícola em Santa Catarina - uma visão histórica de sua } \\
\text { organização. }\end{array}$ & 26 & 1997 (2.Sem.) & \\
\hline & Ciência e agricultura no início do século XX em Santa Catarina. & 31 & $2000\left(1^{\circ}\right.$. Sem. $)$ & \\
\hline $\begin{array}{l}\text { Maria Cristina d'Eça Neves Luz da } \\
\text { Conceição }\end{array}$ & & & & $\begin{array}{l}\text { Ver: Cleuza Regina Costa Martins } \\
\text { (trabalho conjunto). }\end{array}$ \\
\hline Maria Denise Bortolini & Percepção: um sensível caminho do conhecimento histórico. & 30 & 1999 (2º. Sem.) & \\
\hline Maria Elita S.Alves & Preservação histórica. & 10 & 1989 (dez.) & \\
\hline Maria Goreti Pagani (org.). & $\begin{array}{l}\text { Catálogo onomástico das imagens fotográficas identificadas em livros no } \\
\text { acervo da Biblioteca Apoio e Divulgação Cultural }\end{array}$ & 36 & $2002\left(2^{\circ}\right.$. Sem. $)$ & \\
\hline Maria Lourdes Blatt Ohira & $\begin{array}{l}\text { Arquivos públicos municipais catarinenses: instrumentos de exercício da } \\
\text { cidadania. }\end{array}$ & 31 & $2000\left(1^{\circ}\right.$. Sem. $)$ & $\begin{array}{l}\text { Co-autoras: Priscila A. Martinez, } \\
\text { Neusa Rosane Damiani Nunes, } \\
\text { Cláudia Gonçalves de Souza. }\end{array}$ \\
\hline \multirow[t]{3}{*}{ Maria Regina Boppré } & A propósito da criação do Arquivo de Tubarão. & 10 & 1989 (dez.) & \\
\hline & $\begin{array}{l}\text { "O Lingote": fonte jornalística para a história popular tubaronense (1953- } \\
1958)\end{array}$ & 12 & 1990 (dez.) & \\
\hline & $\begin{array}{l}\text { A Instrução Pública Catarinense através do regulamento para a instrução } \\
\text { primária. }\end{array}$ & 18 & 1993 (dez.) & \\
\hline Maria Tereza Tertitschnij & $\begin{array}{l}\text { Relato de visita ao Arquivo Municipal e Biblioteca Histórica Estadual de } \\
\text { Bielefeld, Alemanha }\end{array}$ & 14 & 1991 (dez.) & $\begin{array}{l}\text { Ver também: Valéria Gouvêa } \\
\text { Ghanem (trabalho conjunto) }\end{array}$ \\
\hline Maria Thereza Böbel & $\begin{array}{l}\text { Projeto "Intercâmbio de informação entre o Arquivo Histórico de Joinville } \\
\text { e a República Federal da Alemanha". }\end{array}$ & 12 & 1990 (dez.) & \\
\hline \multirow[t]{2}{*}{ Maura Soares } & O teatro no contexto da história catarinense $-\mathrm{O}$ Contestado. & $20 / 21$ & $\begin{array}{l}1994 \text { (dez.) a } \\
1995 \text { (jul.) }\end{array}$ & \\
\hline & Na rua da pedreira. & 31 & $2000\left(1^{\circ}\right.$. Sem. $)$ & \\
\hline Maurício Higino da Silva & A propósito de um benefício: a necessidade de uma elite em ascender. & 27 & 1998 (1º. Sem.) & $\begin{array}{l}\text { Ver também: Rosângela Miranda } \\
\text { Cherem (trabalho conjunto). }\end{array}$ \\
\hline Milton Luz da Conceição & A Igreja Católica na evolução urbana da Ilha de Santa Catarina. & $33 / 34$ & $\begin{array}{c}2001 \\
\left(1^{\circ} . / 2^{\circ} . \text { Sem. }\right) \\
\end{array}$ & \\
\hline Nelma Baldin & $\begin{array}{l}\text { A Itália, a crise econômica do final do século passado e o processo } \\
\text { imigratório. }\end{array}$ & $20 / 21$ & $\begin{array}{l}1994 \text { (dez.) a } \\
1995 \text { (jul.) }\end{array}$ & \\
\hline
\end{tabular}




\begin{tabular}{|c|c|c|c|c|}
\hline Autor(es) & Título & $N^{o}$. & Período & Obs. \\
\hline Nélvio Paula Dutra Santos & $\begin{array}{l}\text { Algumas fontes para o estudo da economia catarinense do fim do século } \\
\text { XIX: os relatórios da Alf6andega do Desterro. }\end{array}$ & 19 & 1994 (jul.) & \\
\hline \multirow[t]{2}{*}{ Neusa Rosane Damiani Nunes } & Guia dos arquivos municipais do Estado de Santa Catarina. & 15 & 1992 (jul.) & $\begin{array}{l}\text { Ver também: Ana Maria Soares M. } \\
\text { de Araújo; Maria Lourdes Blatt } \\
\text { Ohira (trabalhos conjuntos). }\end{array}$ \\
\hline & Manual de arquivo. & 17 & 1993 (jul.) & $\begin{array}{lll}\text { Co-autora: } & \text { Valéria } & \text { Gouvêa } \\
\text { Ghanem. } & & \\
\end{array}$ \\
\hline \multicolumn{4}{|l|}{ Neusa Schmitz } & $\begin{array}{l}\text { Ver: Cleuza Regina Costa Martins } \\
\text { (trabalho conjunto); José Mariano } \\
\text { de A. Cavalcante (transcrição). }\end{array}$ \\
\hline \multicolumn{4}{|l|}{ Ninarosa Mozzato da Silva Manfroi } & Ver: Ana Lúcia V.Nötzold \\
\hline Norberto Dallabrida & A pesquisa histórica e a organização de bancos de dados. & 19 & 1994 (jul.) & \\
\hline \multirow[t]{2}{*}{ Norberto Ungaretti } & Jerônimo Coelho no Desterro em 1831. & $20 / 21$ & $\begin{array}{l}1994 \text { (dez.) a } \\
1995 \text { (jul.) }\end{array}$ & \\
\hline & Santo Antônio dos Anjos da Laguna. & 23 & $1996\left(1^{\circ}\right.$. Sem. $)$ & \\
\hline Odilon N. de Matos & Mestre Afonso de Taunay. & 18 & 1993 (dez.) & \\
\hline Orivalda Lima Silva & Museu do Judiciário Catarinense: o resgate da memória histórica. & 14 & 1991 (dez.) & Co-autor: Ilson Luiz Coelho. \\
\hline Oswaldo A. Furlan & 250 anos de influência açoriana no português do Brasil. & 27 & $1998\left(1^{\circ}\right.$. Sem. $)$ & \\
\hline Oswaldo R. Cabral & A Independência e a Capitania de Santa Catarina. & 23 & $1996\left(1^{\circ}\right.$. Sem. $)$ & \\
\hline Patrícia de Freitas & $\begin{array}{l}\text { Algumas pistas sobre o negro no período colonial através da } \\
\text { documentação do Arquivo Público do Estado de Santa Catarina. }\end{array}$ & $33 / 34$ & $\begin{array}{c}2001 \\
\left(1^{\circ} . / 2^{\circ} . \text { Sem. }\right) \\
\end{array}$ & \\
\hline Paulo Cattelan & $\begin{array}{l}\text { Winbusca-GED: construção do banco de dados do Arquivo Histórico para } \\
\text { o Memorial do Rio Grande do Sul. }\end{array}$ & 31 & $2000\left(1^{\circ}\right.$. Sem. $)$ & \\
\hline \multicolumn{4}{|l|}{ Priscila A. Martinez } & $\begin{array}{l}\text { Ver: Maria Lourdes Blatt Ohira } \\
\text { (trabalho conjunto) }\end{array}$ \\
\hline Renzo M. Grosselli & A imigração trentina em Santa Catarina (história de um livro). & 5 & 1987 (jun.) & \\
\hline Romualdo B. Ferlin & O Serviço Público visto de frente e de perfil. & 10 & 1989 (dez.) & \\
\hline Rosângela Miranda Cherem & Eduardo Dias: fragmentos da obra, faces da cidade. & 24 & $1996\left(2^{\circ}\right.$. Sem. $)$ & Co-autor: Maurício Higino da Silva. \\
\hline \multirow[t]{2}{*}{ Rosemari Conti Gonçalves } & Pesquisa histórica: quando o documento é "ilegível” & 29 & 1999 (1‥Sem.) & \\
\hline & $\begin{array}{l}\text { A inspeção escolar em Santa Catarina no século XIX: primeiras } \\
\text { aproximações. }\end{array}$ & 30 & $1999\left(2^{\circ}\right.$. Sem. $)$ & \\
\hline Rui Vieira da Cunha & Títulos para os príncipes. & 18 & 1993 (dez.) & \\
\hline Sandro da Silveira Costa & Transfigurações urbanas em Florianópolis (1880-1930) & 29 & $1999\left(1^{\circ}\right.$. Sem. $)$ & \\
\hline Santos Verani & O Arquivo de meados de 1971 a meados de 1976. & 1 & 1985 (jun.) & \\
\hline Sérgio Ribeiro da Luz & Algumas notas sobre a presença germânica na freguesia do Ribeirão. & 26 & $1997\left(2^{\circ}\right.$. Sem. $)$ & \\
\hline
\end{tabular}




\begin{tabular}{|c|c|c|c|c|}
\hline Autor(es) & Título & $N^{o}$. & Período & Obs. \\
\hline \multirow[t]{5}{*}{ Sérgio Schmitz } & BDE, um banco empreendedor. & 10 & 1989 (dez.) & \\
\hline & Gustavo Richard: um banqueiro? & 18 & 1993 (dez.) & \\
\hline & A gênese da Faculdade de Educação. & $20 / 21$ & $\begin{array}{l}1994 \text { (dez.) a } \\
1995 \text { (jul.) }\end{array}$ & \\
\hline & As casas bancárias da Ilha & 24 & $1996\left(2^{\circ}\right.$. Sem. $)$ & \\
\hline & Introdução à história da iluminação pública em Florianópolis & 25 & $1997\left(1^{\circ}\right.$. Sem.) & \\
\hline Sílvia Amélia & Breve comentário sobre uma coletânea de cartas do Dr. Adolfo Konder. & 5 & 1987 (jun.) & \\
\hline Sílvia Maria Fávero Arend & $\begin{array}{l}\text { O caso do menino Francisco e outras histórias: pais, filhos e irmão na } \\
\text { família popular. }\end{array}$ & 25 & 1997 (1'. Sem.) & \\
\hline Solange Rocha & Preservação de acervos. & 38 & $2003\left(2^{\circ}\right.$. Sem. $)$ & \\
\hline Sueli Maria Vanzuita Petry & As cheias em Blumenau e os danos causados no setor cultural. & 2 & 1985 (dez.) & \\
\hline Talita de Almeida Telemberg Soares & Padronização dos atos oficiais do Governo do Estado de Santa Catarina. & 16 & 1992 (dez.) & $\begin{array}{l}\text { Ver também: Jeferson Antonio } \\
\text { Martins (trabalhos conjuntos). }\end{array}$ \\
\hline \multirow[t]{2}{*}{ Thaís Luzia Colaço } & Carnaval no Desterro - século XIX. & 9 & 1989 (jun.) & \\
\hline & Fragmentos do cotidiano das fortificações catarinenses. & 19 & 1994 (jul.) & \\
\hline \multirow[t]{2}{*}{ Theobaldo Costa Jamundá } & O incêndio na Prefeitura de Blumenau. & 1 & 1985 (jun.) & \\
\hline & Fotografias 3/4 de "Herr Doktor" Fritz Muller. & 27 & $1998\left(1^{\circ}\right.$. Sem. $)$ & \\
\hline Toni Vidal Jochem & Professor Francisco Schaden. & 15 & 1992 (jul.) & \\
\hline \multirow[t]{2}{*}{ Valéria Gouvêa Ghanem } & A importância da documentação privada. & 7 & 1988 (jun.) & $\begin{array}{l}\text { Ver também: } \\
\text { Ana Lúcia C. Locks; } \\
\text { Neusa Rosane D. Nunes (trabalhos } \\
\text { conjuntos). }\end{array}$ \\
\hline & Instrumentos de pesquisa & 14 & 1991 (dez.) & $\begin{array}{l}\text { Co-autora: Maria Tereza } \\
\text { Tertitschnij. }\end{array}$ \\
\hline Valmir Francisco Muraro & Brasil: 500 anos de história messiânica e providencialista. & 29 & $1999\left(1^{\circ}\right.$. Sem. $)$ & \\
\hline Vilson Francisco de Farias & $\begin{array}{l}\text { Hospital de Caridade: realidade histórico-cultural (documentação } \\
\text { histórica). }\end{array}$ & 5 & 1987 (jun.) & \\
\hline \multirow[t]{9}{*}{ Walter Fernando Piazza } & O Arquivo Público do Estado e a pesquisa histórica. & 1 & 1985 (jun.) & \\
\hline & Arquivos catarinenses: uma reavaliação & 2 & 1985 (dez.) & \\
\hline & Os arquivos dos Açores e a história catarinense. & 3 & 1986 (jul.) & \\
\hline & Os estudos genealógicos de Lucas Alexandre Boiteux. & 4 & 1986 (dez.) & \\
\hline & Um “auto-de-fé" em Santa Catarina & 5 & 1987 (jun.) & \\
\hline & A lembrança de José Honório Rodrigues. & 6 & 1987 (dez.) & \\
\hline & A obra de José Gonçalves dos Santos Silva. & 7 & 1988 (jun.) & \\
\hline & Paulo José Miguel de Brito e a "Memória Política" & 8 & 1988 (dez.) & \\
\hline & Almeida Coelho e sua contribuição historiográfica. & 9 & 1989 (jun.) & \\
\hline
\end{tabular}




\begin{tabular}{|c|c|c|c|c|}
\hline Autor(es) & Título & $N^{o}$. & Período & Obs. \\
\hline \multirow[t]{5}{*}{ Walter Fernando Piazza } & Uma política de preservação documental & 10 & 1989 (dez.) & \\
\hline & "Archivo Catharinense": um ideal proposto. & 12 & 1990 (dez.) & \\
\hline & Escritores, livros, editores e livreiros. & 15 & 1992 (jul.) & \\
\hline & Raulino Reitz: as encruzilhadas de um escritor. & 16 & 1992 (dez.) & \\
\hline & Contestado: documentação existente no Arquivo do Exército. & 35 & $2002\left(1^{\circ}\right.$. Sem. $)$ & \\
\hline Wanda Ritta & Conscientização da preservação do patrimônio histórico. & 26 & $1997\left(2^{\circ}\right.$. Sem.) & \\
\hline Wilmar Pacheco & Minha passagem pelo Arquivo Público. & 1 & 1985 (jun.) & \\
\hline Yeda de Castro Brüscher Goulart & IEE - Cem anos de educação & 15 & 1992 (jul.) & \\
\hline
\end{tabular}

Obs.:

- Notas, informes e relatórios não foram aqui incluídos.

- $\mathrm{O} \mathrm{n}^{\circ} .11$ da revista foi composto apenas por um índice dos dez primeiros números.

Fontes:

- Ágora, Florianópolis, n.1 (jun.1985)- 39 (1º. sem. 2004).

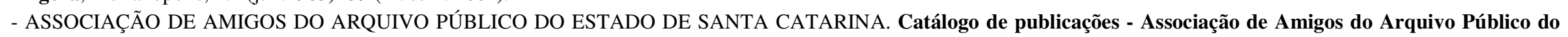
Estado de Santa Catarina e Arquivo Público do Estado de Santa Catarina. Florianópolis: 2001. 
Apêndice II-10:

Publicações do Arquivo Público do Estado de Santa Catarina e da Associação de Amigos do Arquivo Público

\begin{tabular}{|c|c|c|c|}
\hline Ano & Autor(es) & Título & Obs. \\
\hline 1984 & --- & $\begin{array}{l}\text { Sesmarias concedidas por Manoel } \\
\text { Escudeiro Ferreira de Souza }-1753 .\end{array}$ & $\begin{array}{l}\text { Edição do Arquivo Público do Estado; número } 1 \text { da coleção José Arthur Boiteux. Nota } \\
\text { explicativa de Walter F. Piazza. }\end{array}$ \\
\hline 1985 & José Bessa & $\begin{array}{l}\text { Gente da minha terra: memória da } \\
\text { Laguna. }\end{array}$ & Edição da Associação de Amigos do Arquivo Público. \\
\hline 1985 & Feliciano Nunes Pires & $\begin{array}{l}\text { Relatório e fala no governo de Santa } \\
\text { Catarina, 1833-1835. }\end{array}$ & $\begin{array}{l}\text { Edição do Arquivo Público do Estado de Santa Catarina, em conjunto com o Arquivo } \\
\text { Público do Estado de São Paulo; número } 2 \text { da coleção José Arthur Boiteux. }\end{array}$ \\
\hline 1985 & Ana Maria Martins Coelho Correia & $\begin{array}{l}\text { A Secretaria da Justiça e sua relação com } \\
\text { a educação. }\end{array}$ & $\begin{array}{l}\text { Edição do Arquivo Público do Estado em conjunto com a Universidade Federal de } \\
\text { Santa Catarina. }\end{array}$ \\
\hline 1985 & Henrique Boiteux & $\begin{array}{l}\text { A República Catharinense: notas para sua } \\
\text { história. }\end{array}$ & $\begin{array}{l}\text { Edição do Arquivo Público do Estado, em conjunto com a Xerox do Brasil; edição } \\
\text { facsimilar. }\end{array}$ \\
\hline $\begin{array}{c}\text { Desde } \\
1985\end{array}$ & [Vários autores] & Revista Ágora. & Edição da Associação de Amigos do Arquivo Público; semestral. \\
\hline 1986 & $\begin{array}{l}\text { Lêda Maria d'Ávila da Silva Prazeres } \\
\text { (org.). }\end{array}$ & $\begin{array}{l}\text { Arquivo Público: inventário da produção } \\
\text { intelectual, 1983-1986. }\end{array}$ & Edição da Associação de Amigos do Arquivo Público. \\
\hline 1987 & Leatrice Moellmann & Confissões de amor. & Edição da Associação de Amigos do Arquivo Público. \\
\hline 1988 & Iaponan Soares de Araújo & História do Município de Biguaçu. & Edição da Associação de Amigos do Arquivo Público. \\
\hline 1988 & Raquel S.Thiago & $\begin{array}{l}\text { Coronelismo urbano em Joinville: o caso } \\
\text { de Abdon Baptista. }\end{array}$ & $\begin{array}{l}\text { Edição do Arquivo Público do Estado; número } 1 \text { da coleção "Memória Pública de } \\
\text { Santa Catarina" (Historiografia). }\end{array}$ \\
\hline 1989 & Flávio José Cardoso e Nereu Corrêa & Como quem acha um tesouro. & Edição da Associação de Amigos do Arquivo Público. \\
\hline 1989 & Maria Regina Boppré & $\begin{array}{l}\text { Eleições diretas e primórdios do } \\
\text { coronelismo catarinense, } 1881-1889 .\end{array}$ & $\begin{array}{l}\text { Edição do Arquivo Público do Estado; número } 2 \text { da coleção "Memória Pública de } \\
\text { Santa Catarina" (Historiografia). }\end{array}$ \\
\hline 1990 & [Vários autores] & $\begin{array}{l}\text { Arquivo Público do Estado de Santa } \\
\text { Catarina, } 30 \text { anos: } 1960-1990 .\end{array}$ & Edição do Arquivo Público do Estado. \\
\hline 1992 & $\begin{array}{l}\text { Neusa Rosane Damiani Nunes e } \\
\text { Maria Tereza Tertitschnij (orgs.). }\end{array}$ & $\begin{array}{l}\text { Guia dos Arquivos Municipais de Santa } \\
\text { Catarina. }\end{array}$ & Edição do Arquivo Público do Estado. \\
\hline $\begin{array}{c}\text { Desde } \\
1993\end{array}$ & --- & Boletim informativo. & $\begin{array}{l}\text { Edição da Associação de Amigos do Arquivo Público em conjunto com o Arquivo } \\
\text { Público do Estado; trimestral. }\end{array}$ \\
\hline
\end{tabular}

Obs.: não foram aqui incluídas as edições dos anais dos encontros de arquivos catarinenses (ver Apêndice II-1).

Fontes:

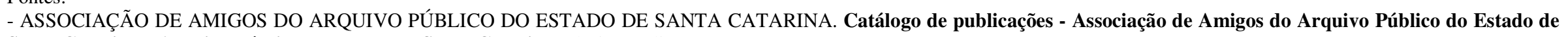
Santa Catarina e Arquivo Público do Estado de Santa Catarina. Florianópolis: 2001.

- As próprias publicações. 
Apêndice II-11:

Arquivo Público do Estado de Santa Catarina - exposições promovidas

\begin{tabular}{|c|c|c|}
\hline Exposição & Período & Local \\
\hline Publicações sobre a história regional de Santa Catarina. & Jan.-fev. 1985 & Sede do Arquivo. \\
\hline Centenário de nascimento do Prof. Henrique da Silva Fontes. & 15 a 25 mar. 1985 & Hall da Biblioteca Pública do Estado, Florianópolis, SC. \\
\hline $\begin{array}{l}\text { Documentos de Camboriú em comemoração ao centenário de instalação do } \\
\text { município. }\end{array}$ & Abr. 1985. & Sede do Arquivo. \\
\hline Documentos sobre a Polícia Militar em comemoração ao seu sesquicentenário. & 20 maio a 17 jun. 1985 & Sede do Arquivo. \\
\hline Relatórios originais dos Presidentes da Província: 1836-1889. & [Jun. 1985 ] & Sede do Arquivo. \\
\hline Documentos para a história do Arquivo Público. & 21 a 27 jun. 1985 & Sede do Arquivo. \\
\hline $\begin{array}{l}\text { Teses e livros em homenagem ao Jubileu de Prata do Arquivo Público de Santa } \\
\text { Catarina. }\end{array}$ & 28 jun. a 18 jul. 1985 & Sede do Arquivo. \\
\hline Documentos para a história da Revolução Farroupilha: 1835-1839 & 15 set. a 15 out. 1985 & Sede do Arquivo. \\
\hline $\begin{array}{l}\text { Documentos em comemoração aos } 200 \text { anos de nascimento do presidente da } \\
\text { província Feliciano Nunes Pires. }\end{array}$ & Dez. 1985 & Sede do Arquivo. \\
\hline $\begin{array}{l}\text { Documentos em homenagem ao sesquicentenário de nascimento de Joaquim da } \\
\text { Silva Ramalho. }\end{array}$ & 5 a 29 fev. 1986 & Sede do Arquivo. \\
\hline $\begin{array}{l}\text { Documentos para a história de Florianópolis em homenagem aos } 260 \text { anos de seu } \\
\text { aniversário. }\end{array}$ & 10 mar. a 30 abr. 1986 & Sede do Arquivo. \\
\hline Documentos para a história de Joinville em homenagem aos 120 anos de criação. & 5 maio a 2 jun. 1986 & Sede do Arquivo. \\
\hline $\begin{array}{l}\text { Documentos do governador João Capistrano Bandeira de Mello Filho, em } \\
\text { comemoração ao sesquicentenário de seu aniversário. }\end{array}$ & 2 a 27 jun. 1986 & Sede do Arquivo. \\
\hline $\begin{array}{l}\text { Fotografias de personalidades políticas de Santa Catarina, no aniversário do } \\
\text { Arquivo Público. }\end{array}$ & 27 jun. a 31 jul. 1986 & Sede do Arquivo. \\
\hline Educação de ontem. & 4 ago. a 2 set. 1986 & Sede do Arquivo. \\
\hline $\begin{array}{l}\text { Documentos em homenagem ao centenário de falecimento do Presidente da } \\
\text { Província Francisco Carlos de Araújo Brusque. }\end{array}$ & 3 set. a 5 out. 1986 & Sede do Arquivo. \\
\hline
\end{tabular}




\begin{tabular}{|c|c|c|}
\hline Exposição & Período & Local \\
\hline Cinqüentenário de falecimento de Eugênio Luiz Muller. & 6 out. a 5 dez. 1986 & Sede do Arquivo. \\
\hline $\begin{array}{l}\text { Documentos em homenagem aos } 200 \text { anos de nascimento de Antero José Ferreira } \\
\text { de Brito, Presidente da Província de Santa Catarina - 1840-1848. }\end{array}$ & 5 a 31 mar. 1987 & Sede do Arquivo. \\
\hline $\begin{array}{l}\text { Documentos em homenagem ao centenário de instalação do município de São } \\
\text { Joaquim: } 1887-1987 .\end{array}$ & 1 a 30 abr. 1987 & Sede do Arquivo. \\
\hline $\begin{array}{l}\text { Documentos em homenagem ao sesquicentenário de nascimento de Duarte } \\
\text { Paranhos Schutel. }\end{array}$ & 4 maio a 17 jun. 1987 & Sede do Arquivo. \\
\hline Exposição de fotos, plantas e mapas antigos da Grande Florianópolis. & 18 jun. a 31 jul. 1987 & Sede do Arquivo. \\
\hline Documentos sobre as Constituintes do Estado de Santa Catarina. & 3 a 31 ago. 1987 & Sede do Arquivo. \\
\hline $\begin{array}{l}\text { Documentação da Câmara Municipal de Porto Belo, em comemoração ao } \\
\text { sesquicentenário de instalação, em } 7 \text { dez. } 1837 .\end{array}$ & 8 a 31 set. 1987 & Sede do Arquivo. \\
\hline $\begin{array}{l}\text { Documentos em homenagem ao centenário de falecimento de Antônio de } \\
\text { Almeida Oliveira, presidente da província (1879-1880) e Pedro Leitão da Cunha } \\
\text { (presidente da província em 1862-1863). }\end{array}$ & 5 a 31 out. 1987 & Sede do Arquivo. \\
\hline $\begin{array}{l}\text { Documentos do vice-presidente da província Manoel Nascimento da Fonseca } \\
\text { Galvão, em comemoração ao sesquicentenário de nascimento. }\end{array}$ & 10 nov. a 31 dez. 1987 & Sede do Arquivo. \\
\hline 90 anos sem Cruz e Sousa. & 1 jan. a 29 fev. 1988 & Sede do Arquivo. \\
\hline 10 anos de falecimento de Oswaldo Rodrigues Cabral. & 4 a 31 mar. 1988 & Sede do Arquivo. \\
\hline Sesquicentenário de criação da Freguesia de São João Batista do Alto Tijucas. & 8 a 24 abr. 1988 & Sede do Arquivo. \\
\hline $\begin{array}{l}\text { O escravo na documentação do Arquivo Público - homenagem aos } 100 \text { anos da } \\
\text { Abolição. }\end{array}$ & 11 maio a 15 jun. 1988 & Sede do Arquivo. \\
\hline Governador Jorge Lacerda, 30 anos depois... & 16 jun. 1988 & Sede do Arquivo. \\
\hline 250 anos da criação da capital de Santa Catarina. & 19 jul. a 20 ago. 1988 & Sede do Arquivo. \\
\hline Nereu Ramos - 100 anos de nascimento. & 12 ago. a 17 set. 1988 & Sede do Arquivo. \\
\hline Cinqüentenário de falecimento de Antônio Pereira da Silva e Oliveira. & [Set. 1988 ] & Sede do Arquivo. \\
\hline Município de Jaguaruna no Arquivo Público. & 22 set. a 22 out. 1988 & Sede do Arquivo. \\
\hline
\end{tabular}




\begin{tabular}{|c|c|c|}
\hline Exposição & Período & Local \\
\hline Exposição fotográfica sobre governantes catarinenses. & 25 out. a 28 nov. 1988 & Sede do Arquivo. \\
\hline $\begin{array}{l}\text { A memória sendo preservada - o que fazer com os documentos antigos de sua } \\
\text { família? }\end{array}$ & Jan. 1989 & Sede do Arquivo. \\
\hline Sesquicentenário de nascimento de Alexandre Marcelino Bayma. & 1 a 28 fev. 1989 & Sede do Arquivo. \\
\hline A Revolução Farroupilha - Laguna e Lages. & 9 mar. 1989 & Sede do Arquivo. \\
\hline Centenário de nascimento de Cândido Caldas. & 3 abr. a 5 maio 1989 & Sede do Arquivo. \\
\hline Os últimos meses do Império em Santa Catarina. & 8 maio a 31 ago. 1989 & Sede do Arquivo. \\
\hline A imprensa catarina. [sic] & 1 a 30 set. 1989 & Sede do Arquivo. \\
\hline Junta Comercial de Santa Catarina. & 2 a 31 out. 1989 & Sede do Arquivo. \\
\hline Centenário da Proclamação da República em Santa Catarina. & 5 nov.1989 a 30 mar. 1990 & Sede do Arquivo. \\
\hline A Educação em Santa Catarina: primeira metade do século XX. & 2 abr. a 8 jun. 1990 & Sede do Arquivo. \\
\hline Arquivo Público: 30 anos. & 13 a 26 jun. 1990 & $\begin{array}{l}\text { Sala VIP do Terminal Rodoviário Rita Maria, Florianópolis, } \\
\text { SC. }\end{array}$ \\
\hline A Saúde em Santa Catarina: 1830-1950. & 1 ago. a 6 set. 1990 & Sede do Arquivo. \\
\hline Estradas em Santa Catarina no período imperial. & 10 set. a 5 nove. 1990 & Sede do Arquivo. \\
\hline Eleições em Santa Catarina: do passado aos nossos dias. & 5 a 30 nov. 1990 & Sede do Arquivo. \\
\hline Documentos interessantes no Arquivo. & 16 dez. 1990 a 1 mar. 1991 & Sede do Arquivo. \\
\hline A imigração em Santa Catarina. & 15 abr. a 14 jul. 1991 & Sede do Arquivo. \\
\hline Os engenheiros e a construção de obras públicas. & 15 jul. a 14 out. 1991 & Sede do Arquivo. \\
\hline Relatórios interessantes. & 15 abr. a 13 jul. 1992 & Sede do Arquivo. \\
\hline 100 anos do Instituto Estadual de Educação. & 13 jul. a 15 out. 1992 & Sede do Arquivo. \\
\hline A mulher e a Justiça no século passado. & 15 out.1992 a 31 mar. 1993 & Sede do Arquivo. \\
\hline Jorge Lacerda: 35 anos de saudades. & 12 jul. a 29 out. 1993 & Sede do Arquivo. \\
\hline
\end{tabular}




\begin{tabular}{|c|c|c|}
\hline Exposição & Período & Local \\
\hline 10 anos de conservação e restauração. & 3 nov. 1993 a 2 jan. 1994 & Sede do Arquivo. \\
\hline Florianópolis e sua história. & 7 jun. a 7 ago. 1994 & Sede do Arquivo. \\
\hline Arquivo Público: 35 anos. & Jun. a set. 1995 & Sede do Arquivo. \\
\hline Alguém fotografou, agora precisamos identificar as imagens: venha nos ajudar. & 20 dez. 1995 a 29 fev. 1996 & Sede do Arquivo. \\
\hline Memória da cidade. & 16 abr. a 14 jun. 1996 & Sede do Arquivo. \\
\hline Herança cultural açoriana. & 12 jul. a 11 out. 1996 & Sede do Arquivo. \\
\hline Alguém fotografou, agora precisamos identificar as imagens: venha nos ajudar. & 10 dez. 1996 a 10 mar. 1997 & Sede do Arquivo. \\
\hline Lembranças do passado. & 22 abr. a 22 jul. 1997 & Sede do Arquivo. \\
\hline Esquinas de Florianópolis. & 1 set. a 1 nov. 1997 & Sede do Arquivo. \\
\hline Conheça um pouquinho de Santa Catarina. & 3 nov. a 8 dez. 1997 & Sede do Arquivo. \\
\hline Alguém fotografou, agora precisamos identificar as imagens: venha nos ajudar. & 11 dez. 1997 a 11 mar. 1998 & Sede do Arquivo. \\
\hline Homenagem a Cruz e Sousa. & 19 mar. a 19 jun. 1998 & Sede do Arquivo. \\
\hline Caminhos da Arqueologia. & 20 ago. a 20 set. 1998 & Sede do Arquivo. \\
\hline 250 anos de cultura açoriana & 29 out. 1998 a 30 mar.1999 & Sede do Arquivo. \\
\hline Cultura Açoriana & 16 a 18 jul. 1999 & $6^{\mathrm{a}} . \mathrm{AÇOR}$ - Porto Belo, SC \\
\hline Colonização açoriana e alemã & Set. 1999 & $\begin{array}{l}\text { X Festa do Folclore: Escola básica no bairro Armação do } \\
\text { Pântano do Sul, Florianópolis, SC. }\end{array}$ \\
\hline 170 anos de cultura alemã em Santa Catarina & 25 maio a 25 de ago. 1999 & Sede do Arquivo. \\
\hline Memórias de Garopaba & 23 a 26 jun. 2000 & $7^{\mathrm{a}}$. AÇOR - Garopaba, SC \\
\hline Trajetória de uma catarinense: escritora - poeta - artista plástica [Janice Pavam] & 11 nov. 1999 a 11 fev. 2000 & Sede do Arquivo. \\
\hline Santa Catarina nos 500 anos do Brasil & 6 de abr. a 6 jul. 2000 & Sede do Arquivo. \\
\hline Momentos da história de Santa Catarina & 22 set. a 25 out. 2000 & Sede do Arquivo. \\
\hline
\end{tabular}




\begin{tabular}{|c|c|c|}
\hline Exposição & Período & Local \\
\hline Antologia de uma artista [artista plástica Dircéa Binder] & 22 mar. a 30 jul. 2001 & Sede do Arquivo. \\
\hline Recordando a Vila de São José da Terra Firme & 26 a 28 out. 2001 & $8^{\mathrm{a}}$. AÇOR - São José, SC \\
\hline $\begin{array}{l}\text { Olhares catarinenses em solo açoriano: o que vimos, ouvimos e sentimos na terra } \\
\text { de nossas raízes }\end{array}$ & $\begin{array}{l}4 \text { dez. } 2001 \text { a } 29 \text { mar. } 2002 \\
3 \text { a } 31 \text { maio } 2002\end{array}$ & $\begin{array}{c}\text { Sede do Arquivo. } \\
\text { Casa da Cultura Pe. Bernardo Junkes (Içara, SC) }\end{array}$ \\
\hline Memória Fotográfica da Ilha de Santa Catarina & 20 maio a 9 ago. 2002 & Sede do Arquivo. \\
\hline Homenageando Araquari & $\begin{array}{l}15 \text { a } 17 \text { nov. 2002 } \\
\text { [Dez. 2002] }\end{array}$ & $\begin{array}{l}9^{\mathrm{a}} . \text { AÇOR - Araquari, SC } \\
\text { Sede do Arquivo. }\end{array}$ \\
\hline Festa do Divino, por Dircéa Binder & 26 jun. a 26 set. 2003 & Sede do Arquivo. \\
\hline Homenageando Tijucas & 17 a 19 out. 2003 & $10^{\mathrm{a}} . \mathrm{AÇOR}$ - Tijucas, SC \\
\hline Arquivo Público divulga parte de seu acervo & Abr. 2004 & Sede do Arquivo. \\
\hline São Francisco do Sul: 500 anos de história & 20 a 22 ago. 2004 & $11^{\mathrm{a}}$. AÇOR - São Francisco do Sul, SC \\
\hline $\begin{array}{l}\text { Arquivo Público do Estado homenageia São Francisco do Sul, Município - Sede } \\
\text { da } 11^{\text {a }} \text {. AÇOR }\end{array}$ & 8 set. a 8 dez. 2004 & Sede do Arquivo. \\
\hline Parabéns Florianópolis: 279 anos de História & 23 mar. a 23 jun. 2005 & Sede do Arquivo. \\
\hline Arquivo vivo: 45 anos de História & 24 jun. a 28 set. 2005 & Sede do Arquivo. \\
\hline Florianópolis: 280 anos de História & 24 fev. a 19 maio 2006 & Sede do Arquivo. \\
\hline
\end{tabular}

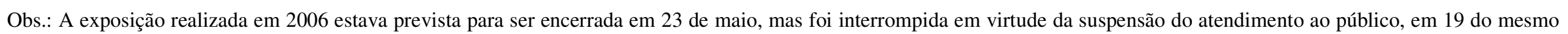
mês. A suspensão foi decidida em função dos preparativos para mudança de endereço da sede do Arquivo.

Fontes:

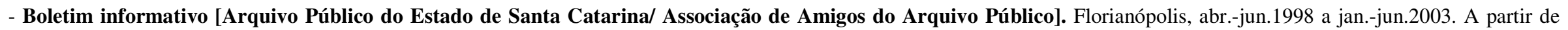
julho de 2003, as informações são mais pontuais, dada a redução das dimensões do boletim (de caderno de 12 páginas, em média, para folder).

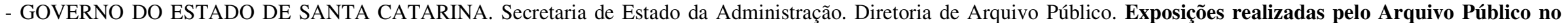
período de 1985 a 2005. Florianópolis: 2005.

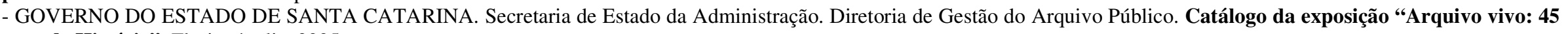
anos de História”. Florianópolis: 2005. 
Apêndice II-12:

Arquivo Público do Estado de Santa Catarina - presença de representantes da instituição em eventos (1998-2005)

\begin{tabular}{|c|c|c|c|c|c|c|c|c|c|}
\hline Tipo de Evento & Especificação/local & $\begin{array}{l}1 \\
9 \\
9 \\
8 \\
\end{array}$ & \begin{tabular}{l|}
$\mathbf{1}$ \\
$\mathbf{9}$ \\
$\mathbf{9}$ \\
$\mathbf{9}$
\end{tabular} & $\begin{array}{l}\mathbf{2} \\
\mathbf{0} \\
\mathbf{0} \\
\mathbf{0}\end{array}$ & $\begin{array}{l}\mathbf{2} \\
\mathbf{0} \\
\mathbf{0} \\
\mathbf{1}\end{array}$ & $\begin{array}{l}2 \\
0 \\
0 \\
2\end{array}$ & $\begin{array}{l}\mathbf{2} \\
\mathbf{0} \\
\mathbf{0} \\
\mathbf{3}\end{array}$ & $\begin{array}{l}2 \\
0 \\
0 \\
4\end{array}$ & $\begin{array}{l}2 \\
0 \\
0 \\
5\end{array}$ \\
\hline Assembléia Geral & Eleição da nova diretoria da Casa dos Açores Ilha de Santa Catarina (Florianópolis, SC) & & & & & $\mathrm{X}$ & & & \\
\hline \multirow[t]{9}{*}{ Curso / oficina } & Curso "Fundamentos científicos da conservação - pintura de cavalete" (Florianópolis, SC) & $\mathrm{X}$ & & & & & & & \\
\hline & Curso "Preparando mudanças" [capacitação na área de administração] (Florianópolis, SC) & $\mathrm{X}$ & & & & & & & \\
\hline & Curso “Descrição arquivística” (Arquivo Nacional, Rio de Janeiro, RJ) & & $\mathrm{X}$ & & & & & & \\
\hline & Curso "Redação oficia”l (Florianópolis, SC) & & $\mathrm{X}$ & & & & & & \\
\hline & Oficinas promovidas pela Associação de Arquivistas de São Paulo (São Paulo, SP) & & & $\mathrm{X}$ & & & & & \\
\hline & Curso "Santa Catarina no século XX" (IHGSC) & & & $\mathrm{X}$ & & & & & \\
\hline & Oficina “Descrição Arquivística Codificada - EAD” (Arquivo Nacional, Rio de Janeiro, RJ) & & & & $\mathrm{X}$ & & & & \\
\hline & $5^{\circ}$. Curso "Açores à descoberta das raízes" (Açores) & & & & $\mathrm{X}$ & & & & \\
\hline & $6^{\circ}$. Curso "Açores à descoberta das raízes" (Açores) & & & & & $\mathrm{X}$ & & & \\
\hline Defesa de tese & Defesa pública da tese de doutorado em História “Memória de uma (outra) guerra” (UFSC, Florianópolis, SC) & & & & $\mathrm{X}$ & & & & \\
\hline \multirow{19}{*}{$\begin{array}{l}\text { Encontro profissional / } \\
\text { científico }\end{array}$} & $1^{\circ}$. Congresso Internacional das Festas do Divino Espírito Santo (Florianópolis, SC) & & $\mathrm{X}$ & & & & & & \\
\hline & Congresso Nacional - Federação dos Centros de Cultura Alemã no Brasil (Águas Mornas, SC) (1) & & $\mathrm{X}$ & & & & & & \\
\hline & Integrar: $1^{\circ}$. Congresso Internacional de Arquivos, Bibliotecas, Centros de Documentação e Museus (S.Paulo, SP) & & & & $\mathrm{X}$ & & & & \\
\hline & Encontro da Comissão de Estudos do Currículo do Curso de Biblioteconomia da UFSC (Florianópolis, SC) & $\mathrm{X}$ & & & & & & & \\
\hline & Encontro do Núcleo de Estudos Museológicos - UFSC (Rio do Sul, SC) & & $\mathrm{X}$ & & & & & & \\
\hline & Encontro do Núcleo de Estudos Museológicos - UFSC (São Joaquim, SC) & & $\mathrm{X}$ & & & & & & \\
\hline & Encontro do Núcleo de Estudos Museológicos - UFSC (Videira, SC). (2) & & & $\mathrm{X}$ & & & & & \\
\hline & Encontro Estadual de História (Florianópolis, SC) (1) & & & $\mathrm{X}$ & & & & & \\
\hline & Encontro dos Prefeitos do Vale do Itajaí e instituições que veiculam [sic] arquivos municipais (Blumenau, SC) & & & & $\mathrm{X}$ & & & & \\
\hline & Fórum Nacional de Diretores de Arquivos Públicos Estaduais & & & $\mathrm{X}$ & & & & & \\
\hline & 38․ Fórum Nacional de Secretários de Estado da Administração (Florianópolis, SC) & & & $\mathrm{X}$ & & & & & \\
\hline & Fórum Nacional de Diretores de Arquivos Públicos (Porto Alegre, RS) & & & & $\mathrm{X}$ & & & & \\
\hline & Fórum Nacional de Diretores de Arquivos Públicos (Rio de Janeiro, RJ) & & & & $\mathrm{X}$ & & & & \\
\hline & Jornada Científica do Serviço Público (Florianópolis, SC) & & & & $\mathrm{X}$ & & & & \\
\hline & $18^{\circ}$. Painel de Biblioteconomia em SC (Florianópolis, SC) (3) & & $\mathrm{X}$ & & & & & & \\
\hline & $2^{\text {a }}$. Semana do Servidor (Florianópolis, SC) & & & & $\mathrm{X}$ & & & & \\
\hline & Semana do Sesquicentenário do Arquivo Público do Paraná (Curitiba, SC) & & & & & & & & $\mathrm{X}$ \\
\hline & $1^{\circ}$. Seminário sobre Conservação Preventiva de Arquivos e Bibliotecas - Centro-Oeste (Campo Grande, MTS) (3) & & $\mathrm{X}$ & & & & & & \\
\hline & Seminário para implantação do manual de padronização e redação dos atos oficiais (Florianópolis, SC) & & & $\mathrm{X}$ & & & & & \\
\hline
\end{tabular}




\begin{tabular}{|c|c|c|c|c|c|c|c|c|c|}
\hline Tipo de Evento & Especificação/local & $\begin{array}{l}1 \\
9 \\
9 \\
8\end{array}$ & \begin{tabular}{|l|}
1 \\
9 \\
9 \\
9 \\
\end{tabular} & \begin{tabular}{|l|}
$\mathbf{2}$ \\
$\mathbf{0}$ \\
$\mathbf{0}$ \\
$\mathbf{0}$
\end{tabular} & $\begin{array}{l}\mathbf{2} \\
\mathbf{0} \\
\mathbf{0} \\
\mathbf{1}\end{array}$ & $\begin{array}{l}\mathbf{2} \\
\mathbf{0} \\
\mathbf{0} \\
\mathbf{2}\end{array}$ & $\begin{array}{l}\mathbf{2} \\
\mathbf{0} \\
\mathbf{0} \\
\mathbf{3}\end{array}$ & $\begin{array}{l}2 \\
0 \\
0 \\
4\end{array}$ & $\begin{array}{l}2 \\
0 \\
0 \\
5\end{array}$ \\
\hline \multirow{16}{*}{$\begin{array}{l}\text { Encontro profissional / } \\
\text { científico }\end{array}$} & 11 . Seminário Nacional de Bibliotecas Universitárias (Florianópolis, SC) & & & $\mathrm{X}$ & & & & & \\
\hline & $1^{\circ}$. Seminário de Documentos Eletrônicos (Florianópolis, SC) & & & & $\mathrm{X}$ & & & & \\
\hline & Seminário "Revisitando a História por meio de fontes documentais" & & & & $\mathrm{X}$ & & & & \\
\hline & Seminário de multiplicadores da desburocratização (Florianópolis, SC) & & & & & $\mathrm{X}$ & & & \\
\hline & $2^{\circ}$. Seminário Internacional de Arquivos de Tradição Ibérica (Rio de Janeiro, RJ) & & & & & $\mathrm{X}$ & & & \\
\hline & $2^{\circ}$. Seminário Internacional sobre conhecimentos tradicionais, folclore e artesanato (Florianópolis, SC) & & & & & $\mathrm{X}$ & & & \\
\hline & Simpósio Internacional de Arquivos Municipais (Rio de Janeiro, RJ) & & & & & $\mathrm{X}$ & & & \\
\hline & Reunião do Grupo de Estudos sobre Restauração (Museu Histórico de SC, Florianópolis, SC) & & $\mathrm{X}$ & & & & & & \\
\hline & Reunião do Núcleo de Estudos Açorianos - UFSC (Prefeitura Municipal de Garopaba, SC) & $\mathrm{X}$ & & & & & & & \\
\hline & Reunião do Núcleo de Estudos Açorianos - UFSC (Porto Belo, SC) & & $\mathrm{X}$ & & & & & & \\
\hline & Reuniões do Núcleo de Estudos Açorianos - UFSC (Florianópolis, SC) & & $\mathrm{X}$ & & & & & & \\
\hline & Reuniões do Núcleo de Estudos Açorianos - UFSC (local não especificado) & & & & $\mathrm{X}$ & & & & \\
\hline & Reuniões da Casa dos Açores (local não especificado) & & & & $\mathrm{X}$ & & & & \\
\hline & Reuniões do GT-Acervos (ANPUH-SC) (local não especificado) & & & & $\mathrm{X}$ & & & & \\
\hline & Reuniões do Núcleo de Estudos Museológicos - UFSC (local não especificado) & & & & $\mathrm{X}$ & & & & \\
\hline & Reunião do Conselho Nacional de Arquivos & & & & & $\mathrm{X}$ & & & \\
\hline Estágio & Estágio na área de conservação de fotografias e montagem de exposições (Lisboa) & & & & & $\mathrm{X}$ & & & \\
\hline \multirow[t]{9}{*}{ Exposição } & 5a. Mostra do Potencial Educativo da Escola Técnica Federal de SC (Florianópolis, SC) (4) & $\mathrm{X}$ & & & & & & & \\
\hline & $6^{\mathrm{a}}$. AÇOR - Festa da Cultura Açoriana (4) & & $\mathrm{X}$ & & & & & & \\
\hline & 7a. AÇOR - Festa da Cultura Açoriana (Garopaba, SC) (4) & & & $\mathrm{X}$ & & & & & \\
\hline & $8^{\circ}$. AÇOR - Festa da Cultura Açoriana (São José, SC) (4) & & & & $\mathrm{X}$ & & & & \\
\hline & 9a. AÇOR - Festa da Cultura Açoriana (Araquari, SC) (4) & & & & & $\mathrm{X}$ & & & \\
\hline & $10^{\mathrm{a}}$. AÇOR - Festa da Cultura Açoriana (Tijucas, SC) & & & & & & $\mathrm{X}$ & & \\
\hline & $11^{\mathrm{a}}$. AÇOR - Festa da Cultura Açoriana (São Francisco do Sul, SC) & & & & & & & $\mathrm{X}$ & \\
\hline & $11^{\text {a }}$. Festa do Folclore - Escola Básica Municipal Pres.Castelo Branco (Florianópolis, SC) (5) & & & & $\mathrm{X}$ & & & & \\
\hline & Festa do Folclore (Escola Municipal Pres. Castelo Branco, Florianópolis, SC) (5) & & $\mathrm{X}$ & & & & & & \\
\hline Lançamento (evento) & Lançamento oficial da Festa das Etnias (Florianópolis, SC) & & & $\mathrm{X}$ & & & & & \\
\hline Lançamento (prêmio) & Prêmio Talentos Empreendedores 1999 (Hotel Coral Plaza, Florianópolis, SC) & & $\mathrm{X}$ & & & & & & \\
\hline \multirow{4}{*}{$\begin{array}{l}\text { Lançamento } \\
\text { (publicação) }\end{array}$} & Livros "Florianópolis - Ilha açoriana" e "Florianópolis - ilha de sonhos" (Restaurante Pirão, Florianópolis, SC) & $\mathrm{X}$ & & & & & & & \\
\hline & Revista “Ciclo vital” (Florianópolis, SC) & $\mathrm{X}$ & & & & & & & \\
\hline & Livro "Santa Catarina: 100 anos de história” (Livraria Siciliano, Florianópolis, SC) & $\mathrm{X}$ & & & & & & & \\
\hline & Livro: Coleção Poética (Biblioteca Pública Municipal, Florianópolis, SC) & & $\mathrm{X}$ & & & & & & \\
\hline
\end{tabular}




\begin{tabular}{|c|c|c|c|c|c|c|c|c|c|}
\hline Tipo de Evento & Especificação/local & $\begin{array}{l}1 \\
9 \\
9 \\
8 \\
\end{array}$ & \begin{tabular}{l|}
1 \\
9 \\
9 \\
9 \\
\end{tabular} & $\begin{array}{l}\mathbf{2} \\
\mathbf{0} \\
\mathbf{0} \\
\mathbf{0} \\
\end{array}$ & $\begin{array}{l}\mathbf{2} \\
\mathbf{0} \\
\mathbf{0} \\
\mathbf{1} \\
\end{array}$ & $\begin{array}{l}\mathbf{2} \\
\mathbf{0} \\
\mathbf{0} \\
\mathbf{2} \\
\end{array}$ & $\begin{array}{l}\mathbf{2} \\
\mathbf{0} \\
\mathbf{0} \\
\mathbf{3} \\
\end{array}$ & $\begin{array}{l}2 \\
0 \\
0 \\
4 \\
\end{array}$ & \begin{tabular}{|l|}
2 \\
0 \\
0 \\
5 \\
\end{tabular} \\
\hline \multirow[t]{4}{*}{$\begin{array}{l}\text { Lançamento } \\
\text { (publicação) }\end{array}$} & $\begin{array}{l}\text { Livro: Tão fortes quanto a vontade: história da imigração italiana no Brasil - os vênetos em SC (Assembléia } \\
\text { Legislativa do Estado, Florianópolis, SC) }\end{array}$ & & $\mathrm{X}$ & & & & & & \\
\hline & $\begin{array}{l}\text { Livro: "Incapacidade" indígena: tutela religiosa e violação do direito guarani nas missões jesuíticas (Galeria de } \\
\text { Artes da UFSC, Florianópolis, SC) }\end{array}$ & & & $\mathrm{X}$ & & & & & \\
\hline & CD-ROM e livro: Catálogo de documentos manuscritos avulsos referentes à Capitania de SC - 1717-1827 & & & $\mathrm{X}$ & & & & & \\
\hline & Livro: Santa Catarina - projeções populacionais, 1991-2020 (Florianópolis, SC) & & & $\mathrm{X}$ & & & & & \\
\hline Palestra & Palestra “Educação patrimonial” (Museu Universitário Oswaldo Rodrigues Cabral, UFSC, Florianópolis, SC) & $\mathrm{X}$ & & & & & & & \\
\hline \multirow[t]{6}{*}{ Palestra } & Palestra "O funcionário do setor público num cenário de mudanças" (Florianópolis, SC) & $\mathrm{X}$ & & & & & & & \\
\hline & Palestra "Novas técnicas de conservação e restauração de pinturas de cavalete" (Florianópolis, SC) & & $\mathrm{X}$ & & & & & & \\
\hline & Palestra "Uma vida entre livros" (Aliança Francesa, Florianópolis, SC) & & $\mathrm{X}$ & & & & & & \\
\hline & Palestra “Marinha do Brasil, 500 anos - SC no mar" (Escola de Aprendizes Marinheiros, Florianópolis, SC) & & & $\mathrm{X}$ & & & & & \\
\hline & Palestras promovidas pela Associação Catarinense de Conservadores e Restauradores (Florianópolis, SC) & & & & & $\mathrm{X}$ & & & \\
\hline & Palestra “Tecnologias e políticas de avaliação e preservação de acervos arquivísticos” (Florianópolis, SC) & & & & & & $\mathrm{X}$ & & \\
\hline \multirow[t]{19}{*}{ Solenidade } & Abertura da exposição “Balanço do Mar” (Biblioteca Pública Municipal, Florianópolis, SC) & $\mathrm{X}$ & & & & & & & \\
\hline & Abertura da exposição Anita Garibaldi (Assembléia Legislativa do Estado, Florianópolis, SC) & & $\mathrm{X}$ & & & & & & \\
\hline & Abertura da exposição Memórias do Carnaval de Florianópolis (Florianópolis, SC) & & & $\mathrm{X}$ & & & & & \\
\hline & Abertura da CONINFO 2001 [Feira de Informática] (Blumenau, SC) & & & & $\mathrm{X}$ & & & & \\
\hline & $43^{\circ}$. Aniversário da Biblioteca Pública Municipal (Florianópolis, SC) & & $\mathrm{X}$ & & & & & & \\
\hline & $145^{\circ}$. Aniversário da Biblioteca Pública do Estado de SC & & $\mathrm{X}$ & & & & & & \\
\hline & $170^{\circ}$. Aniversário da Imigração Alemã no Município de S.Pedro de Alcântara (S.Pedro de Alcântara,SC) & & $\mathrm{X}$ & & & & & & \\
\hline & Assinatura de termo de cooperação técnica relativo ao Núcleo de Estudos Museológicos (Florianópolis, SC) & & & $\mathrm{X}$ & & & & & \\
\hline & Entrega do Troféu Açorianidade 2000 (Florianópolis, SC) & & & $\mathrm{X}$ & & & & & \\
\hline & Entrega do Troféu Açorianidade e do lançamento da $10^{\mathrm{a}}$. AÇOR - Festa da Cultura Açoriana (Tijucas, SC) & & & & & & $\mathrm{X}$ & & \\
\hline & Homenagem a Cruz e Sousa (Biblioteca Pública Municipal, Florianópolis, SC) & $\mathrm{X}$ & & & & & & & \\
\hline & Inauguração da nova sede do Arquivo Histórico de Itajaí (Itajaí, SC) & $\mathrm{X}$ & & & & & & & \\
\hline & Inauguração do Espaço Cultural da Biblioteca Pública Municipal (Florianópolis, SC) & & $\mathrm{X}$ & & & & & & \\
\hline & Inauguração do Espaço Cultural da Secretaria de Estado da Administração & & & $\mathrm{X}$ & & & & & \\
\hline & Inauguração do Biblioteca Pública Municipal e Escolar de Itajaí (SC) & & & $\mathrm{X}$ & & & & & \\
\hline & Inauguração do Centro de Memória Histórica Genésio de Miranda Lins (Itajaí, SC) & & & & $\mathrm{X}$ & & & & \\
\hline & Inauguração do Arquivo Intermediário da Prefeitura Municipal de Itajaí - SC & & & & & $\mathrm{X}$ & & & \\
\hline & Noite de gratidão aos imigrantes (Centro Evangélico Pastor Christian Sluhan, Águas Mornas, SC) & $\mathrm{X}$ & & & & & & & \\
\hline & Posse da diretoria da Fundação Senhor Jesus dos Passos (Florianópolis, SC) & & $\mathrm{X}$ & & & & & & \\
\hline
\end{tabular}




\begin{tabular}{|c|c|c|c|c|c|c|c|c|c|}
\hline Tipo de Evento & Especificação/local & $\begin{array}{l}1 \\
9 \\
9 \\
8\end{array}$ & $\begin{array}{l}1 \\
9 \\
9 \\
9\end{array}$ & $\begin{array}{l}\mathbf{2} \\
0 \\
0 \\
0\end{array}$ & $\begin{array}{l}2 \\
0 \\
0 \\
1\end{array}$ & $\begin{array}{l}\mathbf{2} \\
\mathbf{0} \\
\mathbf{0} \\
\mathbf{2}\end{array}$ & $\begin{array}{l}\mathbf{2} \\
\mathbf{0} \\
\mathbf{0} \\
\mathbf{3}\end{array}$ & $\begin{array}{l}2 \\
0 \\
0 \\
4\end{array}$ & $\begin{array}{l}2 \\
0 \\
0 \\
5\end{array}$ \\
\hline & $\begin{array}{l}\text { Posse dos novos conselheiros do Conselho Regional de Biblioteconomia (Biblioteca Pública do Estado de SC, } \\
\text { Florianópolis, SC) }\end{array}$ & & & $\mathrm{X}$ & & & & & \\
\hline & Reabertura da Biblioteca Pública do Estado de Santa Catarina (Florianópolis, SC) & & & & & & $\mathrm{X}$ & & \\
\hline & Sessão de encerramento do ano acadêmico do IHGSC (IHGSC, Florianópolis, SC) & $\mathrm{X}$ & & & & & & & \\
\hline & Sessão de encerramento do ano de 1999 - Academia Catarinense de Letras (Florianópolis, SC) & & $\mathrm{X}$ & & & & & & \\
\hline & Sessões solenes do IHGSC homenageando catarinenses ilustres & & & & & $\mathrm{X}$ & & & \\
\hline
\end{tabular}

Obs::

- Não foram incluídos os encontros catarinenses de arquivos.

- Observações relativas à segunda coluna:

(1) Participação com palestra;

(2) Participação ministrando oficina;

(3) Participação com apresentação de trabalho;

(4) Participação com stand e exposição relativa ao acervo;

(5) Participação com mostra.

Fontes:

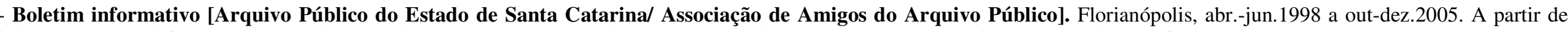
julho de 2003, as informações são mais pontuais, dada a redução das dimensões do boletim (de caderno de 12 páginas, em média, para folder).

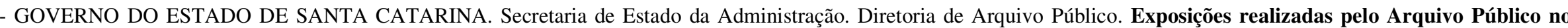
período de 1985 a 2005. Florianópolis: 2005. 
Apêndice II-13:

Arquivo Público do Estado de Santa Catarina - visitas de grupos/ turmas de estudantes (1998-2002)

\begin{tabular}{|c|c|c|c|c|c|c|c|}
\hline Instituição de ensino / Curso & $\begin{array}{l}\mathrm{N}^{\mathrm{o}} . \text { de alunos } \\
\text { (total por ano) }\end{array}$ & Nível de ensino & \begin{tabular}{|l|}
1 \\
9 \\
9 \\
8
\end{tabular} & $\begin{array}{l}1 \\
9 \\
9 \\
9\end{array}$ & $\begin{array}{l}\mathbf{2} \\
\mathbf{0} \\
\mathbf{0} \\
\mathbf{0}\end{array}$ & \begin{tabular}{|l|}
2 \\
0 \\
0 \\
1
\end{tabular} & $\begin{array}{l}2 \\
0 \\
0 \\
2\end{array}$ \\
\hline Centro Educacional de Barreiros (São José, SC) & 62 & Ensino fundamental & $\mathrm{X}$ & & & & \\
\hline Centro Educacional Lucaz & 29 & Ensino fundamental & & $\mathrm{X}$ & & & \\
\hline Centro Federal de Educação Tecnológica - CEFET & 73 & Ensino médio & & & & & $\mathrm{X}$ \\
\hline Colégio Bardall & 28 & Ensino médio & & & & & $\mathrm{X}$ \\
\hline Colégio de Aplicação - UFSC & 50 & Ensino médio & & & & & $\mathrm{X}$ \\
\hline Colégio Dom Bosco & 13 & Ensino médio & & & & & $\mathrm{X}$ \\
\hline Colégio Energia & 23 & Ensino médio & & & & & $\mathrm{X}$ \\
\hline Colégio Santa Catarina & 63 & Ensino fundamental & & & & $\mathrm{X}$ & \\
\hline Escola Antonieta de Barros & 30 & Ensino fundamental & & & & & $\mathrm{X}$ \\
\hline \multirow[t]{2}{*}{ Escola Autonomia } & 50 & Ensino fundamental & $\mathrm{X}$ & & & & \\
\hline & 15 & Ensino fundamental & & & & & $\mathrm{X}$ \\
\hline Escola Básica Municipal Batista Pereira & 23 & Ensino fundamental & & $\mathrm{X}$ & & & \\
\hline Escola Básica Municipal Dr. Adalberto Tolentino de Carvalho (São Pedro de Alcântara, SC) & 32 & Ensino fundamental & & & & & $\mathrm{X}$ \\
\hline Escola Básica Municipal João Gonçalves Pinheiro & 40 & Ensino fundamental & & & & $\mathrm{X}$ & \\
\hline Escola Básica Municipal Pe. Anchieta & 15 & Ensino fundamental & & & & & $\mathrm{X}$ \\
\hline \multirow{2}{*}{ Escola Básica Municipal Vitor Miguel de Souza } & 45 & Ensino fundamental & & $\mathrm{X}$ & & & \\
\hline & 40 & Ensino fundamental & & & $\mathrm{X}$ & & \\
\hline Escola Básica Henrique Veras & 35 & Ensino fundamental & & & & $\mathrm{X}$ & \\
\hline Escola Desdobrada Retiro da Lagoa & 18 & Ensino fundamental & & & & & $\mathrm{X}$ \\
\hline Escola Dinâmica & 34 & Ensino fundamental & & & & $\mathrm{X}$ & \\
\hline Escola Fazenda & 17 & Ensino fundamental & & & & & $\mathrm{X}$ \\
\hline Escola Maria Vargas Jr. [sic] & 9 & Ensino fundamental & & & & $\mathrm{X}$ & \\
\hline \multirow[t]{3}{*}{ Escola Santa Catarina } & 104 & Ensino fundamental & $\mathrm{X}$ & & & & \\
\hline & 118 & Ensino fundamental & & $\mathrm{X}$ & & & \\
\hline & 62 & Ensino fundamental & & & & & $\mathrm{X}$ \\
\hline Escola Silveira de Souza & 40 & Ensino médio & & & & $\mathrm{X}$ & \\
\hline \multirow[t]{3}{*}{ Escola Técnica Federal de SC [ver também Centro Federal de Educação Tecnológica] } & 44 & Ensino médio & & $\mathrm{X}$ & & & \\
\hline & c. 100 & Ensino médio & & & $\mathrm{X}$ & & \\
\hline & 40 & Ensino médio & & & & & $\mathrm{X}$ \\
\hline Escola Tupy (Joinville, SC) & 10 & Ensino fundamental & & $\mathrm{X}$ & & & \\
\hline
\end{tabular}




\begin{tabular}{|c|c|c|c|c|c|c|c|}
\hline Instituição de ensino / Curso & $\begin{array}{l}\mathrm{N}^{\mathrm{o}} \text {. de alunos } \\
\text { (total por ano) }\end{array}$ & Nível de ensino & \begin{tabular}{|l|}
1 \\
9 \\
9 \\
8
\end{tabular} & $\begin{array}{l}1 \\
9 \\
9 \\
9\end{array}$ & $\begin{array}{l}\mathbf{2} \\
\mathbf{0} \\
\mathbf{0} \\
\mathbf{0}\end{array}$ & \begin{tabular}{|l}
$\mathbf{2}$ \\
$\mathbf{0}$ \\
$\mathbf{0}$ \\
$\mathbf{1}$
\end{tabular} & $\begin{array}{l}\mathbf{2} \\
\mathbf{0} \\
\mathbf{0} \\
\mathbf{2}\end{array}$ \\
\hline \multirow{5}{*}{ UDESC - Curso de Biblioteconomia } & 21 & Ensino superior & $\mathrm{X}$ & & & & \\
\hline & 21 & Ensino superior & & $\mathrm{X}$ & & & \\
\hline & 12 & Ensino superior & & & $\mathrm{X}$ & & \\
\hline & 4 & Ensino superior & & & & $\mathrm{X}$ & \\
\hline & 69 & Ensino superior & & & & & $\mathrm{X}$ \\
\hline UDESC - Curso de História & 10 & Ensino superior & $\mathrm{X}$ & & & & \\
\hline UFSC - Curso de Arquitetura & 15 & Ensino superior & & & $\mathrm{X}$ & & \\
\hline \multirow[t]{2}{*}{ UFSC - Curso de Biblioteconomia } & 82 & Ensino superior & & $\mathrm{X}$ & & & \\
\hline & 2 & Ensino superior & & & & & $\mathrm{X}$ \\
\hline \multirow{4}{*}{ UFSC - Curso de História } & 42 & Ensino superior & $\mathrm{X}$ & & & & \\
\hline & 118 & Ensino superior & & $\mathrm{X}$ & & & \\
\hline & 40 & Ensino superior & & & $\mathrm{X}$ & & \\
\hline & 56 & Ensino superior & & & & & $\mathrm{X}$ \\
\hline \multirow[t]{3}{*}{ UFSC - Curso de Letras } & 32 & Ensino superior & $\mathrm{X}$ & & & & \\
\hline & 30 & Ensino superior & & $\mathrm{X}$ & & & \\
\hline & 15 & Ensino superior & & & $\mathrm{X}$ & & \\
\hline UFSC - Curso de Pedagogia & 19 & Ensino superior & & & & & $\mathrm{X}$ \\
\hline UNISUL - Curso de Arquitetura e Urbanismo & 62 & Ensino superior & & & & & $\mathrm{X}$ \\
\hline UNOESC - Curso de História & 43 & Ensino superior & & & & $\mathrm{X}$ & \\
\hline Universidade Federal de Londrina (PR) - Curso de Secretariado Executivo & 42 & Ensino superior & & & & $\mathrm{X}$ & \\
\hline
\end{tabular}

Obs.:

1. Em 1998, também visitaram o APESC 78 estudantes que participavam, em Florianópolis, do XXI Encontro Nacional de Estudantes de Biblioteconomia

2. O fornecimento irregular de dados acerca das séries ou fases que os alunos estavam cursando por ocasião da visita, bem como acerca das disciplinas da grade curricular às quais a visita estava mais diretamente vinculada, fizeram com que não fossem incorporados ao quadro.

3. Não havendo indicação em contrário, as instituições de ensino têm sede em Florianópolis, SC.

Fonte: Boletim informativo [Arquivo Público do Estado de Santa Catarina/ Associação de Amigos do Arquivo Público]. Florianópolis, abr.-jun.1998 a jul-dez.2002. A partir de julho de 2003, as informações são mais pontuais, dada a redução das dimensões do boletim (de caderno de 12 páginas, em média, para folder). 
Apêndice II-14:

Arquivo Público do Estado de Santa Catarina - estatística de atendimento ao público

\begin{tabular}{|c|c|c|c|c|c|c|c|c|}
\hline \multirow[t]{2}{*}{ PESQUiSAS EFETUADAS } & \multicolumn{2}{|c|}{1998} & \multicolumn{2}{|c|}{1999} & \multirow[t]{2}{*}{2000} & \multirow[t]{2}{*}{2001} & \multirow[t]{2}{*}{2002} & \multirow[t]{2}{*}{2003} \\
\hline & $B A$ & $S P C$ & $B A$ & $S P C$ & & & & \\
\hline \multirow[t]{2}{*}{ Pesquisas in loco } & 400 & 1301 & 26 & 325 & \multirow[b]{2}{*}{1474} & \multirow[b]{2}{*}{942} & \multirow[b]{2}{*}{743} & \multirow[b]{2}{*}{500} \\
\hline & \multicolumn{2}{|c|}{ [total: 1701] } & \multicolumn{2}{|c|}{+730 [total: 1081] } & & & & \\
\hline \multirow[t]{2}{*}{ Pesquisas por telefone } & \multirow[b]{2}{*}{19} & \multirow[b]{2}{*}{57} & 7 & 14 & \multirow[b]{2}{*}{169} & \multirow[b]{2}{*}{131} & \multirow[b]{2}{*}{156} & \multirow[b]{2}{*}{45} \\
\hline & & & \multicolumn{2}{|c|}{+30 [total: 51] } & & & & \\
\hline Pesquisas por correspondência & - & - & \multicolumn{2}{|c|}{5} & 10 & 3 & 52 & 20 \\
\hline
\end{tabular}

\begin{tabular}{|c|c|c|c|c|c|c|c|c|}
\hline \multirow{2}{*}{ MATERIAL PESQUISADO } & \multicolumn{2}{|c|}{1998} & \multicolumn{2}{|c|}{1999} & \multirow[t]{2}{*}{2000} & \multirow[t]{2}{*}{2001} & \multirow[t]{2}{*}{2002} & \multirow[t]{2}{*}{2003} \\
\hline & $B A$ & $S P C$ & $B A$ & $S P C$ & & & & \\
\hline Legislação & 333 & - & 8 & - & - & - & - & - \\
\hline \multirow[t]{2}{*}{ Manuscritos/datilografados } & \multirow[b]{2}{*}{-} & \multirow[b]{2}{*}{$1516^{*}$} & - & 693* & \multirow[b]{2}{*}{4339} & \multirow[b]{2}{*}{3213} & \multirow[b]{2}{*}{3534} & \multirow[b]{2}{*}{2400} \\
\hline & & & \multicolumn{2}{|c|}{+1157 [total: 1850] } & & & & \\
\hline \multirow{2}{*}{ Fotos } & \multirow[b]{2}{*}{905} & \multirow[b]{2}{*}{-} & 16 & - & \multirow[b]{2}{*}{222} & \multirow[b]{2}{*}{77} & \multirow[b]{2}{*}{20} & \multirow[b]{2}{*}{75} \\
\hline & & & \multicolumn{2}{|c|}{$+905[$ total: $\mathbf{9 2 1}]$} & & & & \\
\hline Mapas /plantas & \multicolumn{2}{|c|}{-} & \multicolumn{2}{|c|}{12} & 114 & 43 & 39 & 63 \\
\hline \multirow[t]{2}{*}{ Livros/periódicos } & \multirow[b]{2}{*}{$861^{*}$} & \multirow[b]{2}{*}{-} & $92 *$ & - & \multirow[b]{2}{*}{989} & \multirow[b]{2}{*}{471} & \multirow[b]{2}{*}{471} & \multirow[b]{2}{*}{247} \\
\hline & & & +808 & 900] & & & & \\
\hline
\end{tabular}

*Identificados apenas como "volumes".

\begin{tabular}{|c|c|c|c|c|c|c|c|c|}
\hline \multirow[t]{4}{*}{ NOVOS PESQUISADORES CADASTRADOS } & \multicolumn{2}{|c|}{1998} & \multicolumn{2}{|c|}{1999} & \multirow[t]{2}{*}{2000} & \multirow[t]{2}{*}{2001} & \multirow[t]{2}{*}{2002} & \multirow[t]{2}{*}{2003} \\
\hline & $B A$ & $S P C$ & $B A$ & $S P C$ & & & & \\
\hline & \multirow[b]{2}{*}{ - } & \multirow[b]{2}{*}{187} & - & 17 & \multirow[b]{2}{*}{214} & \multirow[b]{2}{*}{170} & \multirow[b]{2}{*}{185} & \multirow[b]{2}{*}{118} \\
\hline & & & +126 & :143] & & & & \\
\hline
\end{tabular}

Obs.:

1. No quadro, BA = "Biblioteca [de] Apoio" e SPC = Setor de Pesquisa e Consulta [Arquivo Permanente].

2. Até jan.-mar.1999, os dados relativos ao atendimento: diferenciavam o atendimento na Biblioteca Apoio e no Setor de Pesquisa e Consulta; não incluíam pesquisas por correspondência; em relação ao material consultado, diferenciavam apenas "volumes", "fotos" e "legislação".

3. O que até jan.-mar.1999 era computado para "pesquisadores" foi incluído no item "pesquisas in loco", que aparece a partir de abril de 1999.

4. Não há dados sobre atendimento no boletim de out.-dez.1999, bem como a partir de jul.-set.2003.

Fonte: Boletim informativo [Arquivo Público do Estado de Santa Catarina / Associação de Amigos do Arquivo Público]. Florianópolis, abr.-jun.1998 a jan.-jun.2003 (seções "Atendimento ao público" e, a partir de abril de 1999, da seção "Arquivo Público - Estatística"). 
Apêndice II-15:

Instrumentos de pesquisa produzidos pelo Arquivo Público do Estado de Santa Catarina

Descrição do acervo arquivístico do Arquivo Público do Estado de Santa Catarina

\begin{tabular}{|c|c|c|c|}
\hline Instrumento de pesquisa & $\begin{array}{l}\text { Período da } \\
\text { documentação } \\
\text { descrita }\end{array}$ & $\begin{array}{c}\text { Data de } \\
\text { disponibilização }\end{array}$ & Obs.: \\
\hline Catálogo da Guarda Nacional & 1791 a 1882 [sic] & 1991 & Datilografado; 3530 fichas. \\
\hline Catálogo das correspondências das Câmaras Municipais & $1776-1869$ & [1984-1985] & $\begin{array}{l}7.600 \text { fichas. Elaborado a partir de } 34 \text { códices relativos às } \\
\text { Câmaras Municipais. }\end{array}$ \\
\hline Catálogo de mapas e plantas de Santa Catarina & $1748-1999$ & 1999 & Digitado; 99p. Abrangendo 643 mapas e plantas. \\
\hline Catálogo de unitermo do acervo fotográfico de Santa Catarina & $\begin{array}{c}\text { Não } \\
\text { especificado. }\end{array}$ & $1986-2001$ & Digitado; 399 fichas. \\
\hline Catálogo do fundo cartorial & 1929-1989 & 1995 & $\begin{array}{l}\text { Publicado na revista Ágora, no. } 22 \text { (dez.1995). 38p. Elaborado por } \\
\text { Cleuza R.C.Martins, Maria Cristina d'Eça N. L. da Conceição e } \\
\text { Neusa Maria Schmitz. }\end{array}$ \\
\hline $\begin{array}{l}\text { Catálogo dos processos (Cível e Crime) do Cartório de Santa } \\
\text { Catarina }\end{array}$ & $1825-1945$ & [1982] & Datilografado; 308 fichas. \\
\hline Índice alfabético geográfico dos Paquetes e Capitania dos Portos & $1857-1891$ & $1997-1998$ & $\begin{array}{l}\text { Digitado; } 2 \text { v., } 35 \text { p. Elaborado por Gabriela Vieira Ferreira, a } \\
\text { partir da correspondência entre o Presidente da Província, os } \\
\text { agentes de paquetes e a Capitania dos Portos. Inclui índice } \\
\text { onomástico dos imigrantes. }\end{array}$ \\
\hline $\begin{array}{l}\text { Índice alfabético por assunto dos documentos do Departamento } \\
\text { Estadual de Estatística }\end{array}$ & 1943-1974 & s.d. & Datilografado. \\
\hline $\begin{array}{l}\text { Índice cronológico de diversos para o Governo, Secretaria da } \\
\text { Justiça, Secretaria Geral dos Negócios do Estado e Prefeitura }\end{array}$ & $1748-1973$ & {$[1995-2004]$} & 10v., 1655p. \\
\hline Índice cronológico dos requerimentos de terras & $1836-1926$ & s.d. & Datilografado; 66p. \\
\hline Índice de títulos definitivos de terras & 1860 a 1976 & [1983] & Em fichas. Indexa o conteúdo de 167 códices. \\
\hline $\begin{array}{l}\text { Índice do Programa Integrado de Desenvolvimento Sócio- } \\
\text { Cultural e Diagnóstico Municipal }\end{array}$ & Não especificado & 1993 & $\begin{array}{l}\text { Datilografado; 13p. Elaborado por Cleuza R. C. Martins e Maria } \\
\text { Cristina d'Eça N.L.da Conceição. }\end{array}$ \\
\hline Índice dos imigrantes vindos pelo Hersey e McRai [sic]. & 1949 & 1991 & Datilografado; 35p. \\
\hline Índice dos processos de terras & $1874-1977$ & [1983] & $\begin{array}{l}\text { Manuscrito; } 8 \text { pastas. Relativo a processos da Coordenação de } \\
\text { Legitimação e Cadastramento de Terras Devolutas. }\end{array}$ \\
\hline $\begin{array}{l}\text { Índice duplex numérico por assunto da legislação estadual e } \\
\text { federal. }\end{array}$ & $1907-1978$ & 1996 & Digitado. Elaborado por Maria Cristina d'Eça N. L. da Conceição. \\
\hline
\end{tabular}




\begin{tabular}{|c|c|c|c|}
\hline Índice duplex numérico por assunto de relatórios & 1869 e 1989 & 1992 & $\begin{array}{l}\text { Datilografado; } 3 \mathrm{v} ., 454 \mathrm{p} \text {. Elaborado por Maria Tereza Tertitschnij, } \\
\text { abrangendo } 1690 \text { relatórios, basicamente oficiais. }\end{array}$ \\
\hline Índice duplex numérico por assunto dos regimentos & 1854-1989 & 1996 & Digitado; 55p. Elaborado por Neusa Maria Schmitz. \\
\hline Índice duplex numérico por assunto dos regulamentos & $1868-1986$ & 1996 & Digitado; 126p. Elaborado por Neusa Maria Schmitz. \\
\hline $\begin{array}{l}\text { Índice geográfico das correspondências dos juízes de paz, } \\
\text { Câmara Municipal, Superintendência e Intendência para o } \\
\text { Governo }\end{array}$ & $1776-1928$ & s.d. & Digitado; 60p. \\
\hline $\begin{array}{l}\text { Índice geográfico das correspondências entre as prefeituras } \\
\text { municipais e o Governo do Estado }\end{array}$ & $1888-1964$ & 2002 & Datilografado [sic]; 161p. \\
\hline $\begin{array}{l}\text { Índice geográfico dos documentos da Coordenação de Defesa } \\
\text { Civil }\end{array}$ & $1972-1986$ & [1985] & Datilografado; 2v.,. 234p. Atualizado em 2003 (Digitado, 107 p.) \\
\hline $\begin{array}{l}\text { Índice geográfico dos fundos documentais: Chefe de Polícia, } \\
\text { Subdelegado de Polícia, Comissário de Polícia, Autoridades } \\
\text { Policiais, Força Pública e Promotoria Pública }\end{array}$ & $1833-1942$ & 2003 & Digitado; 200p. \\
\hline $\begin{array}{l}\text { Índice onomástico das correspondências dos Governadores de } \\
\text { Santa Catarina }\end{array}$ & 1871-1979 & 1996 & Digitado; 14p. Elaborado por Luci Maria da Luz. \\
\hline Índice onomástico de imigrantes & $1869-1876$ & 1999 & $\begin{array}{l}\text { Digitado; } 24 \text { p. Elaborado por Neusa Maria Schmitz, a partir dos } \\
\text { documentos da Agência do } 1^{\text {o }} \text {. Distrito de Terras e Colonização } \\
\text { encaminhados ao Presidente da Província. }\end{array}$ \\
\hline Índice onomástico de registro de vigários & $1850-1860$ & [1983] & $\begin{array}{l}\text { Datilografado; em fichas. Elaborado a partir de } 63 \text { códices com } \\
\text { registros de terras. Atualizado em } 2003 \text { (digitado, 3v., 588p.), por } \\
\text { Neusa M. Schmitz. }\end{array}$ \\
\hline $\begin{array}{l}\text { Índice onomástico do registro geral do Governador da Capitania/ } \\
\text { Presidente da Província }\end{array}$ & $1770-1887$ & 1991 & Datilografado; 2v., 177p. Elaborado por Aristeu A. Oliveira. \\
\hline Índice onomástico dos imigrantes & $\begin{array}{c}\text { 1869-1876; } \\
1891-1893\end{array}$ & 1998-1999 & $\begin{array}{l}\text { Digitado; 2v., 36p. Elaborado por Neusa Maria Schmitz, } \\
\text { abrangendo ofícios e telegramas da Inspetoria Geral da Delegacia } \\
\text { de Terras e Colonização para Campanha Torrens (1891-1893) e da } \\
\text { Agência de Terras e Colonização para o Presidente da Província } \\
\text { (1869 e 1876). }\end{array}$ \\
\hline $\begin{array}{l}\text { Índice onomástico dos memoriais de lotes e títulos definitivos e } \\
\text { provisórios de terras }\end{array}$ & $1846-1930$ & $1997-2002$ & Digitado; 236 p. Elaborado por Neusa Maria Schmitz. \\
\hline Índice onomástico dos processos da Secretaria da Justiça & $1959-1978$ & 1996 & Datilografado; $123 \mathrm{p}$. \\
\hline Índice onomástico dos processos dos ex-combatentes & $1979-1986$ & s.d. & 21p. Processos envolvendo requerimentos de pensões. \\
\hline Índice onomástico dos termos de juramento de naturalização & $1856-1963$ & 1990 & Datilografado; 59p. \\
\hline Índice onomástico dos termos de juramento de nomeação & $1791-1926$ & 1990 & Datilografado; 2v., 70p. Elaborado por Aristeu A. Oliveira. \\
\hline Índice onomástico e geográfico dos imigrantes & $1859-1888$ & 1998 & Digitado; 34p. Elaborado por Gabriela Vieira Ferreira, a partir dos \\
\hline
\end{tabular}




\begin{tabular}{|c|c|c|c|}
\hline & & & $\begin{array}{l}\text { registros da correspondência do Presidente da Província com a } \\
\text { Capitania dos Portos (1859-1888) e com agentes de paquetes } \\
(1860-1875) \text {. }\end{array}$ \\
\hline Índice topográfico [dos fundos] & Não especificado & 1981 & Datilografado; 101p. \\
\hline $\begin{array}{l}\text { Inventário Analítico das Correspondências dos Engenheiros com } \\
\text { o Presidente da Província }\end{array}$ & $1830-1882$ & 1990 & Datilografado; 4 v., 661p. Elaborado por Noêmia Kuhnen Lopes. \\
\hline $\begin{array}{l}\text { Inventário analítico do Fundo Campanha Pró-Monumento Vidal } \\
\text { Ramos }\end{array}$ & $1965-1966$ & 1991 & Datilografado; 8p. Elaborado por Valéria Gouvêa Ghanem. \\
\hline Inventário analítico do Fundo Privado Álvaro Alves & $1926-1938$ & 2003 & Digitado; 2p. Elaborado por Neusa Rosane Damiani Nunes. \\
\hline $\begin{array}{l}\text { Inventário analítico do Fundo Privado do ex-governador Jorge } \\
\text { Lacerda }\end{array}$ & $1931-1973$ & 1993 & $\begin{array}{l}\text { Publicado pelo Senado Federal; 876p. Elaborado por Valéria } \\
\text { Gouvêa Ghanem. }\end{array}$ \\
\hline $\begin{array}{l}\text { Inventário analítico do Fundo Privado General José Vieira da } \\
\text { Rosa }\end{array}$ & $1889-1969$ & 1989 & Datilografado; 18p. Elaborado por Valéria Gouvêa Ghanem. \\
\hline $\begin{array}{l}\text { Inventário sumário dos relatórios da Secretaria Geral dos } \\
\text { Negócios do Estado }\end{array}$ & $1893-1918$ & 1994 & Datilografado; 110p. Elaborado por José Heitor Farias Zomer. \\
\hline $\begin{array}{l}\text { Inventário sumário dos relatórios, falas e mensagens dos } \\
\text { governantes do Estado de Santa Catarina }\end{array}$ & $1830-1998$ & 1994 & $\begin{array}{l}\text { Datilografado; 263p. Elaborado por Maria Tereza Tertitschnij. } \\
\text { Atualizado em } 1998 \text {. }\end{array}$ \\
\hline
\end{tabular}

Descrição do acervo bibliográfico do Arquivo Público do Estado de Santa Catarina

\begin{tabular}{|c|c|c|c|}
\hline Instrumento de pesquisa & $\begin{array}{c}\text { Período da } \\
\text { documentação } \\
\text { descrita }\end{array}$ & $\begin{array}{c}\text { Data de } \\
\text { disponibilização }\end{array}$ & Obs.: \\
\hline $\begin{array}{l}\text { Catálogo de imagens fotográficas existentes no material } \\
\text { bibliográfico }\end{array}$ & [séc.XX] & $1991-2000$ & $\begin{array}{l}\text { Digitado; } 2000 \text { fichas. Foi parcialmente publicado como } \\
\text { "Catálogo onomástico das imagens fotográficas identificadas em } \\
\text { livros no acervo da Biblioteca Apoio e Divulgação Cultural" } \\
\text { (revista Ágora, } \mathrm{n}^{\circ} .36,2^{\circ} \text {. sem. 2002; elaborado por Maria Goreti } \\
\text { Pagani). }\end{array}$ \\
\hline Catálogo de teses e monografias & Não especificado & $1988-2003$ & Digitado; $14 \mathrm{p}$. \\
\hline Índice de artigos de periódicos & $1900-1998$ & 1991 & Manuscrito; 81p. \\
\hline
\end{tabular}

Transcrições de documentos do acervo arquivístico do Arquivo Público do Estado de Santa Catarina

\begin{tabular}{|c|c|c|c|}
\hline Instrumento de pesquisa & $\begin{array}{c}\text { Período da } \\
\text { documentação } \\
\text { transcrita }\end{array}$ & $\begin{array}{c}\text { Data de } \\
\text { disponibilização }\end{array}$ & Obs.: \\
\hline Catálogo seletivo da Revolução Farroupilha & $1836-1844$ & 1993 & $\begin{array}{l}\text { Datilografado; 81p. Transcreve documentos selecionados nos } \\
\text { conjuntos documentais Câmaras municipais, Ministério da }\end{array}$ \\
\hline
\end{tabular}




\begin{tabular}{|c|c|c|c|}
\hline & & & Marinha e Juízes de Paz. \\
\hline Catálogo seletivo de Brusque & $1861-1903$ & [1984] & $\begin{array}{l}\text { Datilografado; 70p. Abarca documentos existentes nos conjuntos } \\
\text { documentais Câmaras Municipais, Intendências Municipais e } \\
\text { Arciprestes e Vigários. }\end{array}$ \\
\hline Catálogo seletivo do Centenário da República & 1889 & 1993 & $\begin{array}{l}\text { Datilografado; 61p. Abarca documentos relativos à proclamação } \\
\text { da república existentes em diversos conjuntos documentais. }\end{array}$ \\
\hline Catálogo seletivo sobre a escravidão & $1833-1888$ & 1993 & $\begin{array}{l}\text { Datilografado; 12v., 1443p. Transcreve documentos existentes } \\
\text { nos conjuntos documentais Juízes, Chefes de Polícia e Delegados. }\end{array}$ \\
\hline $\begin{array}{l}\text { Documentos selecionados do conjunto documental Grupos } \\
\text { Escolares }\end{array}$ & $1941-1946$ & 2003 & Publicados na revista Ágora, n.37, 2003. \\
\hline $\begin{array}{l}\text { Edição de fontes - Avisos do Ministério da Marinha ao Presidente } \\
\text { da Província de Santa Catarina }\end{array}$ & 1823 a 1825 & 1997 & Digitado; 125 p. * \\
\hline $\begin{array}{l}\text { Edição de fontes - Avisos do Ministério do Império ao } \\
\text { Governador da Capitania / Presidente da Província }\end{array}$ & $1821-1829$ & 1999 & Digitado; 2v., 418p. * \\
\hline $\begin{array}{l}\text { Edição de fontes - Cadastro de proprietários de imóveis da rua da } \\
\text { Pedreira e do largo do Campo do Manejo [Desterro] }\end{array}$ & 1817 & 1999 & Digitado; 2v., 202 p. * \\
\hline Edição de fontes - Cartas de Dom João VI & 1805 & 1997 & Digitado; 35p. * \\
\hline Edição de fontes - Correspondências com o Ministério da Guerra & 1814 a 1824 & $1997-1998$ & Digitado; 3v., 851 p. * \\
\hline $\begin{array}{l}\text { Edição de fontes - Correspondências com o Ministério dos } \\
\text { Estrangeiros }\end{array}$ & 1822 a 1825 & 1997 & Digitado, 304 p. * \\
\hline $\begin{array}{l}\text { Edição de fontes - Correspondências de Arciprestes e Vigários ao } \\
\text { Governador da Capitania }\end{array}$ & 1785 a 1830 & 1995 & Digitado; 151 p. * \\
\hline $\begin{array}{l}\text { Edição de fontes - Correspondências do Conselho Supremo } \\
\text { Militar ao Presidente da Província de Santa Catarina }\end{array}$ & 1827 a 1840 & 1996-1999 & Digitado; 2v., 426 p. * \\
\hline $\begin{array}{l}\text { Edição de fontes - Ofícios da Administração Geral dos Correios } \\
\text { ao Presidente da Província de Santa Catarina }\end{array}$ & 1829 a 1843 & 1996 & Digitado; 289 p. * \\
\hline $\begin{array}{l}\text { Edição de fontes - Ofícios da Junta Governativa Provisória de } \\
\text { Santa Catarina a diversos }\end{array}$ & 1821 a 1823 & 1997 & Digitado; 88p. * \\
\hline $\begin{array}{l}\text { Edição de fontes - Ofícios das Câmaras Municipais ao } \\
\text { Governador da Capitania }\end{array}$ & $1776-1808$ & 1999 & Digitado; 216p. * \\
\hline Edição de fontes - Ofícios de El Rei ao Governador da Capitania & $1820-1821$ & 1999 & Digitado; 294 p. * \\
\hline $\begin{array}{l}\text { Edição de fontes - Ofícios do Governador da Capitania a Câmara } \\
\text { Municipal }\end{array}$ & 1752 a 1817 & 1997 & Digitado; 83 p. * \\
\hline $\begin{array}{l}\text { Edição de fontes - Ofícios do Tesouro Provincial ao Governador } \\
\text { da Capitania e Presidente da Província de Santa Catarina }\end{array}$ & 1805 a 1831 & 1998 & Digitado; 420 p. * \\
\hline Edição de fontes-Ofícios do Vice-Rei ao Governador da Capitania & 1779 a 1820 & $1997-1998$ & Digitado; 4 v., 549 p. $*$ \\
\hline $\begin{array}{l}\text { Edição de fontes - Ofícios dos governadores das capitanias/ } \\
\text { presidentes das Províncias de outros estados aos governadores da }\end{array}$ & $1797-1827$ & 1999 & Digitado; 177 p. * \\
\hline
\end{tabular}




\begin{tabular}{|c|c|c|c|}
\hline Capitania / presidentes da Província de Santa Catarina & & & \\
\hline $\begin{array}{l}\text { Edição de fontes - Ofícios dos juízes de fora ao Presidente da } \\
\text { Província de Santa Catarina }\end{array}$ & 1814 a 1832 & 1996 & Digitado; 2v., 343 p. * \\
\hline $\begin{array}{l}\text { Edição de fontes - Ofícios dos juízes de órfãos ao Presidente da } \\
\text { Província de Santa Catarina }\end{array}$ & 1806 a 1837 & 1996 & Digitado; 190 p. * \\
\hline $\begin{array}{l}\text { Edição de fontes - Ofícios dos juízes de paz ao Presidente da } \\
\text { Província de Santa Catarina }\end{array}$ & 1828 a 1831 & 1996 & Digitado; 324 p. * \\
\hline $\begin{array}{l}\text { Edição de fontes - Ofícios dos juízes ordinários ao Presidente da } \\
\text { Província de Santa Catarina }\end{array}$ & 1787 a 1825 & 1996 & Digitado; 129 p. * \\
\hline $\begin{array}{l}\text { Edição de fontes - Processo da Ouvidoria Geral da Câmara de } \\
\text { Santa Catarina, ação João Lopes e outros }\end{array}$ & 1825 & 1997 & Digitado; 91 p. $*$ \\
\hline Edição de fontes - Provisões do Conselho Ultramarino & 1769 a 1807 & 1993-1995 & Digitado e manuscrito; 3v., 220p. * \\
\hline Edição de fontes - Registro das Sesmarias & 1753 a 1823 & $1997-1998$ & Digitado; 4v.,. 1009 p. * \\
\hline $\begin{array}{l}\text { Edição de fontes - Registro geral das correspondências do } \\
\text { Governador da Capitania e Presidente da Província de Santa } \\
\text { Catarina }\end{array}$ & 1770 a 1835 & 1995-1999 & $\begin{array}{l}\text { Digitado; } 5 \mathrm{v} ., 207 \mathrm{p} .^{*} \text { Há fichas-índice para os documentos } \\
\text { relativos a período posterior (1836-1860). }\end{array}$ \\
\hline Edição de fontes - Repertório sobre os índios & $1842-1892$ & 1996 & $\begin{array}{l}\text { Digitado; 129p. * Transcreve documentos do conjunto } \\
\text { documental Delegados e Subdelegados de Polícia. }\end{array}$ \\
\hline $\begin{array}{l}\text { Relatório de José Mariano de Albuquerque Cavalcanti } \\
\text { apresentado à Assembléia Legislativa, } 5 \text { abr. } 1836\end{array}$ & 1836 & 2000 & $\begin{array}{l}\text { Publicado na revista Ágora, } \mathrm{n}^{\circ} .32\left(2^{\circ} . \text { sem. 2000). Transcrito por }\right. \\
\text { Neusa M. Schmitz e revisto por Leda Maria d'Ávila da Silva } \\
\text { Prazeres. }\end{array}$ \\
\hline $\begin{array}{l}\text { Relatório e fala de Feliciano Nunes Pires no governo de Santa } \\
\text { Catarina. }\end{array}$ & $1833-1835$ & 1985 & $\begin{array}{l}\text { Publicação conjunta do Arquivo do Estado de São Paulo e do } \\
\text { APESC; segundo número da Coleção José Arthur Boiteux.. 22p. }\end{array}$ \\
\hline Sesmarias concedidas por Manoel Escudeiro Ferreira de Souza & 1753 & 1984 & $\begin{array}{l}\text { Publicação feita através da Imprensa Oficial do Estado de SC; } \\
\text { primeiro número da Coleção José Arthur Boiteux. Edição fac- } \\
\text { similar. }\end{array}$ \\
\hline Repertório sobre imigrantes em Santa Catarina & $1858-1891$ & 1992-1997 & $\begin{array}{l}\text { Datilografado; 16v., 1491p. Elaborado por Valéria Gouvêa } \\
\text { Ghanem e Neusa M. Schmitz, a partir dos documentos } \\
\text { pertencentes aos conjuntos do Ministério da Agricultura e de } \\
\text { Terras e Colonização. Transcrição integral dos documentos } \\
\text { selecionados. }\end{array}$ \\
\hline Repertório sobre os municípios de Tubarão e Laguna & $1824-1890$ & 1997 & $\begin{array}{l}\text { Datilografado; 3v., 454p. Elaborado a partir dos conjuntos } \\
\text { documentais Câmaras Municipais, Vigários e Juízes de Paz. } \\
\text { Transcrição integral dos documentos selecionados. }\end{array}$ \\
\hline $\begin{array}{l}\text { Transcrição paleográfica - Avisos diversos ao Governador da } \\
\text { Capitania }\end{array}$ & 1748 a 1804 & 1987 & Datilografado; 54p. Elaborado por Vilma R. Arrial Bueno. \\
\hline $\begin{array}{l}\text { Transcrição paleográfica - Cartas do Vice-Rei para a Câmara } \\
\text { Municipal de Desterro }\end{array}$ & $1760-1801$ & 2002 & Digitado; 82 p. Elaborado por Neusa Maria Schmitz. \\
\hline
\end{tabular}




\begin{tabular}{|c|c|c|c|}
\hline Transcrição paleográfica - Cartas régias imperiais & $1703-1830$ & 1993 & Manuscrito; 90p. Elaborado por Valéria Gouvêa Ghanem. \\
\hline $\begin{array}{l}\text { Transcrição paleográfica - Correspondências do Ministério da } \\
\text { Guerra }\end{array}$ & $1890-1915$ & 2000 & Digitado; 4 v., 563 p. Elaborado por Neusa Maria Schmitz. \\
\hline $\begin{array}{l}\text { Transcrição paleográfica - Ofícios da Inspetoria da Saúde para o } \\
\text { Presidente da Província }\end{array}$ & $1843-1862$ & 2004 & Digitado; 339 p.Elaborado por Neusa Maria Schmitz. \\
\hline $\begin{array}{l}\text { Transcrição paleográfica - Ofícios da Secretaria dos Negócios do } \\
\text { Império para o Presidente da Província de Santa Catarina }\end{array}$ & $1831-1848$ & 2001 & Digitado; 179 p. Elaborado por Neusa Maria Schmitz. \\
\hline $\begin{array}{l}\text { Transcrição paleográfica - Ofícios do Chanceler da Corte e } \\
\text { Império do Brasil para a Junta Governativa Provisória da } \\
\text { Província/Presidente da Província de Santa Catarina. }\end{array}$ & $1824-1830$ & 2000 & Digitado; 102p. Elaborado por Neusa Maria Schmitz. \\
\hline $\begin{array}{l}\text { Transcrição paleográfica - Ofícios do Ministério do Império para } \\
\text { o Presidente da Província }\end{array}$ & $1808-1829$ & 2003 & Digitado; 2v., 323p. Elaborado por Neusa Maria Schmitz. \\
\hline $\begin{array}{l}\text { Transcrição paleográfica - Ofícios do Ministério dos Estrangeiros } \\
\text { para o Presidente da Província }\end{array}$ & $1828-1845$ & 2003 & Digitado; 197p. Elaborado por Neusa Maria Schmitz. \\
\hline $\begin{array}{l}\text { Transcrição paleográfica - Ofícios dos comissários e } \\
\text { subcomissários da Polícia para o Palácio do Governo }\end{array}$ & $1892-1907$ & 2002 & Digitado; 350p. Elaborado por Neusa Maria Schmitz. \\
\hline Transcrição paleográfica - Registro de Cartas de Naturalização & 1882 a 1938 & 1990 & Manuscrito; 164p. Elaborado por Valéria Gouvêa Ghanem. \\
\hline
\end{tabular}

* Elaboração: Núcleo de Estudos Portugueses da Universidade Federal de Santa Catarina (Série Filológica), com colaboração da Supervisão de Arquivo Permanente e Setor de Pesquisa do APESC.

Obs.:

1. Em relação ao acervo permanente do Arquivo Público do Estado de Santa Catarina, cabe mencionar ainda instrumento de pesquisa elaborado fora do âmbito da instituição: MARTINS, Cleuza Regina Costa. Indexação e análise da documentação administrativa municipal de Florianópolis e Blumenau, no período compreendido entre 1941 e 1950. Florianópolis, 1990. 95 p. Monografia (Graduação em Biblioteconomia). Depto. de Biblioteconomia e Documentação, Universidade Federal de Santa Catarina.

2. Não foram aqui incluídos instrumentos de pesquisa relativos a outros acervos institucionais (como o relativo aos documentos da Mesa da Consciência e Ordens, existentes no Arquivo Nacional, ou o catálogo de documentos referentes a Santa Catarina existentes no Arquivo Histórico Ultramarino, em Portugal).

3. Não constam dos quadros, igualmente, instrumentos que apenas sistematizam informações levantadas a partir da documentação (como o "índice onomástico dos deputados estaduais, federais, presidentes das Câmaras de deputados e senadores no período 1826 a 1999”, ou o “índice dos consulados com jurisdição em Santa Catarina”).

Fontes:

- NUNES, Neusa Rosane Damiani, SOARES, Ana Maria. Catálogo de instrumentos de pesquisa [do Arquivo Público do Estado de Santa Catarina]. Florianópolis: Secretaria de Estado da Administração, 2000.

- NUNES, Neusa Rosane Damiani, SOARES, Ana Maria. Catálogo de instrumentos de pesquisa [do Arquivo Público do Estado de Santa Catarina]. Florianópolis: Secretaria de Estado da Administração, 2004.

- NUNES, Neusa Rosane Damiani. Arquivos intermediário e permanente. In: Arquivo Público do Estado de Santa Catarina - 30 anos (1960-1990). Florianópolis: Secretaria de Estado da Administração, 1990. p.55-63. 
Apêndice II-16:

Produção documental da Secretaria da Presidência da Província de Santa Catarina

\begin{tabular}{|c|c|c|c|c|c|c|}
\hline Especificação do documento & 1861 & 1863 & 1864 & 1865 & 1873 & 1874 \\
\hline \multirow{2}{*}{$\begin{array}{l}\text { Atos da Presidência e regulamentos. } \\
\text { Atos da Presidência. } \\
\end{array}$} & 23 & 32 & 29 & 160 & & \\
\hline & & & & & 222 & 223 \\
\hline \multirow{3}{*}{$\begin{array}{l}\text { Cartas de naturalização. } \\
\text { Cartas de naturalização e de confirmação de compromissos. } \\
\text { Cartas de aprovação de compromissos de irmandades e estatutos de sociedades. }\end{array}$} & & 24 & & 13 & 44 & 4 \\
\hline & 4 & & 40 & & & \\
\hline & & & & & 3 & \\
\hline Cópias. & & & & & 825 & \\
\hline \begin{tabular}{|l|} 
Despachos em requerimentos. \\
\end{tabular} & 1.030 & 1.255 & 1.269 & 1.790 & 1.389 & \\
\hline \multirow{3}{*}{$\begin{array}{l}\text { Editais, declarações e certidões. } \\
\text { Editais e certidões. } \\
\text { Editais, certificados etc. }\end{array}$} & 100 & 104 & 26 & & & \\
\hline & & & & 30 & & \\
\hline & & & & & 10 & 10 \\
\hline \multirow{3}{*}{$\begin{array}{l}\text { Extratos das ordens do Tesouro e diferentes ministérios expedidos à Tesouraria. } \\
\text { Extratos das ordens do Tesouro. } \\
\text { Registros das ordens do Tesouro à Tesouraria de Fazenda. }\end{array}$} & 79 & 83 & & 95 & & \\
\hline & & & 92 & & & \\
\hline & & & & & 91 & 123 \\
\hline 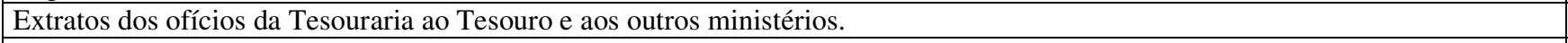 & 191 & 182 & 242 & 255 & 268 & 266 \\
\hline Guias do correio de Lages. & 12 & 12 & 16 & 16 & & \\
\hline \multirow{2}{*}{$\begin{array}{l}\text { Informações em requerimentos, ao governo imperial. } \\
\text { Informações em requerimentos, ao governo imperial, a secretários e diretores gerais de Estado. }\end{array}$} & & 74 & 59 & 78 & & \\
\hline & 28 & & & & & \\
\hline Leis provinciais. & 9 & - & 28 & 11 & 11 & 46 \\
\hline \multirow{2}{*}{$\begin{array}{l}\text { Minutas dos ofícios, atos e outros. } \\
\text { Minutas de ofícios. } \\
\end{array}$} & 6.308 & 6.074 & 6.358 & & & \\
\hline & & & & $\mathbf{7 . 5 0 2}$ & & \\
\hline \begin{tabular}{|l|} 
Notas explicativas dos avisos recebidos. \\
\end{tabular} & 34 & 47 & 48 & & & \\
\hline Notas para pagamentos de direitos. & 175 & 135 & 193 & & 83 & 90 \\
\hline Notas para pagamento de emolumentos. & & & & 176 & 223 & 235 \\
\hline Ofício ao Cônsul Geral do Brasil em Hamburgo. & 1 & & & & & \\
\hline Ofícios ao presidente do Tribunal do Comércio da capital do Império e inspetor da Caixa de Amortização. & 1 & 1 & 4 & & & \\
\hline \multirow{4}{*}{$\begin{array}{l}\text { Ofícios ao inspetor do Instituto Vacínico. } \\
\text { Ofícios ao inspetor do Instituto Vacínico e bispo diocesano. } \\
\text { Ofícios aos inspetores da Caixa de Amortização e do Instituto Vacínico. } \\
\text { Ofícios ao comissário vacinador. }\end{array}$} & 2 & 1 & & & & \\
\hline & & & 6 & & & \\
\hline & & & & 6 & & \\
\hline & & & 16 & & & \\
\hline \begin{tabular}{|l|} 
Ofícios. \\
\end{tabular} & 46 & & & & & \\
\hline \multirow{2}{*}{$\begin{array}{l}\text { Ofícios a arcipreste, párocos e outros padres de SC. } \\
\text { Ofícios a arcipreste, vigários e párocos. }\end{array}$} & 128 & 134 & & & & \\
\hline & & & 85 & & & \\
\hline
\end{tabular}




\begin{tabular}{|c|c|c|c|c|c|c|}
\hline Especificacão do documento & 1861 & 1863 & 1864 & 1865 & 1873 & 1874 \\
\hline \multirow{2}{*}{$\begin{array}{l}\text { Ofícios a bispo, arcipreste, vigários e outros padres. } \\
\text { Ofícios às autoridades eclesiásticas. }\end{array}$} & & & & 133 & & \\
\hline & & & & & 9 & 20 \\
\hline Ofícios a cônsules e vice-cônsules em SC. & 65 & 62 & 13 & 71 & 28 & 13 \\
\hline Ofícios a diversos, não especificados, do interior/exterior SC & 244 & 352 & 230 & 473 & 322 & 330 \\
\hline Ofícios ao agente da colonização. & 13 & 21 & 17 & 11 & 17 & 25 \\
\hline Ofícios ao chefe de polícia. & 179 & 194 & 279 & 421 & 183 & 157 \\
\hline Ofícios ao delegado do cirurgião-mór do Exército. & & 12 & 10 & & & \\
\hline Ofícios ao delegado do diretor geral das terras públicas. & 498 & 328 & 278 & 170 & & \\
\hline \multirow{3}{*}{$\begin{array}{l}\text { Ofícios ao diretor geral da Fazenda, administrador da Mesa de Rendas e coletorias provinciais. } \\
\text { Ofícios ao diretor geral da Fazenda Provincial e coletorias. } \\
\text { Ofícios à Diretoria Geral da Fazenda Provincial. }\end{array}$} & 409 & & & 445 & & \\
\hline & & 533 & 591 & & & \\
\hline & & & & & 387 & \\
\hline \multirow{3}{*}{$\begin{array}{l}\text { Ofícios aos inspetores da Tesouraria, Alfândega e Mesa de Rendas. } \\
\text { Ofícios aos inspetores da Tesouraria e Alfândega. } \\
\text { Ofícios à Tesouraria de Fazenda e Alfândega. }\end{array}$} & 861 & 675 & 838 & & & \\
\hline & & & & 1.432 & & \\
\hline & & & & & 686 & 791 \\
\hline $\begin{array}{l}\text { Ofícios ao presidente do Supremo Tribunal de Justiça, à Biblioteca Fluminense, a diretores do Arquivo Público e Arsenal de } \\
\text { Guerra }\end{array}$ & 10 & 15 & 17 & 15 & - & - \\
\hline Ofícios ao presidente e $1^{\circ}$. secretário da Assembléia Legislativa Provincial & 66 & 4 & 80 & 51 & 58 & 67 \\
\hline \multirow{3}{*}{$\begin{array}{l}\text { Ofícios aos agentes das companhias de paquetes a vapor. } \\
\text { Ofícios aos agentes das companhias de paquetes a vapor e ao administrador do Correio. } \\
\text { Ofícios ao administrador do Correio. }\end{array}$} & 154 & 191 & 253 & & 146 & 138 \\
\hline & & & & 286 & & \\
\hline & & & 82 & & & \\
\hline \multirow{5}{*}{$\begin{array}{l}\text { Ofícios aos comandantes de corpos, fortalezas, encarregado de artigos bélicos e engenheiros. } \\
\text { Ofícios aos comandantes de corpos, fortalezas e encarregado de artigos bélicos e hospital militar. } \\
\text { Ofícios aos comandantes de corpos e fortalezas. } \\
\text { Ofícios aos engenheiros empregados na província. } \\
\text { Ofícios aos engenheiros. }\end{array}$} & 199 & 324 & 139 & & & \\
\hline & & & & 78 & & \\
\hline & & & & & 19 & 4 \\
\hline & & & & 24 & & \\
\hline & & & & & 136 & 168 \\
\hline \multirow{5}{*}{$\begin{array}{l}\text { Ofícios à Capitania do Porto. } \\
\text { Ofícios aos comandantes de navios d'Armada e força naval estacionada em SC } \\
\text { Ofícios ao capitão do porto e comandantes de navios d'Armada. } \\
\text { Ofícios ao capitão do porto. } \\
\text { Ofícios aos comandantes de navios d'Armada. }\end{array}$} & 227 & & & 434 & & \\
\hline & 53 & & & & & \\
\hline & & 168 & 228 & & & \\
\hline & & & & & 260 & 236 \\
\hline & & & & & 36 & 83 \\
\hline \multirow{3}{*}{$\begin{array}{l}\text { Ofícios aos comandantes superiores da Guarda Nacional e comandante da Força Policial. } \\
\text { Ofícios aos comandantes superiores da Guarda Nacional. } \\
\text { Ofícios ao comandante da Força Policial. }\end{array}$} & & 187 & 140 & 432 & & \\
\hline & & & & & 104 & 51 \\
\hline & & & & & 25 & 65 \\
\hline Ofícios aos delegados e subdelegados. & 267 & 131 & 88 & 100 & 31 & 11 \\
\hline Ofícios aos diretores de colônias, inclusive a militar. & 366 & 316 & 289 & 219 & 148 & 189 \\
\hline
\end{tabular}




\section{Especificação do documento}

Ofícios aos diretores de Liceu, instrução primária e bibliotecário da província.

Ofícios aos diretores de instrução primária e secundária e Biblioteca.

Ofícios aos diretores de instrução primária e secundária.

Ofícios ao encarregado da Instrução Pública.

Ofícios aos encarregados de obras.

Ofícios aos juízes comissários das legitimações e revalidações de terras.

Ofícios aos juízes comissários.

Ofícios aos juízes municipais, de direito e de paz.

Ofícios aos ministros.

Ofícios aos presidentes de províncias.

Ofícios aos presidentes de províncias e comandante de armas

Ofícios aos secretários do Senado e da Câmara dos Deputados à Assembléia Geral.

Ofícios aos senadores e deputados à Assembléia Geral.

Ofícios aos senadores e deputados gerais por SC à Assembléia Geral.

Ofícios aos secretários e diretores gerais de Secretarias de Estado.

Ofícios às Câmaras Municipais

Ofícios, despachos de requerimentos etc., extratados para serem publicados no jornal.

Patentes e apostilas do governo nacional.

Patentes e apostilas a oficiais da Guarda Nacional.

Patentes de oficiais da Guarda Nacional.

Apostilas nas patentes dos Oficiais.

Portarias diversas e passaportes a passageiros.

Portarias diversas.

Registros de avisos dos diferentes ministérios.

Registros de cartas imperiais.

Registros de passaportes de navios e títulos.

Registros de títulos, passaportes etc.

Passaportes a estrangeiros.

Títulos de terras.

Termos de juramento e contratos.

Termos de juramento.

Títulos de delegados e subdelegados e seus suplentes.

Títulos de nomeações de autoridades policiais.

Títulos de autoridades policiais.

\begin{tabular}{|c|c|c|c|c|c|}
\hline 1861 & $\mathbf{1 8 6 3}$ & $\mathbf{1 8 6 4}$ & $\mathbf{1 8 6 5}$ & $\mathbf{1 8 7 3}$ & $\mathbf{1 8 7 4}$ \\
\hline 168 & 206 & & & & \\
\hline & & 137 & & & \\
\hline & & & 103 & & \\
\hline & & & & 84 & 139 \\
\hline 42 & - & 26 & 21 & - & - \\
\hline & 33 & 25 & 37 & & \\
\hline & & & & 22 & 28 \\
\hline 750 & 553 & 487 & 484 & 406 & 189 \\
\hline 649 & 726 & $\mathbf{1 . 0 2 7}$ & $\mathbf{1 . 1 6 7}$ & 521 & 481 \\
\hline 195 & 145 & 229 & & 84 & 127 \\
\hline & & & 222 & & \\
\hline 8 & 2 & 4 & 3 & - & - \\
\hline & 3 & & & & \\
\hline 8 & & & & & \\
\hline- & 6 & 10 & 29 & - & - \\
\hline 278 & 352 & 318 & 250 & 318 & 322 \\
\hline $\mathbf{7 . 2 2 7}$ & $\mathbf{7 . 2 4 5}$ & $\mathbf{7 . 3 9 0}$ & $\mathbf{9 . 2 9 2}$ & - & - \\
\hline 12 & & & & & \\
\hline & 11 & 13 & 75 & & \\
\hline & & & & 44 & 33 \\
\hline & & & & 6 & 2 \\
\hline 70 & 44 & & & & \\
\hline & & 78 & 40 & 36 & 58 \\
\hline & 516 & & & & \\
\hline & & & & 4 & 1 \\
\hline 20 & & & & & \\
\hline & 25 & 29 & & & \\
\hline & & & 7 & & \\
\hline & & & 2 & 22 & 32 \\
\hline 10 & 9 & 12 & & & \\
\hline 31 & & & & & \\
\hline & 37 & & & & \\
\hline & & & 31 & & \\
\hline
\end{tabular}




\begin{tabular}{|c|c|c|c|c|c|c|c|}
\hline Especificacão do documento & Ano & 1861 & 1863 & 1864 & 1865 & 1873 & 1874 \\
\hline Nomeações de autoridades policiais. & & & & 27 & & 86 & 62 \\
\hline \multirow{4}{*}{$\begin{array}{l}\text { Títulos de nomeações de empregados. } \\
\text { Títulos de nomeações de empregados públicos. } \\
\text { Títulos de nomeações de empregados provinciais. } \\
\text { Nomeações de empregados. }\end{array}$} & & 12 & 12 & & & & \\
\hline & & & & 36 & & & \\
\hline & & & & & 24 & & \\
\hline & & & & & & 61 & 91 \\
\hline
\end{tabular}

Obs.:

1) Os números envolvem dupla escrituração (elaboração e registro). Assim, p.ex., em 1861, 649 ofícios aos ministros foram expedidos e 649 foram registrados. Exceções, envolvendo apenas elaboração: extratos, minutas, notas para pagamento de direitos, registros de passaportes e de títulos, registros de avisos de ministérios, registros de ofícios da Tesouraria aos ministérios, termos de juramento e contratos.

2) Relativamente a 1861, não foram incluídos “cópias, mapas e relações, cujo número, pela grande afluência que delas houve, sem exageração, pode-se calcular em 1.000", além da correspondência reservada. A mesma observação é feita relativamente a 1863 e 1864 . Relativamente a 1873, foram excluídos "relações, mapas e pareceres das Seções, minutas e a correspondência reservada"; a essa lista acrescentam-se, em 1874, as "cópias".

\section{Fontes:}

- Falla dirigida á Assembléa Legislativa Provincial de Santa Catharina em 25 de março de 1874 pelo exm. Sr. Presidente da Província, dr. João Thomé da Silva. Cidade do Desterro: Typ. De J.J.Lopes, 1874. (anexo: "Quadro demonstrativo do serviço feito na Secretaria do Governo da Província de Santa Catharina do $1^{\circ}$. de janeiro ao último de dezembro de 1873 ”).

- Falla dirigida á Assembléa Legislativa Provincial de Santa Catharina em 21 de março de 1875 pelo exm. Sr. Presidente da Província, dr. João Thomé da Silva. Cidade do Desterro: Typ. De J.J.Lopes, 1875. (anexo: "Quadro demonstrativo do serviço feito na Secretaria do Governo da Província de Santa Catharina do $1^{\circ}$. de janeiro ao último de dezembro de 1874").

- Relatório apresentado á Assembléa Legislativa Provincial de Santa Catharina na sessão ordinária do $1^{\circ}$. de Março; e Falla dirigida á mesma Assembléa na sessão extraordinária de 11 de Junho pelo presidente Adolpho de Barros Cavalcanti de Albuquerque Lacerda no anno de 1866. Desterro: Typographia do Jornal Mercantil, 1866. (anexo: "Quadro demonstrativo do serviço feito na Secretaria do Governo da Província de Santa Catharina do $1^{\circ}$. de janeiro ao último de dezembro de 1865 ").

- Relatório do Presidente da Província de Santa Catharina, o conselheiro Vicente Pires da Mota, apresentado á Assembléa Legislativa Provincial, na $1^{\text {a }}$. sessão da 11 a Legislatura. Santa Catharina [sic]: Typ. Desterrense de J.J.Lopes, 1862. (anexo: "Quadro demonstrativo do serviço feito na Secretaria do Governo da Província de Santa Catharina do $1^{\circ}$. de janeiro ao último de dezembro de 1861 ").

- Relatório do Presidente da Província de Santa Catharina, o doutor Alexandre Rodrigues da Silva Chaves, apresentado á Assembléa Legislativa Provincial na $2^{\text {a }}$. Sessão da 12 ${ }^{\text {a }}$. legislatura em o $\mathbf{1}^{\mathbf{0}}$. de março de 1865. Santa Catharina: Typ. Catharinense de Avila \& Rodrigues, 1865. (anexo: "Quadro demonstrativo do serviço feito na Secretaria do Governo da Província de Santa Catharina do $1^{\circ}$. de janeiro ao último de dezembro de 1864").

- Relatório do Vice-Presidente da Província de Santa Catharina, o commendador Francisco José d'Oliveira, apresentado á Assembléa Legislativa Provincial na $1^{a}$. Sessão da 12 ${ }^{a}$. Legislatura. Santa Catharina: Typ. Catharinense de F.V.Avila \& Ca ., 1864. (anexo: "Quadro demonstrativo do serviço feito na Secretaria do Governo da Província de Santa Catharina do $1^{\circ}$. de janeiro ao último de dezembro de $\left.1863 "\right)$. 
Apêndice II-17:

Arquivo Público do Estado de Santa Catarina - consultoria /atendimento técnico a instituições (1998-2002)

\begin{tabular}{|c|c|c|c|c|c|c|}
\hline Instituição & Assuntos & \begin{tabular}{|l|}
1 \\
9 \\
9 \\
8 \\
\end{tabular} & \begin{tabular}{|l|}
1 \\
9 \\
9 \\
9 \\
\end{tabular} & $\begin{array}{l}\mathbf{2} \\
\mathbf{0} \\
\mathbf{0} \\
\mathbf{0} \\
\end{array}$ & $\begin{array}{l}2 \\
0 \\
0 \\
1 \\
\end{array}$ & $\begin{array}{l}2 \\
0 \\
0 \\
2 \\
\end{array}$ \\
\hline \multirow[t]{2}{*}{ Arquivo Histórico do Município de Biguaçu (SC) } & Organização de acervos e legislação arquivística. & & & & $\mathrm{X}$ & \\
\hline & Legislação arquivística. & & & & & $\mathrm{X}$ \\
\hline \multirow{3}{*}{ Arquivo Histórico do Município de Florianópolis (SC) } & [Visita técnica] & & $\mathrm{X}$ & & & \\
\hline & Criação da Casa da Memória, em Florianópolis. & & & & & $\mathrm{X}$ \\
\hline & Organização e conservação de documentos; legislação arquivística. & & & & & $\mathrm{X}$ \\
\hline Arquivo Histórico do Município de Itajaí (SC) & [Visita técnica] & $\mathrm{X}$ & & & & \\
\hline Arquivo Histórico do Município de Joinville (SC) & Avaliação de documentos. & & & $\mathrm{X}$ & & \\
\hline Arquivo Histórico do Município de Laguna (SC) & [Visita técnica] & & & & & $\mathrm{X}$ \\
\hline \multirow{2}{*}{ Arquivo Histórico do Município de Palhoça (SC) } & Avaliação de documentos de arquivo. & & & & $\mathrm{X}$ & \\
\hline & Organização de documentos de caráter permanente. & & & $\mathrm{X}$ & & \\
\hline Arquivo Histórico do Município de Porto Alegre (RS) & [Visita técnica.] & & $\mathrm{X}$ & & & \\
\hline Arquivo Histórico do Município de Rio Negrinho (SC) & Mensuração de acervos documentais. & & & $\mathrm{X}$ & & \\
\hline \multirow[t]{3}{*}{ Arquivo Histórico do Município de São José (SC) } & [Visita técnica] & & $\mathrm{X}$ & & & \\
\hline & Avaliação de documentos. & & $\mathrm{X}$ & & & \\
\hline & Organização, conservação e restauração de documentos. & & $\mathrm{X}$ & & & \\
\hline \multirow[t]{2}{*}{ Arquivo Histórico do Município de Tubarão (SC) } & [Visita técnica] & & & & $\mathrm{X}$ & \\
\hline & Organização e recolhimento de documentos; legislação arquivística. & & & & & $\mathrm{X}$ \\
\hline Assembléia Legislativa do Estado de SC & Armazenagem de documentos de caráter permanente. & & & & $\mathrm{X}$ & \\
\hline Assessoria de Gabinete do Governador (SC) & Avaliação de documentos. & & & $\mathrm{X}$ & & \\
\hline Biblioteca Particular Osni Regis (Florianópolis, SC) & Conservação de acervos bibliográficos. & $\mathrm{X}$ & & & & \\
\hline Biblioteca Pública do Estado (Florianópolis, SC) & Elaboração de projeto de reestruturação administrativa da Biblioteca Pública do Estado. & & & & & $\mathrm{X}$ \\
\hline Câmara de Vereadores de Três Barras (SC) & Criação de arquivo municipal, acervos documentais, legislação arquivística. & & & & $\mathrm{X}$ & \\
\hline Casa de Cultura de Wittmarsum (SC) & Conservação de documentos. & & & & $\mathrm{X}$ & \\
\hline CELESC (Florianópolis, SC) & Elaboração de tabela de temporalidade. & $\mathrm{X}$ & & & & \\
\hline Conselho Regional de Serviço Social (SC) & Avaliação de documentos; legislação arquivística. & & & & & $\mathrm{X}$ \\
\hline Delegacia de Trabalho (SC) & Avaliação e organização de documentos; legislação arquivística. & & & & $\mathrm{X}$ & \\
\hline Depto. de Transportes e Terminais (Florianópolis, SC) & Eliminação de documentos. & $\mathrm{X}$ & & & & \\
\hline DER & Eliminação de documentos. & & & & $\mathrm{X}$ & \\
\hline DETRAN & Avaliação de documentos. & & $\mathrm{X}$ & & & \\
\hline Escola Técnica Federal de SC (Florianópolis, SC) & Organização de arquivo intermediário. & $\mathrm{X}$ & & & & \\
\hline
\end{tabular}




\begin{tabular}{|c|c|c|c|c|c|c|}
\hline Instituição & Assuntos & \begin{tabular}{|l|}
1 \\
9 \\
9 \\
8
\end{tabular} & $\begin{array}{l}1 \\
9 \\
9 \\
9\end{array}$ & $\begin{array}{l}\mathbf{2} \\
\mathbf{0} \\
\mathbf{0} \\
\mathbf{0}\end{array}$ & $\begin{array}{l}\mathbf{2} \\
\mathbf{0} \\
\mathbf{0} \\
\mathbf{1}\end{array}$ & $\begin{array}{l}\mathbf{2} \\
\mathbf{0} \\
\mathbf{0} \\
\mathbf{2}\end{array}$ \\
\hline FATMA & Protocolo-padrão. & & $\mathrm{X}$ & & & \\
\hline Fundação Catarinense de Educação Especial & Microfilmagem. & & $\mathrm{X}$ & & & \\
\hline \multirow{2}{*}{$\begin{array}{l}\text { Fundação Cultural Senhor Jesus dos Passos } \\
\text { (Florianópolis, SC) }\end{array}$} & Conservação de documentos. & $\mathrm{X}$ & & & & \\
\hline & Conservação e restauração de documentos. & & & & $\mathrm{X}$ & \\
\hline Fundação Educacional Barriga Verde (Orleans, SC) & Organização, conservação e restauração de acervos documentais de caráter permanente. & & & $\mathrm{X}$ & & \\
\hline Fundação Florianópolis Convention Visitor Bureau (SC) & Organização de arquivos e avaliação de documentos. & & & & $\mathrm{X}$ & \\
\hline Fundação Sociedade Amigos de Brusque (SC) & Conservação de documentos. & $\mathrm{X}$ & & & & \\
\hline Hospital de Caridade (Florianópolis, SC) & Organização de documentos de arquivo. & & & & $\mathrm{X}$ & \\
\hline \multirow[t]{2}{*}{ Instituto de Previdência do Estado de SC - IPESC (SC) } & Avaliação e destinação de documentos. & & & $\mathrm{X}$ & & \\
\hline & Organização de documentação médica. & & & $\mathrm{X}$ & & \\
\hline Loja Maçônica Grande Oriente (Florianópolis, SC) & Organização e montagem de exposições de documentos. & & & $\mathrm{X}$ & & \\
\hline $\begin{array}{l}\text { Ministério das Minas e Energia - Depto. Nacional de } \\
\text { Produção Mineral (SC) }\end{array}$ & Avaliação de documentos; legislação arquivística. & & & & $\mathrm{X}$ & \\
\hline \multirow[t]{2}{*}{ Museu de Arte de Santa Catarina (Florianópolis, SC) } & Conservação de documentos originais de séculos passados integrantes de exposição. & & & $\mathrm{X}$ & & \\
\hline & Montagem de exposição. & & & $\mathrm{X}$ & & \\
\hline Museu do Vinho (Videira, SC) & Criação de arquivo público municipal. & $\mathrm{X}$ & & & & \\
\hline \multirow[t]{4}{*}{ Museu Histórico de Santa Catarina (Florianópolis, SC) } & Conservação de acervos bibliográficos. & & $\mathrm{X}$ & & & \\
\hline & Organização de arquivo corrente, arquivo intermediário e de acervo fotográfico. & & & $\mathrm{X}$ & & \\
\hline & Organização de acervo fotográfico. & & & $\mathrm{X}$ & & \\
\hline & Restauração de documentos. & & & & $\mathrm{X}$ & \\
\hline Museu Paraense Emílio Goeldi (Belém, PA) & [Visita técnica] & $\mathrm{X}$ & & & & \\
\hline Museu Thiago de Castro (Lages, SC) & Conservação de documentos. & $\mathrm{X}$ & & & & \\
\hline $\begin{array}{l}\text { Prefeitura Municipal de Caçador - Depto. de Cultura } \\
\text { (Caçador, SC) }\end{array}$ & Criação de arquivo público municipal. & & $\mathrm{X}$ & & & \\
\hline Prefeitura Municipal de Paulo Lopes (SC) & Criação de arquivo público municipal. & & & & & $\mathrm{X}$ \\
\hline Prefeitura Municipal de São Francisco do Sul (SC) & Criação de arquivo público municipal. & $\mathrm{X}$ & & & & \\
\hline \multirow[t]{3}{*}{ Procuradoria Geral do Estado } & Elaboração de tabela de temporalidade. & $\mathrm{X}$ & & & & \\
\hline & $\begin{array}{l}\text { Avaliação de documentos e elaboração de tabela de temporalidade, organização de } \\
\text { acervos. }\end{array}$ & & & & $\mathrm{X}$ & \\
\hline & Elaboração de tabela de temporalidade; legislação arquivística. & & & & & $\mathrm{X}$ \\
\hline Santa Casa de Misericórdia de Porto Alegre (RS) & [Visita técnica.] & & $\mathrm{X}$ & & & \\
\hline \multirow[t]{3}{*}{ Secretaria de Estado da Administração (SC) } & Eliminação de documentos. & & $\mathrm{X}$ & & & \\
\hline & Elaboração de tabela de temporalidade. & & & & $\mathrm{X}$ & \\
\hline & Protocolo, avaliação e organização de documentos e criação de Arquivo Central. & & & & $\mathrm{X}$ & \\
\hline
\end{tabular}




\begin{tabular}{|c|c|c|c|c|c|c|}
\hline Instituição & Assuntos & \begin{tabular}{|l|}
1 \\
9 \\
9 \\
8 \\
\end{tabular} & $\begin{array}{l}1 \\
9 \\
9 \\
9\end{array}$ & $\begin{array}{l}\mathbf{2} \\
\mathbf{0} \\
\mathbf{0} \\
\mathbf{0}\end{array}$ & $\begin{array}{l}\mathbf{2} \\
\mathbf{0} \\
\mathbf{0} \\
\mathbf{1}\end{array}$ & $\begin{array}{l}2 \\
0 \\
0 \\
2\end{array}$ \\
\hline \multirow[t]{3}{*}{ Secretaria de Estado da Casa Civil (SC) } & Criação e instalação de biblioteca. & & & & $\mathrm{X}$ & \\
\hline & Seleção de documentos para eliminação. & & & & $\mathrm{X}$ & \\
\hline & Eliminação de documentos. & & & & $\mathrm{X}$ & \\
\hline Secretaria de Estado da Educação - Arquivo Central (SC) & [Visita técnica] & & $\mathrm{X}$ & & & \\
\hline \multirow[t]{2}{*}{ Secretaria de Estado da Família (SC) } & $\begin{array}{l}\text { Avaliação de documentos e elaboração de tabela de temporalidade; organização de } \\
\text { acervos documentais; legislação arquivística. }\end{array}$ & & & & $\mathrm{X}$ & \\
\hline & Avaliação de documentos; legislação arquivística; terceirização de serviços arquivísticos. & & & & & $\mathrm{X}$ \\
\hline \multirow[t]{2}{*}{ Secretaria de Estado da Fazenda (SC) } & Avaliação de documentos e elaboração de tabela de temporalidade. & & & $\mathrm{X}$ & & \\
\hline & Elaboração de tabela de temporalidade. & & & & & $\mathrm{X}$ \\
\hline \multirow[t]{2}{*}{ Secretaria de Estado da Saúde (SC) } & Protocolo, avaliação de documentos e legislação arquivística. & & & $\mathrm{X}$ & & \\
\hline & Criação do Arquivo Central da Secretaria e elaboração de tabela de temporalidade. & & & & $\mathrm{X}$ & \\
\hline $\begin{array}{l}\text { Secretaria de Estado de Desenvolvimento Rural e } \\
\text { Agricultura (SC) }\end{array}$ & Elaboração de tabela de temporalidade. & $\mathrm{X}$ & & & & \\
\hline $\begin{array}{l}\text { Secretaria de Estado de Desenvolvimento Social e da } \\
\text { Família (SC) }\end{array}$ & Avaliação e eliminação de documentos. & & & $\mathrm{X}$ & & \\
\hline Secretaria de Estado do Meio Ambiente (SC) & Arranjo de processos. & & & & & $\mathrm{X}$ \\
\hline \multirow[t]{2}{*}{ Secretaria de Estado dos Transportes e Obras (SC) } & Elaboração de tabela de temporalidade. & $\mathrm{X}$ & & & & \\
\hline & Avaliação de documentos e elaboração de tabela de temporalidade. & & & & & $\mathrm{X}$ \\
\hline Secretaria Municipal de Administração de Laguna (SC) & Criação de arquivo público municipal; organização de arquivo intermediário. & $\mathrm{X}$ & & & & \\
\hline Secretaria Municipal de Cultura de Águas Mornas (SC) & [visita técnica] & & $\mathrm{X}$ & & & \\
\hline Secretaria Municipal de Educação de Apiúna (SC) & Criação de biblioteca e arquivo municipais; financiamento de projetos culturais. & & & & $\mathrm{X}$ & \\
\hline $\begin{array}{l}\text { Secretaria Municipal de Educação, Cultura e Esporte de } \\
\text { Nova Erechim (SC) }\end{array}$ & [Visita técnica] & $\mathrm{X}$ & & & & \\
\hline $\begin{array}{l}\text { Secretaria Municipal de Turismo de S.Pedro de Alcântara } \\
\text { (SC) }\end{array}$ & [visita técnica] & & $\mathrm{X}$ & & & \\
\hline $\begin{array}{l}\text { Secretaria Municipal de Turismo e Desenvolvimento de } \\
\text { Anitápolis (SC) }\end{array}$ & Criação de arquivo público municipal. & $\mathrm{X}$ & & & & \\
\hline SENAI (SC) & Avaliação de documentos e elaboração de tabela de temporalidade. & & & & & $\mathrm{X}$ \\
\hline Serviço Autônomo de Águas (Blumenau, SC) & Gestão de documentos. & & & & $\mathrm{X}$ & \\
\hline TRACTEBEL - Empresa Geradora de Energia (SC) & Avaliação de documentos e elaboração de tabela de temporalidade. & & & & & $\mathrm{X}$ \\
\hline Tribunal Regional do Trabalho (SC) & Organização de acervos fotográficos. & $\mathrm{X}$ & & & & \\
\hline UFSC - Biblioteca Central e Biblioteca do CED (SC) & Organização de acervo de caráter permanente. & & & & & $\mathrm{X}$ \\
\hline UNESC (SC) & Organização de documentos (inclusive fotográficos); patrimônio documental. & & & & $\mathrm{X}$ & \\
\hline União Catarinense de Educação Marista (SC) & Avaliação de documentos; legislação arquivística. & & & $\mathrm{X}$ & & \\
\hline
\end{tabular}




\begin{tabular}{|c|c|c|c|c|c|c|}
\hline Instituição & Assuntos & $\begin{array}{l}1 \\
9 \\
9 \\
8 \\
\end{array}$ & $\begin{array}{l}1 \\
9 \\
9 \\
9 \\
\end{array}$ & $\begin{array}{l}\mathbf{2} \\
\mathbf{0} \\
\mathbf{0} \\
\mathbf{0} \\
\end{array}$ & $\begin{array}{l}\mathbf{2} \\
\mathbf{0} \\
\mathbf{0} \\
\mathbf{1} \\
\end{array}$ & $\begin{array}{l}2 \\
0 \\
0 \\
2 \\
\end{array}$ \\
\hline UNIVALI (SC) & Planejamento e organização de acervos. & & $\mathrm{X}$ & & & \\
\hline Universidade Estácio de Sá (SC) & Conservação de acervos bibliográficos. & & & & & $\mathrm{X}$ \\
\hline UNOESC (SC) & [Visita técnica] & $\mathrm{X}$ & & & & \\
\hline
\end{tabular}

Obs.: Na fonte consultada, os arquivos municipais nem sempre foram referidos com seu nome oficial; para a elaboração do quadro, tais instituições foram designadas como "arquivo histórico do município".

Fonte: Boletim informativo [Arquivo Público do Estado de Santa Catarina/ Associação de Amigos do Arquivo Público]. Florianópolis, abr.-jun.1998 a jul-dez.2002. 
Apêndice II-18:

Legislação relativa à institucionalização dos arquivos públicos municipais de Santa Catarina

\begin{tabular}{|c|c|c|c|}
\hline Ano & Município & Legislação relacionada à institucionalização & Legislação posterior pertinente \\
\hline 1971 & Jaraguá do Sul & $\begin{array}{l}\text { Lei municipal } \mathrm{n}^{0} .321 / 71 \text { de } 12 \text { de agosto de 1971: cria o Museu e Arquivo } \\
\text { Municipal. }\end{array}$ & $\begin{array}{l}\text { Lei municipal } \mathrm{n}^{\circ} .1 .464 \text {, de } 10 \text { de maio de 1991: cria o Arquivo } \\
\text { Histórico de Jaraguá do Sul e dá outras providências. } \\
\text { - extingue o Arquivo Municipal criado pela Lei Municipal } \\
\text { n.321/71 de } 12 \text { de agosto de } 1971 \text { (Art. } 9^{\circ} \text {.). }\end{array}$ \\
\hline 1972 & Joinville & $\begin{array}{l}\text { Lei municipal } \mathrm{n}^{\mathrm{o}} .1 .182 \text {, de } 20 \text { de março de 1972: cria o Arquivo Histórico } \\
\text { Municipal de Joinville. }\end{array}$ & $\begin{array}{l}\text { Decreto municipal } \mathrm{n}^{\circ} .5 .994 \text {, de } 14 \text { de novembro de 1988: declara } \\
\text { de interesse público documentos históricos relacionados com as } \\
\text { atividades da Colônia Dona Francisca. }\end{array}$ \\
\hline 1972 & Blumenau & $\begin{array}{l}\text { Lei municipal no. 1.835, de } 7 \text { de abril de 1972: cria a Fundação "Casa Dr. } \\
\text { Blumenau” } \\
\text { - dispõe sobre o Arquivo Histórico do Município. } \\
\text { Decreto municipal no. 221, de } 20 \text { de junho de 1972: aprova o Estatuto da } \\
\text { Fundação "Casa Dr. Blumenau" } \\
\text { - dispõe sobre o Arquivo Histórico do Município. }\end{array}$ & $\begin{array}{l}\text { Lei municipal n. } 108 \text {, de } 22 \text { de dezembro de } 1995 \text { : altera a } \\
\text { denominação, dispõe sobre a estrutura administrativa da } \\
\text { Fundação "Casa Dr. Blumenau" e dá outras providências. } \\
\text { - dispõe sobre o setor de arquivo histórico. }\end{array}$ \\
\hline 1976 & Itajaí & $\begin{array}{l}\text { Lei municipal } n^{\circ} .1 .515 \text {, de } 1^{\circ} \text {. de dezembro de 1976: institui a Fundação } \\
\text { Genésio Miranda Lins e dá outras providências. } \\
\text { Decreto municipal }{ }^{\circ} .1543 \text {, de } 27 \text { de janeiro de 1977: aprova o Estatuto da } \\
\text { Fundação Genésio Miranda Lins. } \\
\text { - dispõe sobre o Arquivo Histórico do Município. }\end{array}$ & $\begin{array}{l}\text { Lei municipal no. 3.343, de } 27 \text { de novembro de 1998: estabelece } \\
\text { normas de gestão para os documentos da administração pública } \\
\text { do Município de Itajaí e dá outras providências. } \\
\text { Lei municipal no. } 4.263 \text { de } 16 \text { de março de 2005: modifica a } \\
\text { estrutura administrativa da Fundação Genésio Miranda Lins e dá } \\
\text { outras providências. } \\
\text { Decreto municipal no. } 7.575 \text {, de } 19 \text { de julho de 2005: aprova o } \\
\text { estatuto da Fundação Genésio Miranda Lins. } \\
\text { - dispõe sobre o Centro de Documentação e Memória Histórica } \\
\text { "Genésio Miranda Lins". }\end{array}$ \\
\hline 1983 & São Bento do Sul & 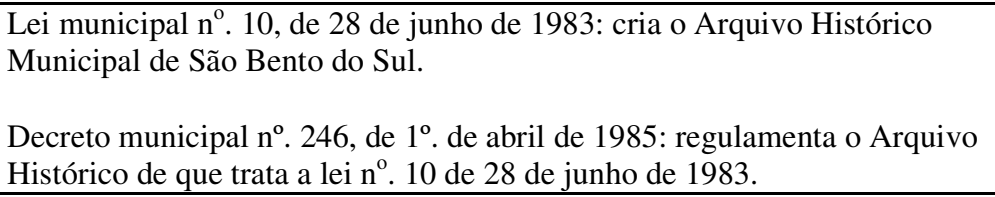 & \\
\hline
\end{tabular}




\begin{tabular}{|c|c|c|c|}
\hline 1986 & Indaial & $\begin{array}{l}\text { Lei municipal no. } 1530 \text {, de } 26 \text { de março de 1986: cria o Centro de Cultura do } \\
\text { Município de Indaial. } \\
\text { - dispõe sobre o Arquivo Histórico. } \\
\text { Lei municipal no. } 1660 \text {, de } 12 \text { de novembro de 1987: institui a Fundação } \\
\text { Indaialense de Cultura. } \\
\text { - dispõe sobre o Arquivo Histórico do Município. }\end{array}$ & $\begin{array}{l}\text { Decreto municipal } \mathrm{n}^{\circ} .486 \text {, de } 21 \text { de março de 1994: cria o } \\
\text { Arquivo Histórico Municipal Theobaldo Costa Jamundá. } \\
\text { Lei municipal } \mathrm{n}^{\circ} .2749 \text {, de } 13 \text { de novembro de 1998: altera e } \\
\text { modifica a Lei } \mathrm{n}^{\circ} .1660 \text {, de } 12 \text { de novembro de 1987, que criou a } \\
\text { Fundação Indaialense de Cultura. }\end{array}$ \\
\hline 1988 & Ipumirim & $\begin{array}{l}\text { Lei municipal } \mathrm{n}^{\circ} .788 \text {, de } 28 \text { de outubro de 1988: cria a Fundação Cultural e } \\
\text { dá outras providências. } \\
\text { - dispõe sobre o Arquivo Histórico Municipal Ipumirense. }\end{array}$ & \\
\hline 1989 & Itaiópolis & $\begin{array}{l}\text { Lei municipal } \mathrm{n}^{\circ} .16 \text {, de } 22 \text { de fevereiro de 1989: cria o Arquivo Público e } \\
\text { Histórico e dá outras providências. }\end{array}$ & \\
\hline 1989 & Campos Novos & $\begin{array}{l}\text { Decreto municipal } \mathrm{n}^{\mathrm{o}} .2 .443 \text {, de } 12 \text { de abril de 1989: aprova o regulamento } \\
\text { da Casa de Cultura de Campos Novos. } \\
\text { - dispõe sobre o Arquivo Histórico. }\end{array}$ & \\
\hline 1989 & Porto União & $\begin{array}{l}\text { Lei municipal } \mathrm{n}^{\circ} .1 .581 \text {, de } 18 \text { de setembro de 1989: cria o Arquivo Público } \\
\text { e Histórico de Porto União. }\end{array}$ & \\
\hline 1990 & Tubarão & $\begin{array}{l}\text { Lei municipal } \mathrm{n}^{\circ} .1 .463 \text {, de } 17 \text { de julho de 1990: cria o Arquivo Público e } \\
\text { Histórico de Tubarão e dá outras providências. }\end{array}$ & \\
\hline 1991 & Concórdia & $\begin{array}{l}\text { Decreto municipal } \mathrm{n}^{\circ} .2 .892 \text { de } 19 \text { de dezembro de 1991: dispõe sobre a } \\
\text { política municipal de arquivos públicos e privados. } \\
\text { - estabelece competências para o Arquivo Central do Município. }\end{array}$ & $\begin{array}{l}\text { Decreto municipal } \mathrm{n}^{\circ} .3 .779 \text { de } 28 \text { de novembro de 1996: dá } \\
\text { nova redação ao Art. } 17 \text { do Decreto n }{ }^{\circ} .2 .892 / 91 \text {. } \\
\text { - cria, no Arquivo Central do Município, o Arquivo Histórico de } \\
\text { Concórdia e o Registro Geral de Arquivos Privados. }\end{array}$ \\
\hline 1992 & Pinheiro Preto & $\begin{array}{l}\text { Lei municipal } \mathrm{n}^{\circ} .623 \text {, de } 20 \text { de maio de 1992: cria o Arquivo Histórico } \\
\text { Municipal de Pinheiro Preto e dá outras providências. }\end{array}$ & \\
\hline 1992 & Biguaçu & $\begin{array}{l}\text { Lei municipal } \mathrm{n}^{\circ} \text {. 714, de } 22 \text { de maio de 1992: dispõe sobre a criação do } \\
\text { Arquivo Histórico Municipal de Biguaçu. }\end{array}$ & \\
\hline 1992 & São José & $\begin{array}{l}\text { Lei municipal no }{ }^{\circ} .2 .436 \text {, de } 10 \text { de dezembro de 1992: cria o Arquivo } \\
\text { Histórico de São José e dá outras providências. }\end{array}$ & \\
\hline 1993 & Chapecó & $\begin{array}{l}\text { Lei } n^{\circ} .3 .532 \text {, de } 25 \text { de junho de 1993: dispõe sobre a ação de proteção do } \\
\text { patrimônio cultural do município, com outras providências. } \\
\text { - estabelece competências para o Arquivo Público Municipal de Chapecó. } \\
\text { Lei municipal no }{ }^{\circ} .3 .536 \text {, de } 10 \text { de agosto de 1993: cria o Arquivo Público } \\
\text { Municipal de Chapecó, com outras providências. }\end{array}$ & \\
\hline 1993 & Balneário Camboriú & $\begin{array}{l}\text { Lei municipal } \mathrm{n}^{\circ} \text {. 1.293, de } 29 \text { de novembro de 1993: cria o Arquivo } \\
\text { Histórico do Município de Balneário Camboriú e dá outras providências. }\end{array}$ & \\
\hline
\end{tabular}




\begin{tabular}{|c|c|c|c|}
\hline 1994 & Florianópolis & $\begin{array}{l}\text { Lei municipal no }{ }^{\circ} .4 .491 \text {, de } 14 \text { de setembro de 1994: cria o Arquivo } \\
\text { Histórico do Município de Florianópolis e dá outras providências. }\end{array}$ & $\begin{array}{l}\text { Decreto municipal n. }{ }^{\circ} \text { 622/95: estabelece o Plano de Destinação e } \\
\text { Implantação da Política de Gestão e Administração da } \\
\text { Documentação Municipal" . } \\
\text { Decreto municipal n. } \\
\text { destinação para os documentos da administração pública do } \\
\text { município de Florianópolis e dá outras providências. }\end{array}$ \\
\hline 1994 & Rio do Sul & $\begin{array}{l}\text { Lei municipal no }{ }^{\circ} .2 .956 \text {, de } 16 \text { de dezembro de 1994: cria o Arquivo Público } \\
\text { Histórico de Rio do Sul e dá outras providências. }\end{array}$ & \\
\hline 1995 & Serra Alta & $\begin{array}{l}\text { Lei municipal } \mathrm{n}^{\circ} .314 \text {, de } 25 \text { de outubro de 1995: cria o Arquivo Público } \\
\text { Municipal de Serra Alta e dá outras providências. }\end{array}$ & \\
\hline 1997 & Canoinhas & $\begin{array}{l}\text { Lei municipal } n^{\circ} .2 .903 \text { de } 22 \text { de outubro de 1997: cria o Arquivo Histórico } \\
\text { de Canoinhas. } \\
\text { Decreto municipal } n^{\circ} .108 \text {, de } 1997 .\end{array}$ & \\
\hline 1998 & Nova Erechim & $\begin{array}{l}\text { Lei municipal } \mathrm{n}^{\circ} .890 \text {, de } 10 \text { de março de 1998: cria o Arquivo Público } \\
\text { Municipal de Nova Erechim e dá outras providências. }\end{array}$ & \\
\hline 1998 & Criciúma & $\begin{array}{l}\text { Lei municipal } \mathrm{n}^{\circ} .3 .670 \text {, de } 11 \text { de setembro de 1998: cria o Arquivo } \\
\text { Histórico do Município de Criciúma e dá outras providências. }\end{array}$ & \\
\hline 1998 & Ibirama & $\begin{array}{l}\text { Lei municipal } n^{\circ} 2.031 \text {, de } 18 \text { de dezembro de 1998: cria o Arquivo Público } \\
\text { Municipal de Ibirama, e dá outras providências. }\end{array}$ & \\
\hline 2003 & Capivari de Baixo & $\begin{array}{l}\text { Lei municipal no } 892 \text {, de } 1 \text { de julho de 2003: cria o Arquivo Público e } \\
\text { Histórico do Município de Capivari de Baixo e dá outras providências. }\end{array}$ & \\
\hline
\end{tabular}

Fontes:

- A própria legislação acima referida: originais ou cópias consultados no Arquivo Público do Estado de Santa Catarina, no Arquivo Histórico José Ferreira da Silva e no Arquivo Histórico de Itajaí; também consulta ao website: <http://www.leismunicipais.com.br> (acesso em: 13 out. 2005). Cópia da lei de criação do Arquivo Histórico Municipal de Joinville foi gentilmente fornecida pela pesquisadora Ilanil Coelho.

- NUNES, Neusa Rosane D., TERTITCHNIJ, Maria Tereza (orgs.). Guia dos arquivos municipais. Florianópolis: Arquivo Público do Estado, 1992.

- OHIRA, Maria Lourdes Blatt, MARTINEZ, Priscila Amorim. Acessibilidade aos documentos nos arquivos públicos municipais do Estado de Santa Catarina - Brasil. $1^{\circ}$. Integrar:

Congresso Internacional de Arquivos, Bibliotecas, Centros de documentação e Museus: textos. São Paulo: Imprensa Oficial do Estado, 2002 . p. 335-358.

Obs.:

1. OHIRA \& MARTINEZ (p.344) apontam datas distintas para a institucionalização dos arquivos de São Bento do Sul, Criciúma, Balneário Camboriú e Indaial, que teriam sido criados, respectivamente, em 1971, 1983, 1992 e 1994. No caso dos três primeiros arquivos, entretanto, os instrumentos legais de criação identificados pelas autoras são posteriores a tais datas e coincidem com os acima relacionados.

2. O Museu e Arquivo Histórico do Vale do Itajaí-Mirim (conhecido como "Casa de Brusque") e o Museu Histórico Thiago de Castro, em Lages, não foram aqui incluídos, embora abriguem documentação pública municipal de caráter arquivístico: são mantidos por particulares (a entidade de Brusque, pela Sociedade Amigos de Brusque; a entidade lageana, pela família de Danilo Thiago de Castro). 
Apêndice II-19:

Vinculação administrativa dos arquivos públicos municipais de Santa Catarina de acordo com a legislação de institucionalização

\begin{tabular}{|c|c|c|c|}
\hline Ano & Município & Vinculação & Obs.: \\
\hline 1971 & Jaraguá do Sul & $\begin{array}{l}\text { Biblioteca Pública Municipal / Prefeitura Municipal: criados conjuntamente, o Arquivo e o Museu do } \\
\text { Município fariam parte da Biblioteca Pública Municipal "até ulterior deliberação" (Lei municipal n”. } 321 / 71 \\
\text { de } 12 \text { de agosto de 1971, Art.1 }{ }^{\circ} \text {.). }\end{array}$ & $\begin{array}{l}\text { Vinte anos depois, o "Arquivo } \\
\text { Histórico de Jaraguá do Sul”, a ser } \\
\text { instituído, estaria vinculado à } \\
\text { Secretaria Municipal de Cultura, } \\
\text { Esporte e Turismo (Lei municipal n }{ }^{\circ} \text {. } \\
\text { 1.464, de } 10 \text { de maio de } 1991 \text {, Art. } 1^{\circ} \text {.). }\end{array}$ \\
\hline 1972 & Joinville & $\begin{array}{l}\text { Biblioteca Pública Municipal / Prefeitura Municipal: Arquivo Histórico Municipal e Biblioteca Pública } \\
\text { Municipal funcionariam "sob a mesma direção", até que ao Arquivo fossem destinados "sede e prédio } \\
\text { próprios" (Lei municipal no. 1.182, de } 20 \text { de março de 1972, Art. } 2^{\circ} \text {.) }\end{array}$ & \\
\hline 1972 & Blumenau & 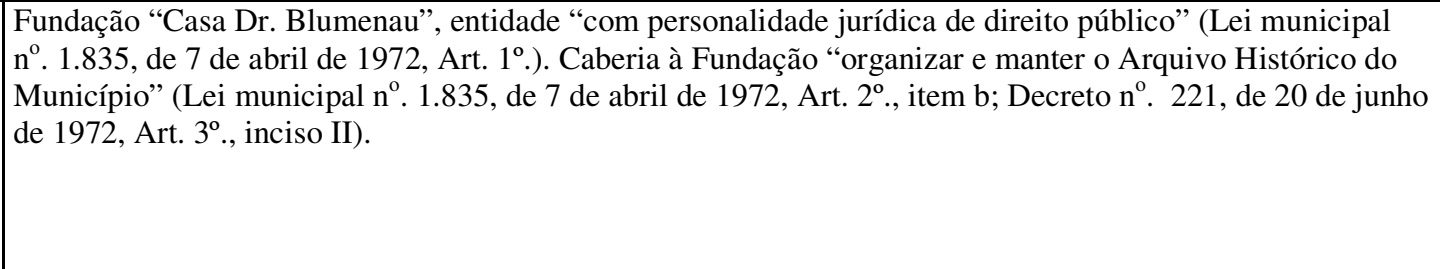 & $\begin{array}{l}\text { A Fundação posteriormente passou a } \\
\text { denominar-se "Fundação Cultural de } \\
\text { Blumenau" (Lei complementar no } \\
\text { 108, de } 22 \text { de dezembro de } 1995 \text {, Art. } \\
1^{\circ} \text { ), passando o Arquivo a ser uma } \\
\text { divisão do Departamento Histórico- } \\
\text { Museológico. }\end{array}$ \\
\hline 1976 & Itajaí & $\begin{array}{l}\text { Fundação Genésio Miranda Lins, "pessoa jurídica de direito público, com função técnica desvinculada da } \\
\text { Administração Municipal e com a finalidade exclusivamente cultural" (Lei municipal } n^{\circ} .1 .515 \text {, de } 1^{\circ} \text {. de } \\
\text { dezembro de } 1976, \text { Art. } 1^{\circ} \text {.). }\end{array}$ & $\begin{array}{l}\text { A vinculação foi mantida, mesmo com } \\
\text { a reestruturação da Fundação, em } \\
2005 \text { (Lei municipal no. } 4.263 \text {, de } 16 \\
\text { de março de } 2005 \text {, e Decreto } \\
\text { municipal no. } 7.575 \text {, de } 19 \text { de julho de } \\
\text { 2005); o Arquivo, no entanto, aparece } \\
\text { como Centro de Documentação e } \\
\text { Memória Histórica "Genésio Miranda } \\
\text { Lins" (Decreto municipal 6.575/2005, } \\
\text { Arts. 8. e 18). }\end{array}$ \\
\hline 1983 & $\begin{array}{c}\text { São Bento do } \\
\text { Sul }\end{array}$ & $\begin{array}{l}\text { Prefeitura Municipal. Não é mencionada a vinculação administrativa a nenhuma Secretaria Municipal, nem } \\
\text { na lei de criação (Lei municipal no }{ }^{\circ} \text {. 10, de } 28 \text { de junho de } 1983 \text { ) nem no decreto de regulamentação (Decreto } \\
\text { municipal no. } 246 \text {, de } 1^{\circ} \text {. de abril de 1985). O Arquivo seria dirigido por "um funcionário nomeado que } \\
\text { tenha conhecimentos e prática arquivística." (Decreto municipal } 246 / 1985 \text {, Art. } 3^{\circ} \text {.) }\end{array}$ & \\
\hline
\end{tabular}




\begin{tabular}{|c|c|c|c|}
\hline 1986 & Indaial & $\begin{array}{l}\text { Centro de Cultura do Município de Indaial (Lei municipal no. 1530, de } 26 \text { de março de 1986). O Centro, por } \\
\text { sua vez, seria “diretamente subordinado ao Chefe do Executivo Municipal." (Art. } 4^{\circ} \text {.) }\end{array}$ & $\begin{array}{l}\text { Passa a estar vinculado à Fundação } \\
\text { Indaialense de Cultura, em } 1987 \text { (Lei } \\
\text { municipal } \mathrm{n}^{\circ} .1660 \text {, de } 12 \text { de } \\
\text { novembro). }\end{array}$ \\
\hline 1988 & Ipumirim & $\begin{array}{l}\text { Fundação Cultural Félix Bonissoni, instituição “com personalidade jurídica de direito privado" (Lei } \\
\text { municipal n.788 de } 28 \text { de outubro de } 1988 \text {, Art. } 1^{\circ} \text {.). Apesar disso, a Fundação estaria estreitamente } \\
\text { vinculada à administração municipal (o Diretor Municipal de Educação e Cultura participaria } \\
\text { obrigatoriamente dos conselhos Curador e Deliberativo, as contas da Fundação deveriam ser submetidas à } \\
\text { Prefeitura etc.). }\end{array}$ & \\
\hline 1989 & Itaiópolis & Subordinado ao Executivo Municipal (Lei municipal $\mathrm{n}^{\circ} .16$, de 22 de fevereiro de 1989, Art. $^{\circ}$.) & \\
\hline 1989 & Campos Novos & $\begin{array}{l}\text { Vinculado à Casa de Cultura de Campos Novos (na unidade de "Ciências", junto com o "Setor de Pesquisas } \\
\text { Históricas"). A Casa de Cultura, por sua vez, estava vinculada à Secretaria Municipal de Educação, Cultura } \\
\text { e Esportes (Decreto municipal no }{ }^{\circ} .2 .443 \text {, de } 12 \text { de abril de 1989, Regulamento, Arts. } 3^{\circ} \text {. e } 4^{\circ} \text {.). }\end{array}$ & \\
\hline 1989 & Porto União & $\begin{array}{l}\text { Informação não obtida (não foi possível efetuar a consulta à Lei municipal n }{ }^{\circ} .1 .581 \text {, de } 18 \text { de setembro de } \\
\text { 1989). }\end{array}$ & \\
\hline 1990 & Tubarão & $\begin{array}{l}\text { Vinculado à Secretaria Municipal de Educação e Cultura (Lei municipal n }{ }^{\circ} .1 .463 \text {, de } 17 \text { de julho de 1990, } \\
\text { Art. } 1^{\circ} \text {.). }\end{array}$ & \\
\hline 1991 & Concórdia & $\begin{array}{l}\text { Haveria um Arquivo Central do Município (Decreto municipal no. } 2892 \text { de } 19 \text { de dezembro de 1991), sendo } \\
\text { que o "Arquivo Histórico de Concórdia" estaria nele abarcado (Decreto municipal nº } 3.779 \text { de } 28 \text { de } \\
\text { novembro de 1996). Dá-se a entender que o Arquivo Central estaria ligado à Secretaria de Administração: } \\
\text { "À Secretaria de Administração do Município, por intermédio da Coordenadoria de Documentação e } \\
\text { Publicações, compete definir as diretrizes da política arquivística do Município" (Decreto municipal n”. } \\
2.892 \text { de } 19 \text { de dezembro de 1991, Art.18). }\end{array}$ & \\
\hline 1992 & Pinheiro Preto & Diretamente subordinado ao Gabinete do Prefeito (Lei municipal no ${ }^{\circ} .623$, de 20 de maio de 1992, Art. 13). & \\
\hline 1992 & Biguaçu & Diretamente subordinado ao Gabinete do Prefeito (Lei municipal $n^{\circ} .714$, de 22 de maio de 1992, Art.13). & \\
\hline 1992 & São José & $\begin{array}{l}\text { Não fica clara a vinculação administrativa, mas o Art. } 22 \text { da Lei municipal no. 2.436, de } 10 \text { de dezembro de } \\
1992 \text { dispõe: “Ả Secretaria de Administração do Município de São José, por intermédio da Coordenação de } \\
\text { Documentação e Publicações, compete definir as diretrizes da Política Arquivística do Município." }\end{array}$ & \\
\hline 1993 & Chapecó & $\begin{array}{l}\text { Subordinado à Secretaria da Fazenda a Administração (Lei municipal no. 3.536, de } 10 \text { de agosto de 1993, } \\
\text { Art. } 1^{\circ} \text {.). No entanto, estabelece o Art. } 3^{\circ} \text {.., em seu parágrafo único: "No interesse da Administração } \\
\text { Municipal e sempre que oportuno, a Secretaria da Fazenda e Administração, por seu Departamento de } \\
\text { Serviços Gerais, atuará articuladamente com o Departamento de Patrimônio Histórico e Memória, da } \\
\text { Secretaria da Educação e Cultura." Caberia a ambos os departamentos "definir as diretrizes da política }\end{array}$ & \\
\hline
\end{tabular}




\begin{tabular}{|c|c|c|c|}
\hline & & arquivística do Município” (Art.12). & \\
\hline 1993 & $\begin{array}{l}\text { Balneário } \\
\text { Camboriú }\end{array}$ & $\begin{array}{l}\text { Vinculado à Secretaria Municipal de Administração (Lei municipal nº. 1.293, de } 29 \text { de novembro de 1993, } \\
\text { Art. } 1^{\circ} \text {.). }\end{array}$ & \\
\hline 1994 & Florianópolis & $\begin{array}{l}\text { Vinculado à Secretaria Municipal de Administração (Lei municipal nº }{ }^{\circ} .491 \text {, de } 14 \text { de setembro de 1994, } \\
\text { Art. } 1^{\circ} \text {.). }\end{array}$ & \\
\hline 1994 & Rio do Sul & Subordinado à Fundação Cultural (Lei municipal no ${ }^{\circ} .2 .956$, de 16 de dezembro de 1994. Art. ${ }^{\circ}$.). & \\
\hline 1995 & Serra Alta & $\begin{array}{l}\text { Subordinado às Secretarias de Administração e Fazenda (Lei municipal no. } 314 \text {, de } 25 \text { de outubro de } 1995 \text {, } \\
\text { Art. } 1^{\circ} \text {.). No entanto, estabelece o Art. } 3^{\circ} \text {.., em seu parágrafo único: "No interesse da Administração } \\
\text { Municipal, e sempre que oportuno, as Secretarias de Administração e Fazenda, por seu Departamento de } \\
\text { Serviços e Encargos Gerais [sic], atuará [sic] articuladamente com a Biblioteca Pública Municipal, da } \\
\text { Secretaria da Educação, Cultura e Esportes." Caberia ao Departamento de Serviços e Encargos Gerais e à } \\
\text { Biblioteca Pública Municipal "definir as diretrizes da política arquivística do Município" (Art.12). }\end{array}$ & \\
\hline 1997 & Canoinhas & $\begin{array}{l}\text { Não há referências à vinculação administrativa do Arquivo Histórico de Canoinhas (Lei municipal no }{ }^{\circ} 2.903 \\
\text { de } 22 \text { de outubro de 1997). }\end{array}$ & \\
\hline 1998 & Nova Erechim & $\begin{array}{l}\text { Integrado à estrutura da Secretaria Municipal da Educação, Cultura e Esporte (Lei municipal n }{ }^{\circ} .890, \text { de } 10 \\
\text { de março de } 1998, \text { Art. }^{\circ} \text {.) }\end{array}$ & \\
\hline 1998 & Criciúma & Vinculado à Fundação Cultural de Criciúma (Lei municipal no ${ }^{\circ} .3 .670$, de 11 de setembro de 1998, Art. $^{\circ}$.). & \\
\hline 1998 & Ibirama & $\begin{array}{l}\text { Vinculado à Secretaria da Educação, Cultura e Esportes (Lei municipal nº. 2031, de } 18 \text { de dezembro de } \\
\text { 1998, Art. } 1^{\text {o. }} \text {.). }\end{array}$ & \\
\hline 2003 & $\begin{array}{l}\text { Capivari de } \\
\text { Baixo }\end{array}$ & Vinculado ao Gabinete do Prefeito (Lei municipal $n^{\circ}$ 892, de 1 de julho de 2003, Art. $1^{\circ}$.). & \\
\hline
\end{tabular}

Fontes:

- A própria legislação acima referida: originais ou cópias consultados no Arquivo Público do Estado de Santa Catarina, no Arquivo Histórico José Ferreira da Silva e no Arquivo Histórico de Itajaí; também consulta ao website: <http://www.leismunicipais.com.br> (acesso em: 13 out. 2005). Cópia da lei de criação do Arquivo Histórico Municipal de Joinville foi gentilmente fornecida pela pesquisadora Ilanil Coelho.

Obs.: O Museu e Arquivo Histórico do Vale do Itajaí-Mirim (conhecido como "Casa de Brusque") e o Museu Histórico Thiago de Castro, em Lages, não foram aqui incluídos, embora abriguem documentação pública municipal de caráter arquivístico: são mantidos por particulares (a entidade de Brusque, pela Sociedade Amigos de Brusque; a entidade lageana, pela família de Danilo Thiago de Castro). 
Apêndice II-20:

Sedes dos arquivos públicos municipais de Santa Catarina de acordo com a legislação de institucionalização

\begin{tabular}{|c|c|c|}
\hline Ano & Município & Sede \\
\hline 1971 & Jaraguá do Sul & $\begin{array}{l}\text { Biblioteca Pública Municipal (criados conjuntamente, o Arquivo e o Museu do Município fariam parte da Biblioteca Pública Municipal "até } \\
\text { ulterior deliberação" - Lei municipal n. 321/71 de } 12 \text { de agosto de } 1971 \text {, Art.1 }{ }^{\circ} \text {.). }\end{array}$ \\
\hline 1972 & Joinville & $\begin{array}{l}\text { Biblioteca Pública Municipal, até que ao Arquivo fossem destinados "sede e prédio próprios, mais amplo [sic] e à prova de fogo e de umidade" } \\
\text { (Lei municipal } \mathrm{n}^{\mathrm{o}} .1 .182 \text {, de } 20 \text { de março de } 1972 \text {, Art. } 2^{\circ} \text {.) }\end{array}$ \\
\hline 1972 & Blumenau & $\begin{array}{l}\text { Não há referências à sede do Arquivo Histórico de Blumenau na legislação de } 1972 \text { (Lei municipal no }{ }^{\circ} .835 \text {, de } 7 \text { de abril de } 1972 \text {, e Decreto } \\
\text { municipal } n^{\circ} .221 \text {, de } 20 \text { de junho de 1972). }\end{array}$ \\
\hline 1976 & Itajaí & $\begin{array}{l}\text { Não há referências à sede do Arquivo Histórico Municipal de Itajaí na lei de criação da Fundação Genésio Miranda Lins (Lei municipal no } \\
1.515 \text {, de } 1^{\circ} \text {. de dezembro de 1976) ou no decreto que fixou seu estatuto (Decreto municipal n }{ }^{\circ} \text {. } 1.543 \text {, de } 27 \text { de janeiro de } 1977 \text { ). }\end{array}$ \\
\hline 1983 & São Bento do Sul & $\begin{array}{l}\text { Não há referências à sede do Arquivo Histórico Municipal de São Bento do Sul na Lei municipal no }{ }^{\circ} 10 \text {, de } 28 \text { de junho de } 1983 . \text { No decreto de } \\
\text { regulamentação, entretanto (Decreto municipal no } .246 \text {, de } 1^{\circ} \text {. de abril de 1985), estabelece-se que funcionaria "em caráter provisório, em salas } \\
\text { anexo [sic] ao Museu Municipal Dr. Felippe Maria Wolff" (Art. } 3^{\circ} \text {.). }\end{array}$ \\
\hline 1986 & Indaial & $\begin{array}{l}\text { "Antigo prédio da Estação Rodoviária [sic] da RFFSA, na Rua Marechal Deodoro da Fonseca", onde também funcionariam a Biblioteca Pública } \\
\text { Municipal Cruz e Sousa e o Centro de Mostras Culturais (Lei municipal no }{ }^{\circ} .530 \text {, de } 26 \text { de março de 1986, Arts. } 2^{\circ} \text {. e } 3^{\circ} \text {.). }\end{array}$ \\
\hline 1988 & Ipumirim & $\begin{array}{l}\text { Embora a sede não seja especificada, determina-se: “A Prefeitura Municipal garantirá pelo espaço de tempo em que a Fundação [Cultural Félix } \\
\text { Bonissoni] não dispuser de sede própria, o espaço físico necessário para o exercício de todas as suas atividades, em local que as centralize.” (Lei } \\
\text { n }^{\circ} .788 \text { de } 28 \text { de outubro de } 1988 \text {, Art. 12). }\end{array}$ \\
\hline 1989 & Itaiópolis & Não há referências à sede do Arquivo Público e Histórico de Itaiópolis na Lei municipal nº. 16, de 22 de fevereiro de 1989. \\
\hline 1989 & Campos Novos & $\begin{array}{l}\text { A Casa de Cultura de Campos Novos, à qual estava vinculado o Arquivo Histórico do Município, deveria estar sediada "na Praça Lauro Müller } \\
\mathrm{n}^{\mathrm{o}} \text {. 39, no antigo prédio da Prefeitura Municipal de Campos Novos" (Decreto municipal } \mathrm{n}^{\circ} .2 .443 \text {, de } 12 \text { de abril de } 1989 \text {, Regulamento, } \\
\text { Art. } 2^{\circ} \text {.). Conforme a Lei } \mathrm{n}^{\circ} \text {. } 1.335 / 83 \text {, o "prédio do antigo Paço Municipal, localizado na praça Lauro Müller", foi "tombado como monumento } \\
\text { histórico do Município, não podendo ser demolido nem alteradas suas características básicas." (Art. }{ }^{\circ} \text {.) }\end{array}$ \\
\hline 1989 & Porto União & Informação não obtida (não foi possível efetuar a consulta à Lei municipal nº. 1.581, de 18 de setembro de 1989). \\
\hline 1990 & Tubarão & Não há referências à sede do Arquivo Público e Histórico de Tubarão na Lei municipal nº. 1.463, de 17 de julho de 1990. \\
\hline 1991 & Concórdia & $\begin{array}{l}\text { Não há referências à sede do Arquivo Central do Município (Decreto municipal n }{ }^{\circ} .2 .892 \text { de } 19 \text { de dezembro de } 1991 \text { e Decreto municipal n }{ }^{\circ} \text {. } \\
3.779 \text { de } 28 \text { de novembro de 1996). }\end{array}$ \\
\hline
\end{tabular}




\begin{tabular}{|c|c|c|}
\hline 1992 & Pinheiro Preto & $\begin{array}{l}\text { Funcionaria "no antigo prédio da Prefeitura Municipal, sala anexa ao Museu Histórico Municipal Pedro Lorenzoni, sito à Avenida Marechal } \\
\text { Castelo Branco, n.658." (Lei municipal n }{ }^{\circ} .623 \text {, de } 20 \text { de maio de 1992, Art. } 2^{\circ} \text {.). Deve-se notar que o Museu foi criado na lei imediatamente } \\
\text { anterior (Lei municipal no }{ }^{\circ} \text {. 622/92 de } 20 \text { de maio de 1992). }\end{array}$ \\
\hline 1992 & Biguaçu & Funcionaria em “prédio próprio à rua Hermógenes Prazeres, na Biblioteca Municipal” (Lei municipal n”. 714 , de 22 de maio de 1992, Art. $2^{\circ}$.). \\
\hline 1992 & São José & $\begin{array}{l}\text { Sede provisória "no local onde hoje se encontram depositados os documentos dos arquivos remanescentes [sic], subordinados à Secretaria da } \\
\text { Administração, até que se lhes destine sede e prédio próprios, mais amplos e à prova de fogo e umidade." (Lei municipal } \mathrm{n}^{\circ} .2436 \text { de } 10 \text { de } \\
\text { dezembro de } 1992, \text { Art. } 2^{\circ} \text {.) }\end{array}$ \\
\hline 1993 & Chapecó & Não há referências à sede do Arquivo Público Municipal de Chapecó (Lei municipal nº. 3.536, de 10 de agosto de 1993). \\
\hline 1993 & Balneário Camboriú & Não há referências à sede do Arquivo Público do Município de Balneário Camboriú (Lei municipal nº 1.293 , de 29 de novembro de 1993). \\
\hline 1994 & Florianópolis & $\begin{array}{l}\text { A lei de criação estabelece: "O Arquivo Histórico do Município de Florianópolis funcionará na área central da cidade, em prédio específico, } \\
\text { com adequadas condições de segurança para armazenar os documentos públicos municipais que constituem o patrimônio documental dos } \\
\text { florianopolitanos." (Lei municipal no }{ }^{\circ} .491 \text {, de } 14 \text { de setembro de } 1994, \text { Art. } 2^{\circ} \text {.) }\end{array}$ \\
\hline 1994 & Rio do Sul & Não há referências à sede do Arquivo Público Histórico de Rio do Sul (Lei municipal nº. 2.956, de 16 de dezembro de 1994). \\
\hline 1995 & Serra Alta & Não há referências à sede do Arquivo Público Municipal de Serra Alta (Lei municipal nº. 314, de 25 de outubro de 1995). \\
\hline 1997 & Canoinhas & Não há referências à sede do Arquivo Histórico de Canoinhas (Lei municipal nº.2.903 de 22 de outubro de 1997). \\
\hline 1998 & Nova Erechim & Não há referências à sede do Arquivo Público Municipal de Nova Erechim (Lei municipal nº. 890, de 10 de março de 1998). \\
\hline 1998 & Criciúma & $\begin{array}{l}\text { Funcionaria "anexo à Biblioteca Pública Municipal Donatila Borba, com adequadas condições de segurança para armazenar os Documentos } \\
\text { Públicos Municipais que constituem o patrimônio documental dos criciumenses." (Lei municipal no. } 3.670 \text {, de } 11 \text { de setembro de } 1998, \text { Art. } 2^{\circ} \text {.) }\end{array}$ \\
\hline 1998 & Ibirama & $\begin{array}{l}\text { A lei de criação estabelece: "O Arquivo funcionará em prédio específico com adequadas condições de segurança para armazenar os documentos } \\
\text { públicos municipais que constituem o patrimônio documental dos ibiramenses." (Lei municipal n. 2031, de } 18 \text { de dezembro de } 1998 \text {, Art. } 2^{\circ} \text {.). }\end{array}$ \\
\hline 2003 & Capivari de Baixo & uivo Público e Histórico de Capivari de Baixo (Lei municipal nº. 892, de 1 de julho de 2003). \\
\hline
\end{tabular}

Fontes:

- A própria legislação acima referida: originais ou cópias consultados no Arquivo Público do Estado de Santa Catarina, no Arquivo Histórico José Ferreira da Silva e no Arquivo Histórico de Itajaí; também consulta ao website: <http://www.leismunicipais.com.br> (acesso em: 13 out. 2005). Cópia da lei de criação do Arquivo Histórico Municipal de Joinville foi gentilmente fornecida pela pesquisadora Ilanil Coelho.

Obs.: O Museu e Arquivo Histórico do Vale do Itajaí-Mirim (conhecido como "Casa de Brusque") e o Museu Histórico Thiago de Castro, em Lages, não foram aqui incluídos, embora abriguem documentação pública municipal de caráter arquivístico: são mantidos por particulares (a entidade de Brusque, pela Sociedade Amigos de Brusque; a entidade lageana, pela família de Danilo Thiago de Castro). 
Apêndice III-1

Arquivo Histórico de Joinville: diretores, coordenadores e responsáveis.

\begin{tabular}{|c|c|c|}
\hline Responsável/Diretor(a) & Período de atuação & Obs. \\
\hline Adolfo Bernardo Schneider & $1972-1977$ & Escritor e historiador de Joinville. \\
\hline Apolinário Ternes & 1977 - abr. 1979 & Jornalista e historiador. Entre março de 1978 e fevereiro de 1979, esteve afastado do cargo. \\
\hline Norma Rathunde [responsável interina] & $1979] 1980-1981[1982 ?$ & Funcionária do Arquivo. \\
\hline Sarah Maria Isabel Gomes & 1982 - jun. 1984 & $\begin{array}{l}\text { Bibliotecária. Afastou-se em junho de 1984, para participar de projeto na Biblioteca } \\
\text { Nacional; solicitou demissão retroativa a março em abril de } 1985 .\end{array}$ \\
\hline Maria Thereza Böbel [responsável] & jun. 1984 - jun. 1986 & $\begin{array}{l}\text { Funcionária do Arquivo (tradutora de alemão). Interina de junho de } 1984 \text { a março de 1985; } \\
\text { efetiva a partir de abril de } 1985 \text {. }\end{array}$ \\
\hline Raquel S.Thiago & jun. 1986 - fev. 1989 & Historiadora. Nomeada como diretora do Arquivo de Joinville em 14 de junho de 1986. \\
\hline Apolinário Ternes & fev. $1989-1992$ & \\
\hline Ilanil Coelho & [1993-1996] & Historiadora. \\
\hline Afonso Imhof & [maio1997-dez.2000] & $\begin{array}{l}\text { Nomeado para o cargo de Coordenador do Patrimônio Histórico em maio de 1997, e } \\
\text { exonerado em dezembro de 2000. No jornal A Notícia, identificado como Coordenador do } \\
\text { Patrimônio Histórico da Fundação Cultural de Joinville (agosto de 1999) e Coordenador do } \\
\text { Arquivo Histórico (dezembro de 1999). }\end{array}$ \\
\hline Apolinário Ternes & [2001?] & Segundo o colunista A. Neves, teria sido nomeado diretor do Arquivo em fevereiro de 2001. \\
\hline Reginaldo Jorge dos Santos & [fev.2001-dez.2002] & $\begin{array}{l}\text { Nomeado para o cargo de Coordenador do Patrimônio Histórico em fevereiro de 2001, e } \\
\text { exonerado em dezembro de 2002. Em setembro de 2002, o jornal A Notícia o identifica } \\
\text { como Coordenador do Arquivo. }\end{array}$ \\
\hline Miraci Deretti & A partir de dez.2002. & $\begin{array}{l}\text { Nomeado para o cargo de Coordenador do Patrimônio Histórico em dezembro de } 2002 . \text { No } \\
\text { noticiário de } 2003 \text { e } 2004 \text {, Miraci Deretti aparece como Coordenador do Arquivo (fev. } \\
\text { 2003), Coordenador da área de Patrimônio Histórico da Fundação (abr. 2003) e "diretor de } \\
\text { unidade" (ago. 2004). }\end{array}$ \\
\hline
\end{tabular}

Fontes:

- Boletim do Arquivo Histórico de Joinville: Arquivo Histórico Municipal de Joinville - AHMJ / Arquivo Histórico de Joinville - AHJ: Joinville (SC), out.1983-dez. 1988; Boletim do Arquivo Histórico de Joinville - AHMJ, Joinville (SC), mar.1990- jun.1996.

- Noticiário de imprensa (A Notícia): IMHOF, Afonso. Bem cultural: um patrimônio singular. A Notícia, Joinville (SC), 15 ago. 1999 ; Arquivo ensina o valor de conhecer o passado. A Notícia, Joinville (SC), 16 dez. 1999; NEVES, A. Prestigiado. A Notícia, Joinville (SC), 6 fev. 2001; HERBST, Rubens. Arquivo tem 10 dias para consertar ar condicionado. A Notícia, Joinville (SC), 7 set. 2002; FELTHAUS, Rosane. Cidade sem Arquivo Histórico. A Notícia, Joinville (SC), 28 fev. 2003; HERBST, Rubens. Comissão traça metas para Arquivo. A Notícia, Joinville (SC), 5 abr. 2003; GROTH, Marlise. Arquivo Histórico fecha portas por 4 meses. A Notícia, Joinville (SC), 30 ago. 2004.

- Legislação e atos municipais (Joinville): Portaria $n^{\circ} .017 / 1997$; Decreto $n^{\circ} .9907$, de 28 dez.2000; Decreto ${ }^{\circ}$. 9939 , de 14 fev.2001; Decreto ${ }^{\circ} .10883$, de 9 dez.2002. Agradeço a Arselle de Andrade da Fontoura, funcionária do Arquivo Histórico de Joinville, pelo fornecimento dos dados relativos à portaria e aos decretos. 
Apêndice III-2

Arquivo Histórico de Blumenau: diretores e responsáveis.

\begin{tabular}{|l|c|l|}
\hline \multicolumn{1}{|c|}{ Diretor(a)/Responsável } & Período de atuação & \multicolumn{1}{c|}{ Obs. } \\
\hline Christiana Deeke Barreto & ] 1950 [ & \\
\hline José Ferreira da Silva & Déc. 1960 - 1973 & $\begin{array}{l}\text { Na década de 1960, foi diretor da Biblioteca Pública, sendo possível que tivesse } \\
\text { responsabilidade sobre a documentação do Arquivo; no início da década de 1970, } \\
\text { foi diretor executivo da Fundação Casa Dr. Blumenau. }\end{array}$ \\
\hline Inge von Hertwig & 1973 & Identificada como funcionária do "arquivo histórico e fotográfico". \\
\hline Emílio João Sada & 1974 & Funcionário responsável pelo Arquivo Histórico. \\
\hline Sueli M. V. Petry & {$[1977$ até hoje } & $\begin{array}{l}\text { Mesmo tendo se tornado Diretora de Patrimônio Histórico-Cultural, continuou } \\
\text { responsável pelo Arquivo. }\end{array}$ \\
\hline
\end{tabular}

Obs.: Não houve aqui a preocupação de realizar um levantamento exaustivo, apenas a de sistematizar os dados a respeito encontrados nos materiais consultados.

Fontes:

- Depoimento de Sueli Petry, em 17 de novembro de 2005 - versão transcrita. Arquivo pessoal de Janice Gonçalves.

- Relatório dos negócios administrativos do Município de Blumenau, referente ao ano de 1950, apresentado à Câmara Municipal pelo Prefeito Frederico Guilherme Busch Junior. S.l.p., s.c.p., s.d.

- Relatório apresentado por José Ferreira da Silva ao Prefeito Municipal, Dr. Carlos C. Zadrozny, sobre os setores culturais do governo municipal, 20 de janeiro de 1966. Cópia carbono datilografada carbono.

- Relatórios de atividades da Fundação Casa Dr. Blumenau, entre 1972 e 1982. Acervo: Arquivo Histórico Prof. José Ferreira da Silva.

- Relatórios anuais e parciais do Arquivo Histórico "Prof. José Ferreira da Silva", entre 1983 e 1992 (com exceção do de 1986 , não localizado). Acervo: Arquivo

Histórico Prof. José Ferreira da Silva. 
Apêndice III-3

Composição do Conselho Curador da Fundação Genésio Miranda Lins (Itajaí)

\begin{tabular}{|c|c|c|c|c|c|c|c|c|c|c|c|}
\hline & \begin{tabular}{|l|}
$1986-88$ \\
\end{tabular} & \begin{tabular}{|l|l|}
$1989-90$ \\
\end{tabular} & 1990-92 & 1992-94 & 1994-96 & \begin{tabular}{|l|}
$1996-98$ \\
\end{tabular} & 1998-00 & \begin{tabular}{|l|}
$2000-02$ \\
\end{tabular} & \begin{tabular}{|l|} 
2002-04 \\
\end{tabular} & \begin{tabular}{|l|l|}
$2004-06$ \\
\end{tabular} & Obs. \\
\hline Antônio Carlos de Campos Silva & Cs & Cs & Cs & - & - & - & - & - & - & - & \\
\hline Edison d'Ávila & $\mathrm{P}$ & $\mathrm{P}$ & $\mathrm{P}$ & VP & Cs & - & $\mathrm{P}$ & $\mathrm{P}$ & $\mathrm{P}$ & $\mathrm{P}$ & \\
\hline Edison Villela & Cs & $\mathrm{S}$ & Cs & - & - & - & - & - & - & - & \\
\hline Eliziário Pereira Neto & & & & Cs & VP & VP & Cs & - & - & - & \\
\hline Ewaldo Germano Joaquim Willerding & VP & - & - & - & - & - & - & - & - & - & \\
\hline Hilene Amaral Pereira Granja Russo & - & - & - & - & - & Cs & - & - & - & - & \\
\hline Homero Bruno Malburg & $\mathrm{T}$ & $\mathrm{T}$ & Cs & $P$ & $P$ & $\mathrm{P}$ & VP & $\mathrm{T}$ & VP & VP & $\begin{array}{l}\text { No biênio 1986-1988, integrou o } \\
\text { Conselho a partir de } 1987 .\end{array}$ \\
\hline José Maria Pfeil Sticker Zimmermann & - & - & - & - & - & Cs & - & - & - & - & \\
\hline José Roberto Provesi & - & - & - & - & - & - & - & $\mathrm{VP}$ & Cs & - & \\
\hline Lindinalva Deola da Silva & - & - & $S$ & $\mathrm{~S}$ & Cs & $\mathrm{S}$ & $\mathrm{S}$ & Cs & $\mathrm{T}$ & $\mathrm{T}$ & \\
\hline Lúcia de Carvalho Mendes & - & - & - & - & - & Cs & - & - & - & - & \\
\hline Ludgerio Niehues & Cs & VP & VP & Cs & $\mathrm{T}$ & $\mathrm{T}$ & - & - & - & - & $\begin{array}{l}\text { No biênio 1986-1988, integrou o } \\
\text { Conselho a partir de dezembro de } 1987 .\end{array}$ \\
\hline Luiz Felipe Sada Graff & - & Cs & - & - & - & - & - & - & - & - & $\begin{array}{l}\text { No biênio 1989-1990, foi empossado } \\
\text { em julho de } 1989 .\end{array}$ \\
\hline Manoel Rodrigues Conceição & - & - & $\mathrm{T}$ & $\mathrm{T}$ & Cs & - & - & - & - & - & \\
\hline Maria Bernardete Ramos Flores & $\mathrm{S}$ & Cs & - & - & - & - & - & - & - & - & \\
\hline Maria Glória Mafra Niehues & - & - & - & - & - & - & - & - & - & Cs & \\
\hline Mário Uriarte Neto & - & - & - & - & - & - & $\mathrm{Cs}$ & - & - & - & \\
\hline Marlene Dalva da Silva Rothbarth & - & - & - & Cs & $\mathrm{S}$ & - & - & - & - & - & \\
\hline Mauro César de Azevedo Machado & & & & & & & Cs & Cs & Cs & - & \\
\hline Mônica Zewe Uriarte & & & & & & & & & & Cs & \\
\hline Paulo Afonso Schmitt & $\mathrm{T}$ & - & - & - & - & - & - & - & - & - & $\begin{array}{l}\text { No biênio 1986-1988, integrou o } \\
\text { Conselho até 1987 (faleceu). }\end{array}$ \\
\hline Rosa de Lourdes Vieira da Silva & - & - & - & - & - & - & - & $\mathrm{Cs}$ & Cs & Cs & \\
\hline Rosane W. Rothbarth & - & - & - & - & - & - & $\mathrm{T}$ & $\mathrm{S}$ & $\mathrm{S}$ & $\mathrm{S}$ & \\
\hline
\end{tabular}

Onde: $\mathrm{P}=$ Presidente; VP = Vice-Presidente; S = Secretário(a); T = Tesoureiro; Cs = Conselheiro(a).

Obs.: A gestão 2004-2006 não foi concluída em função de o Conselho Curador ter sido extinto em 2005.

Fontes: Relatórios anuais de atividades da Fundação Genésio Miranda Lins, relativos aos anos de 1986 a 2004 (excetuados os de 1997 e 2000 , não localizados. Acervo:

Centro de Documentação e Memória Histórica “Genésio Miranda Lins” / Arquivo Público de Itajaí). 
Apêndice III-4

Arquivo Histórico de Itajaí: diretores e coordenadores.

\begin{tabular}{|l|c|l|}
\hline \multicolumn{1}{|c|}{ Diretor/coordenador } & Período de atuação & \multicolumn{1}{|c|}{ Obs. } \\
\hline Edison d'Ávila & $1987-1991$ & $\begin{array}{l}\text { No período, exerceu a função de diretor do Arquivo. Historiador. } \\
\text { Atuou ainda na instituição desde 1986 até 2004, direta ou indiretamente } \\
\text { (como historiador, presidente da Fundação Genésio Miranda Lins e } \\
\text { membro do Conselho Curador da Fundação). }\end{array}$ \\
\hline Vera Lúcia Nóbrega Pecego Estork & 1992 ?] 1999-2004 & Coordenadora do Arquivo. Bibliotecária e arquivista. \\
\hline José Bento Rosa da Silva & Desde 2005. & $\begin{array}{l}\text { Coordenador do Centro de Documentação e Memória Histórica, ao qual } \\
\text { passou a estar vinculado o Arquivo. Historiador. }\end{array}$ \\
\hline
\end{tabular}

Obs.: O relatório de atividades referente a 1998 menciona a "eleição e posse do primeiro Diretor e Secretário do Museu e Arquivo Histórico de Itajaí", em 13 de agosto, o que teria eliminado o "cargo de coordenador administrativo até então vigente". As referências a esse diretor não aparecem, contudo, nos relatórios seguintes.

Fontes:

- Depoimento de José Bento Rosa da Silva, em 6 de outubro de 2005 - versão transcrita. Arquivo pessoal de Janice Gonçalves.

- Relatórios anuais de atividades da Fundação Genésio Miranda Lins, relativos aos anos de 1986 a 2004 (excetuados os de 1997 e 2000 , não localizados. Acervo: Centro de Documentação e Memória Histórica "Genésio Miranda Lins" / Arquivo Público de Itajaí). 
Apêndice III-5

Arquivo Histórico de Florianópolis: diretores.

\begin{tabular}{|l|c|l|}
\hline \multicolumn{1}{|c|}{ Diretor/coordenador } & Período de atuação & Obs. \\
\hline Nelma Baldin & Dez. 1994 - 1 $^{\text {. fev. } 1996}$ & Historiadora. \\
\hline Marilene Filomeno Machado Ribeiro & $1^{\text {}}$. fev. 1996- jan. 1997 & Bibliotecária. \\
\hline Leda Rosa Cardoso Vieira & Jan. 1997 - jan. 2002 & Bibliotecária. \\
\hline Suely Veiga Quinteiro & 15 fev. 2002 - 31 dez. 2004 & Bibliotecária. \\
\hline Antonio Dario Neves & A partir de 2005 & Engenheiro. \\
\hline
\end{tabular}

Fontes:

- Decreto municipal [Florianópolis] nº 053/96 - resolve exonerar, a pedido, Nelma Baldin, do cargo em comissão de Diretora do Arquivo Histórico do Município de Florianópolis, a partir de 01/02/1996. Florianópolis, 7 de fevereiro de 1996. Arquivo corrente do AHMF, Outros documentos de funcionários, vários anos.

- Decreto municipal [Florianópolis] no. 054/96 - resolve nomear Marilene Filomeno Machado Ribeiro para o cargo em comissão de Diretora do Arquivo Histórico do Município de Florianópolis, a partir de 01/02/1996. Florianópolis, 7 de fevereiro de 1996. Arquivo corrente do AHMF, Outros documentos de funcionários - vários anos.

- Depoimento de Antonio Dario Neves e Fábio Andréas Richter, em 11 de novembro de 2005 - versão transcrita. Arquivo pessoal de Janice Gonçalves.

- QUINTEIRO, Suely Veiga. Arquivo Histórico do Município de Florianópolis. In: Caderno de resumos do X Encontro Catarinense de Arquivos e V Painel de Arquivos Municipais - 2 a 4 de setembro de 2002. Florianópolis: 2002. p.26.

- Relatório de atividades referente a 1994, elaborado por Nelma Baldin, diretora do Arquivo Histórico do Município de Florianópolis. Florianópolis, s.d. [janeiro de 1995?].Arquivo corrente do Arquivo Histórico Municipal de Florianópolis "Oswaldo Rodrigues Cabral” - AHMF, Ofícios expedidos, 1995.

- Website da Prefeitura Municipal de Florianópolis, página eletrônica referente ao Arquivo Histórico: http://www.pmf.sc.gov.br/arquivo_historico. Acesso em: 17 out. 2005. 
Apêndice III-6

Atendimento a usuários no Arquivo Histórico de Joinville (1983-1992)

\begin{tabular}{|c|c|c|c|c|c|c|c|c|c|c|}
\hline Pesquisas/consultas & 83 & 84 & 85 & 86 & 87 & 88 & 89 & 90 & 91 & 92 \\
\hline Pesquisas escolares & & 103 & & & & & & & & \\
\hline Pesquisas históricas & & 2 & & & & & & & & \\
\hline Consultas & & & & 135 & 259 & 331 & & & & \\
\hline Outras pesquisas / outras consultas & & & & 98 & & & 622 & 458 & 1568 & 2680 \\
\hline
\end{tabular}

\begin{tabular}{|c|c|c|c|c|c|c|c|c|c|c|}
\hline Usuários/visitantes & 83 & 84 & 85 & 86 & 87 & 88 & 89 & 90 & 91 & 92 \\
\hline Usuários & 331 & & 346 & & & & & & & \\
\hline Visitantes & 30 & 655 & & & & & $396 *$ & $390^{*}$ & $1593 *$ & $1038^{*}$ \\
\hline
\end{tabular}

\begin{tabular}{|c|c|c|c|c|c|c|c|c|c|c|}
\hline Área de pesquisa & 83 & 84 & 85 & 86 & 87 & $\mathbf{8 8}$ & 89 & 90 & 91 & 92 \\
\hline "Genealogia[s] / pesquisas genealógicas & 9 & 12 & 10 & 30 & 34 & 86 & 70 & 85 & 101 & 71 \\
\hline História & 17 & & 227 & 59 & & & & & & \\
\hline Geografia & 20 & & & & & & & & & \\
\hline
\end{tabular}

\begin{tabular}{|c|c|c|c|c|c|c|c|c|c|c|}
\hline Materiais consultados & 83 & 84 & 85 & 86 & 87 & 88 & 89 & 90 & 91 & 92 \\
\hline Diários oficiais & 59 & & 327 & 55 & & & & & & \\
\hline Jornais & 74 & & 518 & 120 & & & & & & \\
\hline Jornais e diários oficiais & & 571 & & & & & & & & \\
\hline Listas de imigrantes & 3 & & & & & & & & & \\
\hline Diversos & 119 & & & & & & & & & \\
\hline
\end{tabular}

Obs.:

1. Os dados referentes a 1983 cobrem apenas o período de janeiro a julho; os referentes a 1984 não incluem dezembro.

2. No segundo semestre de 1984, o atendimento ao público foi interrompido em função de duas inundações, no prédio.

3. Em 1986, as consultas foram suspensas entre $1^{\circ}$. e 19 de junho, em função da mudança para novo prédio.

4. Os materiais consultados foram discriminados, no boletim do Arquivo, apenas até o primeiro trimestre de 1986.

5. Não foram publicados boletins do Arquivo de Joinville nos anos de 1989, 1993 e 1994.

6. Não foram fornecidos, nos boletins, dados estatísticos sobre o atendimento a usuários no ano de 1995.

Fontes:

Arquivo Histórico Municipal de Joinville - AHMJ / Arquivo Histórico de Joinville - AHJ: Joinville (SC), out.1983-dez. 1988; Boletim do Arquivo Histórico de

Joinville - AHMJ, Joinville (SC), mar.1990- jun.1996. 
Apêndice III-7

Atendimento a usuários no Arquivo Histórico de Blumenau (1983-1992)

\begin{tabular}{|c|c|c|c|c|c|c|c|c|c|c|}
\hline Pesquisas realizadas & 83 & 84 & $\mathbf{8 5}$ & 86 & 87 & 88 & 89 & 90 & 91 & 92 \\
\hline Pesquisas escolares (alunos da rede municipal e estadual) & 634 & 748 & & & & & & & & \\
\hline Pesquisas de pós-graduação & 180 & 240 & & & & & & [7] & & \\
\hline Pesquisas para reportagens jornalísticas & 58 & 120 & & & & & & & & \\
\hline Pesquisas genealógicas & & & & & & & & & & [440] \\
\hline Pesquisas & & & & & & & & [208] & & \\
\hline Total: & 872 & 1108 & & & 418 & 1298 & & {$[208]$} & & \\
\hline
\end{tabular}

\begin{tabular}{|c|c|c|c|c|c|c|c|c|c|c|}
\hline Usuários & 83 & 84 & 85 & 86 & 87 & 88 & 89 & 90 & 91 & 92 \\
\hline Alunos / "escolares" & & & 1440 & & 229 & 741 & 940 & 1717 & 2184 & 2149 \\
\hline Pesquisadores & & & & & 502 & 675 & 847 & 794 & 888 & 1359 \\
\hline Total: & & & 1440 & & 731 & 1416 & 1787 & 2511 & 3072 & 3508 \\
\hline
\end{tabular}

\begin{tabular}{|c|c|c|c|c|c|c|c|c|c|c|}
\hline Visitantes & 83 & 84 & 85 & 86 & 87 & 88 & 89 & 90 & 91 & 92 \\
\hline Visitas "ilustres" & 8 & & {$[2]$} & & [3] & & & & & \\
\hline $\begin{array}{l}\text { Visitas de representantes de municípios } \\
\text { (implicando assistência técnica por parte do Arquivo de Blumenau) }\end{array}$ & & & & & & 7 & & & & \\
\hline
\end{tabular}

Obs.:

1. Nos relatórios referentes a 1983 e 1984, informa-se: "Temos sido procurados por várias pessoas interessadas, das que nos escrevem e visitam, procurando material para a confecção e estudo de árvores genealógicas."

2. Em relação a 1985 e ao período 1989-1992 não foram fornecidos dados estatísticos acerca das pesquisas realizadas; não foi localizado relatório referente a 1986.

3. Os dados referentes a 1990 dizem respeito apenas ao $1^{\circ}$. trimestre.

4. Nas visitas de alunos, foram computadas tanto as visitas de turmas como as isoladas; nas visitas de representantes de municípios, o número indicado refere-se à quantidade de municípios.

5. Os relatórios indicam inconsistência de dados: veja-se que, no relatório referente ao biênio 1987-1989, assinalam-se 4.186 "visitas de estudantes c/prof. (rede municipal, estadual , particular)" e 3.776 "pesquisadores" (números superiores aos disponibilizados nos relatórios parciais).

6. Os números entre colchetes referem-se a dados mencionadas no corpo dos relatórios, e não em quadros estatísticos.

Fontes: Relatórios anuais e parciais do Arquivo Histórico "Prof. José Ferreira da Silva", entre 1983 e 1992 (com exceção do de 1986 , não localizado). Acervo: Arquivo Histórico Prof. José Ferreira da Silva. 
Apêndice III-8

Atendimento a usuários no Arquivo Histórico de Itajaí (1986-2002)

\begin{tabular}{|c|c|c|c|c|c|c|c|c|c|c|c|c|c|c|c|c|c|}
\hline Usuários & 1986 & 1987 & 1988 & 1989 & 1990 & 1991 & 1992 & 1993 & 1994 & 1995 & 1996 & 1997 & 1998 & 1999 & 2000 & 2001 & 2002 \\
\hline "De Itajaí & 81 & 215 & & & & & & & & & & & & & & & \\
\hline Externos & 55 & 101 & & & & & & & & & & & & & & & \\
\hline Homens & & & 62 & 59 & 124 & 77 & 92 & 137 & 157 & 323 & 261 & & & & & & \\
\hline Mulheres & & & 115 & 75 & 69 & 110 & 182 & 153 & 297 & 333 & 360 & & & & & & \\
\hline Pesquisadores & & & & & & & & & & & & & & 652 & & 888 & 599 \\
\hline Pesquisadores em grupo & & & & & & & & & & & & & & & & 539 & 657 \\
\hline Total: & 136 & 316 & 177 & 134 & 193 & 187 & 274 & 290 & 454 & 656 & 621 & & & 652 & & 1427 & 1256 \\
\hline Consultas & 1986 & 1987 & 1988 & 1989 & 1990 & 1991 & 1992 & 1993 & 1994 & 1995 & 1996 & 1997 & 1998 & 1999 & 2000 & 2001 & 2002 \\
\hline Consultas [in loco] & & & & & & & & & & & & & & 561 & & 335 & 185 \\
\hline Consultas por telefone & & & & & & & & & & & & & & 368 & & 359 & 140 \\
\hline Total: & & & & & & & & & & & & & & 929 & & 694 & 325 \\
\hline
\end{tabular}

\begin{tabular}{|c|c|c|c|c|c|c|c|c|c|c|c|c|c|c|c|c|c|}
\hline Material consultado & 1986 & 1987 & 1988 & 1989 & 1990 & 1991 & 1992 & 1993 & 1994 & 1995 & 1996 & 1997 & 1998 & 1999 & 2000 & 2001 & 2002 \\
\hline Catálogos / folhetos & & & & & & & & & & & & & 15 & 40 & & 69 & 13 \\
\hline Documentos & & & & & & & & & & & & & 708 & 2019 & & 2010 & 2539 \\
\hline Fotografias & & & & & & & & & & & & & 2697 & 3028 & & 1510 & 1741 \\
\hline Gravuras / desenhos & & & & & & & & & & & & & & & & 32 & 32 \\
\hline \begin{tabular}{|l|} 
Jornais \\
\end{tabular} & & & & & & & & & & & & & 621 & 3324 & & 5122 & 12803 \\
\hline Livros & & & & & & & & & & & & & 1050 & 1675 & & 1166 & 1981 \\
\hline Plantas / mapas/ cartazes & & & & & & & & & & & & & 48 & 15 & & 75 & 46 \\
\hline Revistas/ anuários & & & & & & & & & & & & & 153 & $451 *$ & & 376 & 1121 \\
\hline 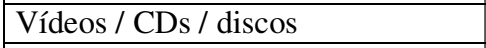 & & & & & & & & & & & & & & 7 & & 11 & 11 \\
\hline Total: & & & & & & & & & & & & & 5292 & 10559 & & 10371 & 20287 \\
\hline
\end{tabular}

*Incluídos 10 "periódicos".

Obs.:

1. Entre 1986 e 1991, os relatórios de atividades consideraram as consultas à Biblioteca de Apoio e ao acervo do Arquivo Histórico propriamente dito; após 1991, fica subentendido o mesmo procedimento. 
2. Em janeiro e fevereiro de 1988 o atendimento ao público foi suspenso em virtude de atividades de organização do acervo; houve interrupção do atendimento também nos meses de setembro a dezembro de 1998, em função da mudança do Arquivo para a Casa Konder (retomado a partir de dezembro), e nos primeiros meses de 2001, em função da mudança do Arquivo para a Casa Lins (retomado a partir de maio).

3. Os relatórios de atividades referentes a 1997 e 2000 não foram localizados.

4. Os relatórios consultados referentes às atividades de 2003 e 2004 não continham dados estatísticos sobre os materiais consultados.

Fontes: Relatórios anuais de atividades da Fundação Genésio Miranda Lins, relativos aos anos de 1986 a 2004 (excetuados os de 1997 e 2000 , não localizados. Acervo: Centro de Documentação e Memória Histórica “Genésio Miranda Lins” / Arquivo Público de Itajaí). 
Apêndice III-9

Exposições promovidas pelo Arquivo Histórico de Joinville (1984-1996)

\begin{tabular}{|c|c|c|c|}
\hline Exposição & Período & $\begin{array}{l}\text { Número de } \\
\text { visitantes }\end{array}$ & Obs. \\
\hline História de Joinville & $\begin{array}{l}15 \text { a } 19 \text { nov. } 1984 \\
\text { [Festa das Flores] }\end{array}$ & NI & $\begin{array}{l}\text { Estendida até } 8 \text { dez. } 1984 \text { (saguão da Secretaria de } \\
\text { Turismo); mantida em exibição posteriormente, mas no } \\
\text { Museu do Sambaqui. }\end{array}$ \\
\hline Joinville - seus tempos, seus lugares, sua gente & 18 jul.- 31 ago. 1986 & 1918 & \\
\hline $\begin{array}{l}\text { August Sander - Ernest Salomon: dois precursores da fotografia } \\
\text { alemã }\end{array}$ & 1 a 8 set. 1986 & 313 & \\
\hline Sala especial - Victor Kursancew & 5 a 30 set. 1986 & 455 & \\
\hline Franz Kafka & Set. /out. $1986 ?$ & 133 & \\
\hline Joinville através da filatelia & 8 out.- 17 nov. 1986 & 348 & \\
\hline Intercâmbio Joinville-Langenhagen & 31 out.- 18 nov. 1986 & 220 & \\
\hline De Gutenberg à eletrônica & 20 nov.-10 dez. 1986 & 101 & \\
\hline Cidade como caricatura & 15 jan.- 20 fev. 1987 & 134 & \\
\hline Joinville - sua gente & 23 fev.- 4 mar. 1987 & 24 & \\
\hline Nossos compositores - 1900-1940 & 6 a 27 mar. 1987 & 145 & $\begin{array}{l}\text { Inaugurada junto com lançamento de livro de Elly } \\
\text { Herkenhoff; músicos da Escola de Música Villa-Lobos } \\
\text { executaram cinco peças cujas partituras estavam expostas. }\end{array}$ \\
\hline Joinville - seus tempos, seus lugares, sua gente & 27 mar.-8 maio 1987 & 216 & \\
\hline A gravura em madeira ao longo de seis séculos & 11 a 29 maio 1987 & 53 & \\
\hline Joinville - seus tempos, seus lugares, sua gente & 1 ago.- 8 set. 1987 & 72 & \\
\hline Cartilha da guerra - Bertolt Brecht & 11 a 24 set. 1987 & 67 & \\
\hline Nossos compositores - 1900-1940 & 28 set. -30 out. 1987 & 76 & \\
\hline Joinville - seus tempos, seus lugares, sua gente & 3 nov.-23 dez.1987 & 103 & \\
\hline Joinville - seus tempos, seus lugares, sua gente & 4 jan.-10 mar.1988 & 197 & \\
\hline Revitalização do Centro Histórico de Joinville & 11 mar.-19 abr.1998 & 48 & \\
\hline Auto-retrato de Santa Catarina & 25 abr. -15 maio 1988 & 15 & \\
\hline Nossos compositores - 1900-1940 & 16 maio-30 jun. 1988 & 73 & \\
\hline Joinville - seus tempos, seus lugares [sic] & 4 jul.-30 ago. 1988 & 216 & \\
\hline Retrato dos anos vinte & 5 a 25 set. 1988 & 31 & \\
\hline Joinville - seus tempos, sua gente [sic] & 5 nov. -9 dez. 1988 & 103 & \\
\hline Nossas escolas & 10 a 31 dez.1988 & 240 & \\
\hline Nossas escolas & 1 jan.-5 mar.1989 & $240[$ sic $]$ & \\
\hline
\end{tabular}




\begin{tabular}{|c|c|c|c|}
\hline Retratos de Joinville hoje & 8 mar. -24 abr. 1989 & 94 & \\
\hline Retratos de Joinville hoje & 18 [28?] abr.- 2 jun. 1989 & NI & Exibida no Palácio Cruz e Souza, em Florianópolis (SC). \\
\hline Nossas escolas & 24 maio-7 jun. 1989 & NI & Exibida na Escola Básica Germano Timm, Joinville (SC). \\
\hline Nossas escolas & 8 a 19 jun. 1989 & NI & Exibida no Colégio Bom Jesus, Joinville (SC). \\
\hline Retratos de Joinville hoje & 13 a 30 jun. 1989 & NI & Exibida na FURJ, Joinville (SC). \\
\hline Prêmio Esso de Jornalismo & 2 a 9 maio 1989 & 91 & \\
\hline Joinville - seus tempos, seus lugares, sua gente & 12 maio-21 jun.1989 & 133 & \\
\hline A escolha dos artistas, do Royal College of Arts, de Londres & 27 jun-5 jul. 1989 & 195 & \\
\hline Dança das imagens & 11 jun. -25 jul.1989 & 366 & \\
\hline Ciências naturais e técnicas - a Alemanha no século XIX & 31 jul. a 20 ago. 1989 & 82 & \\
\hline E assim se proclamou a República & 18 a 29 set. 1989 & 214 & \\
\hline Fotografias e cartazes da Festa das Flores do passado & 20 nov.- ? 1989 & NI & Integrou a programação da Festa das Flores. \\
\hline Maquete do Teatro Municipal & 24 maio- [dez.?] 1989 & NI & \\
\hline A Dança do Universo & 20 a 30 jul. 1990 & NI & $\begin{array}{l}\text { "Organizada por órgãos científicos da França, com apoio } \\
\text { do Ministério da Cultura e do Comércio da daquele país." } \\
\text { (BAHJ, nov.1990, p.24). }\end{array}$ \\
\hline Joinville - seus tempos, seus lugares, sua gente & 1 ago.-30 set. 1990 & NI & \\
\hline 40 anos da República Federal da Alemanha & 11 a 31 out. 1990 & NI & Organizada pelo Instituto Goethe de Curitiba. \\
\hline Patrimônio Cultural de SC - sua arquitetura & 6 a 16 nov. 1990 & NI & Organizada pela Fundação Catarinense de Cultura. \\
\hline Grafites do muro de Berlim & 21 a 30 nov. 1990 & NI & Organizada pelo Instituto Goethe de Curitiba. \\
\hline Família Heinzelmann -100 anos em Joinville & 3 a 13 dez. 1990 & NI & \\
\hline A vida do Príncipe e da Princesa de Joinville & 7 a 30 mar. 1991 & NI & \\
\hline Joinville - seus tempos, seus lugares, sua gente & 20 maio 1991 & NI & $\begin{array}{l}\text { Exibida no projeto "Mutirão Cultural”, da Fundação } \\
\text { Cultural de Joinville. }\end{array}$ \\
\hline Mozart - 1756-1791 & 31 maio-20 jun.1991 & NI & Organizada pelo Instituto Cultural Brasil-Alemanha. \\
\hline Vamos salvar nosso meio ambiente (mostra filatélica) & 31 maio-20 jun. 1991 & NI & Organizada pela Associação Filatélica de Joinville. \\
\hline Prêmio Matriz de Fotografia & 11 a 27 jul.1991 & NI & $\begin{array}{l}\text { Organizada pela Agência de Propaganda Matriz de } \\
\text { Comunicação, na programação do Festival de Dança. }\end{array}$ \\
\hline Cartazes escolares sobre o meio ambiente & 13 a 14 jul. 1991 & NI & Organizada pela FUNDEMA. \\
\hline Iconografia náutica da costa catarinense & 14 a 30 nov. 1991 & NI & $\begin{array}{l}\text { Reunindo desenhos a bico de pena e Carlos da Costa } \\
\text { Pereira Filho, e apenas co-promovida pelo AHJ. }\end{array}$ \\
\hline Cartões antigos de Natal & 4 a 31 dez. 1991 & NI & \\
\hline $\begin{array}{l}\text { Exposição especial contendo documentos do AHJ considerados } \\
\text { preciosos e importantes }\end{array}$ & mar. 1992 & NI & $\begin{array}{l}\text { O relatório do quadriênio 1989-1992 informa ainda terem } \\
\text { sido realizadas } 11 \text { exposições em } 1992 \text { (cinco no próprio } \\
\text { Arquivo, seis em outras instituições), mas não informa } \\
\text { seus temas nem o número de visitantes (BAHMJ, }\end{array}$ \\
\hline
\end{tabular}




\begin{tabular}{|c|c|c|c|}
\hline & & & dez.1992, p.15-16). \\
\hline Emigração, navegar foi preciso & 1 a 30 jul.1995 & - & Exposta no próprio Arquivo. \\
\hline Joinville - seus tempos, seus lugares, sua gente & $17 ?-13$ ago. 1995 & - & \multirow{6}{*}{$\begin{array}{l}\text { Informação disponível (boletim de julho de 1995) apenas } \\
\text { previa as exposições. A primeira seria realizada no } \\
\text { Shopping Cidade das Flores; a segunda, no AHJ; a } \\
\text { terceira, na UNIVILLE; a quarta, no AHJ; a quinta, na } \\
\text { Expoville; a sexta e última, no AHJ. }\end{array}$} \\
\hline Nossas escolas & 1 ago. -10 set. 1995 & - & \\
\hline Emigração, navegar foi preciso & 28 ago. -10 set. 1995 & - & \\
\hline Retrospectiva da Festa das Flores & 15 set.- 30 nov. 1995 & - & \\
\hline Rio Cachoeira em perspectiva & 17 a 26 nov. 1995 & - & \\
\hline Nossos compositores & 1 a 30 dez. 1995 & - & \\
\hline O cartão postal viaja no tempo & Jun. 1996 & - & \multirow{10}{*}{$\begin{array}{l}\text { Informação disponível (boletim de junho de 1996) apenas } \\
\text { previa as exposições. Todas as exposições seriam } \\
\text { realizadas no AHJ, com exceção da "Rio Cachoeira em } \\
\text { perspectiva" (em junho, na UNIVILLE; em agosto, no } \\
\text { Shopping Cidade das Flores). }\end{array}$} \\
\hline Rio Cachoeira em perspectiva & Jun. 1996 & - & \\
\hline Vivendo a arte de vestir a dança & 11 a 29 jul.1996 & - & \\
\hline Rio Cachoeira em perspectiva & 10 ago. 1996 & - & \\
\hline Repensando a Era Vargas & 2 a 16 set. 1996 & - & \\
\hline Fontes iconográficas para a história regional & 17 a 30 set. 1996 & - & \\
\hline O cartão postal viaja no tempo & 2 a 13 out. 1996 & - & \\
\hline Repensando a independência do Brasil & 15 a 31 out. 1996 & - & \\
\hline Retrospectiva da Festa das Flores & Nov.1996 & - & \\
\hline Cartões antigos de Natal & Dez.1996 & - & \\
\hline
\end{tabular}

Onde NI = Não informado

Fontes: Arquivo Histórico Municipal de Joinville - AHMJ / Arquivo Histórico de Joinville - AHJ: Joinville (SC), out.1983-dez. 1988; Boletim do Arquivo Histórico de Joinville - AHMJ, Joinville (SC), mar.1990- jun.1996. 
Apêndice III-10

Exposições promovidas pelo Arquivo Histórico de Blumenau (1983-1992)

\begin{tabular}{|c|c|c|c|}
\hline Título/tema & Período & $\begin{array}{l}\text { Número de } \\
\text { visitantes }\end{array}$ & Obs. \\
\hline Vida e a obra de José Ferreira da Silva & maio 1983 & $\mathrm{NI}$ & $\begin{array}{l}\text { Realizada para comemorar a transferência e a reabertura } \\
\text { do Arquivo Histórico. }\end{array}$ \\
\hline Sociedade Recreativa Ipiranga - 90 anos & [1983] & NI & Realizada na própria Sociedade Recreativa. \\
\hline Escola Básica Estadual Luís Delfino - 70 anos & [1983] & NI & Realizada na própria escola básica. \\
\hline Um pouco da história do bairro do Garcia e as cheias de Blumenau & [1983] & $\mathrm{NI}$ & Realizada no Conjunto Educacional Celso Ramos. \\
\hline A História de Blumenau & [fevereiro de 1985] & $\mathrm{NI}$ & $\begin{array}{l}\text { Realizada como suporte às atividades de círculo de } \\
\text { estudos iniciado naquele mês com os professores da } \\
\text { rede municipal de ensino. }\end{array}$ \\
\hline A evolução cultural de Blumenau & [1985] & $\mathrm{NI}$ & Realizada no Conjunto Educacional Celso Ramos. \\
\hline A História de Blumenau & [1985] & NI & Realizada na Escola Básica Adolfo Konder. \\
\hline O calendário através dos tempos & mar.-jun. 1987 & NI & Exposta no Museu da Família Colonial. \\
\hline Imagens de Blumenau Antiga & ago-set. 1987 & $\mathrm{NI}$ & Exposta no Museu da Família Colonial. \\
\hline Blumenau em cartaz & out.-nov 1987 & NI & Exposta no Museu da Família Colonial. \\
\hline Vida e obra de José Ferreira da Silva & 1 nov. $1987-15$ jan. 1988 & NI & $\begin{array}{l}\text { Exposta no Museu da Família Colonial, em } \\
\text { comemoração aos } 30 \text { anos da revista Blumenau em } \\
\text { Cadernos. }\end{array}$ \\
\hline O Vale em cartaz & jan.-mar.1988 & NI & Exposta no Museu da Família Colonial. \\
\hline Imagens de Blumenau & set. 1988 & $\mathrm{NI}$ & Exposta no Museu da Família Colonial. \\
\hline Escravidão - Abolição - Resistência - Religião & 5 a 12 dez. 1988 & NI & Exposta no Museu da Família Colonial. \\
\hline Imagens de Blumenau & 14 mar. 1992 & NI & Exposta no calçadão. \\
\hline 500 anos da América & 18 mar. 1992 & $\mathrm{NI}$ & Exposta no calçadão. \\
\hline Imagens de Blumenau & 21 mar. 1992 & NI & Exposta no calçadão. \\
\hline Indígenas do Vale do Itajaí & 27 abr. 1992 & NI & Exposta no calçadão. \\
\hline Ponte metálica & 14 maio 1992 & $\mathrm{NI}$ & Exposta no calçadão. \\
\hline Centenário da morte do Pe. José Maria Jacobs & 27 jul. - 10 ago. 1992 & NI & Exposta na Igreja Matriz São Paulo Apóstolo. \\
\hline 40 anos da Fraternidade Blumenauense n. 6 & 17 ago. - 7 set. 1992 & NI & Exposta na sala Humanitas, da Fraternidade. \\
\hline Edith Gaertner: uma blumenauense defensora da natureza & 28 ago. -13 set. 1992 & $\mathrm{NI}$ & Exposta na PROEB, durante a Semana Verde. \\
\hline Rua XV de Novembro através dos tempos & 31 ago. - 18 set. 1992 & NI & Exposta no Restaurante Doktor Blumenau. \\
\hline O militarismo em Blumenau & 15 set. - 16 nov. 1992 & NI & Exposta no Arquivo Histórico José Ferreira da Silva. \\
\hline Estrada de Ferro Santa Catarina & 5 a 16 out. 1992 & $\mathrm{NI}$ & Exposta na FURB. \\
\hline Mostra documental do Arquivo Histórico de Blumenau & 5 out. -5 nov. 1992 & NI & Exposta na FURB. \\
\hline
\end{tabular}


Obs:

1. Não foram mencionadas, nos relatórios consultados, exposições referentes a 1984, 1989, 1990 e 1991.

2. Relativamente a 1985, foram destacadas, no relatório alusivo ao período, apenas algumas das exposições realizadas.

3. Não foi localizado o relatório referente a 1986

Fontes:

- Relatórios anuais e parciais do Arquivo Histórico "Prof. José Ferreira da Silva", entre 1983 e 1992 (com exceção do de 1986 , não localizado). Acervo: Arquivo Histórico Prof. José Ferreira da Silva. 